José de Paula Ramos Jr.

\title{
A FORTUNA CRÍTICA DE MACUNAÍMA: PRIMEIRA ONDA (1928-1936)
}

Tese de doutoramento

Área: Literatura Brasileira

Departamento de Letras Clássicas e Vernáculas

Faculdade de Filosofia, Letras e Ciências Humanas

Universidade de São Paulo

Orientadora

Profa. Dra. Therezinha Apparecida Porto Ancona Lopez

SÃO PAULO

2006 


\section{URSA MAIOR}

para Telê

Não a pedra, mas a luz das estrelas está no coração

daquela idéia bela, andradina, que dá orientação. 
Minha gratidão a

Telê Porto Ancona Lopez, pelo rigor, vigor e solidez da orientação instigadora;

Diléa Zanotto Manfio, pela generosidade com que compartilhou sua pesquisa bibliográfica ainda inédita;

Antônio Dimas, Antônio Medina Rodrigues, Cely Arena, Dácio Antônio de Castro, Fernando Marcílio Couto, Francisco Achcar, Francisco Roberto Savioli (Platão), Frederico Barbosa, Ivan Prado Teixeira, José Antonio Alves Torrano, José Luiz Fiorin, Marcos Antonio de Moraes, Regina Rocha Oliveira (in memoriam) e Valquíria Pereira Alcântara, pela amizade, pelo incentivo e pelos ensinamentos;

Funcionários do Arquivo da Biblioteca do IEB-USP e da Fundação Biblioteca Nacional, pela colaboração que tornou possível este trabalho;

Cláudia, Leandro e Rodrigo, pela presença querida e luminosa. 


\section{SUMÁRIO}

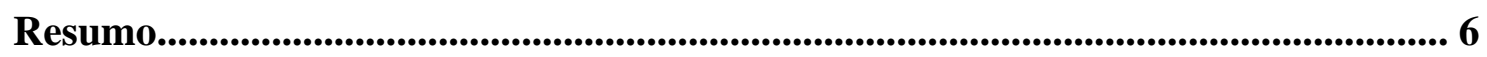

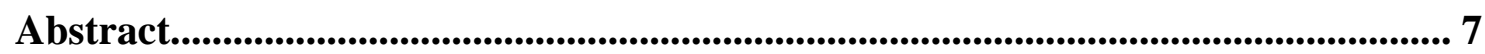

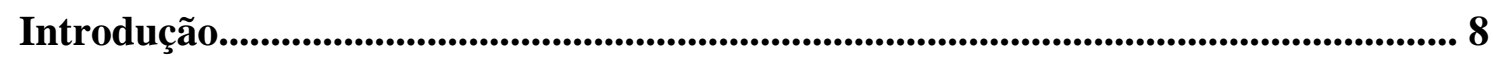

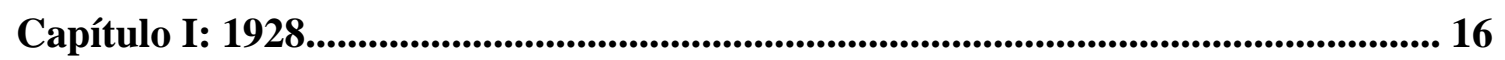

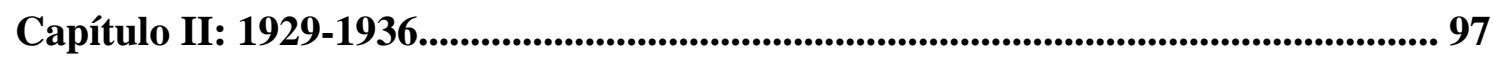

Epílogo....................................................................................................................................... 186

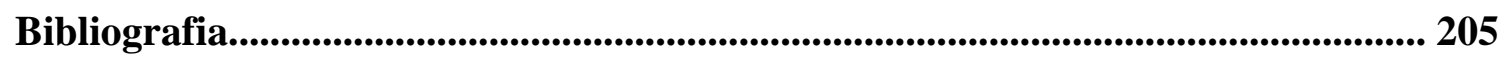

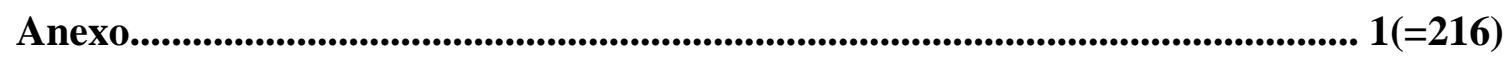




\section{RESUMO}

Esta tese propõe uma leitura da recepção crítica de Macunaíma no período circunscrito entre 1928 e 1936, correspondente à vigência da edição príncipe da rapsódia de Mário de Andrade.

A análise de vinte e quatro pronunciamentos, recuperados na quase totalidade em fontes primárias, ressalta a contribuição de cada um e demonstra como os juízos estéticos expedidos se associam a perspectivas ideológicas nacionalistas em vigor no momento em que o modernismo estava no auge e buscava respostas estéticas e culturais - mas com implicações sociais ou mesmo políticas - para problemas decorrentes do processo histórico de modernização do Brasil.

O confronto de opiniões da crítica com pronunciamentos de Mário de Andrade, contidos na correspondência privada ou textos publicados (em que há menção a Macunaíma, bem como a temas discutidos ou juízos expedidos nas recepções), constitui um diálogo de múltiplas vozes, cuja análise revela a coincidência das posturas críticas adversas com as principais matrizes ideológicas nacionalistas conservadoras (Alceu Amoroso Lima, Graça Aranha e Gilberto Freyre), enquanto as posturas favoráveis se aproximam do modernismo de resistência implícito na rapsódia.

O exame dos pronunciamentos de Mário esclarece, também, a relação entre Macunaíma e o projeto modernista do próprio autor: a rapsódia é concebida, sobretudo, como obra de arte, fato estético de linguagem e, não obstante, realização máxima de "literatura de circunstância”, associada às noções andradianas de “primitivismo” e de "nacionalismo crítico” (cosmopolita).

PALAVRAS-CHAVE: Macunaíma, Mário de Andrade, crítica literária, modernismo, literatura brasileira. 


\section{ABSTRACT}

The aim of this thesis is to analyse the critical reception of Macunaíma within 1928 and 1936 which corresponds to the period when only the first edition of Mário de Andrade’s work of art was available.

The analysis of twenty-four statements, almost all of them taken from primary sources, highlights the contribution given by each text and demonstrates how the esthetical judgement issued at that time are related to national ideological perspectives which were held when Modernism was at its height and there was the search for esthetical and cultural answers but with social and even political implications of problems derived from the historical process of modernization in Brazil.

The comparison between critical opinions and Mário de Andrade’s statements found in private correspondence or in published texts in which Mário de Andrade refers to Macunaíma as well as to discussed themes or judgements concerning his book, constitutes a multiple voiced dialogue whose analysis reveals that there was a coincidence between the negative critical view of his work and the main national conservative paradigmatic ideologies (represented by Alceu de Amoroso Lima, Graça Aranha and Gilberto Freyre). Whereas the favourable views of his work are close to the opposition set by the revolutionary wing of Modernism and this was made implicit in Macunaíma.

The examination of Mário’s statements also clarifies the relation between Macunaíma and the author's own project: his work is conceived, above all, as being a work of art, an esthetical issue of language and as a supreme performance of "social active literature" associated to the Andradian notions of "primitivism” and cosmopolitan “critical nationalism”.

KEYWORDS: Macunaíma, Mário de Andrade, literary criticism, Modernism, Brazilian literature. 


\section{INTRODUÇÃO}

Esta tese propõe uma leitura da recepção crítica de Macunaíma no período circunscrito entre 1928 e 1936, correspondente à vigência da edição príncipe da rapsódia de Mário de Andrade. Ao corpus pesquisado e aqui documentado atribuímos a imagem de primeira onda por razão que ultrapassa o objeto de estudo discriminado, e merece breve explicação.

O ponto de partida deste trabalho consistiu no levantamento da bibliografia crítica de Macunaíma, facilitado graças ao catálogo apresentado por Telê Porto Ancona Lopez na primeira edição crítica que preparou para a rapsódia (1978) e a uma pesquisa ainda inédita, de Diléa Zanotto Manfio, que inventaria a fortuna crítica, tão completa quanto possível, de Mário de Andrade. Dessa listagem admirável, foram extraídas e organizadas as referências bibliográficas relativas a Macunaíma, às quais se somaram pouquíssimas outras não arroladas pela pesquisadora. Ao todo, são cerca de duas centenas e meia de registros, entre resenhas, artigos, ensaios, livros e teses dedicados às peripécias do "herói sem nenhum caráter”, publicados no Brasil entre 1928 e 2005. Essa bibliografia, que inclui notícia de algumas dissertações ou teses inéditas, agrega-se a esta tese como parte do Anexo, contribuição certamente lacunosa e desde sempre perfectível.

No que diz respeito à pesquisa bibliográfica, este trabalho aspira estritamente à confecção de uma separata do referido levantamento de Diléa Manfio, relativa à fortuna crítica de Macunaíma, além da organização e normatização (sempre provisória) desse material. Contudo, quanto ao período circunscrito entre 1928 e 1954, foi possível conferir minuciosamente os dados por meio do resgate de toda a documentação registrada, sobretudo em fontes primárias. O resultado disso se oferece no referido Anexo, que contém as imagens digitalizadas dos documentos e transcrição anotada dos textos.

Um primeiro exame, superficial, dessa fortuna despertou a suspeita, depois tornada convicção, de que ela poderia ser dividida em três fases. A primeira compreende o período entre 1928 e 1954; a segunda, de 1955 a 1969; a terceira, de 1970 em diante.

A primeira fase é constituída por pronunciamentos correspondentes às três edições de Macunaíma em vida do autor: 1928, 1937 e 1944. São resenhas mais ou menos curtas ou ensaios publicados entre 1928 e 1954 - ano em que, aliás, não há qualquer registro de publicação e antecede o da quarta edição da rapsódia -, sobretudo em jornais e revistas. 
Comumente, num gráfico imaginário, a curva desenhada entre as coordenadas cartesianas da freqüência de pronunciamentos críticos sobre uma obra lançada e da linha de tempo desde o lançamento sugere um movimento ondular: após o forte influxo de recepções registradas no ano subseqüente ao de edição, sucede um refluxo acentuado. Esse modelo se verifica nitidamente no caso da primeira e da segunda edições de Macunaíma; no da terceira, o desenho da curva difere, pois a maior freqüência incide nos dois anos posteriores ao de lançamento. Em parte, isso se explica pela morte de Mário de Andrade, em fevereiro de 1945, que provocou um forte incremento da fortuna crítica do autor; por outro lado, o minguado acolhimento da obra no ano subseqüente ao de sua terceira edição indicia um certo desinteresse da crítica.

Assim, a primeira fase da recepção a Macunaíma é constituída por três ondas de pronunciamentos, cujos documentos, apurados na bibliografia, a pesquisa logrou reunir por meio de reproduções xerográficas, cópias de microfilmes ou montagem de imagens digitalizadas. Como dissemos, além do corpus constituinte da primeira onda (1928-1936), a documentação relativa à segunda (1937-1943) e à terceira ondas (1944-1954) da fortuna crítica da rapsódia, que completam a primeira fase dessa fortuna, também se agrega a este trabalho como parte do Anexo.

As três ondas apresentam um perfil muito semelhante, quer pela veiculação da quase totalidade dos pronunciamentos em periódicos, quer pelo tipo de abordagem adotada - comentário fundamentado na opinião entre estética e ideológica -, quer pela coincidência de tópicos discutidos, quer, sobretudo, por uma particularidade que esta tese procurará demonstrar, embora no restrito âmbito da primeira onda. Trata-se da influência decisiva do diálogo estabelecido entre Mário de Andrade e Alceu de Amoroso Lima (Tristão de Ataíde), a partir de um artigo desse último (“Macunaíma”. O Jornal: Rio de Janeiro, 09 de setembro de 1928), que repercutiu de modo notável nos discursos posteriores, a ponto de definir o repertório crítico e influenciar os juízos, favoráveis ou desfavoráveis, emitidos sobre a rapsódia.

A segunda fase da recepção crítica a Macunaíma, compreendida entre 1955 e 1969, caracteriza-se por um duplo aspecto: por um lado, dá continuidade às discussões da primeira, por intermédio de veículo periodista, revisitando os mesmos temas e, raramente, acrescentando matizes às opiniões dos predecessores; por outro lado, inaugura um patamar superior na apreciação da obra com a publicação do primeiro livro inteiramente dedicado ao estudo da rapsódia de Mário de Andrade, talvez o primeiro voltado totalmente ao exame crítico de uma obra modernista: o Roteiro de Macunaíma (1955), de M. Cavalcanti Proença, cronologica- 
mente coincidente com a quarta edição da rapsódia, segunda da editora Martins e primeira póstuma.

O Roteiro de Macunaíma, como divisor de águas, alude às especulações centrais da primeira fase, especialmente à contribuição de Tristão de Ataíde, e realiza a primeira exegese sistemática da rapsódia; não mais opinião sobre o texto, mas exame minucioso do discurso ficcional e das relações intertextuais deste com as suas fontes, na perspectiva combinada de campos do saber como a filologia, a estilística, a hermenêutica, a crítica e a história literária. A obra admirável de Cavalcanti Proença, por um tempo, pareceu esgotar a matéria. Desde sua publicação até 1969, ano em que recebe segunda edição, o assunto Macunaíma continuou a freqüentar páginas de periódicos, mas de modo escasso. Alguns desses artigos, por exemplo, “Morfologia de Macunaíma”, de Haroldo de Campos (Correio da Manhã: Rio de Janeiro, 26 de novembro de 1967), em vez de manifestar opiniões, já assumem a perspectiva inaugurada por Proença, de estudo metódico do discurso, e antecipam um traço distintivo da terceira fase: a investigação acadêmica de orientação científica.

De 1970 em diante, acentua-se o processo de enriquecimento da fortuna crítica de $M a$ cunaíma com farta produção universitária, teoricamente fundamentada e desenvolvida com rigor metodológico. A especificidade acadêmica, no sentido de trabalho científico produzido em Universidade, e a importância assumida por essa produção podem ser consideradas como diferenciais da terceira fase da recepção crítica de Macunaíma. Pelos avanços que trouxeram, algumas obras desse período tornaram-se referências obrigatórias a quem deseje compreender a rapsódia de Mário de Andrade e o seu alcance.

Telê Porto Ancona Lopez, com Macunaíma: a margem e o texto ${ }^{1}$, inaugurou a sua "contribuição para o estudo de Macunaíma”, que se estenderia a toda a obra de Mário de Andrade. A margem e o texto (1974) rastreou com rigor o percurso criativo da rapsódia, preparando o terreno para a edição crítica da mesma, cuja primeira versão foi publicada em $1978^{2}$. Segue-se a ela a segunda versão, de 1988, e, finalmente, a terceira, de 1996, na exemplar publicação da Coleção Archivos ${ }^{3}$, que alia a perspectiva de edição crítica à de edição genética e conta com a colaboração de vários estudiosos que se pronunciaram de modo relevante sobre a

\footnotetext{
${ }^{1}$ LOPEZ, Telê Porto Ancona. “A margem e o texto: contribuição para o estudo de Macunaíma”. In: Boletim Bibliográfico Biblioteca Municipal “Mário de Andrade”. São Paulo, no especial, fevereiro de 1970, p. 9-81. Depois, publicado em LoPEZ, T. P. A. Macunaíma: a margem e o texto. São Paulo: Secretaria Cultura, Esporte e Turismo / Hucitec, 1974.

${ }^{2}$ AnDRAde, Mário de. Macunaíma. Edição crítica de Telê Porto Ancona Lopez. Rio de Janeiro: Livros Técnicos e Científicos / São Paulo: Secretaria da Cultura, Ciência e Tecnologia, 1978.

${ }^{3}$ ANDRADE, Mário de. Macunaíma, o herói sem nenhum caráter. Edição crítica de Telê Porto Ancona Lopez (coord.). $2^{\underline{a}}$ ed., $1^{\underline{a}}$ reimp. Madri etc.: ALLCA XX / São Paulo: Scipione, 1997. Coleção Arquivos, 6. (1 $1^{\underline{a}}$ ed. Paris: ALLCA XX / Brasília: CNPq, 1988; 2ª ed., 1996).
} 
obra. Deve-se à pesquisadora a continuidade, alargamento e aprofundamento do trabalho de M. Cavalcanti Proença.

Intertexto $^{4}$, de Mário Chamie, e Morfologia do Macunaíma ${ }^{5}$, de Haroldo de Campos destacam-se entre as produções da terceira fase, chamada de acadêmica pela presença significativa de trabalhos de investigação científica desenvolvidos, sobretudo, em programas de pósgraduação universitária.

Embora fora do espaço estritamente acadêmico, Mário Chamie procurou apreender as matrizes estruturais da rapsódia orientado por teorias da lingüística que marcaram grande parte da produção universitária da década de 1970, no campo das ciências humanas. O autor de Intertexto, além do suporte fornecido pela lingüística estruturalista, valeu-se em seu estudo de noções teóricas de Bakhtin, como “dialogismo”, “polifonia” e "sátira menipéia”. Mais tarde, Susana Camargo ${ }^{6}$ fundamentou sua leitura comparada das obras de Rabelais com Macunaíma nos protocolos críticos bakthinianos introduzidos por Chamie.

Em Morfologia do Macunaíma, cuja primeira versão foi apresentada como tese de doutorado na Universidade de São Paulo, Haroldo de Campos aplicou o método do módulo fabular, colhido nos estudos de Vladimir Propp, para realizar um erudito trabalho de análise estrutural da narrativa.

Gilda de Mello e Souza, com O tupi e o alaúde ${ }^{7}$, polemizou com Haroldo de Campos e propôs uma sólida e fecunda leitura interpretativa de Macunaíma, aproximando-a da novela de cavalaria medieval, sobretudo à Demanda do Santo Graal, e ao modelo compositivo da música popular de nossos cantadores, bem como à estrutura musical culta da suíte.

Eneida Maria de Sousa empreendeu uma análise semiológica preocupada com a "prática discursiva, entendida enquanto articulação entre sujeito e linguagem”, aproximando-se de formulações de Bakhtin sem descartar a abordagem estrutural cuja raiz está em LéviStrauss; relações entre Macunaíma e o universo latino-americano foram estudadas por Raúl Antelo ${ }^{9}$; Mario M. González ${ }^{10}$ examinou vínculos possíveis entre a rapsódia de Mário de Andrade e a narrativa picaresca espanhola.

\footnotetext{
${ }^{4}$ CHAMIE, Mário. Intertexto: escrita rapsódica - ensaio de leitura produtora. São Paulo: Práxis, 1970.

${ }^{5}$ CAMPos, Haroldo de. Morfologia do Macunaíma. São Paulo: Perspectiva, 1973. Coleção Estudos, 19.

${ }^{6}$ CAMARgo, Maria Susana. Macunaíma - ruptura e tradição. São Paulo: Massao Ohno / João Farkas Editores, 1977.

${ }^{7}$ Mello e SouZA, Gilda de. O tupi e o alaúde: uma interpretação de Macunaíma. São Paulo: Duas Cidades, 1979.

${ }^{8}$ SouZA, Eneida Maria de. A pedra mágica do discurso. 2ª ed. revista e ampliada. Belo Horizonte: Ed. UFMG, 1999.

${ }^{9}$ ANTELO, Raúl. Na ilha de Marapatá. São Paulo: Hucitec; Brasília: MINC/Pró-Memória/INL, 1986.

${ }^{10}$ GonZÁleZ, Mario M. "Macunaíma”. In: A saga do anti-herói. São Paulo: Nova Alexandria / Embaixada de Espanha, 1994, p. 297-314.
} 
Muitos outros estudos foram apresentados em dissertações de mestrado e em teses de doutorado, novos ensaios são divulgados em livros ou revistas especializadas, novas pesquisas são empreendidas, outros preciosos subsídios à matéria surgem nas publicações da correspondência de Mário de Andrade, como os trabalhos exemplares de Marcos Antonio de Mora$\mathrm{es}^{11}$ e de Lélia Coelho Frota $^{12}$, ou com a publicação de obras póstumas como O Turista Aprendiz $^{13}$, por Telê Porto Ancona Lopez, sem mencionar estudos que se acumulam lentamente no exterior, interessados no "herói de nossa gente".

Tudo indica que a fortuna crítica de Macunaíma, já bem consistente, tende a multiplicar-se mais ainda, pois a rapsódia do "herói sem nenhum caráter" continua a repor o seu enigma a cada releitura. Apesar de tantos esforços críticos reveladores, como disse Darcy Ribeiro, “Macunaíma permanece um mistério."14

Perante a abundância da fortuna, a escolha do objeto de estudo incidiu sobre a mais obscura das fases: a primeira, ou seja, as três primeiras ondas críticas. Daí, procedeu-se a organização do corpus pré-selecionado, a transcrição e a anotação dos documentos relativos ao período compreendido entre 1928 e 1954.

No entanto, o esforço de leitura rigorosa de todos os documentos e a riqueza percebida na análise deles mostraram que seria impossível abranger todo esse material, dentro do prazo previsto para a apresentação desta tese. Assim, ao invés das três primeiras ondas da fortuna crítica de Macunaíma, correspondentes ao que caracterizamos como primeira fase dessa, a nossa leitura se limita ao exame da primeira onda, isto é, à recepção crítica da edição príncipe de Macunaíma, pertinente ao período de 1928 a 1936. Oxalá, um próximo trabalho será dedicado ao estudo dos demais documentos que perfazem a aqui chamada primeira fase da fortuna.

O corpus próprio desta tese, portanto, restringe-se a vinte e quatro documentos, publicados em periódicos e livros, no período especificado, que a pesquisa pôde apurar. Os registros foram colhidos no Instituto de Estudos Brasileiros da Universidade de São Paulo (IEBUSP), na série matéria extraída de periódicos, do Arquivo Mário de Andrade.

\footnotetext{
${ }^{11}$ Andrade, Mário e BAndeIrA, Manuel. Correspondência Mário de Andrade \& Manuel Bandeira. Organização, introdução e notas Marcos Antonio de Moraes. 1ª ed. São Paulo: Edusp/IEB, 2000 (2ª ed., 2001).

${ }^{12}$ FrotA, Lélia Coelho (org.). Carlos e Mário: correspondência entre Carlos Drummond de Andrade - inédita e Mário de Andrade. Apresentação e notas às cartas de Mário de Andrade: Carlos Drummond de Andrade; prefácio e notas às cartas de Carlos Drummond de Andrade: Silviano Santiago. Rio de Janeiro: Bem-Te-Vi, 2002.

${ }^{13}$ Andrade, Mário de. O turista aprendiz. Estabelecimento de texto, introdução e notas de Telê Porto Ancona Lopez. 1ํㅡㄹ ed. São Paulo: Duas Cidades / Secretaria Ciência, Cultura e Tecnologia, 1976 (2ª̣ ed., 1983).

${ }^{14}$ Ribeiro, Darcy. "Liminar / Macunaíma”. In: AndRAdE, Mário de. Macunaíma. Edição crítica de Telê Porto Ancona Lopez (coord.). Ed. cit., p. XVIII.
} 
Nem todos os documentos arrolados, quer por Telê Ancona Lopez, quer por Diléa Zanotto Manfio, foram encontrados nesses arquivos. As lacunas foram preenchidas por intermédio de pesquisa empreendida no Arquivo Carlos Alberto Passos ${ }^{15}$, também pertencente ao IEB-USP, e no acervo de periódicos da Fundação Biblioteca Nacional. Alguns documentos foram recolhidos de uma edição fac-similar da Revista de Antropofagia ${ }^{16}$. Na Biblioteca de Mário de Andrade, no Instituto de Estudos Brasileiros da Universidade de São Paulo (IEBUSP), localizou-se um exemplar com dedicatória do autor, Jorge de Lima, da primeira edição de Dois ensaios, livro de onde se extraiu o ensaio “Todos cantam sua terra...” 17.

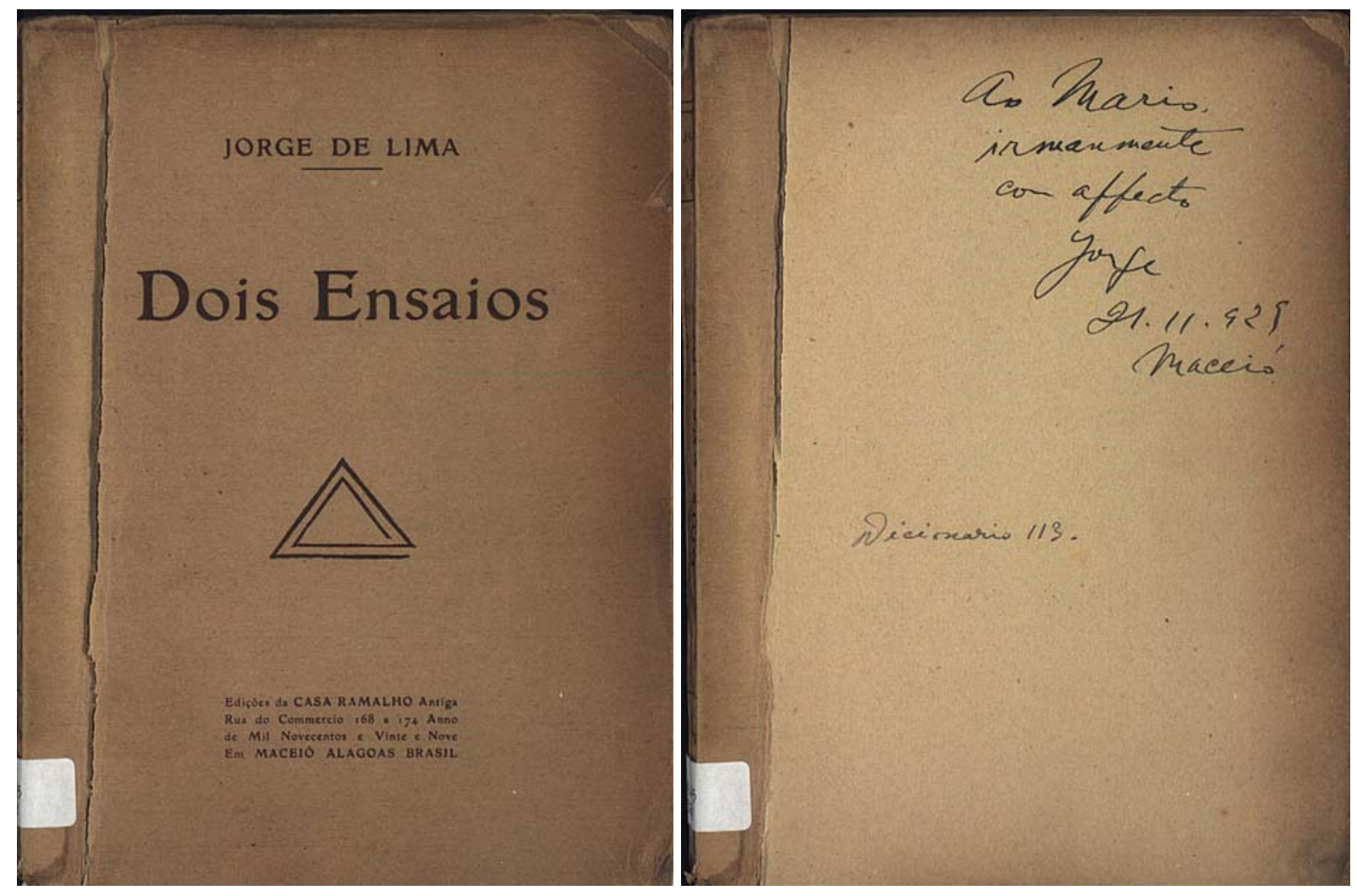

Capa da primeira edição de Dois ensaios e página com dedicatória de Jorge de Lima a Mário de Andrade. Biblioteca IEB-USP.

O corpus - restrito, portanto, ao período compreendido entre 1928 e 1936 - está contido está contido no Anexo como contribuição ao estudo da fortuna crítica de Macunaíma.

A tese resulta do estudo desse corpus bem delimitado e se compõe desta introdução, dois capítulos e um epílogo. O primeiro capítulo abrange o estudo da recepção pioneira, assim

\footnotetext{
${ }^{15}$ Alvitre devido ao Prof. Dr. Marcos Antonio de Moraes.

${ }^{16}$ São Paulo: Abril / Metal Leve, 1975.

${ }^{17}$ In: LiMA, Jorge de. Dois ensaios. 1ª ed. Maceió (AL): Casa Ramalho, 1929, p. 86-138. Exemplar com dedicatória do autor a Mário de Andrade. Biblioteca IEB-USP.
} 
considerados os pronunciamentos publicados no mesmo ano da primeira edição da rapsódia de Mário de Andrade (1928), e o segundo atém-se aos documentos compreendidos entre 1929 e 1936, ano anterior ao lançamento da segunda edição.

Ambos os capítulos estruturam-se em três partes. Na primeira cabe, sobretudo, a resenha dos documentos, com o propósito de identificar a contribuição crítica de cada um e os juízos expedidos. A segunda parte compara e analisa esses documentos, examina os temas discutidos e distingue os argumentos, explícitos ou implícitos, de suporte aos juízos de valor. A terceira parte dos dois capítulos discute os pronunciamentos críticos em confronto com depoimentos contemporâneos de Mário de Andrade, pertinentes às questões levantadas, contidos na correspondência e em outros escritos do autor, como nos dois prefácios que Mário esboça para a obra e decide manter inéditos, mas que, confidenciados a Alceu Amoroso Lima, vazaram parcialmente através da recepção crítica desse escritor, no artigo “Macunaíma” (matéria assinada com o pseudônimo de Tristão de Ataíde. O Jornal: Rio de Janeiro, 09 de setembro de 1928), desencadeador de vigorosa polêmica.

O método crítico e histórico adotado nesta tese decorre da própria proposta de trabalho, cujo ponto de partida consiste na pesquisa, identificação, organização cronológica e descrição minuciosa dos pronunciamentos críticos referentes à edição príncipe de Macunaíma, cuja raridade e valor justifica o uso da paráfrase, empregada nas primeiras partes dos dois capítulos. A análise desses documentos enseja a percepção da importância deles não só para o estudo da obra em foco, mas também para a investigação do projeto modernista de Mário de Andrade, fundamentado na idéia de nacionalismo crítico consubstanciada na rapsódia, em confronto com outros projetos nacionalistas então em evidência no Brasil.

O exame da primeiríssima recepção a Macunaíma, publicada no Diário Nacional em 07 de agosto de 1928, induziu à formulação da primeira hipótese desta tese. Matéria não assinada, essa recepção inaugural despertou no crítico Silviano Santiago a suspeita de que o autor seria o próprio Mário de Andrade ${ }^{18}$. Nesse caso, segundo o crítico mineiro, Mário teria definido a "bitola crítica” por onde deveria passar a “justa avaliação da obra”. Este trabalho encontrou elementos que demonstram ser exata a suposição de Santiago quanto à autoria do artigo.

Agora, os elementos críticos arrolados na recepção anônima foram, de fato, balizas para a discussão empreendida pela crítica posterior, ao menos aquela que se circunscreve ao período em foco. No entanto, isso não se deu por direta repercussão do depoimento de Mário,

\footnotetext{
${ }^{18}$ SAnTiago, Silviano. "A trajetória de um livro”. In: ANDRAde, Mário de. Macunaíma, o herói sem nenhum caráter. Edição crítica de Telê Porto Ancona Lopez (coord.). Op. cit., p. 185. Esse ensaio, com o título mudado para "História de um livro", foi recolhido em SANTIAGo, Silviano. Nas malhas da letra. São Paulo: Cia. das Letras. $2^{\mathrm{a}}$ ed. Rio de Janeiro: Rocco, 2002.
} 
mascarado de resenha crítica, mas de modo indireto, na medida em que tais elementos também se manifestam em escritos como os prefácios esboçados por Mário para Macunaíma, inacabados e "inéditos”, mas revelados parcialmente na recepção de Tristão de Ataíde, cuja admitida “indiscrição" repercutiu fortemente.

Uma vez que a resenha anônima do Diário Nacional se desvela como depoimento mascarado, a primeira recepção crítica a Macunaíma, propriamente, consolida-se no ensaio de Tristão de Ataíde, articulado como diálogo polêmico entre pressupostos estéticos e ideológicos do líder católico, evidenciados no discurso crítico, e os de Mário de Andrade, consubstanciados na rapsódia e comentados na correspondência do segundo com o primeiro, a qual inclui os dois prefácios mencionados.

O ensaio de Tristão instaurou um paradigma que definiu o repertório crítico para a apreciação estética da obra e desencadeou o debate sobre ela, em que vários projetos artísticos e ideológicos nacionalistas, explicitados mais ou menos claramente na quase totalidade dos pronunciamentos da primeira onda, revelam-se como instâncias de juízo.

Esta tese se propõe também a distinguir cada um desses projetos, que têm a função de protocolos de leitura sob os quais a obra de Mário foi apreciada, e a confrontá-los com o projeto modernista inerente à rapsódia, no âmbito do pensamento estético-ideológico do artista. 


\section{CAPÍTULO I: 1928}

\section{LEITURAS PIONEIRAS}

\section{A RECEPČ̃o MASCARADA}

Macunaíma saiu do prelo do Estabelecimento Gráfico Eugênio Cúpolo no dia 26 de julho de 1928, com tiragem de oitocentos exemplares paga pelo autor. Duas semanas depois, na edição de 07 de agosto, o Diário Nacional publicou a primeira recepção crítica à rapsódia de Mário de Andrade:

S/A [Mário de Andrade]. "Macunaíma. O livro de Mário de Andrade”. Diário Nacional: São Paulo, 07 de agosto de 1928. IEB-USP - CAP-MP.

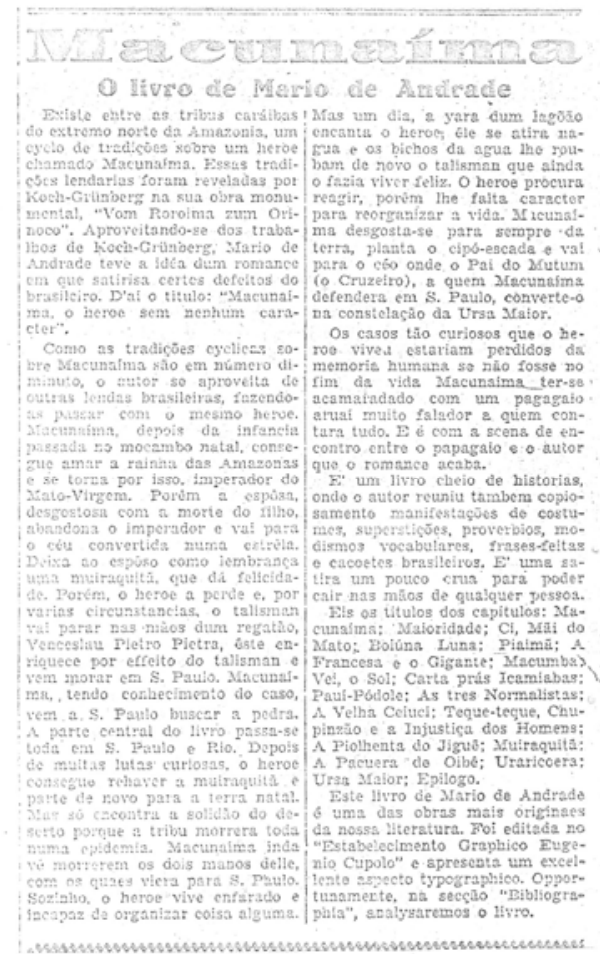

Em resenha curta, mas densa, o articulista anônimo informa que o autor compusera um "romance em que satiriza certos defeitos do brasileiro”, aproveitando-se de material mítico amazônico: "um ciclo de tradições sobre um herói chamado Macunaíma”, figura do imaginário de tribos caribes, recolhido e divulgado pelo estudioso alemão Koch-Grünberg “na sua obra monumental, Vom Roroima zum Orinoco”. A resenha destaca que Mário de Andrade havia misturado esse material com "outras lendas brasileiras, fazendo-as passar com o mesmo herói”, apresenta uma visão geral do enredo, tão sumária quanto aguda, e faz uma ligeira menção ao complexo narrador de Macunaíma, referido como "autor” de uma história transmitida por um papagaio que, 
por sua vez, a ouvira do próprio protagonista, o "herói sem nenhum caráter”. O crítico acrescenta: “o autor reuniu também copiosamente manifestações de costumes, superstições, provérbios, modismos vocabulares, frases feitas e cacoetes brasileiros”, apresentando a obra como “uma sátira um pouco crua para poder cair nas mãos de qualquer pessoa”. A resenha se encerra com a enumeração dos capítulos da obra, a afirmação de que a considerara das "mais originais da nossa literatura” e a promessa, ao que parece não cumprida, de voltar em outro artigo com uma análise do livro.

A matéria do jornal mostra notável segurança na abordagem de uma obra tão revolucionária quanto foi Macunaíma no contexto de seu lançamento. A identificação de KochGrünberg, que pouquíssimos leitores brasileiros conheciam na época (e ainda hoje), como detonador da rapsódia, a informação precisa de que Mário de Andrade havia misturado o ciclo do herói amazônico a “outras lendas brasileiras”, a nítida percepção de que certas formas reveladoras de constantes comportamentais, espirituais e lingüísticas nacionais foram profusamente reunidas e integradas à narrativa, a convicção quanto ao caráter satírico e a originalidade dela no âmbito da literatura brasileira, tudo indica o excepcional descortino crítico da primeira recepção a Macunaíma, cujo autor se desconhece, pois não assinou a matéria.

Em edição crítica da rapsódia coordenada por Telê Porto Ancona Lopez ${ }^{1}$, a bibliografia dos colaboradores, unificada por Darcilene de Serra Rezende e Tatiana Maria Longo dos Santos, atribuiu a autoria da resenha a Ascenso Ferreira, com indicação de que Silviano Santiago o teria referido no estudo com que contribuiu para tal edição. Deve haver algum equívoco nisso, pois não há menção ao poeta pernambucano no texto desse crítico; a hipótese aventada por ele é a de o resenhista ser o próprio Mário de Andrade².

Se o anônimo não fosse Mário, certamente seria alguém bem próximo a ele, que tivesse notícia não só da obra como também das fontes e de reflexões críticas explicitadas pelo autor da rapsódia na correspondência pessoal ou em outros escritos, elaborados e publicados na época ou posteriormente. Contudo, consideramos certeira a indicação de Silviano Santiago, sumariamente justificada por ele pela “precisão e a concisão das informações contidas na nota [do jornal]”3.

\footnotetext{
${ }^{1}$ ANDRADE, Mário de. Macunaíma, o herói sem nenhum caráter. Edição crítica de Telê Porto Ancona Lopez (coord.). $2^{\mathrm{a}}$ ed., $1^{\mathrm{a}}$ reimp. Madri etc.: ALLCA XX / São Paulo: Scipione, 1997. Coleção Arquivos, 6, p. 577. (1ª ed. Paris: ALLCA XX / Brasília: CNPq, 1988; 2ª ed., 1996).

2 SAnTiAgo, Silviano. “A trajetória de um livro". In: ANDRADE, Mário de. Macunaíma, o herói sem nenhum caráter. Edição crítica de Telê Porto Ancona Lopez (coord.). Ed. cit., 1997, p. 185. Esse ensaio, com o título mudado para "História de um livro", foi recolhido em SANTIAGo, Silviano. Nas malhas da letra. São Paulo: Cia. das Letras, 1989. $2^{\underline{a}}$ ed. Rio de Janeiro: Rocco, 2002.

${ }^{3}$ Idem.
} 
De fato, a concisão do artigo depõe contra a possibilidade de Ascenso Ferreira ser o autor, pois a prosa crítica do poeta de Catimbó é prolixa e digressiva, ao contrário da estrutura discursiva cerrada que se verifica na matéria jornalística em questão. Por outro lado, é conhecida a habilidade de Mário de Andrade na produção de sínteses críticas enxutas, mas isso seria critério vago e insuficiente para estabelecimento de autoria. Porém, à precisão e concisão destacadas pelo autor de Nas malhas da letra juntam-se elementos apresentados como achegas à hipótese do crítico mineiro.

Além da pertinência e acuidade da resenha, que só alguém de notável erudição e agudíssima percepção crítica poderia apresentar na primeira hora, há uma coincidência que não deixa de ser uma pista para a possível identificação do autor. Mário de Andrade, em carta a Carlos Drummond de Andrade, datada de 18 (ou 19) de janeiro de 1927, ao dar notícia do “romance engraçado”, cuja segunda redação estava pronta, comenta que ainda pretendia “fazer uma terceira redação depois do livro descansado duns seis meses” e, tal como se observa na resenha, enumera os capítulos da obra: "Macunaíma; Maioridade; Ci, Mãe-do-Mato; Piaimã; A francesa e o gigante; Macumba; Vei, o Sol; Carta pras Icamiabas; Pauí-Pódole; As três normalistas; A velha Ceiuici; Tequeteque, Chupinzão e a injustiça dos homens; A piolhenta do Guiguê; Muiraquitã; A pacuera de Oibê; Uraricoera; Torre Eiffel; Epílogo”4.

Em uma carta de Mário a Luís da Câmara Cascudo, de 01 de março de 1927, encontrase outro indício. Ao referir-se a uma intenção que tivera na composição de Macunaíma, Mário destaca seu esforço em “aproveitar no máximo possível lendas tradições costumes frases feitas etc. brasileiros” 5 . É notável a semelhança desse trecho com as passagens já citadas da resenha, em que se assinala a mistura do material mítico amazônico com “outras lendas brasileiras” e a reunião de “manifestações de costumes, superstições, provérbios, modismos vocabulares, frases feitas e cacoetes brasileiros”.

Ainda outro sinal de que Mário de Andrade poderia ser o autor da resenha está na observação, também já referida, de que Macunaíma é uma obra “um pouco crua para poder cair

\footnotetext{
${ }^{4}$ Andrade, Carlos Drummond de (org.). A lição do amigo: cartas de Mário de Andrade a Carlos Drummond de Andrade. Rio de Janeiro: José Olympio, 1982, p. 100-101. Também em FrotA, Lélia Coelho (org.). Carlos e Mário: correspondência entre Carlos Drummond de Andrade - inédita - e Mário de Andrade. Apresentação e notas às cartas de Mário de Andrade: Carlos Drummond de Andrade; prefácio e notas às cartas de Carlos Drummond de Andrade: Silviano Santiago. Rio de Janeiro: Bem-Te-Vi, 2002, p. 266. Essa edição repete o erro tipográfico daquela: em ambas, lê-se "As três jornalistas" em vez de "As três normalistas”. Na carta, a personagem Vei é chamada "o Sol”; na rapsódia publicada, "a Sol”. Na carta, lê-se "Guiguê" e "Ceiuici”; no livro de Mário, “Jiguê" e "Ceiuci”. Quando da publicação de Macunaíma, houve acréscimo do capítulo "Boiúna Luna”, enquanto o chamado "Torre Eiffel” foi eliminado e substituído pelo "Ursa Maior”.

${ }^{5}$ Melo, Veríssimo de (org.). Cartas de Mário de Andrade a Luís da Câmara Cascudo. Belo Horizonte/Rio de Janeiro: Itatiaia, 2000, p. 75. (1ํㅗㄹ ed.: Belo Horizonte/Rio de Janeiro: Itatiaia, Villa Rica, 1991).
} 
nas mãos de qualquer pessoa”. Assim, o resenhista manifesta, discretamente, o mesmo pudor e até mesmo o temor declarado várias vezes por Mário em sua correspondência quanto à possível imoralidade contida na obra. Em carta a Prudente de Moraes, neto (25 de março de 1928), ele considera que “é o livro mais imoralíssimo do mundo. Isso me enquizila porque minha intenção foi mesmo botar sujeira no livro porém, como falaria o Graça ${ }^{6}$, uma sujeira integralista e transcendental. Não me parece que está não"7 . Para Alceu de Amoroso Lima, em missiva de 19 de maio do mesmo ano, declara: “Aliás a imoralidade do livro é uma das coisas que mais me preocupa. Será entendida? Meu destino é mesmo fazer escândalo, meu Deus! Se o livro fizer escândalo como não desejo mas tenho medo, palavra que vou sofrer bastante»8. Para Anita Malfatti, em 27 de maio de 1928, Mário confessa: “(...) estou corrigindo provas do meu livro novo, Macunaíma, que é de fazer corar os gafanhotos. Nunca vi tanta imoralidade, puxa! Si me compreenderem...” ${ }^{9}$. Nas vésperas do lançamento do livro, 14 de julho de 1928, em outra carta a Alceu de Amoroso Lima, Mário volta ao assunto: "Sei que levei um pouco longe a complacência com o sensual no Macunaíma (...)”"10. Como se sabe, reflexões como essas levaram Mário de Andrade a suprimir o episódio “As três normalistas” na segunda edição da rapsódia.

Para o possível estabelecimento de autoria da primeira recepção crítica a Macunaíma, porém, a mais forte evidência patenteia-se na revelação contida em carta (15 de outubro de 1928) de Mário a Drummond, em que se lê: "Você topou tão certo com a verdade que repetiu o anúncio do livro que escrevi pros jornais paulistas e ninguém não soube que escrevi. Macunaíma é uma ‘sátira', palavra que você empregou e foi a mesma que empreguei”"11. De fato, na matéria do Diário Nacional, o resenhista anônimo refere-se duas vezes ao caráter satírico de Macunaíma, no primeiro e no antepenúltimo parágrafo do texto. Ora, além dessa, há somente uma outra matéria não assinada entre as conhecidas que se ocuparam da obra no ano de lançamento. Trata-se de um breve comentário publicado na edição de 01 de outubro do jornal Movimento. Mas esse periódico é do Rio de Janeiro e não de São Paulo, sendo Ronald de

\footnotetext{
${ }^{6}$ Referência a Graça Aranha.

${ }^{7}$ Koifman, Georgina (org.). Cartas de Mário de Andrade a Prudente de Moraes, neto: 1924-36. Rio de Janeiro: Nova Fronteira, 1985, p. 268. Mário chama de "integralista” a doutrina de Graça Aranha, que propõe a integração do “eu” no "todo infinito”; não confundir com o “integralismo” de Plínio Salgado.

${ }^{8}$ Fernandes, Lygia (org.). 71 cartas de Mário de Andrade. Rio de Janeiro, São José, s.d., p. 32.

${ }^{9}$ BAtistA, Marta Rossetti (org.). Cartas a Anita Malfatti. São Paulo: Forense Universitária, 1989, p. 140.

${ }^{10}$ FERnANDES, Lygia (org.). Op. cit., p. 37.

${ }^{11}$ Andrade, Carlos Drummond de (org.). Op. cit., p. 136. Também em Frota, Lélia Coelho (org.). Op. cit., p. 339.
} 
Carvalho o autor do artigo, posteriormente recolhido no livro Estudos brasileiros ${ }^{12}$. Finalmente, como se sabe, Mário de Andrade foi colaborador do Diário Nacional entre 1927 e 1932.

O conjunto desses indícios leva-nos a confirmar a hipótese de Silviano Santiago quanto à autoria da primeira recepção crítica de Macunaíma. A matéria não assinada do Diário Nacional, assim, seria um depoimento mascarado em crítica, por meio do qual Mário de Andrade aprecia sua própria obra no momento da publicação. Revela-se no documento a lucidez do autor em relação aos materiais empregados, ao método de composição, ao gênero e à linguagem da obra, indicadores da autoconsciência artística do criador perante sua criação e suportes da convicção daquele quanto à originalidade dessa no âmbito da literatura brasileira.

O anonimato pode ser entendido como pudor de Mário. Permanecendo oculto, ele pôde manifestar-se sobre a própria criação de modo favorável, sem agressão à modéstia. Mesmo assim, manteve um tom discreto, mais informativo e menos judicante. Por outro lado, o mascaramento serviria provavelmente de tática para demarcar o território sobre o qual Mário julgava que a crítica poderia mover-se com pertinência na apreciação da obra, sem que isso parecesse ostensiva ingerência do autor.

\section{A “INDISCRIÇÃO NECESSÁRIA”}

Mário de Andrade enviara a Alceu Amoroso Lima, então o crítico literário de maior prestígio no país, manuscritos de dois prefácios que escrevera para a obra e que permaneceram inéditos até $1972^{13}$. Pouco antes de enviá-los, em correspondência de 19 de maio de $1928^{14}$, Mário dera informações sobre o processo criativo de Macunaíma, desde a idéia que tivera de escrevê-la, ao ler sobre o herói dos índios caribes no volume de Koch-Grünberg, até a composição da versão encaminhada à gráfica de Eugênio Cúpolo.

Aproveitando-se desses escritos e assinando com o pseudônimo de Tristão de Ataíde, o escritor e líder católico elaborou sua apreciação da obra, que se mostra, propriamente, como a primeira crítica publicada, pois, conforme discutido, a primeiríssima recepção afigura-se como depoimento crítico mascarado.

\footnotetext{
${ }^{12}$ S/A [Ronald de Carvalho]. "Livros / Macunaíma - o herói sem nenhum caráter - de Mário de Andrade". Movimento: Rio de Janeiro, 01 de outubro de 1928, p. 21. FBN - Periódicos. Recolhido em CARVALHO, Ronald de. "Cadernos de imagens / 4 / Macunaíma, de Mário de Andrade”. In: Estudos Brasileiros. 1ํㅡㄹ ed. Rio de Janeiro: F. Briguiet, 1931, p. 151-152. Reeditado em: Rio de Janeiro: MEC / Nova Aguilar, 1976, p. 143-144.

${ }^{13}$ Batista, Marta Rossetti, LoPez, Telê Porto Ancona e Lima, Yone Soares. Brasil: $1^{\circ}$ tempo modernista 1917/29. São Paulo: IEB-USP, 1972, p. 289-295.

${ }^{14}$ FERNANDES, Lygia (org.). Op. cit., p. 28-33.
} 
AtAíDE, Tristão de [Alceu Amoroso Lima]. “Macunaíma”. O Jornal: Rio de Janeiro, 09

\author{
de setembro de 1928, p. 4. FBN - Periódicos.
}

[O Jornal. Rio de Janeiro, 09/09/1928. Colunas 1, 2, 3 e 4. FBN - Periódicos]

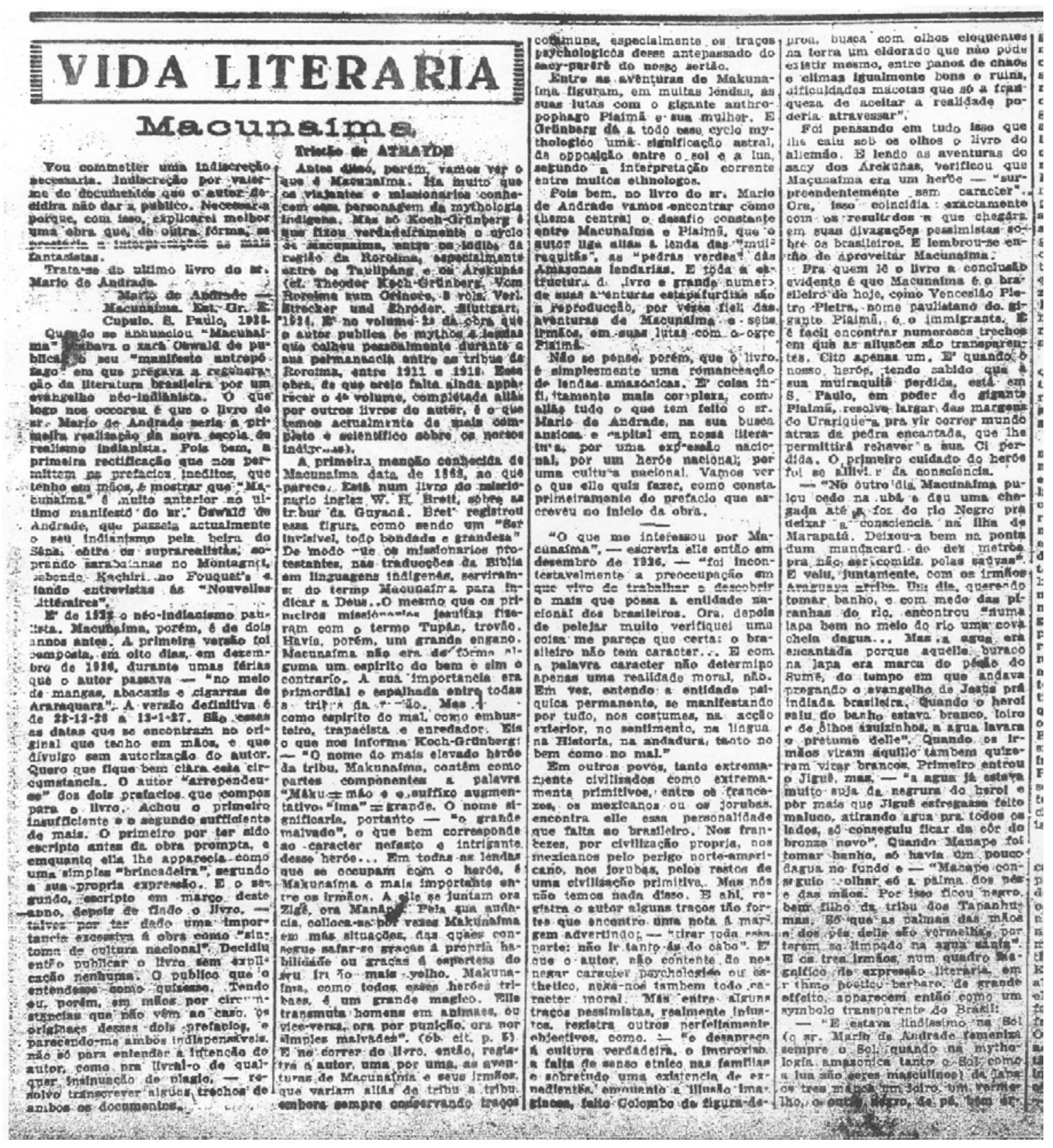

Abre-se o artigo com a advertência de que seu autor cometeria a "indiscrição necessária” de valer-se dos documentos confidenciados por Mário de Andrade, com a justificativa de que eles eram indispensáveis para a explicação da obra e de que, sem eles, ela "se prestaria a interpretações as mais fantasistas”. 
O crítico observa que os documentos permitiam retificar o que primeiro lhe ocorrera quando o livro de Mário de Andrade fora anunciado: que esse "seria a primeira realização da nova escola do realismo indianista”, recém-lançada por Oswald de Andrade mediante o Manifesto antropófago. Revelando que Macunaíma era "muito anterior ao último manifesto do sr. Oswald de Andrade”, o crítico não afirma de modo explícito, mas insinua claramente que a obra de Mário de Andrade não deveria ser associada ao "neo-indianismo paulista” de Oswald, tratado no artigo de modo despiciendo.

Estabelecida a "retificação” e com a ressalva de que Mário decidira manter inéditos os prefácios, Tristão de Ataíde reafirma a necessidade de se valer desses documentos confidenciados, para “não só entender a intenção do autor, como para livrá-lo de qualquer insinuação de plágio”.

Mário de Andrade, informa o crítico, para criar Macunaíma, o “herói sem nenhum caráter”, protagonista da obra homônima, inspirara-se no herói mítico amazônico, Makunaima, cujas aventuras cíclicas se encontram reunidas no segundo volume de Vom Roroima zum Orinoco, de Koch-Grünberg ${ }^{15}$. Tristão de Ataíde considera o herói ameríndio como um "espírito do mal, (...) embusteiro, trapacista e enredador", cujo nome, formado do étimo "Maku" (mau) e do sufixo "ima” (grande), apresentava-se "bem correspondente ao caráter nefasto e intrigante do herói”, reverenciado como uma espécie de demiurgo pelas tribos caribes. O crítico também assinala: “toda a estrutura do livro e grande número de suas aventuras estapafúrdias são a reprodução, por vezes fiel, das aventuras de Macunaíma ${ }^{16}$ e seus irmãos, em suas lutas com o ogro Piaimã”. Ressalva, porém, ser o livro não simples “romanceação de lendas amazônicas”, mas algo muito mais complexo - a busca "por uma expressão nacional, por um herói nacional, por uma cultura nacional”. Para certificar essa afirmação, vale-se do primeiro prefácio, citando a passagem em que Mário de Andrade se refere à ausência de caráter do herói indígena, supostamente correspondente à do brasileiro, sendo a noção de caráter entendida como “realidade moral”, mas também como “entidade psíquica permanente, se manifestando por

\footnotetext{
${ }^{15}$ KoCH-GRÜNBERG, Theodor. Vom Roroima zum Orinoco. Stuttgart: Strecker und Shröder / Verlag, 1924, vol. 2. O ciclo de Makunaima foi traduzido para o português por Henrique Roenick, com revisão de M. Cavalcanti Proença, em: Revista do Museu Paulista, Nova série, vol. VII, São Paulo, março de 1953. Essa versão, revista por Sérgio Medeiros em colaboração com Rafael Lopes Azize, foi reproduzida em MEDEIROs, Sérgio (org.). Makunaíma e Jurupari: cosmogonias ameríndias. São Paulo: Perspectiva, 2002. O primeiro volume da obra do etnólogo alemão foi recentemente traduzido e publicado em: KoCH-GRÜNBERG, Theodor. Do Roraima ao Orinoco. Tradução de Cristina Alberts-Franco. São Paulo: Editora UNESP/Instituto Martius-Staden, 2006, il., vol. 1.

${ }^{16}$ Tristão de Ataíde se refere ao herói indígena Makunaima.
} 
tudo, nos costumes, na ação exterior, no sentimento, na língua, na História, na andadura, tanto no bem como no mal”.

Sugerindo, embora, certa discordância quanto à suposição de Mário de Andrade, Tristão de Ataíde reconhece nela o registro de alguns traços considerados objetivos no perfil do brasileiro, tais como “o desapreço à cultura verdadeira, o improviso, a falta de senso étnico nas famílias e sobretudo uma existência de expedientes, enquanto a ilusão imaginosa, feito Colombo de figura-de-proa, busca com olhos eloqüentes na terra um eldorado que não pode existir mesmo, entre panos de chãos e climas igualmente bons e ruins, dificuldades macotas que só a franqueza de aceitar a realidade poderia atravessar” (segundo prefácio).

O crítico entendeu que se tratava de uma visão pessimista, por meio da qual Mário de Andrade representava o herói Macunaíma como “o brasileiro de hoje”, enquanto Venceslau Pietro Pietra, o gigante Piaimã, representava o imigrante. Para ilustrar seu juízo, cita da obra o episódio do pezão de Sumé e conclui que a imagem do herói e seus dois irmãos metamorfoseados pela água mágica seria “um símbolo transparente do Brasil”.

Como contraponto à sua afirmação, cita novamente os prefácios, revelando que Mário de Andrade negava à obra qualquer intenção simbólica: "Macunaíma não é um símbolo" (primeiro prefácio); “Só não quero é que tomem Macunaíma e outros personagens como símbolos. É certo que não tive intenção de sintetizar o brasileiro em Macunaíma, nem o estrangeiro no gigante Piaimã... Me repugnaria bem que se enxergasse em Macunaíma a intenção minha dele ser o herói nacional. É o herói desta brincadeira isso sim” (segundo prefácio).

No entanto, Tristão de Ataíde se refere a dois outros pontos abordados nos prefácios para reafirmar sua avaliação sobre o caráter simbólico do livro, em detrimento de declarações contrárias do autor. O primeiro diz respeito à obscenidade e à pornografia contidas em Macunaíma, nas quais o crítico reconhece a conservação de um traço típico das narrativas recolhidas por Koch-Grünberg, comum “de todas as lendas de primitivos”, uma espécie de "instintivismo, tão adaptado à mentalidade e às inclinações de nossos dias”. Mário de Andrade teria visto nisso "um caráter bem brasileiro”, tal como seria possível deduzir de observações contidas nos prefácios: “Uma pornografia desorganizada é também uma cotidianidade nacional” (primeiro prefácio); “Minha intenção aí [na “imoralidade” contida em Macunaíma] foi verificar uma constância brasileira que não sou o primeiro a verificar” (segundo prefácio).

Na construção do argumento em favor do caráter simbólico de Macunaíma, Tristão destaca também o esforço de Mário no sentido de desregionalizar “o mais possível a criação ao mesmo tempo que conseguia o mérito de conceber literariamente o Brasil como entidade 
homogênea, um concerto étnico nacional e geográfico” (nota do primeiro prefácio). Para reforçar esse aspecto, é citada ainda outra passagem do segundo prefácio, tida pelo crítico como um dos motivos que teriam levado Mário de Andrade à decisão de não publicá-lo - a suspeita de que ela poderia dar ao escrito a aparência de “suficiente demais”. Nessa passagem, inteiramente reproduzida no artigo, Mário de Andrade assim se pronuncia a propósito de sua obra: “Me parece que os melhores elementos duma cultura nacional aparecem nele. Possui psicologia própria e maneira de expressão própria. Possui uma filosofia aplicada entre otimismo ao excesso e pessimismo ao excesso dum país onde o praciano considera a Providência como sendo brasileira e o homem da terra pita o conceito da pachorra mais que fumo. Possui aceitação sem timidez nem vanglória da entidade nacional e a concebe tão permanente e unida que o país parece ‘desgeograficado’ no clima, na flora, na fauna, no homem, na lenda, na tradição histórica, até quanto isso possa divertir ou concluir um dado sem repugnar pelo absurdo... O próprio herói do livro, que tirei do alemão Koch-Grünberg, nem se pode falar que é do Brasil. É tão, ou mais, venezuelano que da gente e desconhece a estupidez dos limites para parar na 'terra dos ingleses', como ele chama a Guiana Inglesa. Essa circunstância do herói do livro não ser absolutamente brasileiro me agrada como quê”.

A parte final da citação enfraquece o argumento de Tristão de Ataíde. A despeito disso, o que foi dito antes pareceu-lhe suficiente para corroborar sua conclusão: "Pois queira ou não queira o ‘consciente’ do autor, o que o seu subconsciente nos deu, em Macunaíma, foi, em grande parte, o 'homo-brasilicus' em toda a sua deficiência, embora sem os sinais de tese sistemática e antes uma enorme liberdade de composição”.

Antes de apresentar tal conclusão, ainda opinara: “Toda a obra literária do sr. Mário de Andrade é mais, talvez, obra de crítico social do que propriamente de artista. O sr. Mário de Andrade é o homem menos romântico que possa haver. Nunca escreve por paixão. Por prazer sim. Mas, sobretudo, por procura, por pesquisa, para encontrar o Brasil. O Brasil-alma e o Brasil-corpo, mas não o Brasil-país. Penso que lhe falta singularmente o sentido do nacionalismo político. Mas tem agudamente o senso de nacionalismo orgânico e social, da busca ao caráter que nos distinga na América e nos marque para sempre. Daí a sua irritação contra a nossa falta de personalidade e a consagração dessa ausência em distintivo, por meio de uma figura como Macunaíma”.

Com a conclusão de que, ao menos “em grande parte”, Macunaíma é símbolo do homem brasileiro, Tristão de Ataíde cumpre o primeiro objetivo de seu artigo, enunciado logo após a abertura: o de “entender a intenção do autor” para evitar “interpretações as mais fanta- 
sistas”. Essa conclusão inaugura a polêmica sobre o caráter simbólico da obra e do herói, respectivamente associados ao Brasil e ao homem brasileiro. Seriam símbolos ou não? Em que sentido, direção e medida? Seriam verdadeiros ou falsos em relação aos referentes? A essas questões subjaz uma outra, que não seria tão cedo explicitada claramente, mas que sempre esteve implícita nessa discussão, prolongada na fortuna crítica daí em diante: a hipótese de que Macunaíma, por conter uma síntese artística - simbólica? - do brasileiro, conteria também uma interpretação do Brasil. O fulcro desse problema, por sua vez, está no projeto modernista de Mário de Andrade, de contribuir no esforço de integração nacional por meio da apropriação artística culta e crítica do patrimônio da cultura popular. No passo seguinte de seu escrito, Tristão de Ataíde tangencia esse fulcro e deixa entrever sua repulsa à assimilação cultural processada por Mário de Andrade.

Como antecipamos, o segundo objetivo declarado do artigo seria o de livrar Mário de Andrade de “qualquer insinuação de plágio”. Para isso, embora considerasse Macunaíma um livro caracterizado por "uma enorme facilidade de composição", uma vez que "a maioria dos dados principais” são tirados de Koch-Grünberg, o crítico pondera que a obra apresenta "uma combinação imensa de elementos os mais disparatados ('este livro afinal não passa duma antologia do folclore brasileiro’, dizia uma nota do primeiro prefácio), de origem popular, inclusive uma macumba, muito bem descrita da nossa zona do Mangue, que revelam quanto o autor assimilou toda essa ebulição fetichista do nosso povo e como o seu estilo bárbaro consegue dar uma vida intensa e um pitoresco expressivo a essa supuração das nossas mazelas ocultas”.

Com restrições feitas à extensão do livro (“longo demais”), tido como “cacete muitas vezes como na imensa carta, em estilo médico-purista, que o nosso herói escreve às suas súditas do Uraricoera, bancando a lettre persane”, à “pornografia muitas vezes dispensável” e à “complacência ao instintivismo que é a marca da época”, mas reconhecendo que o livro é “recheado de coisas saborosas e de muito espírito”, o crítico conclui que Macunaíma não se enquadra no cânon de um gênero determinado, pois seria mais propriamente uma mistura de vários gêneros: “Não é um romance, nem um poema, nem uma epopéia. Eu diria antes - um coquetel”.

No desfecho do artigo, Tristão de Ataíde alega que a literatura brasileira padecia de uma deficiência. Antes do modernismo, ela ficara além do foco, "fechada em preconceitos acadêmicos, olhando o Brasil através da Europa, escrevendo uma língua que se falava em Portugal mas não mais aqui, pecava a literatura por excesso de literatura”; na época em que o 
modernismo vigorava, por excesso oposto, ficara aquém do foco: “à custa de desliteratizarmos as letras, estão elas ficando pra trás de nós. Falam uma língua tão 'nossa', que já não é nossa. Refletem uma realidade tão 'real', que já não nos reconhecemos nela”. Assim, avalia que Macunaíma, como exemplo típico da segunda atitude, não lograva uma imagem nítida da totalidade nacional, uma vez que se fixara no que é "acidental” e, a despeito de todo esforço de Mário de Andrade, a imagem “de nosso totalismo nacional” construída por ele seria "de fato só dele”, embora fosse expressão “do que é a barbaria dos nossos fermentos em ebulição. O modelo do que devemos ‘combater’ em nós”.

\section{UMA DEFESA E UM ATAQUE}

A crítica de Tristão de Ataíde, que oscila entre louvor e censura e evita um juízo decidido sobre a obra de Mário, provocou uma resposta aguerrida de Oswald de Andrade. Antes dela, porém, dois outros artigos recepcionaram o livro. Um é assinado por J. P., iniciais de João Pacheco, que, aos dezoito anos, iniciava sua colaboração em periódicos como crítico literário, alinhado ao grupo modernista de São Paulo; o outro é de Cândido Motta Filho, que participara da Semana de 22 e da revista Klaxon. Vejamos, primeiro, o de J. P.

\section{J. P. [João Pacheco]. “Bibliografia / 'Macunaíma' - Mário de Andrade - São Paulo”. Folha Acadêmica: Rio de Janeiro, 13 de setembro de 1928, p. 484. IEB-USP - MA-MP.}

A matéria de João Pacheco (1910-1966) é um tanto descosida. Seus leitores certamente teriam dificuldade de compreendê-la, pois é feita de alusões a Macunaíma que são retalhos de situações desconexas, obscuras para quem não tivesse lido o livro. A enunciação discursiva, que é um arremedo mal-amanhado da “língua brasileira” praticada por Mário de Andrade, certamente não deve ter contribuído para o esclarecimento da matéria ou a sedução de leitores, tendo em vista a hostilidade de então a tal registro lingüístico. 


\begin{tabular}{|c|c|c|}
\hline [IEB - MA-MP] & $\begin{array}{r}328 \\
\text { FOLHA ACADEMICA }\end{array}$ & \\
\hline 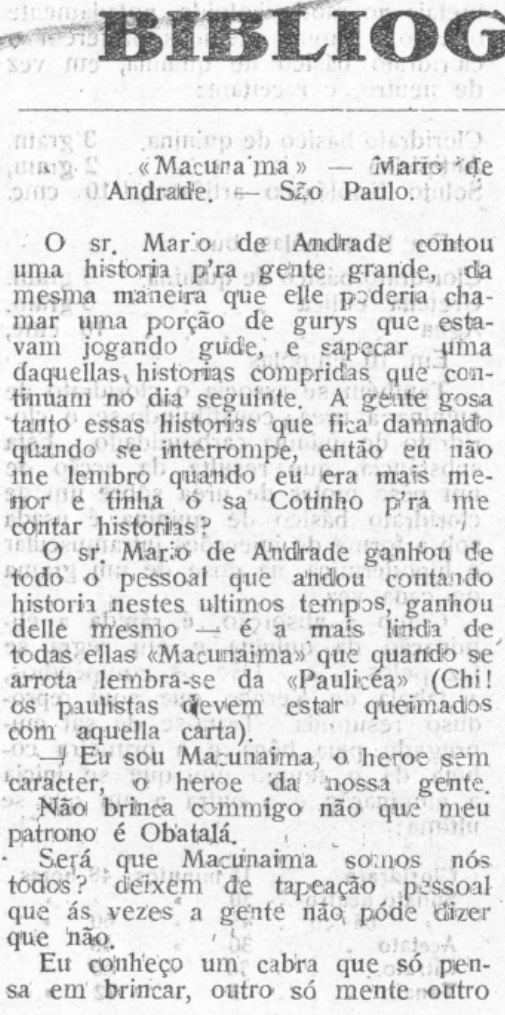 & 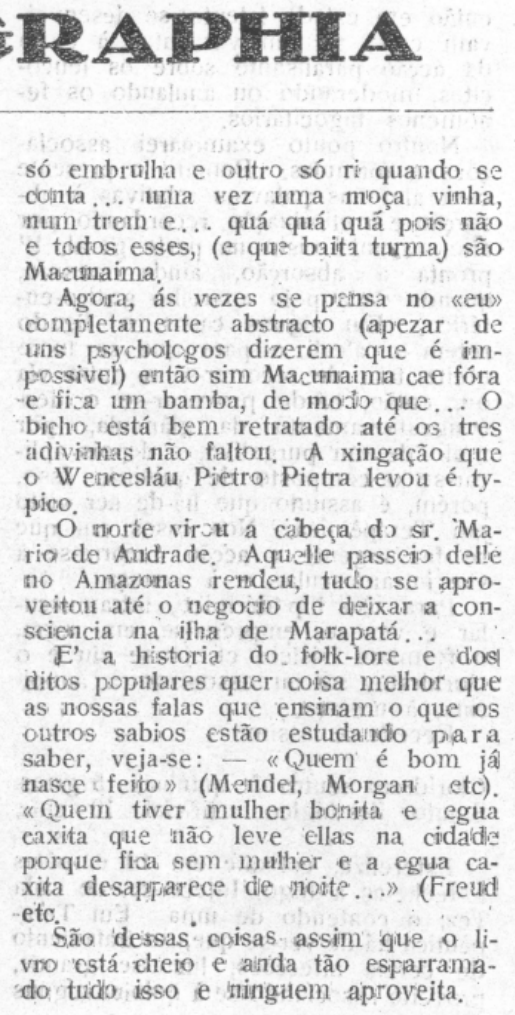 & 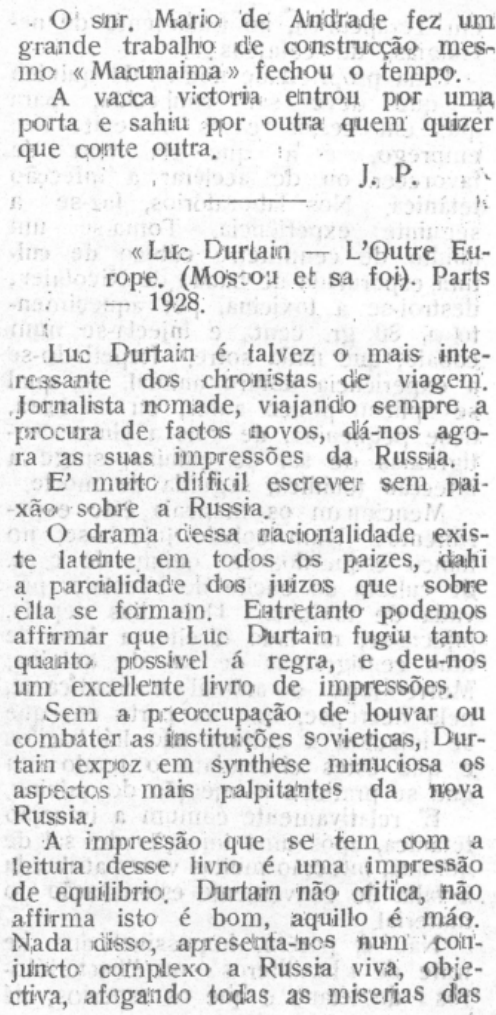 \\
\hline
\end{tabular}

Do ponto de vista crítico, o autor ressalta, embora de modo diluído, que a narrativa se associa à prática tradicional dos contadores de histórias, caracterizada pela oralidade, pela articulação seriada e por um saber comumente contido em manifestações da cultura popular. J. P. não diz explicitamente que o "herói de nossa gente” simboliza os brasileiros, mas é como se o dissesse: "Será que Macunaíma somos nós todos? Deixem de tapeação pessoal que às vezes a gente não pode dizer que não.”

Sem explicações, o articulista ainda destaca o "grande trabalho de construção mesmo" realizado por Mário de Andrade. Por fim, assevera: “Macunaíma fechou o tempo”. Impossível saber exatamente o sentido dessa afirmação em seu contexto. A expressão idiomática popular "fechar o tempo" pode ser entendida por “provocar grande irritação” ou "desencadear briga ou desinteligência”, sentidos coesos ao texto quando esse se refere à exasperação ou raiva causada pela “Carta pras Icamiabas” nos paulistas (“Chi! Os paulistas devem estar queimados com aquela carta”), que se sentiriam ofendidos com a imagem nada lisonjeira a São Paulo nela contida; no mesmo sentido de algo infesto, a expressão também pode ser compreendida como possível referência à repercussão da crítica de Tristão de Ataíde, que teria indisposto 
Oswald e membros do grupo antropófago contra Mário. Outro modo, ainda, de entender a gíria seria a de tomá-la na acepção de espanto provocado por alguém ou algo de rara beleza, sentido compartilhado com outra imagem popular: “fechar o comércio”. Essa parece ser a intenção do autor, mas tal significado seria certamente válido só no âmbito de pequenos, embora importantes, círculos letrados. Há ainda um quarto significado possível, que redundaria num achado crítico notável se J. P. tivesse consciência dele, o que não parece provável: o de Macunaíma encerrar uma fase da obra de Mário de Andrade, ou mesmo de coroar a dita fase heróica do modernismo. Considerando essa hipótese improvável, poder-se-ia dizer, conforme a voz popular, que João Pacheco atirou no que viu e acertou no que não viu.

MotTA FILHo, Cândido. “As leituras da semana / Literatura / Macunaíma - Mário Moraes de Andrade - São Paulo - 1928”. Correio Paulistano: São Paulo, 20 de setembro de 1928. IEB-USP - CAP-MP.

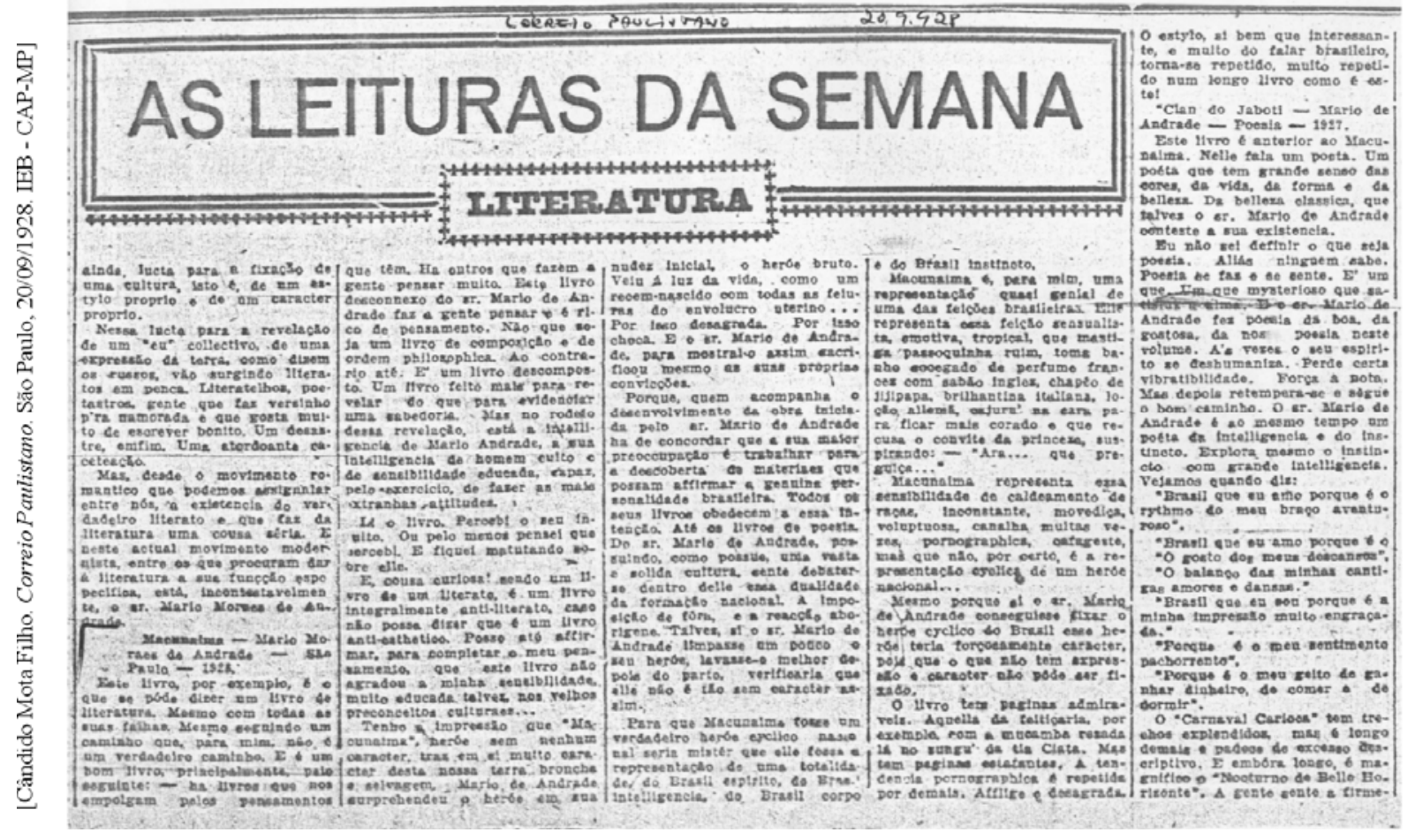

O artigo de Cândido Motta Filho oscila como a crítica de Tristão de Ataíde, mas o elogio não esconde a condenação. Na trilha aberta pelo líder católico, Motta Filho dá destaque a Macunaíma e às obras anteriores de Mário de Andrade como um trabalho voltado "para a descoberta de materiais que possam afirmar a genuína personalidade brasileira”. Embora concedesse que o herói sem nenhum caráter fosse "uma representação quase genial de uma das 
feições brasileiras”, caracterizada pelo sensualismo, pela índole emotiva, pelo comportamento tipificado na combinação de elementos da cultura européia e da tropical, bem como por uma "sensibilidade de caldeamento de raças, inconstante, movediça, voluptuosa, canalha muitas vezes, pornográfica, cafajeste”, Motta Filho nega a Macunaíma a qualidade de “um verdadeiro herói cíclico nacional”, pois ele não seria a "representação de uma totalidade do Brasil espírito, do Brasil inteligência, do Brasil corpo e do Brasil instinto.” Antes, seria uma imagem parcial, afinada com o caráter “desta nossa terra bronca e selvagem”, desagradável e chocante na sua brutalidade, “como [a de] um recém-nascido com todas as feiúras do invólucro uterino”.

O crítico confessa o desagrado sentido na leitura do livro e explicita os motivos de desgosto. Na metáfora do recém-nascido feio está um deles. Conforme supõe Motta Filho, se o herói fosse banhado como se faz com os nascituros, revelar-se-ia o caráter que lhe faltava “Talvez, se o sr. Mário de Andrade limpasse um pouco o seu herói, lavasse-o melhor depois do parto, verificaria que ele não é tão sem caráter assim.” Essa metáfora implica a idéia de condição mestiça do brasileiro em estado bruto, isto é, primitivo, condição pela qual o herói não teria caráter e, por isso, não poderia ser “o verdadeiro herói cíclico nacional”. Depreendese da argumentação que, embora Macunaíma possa ser reconhecido como representação parcial do herói brasileiro, esta seria falsa; a representação verdadeira deveria dar conta da totalidade nacional, sem exclusão do espírito e da inteligência, ou seja, dos elementos da cultura civilizada, com a qual o crítico se alinha claramente ao declarar o livro de Mário de Andrade repulsivo à "minha sensibilidade, muito educada, talvez, nos velhos preconceitos culturais”.

No comentário de Motta Filho insinua-se a filiação de suas idéias às do verdeamarelismo, movimento caracterizado por Antonio Candido como um desvio de certa corrente de escritores modernistas, como Guilherme de Almeida e Ronald Carvalho, que buscavam "exprimir a forma e a essência do país (...), atraídos pela clareza, a harmonia que se poderia captar na terra virgem, no povo moço"17, no rastro da "linha cósmica de Graça Aranha, muito afeita aos ritmos dinâmicos, à exaltação da paisagem, e procurando embriagar-se pela ação e o nativismo" ${ }^{\prime 18}$.

Conforme o manifesto do verdeamarelismo, "Nhengaçu Verde Amarelo”, publicado pelo jornal Correio Paulistano na edição de 17 de maio de 1929, o elemento indígena tupi, substrato primitivo da nacionalidade, sobrevivera ao extermínio objetivo para "viver subjeti-

\footnotetext{
${ }^{17}$ SouzA, Antonio Candido de Mello e. "Literatura e cultura de 1900 a 1945”. In: Literatura e sociedade. $3^{\mathrm{a}}$ ed. revista. São Paulo: Editora Nacional, 1973, p. 122. Grifo do autor.

${ }^{18}$ Idem.
} 
vamente e transformar numa prodigiosa força a bondade do brasileiro e o seu grande sentimento de humanidade.” ${ }^{19}$ Os tapuias teriam sido completamente exterminados, em virtude do caráter isolacionista e refratário aos adventícios; mas os tupis, supostamente gregários e receptivos à cultura européia cristã, absorvidos pela civilização, teriam contribuído para a constituição de um povo de índole bondosa, desprovida de preconceitos raciais, religiosos ou políticos. A índole tupi eternizara-se "no sangue de nossa raça”"20 ao colaborar para o "aparecimento de forças subjetivas nacionais”21. A suposta interioridade tupi, entendida como despreconceituosa, risonha e sentimental, perpetuada como “fisionomia própria da gente brasileira”, torna-se paradigma de um nacionalismo que aceita "as formas de civilização, mas impõe a essência do sentimento”²2. Uma grande nação seria construída no Brasil com a herança subjetiva tupi, capaz de integrar "todas as nossas expressões históricas, étnicas, sociais, religiosas e políticas”23. Mas o índio seria um algarismo inserido na equação formada pela história da civilização, com a função de “denominador comum das raças adventícias”24. Com essa metáfora aritmética, o "Manifesto do verdeamarelismo" sugere que o quociente da operação seria o povo brasileiro, pretensamente desinteressado de sistematizações filosóficas ou estéticas, bem como de doutrinas ideológicas unilaterais, consideradas desprovidas da "amplitude dos largos e desafogados pensamentos e sentimentos americanos e brasileiros”25. Contra os preconceitos vindos da Europa, dos quais supostamente conquistara alforria, e com o propósito de aceitar “todas as instituições conservadoras”, em cujo interior se processaria “a inevitável renovação do Brasil”, o nacionalismo do grupo verde-amarelo proclama a afirmação do espírito “de colaboração coletiva, de igualdade de povos e raças, de liberdade de pensamento, de crença na predestinação do Brasil na humanidade, de fé em nosso valor de construção nacional”, como meio de produzir uma literatura que revelasse "a alma de nossa gente”26.

Embora a crítica de Motta Filho a Macunaíma seja em oito meses anterior ao "Manifesto do verdeamarelismo”, ela se inscreve na mesma visada ideológica dos escritores subsumidos nele (Cassiano Ricardo, Menotti del Picchia, Plínio Salgado, o próprio Cândido Motta Filho etc.), que, aliás, tiveram como principal veículo, desde muito antes do "Manifesto", as

\footnotetext{
19 “Nhengaçu verde amarelo (Manifesto do verdeamarelismo ou da escola da anta)". In: TELES, Gilberto Mendonça. Vanguarda européia e modernismo brasileiro. 2ªe ed. Petrópolis (RJ): Vozes, 1973, p. 233.

${ }^{20}$ Idem.

${ }^{21}$ Idem, p. 234.

${ }^{22}$ Idem.

${ }^{23}$ Idem, p. 236.

${ }^{24}$ Idem, p. 237.

${ }^{25}$ Idem.

${ }^{26}$ Idem, passim, p. 238-239.
} 
páginas do Correio Paulistano, mesmo jornal em que esses dois documentos foram publicados.

Essa vinculação ideológica de propensão fascista ajuda a entender por que Motta Filho, embora considerasse Macunaíma um livro de revelação sapiencial, “que faz a gente pensar e é rico em pensamento”, não concorda com o saber nele contido. Chocava-se com a sua visão idealizada do povo brasileiro aquela apresentada por Mário de Andrade na rapsódia, que deixara o crítico desnorteado ao ponto de se contradizer ao admitir Macunaíma como "o que se pode dizer um livro de literatura” para, mais adiante, afirmar: “é um livro integralmente antiliterato, caso não possa dizer que é um livro antiestético”. Motta Filho se esforça para não parecer totalmente adverso à obra, concedendo que ela é “um bom livro”, que contém "uma representação quase genial de uma das feições brasileiras” e possui “páginas admiráveis”, mas expressa claramente o seu repúdio por considerá-la, além das razões já comentadas, desconexa quanto à composição, desagradável pela pornografia, estafante em virtude do tamanho e repetitiva, embora interessante, quanto ao "muito do falar brasileiro" característico do estilo.

\section{“RAPSÓDIA NACIONAR”}

A. de A. M. [António de Alcântara Machado]. “Um poeta e um prosador / Mário de Andrade - Macunaíma - São Paulo - 1928”. Revista de Antropofagia: São Paulo, a. I, no 5, setembro de 1928, p. 4. Edição fac-similar. São Paulo: Abril / Metal Leve, 1975.

No quinto número da Revista de Antropofagia, António de Alcântara Machado saudou Macunaíma como livro modelar que, de modo oportuno, "veio pôr no seu devido pé a famigerada brasilidade atrás da qual correm suados e errados desde muitos anos os escritores deste Brasil tão imenso mas tão arraial ainda.” Apoiado no ensaio "Instinto de nacionalidade”27, de Machado de Assis, Alcântara Machado pondera que o caráter nacional de uma obra literária brasileira não estaria no registro de aspectos pitorescos da gente e da paisagem, mas em algo invisível e impalpável, capaz de expressar “a vida da terra”. Em vez de proclamar-se por meio de declarações enfáticas de brasilidade aparente, a identidade nacional de nossa literatura configurar-se-ia como manifestação de uma brasilidade subjacente. A obra de Mário de Andrade

\footnotetext{
${ }^{27}$ Assis, Machado de. "Notícia da atual literatura brasileira / Instinto de nacionalidade". In: Obra completa. Rio de Janeiro: Aguilar, 1962, p. 801-809, vol. III. Publicado originalmente no periódico Novo Mundo, edição de 24 de março de 1873. Alcântara Machado se refere a idéias de Machado de Assis contidas nesse ensaio, sem identificá-lo.
} 
serve de exemplo ao crítico. Para este, seria impossível àquele deixar de ser um escritor brasileiro, mesmo que se esforçasse para isso.

[Cópia reduzida de ed. fac-similar São Paulo: Abril / Metal Leve, 1975.]

4

Revista de Antropofagia

[São Paulo, n 5, set. 1928]

\section{UM POETA E UM PROSADOR}

MANUEL DE ABREU Substância - Rio de Janei ro -1928 .

Uma das poesias podia dar o.título do livro: Are you ready? Porque Substância é um jôgo de tenis entre autor e leitor. As bolas vêm violentamente, sem parar, num bate-pula danado. Nem tempo para respirar a gente tem.

Tudo é mais ou menos dêste geito:

Sintó em mim uma Cidade
jarding
lirismo da minha
raça os arranha-céus da ilusão
piscam
na via-lactea das vidraçàs
arrabaldes
debalde!

\section{E tomem bola.}

Nesse fơu e nêsse arrojo não é di. ficil descobrir talento e sensibilidade. A poesic de Mànucl de Abreu não possue colorido brasileiro algum. E' internacional. Europea talvez seja mais certo. Cousa que hoje em dia e entre nós cơnstitue originalidade. E quem sabe qualidade. Porque afinal de contas sempre é meihor tomar um expresso-interuacional do que o mixto de São Pedro do Carirí. Leva onde se queira. Inclusive á própria terra em que a gente nasceu.

MARIO DE ANDRADE Macunaíma - São Paulo 1928.

A's vezes a gente em literatura pede a Deus que apareça um livro bom só para poder dizer aos autores de livros maus: Assim è que vccềs deviam ter feito.

Macunaima tem ésses dois valores: é um livro bom (nằ sei se já repararam na fôrça que há nessa palavra: parece um tiro de cannhão) é um livro oportuno. E' o bcin oportuno portanto. Chegou na hora. Veiu pôr no seu devido pé a famigerada brasilidade atrás da qual correm suados e errados desde muitos anos o: escritores dêste Brasil tão imenso mas tão arraial aînda.

Há que tempo Machødo de Assis dizia por outras palavras que ser escritor brasileiro não \& tãc simplesmente cantar o índio e bolar numa paisagem ipês en flor. $O$ Brasil não é isso só. Ou melhor: o Brasil não é isso. Qualquèr estrangeiro é cøpaz de fazer um romance muito bem feitinho com personagens desta terra movendo-se nesta terra. Agora o romance da terra só um brasileiro pode $\epsilon$ screver. $E$ há de escrever passando alêm do visivel e do palpável. Não se contentar com iquilo que a terra oferece e mete pelos lhos da gente a dentro. Mas sofrer iofrimento da terra, gozar o gôzo da erra, rir o riso da terra, viver a vida da terra.

Só êste refrão de Macunaíma - Ai! que preguiça!... - vale como brasilidade mais do que tocias as ruazinhas de arrabalde, todos os tutús de feijão morenas de chita e tal que enchem os versos dos nossos curumins contemporâneos.
Paulo Prado em conversa costuma caçoar dessa mania que muito novo (ou pretendente a tar) tem de gritar esmurrando o peito: Fu sou brasileiro! Eu sou brasileiro! Ea ì que sou o verdadeiro brasileiro! Burrice, moço. Se você é brasileiro năo precisa gritar que é: a gente vê logo.

Mario de Andrade $t$ dos que não gritam nem fazem questão de parecer. Pois êle é ainda que não queira.

Macunaíma tem tanta moleza, tanta senvergonhice, tanta basófia bem nossas e talvez só nossas que dá vontade da genté se estirar nas páginas dêle como numa rêde e balanço vai balanço vem se abandonar e se esquecer naquela gostosura.

Rapsódia nacionar icom o. $\mathrm{r}$ bem ro. lado) de lendas, de anedotas, "de cheiros. de tudo. A língur então é mais poética possivel. Parece uma música. $O$ violão sempre acompanhando.

E o mais bonito é que Mario se mostra inteirinho no. livro (o que acontece em todos os que publica aliás). Poucas vezes tenho visto tamanha falta de respeito humano. Há páginas em que a gente se contem para não disparar com o autor: Saia dai, diabo Como êle mesmo fêz no Amar, verbo intransitivo.

Percebe-se claramente que Mario ama o heroi a tal pontr. que quer ser o heroi. Mas é bom que a gente o desiluda. Mario é um pedacinho do heroi. O heroi somos nós todos juntos. Até eu, porque não?

A. DE A: M

Além de brasileiro, segundo Alcântara Machado, Mário de Andrade "se mostra inteirinho no livro", o que entende por "falta de respeito humano", com a ressalva de que considera isso "bonito". Tal comentário levanta, sem desenvolvê-la, a questão de uma possível figuração do autor na obra.

Outro ponto crítico indicado e não desenvolvido pelo articulista é o da dimensão simbólica de Macunaíma. Sem se utilizar da palavra "símbolo", Alcântara Machado não deixa 
dúvida sobre o fato de entender o herói como tal. Isso transparece na observação de que é evidente o amor demonstrado pelo autor em relação ao protagonista, a ponto de desejar ser o herói, embora fosse somente parte dele, como todos os brasileiros também seriam, de modo que “o herói somos nós todos juntos”.

Os temas dessas observações críticas de Alcântara Machado já haviam sido tratados de algum modo pelos predecessores. A grande contribuição que ele agrega à fortuna da obra de Mário de Andrade está na definição do gênero e no reconhecimento do caráter musical da língua. Quanto ao gênero, Alcântara Machado não titubeou ao afirmar que Macunaíma é uma “rapsódia nacionar (com o r bem rolado)”. Foi ele o primeiro a identificar com firmeza a obra como tal, antes mesmo de Mário de Andrade, que só decidiu classificar sua narrativa como rapsódia na segunda edição, de $1937^{28}$. Quanto à língua, Alcântara Machado destacou a configuração do registro brasileiro do português, já comentada pelos críticos que o antecederam, mas foi o primeiro a indicar a sua especificidade poética, associada à música: “A língua então é a mais poética possível. Parece uma música. O violão sempre acompanhando.”

No mesmo número da Revista de Antropofagia em que saiu o artigo de Alcântara Machado, Oswald de Andrade irrompeu na discussão de Macunaíma, polemizando com Tristão de Ataíde.

\section{APROPRIAÇÃO ANTROPOFÁGICA}

Andrade, Oswald de. "Esquema ao Tristão de Ataíde”. Revista de Antropofagia: São Paulo, a. I, no ${ }^{-5}$, setembro de 1928, p. 3. Edição fac-similar. São Paulo: Abril / Metal Leve, 1975.

Mais propriamente, o artigo de Oswald é a exposição de alguns pressupostos do movimento antropófago, afirmados em contraposição a idéias que estariam na base das postulações do escritor católico. Nesse sentido, a matéria é, sobretudo, uma declaração de princípios, fundamentada na convicção de que a cultura brasileira não seria mera transposição da civilização européia, mas resultaria do confronto entre os valores trazidos pelos portugueses e os

\footnotetext{
${ }^{28}$ Para uma trajetória das classificações de Macunaíma, percorrida por Mário de Andrade até sua decisão pelo gênero da rapsódia, v. LoPEz, Telê Porto Ancona. "Introdução". In: ANDRADE, Mário de. Macunaíma. Edição crítica de Telê P. A. Lopez, ilustrações de Pedro Nava. São Paulo: Secretaria da Cultura, Ciência e Tecnologia / Rio de Janeiro: Livros Técnicos e Científicos, 1978, p. XV-XXII.
} 
costumes autóctones. Jocosamente, Oswald simboliza tal confronto na imagem que contrapõe “de um lado a lei das doze tábuas sobre uma caravela e do outro uma banana”29.

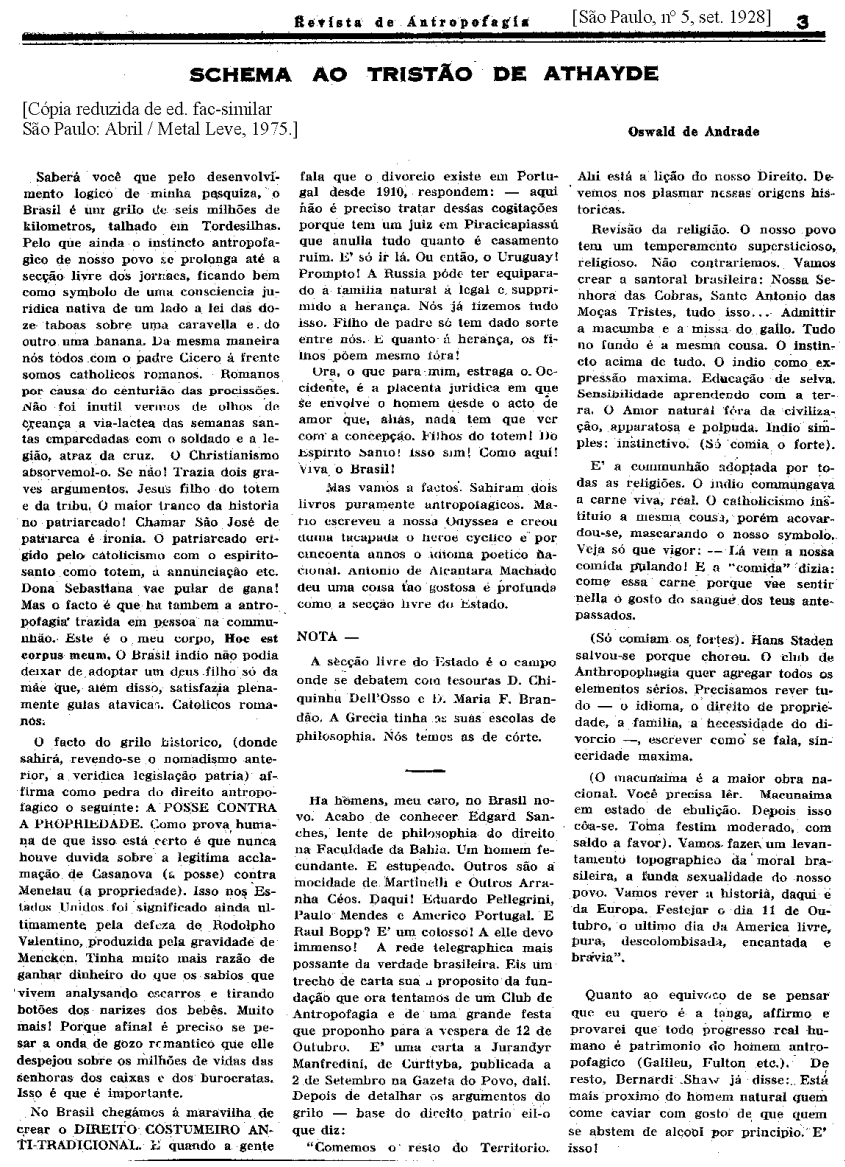

A cultura européia teria sido modificada pelo espírito selvagem, que supostamente assimilara o cristianismo com "olhos de criança”, ou seja, de acordo com o modo de compreensão peculiar ao chamado pensamento primitivo, entendido como análogo ao infantil. O catolicismo teria sido absorvido com facilidade pelos índios em virtude tanto do imaginário totêmico, que receberia com naturalidade o mistério da concepção pelo Espírito Santo (simbolizado por uma ave), quanto da prática antropofágica, identificada com o mistério da comunhão: "Este é o meu corpo, Hoc est corpus meum. O Brasil índio não podia deixar de adotar um deus filho só da mãe que, além disso, satisfazia plenamente gulas atávicas”. O cristianismo que se impusera estaria longe da sua “pureza” européia; ele seria expressão de uma religiosidade híbrida, resultante de uma espécie de grilagem, em que o imaginário primitivo teria se apossado do imaginário cristão e permanecido no comportamento instintivo dos brasileiros contemporâneos, sob a aparência de catolicismo romano.

O “instinto antropofágico de nosso povo” poderia ser igualmente verificado na constituição do território nacional, uma vez que “o Brasil é um grilo de seis milhões de quilômetros quadrados, talhado em Tordesilhas”. A civilização não teria conseguido eliminar o substrato

\footnotetext{
${ }^{29}$ A referência à lei das doze tábuas remete à codificação escrita do direito romano, que pode ser entendida, no contexto, como metonímia da civilização européia, assim como a caravela é metonímia da implantação dessa cultura no Brasil pelos portugueses. A imagem da banana não somente toma a fruta como metonímia da cultura brasílica, de substrato ameríndio, mas lembra também o gesto de recusa "inventado" por Macunaíma. Na verdade, um gesto carregado de intenção obscena adotado nacionalmente no país, mas que se conhece tão bem na Itália como em Portugal, como exemplifica a notável peça cerâmica do artista lusitano Bordalo Pinheiro, conhecida como "Zé Povinho".
} 
primitivo, de modo que o Brasil teria chegado à criação do "DIREITO COSTUMEIRO ANTI-TRADICIONAL"30, em que as leis seriam dribladas por práticas elusivas, que subvertem as instituições oficiais. Segundo Oswald, a prática histórica da grilagem levaria, no futuro, à “verídica legislação pátria”, ao “direito antropofágico”, cuja pedra angular seria a afirmação do princípio da "POSSE CONTRA A PROPRIEDADE"31.

Todo esse excurso de Oswald de Andrade culmina em manifestação de repúdio à cultura jurídica e religiosa ocidental: "o que para mim estraga o Ocidente é a placenta jurídica em que se envolve o homem desde o ato de amor que, aliás, nada tem que ver com a concepção. Filhos do totem! Do Espírito Santo! Isso sim! Como aqui! Viva o Brasil!”

A saudação final é ambígua. Pode ser entendida como ironia, se se compreende o Brasil sujeitado à civilização cristã ocidental; pode ser interpretada no sentido de exortação, se se entende o Brasil como portador do “instinto antropofágico”, possível antídoto ao propalado estrago trazido pela civilização.

Seja como for, depreende-se que Oswald de Andrade veste a carapuça dos pressupostos culturais da civilização cristã ocidental em Tristão de Ataíde, militante católico a quem o texto é remetido desde o título. Ao repudiar tais valores, Oswald justifica a apropriação do livro de Mário de Andrade pela “antropofagia”.

No plano explícito, o texto de Oswald é uma resposta ao artigo de Tristão de Ataíde, que havia dissociado Macunaíma do movimento antropófago; mas, na medida em que tal artigo cometera a indiscrição de revelar que o próprio Mário de Andrade fizera o mesmo numa carta, pode-se supor que a resposta de Oswald, de modo cifrado, dirige-se também ao autor de Macunaíma. Com essa hipótese, entende-se melhor a apologia do “direito antropofágico”, fundamentado no princípio da "POSSE CONTRA A PROPRIEDADE". Oswald estaria legitimando a grilagem antropofágica de Macunaíma, contra a postulação contrária de seu autor, ao qual caberia, na condição de “proprietário” da obra e de católico, a mesma carapuça dos preceitos culturais investidos em Tristão de Ataíde.

Se esse ataque escamoteado tem como alvo a postulação de Mário quanto à independência de Macunaíma em relação ao movimento antropofágico, não atinge, porém, a própria obra, saudada como “a nossa Odisséia”. Segundo a avaliação de Oswald, Mário de Andrade criara “duma tacapada o herói cíclico e por cinqüenta anos o idioma poético nacional.”

\footnotetext{
${ }^{30}$ Caracteres em maiúsculas no original.

${ }^{31}$ Idem.
} 


\section{LOUVOR, LAMENTO E ESCULHAMBACCÃO}

O mês de outubro de 1928 registra três pronunciamentos sobre Macunaíma. O primeiro é uma matéria não assinada, que figura na seção “Livros” do periódico carioca Movimento. Sabe-se que o autor é Ronald de Carvalho, pois tal matéria foi mais tarde por ele incluída, com algumas modificações, em sua coletânea Estudos brasileiros ${ }^{32}$. Assim como Cândido Motta Filho, António de Alcântara Machado e Oswald de Andrade, que o antecederam na recepção a Macunaíma, Ronald de Carvalho fora companheiro de Mário na Semana de 22. Sua acolhida calorosa é registrada num artigo curto, que repete, embora de modo sumário e descuidado, informações prestadas por Tristão de Ataíde.

S/A [Ronald de Carvalho]. "Livros / Macunaíma - o herói sem nenhum caráter - de Mário de Andrade”. Movimento: Rio de Janeiro, 01 de outubro de 1928, p. 21. FBN - Periódicos. Recolhido em CARvalho, Ronald de. “Cadernos de imagens / 4 / Macunaíma, de Mário de Andrade”. In: Estudos brasileiros. 1a ed. Rio de Janeiro: F. Briguiet, 1931, p. 151-152. Reeditado em: . Rio de Janeiro: MEC / Nova Aguilar, 1976, p. 143-144.

Nesse artigo, o vocábulo "Macunaíma” se apresenta, graficamente, de modo confuso. Referido nove vezes, sempre em caracteres itálicos, só na última ocorrência tal palavra tem o livro de Mário de Andrade como referente, tornando confusa a distinção entre herói mítico indígena, herói da obra e esta mesma. Nas primeiras quatro ocorrências, o referente é Makunaima, herói mítico dos índios caribes; nas quatro seguintes, Macunaíma, o herói da narrativa de Mário de Andrade.

O descuido também levou Ronald de Carvalho a definir Makunaima, o indígena, como "o herói do ciclo americano (...) uma força pura da cosmogonia pré-colombiana, acima, ou melhor, fora do bem e do mal”. Em vez de “o herói”, seria apropriado considerá-lo “um herói”. Além disso, há que se tomar como conjectura a assertiva de que o ciclo desse herói é pré-colombiano. Não havia, então, assim como não há hoje, evidência que permita datar o mito indígena com segurança. Pelos registros de Koch-Grünberg, base narrativa utilizada por Mário de Andrade, pode-se dizer que os mitos indígenas já estavam impregnados de elementos europeus, como se vê na referência à “terra dos ingleses”, isto é, à Guiana Inglesa, feita

\footnotetext{
${ }^{32}$ Op. cit., 1931, p. 151-152.
} 
por Mayuluaípu, narrador taulipangue dos "Feitos de Makunaíma”33, e às armas de fogo no mito “Kaláwunség, o mentiroso”34, narrado ao pesquisador alemão por Akúli, índio arecuná.

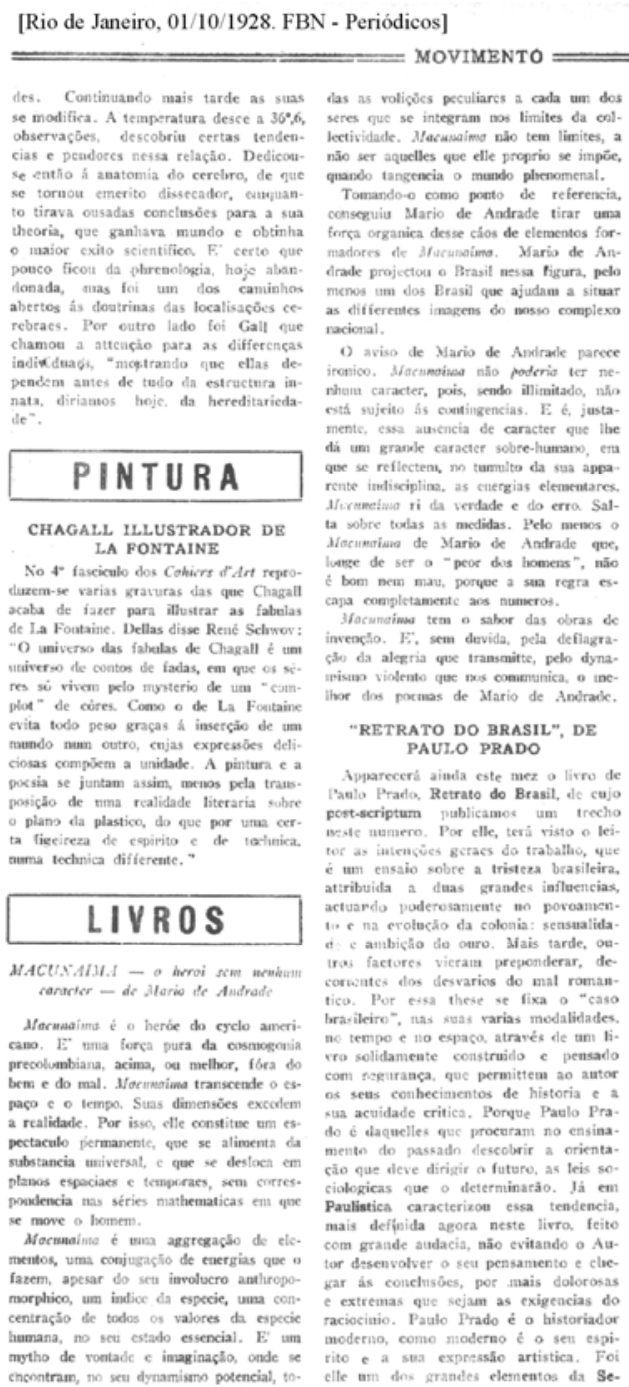

$\mathrm{O}$ articulista ainda afirma que tal herói "se alimenta da substância universal”, associando, de modo descabido, uma noção metafísica da cultura ocidental ao imaginário caribe. Valendo-se de noções vagas, certamente hauridas do repertório conceitual idealista de Graça Aranha, Ronald de Carvalho define esse herói mítico como “uma agregação de elementos, uma conjugação de energias que o fazem, apesar do seu invólucro antropomórfico, um índice da espécie, uma concentração de todos os valores da espécie humana, no seu estado essencial”. Atrás dessa conjectura, apresentada como asserção convicta,

insinua-se a idéia de integração do brasileiro na categoria do “Todo Universal”, postulada por Graça Aranha.

Segundo Ronald de Carvalho, Mário de Andrade tomara como ponto de referência para a criação de seu herói sem nenhum caráter o “caos de elementos formadores” do herói indígena, extraindo desses elementos a “força orgânica” de um ser sobre-humano, sem limites, que transcende as categorias de tempo e espaço da realidade fenomenal, para projetar o Brasil em sua figura, "pelo menos um dos Brasil [sic] que ajudam a situar as diferentes imagens do nosso complexo nacional”.

\footnotetext{
${ }^{33}$ MedeIros, Sérgio (org.). Makunaíma e Jurupari: cosmogonias ameríndias. São Paulo: Perspectiva, 2002, p. 65-66.

${ }^{34}$ Idem, p. 172-174.
} 
Considerando que Macunaíma não poderia mesmo ter caráter, pois "sendo ilimitado, não está sujeito às contingências”, Ronald de Carvalho arremata seu artigo avaliando o livro como uma obra de "invenção" que, pela "alegria que transmite” e "pelo dinamismo violento que nos comunica”, seria “o melhor dos poemas de Mário de Andrade”. Mais uma vez, é necessário ressaltar a apropriação de noções de Graça Aranha (“caos”, “força”, “alegria”, “dinamismo”), pois Ronald de Carvalho filtra sua leitura por essas lentes. Desse modo, a crítica, em vez de exercício de leitura do discurso narrativo, aplica um aparato conceitual extrínseco para ver no texto o que ele não contém: a revelação de um Brasil risonho, otimista e dinâmico, no contexto de uma espécie de projeto cultural que conjugasse nacionalismo e universalismo. De fato, há uma leve semelhança entre esse projeto de Graça Aranha, compartilhado por Ronald de Carvalho, e o de Mário de Andrade, como esse último admitiu em carta a Manuel Bandeira, em que reconhece alguma coincidência entre suas idéias e as de Graça Aranha, “como por exemplo a respeito de abrasileiramento do Brasil”35. Porém, essa mesma carta documenta, já em 1925, a crítica de Mário de Andrade ao projeto nacionalista do autor de $A$ estética da vida: “Já disse no 'Noturno de Belo Horizonte’ que não me agradam os idealistas. Graça querendo fazer do brasileiro um tipão alegre por... teoria filosófica e integração no Todo Infinito com uma incompreensão inteirinha do homem brasileiro que ele não observou, contrariando a psicologia natural desse homem, fazendo da alegria um preconceito a ponto de ver alegria nas minhas 'Danças’ tão tristes e tão doloridas, qual! não tenho tempo pra ler essas coisas, qualquer livro de regionalista besta dá mais documentos verdadeiros.”36 Sob o influxo do mesmo preconceito, Ronald de Carvalho fez uma leitura deformada de Macunaíma. Ao aplicar idéias de Graça Aranha em sua análise, o autor de Toda a América viu só alegria onde há também terrível tristeza - o que, aliás, muitos leitores fizeram, para desconsolo de Mário de Andrade, como veremos em outra parte de nosso estudo.

Até o artigo de Ronald de Carvalho, inclusive, ao menos sete autores se haviam manifestado a propósito de Macunaíma. Seis pertencem à mesma geração, sendo que cinco, considerando Mário de Andrade como autor da primeiríssima recepção, conforme análise anterior, haviam participado da Semana de Arte Moderna; o sexto, Tristão de Ataíde, era, com restrições, simpatizante do modernismo. O sétimo crítico, João Pacheco, bem mais jovem, representa uma nova geração de seguidores entusiastas do movimento de 22. O primeiro crítico da

\footnotetext{
${ }^{35}$ BANDEIRA, Manuel (org.). Cartas de Mário de Andrade a Manuel Bandeira. Rio de Janeiro: Simões, 1958, p. 74-78. Também em MoraEs, Marcos Antonio de (org.). Correspondência Mário de Andrade \& Manuel Bandeira. 2a ed. São Paulo: Edusp/IEB-USP, 2001, p. 206 (1를 ed., 2000). Carta de 07 de maio de 1925.

${ }^{36}$ Idem.
} 
velha geração a discutir a obra de Mário foi Nestor Vítor, ilustre estudioso do simbolismo, com reputação intelectual firmada desde o final do século XIX e formação espiritual consentânea a essa época.

VíTOR, Nestor. “Macunaíma, o herói sem nenhum caráter”. O Globo: Rio de Janeiro, 08 de outubro de 1928. FBN - Periódicos. Recolhido em Vítor, Nestor. “Os de Hoje / Mário de Andrade / Macunaíma". Obra crítica de Nestor Vítor. Rio de Janeiro: MEC / Fundação Casa de Rui Barbosa, 1973, v. II, p. 360-365. (1ª ed., 1938).

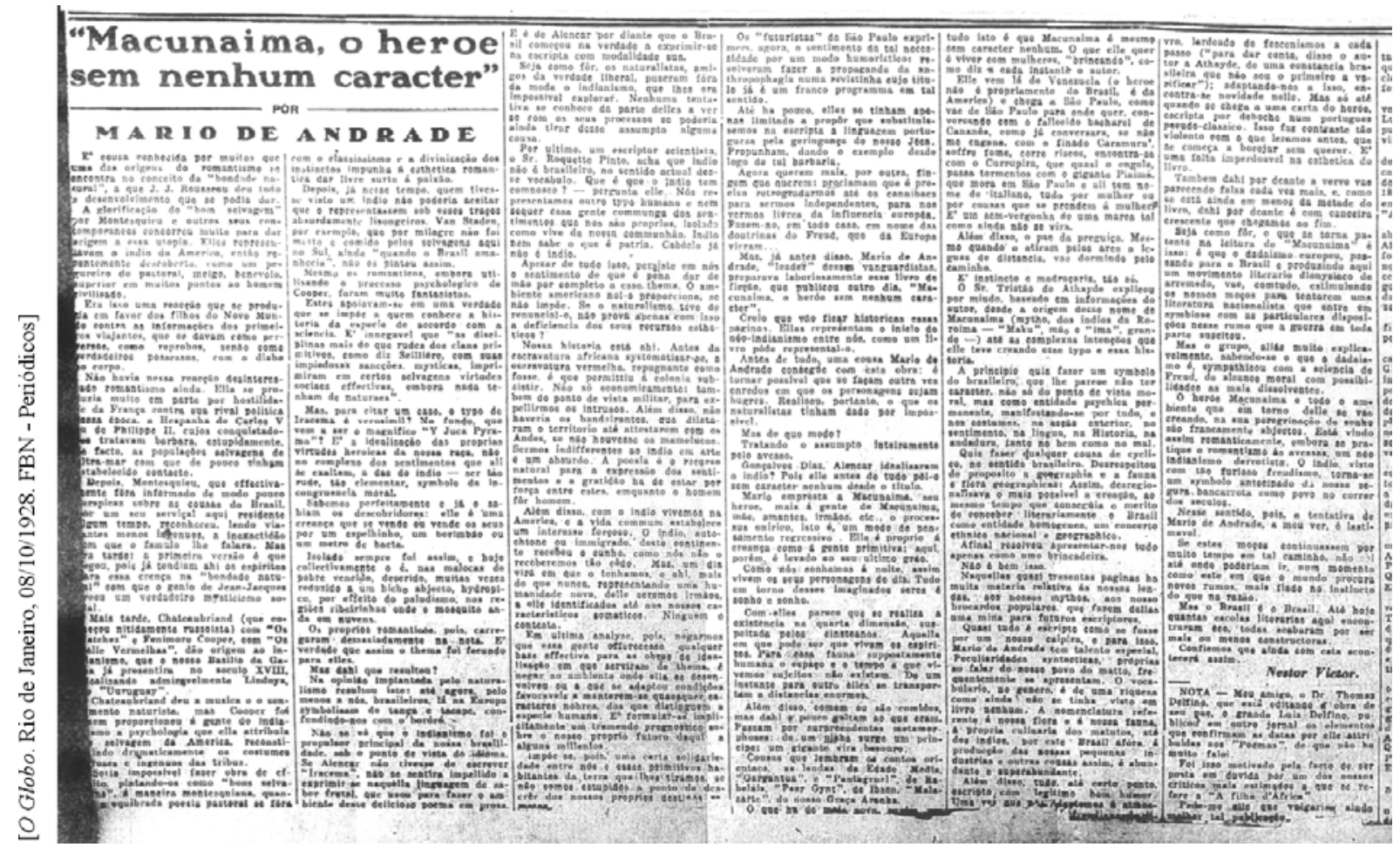

Não foi favorável a Macunaíma a recepção crítica de Nestor Vítor. O ensaio dedicado à obra parte da discussão do indianismo na literatura brasileira, rastreado desde o romantismo, para chegar à consideração de sua ocorrência no livro de Mário de Andrade.

Segundo o crítico, "uma das origens do romantismo se encontra no conceito da 'bondade natural'”, introduzido por Rousseau. A esse conceito se associara a idéia do "bom selvagem”, que Montesquieu difundira com a representação do "índio da América (...) como um pegureiro de pastoral, meigo, benévolo, superior em muitos pontos ao homem civilizado.” Influenciado por Rousseau, Chateaubriand dera origem ao indianismo literário romântico, “que o nosso Basílio da Gama já pressentira no século XVIII, idealizando admiravelmente 
Lindóia, no Uraguai.” O autor de Atala (1801), segundo Nestor Vítor, dera “música e sentimento naturista” ao indianismo, enquanto Fenimore Cooper (por exemplo, em $O$ último dos moicanos, 1826) reconstituíra “dramaticamente os costumes ferozes e ingênuos das tribos” e proporcionara ao “selvagem da América” uma psicologia idealizada. Ponderando que seria impossível ao romantismo explorar a imagem do "bom selvagem” segundo o modelo pastoral clássico, o crítico ressalta que os românticos atualizaram essa imagem segundo o pressuposto da “divinização dos instintos”, que impunha o "livre surto à paixão”. O resultado disso seria a criação de tipos “muito fantasistas”. Nestor Vítor questiona a verossimilhança de Iracema e entende o "I-Juca Pirama” como “a idealização das próprias virtudes heróicas da nossa raça, não no complexo dos sentimentos que ali se exaltam, a das do índio - ser tão rude, tão elementar, símbolo da incongruência moral.” Para completar seu juízo sobre o índio, Vítor aduz que "ele é uma criança que se vende ou vende os seus por um espelhinho" e, isolado em seu meio, reduz-se "a um bicho abjeto, hidrópico, por efeito do paludismo, nas regiões ribeirinhas onde o mosquito anda em nuvens.” Em contraste com essa suposta realidade, os românticos teriam carregado “demasiadamente na nota” fantasista, mas isso lhes proporcionara um tema fecundo.

O indianismo romântico fora rejeitado pelos escritores naturalistas, que responsabilizaram tal temática pela imagem que os europeus teriam adquirido dos brasileiros, confundidos com os selvagens. Isso impedira a percepção de "que o indianismo foi o principal propulsor da nossa brasilidade, sob o ponto de vista do idioma". Nestor Vítor afirma que "é de Alencar por diante que o Brasil começou na verdade a exprimir-se na escrita com modalidade sua.”

Não obstante a fantasia romântica, o crítico assinala que era "pena dar de mão por completo a esse tema”, pois “o ambiente americano no-lo proporciona, se não impõe.” O fato de o naturalismo haver renunciado à temática indianista seria prova de "deficiência dos seus recursos estéticos”. Ressaltando a importância histórica do índio nos tempos coloniais, quer pela subsistência que sua escravização possibilitara à colônia, "repugnante como fosse”, comenta o crítico, quer por sua colaboração militar com o colono português, decisiva para a expulsão de "intrusos”, quer por sua miscigenação, de que resultaram os mamelucos, sem os quais não teriam existido os bandeirantes que expandiram o território, Nestor Vítor conclui que “sermos indiferentes ao índio em arte é um absurdo”.

Outra razão pela qual a literatura brasileira não deveria ser indiferente aos índios seria o fato de que eles estariam perfeitamente adaptados ao ambiente americano, e negar-lhes “qualquer base efetiva para as obras de idealização em que serviram de tema” equivaleria, em 
última análise, a negar ao mesmo ambiente “condições favoráveis a manterem-se quaisquer caracteres nobres, dos que distinguem a espécie humana.” Dessa ilação, Nestor Vítor deduz: "Impõe-se, pois, uma certa solidariedade entre nós [brasileiros] e esses primitivos habitantes da terra que lhes tiramos, se não somos estúpidos a ponto de descrer dos nossos próprios destinos remotos”, uma vez que os brasileiros futuros, finalmente adaptados ao ambiente americano, identificar-se-iam com a gente indígena, “até nos nossos característicos somáticos”, de modo a representar "uma humanidade nova”. A exclusão do índio como tema literário seria "implicitamente um tremendo prognóstico sobre o nosso próprio futuro daqui a alguns milênios.”

Na linha dessas considerações, Nestor Vítor indica sua avaliação da temática indígena como legítima e necessária à literatura brasileira e reconhece em Macunaíma o marco inicial do “neo-indianismo entre nós”. Mário de Andrade conseguira realizar com sua obra o que "os naturalistas tinham dado como impossível”, porém o fizera pelo avesso da idealização com que os românticos haviam tratado o assunto.

O crítico associou Macunaíma à antropofagia ao considerar Mário de Andrade "líder desses vanguardistas”, cujo movimento e propostas são sumariados com desdém e ironia. A Revista de Antropofagia é chamada de "revistinha”; o movimento ter-se-ia limitado, de início, à proposta de substituição "na escrita [d]a linguagem portuguesa pela geringonça do nosso jeca”, para, em seguida, proclamar a necessidade de "retrogradarmos até os canibais para sermos independentes, para nos vermos livres da influência européia”; tal independência, porém, dar-se-ia “em nome das doutrinas de Freud, que da Europa vieram.”

Segundo Nestor Vítor, fora exatamente por influência de Freud que Mário de Andrade construíra a narrativa e as personagens por meio do "processo onírico”, entendido como "um modo de pensamento regressivo (...) próprio à criança como à gente primitiva (...), levado ao seu último grau”. Vivendo num mundo de sonho, os seres “comem ou são comidos, mas daí a pouco voltam ao que eram. Passam por surpreendentes metamorfoses”. É por força do mesmo processo, observa o ensaísta, que as categorias de espaço e de tempo, tal como percebidas no mundo fenomenal, são abolidas. Sempre segundo Vítor, tais qualidades fazem com que $M a$ cunaíma se pareça com “os contos orientais, as lendas da Idade Média, Gargantua e Pantagruel, de Rabelais, Peer Gynt, de Ibsen, Malasarte, do nosso Graça Aranha”.

Além dessas características, o ensaísta destaca como “mais novo” aspecto introduzido por Macunaíma a ausência de caráter do herói, cuja ação seria tão-somente instigada pela se- 
xualidade, de modo a configurar "um sem-vergonha de uma marca tal como ainda não se vira.”

Ressalvando que Macunaíma “não é propriamente do Brasil, é da América”, Nestor Vítor se apóia na crítica de Tristão de Ataíde para assinalar a suposta intenção de Mário de Andrade simbolizar o brasileiro com seu herói, ao qual teria pretendido atribuir "qualquer coisa de cíclico, no sentido brasileiro”, sendo que, para isso, teria desregionalizado "o mais possível a criação”, subvertendo propositalmente “a geografia e a fauna e flora geográficas”, e incluído nas páginas da obra "muita matéria relativa às nossas lendas, aos nossos mitos, aos nossos brocardos populares, que fazem delas uma mina para futuros escritores.” Por tudo isso, não concorda com a afirmação de Mário de Andrade, contida nos prefácios divulgados parcialmente por Tristão de Ataíde, de que a obra era uma "brincadeira”.

Quanto à linguagem, são destacados o léxico abundante, “de uma riqueza como ainda não se tinha visto em livro nenhum”, e as “peculiaridades sintáticas próprias ao falar do nosso povo do mato”. Segundo Nestor Vítor, Mário de Andrade usara o registro da língua caipira em seu livro, exceto na "Carta pras Icamiabas”, “escrita por deboche num português pseudoclássico.” Atribuindo a Mário um “talento especial” para o manejo do registro caipira, o crítico reconhece que o livro é escrito “com legítimo bom humor” e que, “uma vez que nos adaptemos à atmosfera fedorenta, bem freudiana do livro, lardeado de fescenismos a cada passo (...), encontra-se novidade nele”, mas só até a “Carta pras Icamiabas”. Esta é considerada “uma falta imperdoável na estética do livro”, por força do violento contraste com as páginas que a antecedem. A partir dela, diz o ensaísta, o livro fica aborrecido e sua "verve vai parecendo falsa cada vez mais”, de modo que a leitura da segunda metade da narrativa torna-se uma “canseira crescente”.

Da leitura de Macunaíma, Nestor Vítor conclui que a obra exemplifica a tentativa de "uma literatura nacionalista que entre em simbiose com as particulares disposições nesse rumo que a guerra em toda parte suscitou”; literatura nacionalista, embora praticada segundo a orientação de "um movimento literário dionisíaco de arremedo”, produzido pela passagem do dadaísmo europeu, associado à “ciência de Freud”, para o Brasil. Para o ensaísta, a influência de Freud, “de alcance moral com possibilidades as mais dissolventes”, tornara o herói Macunaíma, a respectiva peregrinação e o ambiente criado na narrativa elementos "francamente abjetos”, característicos de um "romantismo às avessas, um neo-indianismo derrotista”, em que o índio "torna-se um símbolo antecipado da nossa segura bancarrota como povo no correr 
dos séculos.” Por essas razões, Nestor Vítor considerou "lastimável” a obra de Mário de Andrade.

O crítico paranaense evidencia haver apreendido muito do projeto nacionalista de Mário de Andrade realizado artisticamente em Macunaíma, como é o caso da percepção da importante perspectiva anti-regionalista. Contudo, repeliu a realização estética modernista da obra, reduzida a imitação do dionisismo dadá e confundida com a antropofagia oswaldiana. Nestor Vítor demonstra acuidade crítica ao apontar a articulação episódica da narrativa, combinada a um método associativo imprevisível e fantástico, chamado por ele de "processo onírico” e entendido como fator de subversão das categorias convencionais de tempo e espaço, além de princípio estrutural da narrativa. Porém, para o ensaísta, Mário de Andrade se apropriara de Freud para construir o herói sem nenhum caráter segundo um "modo de pensamento regressivo (...) próprio à criança como à gente primitiva”. Assim, evidencia haver captado o primitivismo subentendido na obra, mas não como o concebera Mário de Andrade, que se valera de idéias de Freud, especialmente de certas noções contidas em Totem e tabu, com enorme liberdade artística e sem restringir-se a elas. O primitivismo andradiano tem como pressuposto o restabelecimento de certa função prática da arte, não conforme às manifestações típicas do pensamento arcaico, mas de acordo com as exigências históricas de uma era nova ${ }^{37}$, isto é, da sociedade moderna.

Nestor Vítor acusou de moralmente perversora (“dissolvente”) a influência freudiana, entendida como responsável pelo suposto derrotismo do livro: sendo o herói uma revelação simbólica do povo brasileiro, suas peripécias implicariam uma profecia pessimista quanto ao destino desse povo. Sem considerá-las deletérias, Mário de Andrade se aproveitou em Macunaíma de sugestões freudianas, particularmente da noção de totem; no entanto, misturou-as a outros elementos, seja apreendidos em estudos de antropologia, etnografia e folclore, seja resultantes de observação e reflexão pessoais, especialmente à sua particular concepção de primitivismo, para criar com liberdade artística algo que considerava, em vez de uma revelação, um indício ou, melhor, um "sintoma de cultura nacional” (como consta no segundo prefácio e fora divulgado na crítica de Tristão de Ataíde) fustigado pela sátira - aspecto decisivo do nacionalismo crítico consubstanciado em Macunaíma que escapou ao crítico católico, ao paranaense e a muitos outros. O pessimismo derrotista assinalado por Nestor Vítor coincide, em grande parte, com a opinião de Tristão de Ataíde, de que Mário de Andrade discordou.

\footnotetext{
37 "Somos na realidade os primitivos duma era nova." ANDRADE, Mário de. "Prefácio interessantíssimo”. In: Poesias completas. Edição crítica de Diléa Zanotto Manfio. Belo Horizonte: Villa Rica, 1993, p. 74.
} 
Mas continuemos a resenhar os pronunciamentos da crítica pioneira à rapsódia; num momento mais oportuno veremos a posição de Mário quanto ao suposto pessimismo do livro.

Das três críticas a Macunaíma publicadas em outubro de 1928, a terceira é assinada por João Ribeiro, membro da Academia Brasileira de Letras desde 1898, ano seguinte ao de fundação. Filólogo, crítico, jornalista, historiador, estudioso do folclore e dos clássicos da literatura universal, entre outros dotes de espírito, João Ribeiro foi um erudito de orientação intelectual moldada pelo cientificismo materialista e pelo naturalismo, tal como seu conterrâneo e amigo Sílvio Romero.

RIBEIRO, João. “Crônica literária / Macunaíma - herói sem nenhum caráter - por Mário de Andrade”. Jornal do Brasil: Rio de Janeiro, 31 de outubro de 1928, p. 10. IEB-USP CAP-MP. Recolhido em Os modernos. Rio de Janeiro: ABL, 1952, p. 81-84, vol. IX das Obras completas de João Ribeiro. Reproduzido em ANDRADE, Mário de. Macunaíma. Edição crítica de Telê Porto Ancona Lopez. Rio de Janeiro: Livros Técnicos e Científicos / São Paulo: Secretaria da Cultura, Ciência e Tecnologia, 1978.

[João Ribeiro. Jornal do Brasil. Rio de Janeiro, 31/10/1928. IEB - CAP-MP]

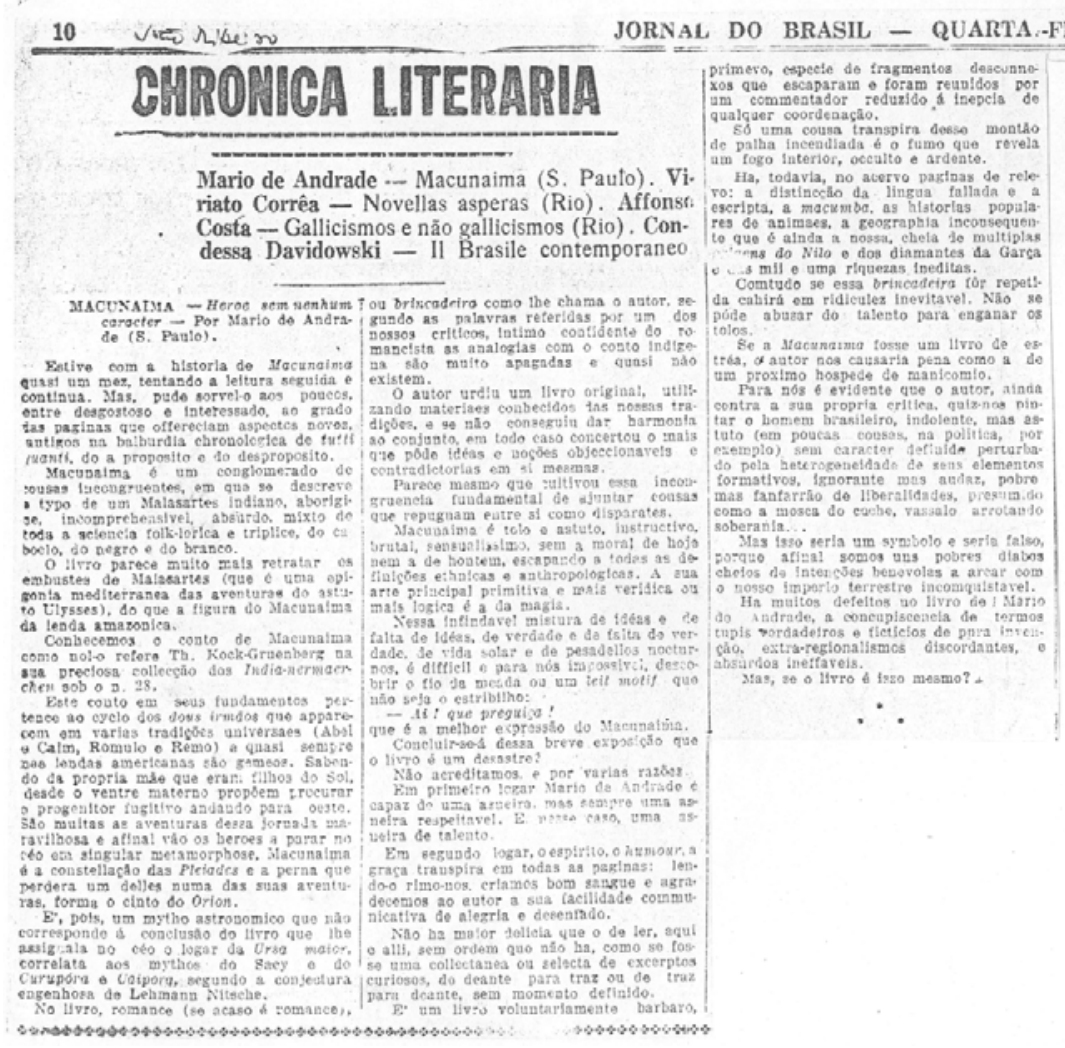

Revelando conhecimento da obra de KochGrünberg, o crítico assinala: a lenda indígena amazônica inclui-se no "ciclo dos dous irmãos [grifo do autor] que aparecem em várias tradições universais" e se constitui num mito astronômico cujo herói, ao fim de muitas aventuras e sem uma perna, torna-se a constelação das Plêiades, enquanto o membro amputado, o cinturão de Orion. Essa observação erudita demonstra não haver

correspondência entre a narrativa do herói indígena e a "conclusão do livro que lhe assinala 
no céu o lugar da Ursa Maior, correlata aos mitos do Saci e do Curupóra e Caipora, segundo a concepção engenhosa de Lehmann Nitsche.” Apoiado nessa observação, João Ribeiro assevera que as peripécias do herói andradiano são mais próximas dos “embustes de Malasartes (que é uma epigonia mediterrânea das aventuras do astuto Ulisses), do que [d]a figura do Macunaíma da lenda amazônica”. Desse modo, assinala, “as analogias com o conto indígena são muito apagadas e quase não existem”, portanto Mário de Andrade compusera um livro verdadeiramente original, utilizando-se livremente de "materiais conhecidos das nossas tradições". No entanto, pondera, o autor não conseguira harmonizar o conjunto.

Em vista dessa suposta falha, pergunta o crítico se o livro seria "um desastre" - pergunta retórica respondida negativamente. Na medida em que a obra transpira graça, espírito e humour, “em todas as páginas”, e provoca uma espécie de riso terapêutico no leitor, gratificado pela “facilidade comunicativa de alegria e desenfado” do autor, João Ribeiro concede que “não há maior delícia que a de ler [o livro], aqui e ali, sem ordem que não há, como se fosse uma coletânea ou seleta de excertos curiosos, de diante para trás ou de trás para diante, sem momento definido.” Dentre tais excertos, destaca como mais relevantes os da "Carta pras Icamiabas”, em que há “a distinção da língua falada e da escrita”, do episódio da macumba, das "histórias populares de animais” e das páginas de "geografia inconseqüente que é ainda a nossa”.

No entanto, essas qualidades não foram suficientes para o crítico avaliar positivamente a obra. Ao contrário, seu juízo foi o mais áspero dentre todos os que se manifestaram desfavoráveis a ela até então e, certamente, o mais demolidor.

Segundo João Ribeiro, “Macunaíma é um conglomerado de coisas incongruentes”, "um livro voluntariamente bárbaro, primevo, espécie de fragmentos desconexos que escaparam e foram reunidos por um comentador reduzido à inépcia de qualquer coordenação”, uma narrativa em que é impossível “descobrir o fio da meada”, uma “asneira”, embora “uma asneira de talento”, um livro que, se fosse de um autor estreante, “nos causaria pena como a de um próximo hóspede de manicômio.”

Quanto ao herói, além das observações já mencionadas, João Ribeiro enfatiza o caráter contraditório: suas aventuras miscigenam relatos folclóricos “do caboclo, do negro e do branco”, de modo a constituir um ser incompreensível e absurdo, cuja arte é a da magia e que seria - contra a opinião do próprio Mário de Andrade, veiculada na crítica de Tristão de Ataíde um símbolo do homem brasileiro. No entanto, esse símbolo seria falso, uma vez que, para João Ribeiro, os brasileiros não seriam conformes ao perfil madraço de Macunaíma, mas ao 
de "uns pobres diabos cheios de intenções benévolas a arcar com nosso império terrestre inconquistável.”

\section{DEFESA ENTUSIÁSTICA}

Em 28 de novembro de 1928, o Diário Nacional estampou uma decidida defesa a certos ataques desferidos contra Macunaíma.

\section{FERreira, Ascenso. “Brasilidade e dinamismo / a propósito do 'Macunaíma’ de Mário de Andrade”. Diário Nacional: São Paulo, 28 de novembro de 1928. IEB-USP - CAP- MP.}

O poeta pernambucano Ascenso Ferreira, pioneiro do modernismo nordestino, é o autor da matéria. Não se trata de uma resposta direta às críticas adversas, mas de uma espécie de louvação em prosa, com o intuito de enumerar certas qualidades que, no entendimento do articulista, fariam “do discutidíssimo livro de Mário de Andrade” um “formidável poema”. Por meio desses elementos destacados e louvados, Ascenso Ferreira, indiretamente, rebate pontos atacados por alguns predecessores seus na recepção crítica a Macunaíma; por outro lado, reforça noções e juízos favoráveis formulados antes e contribui com novas observações para a avaliação crítica da obra.

Ascenso Ferreira assevera que Mário de Andrade preenchera uma lacuna da “vida brasileira” com a construção de uma obra de arte a partir de material folclórico disperso, realização que, na sua compreensão, seria impossível “sem o espírito moderno” inerente ao modernismo brasileiro, que revirara "baús velhos de história pátria” para entornar "potes de sentimento nativista sobre um potici ${ }^{38}$ de cérebros entupidos da poeira do Partenon e do Coliseu” e livrar o "pensamento dos moços brasileiros (...) da sanguessuga terrível chamada 'Espírito de Paris'!” Em outros termos, o poeta pernambucano ressalta o projeto nacionalista que animava o modernismo brasileiro, para indicar Macunaíma como a primeira obra literária em que tal projeto se realizara, não como "simples elemento decorativo, mas como força, vida, expressão.” Para isso, Mário de Andrade teria rompido “com todas as fórmulas de um intelectualismo caduco.”

\footnotetext{
38 "Potici”: grande quantidade. Regionalismo brasileiro, nordestino e nortista.
} 
[Diário Nacional. São Paulo, 28/11/1928. IEB - CAP-MP]

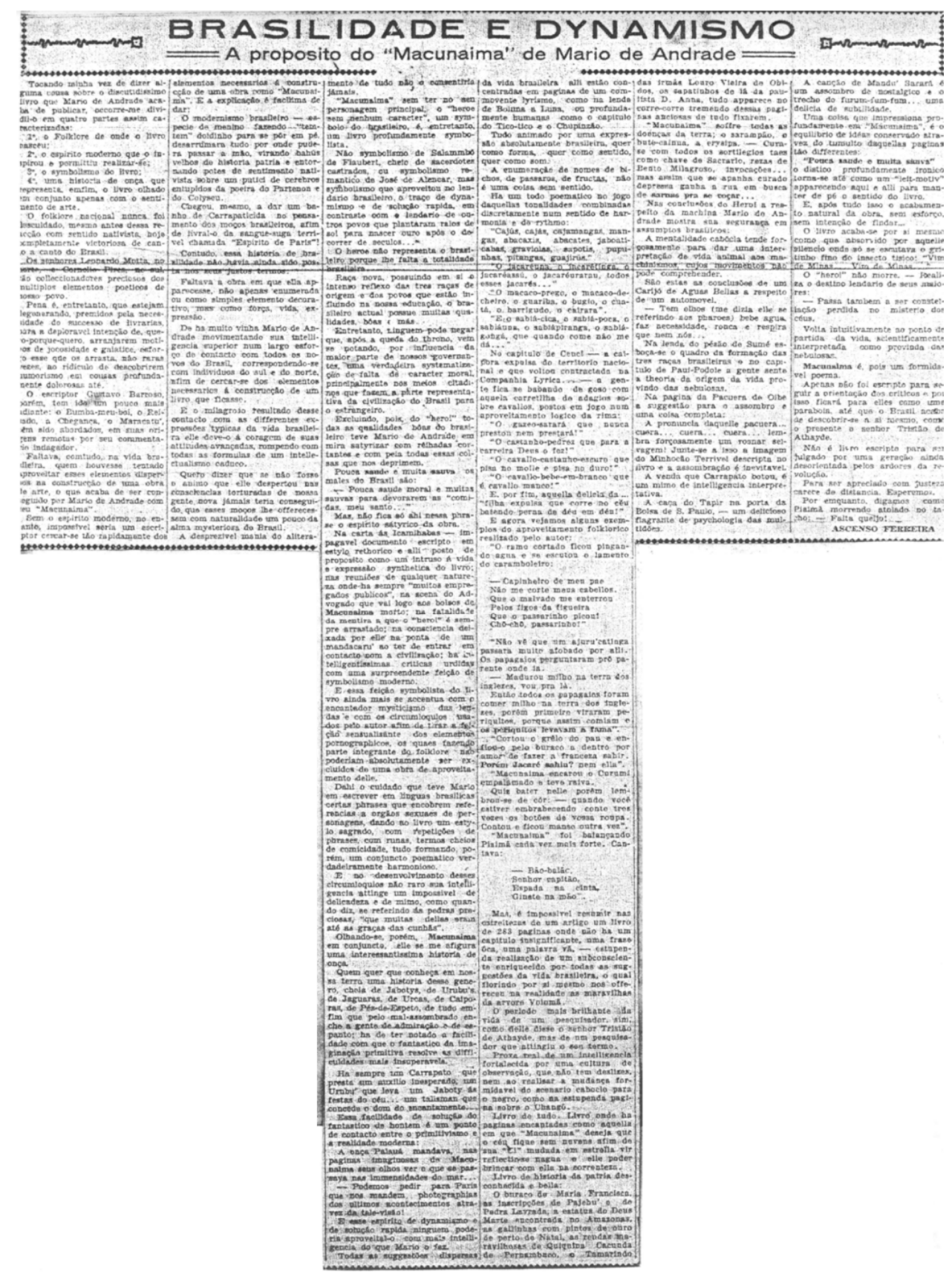

Na perspectiva do projeto nacionalista do modernismo, Mário teria conferido ao seu livro uma dimensão "profundamente simbolista”. Ascenso Ferreira está de acordo com a consideração do autor, veiculada por Tristão de Ataíde, segundo a qual o herói não seria símbolo do brasileiro, “porque lhe falta a totalidade brasileira”, diz o crítico, repetindo o que já haviam consignado o próprio Tristão, Cândido Motta Filho e João Ribeiro, embora esses houvessem discordado de Mário por considerarem o herói sem nenhum caráter como tal símbolo, apesar de falho ou falso. Para Ascenso, a personagem não fora construída com o propósito de simbo- 
lizar o homem brasileiro, mas de constituir a figura de um herói desprovido de "todas as qualidades boas do brasileiro", a fim de castigar a "verdadeira sistematização de falta de caráter moral, principalmente nos meios citadinos que fazem a parte representativa da civilização do Brasil para o estrangeiro”.

O poeta de Catimbó associou a construção da personagem ao "espírito satírico da obra” e viu nesse, e não propriamente no herói, o "simbolismo" do livro, que se manifestaria profusamente - por exemplo: no refrão "Pouca saúde e muita saúva os males do Brasil são”; na “Carta pras Icamiabas”; na freqüente menção a “muitos empregados públicos”; no advogado que assalta os bolsos do morto; na mentira “a que o 'herói' é sempre arrastado”; “na consciência deixada [na ilha de Marapatá] (...) ao ter de entrar em contato com a civilização”. Nas críticas inerentes à sátira, Ascenso Ferreira discerniu “uma surpreendente feição de simbolismo moderno”, diverso daquele utilizado por Flaubert em Salambô ou do simbolismo romântico de que José de Alencar se valera. O que distinguiria o “simbolismo” de Macunaíma, segundo o articulista, seria “o traço de dinamismo e de solução rápida”, característico do "lendário brasileiro (...) em contraste com o lendário de outros povos”.

Desse modo, o “simbolismo moderno” resultaria da apropriação do imaginário popular brasileiro tradicional, cujo traço distintivo seria "a facilidade com que o fantástico da imaginação primitiva resolve as dificuldades mais insuperáveis”. Para Ascenso Ferreira, o “dinamismo e a solução rápida” seriam elementos de contato entre “o primitivismo e a realidade moderna”, sendo que o primeiro teria por suporte o maravilhoso, enquanto o segundo, a tecnologia, diferencial que fica caracterizado na analogia feita entre um episódio de Macunaíma - o da onça Palauá, cujos olhos vão ver o mar e depois voltam ao sertão trazendo as imagens longínquas - e a possibilidade moderna de transmissão de fotografias de um continente a outro por meio de uma máquina. No entanto, o crítico reduziu o confronto ficcional entre pensamento primitivo e máquina, contido em Macunaíma, à suposta intenção de Mário de Andrade registrar como a "mentalidade cabocla tende forçosamente para dar uma interpretação de vida animal aos maquinismos, cujos movimentos não pode compreender.”

Ascenso Ferreira considerou Macunaíma a “estupenda realização de um subconsciente enriquecido por todas as sugestões da vida brasileira”, disseminadas em suas páginas no "encantador misticismo das lendas”; no material folclórico incorporado; no lirismo; nas inúmeras doenças sofridas pelo herói e nos sortilégios curativos; nos mal-assombrados; no "delicioso flagrante de psicologia das multidões”; na menção a inscrições rupestres; na "enumeração de nomes de bichos, de pássaros, de frutas”; na nostalgia ou sutileza de certas passagens; na por- 
nografia; no registro de "línguas brasílicas"; na imagem dos três irmãos banhados nas águas do pezão de Sumé, “quadro da formação das três raças brasileiras”, e em outros incontáveis elementos representativos da cultura nacional.

Todo esse material, tão heterogêneo, seria "animado por uma expressão absolutamente brasileira, quer como forma, quer como sentido, quer como som” e, a despeito do tumulto aparente com que é apresentado, seria portador de um impressionante “equilíbrio de idéias”, que pode ser entendido como fator de organização da obra, cujo fim seria uma "volta ao ponto de partida da vida, cientificamente interpretada como provinda das nebulosas”. Para Ascenso Ferreira, Macunaíma é o termo bem-sucedido da "vida de um pesquisador", no seu momento mais brilhante, ao contrário da opinião de Tristão de Ataíde; mas seria, sobretudo, a realização de “um formidável poema”, em que não haveria “um capítulo insignificante, uma frase oca, uma palavra vã”.

Na conclusão de seu artigo, Ascenso Ferreira avalia que Macunaíma permaneceria “como uma parábola” aos críticos, desorientados perante o caráter revolucionário da obra de Mário de Andrade, até que “o Brasil acabe de descobrir-se a si mesmo”. Não caberia à geração sua contemporânea julgar a obra; só o distanciamento poderia ensejar uma apreciação justa.

Encontram-se nos arquivos do IEB-USP mais três artigos que completam o rol dos pioneiros da fortuna crítica de Macunaíma, assim considerados os autores que se pronunciaram no mesmo ano da primeira edição da obra. Um, assinado por José Vieira, foi publicado pelo periódico Vanguarda, na edição de 10 de dezembro, conforme anotação manuscrita de Mário de Andrade no recorte colecionado por ele. Não consta nos outros dois a data exata de publicação, mas ambos são, seguramente, de 1928. De um deles, assinado pelas iniciais O. M., não se sabe o nome do periódico em que se publicou nem o local; o outro, assinado por Augusto F. Schmidt, saiu na revista católica A Ordem, do Rio de Janeiro, entre novembro e dezembro, a julgar por uma observação do autor, que no segundo parágrafo de seu texto declara: “Há quatro meses já que tento, sempre inutilmente, dizer alguma coisa sobre a última produção de Mário de Andrade. ${ }^{39}$ Com a resenha desses pronunciamentos, a primeira parte deste capítulo será concluída.

\footnotetext{
${ }^{39}$ Documento encontrado na coleção Carlos Alberto Passos, pesquisador que doou seus arquivos ao IEB-USP. Por meio de anotação manuscrita, Passos informa que a publicação é de 1928.
} 


\section{ENTRE ROMANCE E ENSAIO}

\section{VIEIRA, José. “Livros novos / Macunaíma, por Mário de Andrade, S. Paulo, 1928”. Van- guarda: [Rio de Janeiro?], 10 de dezembro de 1928. IEB-USP - MA-MP.}

O artigo do escritor e jornalista paraibano José Vieira (1880-1948) é iniciado com um juízo dúbio e uma observação quanto ao gênero: Macunaíma "é um precioso livro pouco agradável”, misto de "romance e ensaio”. A ficção romanesca seria uma espécie de "história do Brasil pelo método confuso”, que, por intermédio de um “curioso simultaneísmo, e mistério, fantástico mais curioso ainda”, realiza “uma odisséia, penosa para quem a acompanhe desprevenido”. Segundo Vieira, a ficção serve de veículo para idéias de Mário de Andrade sobre a "língua brasileira”. Tais idéias constituiriam um "ensaio” entranhado na narrativa ficcional. A ficção, porém, por apresentar “qualidades que ainda são defeitos para o leitor comum”, em vez de ajudar, teria prejudicado o ensaio; mas o crítico dispõe-se a deixar de lado o exame do veículo romanesco das idéias para concentrar-se nelas.

Por hipótese, o ensaio conteria “o remédio ou veneno curativo para o Brasil empalemado de estrangeirismo”. Para José Vieira, Mário de Andrade, além de defender a diferenciação entre a língua portuguesa e o idioma usado no Brasil, na fala e na escrita, esforçava-se para ajudar esse processo. O crítico descreve metaforicamente o fenômeno em que a língua portuguesa teria originado a "língua dos brasileiros": o idioma peninsular se miscigenara "no mesmo mocambo com o tupi-guarani, com o africano". O "mocambo”, isto é, o ambiente americano, impusera a atribuição de novos significados para velhos vocábulos, a invenção de novas palavras e de novos modos de combiná-las para a expressão de "modos de viver diversos, sentimentos outros, ideais novos”. Assim, a miscigenação lingüística processada no Brasil teria resultado numa língua diferenciada, cuja base não somente é, mas "tem, todavia, que ser a língua portuguesa”. Tal necessidade decorreria da extrema pobreza dessa língua brasílica, que é compreendida não como substituta, mas metamorfose do idioma lusitano.

Para o escritor paraibano, o não reconhecimento da diferenciação manifestaria um “colonialismo inconsciente, ou imbecil, senão safadote”. As ondas de imitação dos clássicos portugueses, ocorridas no século XIX, teriam malogrado porque a “modalidade brasileira” do idioma já seria uma realidade inevitável naquela época, de modo que os nossos escritores, por mais que se esforçassem para “escrever português da banda de lá”, acabavam por escrever na "língua da banda de cá”. 


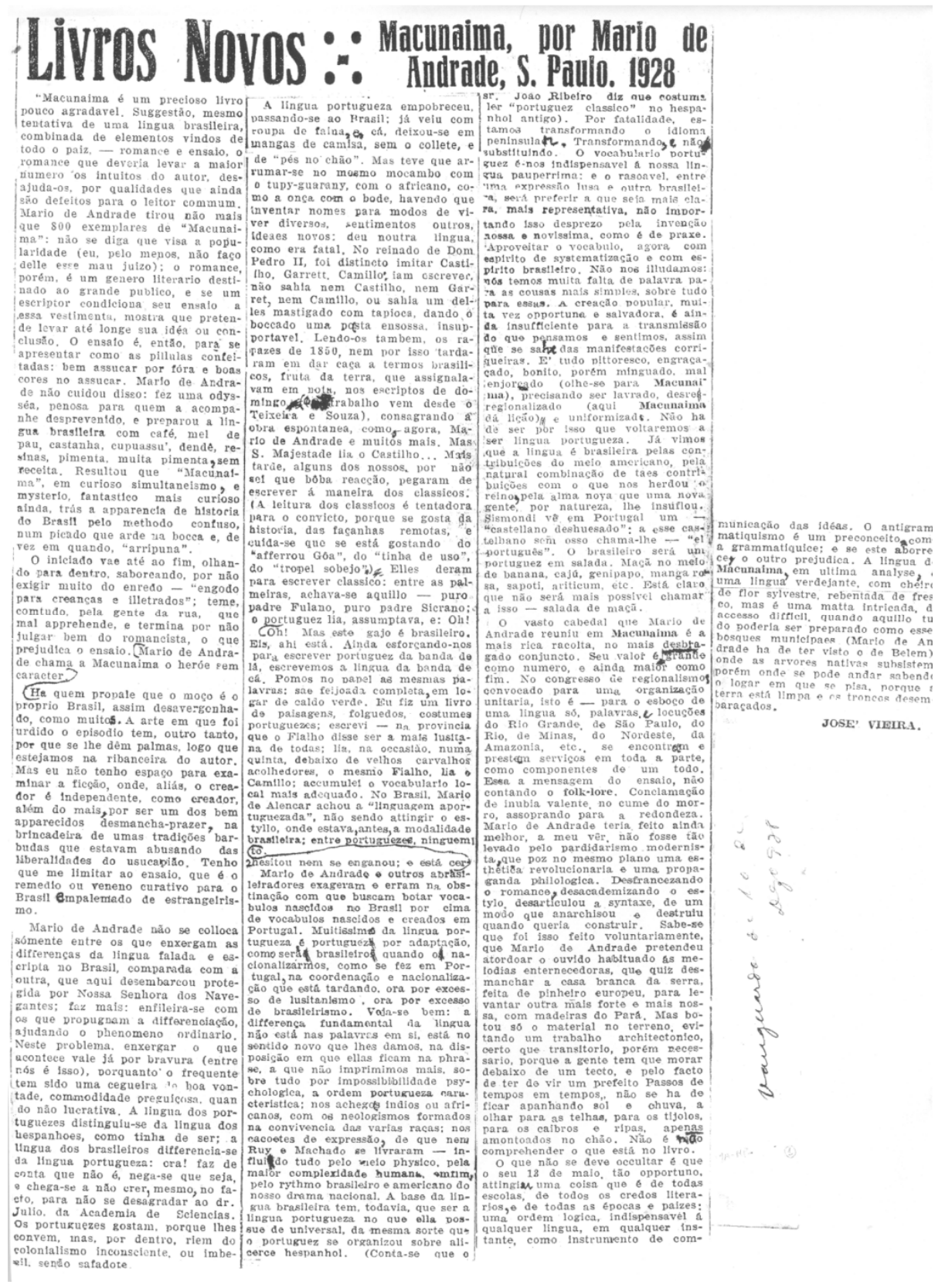

Agora, exagerar no abrasileiramento da língua seria incorrer em erro oposto ao da lusitanização excessiva. O brasileirismo obstinado, que assimila sem critério a criação popular, redundaria em algo “pitoresco, engraçado, bonito, porém minguado, mal-enjorcado”, de que Macunaíma seria exemplo. Conforme o crítico, a obra de Mário de Andrade tem grande valor por ser “a mais rica recolta” da língua brasílica e pelo exemplo que dá com o esforço de desregionalização do cabedal acumulado, mas peca por não haver sistematizado esse material. Como resultado dessa suposta falha, “a língua de Macunaíma, em última análise, é uma lín- 
gua verdejante, com cheiro de flor silvestre, rebentada de fresco, mas é uma mata intrincada, de acesso difícil, quando aquilo tudo poderia ser preparado como esses bosques municipais (Mário de Andrade há de ter visto o de Belém), onde as árvores nativas subsistem, porém onde se pode andar sabendo o lugar em que se pisa, porque a terra está limpa e os troncos desembaraçados.”

José Vieira observa que o resultado teria sido melhor se Mário de Andrade não tivesse colocado "no mesmo plano uma estética revolucionária e uma propaganda filológica”. O "partidarismo modernista” teria impedido que as idéias sobre a "língua dos brasileiros” lograssem um resultado construtivo, levando, ao contrário da intenção do autor, a uma desarticulação destrutiva da sintaxe. Parece-lhe que, embora Mário de Andrade tivesse acertado na escolha do material de construção, teria evitado o “trabalho arquitetônico”, em decorrência de práticas modernistas anarquizantes.

Retomaremos a crítica de José Vieira para discuti-la na segunda e na terceira partes deste capítulo.

\section{COMPLEXIDADE IRRITANTE}

SchmidT, Augusto F. “A propósito de Macunaíma”. A Ordem: Rio de Janeiro, [dezembro?] 1928, p. 34-38. IEB-USP - CAP-MP.

Augusto Frederico Schmidt publicou sua crítica a Macunaíma na revista A Ordem, ligada ao Centro Dom Vital, organização católica conservadora liderada por Alceu Amoroso Lima desde 1928 (ano da morte de Jackson de Figueiredo, que a fundara e dirigira desde 1922). Schmidt publicara recentemente seu livro de estréia, Canto do brasileiro, iniciando uma bem-sucedida carreira de poeta, que se contrapôs ao prosaísmo modernista no esforço de reabilitar, em estilo solene, temas grandiosos e universais, objetos de crítica feita por Mário de Andrade no ensaio "A volta do condor" 40 .

Não foi possível determinar a data precisa da publicação, mas é possível situá-la entre os meses de novembro e dezembro, com base na afirmação do próprio articulista de que desde

\footnotetext{
${ }^{40}$ ANDRADE, Mário de. “A volta do condor (1940-41)”. In: Aspectos da literatura brasileira. $5^{\mathrm{a}}$ ed. São Paulo: Martins, 1974, p. 141-171.
} 
o lançamento de Macunaíma - ou seja, fim de julho - passara quatro meses tentado em vão escrever uma crítica à obra. ${ }^{41}$

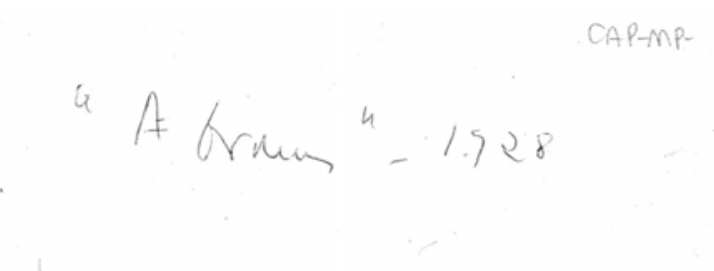

A PROPOSITO DE "MACUNAMA"

AUGUSTO F. SCHMIDT.

"Macunaima" de Mario de Andrade, é o livro mais compiexu, mais difficil de ser criticado, que se escreveu aié hoje no Rrasil. Não eston fazendo arbiliariamente esta affirmaçăo. Falo por experiencia propria e alheia.

Ha quatro mezes já que tento, sempe inutilinente, dizer alguma coisa sobre a ultima producção de Mario de An-cirade.

Tinha assumido, commigo mesmo, um serio compromisso : " escrever logo da sahida de "Mactnaima" (e o primeiro exemplar, por acaso, eu o tive, antes micsiic c..: a set: proprio autor) alguma coisa scbre tão gुrave e significativa obra. Mas quantos obstaculos tive! Não que "Macunaima" seja algo de massudo, de degerivel apenas penosamente, antes pelo contrario, a gente sente sempre interesse c prazer á medida que vae conhecendo as aventuras extraordinarias do extraordinario heroe da lenda brasileira que é "Macunaima". A compiexidade do livro é muito essencial, muto escondiva. Sua origem está, taivez, na sialpliciciade conseguida do trabalho em contraste com a profunda e atormentada genese delle. Para mim "Macunaima" é simples á força de ser difficil.

Ê simples porque é excessivamente complexo. Esta complexidade só é verdadeiramente sentida, quancio se principia

Segundo Schmidt, seus esforços anteriores malograram em razão da complexidade "muito essencial, muito escondida" sob a aparente simplicidade do livro de Mário de Andrade. Diz o crítico que a leitura de Macunaíma, em vez de penosa, fora para ele uma experiência de fácil digestão, pois as peripécias extraordinárias do extraordinário herói foram sempre acompanhadas com "interesse e prazer”. Terminada a leitura, porém, quando principiara a "pensar na significação da obra”, passara a sentir sua complexidade, que lhe provocara perturbação, indecisão e "séria irritação”, nunca experimentadas por ele perante qualquer outra obra da literatura brasileira.

Schmidt abstém-se de "enquadrar Macunaíma", sob o pretexto de que "ele [o livro e o herói] é a própria indeterminação”; reconhece, porém, que a obra tem real importância, "principalmente em relação ao momento brasileiro”, e passa a comentar as “preocupações provocadas” pela leitura refletida.

Inicialmente, o crítico ressalta o “poder de organização” de Mário de Andrade, cuja disciplina enérgica o teria levado a elaborar e executar um "plano de trabalho” dirigido à consecução da “fisionomia exata da arte brasileira (a personalidade artística nacional)”, bem como à fixação do perfil do homem brasileiro. Considerando que o eixo de toda a obra de Mário de Andrade consistiria na "procura de uma expressão verdadeiramente nacional”, Augusto Frederico Schmidt entendeu que o autor de Macunaíma teria preestabelecido um caminho cuja meta sacrificara o geral, o homem, em favor da particularidade brasileira. Como resulta-

\footnotetext{
${ }^{41}$ Ver nota 39.
} 
do disso, o livro de Mário seria “mais obra de crítico”, faltando a ela “o que se pode chamar propriamente de imaginação criadora”.

Concentrado em seu plano de trabalho, Mário de Andrade construíra um herói que o resenhista preferiu chamar de "sem consciência”, vendo nessa falta, em vez da ausência de caráter, algo mais apropriado ao protagonista e ao Brasil. No entanto, a intenção do artista teria ficado aquém da meta, pois, por suposto, faltara também ao herói “alguma coisa de mais amplo” e mais significativo “como símbolo de espírito, de feição, de subconsciente nacional”.

Schmidt reconhece que Macunaíma apresenta traços bem brasileiros e que em certos momentos Mário de Andrade teria logrado elevar sua criação àquela esfera mais geral. Mas isso só se verificaria quando fosse notável o desejo “de despojar o personagem central do seu ambiente lendário", ou nas passagens em que Macunaíma ultrapassaria a "lucidez e espírito orgânico de seu autor”, para "viver à parte do escritor".

Em sua análise, Schmidt destacou a espontaneidade como a característica marcante do herói, a cujos atos faltaria determinação, pois resultariam de impulsos não intencionais. Para o articulista, as atitudes caprichosas fazem de Macunaíma "uma criança sabida; mas criança assim mesmo. Criança como o Brasil”. Tal espontaneidade teria entrado em choque com o espírito crítico do autor de modo a provocar entre esse e o protagonista "um certo desencontro, uma certa falta de acordo" que limitaria a autonomia do herói. Segundo Schmidt, a "falta de identidade" entre o inconsciente e indeterminado Macunaíma e o "lúcido e determinista” Mário de Andrade teria impedido que o livro fosse uma obra genial.

Na segunda parte deste capítulo, discutiremos as postulações de Augusto Frederico Schmidt, comparando-as com o que formularam os predecessores a propósito de temas comuns.

\section{ANTIPATIA PRÉVIA}

O. M. [Olívio Montenegro]. “Livros novos / Macunaíma - Romance - Mário de Andrade - S. Paulo - 1928”. Periódico não identificado, [Recife], s/d. IEB-USP - MA-MP.

A matéria jornalística assinada pelas iniciais O. M. será resenhada como último pronunciamento da fortuna crítica de Macunaíma publicada em 1928 por não sabermos, como já foi dito, a data precisa de sua publicação. Não conhecemos, também, o nome do periódico que a estampou, mas, a julgar pelo que pode ser lido no verso do recorte encontrado no álbum 
R.29 - Recortes de Mário de Andrade - IEB-USP, talvez se trate de um jornal da cidade de Recife. Tal hipótese é reforçada pela convicção de que as iniciais do articulista correspondem às do escritor pernambucano Olívio Montenegro. O que levou a essa identificação de autoria foi a notável coesão entre as idéias veiculadas nessa matéria e no ensaio “Mário de Andrade”, incluído no livro $O$ romance brasileiro ${ }^{42}$.

De fato, tal ensaio, embora retifique parcialmente e para melhor certos juízos sobre a arte de Mário de Andrade ${ }^{43}$, reafirma algumas características apontadas como defeitos no artigo em questão, dedicado a Macunaíma. Dentre elas, destaca-se a intromissão do espírito infantil na criação literária, que teria levado a um freqüente exibicionismo, expresso na linguagem extravagante e no modo voluntarioso com que Mário deformara a sua obra em nome de uma "mensagem” nacionalista, associada ao "jacobinismo no sentimento da arte moderna". Disso resultaria, em grande medida, “um espetáculo de premeditada extravagância mental”, um artificialismo refinado, decorrente da "virtuosidade técnica que esgota toda emoção e toda idéia”. As "qualidades mais felizes da sua prosa” seriam prejudicadas pela não rara intromissão do “diabo do artifício literário” e pela sobreposição de problemas extraliterários à ficção, cuja complexidade seria razão para que Mário de Andrade fosse "mais um autor das elites do que do povo"44. Comparando tais opiniões genéricas do ensaio de Olívio Montenegro com o que se afirma especificamente sobre Macunaíma no artigo de O. M., fica evidente que se trata do mesmo autor.

O artigo destaca como melhores qualidades da obra de Mário a "muita e boa nota lírica, dos vivos até bem vivos de poesia que enchem de um tão claro ritmo, e uma tão plástica animação certas cenas do livro”, bem como a concepção do romance, entendida como uma “fantasia esplêndida”, dotada de "um sentimento do nosso instinto ancestral, e uma verossimilhança de gênio brasileiro nas suas raízes mais secretas”. Segundo O. M., Mário de Andrade mostrara "exigente sensibilidade” na escolha dos motivos de seu romance - "toda essa matéria estranhamente plástica de que é capaz o gênio da nossa vida primitiva; de que é capaz o fulvo pitoresco das nossas lendas.”

Contudo, só em certos momentos Mário teria realizado essas qualidades excelentes; o “fôlego curto” de sua inspiração teria impedido a manutenção do “toque mais puro” e da natu-

\footnotetext{
42 Montenegro, Olívio. “Mário de Andrade”. In: $O$ romance brasileiro. $2^{\underline{a}}$ ed. Rio de Janeiro: José Olympio, 1953, p. 199-214. Na 1aㅡ ed., de 1938, não havia o capítulo dedicado a Mário de Andrade. ${ }^{43}$ Em rigor, o ensaio "Mário de Andrade” não se concentra em Macunaíma. Embora aborde ligeiramente a rapsódia, Olívio Montenegro se dedica à análise da expressão estética peculiar à obra literária de Mário de Andrade, considerada em conjunto.

${ }^{44}$ MonTEnegro, Olívio. Op. cit., passim.
} 
ralidade alcançados nas melhores passagens, de modo que a matéria do livro não se realizara senão "em esboço de caricatura”. Como um todo, faltaria ao livro "o ar mais vivo e forte e humano de criação que era de esperar”. Em vez disso, a literatura teria esgotado "muito do espírito que tem o livro, até reduzi-lo em páginas inteiras de puro palavreado, palavreado brasileiro, mas palavreado.” O. M. observa que há em Macunaíma um desprezo pela literatura, mas que a mesma literatura desdenhada fora utilizada profusamente na forma de "truques engenhosos”, a fim de obter “a impressão de originalidade”. Dentre os recursos de tal prática, o crítico ressalta a sugestão de sensibilidade infantil, tornada moda perniciosa entre os "escritores modernos”, mas que Mário de Andrade não teria logrado sustentar, recaindo em “excessos caricaturescos" e na "grotesquerie”, insistente e desagradavelmente repetidos. A repetição do fantástico é também recriminada por ser “fatigante” a sua banalização. O. M., aliás, nota que o livro "se repete sem cessar com pequenas variantes de imagens”, o que seria, em sua opinião, um grave defeito.

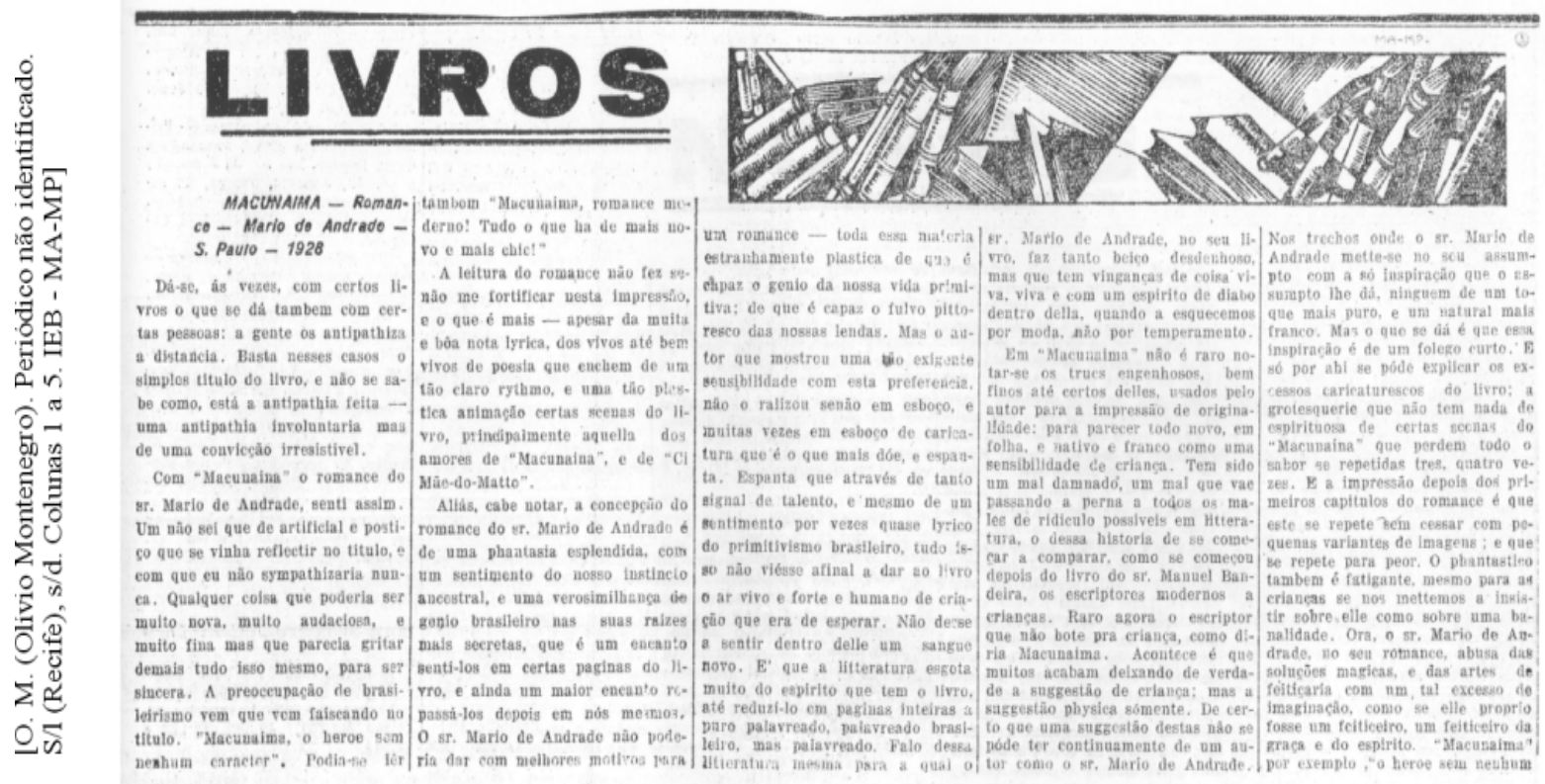

Em sua avaliação, o crítico conclui que Mário de Andrade, ao “explorar demais com o gênio muito dramaticamente supersticioso da raça, e com o novo e o pitoresco da nossa linguagem, atrás de efeitos”, ao “carregar opressivamente em brasileirismos de expressão, muitos deles por sinal bem deselegantes e bem feios”, para não perder a sugestão de "moleque brasileiro”, não encontrara "uma imagem mais simpática do seu espírito”, ficando no pitoresco e no convencional. 
Na abertura do artigo, O. M. já indicara o tipo de convencionalismo que, a seu ver, impregna a obra de Mário de Andrade e que provocara sua antipatia antes mesmo da leitura: “a preocupação de brasileirismo”, percebida no título do livro. Parodiando-o ironicamente na forma de um anúncio publicitário - "Macunaíma, romance moderno! Tudo o que há de mais novo e mais chic!” -, o crítico pernambucano deixa entrever que sua antipatia prévia decorria de seus preconceitos antimodernistas ou ao menos contrários ao modernismo consubstanciado no livro de Mário de Andrade, sobre o qual, por fim, sentenciou que, "feito de motivos do povo, não será nunca um livro popular.”

Adiante, voltaremos a discutir o artigo de Olívio Montenegro, cotejando-o com os demais documentos da fortuna crítica pioneira de Macunaíma, cujas resenhas aqui se completam. 


\section{ACHADOS E PERDIDOS}

Treze pronunciamentos constituem a fortuna crítica pioneira de Macunaíma, a dos autores que se manifestaram no calor da hora, isto é, no mesmo ano da primeira edição da rapsódia de Mário de Andrade. O primeiro deles, se for correta a hipótese de Silviano Santiago, como pretendemos haver demonstrado, tem como autor o próprio artista. Assim sendo, como afirmou o crítico mineiro, é “o próprio autor de Macunaíma quem primeiro define a bitola crítica por onde deve passar a justa avaliação da obra”45.

Tomemos de empréstimo a hipótese do autor de Nas malhas da letra. Nessa perspectiva, a “justa avaliação da obra” deveria levar em conta o material de que ela é composta, associado à inflexão nacionalista, a especificidade do gênero, o método ou estrutura de composição e a peculiaridade do narrador; deveria examinar também o protagonista e sua respectiva ausência de caráter, como propriedade que decide o destino do herói. Além desses elementos, a primeiríssima recepção a Macunaíma ainda destaca como relevante a matéria pornográfica contida na obra, se isso se pode depreender da ponderação de que se tratava de "uma sátira um pouco crua para poder cair nas mãos de qualquer pessoa”. Tais são os elementos do livro, destacados na matéria do Diário Nacional, que teriam ensejado a composição de uma obra das “mais originais da nossa literatura”.

As observações da recepção inaugural são sumárias, adequadas à divulgação jornalística a que se destinavam. Os elementos especificados não são discutidos, mas apresentados sob aspectos que implicam uma certa orientação para a análise crítica da obra. Examinemos, primeiro, os pontos levantados e vejamos como eles foram abordados pelos demais críticos pioneiros; posteriormente, na terceira seção deste capítulo, iremos confrontá-los, no que for pertinente, com comentários de Mário de Andrade, presentes na correspondência e em outros escritos seus da mesma época, como os dois prefácios referidos no artigo de Tristão de Ataíde, que consideraremos como prospecções do próprio artista para a avaliação crítica de sua obra.

\footnotetext{
${ }^{45}$ SAnTiago, Silviano. "A trajetória de um livro”. In: ANDRADE, Mário de. Macunaíma, o herói sem nenhum caráter. Ed. cit., 1997, p. 185.
} 


\section{ROMANCE, QUE ROMANCE?}

Como vimos na matéria do Diário Nacional, em que Mário de Andrade se ocultara no anonimato, o livro recém-lançado foi definido, quanto ao gênero, como um "romance”. No prefácio datado de 19 de dezembro de 1926, Mário de Andrade usara o vocábulo “romancinho” para referir-se à obra e, num manuscrito que contém dedicatória a Paulo Prado e a José de Alencar, registrara a designação “romance”, riscada e substituída por "história”, por fim escolhida para qualificar o gênero no verso da página de rosto da primeira edição.

Para Telê Porto Ancona Lopez, na "Introdução" de sua primeira edição crítica de $M a-$ cunaíma, a troca de "romance” por "história” talvez decorresse de cautela do autor, no esforço de evitar que o leitor associasse a obra à "compreensão convencional”46 do gênero romanesco, pois o artista jamais a considerara desse modo. No mesmo passo, a pesquisadora historiou as hesitações de Mário de Andrade, até que ele chegasse à classificação de rapsódia para fixar o gênero da obra, em 1937, na oportunidade da segunda edição do livro.

Assim, no prefácio de 1926, embora se valesse da noção de “rapsodismo popular”, para caracterizar o estilo praticado conscientemente, e de "literaturas rapsódicas e religiosas" em geral, para justificar com esses modelos certa orientação seguida no aproveitamento de matéria pornográfica, Mário de Andrade não ousara definir seu livro como uma rapsódia. No entanto, essa classificação estava implícita na definição de "romancinho", usada no mesmo prefácio, e de "história”, no referido manuscrito e na primeira edição.

Que tipo de romance então seria aquele? Conforme observou Telê Porto Ancona Lopez, o próprio autor esclarecera, no artigo “A Raimundo de Moraes”47 (Diário Nacional: São Paulo, 20 de setembro de 1931), que, ao topar com o herói indígena na leitura de KochGrünberg, tivera a idéia de “fazer do Macunaíma um herói, não de 'romance’ no sentido literário da palavra, mas de 'romance’ no sentido folclórico do termo.” Esse mesmo artigo deixa evidente que Mário, como autor de Macunaíma, considerava-se um rapsodo, aspecto frisado na advertência de que a criação da obra fora orientada pela “preocupação rapsódica”.

Já na edição de 14 de julho de 1928, do Diário Nacional, Mário de Andrade estampara um excerto da obra para anunciar sua próxima exposição nas livrarias, apresentando-a como “romance folclórico”. Desse modo, a indicação do gênero contida na primeira recepção crítica

\footnotetext{
${ }^{46}$ Lopez, Telê Porto Ancona. “Introdução”. In: Andrade, Mário de. Macunaíma. Ed. crítica de Telê P. A. Lopez. Ed. cit., 1978, p. XIX.

${ }^{47}$ AnDrade, Mário de. “A Raimundo Moraes”. In: Táxi e crônicas no Diário Nacional. Estabelecimento de texto, introdução e notas de Telê Porto Ancona Lopez. São Paulo: Duas Cidades / Secretaria da Cultura, Ciência e Tecnologia, 1976, p. 434.
} 
de Macunaíma não invalida a hipótese de autoria levantada por Silviano Santiago, antes a confirma, desde que por "romance” não se entenda o gênero culto convencional.

Agora, tampouco se deve entender a obra como um "romance folclórico" na acepção de literatura popular tradicional. Mário de Andrade utilizou essa expressão de modo vago e impróprio naquele excerto destinado à divulgação da obra nas vésperas de seu lançamento (Diário Nacional, 14 de julho de 1928); também impropriamente, em uma nota do prefácio de 1926, chegou a considerar seu livro como uma "antologia do folclore brasileiro"48.

Telê Porto Ancona Lopez bem advertiu que Mário de Andrade sempre teve consciência de que Macunaíma era uma criação culta, “construída conforme as histórias populares”49. Na crítica inaugural, o vocábulo "romance” seria fatalmente entendido pelos leitores na acepção de literatura culta, se não se associasse o gênero à informação de que a matéria da obra fora tirada de "um ciclo de tradições sobre um herói [indígena] chamado Macunaíma” e de “outras lendas brasileiras”. Esse vínculo poderia corrigir o entendimento do leitor para algo mais próximo do caráter legítimo do gênero da obra, em que se dá um encontro entre popular e erudito, sugerido na seguinte passagem do artigo: "E é com a cena de encontro entre o papagaio e o autor que o romance acaba”. Nesse contexto, o papagaio e o autor figurado são imagens para, respectivamente, a tradição popular de transmissão oral e a alta literatura.

A conclusão do texto não deixa dúvida sobre a inserção de Macunaíma na esfera da literatura brasileira culta, bem como sobre o fato de se tratar de um "romance” nada convencional, considerado, vale repetir, “uma das obras mais originais da nossa literatura”.

Seja como for, o documento inaugural da fortuna de Macunaíma, testemunho de Mário de Andrade disfarçado em crítica, manifesta, em relação ao gênero, o mesmo estágio conceitual que se encontra em outros textos do autor, escritos na mesma época. A classificação definitiva do gênero, especulou certeiramente Telê Ancona Lopez na citada “Introdução” à primeira edição crítica de Macunaíma, foi decorrência do amadurecimento das reflexões do autor, subsidiadas pelos pronunciamentos da crítica.

Vejamos como as análises pioneiras lidaram com o gênero e a respectiva relação com a matéria folclórica da obra, bem como com elementos de sua estrutura e composição. Além de indiciar a riqueza da obra, a diversidade de opiniões contém achados preciosos para a sua

\footnotetext{
${ }^{48}$ ANDRADE, Mário de. Nota ao Prefácio datado de 19 de dezembro de 1926 . In: BATISTA, Marta Rossetti et alli (org.). Op. cit., 1972, p. 290. As citações de ambos os prefácios serão colhidas nessa edição, salvo indicação contrária.

${ }^{49}$ LOPEZ, Telê Porto Ancona. “Introdução”. In: Andrade, Mário de. Macunaíma. Op. cit., 1978, p. XIX.
} 
compreensão, mas indica também certo desnorteio de alguns críticos perante a narrativa inusitada de Macunaíma.

\section{EM BUSCA DO GÊNERO}

Augusto Frederico Schmidt, após quatro meses de reflexão, concluiu que não era possível enquadrar a obra e se absteve de classificá-la quanto ao gênero, por considerá-la, assim como o protagonista, “a própria indeterminação”. Cândido Motta Filho também não soube classificá-la. O modo como contornou o problema denuncia sua perplexidade diante da narrativa, desagradável aos seus "velhos preconceitos culturais” confessos: em vez de arriscar uma definição, referiu-se a Macunaíma invariavelmente como "livro", a ponto de sobrecarregar o curto primeiro parágrafo de seu texto com oito repetições desse vocábulo, como se estivesse medusado pela obra estranha que o confrontava.

No artigo de 13 de setembro de 1928 (Folha Acadêmica, cit.), terceiro da fortuna desde a publicação de Macunaíma, assinado com as iniciais J. P., o então jovem João Pacheco abrigou-se confortavelmente na lição do próprio artista, estampada no verso da página de rosto da primeira edição, onde a obra é classificada como "história”. J. P. entendeu por essa noção algo assemelhado às histórias infantis transmitidas por meio da tradição oral, estabelecendo assim uma conexão entre a "história” de Mário de Andrade e as narrativas do folclore, sem aferir, todavia, em que medida e em que sentido tal vínculo se daria, exceto pela indicação de certas qualidades compartilhadas por ambas, especialmente a articulação seriada de episódios ("histórias compridas que continuam no dia seguinte”) e o conteúdo sapiencial das narrativas que “ensinam o que os outros sábios estão estudando para saber”.

Nestor Vítor, João Ribeiro, Ascenso Ferreira e José Vieira também se utilizaram do vocábulo "história” para designar a obra então recém-lançada, mas só o poeta de Catimbó o empregou com o sentido que lhe dá João Pacheco ou, melhor, com aquele que lhe deu vagamente Mário de Andrade ao classificar sua obra como "história”, na edição de 1928. No entanto, todos eles, inclusive Ascenso Ferreira, recorreram preferencialmente a outras noções para indicar o gênero de Macunaíma.

Ao referir-se à obra como uma "história de onça", o poeta pernambucano valeu-se dessa expressão como sinédoque das narrativas folclóricas em que "o fantástico da imaginação primitiva resolve as dificuldades mais insuperáveis”. Não se deve concluir daí que ele considerasse Macunaíma como obra folclórica genuína, e sim que, do seu ponto de vista, ela 
se nutrira do repertório tradicional e o autor, transfigurando artisticamente os frutos da pesquisa, adotara a forma da narrativa maravilhosa para refundir o gênero de acordo com "o espírito moderno que o inspirou e permitiu realizar-se”, compreendendo o elemento fantástico como mediação entre “o primitivismo e a realidade moderna”. Para Ascenso Ferreira, Macunaíma teria conseguido pela primeira vez na literatura brasileira o aproveitamento de elementos dispersos do folclore na “construção de uma obra de arte” dotada de uma unidade formidável.

Considerando o livro de Mário na totalidade, Ascenso asseverou que ele constituía “um conjunto poemático verdadeiramente harmonioso”. A unidade da obra é indicada pela noção de “conjunto (...) harmonioso”, ou seja, de um todo cujas partes, apesar de heterogêneas, são articuladas de tal modo que "não há um capítulo insignificante, uma frase oca, uma palavra vã”. Distingue-se, assim, o caráter construtivo da “história de onça” e a natureza dessa construção. De fato, o crítico definiu explicitamente Macunaíma como um “formidável poema”, até mesmo porque a enunciação se lhe afigurava como jogo de "tonalidades combinadas discretamente num sentido de harmonia e de ritmo”, portanto mantendo relações estreitas com a música. Embora sem especificar a espécie de poema que constituiria o gênero da obra de Mário de Andrade, Ascenso reconhece, em suma, a unidade estrutural e estilística nela revelada.

Antes de Ascenso Ferreira, Ronald de Carvalho atribuíra a classificação de poema a Macunaíma, mas o primeiro a se pronunciar desse modo publicamente fora o próprio Mário de Andrade, numa passagem do primeiro prefácio, transcrita na crítica de Tristão de Ataíde (09 de setembro de 1928): “Gastei muito pouca invenção neste poema fácil de escrever”. Ronald de Carvalho nada avançou além da mera definição inespecífica, e naquele momento não se pôde conhecer mais sobre a posição de Mário de Andrade a propósito, pois o artigo de Tristão não mencionou a associação entre o “poema fácil de escrever” e seu respectivo estilo, marcado por “essa fala simples tão sonorizada música mesmo por causa das repetições, que é costume nos livros religiosos e dos cantos estagnados no rapsodismo popular”, conforme se observa no primeiro prefácio. Com a omissão dessa passagem na crítica de Tristão de Ataíde e a decisão de Mário de manter inéditos os prefácios, permaneceu obscura essa conexão intertextual que ajudaria a esclarecer em que sentido Macunaíma poderia ser considerado como um poema.

Ascenso Ferreira assinalou que o livro carecia de distância para ser “apreciado com justeza”, pois, para a crítica sua contemporânea, “desorientada pelos ardores da revolução 
[modernista]”, e mesmo para a crítica vindoura, Macunaíma continuaria "como uma parábola, até que o Brasil acabe de descobrir-se a si mesmo, como o pressente o senhor Tristão de Ataíde.” À parte a estocada na crítica adversa, nomeadamente a de Tristão, que não teria compreendido a obra revolucionária de Mário de Andrade, Ascenso Ferreira, ao associar tal obra com a forma da parábola, estabeleceu uma hipótese de leitura alegórica que, salvo engano, entre os pioneiros da fortuna só ele percebeu, posto que a tônica da crítica recaiu sobre a dimensão simbólica de Macunaíma. Isso talvez porque só ele, entre os pioneiros, exceto o autor da primeiríssima recepção, ou seja, o próprio Mário de Andrade, captou o “espírito satírico da obra” ou, ao menos, referiu-se a ele. O crítico pernambucano, sem talvez ter plena consciência do que fizera, pois não explicitou a noção de alegoria, combinou o que seria uma parábola satírica, implicitamente alegórica, com o aspecto simbólico da obra, uma vez que afirmou, no início de seu texto, ser Macunaíma “um livro profundamente simbolista”.

Os críticos pioneiros ativeram-se ao caráter simbólico, sendo Tristão de Ataíde o primeiro a apontá-lo. Vimos que, contra a posição de Mário de Andrade, explicitada nos prefácios aos quais tivera pleno acesso, o líder católico afirmara: em Macunaíma, o gigante Piaimã representava o imigrante e o herói, “o brasileiro de hoje”, enquanto os três irmãos metamorfoseados pela água mágica do pezão de Sumé constituiriam “um símbolo transparente do Brasil”. Afirmara, também, que o processo de desregionalização incorporado ao livro, o aproveitamento da matéria mítica e lendária brasileira, a combinação de elementos heterogêneos da cultura popular, o "estilo bárbaro" utilizado e os elementos de cultura nacional investidos no protagonista correspondiam à intenção nacionalista, manifesta em toda a obra literária de Mário de Andrade, de pesquisar "para encontrar o Brasil”, de buscar o "caráter que nos distinga na América e nos marque para sempre”. No entanto, o que Mário de Andrade teria conseguido com Macunaíma seria um símbolo parcial do Brasil e do brasileiro. O autor não teria logrado uma “imagem nítida da totalidade nacional”, pois ao conceber o herói como destituído de caráter criara uma imagem do acidental, do pitoresco, que seria expressão da "ebulição fetichista do nosso povo", da "supuração de nossas mazelas ocultas”, “do que é a barbaria dos nossos fermentos em ebulição. O modelo do que devemos ‘combater’ em nós.” Nessa linha de pensamento, Tristão de Ataíde interpretara que Macunaíma expressaria uma visão pessimista do Brasil e do homem brasileiro, em decorrência da "irritação" de Mário de Andrade “contra a nossa falta de caráter”, o que o teria levado a construir uma obra mais de crítico social do que de artista. Tristão de Ataíde, assim, indicou que a obra constituía um gênero híbrido, em que a instância crítica inerente à simbologia do livro misturava-se, "sem os sinais de tese sistemáti- 
ca e antes uma enorme liberdade de composição", com outros gêneros, nomeadamente e por preterição: “Não é um romance, nem um poema, nem uma epopéia”. Essa mescla foi chamada de “um coquetel”, cujo resultado seria uma espécie de retrato médio da "psyche” dos brasileiros, construído por meio da sobreposição de tantas imagens diferentes “que acaba não se parecendo com ninguém.”

Em seu artigo de 10 de dezembro de 1928, José Vieira referiu-se ao livro como "uma odisséia”, não para aproximá-lo ao gênero épico, mas para caracterizar a dificuldade que o leitor desprevenido teria para assimilar qualidades artísticas com as quais não estaria familiarizado, subentendendo-se que essas seriam qualidades próprias ao modernismo. Na trilha aberta por Tristão de Ataíde, Vieira também destacou a natureza híbrida de Macunaíma, mas reduziu o leque de combinações apontadas pelo crítico católico a somente dois gêneros: romance e ensaio.

Quanto à dimensão romanesca, limitou-se a manifestar que, para ele, Macunaíma seria uma espécie de "história do Brasil pelo método confuso", que se apropriara de matéria tradicional para criar uma “brincadeira”. Provavelmente, José Vieira estaria estabelecendo um paralelo com a História do Brasil pelo método confuso ${ }^{50}$, obra de Mendes Fradique, pseudônimo de José Madeira de Freitas. Com isso, estaria atribuindo implicitamente a Macunaíma certas qualidades notáveis da obra de Mendes Fradique, como a paródia, o humor, o disparate, a desordem geográfica, o embaralhamento de épocas e de personagens históricas e a orientação satírica, entre outras características. Mas o crítico paraibano não explorou essa possibilidade de leitura comparativa; deixou de lado a análise estética da obra de Mário de Andrade, só assinalando que o leitor iniciado aplaudiria o “episódio” pela “arte em que foi urdido”, mas “a gente da rua” mal o apreenderia.

Para Vieira, o "romance” revestira a idéia de que "uma língua brasileira” cumpriria função terapêutica contra a doença do estrangeirismo, aflitiva ao país. Essa idéia constituiria o “ensaio” entranhado na ficção. A “sugestão, mesmo tentativa de uma língua brasileira, combinada de elementos vindos de todo o país” pareceu-lhe o modo pelo qual Mário de Andrade realizara a fórmula curativa. No entanto, tal fórmula haveria fracassado. O crítico, embora compartilhasse com Mário a convicção de que a língua portuguesa, ao adaptar-se no Brasil, ganhara feição diversa do padrão lusitano e reconhecesse o valor de Macunaíma como a

\footnotetext{
${ }^{50}$ FradiQUe, Mendes (pseudônimo de José Madeira de Freitas). História do Brasil pelo método confuso. Isabel Lustosa (org.). São Paulo: Companhia das Letras, 2004. Publicada em folhetins pela revista carioca D. Quixote, a partir de 1919. Recolhida em livro em 1920 (Rio de Janeiro: Editora Leite Ribeiro), fez sucesso ao longo de toda a década, o que é atestado pelas várias edições lançadas no período: em 1928, havia ultrapassado a sétima.
} 
“mais rica recolta” dessa língua brasílica, reprovou o resultado obtido, considerando-o exagerado no abrasileiramento. Na sua avaliação, a língua registrada na obra não ultrapassara o registro "pitoresco, engraçado, bonito", parecendo-lhe desajeitada, mal-arrumada, por força da falta de critério na absorção do material e da ausência de sistematização, decorrentes do “partidarismo modernista”, que colocara "no mesmo plano uma estética revolucionária e uma propaganda filológica”.

A “estética revolucionária” teria levado Mário de Andrade a compor um romance diverso do modelo europeu e do estilo acadêmico, um romance anárquico e desarticulado, cujo aspecto destrutivo inviabilizara qualquer intenção construtiva. Assim, José Vieira responsabiliza tal "romance” pelo fracasso do "ensaio", estabelecendo uma estreita relação entre o que considerava desarticulação estrutural do gênero degenerado (com o perdão pelo trocadilho) e o que entendeu por fracasso da idéia. A proposta de construção de uma língua brasileira fora tornada impossível; o material recolhido, tido como bom e até excelente apesar das restrições, ficara desconjuntado, por efeito da composição anárquica do romance, que teria evitado "um trabalho arquitetônico”. José Vieira não percebeu a contradição entre esse juízo e o que ele próprio destacara ao asseverar que o leitor iniciado apreciaria “a arte em que foi urdido” o livro.

O escritor pernambucano Olívio Montenegro, assinando com as iniciais O. M., também qualificou Macunaíma como romance e, tal qual o colega paraibano José Vieira, responsabilizou o modernismo pelo que considerou defeitos do livro. Como vimos anteriormente, O. M. apontou como melhores qualidades da obra de Mário de Andrade os seus elementos poéticos, como o lirismo, o ritmo e a animação plástica de algumas cenas, e a escolha do material lendário, cujo aproveitamento, quando bem-sucedido, teria o dom de propiciar o sentimento do "gênio brasileiro nas suas raízes mais secretas”. Porém, para O. M., tais qualidades só teriam sido realizadas em esboço, devido ao fôlego curto da inspiração de Mário de Andrade, à linguagem excessivamente carregada de brasileirismos e ao convencionalismo modernista.

Esses três fatores combinados teriam levado Mário de Andrade à deformação caricata e grotesca do material, ao padrão fastidiosamente repetitivo do romance e ao seu esgotamento no acúmulo de truques literários, cuja intenção seria a de buscar originalidade, ostensiva no anseio de modernidade do autor, mas o efeito teria sido, em grande medida, o da redução da obra a "puro palavreado, palavreado brasileiro, mas palavreado”. Na perspectiva de O. M., a combinação dos três fatores teria resultado, ainda, num registro nada além de pitoresco e anedótico - que Tristão de Ataíde havia postulado em sua recepção crítica -, quer na linguagem, 
quer na imagem de "moleque brasileiro" refletida pelo protagonista. No início e no final de sua crítica, O. M. atribuiu a Macunaíma um convencionalismo que tornara a obra artificial. Trata-se aqui do tratamento literário dado ao material, que O. M. associou à “moda” modernista $^{51}$, supostamente responsável pela falta de sinceridade do livro.

Olívio Montenegro forçou uma aproximação entre o que chamou de "preocupação com o brasileirismo”, ostentada no título e no subtítulo do livro, e sua caracterização como “romance moderno". Depreende-se nitidamente dessa aproximação uma referência ao movimento modernista, cuja orientação, na segunda metade da década de 1920, concentrava-se num projeto cultural e artístico de acentuado nacionalismo, que tinha em Mário de Andrade uma das figuras de proa. É evidente que a "preocupação com o brasileirismo”, percebida pelo crítico pernambucano como faiscante no título da obra, talvez só o fosse se associada à fama de Mário como expoente do modernismo nacionalista. Aliás, fora exatamente na cidade de Recife, no artigo "Modernismo e ação"52, publicado no Jornal do Commercio em 1925, que Mário de Andrade propusera ao movimento artístico desencadeado em 1922 o desenvolvimento de "certas tendências obscuras ainda naquele tempo [da Semana de Arte Moderna]", evoluindo para uma proposta de "arte de ação”, em que o espírito estivesse "inteiramente voltado para o Brasil”.

A “antipatia involuntária” que o livro provocara no escritor pernambucano fundamenta-se, conforme suas próprias palavras, em uma “convicção irresistível”. Tal seria a de que Macunaíma, apesar de suas virtudes, esgotara-se em artifícios e truques literários, de modo a constituir uma obra insincera, que deixara de ser a criação artística de algo "vivo e forte e humano”, por ser um “romance moderno”, ávido de glamour novidadeiro, caracterizado por uma convencional audácia literária. Assim, O. M. deixa implícito que, a seu critério, a obsessão pelo novo decorreria de uma transposição artificial da literatura vanguardista européia para o modernismo brasileiro.

Nestor Vítor, antes de José Vieira e de Olívio Montenegro, ressaltara o que lhe parecera caráter destrutivo da perspectiva estética adotada por Mário de Andrade, que seria a de "um movimento literário dionisíaco de arremedo”, produzido pela transposição do dadaísmo europeu, impregnado de idéias freudianas, ao Brasil. Concentrando-se na idéia nacionalista inscrita na obra, supostamente geradora de um "neo-indianismo derrotista”, asseverou que, em de-

\footnotetext{
${ }^{51}$ O. M. não se valeu do vocábulo "modernista”. No entanto, o significado do termo está claramente inscrito em expressões utilizadas pelo crítico, como "romance moderno" ou "escritores modernos".

52 ANDRADE, Mário de. "Modernismo e ação". Jornal do Commercio: Recife, 24 de maio de 1925. Recolhido em: AzevêDo, Neroaldo Pontes de. Modernismo e regionalismo (Os anos 20 em Pernambuco). João Pessoa: Secretaria de Educação e Cultura da Paraíba, 1984, p. 223-225.
} 
corrência da opção dadá-freudiana, “o índio torna-se símbolo antecipado da nossa segura bancarrota como povo no correr dos séculos”. Como se vê, Nestor Vítor reduziu a imagem de complexa constituição étnica e cultural investida em Macunaíma a um só de seus elementos formadores, o índio, que o crítico paranaense compreendia, segundo os preconceitos cientificistas do século XIX, como “criança que se vende ou vende os seus por um espelhinho”, ou até mesmo um ser “reduzido a um bicho abjeto”.

Quanto ao gênero da obra, Nestor Vítor ficou indeciso. Chamou-a de "história”, como antecipamos, e recusou a classificação de "brincadeira” - atribuída por Mário de Andrade nos prefácios e divulgada por Tristão de Ataíde -, em virtude do material da nossa cultura popular recolhido em suas páginas, tidas como “uma mina para futuros escritores”. Nestor Vítor compreendeu a expressão “brincadeira” em sua acepção banal e não questionou o que Mário entenderia por ela. O mesmo ocorreu com os demais críticos que tocaram nessa questão: Tristão de Ataíde, José Vieira e João Ribeiro.

O primeiro limitou-se a registrar a presença de tal noção nos dois prefácios de Mário de Andrade e a interpretar que o segundo prefácio, embora ratificasse a classificação de "brincadeira” contida no primeiro, em última análise, retificava-a, pois o autor passara a ver sua obra como algo sério, pelas idéias críticas que continha sobre o caráter do homem brasileiro e sobre a cultura nacional.

José Vieira só de passagem valeu-se da expressão, para confirmar que o livro era a “brincadeira de umas tradições barbudas”, ou seja, antigas, referindo-se, certamente, ao material da cultura popular aproveitado na obra. Depreende-se daí que o crítico entendeu a "brincadeira”, vagamente, como modo travesso e divertido de lidar com o material folclórico recolhido.

Agora, é de estranhar que João Ribeiro, folclorista notável, haja tratado a hipótese andradiana - de Macunaíma ser uma "brincadeira” - com a mesma ligeireza dos colegas, sem averiguar as possíveis conexões dessa noção com o que se entende por ela no âmbito dos estudos da cultura popular, campo do saber em que o crítico se distingue como autor de uma obra de referência, onde são examinados os folguedos populares conhecidos por "brincadeira”, segundo informa Câmara Cascudo ${ }^{53}$. Por fim, João Ribeiro também não soube classificar o gênero de Macunaíma, referindo-se à obra como "brincadeira”, em caracteres itálicos, para indicar que se tratava de designação atribuída por Mário de Andrade, ou como “romance”,

\footnotetext{
${ }^{53}$ RiBeiro, João. O folclore. Rio de Janeiro: (?), 1919. Apud CASCUDo, Luís da Câmara. Dicionário do folclore brasileiro. $2^{\underline{a}}$ ed. Rio de Janeiro: INL, 1962, p. 137, vol. 1.
} 
mas, nesse caso, de modo condicional, conforme patenteou em sua apreciação: “... romance (se acaso é romance)...”

No caminho aberto por Tristão de Ataíde, Augusto Frederico Schmidt considerou Macunaíma "mais obra de crítico". Com isso, mesmo eximindo-se de arriscar uma classificação, o poeta de Canto do brasileiro evidenciou que também para ele se tratava de uma obra de gênero híbrido. Assim como Tristão e José Vieira, Schmidt entendeu haver desequilíbrio entre ficção e idéia. A primeira, ou seja, o trabalho de criação artística, fora sacrificada em favor da segunda, que consistiria num programa nacionalista preestabelecido, fundamentado na pesquisa, à “procura de uma expressão verdadeiramente nacional”. José Vieira reduziu essa procura ao elemento lingüístico; Schmidt, na linha de Tristão de Ataíde, buscou entendê-la de modo mais amplo, abrangendo a língua e tudo que implicasse particularidades do Brasil e de sua gente.

Segundo Schmidt, Mário de Andrade compusera "um livro que é de arte (e não é de arte também)”, mas, ao sobrepor um programa de crítico ao trabalho artístico, teria deixado de fora “o que se pode chamar propriamente de imaginação criadora” e imposto à natureza indeterminada e espontânea do protagonista a sua própria índole lúcida e “determinista” de autor em busca da "verdade, pelo menos brasileira”. Essa razão, segundo Schmidt, não consentira “que Mário de Andrade escrevesse um livro genial”, conclusão que pode ser entendida como lítotes. Depreende-se que o crítico desmereceu Macunaíma como obra de arte, assim como sugeriu desqualificar o alcance crítico da obra ao formular a seguinte pergunta retórica: "Não será um esforço inútil este [trabalho crítico] em que [Mário de Andrade] se empenha?”.

Como vimos na primeira parte deste capítulo, foi António de Alcântara Machado o primeiro a classificar publicamente Macunaíma, quanto ao gênero, como uma rapsódia. Oswald de Andrade não esteve longe disso ao associar a obra de Mário à Odisséia. Ao estabelecer tal vínculo, o poeta de Pau Brasil convida, por metonímia, a uma reflexão sobre o gênero, que pressupõe um diálogo com a alta tradição épica e mítica da narrativa ocidental. Alcântara Machado, porém, caracterizou Macunaíma como “rapsódia nacionar (com o r bem rolado)”, de modo a destacar a relação próxima que entendeu haver entre o livro de Mário e a tradição popular nacional dos cantadores, sugerida ao crítico pelo aspecto musical da linguagem poética de Macunaíma.

João Ribeiro, ao demonstrar os desvios propositais cometidos por Mário de Andrade na narrativa das peripécias do herói sem nenhum caráter em relação às matrizes recolhidas por Koch-Grünberg, assinalou que, em Macunaíma, a mistura de mitos indígenas americanos com 
o folclore “do caboclo, do negro e do branco" urdira uma narrativa assemelhada aos "embustes de Malasartes”, entendidos como “epigonia mediterrânea das aventuras do astuto Ulisses”. Como é sabido, Pedro Malasartes é o herói cíclico de um sem-número de contos populares, difundidos por todo o Brasil. Personagem de vasta tradição no folclore europeu, Malasartes tem em comum com o herói da Odisséia o espírito ladino, mas, segundo conjectura de Luís da Câmara Cascudo ${ }^{54}$, sua origem mais remota estaria no anedotário italiano, francês, espanhol e português, que apresentava o apóstolo São Pedro como finório. Herói de narrativas populares, Pedro Malasartes foi incorporado à literatura culta por vários autores, destacando-se dentre eles Miguel de Cervantes Saavedra, com a sua Comedia famosa de Pedro de Urdemalas, publicada em 1615. De Portugal, o manhoso Malasartes foi transmitido ao Brasil, onde se adaptou e difundiu nacionalmente, incorporado ao nosso imaginário popular, quer no meio urbano, quer no sertanejo. João Ribeiro, com sua observação sobre a semelhança entre Macunaíma e as peripécias de Pedro Malasartes, remotamente associadas às de Odisseu, sugeriu haver na obra de Mário um diálogo multicultural em que se misturam várias tradições universais, quer de origem popular, quer enraizadas na alta literatura, embora haja considerado absurdo esse diálogo e descosida a urdidura narrativa.

Nestor Vítor também aproximou as estrepolias de Macunaíma às aventuras de Malasartes, mas restringiu a associação a uma possível semelhança com Malazartes (1911), peça de teatro de Graça Aranha, traduzida para o francês e publicada na França em 1920, detalhe que bem representa a incorporação do herói popular ao repertório da nossa literatura culta, sem que isso implique qualquer juízo de valor sobre tal obra dramática. O crítico paranaense viu semelhança, ainda, com “os contos orientais”, referindo-se, provavelmente, às Mil e uma noites. Se for correta essa conjectura, estaria implícita na associação de Nestor Vítor a percepção da estruturação episódica da narrativa; se tal hipótese for incorreta, as demais aproximações feitas pelo crítico validam nossa observação. Como já vimos, a leitura de Macunaíma despertou em Nestor Vítor a lembrança das "lendas da Idade Média, Gargantua e Pantagruel, de Rabelais, Peer Gynt, de Ibsen”, obras cujas enunciações se perfazem por meio da articulação justaposta de peripécias. Além do caráter episódico da narrativa de Mário de Andrade, as observações e associações feitas por Nestor Vítor são ricas em sugestões críticas. Nesse senti-

\footnotetext{
${ }^{54}$ CASCUDO, Luís da Câmara. Dicionário do folclore brasileiro. Op. cit., p. 445-446, vol. 2.
} 
do, ele descortinou linhas de pesquisa de literatura comparada que esperaram décadas para ser desenvolvidas por estudiosos de Macunaíma ou ainda esperam por quem delas se ocupe. ${ }^{55}$

\section{SOBRE O TRABALHO ARTÍSTICO: ESTRUTURA E COMPOSIÇÃO}

Se as considerações pioneiras sobre o gênero foram profusas e variadas, as opiniões sobre a estrutura e a composição dividem-se em três categorias. Num extremo, alinham-se os que radicalmente negaram a Macunaíma o reconhecimento de qualquer trabalho arquitetônico, como é o caso de José Vieira. É certo que o crítico paraibano referiu-se sobretudo ao aspecto da língua, mas a suposta ausência de sistematização sintática dessa é apontada como decorrência do que, em seu parecer, era desarticulação da narrativa, intencionalmente composta por intermédio do “método confuso", em que discerniu a prática de um modernismo anárquico e destruidor das formas canônicas. Na mesma linha, Cândido Motta Filho asseverou que Macunaíma é um livro desconexo, descomposto e repetitivo, sem perceber que essa última característica, atribuída explicitamente ao estilo e implicitamente à estrutura narrativa, poderia ser entendida como mediação articuladora dos elementos fragmentários. João Ribeiro, como vimos, foi o mais áspero dos críticos ao assegurar que Macunaíma não passaria de uma reunião de fragmentos desconexos e incongruentes, a que faltaria toda ordem ou aptidão coordenadora.

João Pacheco (J. P.) e Ascenso Ferreira representam o extremo oposto, em que a obra é apreciada por sua construção primorosa. O primeiro não foi além da mera afirmação disso; já o segundo esboçou uma justificativa para essa asserção ao apontar a circularidade da narrativa, cujo fim retorna ao ponto de partida, como imagem de seu caráter construtivo, o equilíbrio de idéias como fator de organização do material heterogêneo e a linguagem poética como determinante de unidade de uma obra de arte exemplar, em que não haveria "um capítulo insignificante, uma frase oca, uma palavra vã.”

Em posições intermediárias, situaram-se Tristão de Ataíde, Nestor Vítor, Augusto Frederico Schmidt e Olívio Montenegro (O. M.). Para esse último, o "romance” revelava a concepção de "uma fantasia esplêndida”, o que pode ser entendido como imaginação criadora e, portanto, espírito ou princípio construtivo. No entanto, a prática teria sido prejudicada pela suposta inspiração de fôlego curto, a qual teria resultado na alternância entre passagens feli-

\footnotetext{
${ }^{55}$ A associação de Macunaíma com o lendário medieval foi estudada por SouZA, Gilda de Melo e. O tupi e o alaúde. São Paulo: Duas Cidades, 1979; a conexão com as obras de Rabelais, por CAMARGo, Suzana. Macunaíma - ruptura e tradição. São Paulo: Massao Ohno/João Farkas editores, 1977.
} 
zes, pela vivacidade lírica nelas contida, e excessivos truques literários modernistas - empregados na busca ansiosa de originalidade, mas que resultavam em artificialismo -, associados à repetição incessante dos mesmos elementos compositivos, com destaque para o fantástico e para a expressão lingüística, carregada “opressivamente em brasileirismos”. Depreende-se daí que, para O. M., seria frouxa e desigual a estrutura compositiva de Macunaíma.

No que pareceu a João Ribeiro carência de qualquer ordenação de "um próximo hóspede de manicômio", Augusto Frederico Schmidt encontrou o toque de lucidez e a capacidade de organização de Mário de Andrade, mas para apontar nessa lucidez construtiva a falta de “imaginação criadora”, não entendida pelo crítico como princípio construtivo, no sentido sugerido por Olívio Montenegro, mas como uma espécie de chamado de "vozes profundas”, portadoras do que haveria de mais “íntimo e irredutível” no homem. Como Schmidt ressaltou, a aparente simplicidade da narrativa fora resultado de intenso trabalho, em que o autor se esforçara para esconder a complexa "significação da obra”. Porém esse trabalho, menos de artista e "mais de crítico", na busca de "uma expressão verdadeiramente nacional”, teria prejudicado a ficção, constrangida a limitar-se ao "apenas pitoresco”, em vez de alcançar "alguma coisa de mais amplo, (...) mais significativa como símbolo de espírito, de feição, de subconsciente nacional”.

Segundo Schmidt, o atormentado “desejo do real” de Mário de Andrade impusera-se à ficção, para que Macunaíma expressasse a “verdade, pelo menos a brasileira”, buscada pelo autor. E como julga haver desencontro entre a espontaneidade do herói, desinteressado de qualquer verdade, e a intromissão do espírito "lúcido e determinista” do autor, à procura da verdade brasileira, Schmidt postula que Macunaíma deixara de ser “um livro genial” em virtude do desequilíbrio entre o “desejo do real” do autor e a desejável autonomia da ficção. Na perspectiva de Augusto Frederico Schmidt, a composição demasiadamente organizada de idéias nacionalistas preestabelecidas, embora ocultas sob a enunciação ficcional, seriam incompatíveis com a natureza da ficção, especialmente no caso de uma narrativa centrada num herói tão espontâneo e instintivo. O suposto desequilíbrio estrutural da obra teria resultado dessa incompatibilidade.

Nestor Vítor aponta o “processo onírico” como princípio compositivo de Macunaíma. Reconhece, portanto, haver uma lógica arquitetônica, embora excêntrica, inerente à narrativa. A excentricidade estaria justamente na articulação da narrativa por meio do "processo onírico”, entendido como radicalização de “um modo de pensamento regressivo (...) próprio à criança como à gente primitiva”, em que os limites do mundo natural - as dimensões conhecidas 
de tempo e espaço - são suspensos para tornar possível o impossível. O crítico paranaense, nitidamente, considera bem-sucedido o intento de Mário de Andrade, mas só até à metade da obra, mais exatamente até ao capítulo “Carta pras Icamiabas”, julgado “uma falta imperdoável na estética do livro". Como efeito dessa quebra de unidade artística, a retomada da "verve” anterior à "Carta pras Icamiabas” na segunda metade do livro pareceu a Nestor Vítor "falsa cada vez mais”, tornando penosa e enfadonha a leitura até o fim.

Para ele, o crescente artificialismo notado na segunda metade da obra patenteava o arremedo do dionisismo dadá, associado ao "furioso freudismo" adotado pela corrente do modernismo brasileiro a que se filiava Macunaíma e que Nestor Vítor chamou de "neoindianismo derrotista”. O intuito construtivo de "conceber literariamente o Brasil como entidade homogênea” teria, assim, colidido com a prática de uma estética demolidora, “de alcance moral com as possibilidades as mais dissolventes”.

Como vimos anteriormente, Tristão de Ataíde asseverou que a estrutura toda do livro consistia na reprodução das aventuras do herói indígena Makunaima, registradas na obra de Koch-Grünberg, com a ressalva de que não se tratava de "simplesmente uma romanceação de lendas amazônicas”, mas de algo bem mais complexo, que implicara vasta pesquisa e dedicada reflexão em busca de uma expressão, de um herói e de uma cultura nacionais; procura manifesta no livro com “enorme liberdade de composição”, sem “sinais de tese sistemática”.

Não obstante o reconhecimento de tal complexidade e liberdade, Tristão de Ataíde afirmou que o livro evidenciava "enorme facilidade de composição”, pretendendo escorar essa assertiva com um trecho do primeiro prefácio, em que Mário de Andrade declara haver gasto “muito pouca invenção neste poema fácil de escrever”. O crítico aceitou essa observação liminarmente, sem questioná-la, sem examinar possíveis mediações contidas nela, mesmo informado do intenso trabalho de Mário com as reescrituras da obra até que ela chegasse à versão dada ao prelo. Associou implicitamente a suposta facilidade de composição ao que, também por suposto, seria o procedimento estruturador da narrativa: a reprodução dos mitos caribes colhidos por Koch-Grünberg. A composição seria fácil porque estruturada pelo processo de "reprodução" dessa fonte germânica misturada a outras de variada procedência (“um coquetel”). Mesmo resguardado o enfático reconhecimento de que esse material fora aproveitado artisticamente de modo legítimo, mesmo proclamando a "enorme liberdade de composição” da obra, Tristão de Ataíde não percebeu, de fato, a liberdade com que Mário de Andrade lidara com as matrizes compulsadas na obra do estudioso alemão e em outras fontes, e foi corrigido, discretamente, por João Ribeiro, que enfatizou as profundas deformações dos mitos 
ameríndios promovidas por Mário: “as analogias com o conto indígena são muito apagadas e quase inexistem. [§] O autor urdiu um livro original (...)”.

Como leitor privilegiado dos prefácios, porém, Tristão de Ataíde pôde destacar que, por intermédio de um deliberado processo de desordenação de elementos estruturais, Mário de Andrade almejara alcançar "o mérito de conceber literariamente o Brasil como entidade homogênea = um concerto étnico nacional e geográfico” (nota do primeiro prefácio). Mário, assim, manifestou a consciência de que seu livro era uma obra de arte, um trabalho de concepção unitária, em que Tristão de Ataíde reconheceu o processo de desgeograficação, "no clima, na flora, na fauna, no homem, na lenda, na tradição histórica” (nota do primeiro prefácio), isto é, a prática da desordenação calculada, como fazer construtivo da unidade "que há por vezes magnificamente no livro”.

Ao lado da "reprodução", Tristão de Ataíde discerniu como outro procedimento arquitetônico decisivo na construção da narrativa a combinação ou mistura de material heterogêneo da cultura brasileira, especialmente de origem popular. No entanto, ao considerar o livro "longo demais”, “cacete muitas vezes como na imensa carta, em estilo médico-purista, que o nosso herói escreve às suas súditas do Uraricoera”, além de excessivo na "pornografia muitas vezes dispensável”, sugeriu claramente que, na sua opinião, faltaria concisão a Macunaíma. Mais, ao restringir o caráter unitário do livro a ocorrências esporádicas (“por vezes”) e ao entender que a combinação por mistura ou sobreposição "de elementos os mais disparatados” teria resultado numa imagem irreconhecível do Brasil, indicou que haveria desequilíbrio na estrutura compositiva da obra, à qual faltariam coesão e clareza.

\section{A LÍNGUA DE MACUNAÍMA}

Se, quanto à estrutura e à composição de Macunaíma, os críticos pioneiros se dividiram nas três posições apontadas, a questão da língua também suscitou divergências. Em geral, os que se ocuparam desse tópico foram unânimes no reconhecimento da orientação nacionalista aplicada ao idioma. Mário de Andrade foi o primeiro a registrar tal orientação, quer na crítica inaugural da fortuna, atribuída a ele, quer em certas observações contidas em trechos dos prefácios, citadas na matéria de Tristão de Ataíde, a exemplo da passagem em que a língua é considerada um dos suportes da buscada “entidade psíquica permanente” dos brasileiros (primeiro prefácio). 
Quem mais extensamente dedicou-se ao tema da língua foi José Vieira. Como vimos, o crítico paraibano entendeu que Macunaíma conteria uma "propaganda filológica” em favor de “uma língua brasileira”, mas, na prática, a realização da idéia teria malogrado. Embora ressalvasse os excelentes resultados obtidos quanto ao inventário léxico (“a mais rica recolta”) e quanto à nacionalização granjeada por meio do processo de desregionalização (“aqui Macunaíma dá lição”), Vieira asseverou que a valorização de brasileirismos, tais como vocábulos de origem indígena ou africana misturados com neologismos e “cacoetes de expressão”, fora excessiva e desprovida de sistematização, constituindo-se num conjunto “desbragado”. A língua de Macunaíma teria falhado como “instrumento de comunicação de idéias”, por ser "uma mata intrincada, de acesso difícil”, aspecto decorrente da desarticulação sintática, associada ao preconceito antigramatical modernista.

João Ribeiro considerou relevante a “distinção da língua falada e da escrita”, mas apontou como defeitos "a concupiscência de termos tupis verdadeiros e fictícios de pura invenção, extra-regionalismos discordantes, e absurdos inefáveis”. Em que pese essa ressalva, o crítico veterano elogiou a “facilidade comunicativa” do artista, ao contrário da opinião de José Vieira.

Oswald de Andrade ressaltou o caráter inventivo da língua experimental de Macunaíma, ao consignar que Mário de Andrade criara o "idioma poético nacional” válido para os cinqüenta anos seguintes, no que as avaliações de António de Alcântara Machado e de Ascenso Ferreira foram concordes, mas sem prescreverem prazo de validade para as conquistas alcançadas.

Nestor Vítor compartilhou com José Vieira a admiração pelo vocabulário de Macunaíma, no qual discerniu "uma riqueza como ainda não se tinha visto em livro nenhum”. O escritor paranaense destacou a oralidade como característica notável da expressão lingüística, ao entender que essa seria uma talentosa síntese léxica e sintática própria "ao falar do nosso povo do mato”. Todavia, o elogio é dissolvido na consideração de que no livro “quase tudo é escrito como se fosse por um nosso caipira”, associada à suposição de que isso decorreria da intenção modernista de substituir a "linguagem portuguesa pela geringonça do nosso jeca”. A carga pejorativa dos vocábulos empregados (“caipira”, “geringonça”, “jeca”) revela a última instância de avaliação, desfavorável à experiência lingüística de Mário de Andrade.

Antes de Nestor Vítor, Tristão de Ataíde louvara certos aspectos da busca andradiana “por uma expressão nacional”, reconhecendo no episódio do pezão de Sumé a composição de um “quadro magnífico de expressão literária, em ritmo poético bárbaro, de grande efeito”. No 
entanto, em sua avaliação final, Ataíde, assim como Nestor Vítor fez depois, entendeu que Mário de Andrade, no esforço de escrever em “uma língua tão 'nossa””, ficara muito aquém da meta, pois a língua de Macunaíma restringira-se à condição de "língua de candomblé”. Tristão assinalou que a “"verve’ de expressão”, em última análise, pertenceria exclusivamente ao próprio artista, mas revelaria a "barbaria dos nossos fermentos em ebulição".

\section{LITERATURA E REALIDADE}

Esse último comentário de Tristão de Ataíde implica o estabelecimento de uma conexão entre ficção e realidade que toda a crítica pioneira destacou, com maior ou menor ênfase, ao compreender Macunaíma como uma imagem literária do país. Todavia, também aqui houve divergência. De um lado, situaram-se os que repudiaram a imagem construída por considerá-la insuficiente ou falsa; no lado oposto, os que a saudaram como bem ajustada ao referente. No primeiro grupo, alinharam-se Tristão de Ataíde, Cândido Motta Filho, Nestor Vítor, João Ribeiro, José Vieira, Olívio Montenegro e Augusto Frederico Schmidt; no segundo, João Pacheco, António de Alcântara Machado, Ronald de Carvalho e Ascenso Ferreira.

O argumento de Tristão de Ataíde balizou os comentários do primeiro grupo. Segundo o crítico católico, Mário de Andrade, consciente ou subconscientemente, tivera a intenção de simbolizar o país e o povo brasileiro em Macunaíma, mas o símbolo resultara parcial, representativo só da face primitiva do Brasil e de sua gente, revelador apenas do "instintivismo, tão adaptado à mentalidade e às inclinações de nossos dias”, que expressaria complacência com a “ebulição fetichista do nosso povo”. Tal "retrato... do Brasil”, limitado à precariedade e vincado “principalmente pelo espírito das macumbas e pela volúpia da dissolução”, seria proveniente da visão pessimista do artista e teria redundado numa concepção do "totalismo nacional” que seria só dele, Mário, e que deveria ser combatida.

Entre os que seguiram os passos de Ataíde, Cândido Motta Filho acrescentou, nesse particular, que o herói sem nenhum caráter não poderia ser a representação de uma totalidade brasileira, mas tão-somente a de sua face feia e bruta, de sua porção mestiça acanalhada, entregue à volúpia e à pornografia. Nestor Vítor aduziu que Macunaíma deixava patente que a intenção nacionalista, associada ao dionisismo dadá e ao freudismo, era uma tentativa de literatura "em simbiose com as particulares disposições nesse rumo que a guerra em toda parte suscitou”, esclarecendo que se tratava de um estado de espírito mundial, "mais fiado no ins- 
tinto, do que na razão” e de uma orientação “de alcance moral com possibilidades as mais dissolventes".

Para João Ribeiro, não haveria em Macunaíma nem “a moral de hoje nem a de ontem"; mas, ao reconhecer no livro a mistura "de verdade e falta de verdade”, admitiu haver nele um diálogo entre arte e vida. Era evidente ao crítico a intenção da obra de produzir uma pintura do homem brasileiro, malgrado as declarações do próprio autor contidas nos excertos dos prefácios reproduzidos na crítica de Tristão, e, assim como o escritor católico, o acadêmico concluiu que o símbolo resultante dos caracteres movediços e indefinidos do herói seria falso, pois, na sua opinião, os brasileiros seriam “uns pobres-diabos cheios de intenções benévolas a arcar com nosso império terrestre inconquistável”. Tal definição, convenhamos, é um tanto obscura. O que se deve entender por "arcar com nosso império terrestre inconquistável”? Suportar o sofrimento imposto pelas injunções institucionais e culturais do país? Sofrer pela impossibilidade de se obter soberania na construção do próprio destino de nação? Ou seria apenas vergar o indivíduo sob a impossibilidade de se realizar uma meta coletiva desejada? Quaisquer dessas hipóteses, se aceitáveis, seriam pertinentes a Macunaíma, desde que examinadas sob perspectivas apropriadas. Do mesmo modo, a caracterização dos brasileiros como uns “pobres-diabos” não seria incompatível com a do herói sem nenhum caráter, se verificada sob um ângulo que a ficção pudesse suportar. Assim, a discordância de João Ribeiro quanto à possibilidade de Macunaíma representar de modo verdadeiro a gente brasileira estaria, provavelmente, nas “intenções benévolas” de que o herói seria destituído, se bem entendemos a opinião do crítico. Nesse caso, sua opinião não destoaria daquela de Tristão de Ataíde e de Cândido Motta Filho, segundo a qual Macunaíma seria um símbolo parcial e falso.

Na mesma linha de argumentação, Olívio Montenegro assinalou que Macunaíma conteria “uma verossimilhança de gênio brasileiro nas suas raízes mais secretas”, mas somente em “esboço de caricatura” limitada ao pitoresco, o que haveria impedido a manifestação de uma legítima representação artística da realidade viva. Assim também Augusto Frederico Schmidt, para quem Macunaíma pareceu um livro "bem brasileiro”, mas não o suficiente para que o herói pudesse representar "alguma coisa (...) mais significativa como símbolo de espírito, de feição, de subconsciente nacional”.

Na linha oposta, João Pacheco discerniu em Macunaíma uma imagem bem-ajustada ao referente extraliterário. António de Alcântara Machado, além de frisar que “o herói somos todos nós”, encontrou no livro a figura do homem que o escrevera, observando que a figura- 
ção do autor era procedimento comum na obra de Mário, a exemplo do romance Amar, verbo intransitivo.

Ronald de Carvalho tangenciou a questão do diálogo entre literatura e realidade ao afirmar que "Mário de Andrade projetou o Brasil” na figura do herói, ou ao menos uma imagem do país que ajudaria a situá-lo “entre as diferentes imagens do nosso complexo nacional”. Desse modo, por conceder que o herói seria uma representação parcial, pagou tributo a Tristão de Ataíde, mas, ao contrário deste e de Cândido Motta Filho, considerou tal representação verdadeira em seus limites.

Ascenso Ferreira, por sua vez, resguardando o caráter de obra de arte de Macunaíma, não hesitou em estabelecer conexões estreitas entre a ficção e a realidade brasileira, consubstanciadas no caráter satírico do livro, cuja função seria a de castigar "todas as coisas” que rebaixavam o país, especialmente a enfermidade moral devoradora das riquezas nacionais, tida como sistemática, "por influência da maior parte de nossos governantes”, desde a instalação da República, e disseminada, sobretudo, "nos meios citadinos”, representativos do que seria a “civilização do Brasil para o estrangeiro”, isto é, o Brasil oficial das elites urbanas.

\section{A CARTA POLÊMICA}

Outro aspecto de Macunaíma destacado pelos críticos pioneiros relaciona-se ao capítulo "Carta pras Icamiabas". Nem todos se pronunciaram sobre ele, mas os que o fizeram ressaltaram seu contraste com os demais capítulos do livro. Ascenso Ferreira, além de acusar os motivos satíricos nela contidos como suportes para a crítica da civilização urbana, assinalou que sua inserção fora proposital e que sua função seria a de representar o papel de "intruso à vida e expressão sintética do livro". Se entendermos a "vida” que há no livro, conforme as próprias palavras de Ascenso, como expressão da brasilidade "posta nos seus justos termos”, marcada pelo "traço de dinamismo e de solução rápida” típico da “imaginação primitiva”, então a "Carta” pode ser compreendida, ao menos em parte, como representativa do reverso da brasilidade, na medida em que as notícias dadas pelo herói às suas súditas caracterizam São Paulo como espaço de uma cultura estranha, imposta à cultura nacional, por sua vez associada à noção de primitivismo. No entanto, o poeta de Catimbó concedeu que haveria "um ponto de contato entre o primitivismo e a realidade moderna”, na semelhança de ambos quanto à suposta facilidade de solução das dificuldades. No plano da expressão, a "Carta” também cumpriria uma função satírica. Vazada em “estilo retórico”, ela constituiria um contraponto 
intencional à linguagem dos demais capítulos, que sintetizaria vários registros da "língua brasílica”. Ascenso Ferreira não definiu a noção de "estilo retórico”; provavelmente seria algo análogo ao “português pseudoclássico” utilizado por Mário de Andrade com intenção escarninha, conforme observara Nestor Vítor. Porém, é importante distinguir: enquanto para o crítico pernambucano tal procedimento estaria harmonicamente integrado à economia da obra, para o estudioso paranaense afigurava-se como falha imperdoável, pois provocaria uma violenta ruptura estilística com os capítulos anteriores e comprometeria irremediavelmente a verossimilhança dos posteriores, além de tornar a leitura enfadonha. Nesse aspecto, Nestor Vítor mostrou-se de acordo com a opinião emitida por Tristão de Ataíde, para quem a "Carta” pareceu “cacete”, além de “imensa”.

Segundo Tristão, a “Carta” fora escrita em “estilo médico-purista, (...) bancando a 'lettre persane””. Uma boa imagem do que poderia ser entendido por tal estilo está contida no romance Triste fim de Policarpo Quaresma (1915), de Lima Barreto. Armando Borges, casado com a afilhada do protagonista, é um médico ambicioso de nomeada e de honrarias oficiais. Para distinguir-se intelectualmente, publica escritos compostos num estilo "clássico" que, de fato, não passa de um maneirismo falso e pedante. Esse estilo é manipulado pela personagem com o intuito de simular a inteligência que não tinha e dissimular a cópia de idéias alheias, mas deixa entrever “a sua [de Armando Borges] falsa ciência e a pobreza de sua instrução" "56 . Se correta essa conjectura, a noção de "estilo médico-purista” é análoga à de "português pseudoclássico”, apontada por Nestor Vítor, e contém a idéia de charlatanismo acadêmico que Mário de Andrade ironizou na "Carta”, mas cujo alcance satírico Tristão de Ataíde não percebeu ou desdenhou. Essa segunda hipótese é mais provável, a julgar pela forma como o crítico apontou a relação de intertextualidade que haveria entre a "Carta pras Icamiabas” e as Cartas persas, de Montesquieu: valendo-se da desdenhosa expressão "bancando a 'lettre persane’”, ele sugere que a carta de Macunaíma procura ostentar uma qualidade de fato inexistente. O verbo "bancar” é usado na acepção de arremedar, isto é, imitar de modo caricato e zombeteiro, mas com um matiz de sentido que, se bem entendemos, implica a idéia de que o artista, falhando na intenção satírica, ficara muito aquém do êxito alcançado na obra de Montesquieu.

\footnotetext{
${ }^{56}$ BARRETo, Lima. Triste fim de Policarpo Quaresma. Apresentação de Ivan Teixeira. Cotia (SP): Ateliê Editorial, 2004, p. 206. Para a descrição mais minuciosa do estilo "clássico" da personagem, v. p. 228-229 da mesma edição.
} 


\section{DIÁLOGO FUNDADOR}

Considerando Mário de Andrade como autor da primeiríssima recepção a Macunaíma, a análise dos demais pronunciamentos da crítica pioneira (publicados no mesmo ano da primeira edição do livro) demonstra que a hipótese de Silviano Santiago, tomada de empréstimo no início desta seção de capítulo, está correta na medida em que, dos elementos levantados na primeira crítica, apenas um, nela insinuado sutilmente, foi negligenciado pelas subseqüentes: a questão da complexidade do narrador.

Agora, é duvidoso que todos os críticos pioneiros tivessem conhecimento da primeira recepção, que não é citada por nenhum deles. Assim, a "bitola crítica”57 estabelecida por Mário de Andrade como adequada à avaliação da obra teria ficado obscura não fosse o ensaio de Tristão de Ataíde. Talvez o líder católico também não tivesse conhecimento da resenha inaugural, mas registra em seu texto as informações e os elementos críticos veiculados nela - o que se explica, em certa medida, porque teve acesso a eles por meio da correspondência com Mário de Andrade e da leitura privilegiada dos prefácios “inéditos”.

Pela repercussão obtida, foi o ensaio de Tristão de Ataíde que, aparentemente, exerceu a função de balizar a primeira onda da fortuna macunaímica, mas, na medida em que ele contém citações dos prefácios, reveladoras de importantíssimas ponderações críticas de Mário, foram as convergências e, sobretudo, as muitas divergências desse diálogo entre o crítico e o autor que, efetivamente, lançaram os fundamentos da fortuna.

\footnotetext{
${ }^{57}$ SANTIAGO, Silviano. Op. cit., loc. cit.
} 


\section{MÁRIO E A CRÍTICA}

A correspondência de Mário de Andrade constitui documentação imprescindível ao estudo de sua postura perante o que foi lavrado pela crítica sobre a sua obra. Quanto a Macunaíma, o exame é favorecido pelo trabalho de pesquisa de Telê Porto Ancona Lopez, que coligiu, com minúcia exaustiva, as cartas em que o autor se manifestou a propósito da rapsódia e de sua recepção ${ }^{58}$.

Entre as cartas escritas em 1927, há uma datada de 04 de outubro, dirigida a Manuel Bandeira, em que Mário se mostra apreensivo quanto ao acolhimento de seu livro, que ainda não havia recebido a redação “definitiva”, encaminhada ao prelo no ano seguinte ${ }^{59}$. Ao amigo, segredou que se tratava da “coisa mais déroutante”60 que fizera até então, prevendo que daria ensejo a "besteira em letra de forma”. Mais, informou que havia escrito um prefácio para o livro e que resolvera tirá-lo, por certa intenção malévola - “uma malvadeza gozada” -, decorrente da incompreensão com que a crítica havia tratado o romance Amar, verbo intransitivo. Com a omissão do prefácio, Mário se vingaria da crítica preguiçosa e superficial, abandonando-a a seus próprios recursos no confronto com a obra “déroutante”. Sete meses antes, quando ainda oscilava entre publicar ou não um prefácio, Mário de Andrade se queixara, ao amigo Carlos Drummond de Andrade, de uma pressentida insensibilidade da crítica na futura recepção ao livro: "É triste a gente ver assim uma obra que é feita com paixão, você bem sabe disso, e é feita com frieza crítica severa ser assim destratada por uma leitura blasée.”61

No entanto, vimos que os dois prefácios vazaram, parcialmente, através da indiscrição de Tristão de Ataíde, que teve pleno acesso a eles.

O líder católico calibrou sua crítica orientado pelo material que tinha em mãos, isto é, os prefácios e a carta de 19 de maio de 1928, em que Mário dera notícia deles e da decisão de não publicá-los, anunciando que os remeteria ao amigo. Nessa carta, Mário também confidenciou sua discordância a propósito da antropofagia, lamentando que seu livro pudesse ser asso-

\footnotetext{
${ }^{58}$ ANDRADE, Mário de. Macunaíma, o herói sem nenhum caráter. Ed. crítica de Telê P. A. Lopez. Ed. cit., 1997, p. 490-519: “Considerações em cartas: 1927-1945”.

${ }^{59}$ Em 25 de fevereiro de 1928, Mário informou ao amigo Pedro Nava que estava a datilografar Macunaíma para encaminhar à gráfica. Cf.: ANDRADE, Mário de. Correspondente contumaz: cartas a Pedro Nava, 1925-1944. Edição preparada por Fernando da Rocha Peres. Rio de Janeiro: Nova Fronteira, 1982, p. 102.

${ }^{60}$ BAndeIRA, Manuel (org.). Cartas de Mário de Andrade a Manuel Bandeira. Ed. cit., 1958, p. 175. Também recolhida em Moraes, Marcos Antônio de (org.). Correspondência Mário de Andrade \& Manuel Bandeira. Ed. cit., 2001, p. 356.

${ }^{61}$ Andrade, Carlos Drummond de (org.). Op. cit., p. 105. Também em FrotA, Lélia Coelho (org.). Op. cit., p. 278. Correspondência datada de 20 de fevereiro de 1927.
} 
ciado ao movimento de Oswald de Andrade, sob a alegação de que fora escrito bem antes da publicação do Manifesto antropófago e de que continha problemas tão complexos que seria prejudicial a ele “complicá-lo com a Antropofagia”. Com esses escritos, o autor de Macunaíma dirigiu a atenção do inconfidente para questões que julgava decisivas para a "justa avaliação da obra”, na expressão de Silviano Santiago. Porém, se essa era a expectativa de Mário de Andrade, foi frustrada, pois ele considerou injusto o ensaio de Tristão de Ataíde.

Mário ficou aborrecido com a crítica. Isso se evidencia na correspondência dirigida a Tristão, em 18 de agosto de 1929. Ao saber que o artigo seria reunido a outros em livro, Mário solicitou: "Soube pelo Schmidt ${ }^{62}$ (...) que você ficara um bocado perplexo com minha insistência sobre a retirada do artigo sobre Macunaíma do terceiro volume dos Estudos. Você foi amigo mandando perguntar e eu como amigo pedi, peço e tripeço a retirada do artigo. As minhas razões continuam as mesmas da carta anterior ${ }^{63}$ e há mais a que você já sabe pelo Schmidt mesmo, que esse artigo me fere especialmente”64.

O que conteria o artigo para suscitar tal inquietação? Ao iniciar sua matéria escusando-se da indiscrição que cometeria ao divulgar o que lhe fora discreteado, Tristão de Ataíde decerto antevia algum possível dissabor. No entanto, seu artigo deixou Mário de Andrade contrariado não só por motivos associados à intimidade ferida, mas por divergência relativa a certos juízos emitidos, como veremos adiante. Antes disso, é preciso lembrar que as indiscrições do artigo geraram áspera resposta de Oswald de Andrade. A situação deveria ser constrangedora para Mário de Andrade, cuja seriedade fora destacada por Tristão de Ataíde em detrimento da suposta frivolidade dos antropófagos, aos quais Mário estava então ligado por laços de amizade e certa afinidade intelectual e artística. As revelações de Tristão devem ter contribuído, sem dúvida, para alimentar a crise de relacionamento que culminaria na ruptura, então iminente, da amizade entre Mário e Oswald, bem como na divisão do núcleo mais consistente do modernismo paulista. A intimidade exposta provocava ou aprofundava um estrago, na vida pessoal de Mário de Andrade, que se tornaria irremediável. Agastado com a indiscri-

\footnotetext{
62 Referência a Augusto Frederico Schmidt.

63 Trata-se de correspondência sem indicação de data, publicada por Lygia Fernandes (op. cit., p. 36) entre a carta de 19/06/1928 e a de 14/07/1929, de modo a parecer continuação da primeira. A missiva sem data deve ser posterior à de 14/07/1929 e, talvez, imediatamente anterior à de 18/08/1929. Esse provável problema editorial induziu a edição crítica organizada por Telê Porto Ancona Lopez (op. cit., 1997, p. 499) a apresentá-la como fragmento da carta de 19/06/1928. Nessa hipótese, Mário de Andrade teria conhecimento do artigo antes de sua publicação em O Jornal e até mesmo antes de Macunaíma sair do prelo. A carta de 18/08/1929 refere-se às mesmas razões indicadas numa "carta anterior” para não querer ver o artigo publicado, sendo que essas razões coincidem perfeitamente ao cotejarmos essa correspondência de 18/08/1929 com aquela sem data: "Este artigo fere por demais a minha intimidade”.

${ }^{64}$ FERNANDES, Lygia (org.). Op. cit., p. 40.
} 
ção que intrigara um Andrade contra o outro, Mário, no dia seguinte à publicação do artigo, queixou-se ao amigo Manuel Bandeira dessa atitude do crítico, nos seguintes termos: "E a crítica do Tristão sobre Macu que achou? (...) Detestavelmente indiscreta: o primeiro gesto de católico do Tristão pra comigo foi justificar o sentido pejorativo da palavra ‘jesuitismo’. Mau começo."

Para além da questão pessoal, a dissensão entre os pressupostos críticos de Mário de Andrade e as formulações de Tristão de Ataíde, a propósito de Macunaíma, pode ser rastreada, em parte, na mesma correspondência a Bandeira (10 de setembro de 1928). Sem cerimônias, Mário considerou a crítica "meio besta” e indecisa (“não tomou posição”); estranhou que, na condição de católico militante, o crítico não houvesse censurado a obra mais decididamente. Do ponto de vista literário, Mário julgou que a crítica continha "algumas coisas justas outras injustas”. Entre as injustas, indignou-se com a opinião de que a língua do livro seria “língua de candomblé”, assinalando que uma de suas preocupações fora exatamente "sair da língua falada e chegar afinal na língua escrita”.

O sentido e o alcance crítico subjacentes a essa observação feita a Manuel Bandeira explicitam-se em outra carta, de 21 de novembro de 1928, dirigida a Rosário Fusco. Nela, Mário se refere nos seguintes termos ao que Ataíde dissera sobre estilo e língua:

“Tristão de Ataíde fez sobre o estilo do livro uma observação perfeitamente boba, não entendeu nada nesse ponto. Falou que de tanto a gente abrasileirar a língua esta acabou não se parecendo com coisa nenhuma. Isso é bobice. Ou então ele me dá a pretensão de criar a Língua Brasileira, pretensão boba, anti-histórica que jamais não tive porque graças a Deus sou um bocado inteligente e possuo minhas leituras. Pretendi mas foi não confundir mais língua escrita com língua falada, coisa que estamos fazendo e inda continuo fazendo nos meus artigos de jornal, repito, só pra irritar, conservar o problema na ordem do dia. Macunaíma é escrito em língua artificial, como é de fato toda língua escrita. Todos os filólogos etc. reconhecem a existência simultânea pelo menos de duas línguas, a falada, a básica, e a escrita baseada na outra, porém artística e artificial. E nem pode ser de outra maneira pois que o próprio fenômeno de escrever é uma artificialidade a seu mo-

\footnotetext{
${ }^{65}$ BAndeIRA, Manuel (org.). Cartas de Mário de Andrade a Manuel Bandeira. Ed. cit., 1958, p. 210. Também em MoraEs, Marcos Antônio de (org.). Correspondência Mário de Andrade \& Manuel Bandeira. Ed. cit., 2001, p. 405-406. Nesta, lê-se em nota de rodapé (nº 85, p. 405) que o artigo de Tristão de Ataíde foi publicado na edição “de $O$ Jornal de 9 de novembro de 1928”. Evidente erro de digitação que a revisão deixou passar; a data correta é 09 de setembro de 1928.
} 
do. Por outro lado a língua de Macunaíma não se parecer com coisa nenhuma é bobagem. Principia se parecendo com Macunaíma, e pois que se trata duma obra de arte isso é que é importante. Além disso se parece comigo mesmo. E é incontestável que é uma estilização lírica puramente individualista da fala brasileira. A reserva do Tristão redunda em verdadeiro elogio pois que prova que não se parecendo com o brasileiro falado meu livro já é em língua escrita, minha. Isso mesmo que eu queria."66

Nesse passo de aguda percepção crítica, Mário de Andrade coloca a questão da língua em seu devido lugar literário. Enfatizando que a obra fora escrita em língua "artística e artificial”, como uma “estilização lírica” da fala brasileira, Mário assinalou que se tratava de linguagem inventada e que essa invenção, o discurso em sua totalidade, era fator de unidade e integridade artística da obra.

A Rosário Fusco, o autor de Macunaíma expôs que se valera da estilização lírica da fala brasileira de modo que o estilo concordasse com as personagens e o assunto. E, quanto a isso, mostrou convicção de que fora bem-sucedido, confirmando sua certeza com o reconhecimento desse fato, de que tivera conhecimento por meio de cartas, por Ronald de Carvalho, Renato Almeida e Graça Aranha, que, mesmo não concordando “com a língua que eu estava escrevendo dantes”, haviam "percebido com muita inteligência (...) concordância do estilo brasileiro do livro com o assunto dele”.

Em outra carta a Bandeira, de 01 de janeiro de 1929, Mário de Andrade acusou o recebimento do artigo de José Vieira, concedendo que o crítico tratara "o assunto língua (...) excelentemente”67. Mas para o público, não para ele, Mário. Pelo que se conhece de tal artigo, depreende-se que seria bom para o público na medida em que assumia, em linhas gerais, a defesa da "língua brasileira”. No entanto, nada do que o crítico dissera a respeito do assunto constituía novidade para Mário, que considerou primárias as opiniões, além de emitidas num “estilo passo-de-elefante, pedante e pesadão”.

Como vimos, José Vieira elogiou Macunaíma quanto ao léxico, mas censurou o que lhe pareceu destruição da sintaxe. Essa suposição ensejou o seguinte comentário de Mário de Andrade: "Quanto a falar que Macunaíma não tem sintaxe é bobagem. Tem a sintaxe dele

\footnotetext{
${ }^{66}$ FerreirA, Delson Gonçalves (org.). Cartas de Mário de Andrade a Rosário Fusco. Belo Horizonte, 1977, inédito. Apud AndRADE, Mário de. Macunaíma o herói sem nenhum caráter. Ed. crítica de Telê Porto Ancona Lopez (org.). Ed. cit., 1997, p. 499.

${ }^{67}$ BAndeIRA, Manuel (org.). Op. cit., p. 214. Também em MoraEs, Marcos Antonio de (org.). Op. cit., p. 412.
} 
(...)”. Subentende-se nessa observação que a sintaxe peculiar ao livro seria de ordem artística e não gramatical.

Quanto ao contraste estilístico entre a "Carta pras Icamiabas” e os demais capítulos do livro, censurado por Tristão de Ataíde, Mário o justificou naquela citada carta a Manuel Bandeira, de 10 de setembro de 1928, ao comentar que "estilo muda com assunto" e ao assinalar que “a carta é um intermezzo”. Com essa notação musical, Mário indica o papel de transição que a "Carta” exerceria, analogamente, na concepção geral do livro. Esse fator de retardamento da ação não poderia ser compreendido como independente do plano geral, devido a "um milhão de intenções” contidas na missiva do herói às suas súditas, como o próprio autor esclareceu a Manuel Bandeira em outra correspondência, “post. 31 de outubro de 1927”,68. Nela, Mário assinalou, esforçando-se para convencer o amigo, recalcitrante contra a "Carta”, que a escrevera, intencionalmente, “em estilo pretensioso, satirizando o português nosso, e pleiteando sub-repticiamente pela linguagem lépida, natural (literatura) simples, dépourvue dos outros capítulos.” A contraposição entre um registro pretensioso, que busca "escrever em português de lei”, mas comete deslizes ridículos por desconhecimento da língua, e a "linguagem literária dépourvue” justificaria, em parte, a “Carta pras Icamiabas” e, assim também, a quebra da unidade estilística, que serviria de caracterização satírica ao pedantismo intelectual de "todo brasileiro que sabe um poucadinho”. Provavelmente, por essa razão Mário de Andrade considerou, na correspondência de 10 de setembro de 1928 a Manuel Bandeira, que a discussão sobre a verossimilhança da “Carta” no livro, como Tristão de Ataíde ensaiara em seu artigo, seria uma "besteira refinada".

Contudo, a "Carta” ainda se justificaria por inúmeras outras intenções, algumas das quais são referidas naquela correspondência, “post. 31 de outubro de 1927”, a Bandeira: a sátira aos cronistas coloniais e ao "estado atual de São Paulo, urbano, intelectual, político, sociológico”, bem como ao modo sorrateiro de Macunaíma pedir dinheiro, deixando à mostra o seu "fundo sexual”, alusivo a uma constante comportamental do brasileiro.

Todas essas ponderações de Mário de Andrade convergem sempre para o mesmo ponto: a afirmação de Macunaíma como obra de arte, como produto de seu trabalho consciente de construção. O autor concebe sua criação como discurso literário construído mediante o processo de estilização lírica da fala brasileira, cujo resultado seria uma linguagem inventada,

\footnotetext{
${ }^{68}$ MoRAES, Marcos Antônio de (org.). Op. cit., p. 359. Na edição das cartas de Mário de Andrade a Manuel Bandeira, organizada pelo destinatário delas para a editora Simões (1958), há a seguinte nota do org.: "Carta sem data, mas que deve ser de novembro de 1927”. Marcos Antonio Moraes, em sua edição, coligiu essa carta entre duas correspondências remetidas por MB a MA, de 31 de outubro e 06 de novembro de 1927, datando-a como "post. 31 de outubro de 1927”. Usaremos essa mesma notação neste estudo.
} 
original, que constituiria o próprio discurso como um todo, de modo a articular numa unidade superior, isto é, artística, elementos díspares e contraditórios.

Como vimos, essa convicção não foi ratificada por Tristão de Ataíde, que considerou Macunaíma, bem como toda a obra de Mário de Andrade, mais “obra de crítico social do que propriamente de artista”. Essa observação ensejou o seguinte comentário de Mário ao amigo Carlos Drummond de Andrade, em carta datada de 15 de outubro de 1928: “Outra bobagem do Tristão dizer que sou sociólogo e não artista, justamente diante da mais artística das minhas obras”69. Aliás, com outras palavras, fizera o mesmo comentário ao próprio Tristão na carta de 19 de maio de 1928, aquela de que o crítico se valera, indiscretamente, no artigo "Macunaíma”: “Às vezes tenho a impressão de que [Macunaíma] é a única obra de arte, deveras artística, isto é, desinteressada que fiz na minha vida”70. O crítico passou ao largo dessa observação de Mário e ateve-se no ensaio a outros aspectos contidos na correspondência, especialmente à declaração de independência em relação à antropofagia e à indicação de que a obra apresentava certa conexão com a realidade brasileira. Tristão de Ataíde minimizou a importância do trabalho de construção artística e maximizou a dimensão crítica de Macunaí$m a$, que, em seu entendimento, residia na questão da língua e na simbologia do livro. Porém, ao diminuir a obra, enquanto construção artística, e ao ajuizar que a crítica nela contida, na linguagem e na simbologia, ficara desfocada, sem ultrapassar o “acidental”, Ataíde sugeriu que Macunaíma, em última instância e apesar de algumas virtudes, haveria malogrado como arte e como crítica. É necessário enfatizar que, no ensaio, o juízo se apresenta disfarçado, tanto que, no dia seguinte à sua publicação, Mário de Andrade, em carta escrita a Manuel Bandeira (10 de setembro de 1928), comenta que o crítico não tomara posição perante a obra. Porém, a análise atenta do texto de Ataíde torna evidente a opinião severa e adversa à obra, que foi seguida por vários outros críticos.

Vimos que Tristão de Ataíde sustentou o caráter simbólico de Macunaíma, contra a suposta negação de Mário quanto a esse particular. Houve aqui um mal-entendido que a correspondência andradiana ajuda a dirimir. Segundo a carta a Drummond (15 de outubro de 1928) recém-citada, seria "bobagem” a suposição de Ataíde de que ele, Mário, não tivera a intenção de se referir ao brasileiro na figura de Macunaíma. Esclarecendo esse ponto, enfatizou a Drummond que "Macu não era o brasileiro porém que ninguém não podia negar que era

\footnotetext{
${ }^{69}$ ANDRADE, Carlos Drummond de (org.). Op. cit., p. 136. Também, FrOTA, Lélia Coelho (org.). Op. cit., p. 339. Grifo do autor.

${ }^{70}$ FERNANDES, Lygia (org.). Op. cit., p. 31.
} 
bem brasileiro"71, aduzindo que o herói não possuía, propositalmente, a "totalidade psicológica” requerida necessariamente para ser um “símbolo totalizado”. Segundo Mário, o herói seria “um símbolo restrito”, referido à intenção satírica, “eminentemente socializadora”, de sua obra. Na mesma linha de pensamento, Mário já dissera a Augusto Meyer, em carta de 16 de julho de 1928: “não tive intenção de fazer de Macunaíma um símbolo do brasileiro. Mas si ele não é o Brasileiro ninguém não pode negar que ele é um brasileiro e bem brasileiro por sinal.,72

A intenção simbólica de Mário de Andrade em Macunaíma pode ser melhor compreendida com auxílio de outra correspondência dirigida a Manuel Bandeira, em 07 de novembro de 1927. Ela esclarece que Macunaíma e Piaimã “evocam ‘sem continuidade’ valores étnicos ou puramente circunstanciais” do brasileiro e do italiano, respectivamente. Esse comentário, associado à observação de que "se Macunaíma mata Piaimã nunca jamais em tempo algum não tive a intenção de simbolizar que brasileiro acabará vencendo italiano (idéia que só me veio agora escrevendo), mata porque de fato mata na lenda arecuná”, deixa entrever que Mário de Andrade concebeu suas personagens de modo polissêmico; elas são representações descontínuas que evocam ora um, ora outros feixes de significados, alguns deles só notados pelo autor ao refletir sobre o livro após havê-lo escrito. Ele observou, na mesma carta, que entendia o símbolo como “síntese duma coisa, que nem Dom Quixote, Ulisses, Dom João e Shylock”, acrescentando que "Macunaíma não é símbolo do brasileiro, aliás, nem no sentido em que Shylock é a Avareza”. Deixa patente que não atribuía a Macunaíma a inteireza de caráter daquelas personagens célebres, devido, justamente, ao fato de o herói não ter caráter. Depreende-se daí que Macunaíma não seria "síntese de uma coisa” (o brasileiro), mas de múltiplas coisas contraditórias, que evocam fragmentária e descontinuamente a pluralidade cultural brasileira, que, então, Mário de Andrade entendia como ainda indefinida, incaracterística, ou, conforme assinalou no segundo prefácio (27 de março de 1928), “como sintoma de cultura nacional”73. Agora, ainda na mesma missiva a Bandeira, ele demonstra convicção de que as peripécias do herói tinham valor em si, independentemente dos ideais que pudessem evocar simbolicamente, embora admitisse que o leitor capaz de perceber numa obra literária, "além da coisa em si, tudo o que ela traz de representações ideais, esse tem um gozo muito infinitamente maior.”

\footnotetext{
${ }^{71}$ ANDRADE, Carlos Drummond de (org.). Op. cit., p. 136. Também, FROTA, Lélia Coelho (org.). Op. cit., p. 338. Grifos do autor.

${ }^{72}$ Fernandes, Lygia (org.). Mário de Andrade escreve. Cartas a Alceu, Meyer e outros. Rio de Janeiro: Editora do Autor, 1968, p. 58. Grifos do autor.

${ }^{73}$ BATISTA, Marta Rossetti et alli. Op. cit., 1972, p. 291.
} 
Tristão de Ataíde, em última análise, não concedeu que Macunaíma pudesse ter valor em si, pois, como obra mais de "crítico social do que propriamente de artista”, seria, sobretudo, veículo de idéias, e o livro não poderia ser dissociado delas. Conforme afirmou, quisesse ou não o autor, o herói seria símbolo nítido do "homo-brasilicus". Porém, ao ater-se à usual noção de símbolo, como síntese de uma totalidade, concluiu ser falsa a configuração simbólica do "brasileiro de hoje”, porque restrita à expressão da "barbaria de nossos fermentos em ebulição”, aquilo que, em seu juízo, deveria ser combatido. Para o crítico, Macunaíma se afigurou como uma visão pessimista do Brasil, mas complacente com valores culturais inaceitáveis para os preconceitos católicos e, em última instância, de classe, implícitos no juízo adverso. Entendendo Macunaíma como apologia da "barbaria”, não soube compreender a dimensão satírica da obra, isto é, o seu caráter crítico-humorístico.

As observações feitas nas recém-citadas cartas a Manuel Bandeira, Carlos Drummond de Andrade e Augusto Meyer revelam que Mário não negava dimensão simbólica a Macunaíma. Porém, nota-se que a simbologia deveria ser entendida de um modo sui generis. Mário de Andrade deu à matéria simbólica de Macunaíma uma dimensão arcaica e moderna, a um só tempo, de acordo com a noção de primitivismo que, então, incorporava-se à sua prática artística.

O componente arcaico dessa mistura se atualiza no símbolo, tropo tratado como síntese de uma experiência intelectual e estética eminentemente associativa e polissêmica, de valor prático para a vida, conforme seriam certas representações espirituais do pensamento mítico, que, na época em que compôs a sua rapsódia, Mário associava às noções de magia e de totemismo.

Telê Porto Ancona Lopez, ao estudar a evolução do conceito de primitivismo nas reflexões de Mário de Andrade, mostrou que, quando compunha Macunaíma, ele ainda não conhecia as idéias de Frazer, sobre a função dos ritos de vegetação, nem as de Lévy-Brühl, sobre a lei de participação, das quais se apropriou pouco mais tarde, mas conhecia as de Dürkheim e de Freud sobre a ligação essencial do homem primitivo com o mundo povoado de mistérios $^{74}$. Leitor de vários outros estudiosos de culturas arcaicas, como Kock-Grünberg e,

\footnotetext{
${ }^{74}$ LoPEZ, Telê Porto Ancona. Mário de Andrade: ramais e caminho. São Paulo: Duas Cidades, 1972, p. 107.
} 
talvez, Lehmann Nitsche ${ }^{75}$, também já entendia a importância do mito como narrativa simbólica de caráter etiológico, que, no contexto das culturas ditas primitivas, cumpre a função de forma de conhecimento útil para a vida e a de modo mágico de agir no mundo.

Conforme Telê Ancona Lopez assinalou, “a classificação do brasileiro como primitivo, que [Mário de Andrade] exprime em Macunaíma, é[,] além de resultado de síntese da criação popular que é o seu romance, uma decorrência da compreensão do comportamento de povos ligados a totens como o mutum, o sapo, a lontra e outros, das lendas colhidas por KochGrünberg."76 Como se sabe, totem é um animal, ou uma planta, considerado ancestral e símbolo de determinados grupos em uma comunidade arcaica. Macunaíma, por exemplo, pertence ao clã do jabuti ${ }^{77}$, bem como os brasileiros representados pelo herói. Nos mitos indígenas, o jabuti é o herói “vingativo, astucioso, ativo, cheio de humor e amigo de discussão"78, que, embora débil, vence oponentes poderosos. Porém o símbolo arcaico é ambivalente, uma vez que o jabuti também figura nas lendas como pacato, silencioso e paciente. Além desses, a figura do jabuti, na rapsódia de Mário de Andrade, agrega outros significados simbólicos, também ambivalentes, como o das oposições morte-vida e terra-céu, contidas na urna funerária do filho de Macunaíma, em forma de jabuti, de onde nasce o pé do guaraná, ou na alusão à lenda da festa no céu, de procedência européia, que associa o jabuti à simbologia ascensional ou uraniana. Na rapsódia de Mário, a figura do jabuti indígena é miscigenada a figurações de muitas procedências e, nessa mistura, verifica-se a coincidência de valores opostos que há também na figura do herói, uma vez que Macunaíma não é índio de fato, assim como não é negro nem branco, mas um ser indeciso, que contém a diversidade cultural dos três grupos étnicos em processo inconcluso de mistura, de modo a registrar um momento, síntese de pas-

\footnotetext{
${ }^{75}$ No capítulo X de Macunaíma, o narrador enuncia: "Dizem que um professor naturalmente alemão andou falando por aí por causa da perna só da Ursa Maior que ela é o saci... Não é não!” Em Roteiro de Macunaíma (São Paulo: Anhembi, 1955), M. Cavalcanti Proença, baseado em Câmara Cascudo (CASCUdo, Luís da Câmara. Geografia dos mitos brasileiros. Rio de Janeiro: José Olympio, 1947), supôs que o professor alemão seria Lehmann Nitsche, que vinculara a Ursa Maior ao saci em "Mitologia Sudamericana” (Revista del Museo de La Plata, no 28, p. 103-145). Em nota ao ensaio "A bagagem poética do turista aprendiz" (in: LoPEZ, Telê P. Ancona. Mariodeandradiando. São Paulo: Hucitec, 1996, nota 17, p. 113), Telê Ancona Lopez informa: "Não se pode saber, ao certo, se Mário de Andrade leu Nitsche ou nele ouviu falar, pois a revista argentina citada não está entre seus livros." A pesquisadora estabelece a informação bibliográfica exata do estudo de Nitsche ("Mitologia Sudamericana”. In: Revista del Museo de La Plata, no 28, t. 4., 1924, p. 103-145. Buenos Aires: Universidad Nacional de La Plata) e acrescenta: “A coleção da Revista del Museo de La Plata, rara, pode ser consultada, em São Paulo, no Museu de Zoologia da USP."

${ }^{76}$ LOPEZ, Telê Porto Ancona. Mário de Andrade: ramais e caminho. Ed. cit., loc. cit.

${ }^{77}$ Paú-Pódole assim saúda Macunaíma no céu: "Era uma honra grande pra mim receber no meu mosqueiro um descendente de jabuti, raça primeira de todas... No princípio era só o Jabuti Grande que existia na vida... Foi ele que no silêncio da noite tirou da barriga um indivíduo e sua cunhã. Estes foram os primeiros fulanos vivos e as primeiras gentes da vossa tribo...” (“Ursa Maior”, p. 279 da $1^{\mathrm{a}}$ ed.).

${ }^{78}$ CASCUDO, Luís da Câmara. Dicionário do folclore brasileiro. Ed. cit., p. 382, vol. 2.
} 
sado e presente, em que a solução não se homogeneizara, mostrando um aspecto ainda disforme da "entidade nacional dos brasileiros” (primeiro prefácio), um “sintoma de cultura nacional” (segundo prefácio).

Mário deu ao símbolo um tratamento análogo ao de certas práticas arcaicas, mas conferindo a ele a função artística e crítica, moderna, de significar de modo descontínuo, fragmentário e ambivalente o processo de mistura cultural inacabada, problemática e contraditória então em curso no país. Segundo as próprias palavras do artista, no segundo prefácio, "uma significação não precisa ser total pra ser profunda”. Macunaíma, assim, conteria uma síntese de valores nacionais, um símbolo parcial capaz de fazer “da arte e da vida um sistema de vasos comunicantes” (segundo prefácio).

Do ponto de vista da criação artística, o primitivismo de Mário de Andrade não deve ser entendido como manifestação de uma prática regressiva, como supôs Nestor Vítor ("Macunaíma, o herói sem nenhum caráter”. O Globo: Rio de Janeiro, 08 de outubro de 1928), mas como procedimento, a um só tempo artístico e crítico, adequado à tarefa de reintegrar arte e vida modernas, dando à primeira uma função socializadora. Atento às lições das vanguardas, mas aproveitando-se delas de modo pessoal, Mário se aproxima, por exemplo, da técnica cubista empregada por Picasso na tela Les demoisellles d'Avignon, na medida em que o conjunto de Macunaíma, aparentemente desconjuntado, integra as partes numa unidade superior, que implica multiplicidade de perspectivas simultâneas e síntese de referentes culturais distintos.

Desde os tempos do "Prefácio interessantíssimo" (1922) ${ }^{79}$ e de A escrava que não é Isaura (1925) ${ }^{80}$, para Mário de Andrade, a linguagem eminentemente associativa, a justaposição de imagens e o caráter sintético, típicos das manifestações culturais primitivas, seriam o modo mais adequado para a expressão artística da vida contemporânea. A partir de 1925, quando ele se dedica inteiramente ao trabalho em favor do nacionalismo crítico, acentua-se a idéia de que a sua arte deveria conter uma finalidade prática, que se justificasse socialmente. Numa entrevista concedia ao jornal A Noite, publicada na edição de 12 de dezembro de 1925, Mário de Andrade esclareceu seu modo de entender o nacionalismo crítico ao referir-se à nova orientação do modernismo nos seguintes termos: “Ora o maior problema atual do Brasil consiste no acomodamento de nossa sensibilidade nacional com a realidade brasileira, reali-

\footnotetext{
79 “Prefácio interessantíssimo” de Paulicéia desvairada, 1aㅡ ed. 1922. In: ANDRADE, Mário de. Poesias completas. Edição crítica de Diléa Zanotto Manfio. Belo Horizonte / Rio de Janeiro: Villa Rica, 1993. As citações do "Prefácio interessantíssimo", bem como de poemas de Mário de Andrade, salvo indicação diferente, serão retiradas dessa edição crítica.

${ }^{80}$ ANDRADE, Mário de. "A escrava que não é Isaura”. In: Obra imatura. $2^{2}$ ed. São Paulo: Martins / Brasília: INL-MEC, 1972. As citações do "Discurso sobre alguma tendências da poesia modernista" (subtítulo de A escrava que não é Isaura, cuja primeira edição é de 1925), serão colhidas nessa edição Martins/INL.
} 
dade que não é só feita de ambiente físico e dos enxertos de civilização que grelam nele, porém comportando também a nossa função histórica para conosco e social para com a humanidade. Nós só seremos de deveras uma Raça o dia em que nos tradicionalizarmos integralmente e só seremos uma Nação quando enriquecermos a humanidade com um contingente original e nacional de cultura. O Modernismo brasileiro está ajudando a conquista desse dia.”81

Macunaíma coroa os esforços de Mário quanto à orientação do projeto estético modernista em direção ao nacionalismo crítico, que, como se pode constatar nas palavras reproduzidas da entrevista, nada tem de xenófobo. Segundo Telê Porto Ancona Lopez, “o sentido social da arte (...) aparece claro em 1928, quando, no segundo prefácio de Macunaíma, trata do sintoma de cultura brasileira que (...) proporcionaria a ligação do Brasil com a sua contemporaneidade particular e com a universal”82. Quanto à rapsódia, propriamente, a autora de Ramais e caminho asseverou que o artista realizara a "síntese nacional como postulado estético criando um herói que simboliza o brasileiro intemporal, firmado nas tradições móveis [da cultura popular] e no substrato nacional.”83 Para Mário, o nacionalismo deveria consistir no aproveitamento culto do material proporcionado pela cultura popular brasileira. Para tanto, seria necessário que a obra de arte proviesse “da consciência duma época e das necessidades sociais, nacionais, humanas dessa época” e incorporasse “a crítica, a observação, a experiência e até a erudição”, evitando a "precariedade técnica” das criações populares e o regionalismo, para se constituir em língua literária, “única que tem reconhecimento universal (aqui sinônimo de [registro] culto)" ${ }^{\text {84 }}$.

No artigo “Modernismo e ação”, publicado no Jornal do Commercio, de Recife, em 24 de maio de 1925 e recolhido por Neroaldo Pontes de Azevêdo, Mário de Andrade postulava que o movimento artístico desencadeado em 1922 desenvolvesse "certas tendências obscuras ainda naquele tempo [da Semana de Arte Moderna]", evoluindo para uma proposta de "arte de ação”, em que o espírito estivesse “inteiramente voltado para o Brasil”. A nacionalização da arte brasileira era vista como condição para que ela alcançasse validade universal: "No dia em que nós formos bem filhos da nossa terra, a humanidade se enriquecerá de mais uma expressão que me parece bem gostosa: o brasileiro”,85.

\footnotetext{
${ }^{81}$ In KoIfMAN, Georgina (org.). Cartas de Mário de Andrade a Prudente de Moraes, neto. Rio de Janeiro: Nova Fronteira, 1985, p. 148.

${ }^{82}$ LOPEZ, Telê Porto Ancona. Mário de Andrade: ramais e caminho. Op. cit., p. 236.

${ }^{83}$ Idem, p. 171.

${ }^{84}$ ANDRADE, Carlos Drummond de (org.). Op. cit., p. 22-27. Também, FrotA, Lélia Coelho (org.). Op. cit., p. 98-105. Carta de Mário a Drummond, datada de 18 de fevereiro de 1925, passim.

${ }^{85}$ In AZEVÊDO, Neroaldo Pontes de. Modernismo e regionalismo (Os anos 20 em Pernambuco). Op. cit., p. 223225, passim.
} 
A nova perspectiva artística implicava a rejeição do regionalismo ("Deixaremos de ser estaduais pra sermos nacionais enfim.”, ${ }^{\text {}) ~ q u e, ~ e x a t a m e n t e ~ n a q u e l e ~ m o m e n t o, ~ r e v i t a l i z a v a-s e ~}$ em torno de Gilberto Freyre e de sua proposta de resgate e valorização das coisas regionais. Com esse intuito, o escritor pernambucano fundara, em 1924, o Centro Regionalista do Nordeste e, no ano de 1925, trabalhando no Diário de Pernambuco, publicara o Livro do Nordeste, comemorativo do centenário do jornal. Esse volume é um documentário histórico, econômico, antropológico e cultural do Nordeste, orientado segundo o critério regional estabelecido por Freyre aos colaboradores.

O regionalismo ganharia corpo no ano seguinte com a realização, em Recife, do Primeiro Congresso Brasileiro de Regionalismo, em cuja sessão de abertura Gilberto Freyre teria lido o seu Manifesto regionalista. Mesmo que esse pronunciamento não tenha correspondido à versão publicada pela primeira vez em 1952, sobre a qual existe a hipótese polêmica de que tenha sido escrita após a realização do Congresso (talvez mesmo após muitos anos), é provável que contivesse os mesmos valores, interesses e programa de ação cultural preconizados no Livro do Nordeste, que, segundo a observação precisa de Antônio Dimas, “pode perfeitamente informar sobre as pretensões em voga naqueles anos”,87 em que Gilberto Freyre articulava o seu félibrige nordestino, inspirado no exemplo do poeta francês Frédéric Mistral (1830-1914) e seguidores. Assim, o Manifesto pode ser lido ao menos como um texto retrospectivo, indispensável para se entender o movimento regionalista nordestino.

Nessa perspectiva, o Manifesto informa que o movimento se articulava em torno dos conceitos de região e tradição. A cultura brasileira deveria ser reabilitada por meio do estudo e da promoção de valores que seriam como antídotos à descaracterização trazida pelo progresso, entendido como transposição mecânica e inautêntica da "novidade estrangeira” ou do que “o Rio ou São Paulo consagram como elegante e como moderno"

Segundo Gilberto Freyre, devia-se ao Nordeste a grande contribuição "para dar à cultura ou à civilização brasileira autenticidade e originalidade” ${ }^{\text {; }}$; para ele, o passado aristocrático do Nordeste açucareiro era inexcedível "em riqueza de tradições ilustres e em nitidez de caráter» ${ }^{90}$. Assim, o regionalismo nordestino, assumindo o papel de matriz básica do caráter

\footnotetext{
${ }^{86}$ Idem, p. 225.

${ }^{87}$ DimAs, Antônio. “Um manifesto guloso”. In: FrEYRE, Gilberto. Manifesto regionalista. 7ª ed. Organização e apresentação de Fátima Quintas. Recife: Massangana, 1996, p. 37.

${ }^{88}$ FREYRE, Gilberto. Manifesto regionalista. $7^{\underline{a}}$ ed. Organização e apresentação de Fátima Quintas. Recife: Massangana, 1996, p. 51. Grifos do autor.

${ }^{89}$ Idem.

${ }^{90}$ Idem, p. 52.
} 
original brasileiro, seria a força de resistência da cultura nacional, necessária para neutralizar a suposta descaracterização estrangeirada promovida por São Paulo e pelo Rio de Janeiro.

Topicamente, algumas ações propostas por Gilberto Freyre e por Mário de Andrade, para a promoção de uma cultura e de uma arte nacionais, parecem coincidentes. Por exemplo, a valorização de estudos etnográficos, etnológicos e folclóricos e o aproveitamento artístico dos resultados desses estudos. No entanto, há que reconhecer as insuperáveis diferenças que separam as duas perspectivas.

Para Mário de Andrade, a cultura e a arte brasileira de caráter nacional eram construções recentes e precárias, que ainda não se haviam firmado plenamente. Em texto de 1944, ele emprestaria à personagem Pastor Fido a seguinte observação: “A literatura brasileira já tomou corpo. A música brasileira ainda não"91 - ainda era preciso muito esforço para que o caráter nacional deixasse de ser barro amorfo e adquirisse um contorno característico. Para Gilberto Freyre, ao contrário, esse caráter já se firmara com a "formação de uma sociedade agrária, escravocrata e híbrida"92 brasileira, embora estivesse em perigo de desagregação devido às modernizações supostamente deletérias do progresso tecnológico e das importações culturais européias acolhidas pelo modernismo.

As posições divergem em virtude de duas perspectivas antagônicas sobre a tradição. O olhar de Gilberto Freyre via o passado aristocrático nordestino como portador de uma tradição fundadora do caráter nacional, ameaçada pelo avanço do capitalismo internacional e pela decorrente padronização burguesa das sociedades. O autor de Casa-grande e senzala, ciente da inevitabilidade desse avanço, entendia que só o resgate e a conservação daqueles valores tradicionais poderiam evitar a dissolução da cultura nacional no incaracterístico da cultura burguesa internacional. Perante a inevitabilidade do progresso desfigurador, a preservação da identidade brasileira dependeria de uma ação afirmativa da tradição, capaz de se articular com as forças do "progresso" e de se sobrepor a elas, de modo semelhante àquilo que mais tarde foi chamado de modernização conservadora, em que o passado se sobrepõe ao presente no esforço de se garantir também no futuro.

Mário de Andrade via a tradição com outro olhar. Paulista como era, a ponto de se pronunciar de modo que poderia ser tomado por bairrista ${ }^{93}$, jamais aceitaria o primado nordestino como matriz do caráter nacional. Em uma crônica de 1928, lê-se:

\footnotetext{
${ }^{91}$ AnDrade, Mário de. O banquete. São Paulo: Duas Cidades, 1977, p. 149.

${ }^{92}$ Expressão contida no título do capítulo I de FREYRE, Gilberto. Casa-grande e senzala. 10ª ed. brasileira. Rio de Janeiro: José Olympio, 1961, 1ํㅜ tomo, p. 3.

${ }^{93}$ Cf. LopeZ, Telê Porto Ancona. Mário de Andrade: ramais e caminho. Ed. cit., p. 215-225.
} 
“Aliás, os brasileiros no geral, dão ao paulista uma personalidade tão definida que, apesar de injusta, nos glorifica inda mais porque faz dos paulistas a única gente bem característica, bem inconfundível do Brasil. Infelizmente não temos tamanha caracterização. Nosso orgulho, nossa independência e altivez, nosso sentimento organizado de pátria... estadual, nosso desprezo pelo alheio, dedicação ao trabalho, conceito fechado de família, secura de trato, etc., etc., tudo isso é falso." 94

Embora negue que os traços distintivos do caráter dos paulistas sejam bem definidos, o modo como os enumera, em vez de os desautorizar, parece confirmar a opinião dos "brasileiros no geral”. Mas, para o autor de Paulicéia desvairada, o característico de seu Estado, ou de outro qualquer, só teria valor na medida em que refletisse uma constante cultural mais ampla, nacional.

Mário de Andrade rejeitava o regionalismo, cuja ação lhe parecia valorizar perniciosamente o característico regional, os traços diferenciadores exclusivistas que promoveriam a segmentação cultural e a xenofobia. Como disse Telê Porto Ancona Lopez, “em 1928, Mário de Andrade deixa bem claro que o abrasileiramento do Brasil culto não se resumira na fusão de regionalismos de todos os naipes, mas que essa mesma busca de regionalismo não passava de uma conseqüência da caracterização da cultura nacional em todas as facetas que pudesse apresentar. O importante, pensa-se agora, seria distinguir as atribuições das partes e não lhes deixar autonomia que pudesse ameaçar o todo, o nacionalismo”95.

É o oposto da proposta de Gilberto Freyre, para quem a ação dos vários regionalismos, integrados sob a hegemonia da tradição nordestina agrária e patriarcal, resultaria na afirmação do caráter nacional brasileiro; para Mário de Andrade, isso seria uma ilusão, por força da lógica balcanizadora do regionalismo. Enquanto Gilberto Freyre supunha atingir o geral pela afirmação conservadora do particular regional já configurado, embora ameaçado pelo "progresso”, por meio de sucessivas aproximações à universalidade, Mário de Andrade compreendia que seria necessário todo um trabalho crítico de construção da cultura e da identidade nacional, que superasse a fixidez de tradições mortas, os localismos excludentes e a desfiguração imposta por um progresso alienante, como um momento necessário do processo de inte-

\footnotetext{
${ }^{94}$ Andrade, Mário de. O turista aprendiz. $2^{\underline{a}}$ ed. Estabelecimento de texto, introdução e notas de Telê Porto Ancona Lopez. São Paulo: Duas Cidades, 1983, p. 247.

${ }^{95}$ Lopez, Telê Porto Ancona. Mário de Andrade: ramais e caminho. Ed. cit., p. 210.
} 
gração no universal. Segundo Telê Porto Ancona Lopez, o “nacionalismo, para Mário, já em 1925, é uma etapa de conhecimento, de autoconhecimento nacional, que futuramente deverá ser suplantada pela integração das artes brasileiras na universalidade”,96.

O nacionalismo crítico de Mário de Andrade realizou-se plenamente na sua rapsódia, em que a elaboração estética não se dissocia de sua função social. Arte de ação, "literatura de circunstância”, no sentido de cumprir um interesse prático, culminância do projeto nacionalista crítico, Macunaíma foi, ao mesmo tempo, entendida por seu autor como a mais artística de suas obras, conforme externou na carta a Drummond de 15 de outubro de 1928, em que se queixava da incompreensão de Tristão de Ataíde, patenteada no artigo publicado em $O$ Jornal (09 de setembro de 1928). Embora já citada, convém reproduzi-la mais extensamente:

“(...) Gozei opinião de você que você imaginou idêntica à do Tristão mas concertou a bobagem dele pro certo. De fato nunca tive intenção de que Macunaíma não tivesse referência com o brasileiro. Até vivia falando que Macu não era $o$ brasileiro porém que ninguém não podia negar que era bem brasileiro. Porém Macunaíma não pode ser símbolo do brasileiro, simplesmente porque ‘símbolo’ empregado assim, sem mais nada, implica necessariamente totalidade psicológica. E essa Macunaíma propositalmente não possui. Tirei dele propositalmente o lado bom do brasileiro. E as bondades expressas no livro são todas caracterizadas em ridicularização: 'Macunaíma agradeceu’; ‘Macunaíma tem paciência’. Como símbolo do brasileiro Macu é pessimista, ora é a maior das bobagens diante da minha personalidade, ação e obra, imaginar que sou um pessimista. Toda a minha vida repousa numa concepção otimista do brasileiro. Bastava essa relação pro Tristão não cair na bobagem em que caiu. Você topou tão certo com a verdade que repetiu o anúncio do livro que escrevi pros jornais paulistas e ninguém não soube que escrevi $^{97}$. Macunaíma é uma 'sátira', palavra que você empregou e foi a mesma que empreguei. Não é um símbolo totalizado, é um símbolo restrito, se referindo à minha obra que é eminentemente socializadora. Outra bobagem do Tristão dizer que sou sociólogo e não artista, justamente diante da mais artística das minhas obras. Como se Dante, Cervantes, Camões et caterva não fossem artistas porque são so-

\footnotetext{
${ }^{96}$ Idem, p. 204.

${ }^{97}$ Conforme a hipótese de Silviano Santiago e de acordo com nossas achegas a ela, trata-se da primeiríssima recepção a Macunaíma (Diário Nacional: São Paulo, 07 de agosto de 1928), publicada anonimamente por Mário de Andrade.
} 
ciólogos! Desculpe lembrar grandões mas positivamente seria bobagem citar, no momento, Romain Rolland ou não sei que mais. Castro Alves é sociólogo ou artista. (...),98

A instância “eminentemente socializadora” a que se refere Mário de Andrade associase à conhecida decisão de "sacrificar" as suas criações artísticas, dando-lhes um caráter de “arte de ação”, mas a consciência de que Macunaíma se constituía na obra mais artística que já escrevera explica sua convicção de que Tristão de Ataíde fora injusto na crítica, por não haver compreendido a questão da simbologia, nem a da linguagem, nem a do sentido satírico do livro. Nem mesmo a questão da “imoralidade” ele haveria entendido, a julgar pelo que escreveu a propósito não em seu ensaio, mas numa carta a Mário de Andrade, que a menciona numa página de diário recolhida por Telê Porto Ancona Lopez: “Tristão de Ataíde, em carta me falou que o livro merecia estar no Índice ${ }^{99}$ (...). Acho isso um absurdo. / (...) Minha imoralidade no Macunaíma é casta, que nem os nus de Gauguin.”100 Tal observação, provavelmente contemporânea à publicação do artigo, põe em destaque a ambivalência da moralidade no livro, não percebida pelo crítico.

No período focalizado neste capítulo dedicado ao estudo da crítica pioneira, isto é, publicada em 1928, a correspondência ativa de Mário de Andrade comenta somente os artigos de Tristão de Ataíde e de José Vieira ${ }^{101}$, mas seus comentários podem ser estendidos às matérias publicadas por outros autores, naquilo em que elas são concordes com os aspectos tratados pelos dois escritores nomeados. O autor de Macunaíma chegou a referir-se a outras recepções pioneiras, em cartas ou outros escritos, mas o fez posteriormente ao período aqui tratado, razão pela qual deixaremos o exame desses documentos para adiante.

Não analisamos exaustivamente os dois prefácios que Mário de Andrade escreveu para a sua rapsódia, limitando-nos, tanto quanto possível, à abordagem daqueles excertos tornados públicos por Tristão de Ataíde, entendidos como prospecções críticas de Mário de Andrade e referidos à repercussão que tiveram na fortuna pioneira. No entanto, a publicação desses fragmentos e as discussões suscitadas por eles indicam ser correta a suposição de que o diálo-

\footnotetext{
${ }^{98}$ Andrade, Carlos Drummond de (org.). Op. cit., p. 136. Também em Frota, Lélia Coelho (org.). Op. cit., p. 338-339. Grifos do autor.

${ }^{99}$ Catálogo de livros proibidos pela Igreja católica apostólica romana.

${ }^{100}$ ANDRADE, Mário de. Macunaíma, o herói sem nenhum caráter. Edição crítica, Telê Porto Ancona Lopez, coord. Ed. cit., 1997, p. 522 (“No diário: década de 20 (?)”).

${ }^{101}$ Em rigor, a carta em que Mário comenta a crítica de José Vieira, que tem Manuel Bandeira como destinatário, é datada de 01 de janeiro de 1929. Por um só dia, não vimos razão para desconsiderá-la no exame dos documentos relativos a 1928, mesmo porque tal recepção crítica foi publicada no mês de dezembro desse ano.
} 
go entre Mário de Andrade e Tristão de Ataíde lançou a pedra fundamental da fortuna crítica de Macunaíma. Tal hipótese é confirmada pela análise dos pronunciamentos da crítica pioneira, que retomou sistematicamente pontos levantados, quer pelos fragmentos das prospecções críticas andradianas, quer pelo ensaio de Tristão de Ataíde, acrescentando-lhes um ou outro motivo, de maior ou menor relevância, para reflexão sobre a obra. 


\section{CAPÍTULO II: 1929-1936}

\section{MAIS LEITURAS DA PRIMEIRA EDIÇÃO}

No ano seguinte ao da edição de Macunaíma, ao menos oito críticas se somaram às treze pioneiras. Sete delas são matérias publicadas em periódicos; a oitava é o primeiro ensaio dedicado à rapsódia impresso em livro.

\section{BRINCADEIRA AMARGURADA}

Em janeiro de 1929, Augusto Meyer, assinado A. M., apresenta a obra de Mário de Andrade aos leitores gaúchos.

\section{A. M. [Augusto Meyer]. “Macunaíma / por Mário de Andrade”. Revista do Globo: Porto} Alegre, a. I, nº 1, janeiro de 1929. IEB-USP - MA-MP. ${ }^{1}$

[Revista do Globo. Porto Alegre, jan. 1929. IEB - MA-MP]

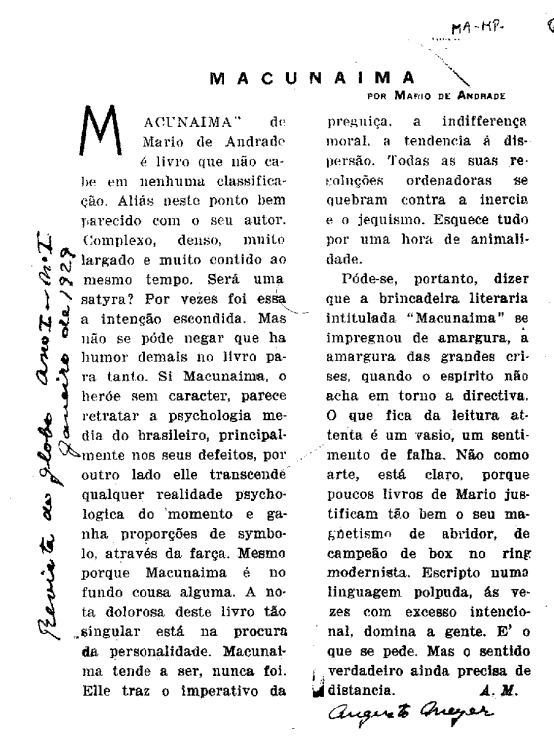

Poeta, crítico, estudioso do folclore e jornalista, - Meyer foi um dos pioneiros do modernismo no Rio Grande do Sul. Num texto enxuto e breve, assinado com as iniciais A. M. e publicado no primeiro número da Revista do Globo, o poeta de Giraluz considera o livro de Mário de Andrade inclassificável quanto ao gênero, devido à complexidade, à densidade e ao paradoxal aspecto compositivo da narrativa, compreendido como "muito largado e muito contido ao mesmo tempo".

Pergunta-se o crítico se o livro é uma sátira. Em resposta, declara que lhe parecera satírica “a intenção escondida” sob um demasiado registro humorístico.

\footnotetext{
${ }^{1}$ A identificação do periódico, da data de publicação e de Augusto Meyer como autor é feita por manuscrito de Mário de Andrade no recorte colecionado (IEB-USP - MA-MP).
} 
Se o herói sem nenhum caráter, segundo Meyer, "parece retratar a psicologia média do brasileiro, principalmente nos seus defeitos”, ele também "transcende qualquer realidade psicológica do momento”, constituindo-se em símbolo farsesco. Macunaíma, diz o crítico, nunca foi nada e nada é; seu traço singular contém a "preguiça, a indiferença moral, a tendência à dispersão (...), a inércia e o jequismo”, além do substrato imperioso “da animalidade”. Contra esses componentes, diz o crítico gaúcho, quebram-se "todas as suas [do herói] resoluções ordenadoras”. Para A. M., essa personagem, entendida como um devir à “procura da personalidade”, constitui "a nota dolorosa do livro".

Como obra de arte, Augusto Meyer considera Macunaíma uma realização plena, dotada de "magnetismo de abridor, de campeão de boxe no ringue modernista", escrita "numa linguagem polpuda, às vezes com excesso intencional”, que “domina a gente”. Porém, do ponto de vista dos significados inscritos na obra, “a brincadeira literária intitulada Macunaíma se impregnou de amargura, a amargura das grandes crises, quando o espírito não acha em torno a diretiva”. Nessa perspectiva, A. M. conclui que a "leitura atenta do livro" deixa "um vazio, um sentimento de falha”, cujo "sentido verdadeiro” só o distanciamento poderia ensejar.

\section{MIRAMAR DO MODERNISMO}

Ao fazer um balanço da literatura modernista publicada em 1928, António de Alcântara Machado, autor de uma das críticas pioneiras (“Um poeta e um prosador”. Revista de Antropofagia, $\mathrm{n}^{\mathrm{0}}$ 5, setembro de 1928), volta a abordar a rapsódia de Mário de Andrade.

\section{MACHADO, António de Alcântara. “O modernismo da literatura de 1928”. A União: [Pa- raíba, $\mathrm{PB}$ ], 31 de janeiro de 1929. IEB-USP - MA-MP. ${ }^{2}$}

Nesse artigo, o autor de Brás, Bexiga e Barra Funda registra o avanço da vanguarda literária, ocorrido em 1928, a despeito da divisão do movimento, que se acentuara no período. Celebra o fato de o modernismo se haver expandido por todo o país, tornando-se uma escola que lhe parecera a mais forte manifestação literária até então surgida no Brasil. Contudo, aponta como maior defeito do modernismo exatamente o fato de se haver transformado em escola, o que possibilitara a entrada de "penetras”, isto é, adventícios que parasitavam certos

\footnotetext{
${ }^{2}$ No recorte que se encontra no álbum R. 27 do IEB-USP - Recortes de Mário de Andrade -, há uma anotação manuscrita de Mário, que identifica o periódico, a cidade e a data de publicação. A cidade da Paraíba viria a chamar-se João Pessoa em 1930.
} 
procedimentos inovadores como, por exemplo, o verso livre. Apesar desse tipo de charlatanismo, o crítico se consola com o surgimento de algumas "surpresas autênticas", nomeadamente, José Américo de Almeida, Jorge de Lima, Ascenso Ferreira, Brasil Pinheiro Machado, Augusto Frederico Schmidt e Yan de Almeida Prado ${ }^{3}$, e com o ponto atingido por alguns modernistas de primeira hora, cuja arte adquirira “uma feição que não é mais de procura mas de coisa achada e estável.” Dentre esses, Alcântara Machado reserva um lugar especial para Mário de Andrade, pelos três livros que o articulista arrola como publicados em 1928, considerados representativos do que de "mais completo" o autor fizera até então como poeta (Clã do jabuti ${ }^{4}$ ), prosador (Macunaíma) e crítico (Ensaio sobre música brasileira). Segundo Alcântara Machado, Mário de Andrade consolidava sua condição de “foco de atração inelutável, uma espécie de Miramar do modernismo”.

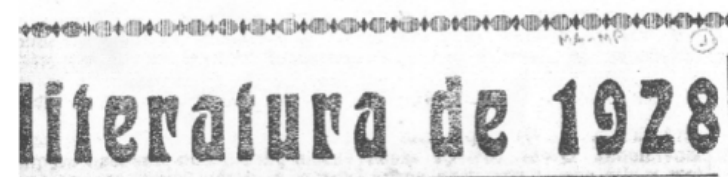

Antonio de Aleantara Machado

de lacto ua foco de atraçso iac- ra e Losango Cágul pieparou no lutevel, uas especie de Mirkentr Clá do jaboti zurgo guro e clsro.

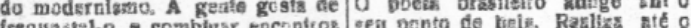

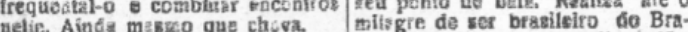
Poia 1928 foi pars Mario um sil o nẫo desia ou Gaqueila tégía.

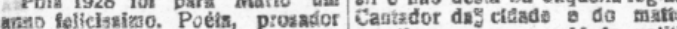
e critico, pablícu vat livzo de repelia zo verso a ualdade polith

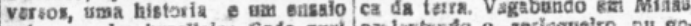

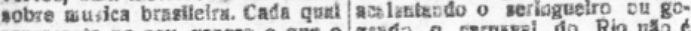
representa no seu genero o que o zandz a carpapal do Ris nă e

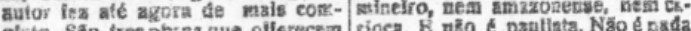

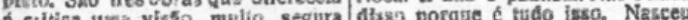
átio eutido. raro do qua so pensa. E sente o Clas do Jaboti of o sueo de ur Brasil como nlngusm. $\mathbf{E}^{\prime}$ ums vóz. Irismo que velu se apuratado dez- Maso teal todos es solaques. B con-

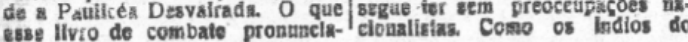

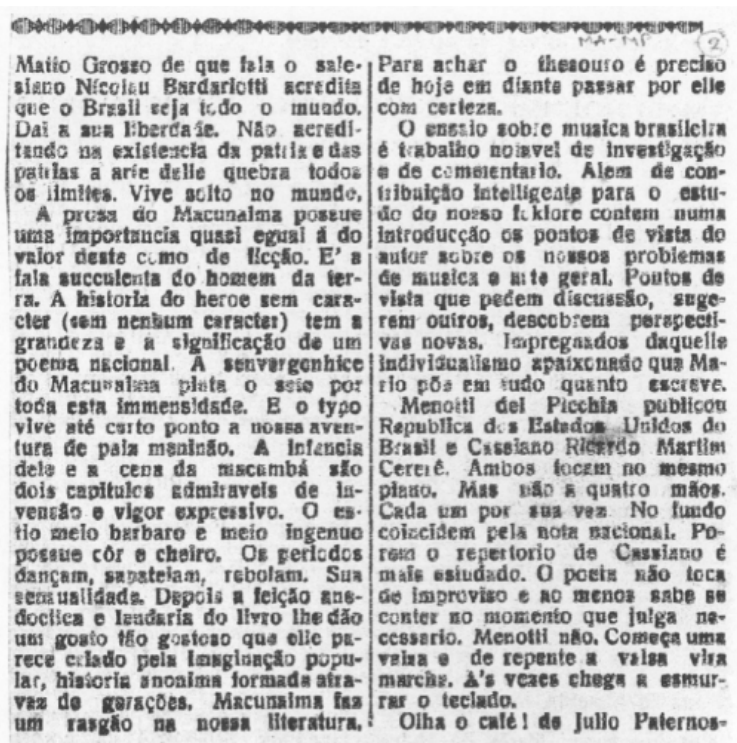

Não deixa de haver uma certa provocação no epíteto atribuído a Mário de Andrade, em que há uma nítida alusão a Oswald de Andrade, autor das Memórias sentimentais de João

\footnotetext{
${ }^{3}$ Em 1928, José Américo de Almeida publicou A bagaceira (romance); Jorge de Lima, Essa negra fulô (poesia); Brasil Pinheiro Machado, Quatro poemas (poesia); Augusto Frederico Schmidt, Canto do brasileiro Augusto Frederico Schmidt (poesia). Os dois primeiros autores já haviam feito antes suas estréias em livros; os outros dois estrearam com as obras referidas. Ascenso Ferreira e Yan de Almeida Prado, que participou da Semana de 22, não publicaram livros nesse ano. O primeiro publicara Catimbó (poesia) no ano anterior; o segundo, salvo engano, só publicaria seus primeiros e, talvez, únicos livros de literatura em 1931: Circo de cavalinhos (crônicas) e Os três sargentos (romance) - cf.: CouTinHo, Afrânio e SousA, J. Galante de (diretores). Enciclopédia da literatura brasileira. 2a ed. rev., ampl., atual. e il. sob a coordenação de Graça Coutinho e Rita Moutinho. São Paulo: Global Editora; Rio de Janeiro: Fundação Biblioteca Nacional/DNL: Academia Brasileira de Letras, 2001, p. 1309, vol. II.

${ }^{4}$ Como se sabe, a primeira edição de Clã do jabuti não é de 1928, mas de 1927.
} 
Miramar, que, por vezes, assinava textos com o pseudônimo "Miramar”. Alcântara Machado ficara ao lado de Mário quando da ruptura desse com Oswald e seguidores da “descida antropofágica”. Com a alusão provocativa, distinguiu Mário como o descortinador dos caminhos modernistas válidos, em detrimento não muito sutil da liderança de Oswald.

Ao elogiar a poesia de Clã do jabuti, "suco de um lirismo que veio se apurando desde a Paulicéia desvairada”, Machado considera que Mário realiza nos poemas desse livro “o milagre de ser brasileiro do Brasil e não desta ou daquela região”, por meio de uma “voz” cujo dom de sintetizar “todos os sotaques” do país não ostentava qualquer preocupação nacionalista; de uma “voz” senhora de liberdade artística capaz de quebrar “todos os limites”, de modo a fazer com que “o Brasil seja todo o mundo”.

Quanto a Macunaíma, o articulista sintetiza em um parágrafo a análise que fizera da obra na Revista de antropofagia, no ano anterior, antes da referida ruptura com o grupo oswaldista. Agora destaca novamente a alta qualidade da prosa, admirável pelo "vigor expressivo”, em que "a fala suculenta do homem da terra” articula-se num "estilo meio bárbaro e meio ingênuo”, dotado de sensualidade sugestiva de "cor e cheiro”, além de movimento coreográfico, nitidamente perceptível na sintaxe: “os períodos dançam, sapateiam, rebolam”. Considera a ficção, construída de modo anedótico, assemelhada às lendas concebidas pela imaginação popular, em virtude de seu simulado aspecto de "história anônima formada através de gerações”. Com isso, implicitamente, Alcântara Machado retoma a classificação de rapsódia, que atribuíra a Macunaíma na mencionada matéria da Revista de antropofagia, para concluir que a obra, com “a grandeza e a significação de um poema nacional”, constitui um profundo marco divisor na literatura brasileira, um “rasgão” por onde essa literatura necessariamente deveria passar "para achar o tesouro” dali em diante.

\section{TACAPADA NO CRISTIANISMO}

Numa série de três artigos, unificados por um título comum - "Moquém” -, divididos em três números do mês de abril de 1929, da Revista de antropofagia, agora na "segunda dentição”, e assinados com o pseudônimo “Tamandaré”, Oswaldo Costa critica asperamente o modernismo, mas poupa Macunaíma do ataque generalizado às obras produzidas pelo movimento. Amigo de polêmica, o jornalista Oswaldo Costa foi um dos diretores da Revista de antropofagia na segunda fase, posterior à ruptura da amizade de Mário com Oswald de Andrade e ao distanciamento do primeiro em relação ao grupo antropófago remanescente. Os- 
waldo Costa foi padrinho de casamento do xará com Pagu e, assim como o casal, militou no Partido Comunista (PCB). Costa foi um dos pivôs da crise de relacionamento pessoal entre os Andrades e, como crítico, um dos que atacaram de modo mais grosseiro a liderança e a influência de Mário na vanguarda modernista.
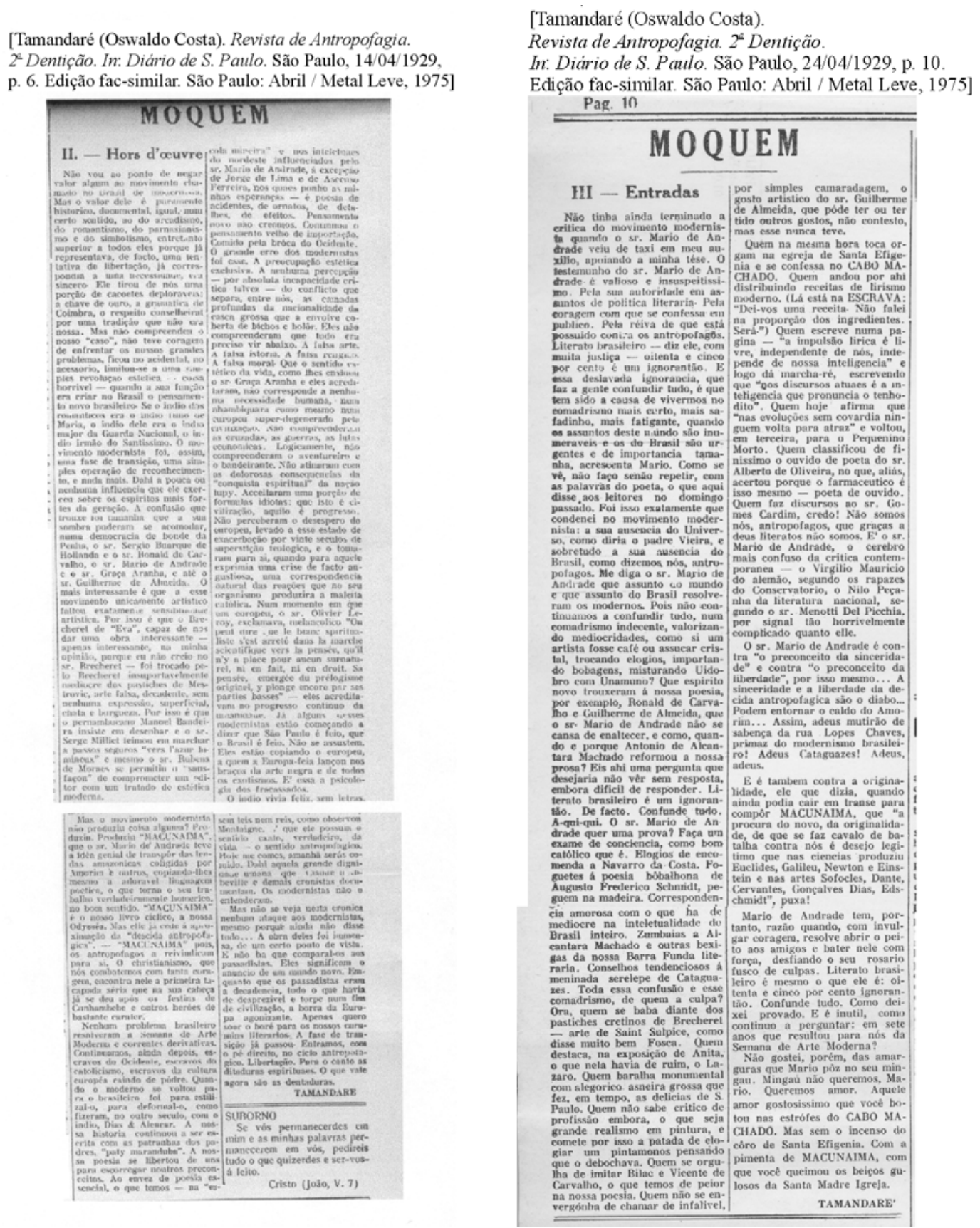
TAMANDARÉ [Oswaldo Costa]. “Moquém / II - Hors d'oeuvre”. Revista de Antropofagia. $2^{\underline{a}}$ Dentição. Encarte do Diário de S. Paulo: São Paulo, 14 de abril de 1929, p. 6. Edição fac-similar. São Paulo: Abril / Metal Leve, 1975.

. “Moquém / III - Entradas”. Revista de Antropofagia.

2a Dentição. Encarte do Diário de S. Paulo: São Paulo, 24 de abril de 1929, p. 10. Edição fac-similar. São Paulo: Abril / Metal Leve, 1975.

O segundo artigo da série “Moquém”, cujo subtítulo é “Hors d’oeuvre”, contém a idéia central da crítica adversa ao modernismo e a referência mais extensa a Macunaíma. Segundo Oswaldo Costa, o modernismo era um movimento datado, assim como o foram romantismo, parnasianismo e simbolismo, embora aquele seja estimado como superior a esses porque corresponderia a uma tentativa sincera de libertação, que extirpara de nossa literatura "uma porção de cacoetes deploráveis: a chave de ouro, a gramática de Coimbra, o respeito conselheiral por uma tradição que não era nossa”. No entanto, o modernismo, preso ao acidental e acessório, não enfrentara “os nossos grandes problemas”; ficara limitado "a uma simples revolução estética - coisa horrível - quando a sua função era criar no Brasil o pensamento novo brasileiro.” Daí, conclui, o modernismo fora só uma fase de transição confusa, em que se aglutinaram personalidades díspares, muitas das quais ainda sujeitas ao espírito esgotado da civilização européia: “Continuamos, ainda depois [da Semana de Arte Moderna], escravos do Ocidente, escravos do catolicismo, escravos da cultura européia caindo de podre”. Para Oswaldo Costa, o modernismo fora o "anúncio do mundo novo", mas, atado à "preocupação estética exclusiva” e a modelos artísticos ou culturais importados, ficara na superfície do problema essencial, sem ter percepção das “camadas profundas da nacionalidade”, que exigia a solução radical da “descida antropofágica”.

De tudo o que o modernismo produzira, porém, Oswaldo Costa salva Macunaíma, em que destaca o “genial” aproveitamento do material lendário e a “adorável linguagem poética”. O crítico considera a obra de Mário de Andrade como “o nosso livro cíclico, a nossa Odisséia” e a reivindica para a antropofagia, asseverando que em Macunaíma se encontra "a primeira tacapada séria” na cabeça do cristianismo, desde "os festins de Cunhambebe e outros heróis de bastante caráter.” ${ }^{5}$ No terceiro artigo da série, que é um violento ataque a vários artistas do

\footnotetext{
${ }^{5}$ Cunhambebe foi líder indígena da chamada “Confederação dos Tamoios” (1554-1567), nas lutas contra os colonizadores portugueses.
} 
modernismo, mas desferido principalmente contra Mário de Andrade, Oswaldo Costa reitera a condenação à “ausência do Brasil”" apontada por ele no movimento modernista, embora, novamente, excetue Macunaíma, cujo tempero apimentado haveria queimado "os beiços gulosos da Santa Madre Igreja”.

Ferreira, Ascenso. “Carta do poeta de Catimbó”. Revista de antropofagia. $2^{\underline{a}}$ Dentição. Encarte do Diário de S. Paulo: São Paulo, 19 de julho de 1929, p. 12. Edição fac-similar. São Paulo: Abril / Metal Leve, 1975.

[Revista de Antropofagia. $2^{\underline{a}}$ Dentição.

In: Diário de S. Paulo. São Paulo, 19/07/1929, p. 12.

Edição fac-similar. São Paulo: Abril / Metal Leve, 1975]

\section{Pag. 12}

\section{carta do poeta de "Catimbó"}

Recife, 2 de julho de 1929. Meu caro Oswaldo Costa.

Recebi sua carta amiga e apresso-me em respondel-a: O programma antropofago é, na sua orientação profundamente nativista, o meu programma já esboçado em "Catimbó".

A minha solidariedade, pois, com Vocês, seria fatal em vista da unidade de pensamentos, e mais que isso: — da uniQuebra, portanto.

dessa solidariedade não será dizer-lhe, afim de evitar explorações, que aquella minha admiração pelo alto espirito orientador desse "Moquem n. 2" não importa em colidariedade total com todos os pensamentos nelle contidos. Assim, eu não posso dar minha solidariedade ao que Você diz. sobre o "Macunaima", chamando-o de lendas amazonicas colligidas por Amorim e copiadas na sua adoravel linguagem pelo autor

mill e uma noites do Brasil.

Não sảo sómente lendas brasileiras o que Você encontra naquellas paginas encantadas!

Pelo contrario: o espirito nordestino passou o pensamento do autor no papo, e, por isso talvez, Vocês do Sul, não tenham podido bem interpretal-o.

Feitas essas consideraçôes que me dita o dever de ser sincero commigo mesmo, espero que Você terá a lealdade de publical-as nas mesmas paginas da Revista que tão generosamente me acolheu.

Gratissimn, assigno-me

seu do coração

ASCENSO FERREIRA.
Na edição de 19 de julho de 1929, a Revista de antropofagia estampou uma carta de Ascenso Ferreira, dirigida a Oswaldo Costa, em que o poeta pernambucano declara ser solidário ao programa antropofágico, em razão da unidade de pensamento e de sentimento nutrida em relação à “orientação profundamente nativista” da revista, órgão de divulgação do movimento. No entanto, diz Ascenso, essa solidariedade não era total porque discordava de certa opinião de Oswaldo Costa, emitida a propósito de Macunaíma no artigo "Moquém II”. Para o poeta de Catimbó,

o livro de Mário não poderia ser reduzido à condição de "lendas amazônicas coligidas por Amorim e copiadas na sua [das lendas] adorável linguagem pelo autor”, como fizera Oswaldo Costa, porque se tratava de "um maravilhoso sonho de mil e uma noites do Brasil”, que não conteria somente lendas amazônicas em suas “páginas encantadas”, mas também o "espírito nordestino” que impregnara o pensamento de Mário de Andrade e que não fora bem interpretado “por Vocês do Sul”. 
Costa, Oswaldo. “Resposta a Ascenso Ferreira”. Revista de antropofagia. $2^{\underline{a}}$ Dentição.

Encarte do Diário de S. Paulo: São Paulo, 19 de julho de 1929, p. 12. Edição fac-similar.

São Paulo: Abril / Metal Leve, 1975.

[Revista de Antropofagia. $2^{\natural}$ Dentição.

In: Diário de S. Paulo. São Paulo, 19/07/1929, p. 12.

Edição fac-similar. São Paulo: Abril / Metal Leve, 1975]

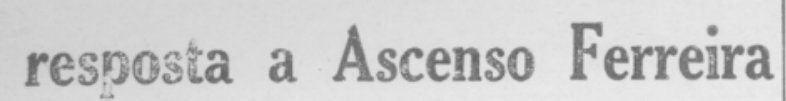

A sua carta, Ascenso, não tem rão no Epstein - que eu reagi nenhuma razão de ser. $\hat{E}$ uma car- de tacape em punho. Você mesta de sentimento, coisa para além mo acha que o espirito do Moda antropofagia, e que eu desco- quem $\mathrm{N}$. 2 foi

de Pirapora e a Echú. Nesse Como poeta, Mario tem real-

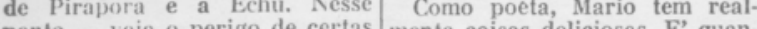
ponto les o perigo se põe de mente coisas deliciosas. E' quangenerosintartes los Drumnd, para muem "toda veu do Conservatorio, que escrelos Drtitnond, para quema boa ve um compendio de Historia literatura năo vale uma boa de Musica, que faz critica proamisade .... .u gosto te vocé, fissional atravez de estampas e Ascenso, porcque vocé tem talende de Art Vivant, e deixa ou não to, portue vece explodir poeta, porque vocé escreveu al dentro dele o negro bom que ele guns dos mits gostosos pocmas quer inutimente esconder por brasileiros que até hoje tenho Ii- medo da Santa Madre Igreja. E do. Mas se um dia vocé ficasse esse samba - como observou burro e tiesse para imitar Bilar Oswaldo de Andrade - que faz e Vicente te Carvalho - como gostosas certas coisas dele. Na o Mario de Andrade - eu dé obra dele, portanto, si nắo me xaria de querer bem a você e nāo interessa a parte doutoral, peteria outro remedio senão devo- dante, falsamente erudita, a parrar o amigo com a maior feroci- te do branco ipocrita do côro de dade pussivel. Mario se colocou Santa Efigenia, me interessa a na posição de mestre diante de parte-bode, que é ás vezes de vocếs, que ele considera dicipu- uma riqueza inegualavel. 0 que los e maternatmente aconselha lastimo, exatamente, é que Macom a brandura mais catolica rio recalque 0 bode. Quanto ao deste mundo. Ora, que vocés de- mais - Macunaima inclusive. vem a ele? Que deve você? Que que elogiei ao ponto mesmo de deve o Jorge de Lima? Que deve reivindical-o para o movimento - Jorge Fernandes? Nada. Pelo antropofagico, dizendo que ele contrario, é a vocês que ele deve era a Odisséa brasileira - está tudo. E' de vocês que vem a força certissimo. Não discuto.

que ele exibe aqui no sul, recla- Nenhuma razão, desse moto, nisticamente. Mario é o cosmeti- assiste ao seu desabafo sentimenso da poesia nordestina. Ora eu tal, meu querido Ascenso. Ele orefiro a cabeleira revolta e des- serviu, entretanto, para firmar a penteada do "Catimbó", da "Nega sua solidariedade com a AntroFulô" e daquele serelepe "Sẩo pofagia, onde você foi recebido Paulo que nẫo sei não". Para com a satisfacão que merece o mim toda a obra de Mario nâo seu grande talento. Dê por mim vale o Inacio da Catingueira. uma tacapada séria na Ácademia Você nâo está de acordo? Foi contra essas atifudes bes- velho tas do autor de Escrava que nấo Isaura - que vocês encontra-

revista de antropofagia,
Logo abaixo da "Carta do poeta de Catimbó”, no mesmo número da Revista de antropofagia, aparece a "Resposta a Ascenso Ferreira”, assinada por Oswaldo Costa. Essa "Resposta...” é mais um pretexto para o polemista insultar Mário de Andrade. O artista é acusado de se colocar "na posição de mestre diante de vocês [jovens poetas modernistas nordestinos, nomeadamente, Ascenso Ferreira, Jorge de Lima e Jorge Fernandes], que ele [Mário] considera discípulos e maternalmente aconselha com a brandura mais católica deste mundo.” Costa afirma: os “discípulos” nada deviam ao "mestre", que se apropriara da "força" provinda dos jovens talentos nordestinos para exibi-la com alarde no Sul. Por essa

suposta razão, o crítico afirma que "Mário é o cosmético da poesia nordestina”, cuja obra não teria o valor de um Inácio da Catingueira ${ }^{6}$. A "parte doutoral, pedante, falsamente erudita, a parte do branco hipócrita do coro de Santa Ifigênia”, que o crítico entende haver nas obras de Mário, não teria interesse para ele, Oswaldo Costa. Porém, quando Mário deixa “explodir dentro dele o negro bom que ele quer inutilmente esconder por medo da Santa Madre Igreja”, a obra dele apresentaria o lado interessante, que, segundo o crítico, seria a "parte bode, que é

\footnotetext{
${ }^{6}$ Inácio da Catingueira (1845-1881), analfabeto e escravo em uma fazenda na Paraíba, foi em vida e é na memória um dos mais célebres cantadores da cultura popular nordestina.
} 
às vezes de uma riqueza inigualável”. Ao encerrar a "Resposta...”, o crítico concorda com a defesa de Macunaíma, feita por Ascenso Ferreira na "Carta do poeta de Catimbó”, reitera o elogio expedido em “Moquém II - Hors d’oeuvre”, em que reconhecera a obra de Mário como “a Odisséia brasileira”, e torna a reivindicá-la para o movimento antropofágico.

\section{MUNDO IMAGINÁRIO}

Na edição de 18 de abril de 1929, o Diário de Pernambuco publicou uma matéria assinada com as iniciais A. F., apresentando Macunaíma a seus leitores. O autor é Aníbal Fernandes. Jornalista e crítico pernambucano, foi precursor do modernismo nordestino ao lado do pintor Vicente do Rego Monteiro, alguns anos antes de aproximar-se do grupo regionalista de Gilberto Freyre e participar do Livro do Nordeste, comemorativo do centenário do jornal Diário de Pernambuco, coordenado por Freyre, em 1925.

\section{A. F. [Aníbal Fernandes]. “Através dos livros / Macunaíma - Mário de Andrade - S. Paulo”. Diário de Pernambuco: Recife, 18 de abril de 1929. IEB-USP - MA-MP. ${ }^{7}$}

Repetindo o que outros críticos já haviam dito sobre o livro de Mário de Andrade, A. F. caracteriza Macunaíma como uma obra que "não chega a ser bem um romance”, tratandose, antes, de “uma história de mil e uma noites, uma fantasia e um símbolo”. Desses três aspectos, é ressaltado o fantástico, entendido como fator da circunscrição da obra "num mundo que parece que é o nosso mas de fato é puramente imaginário”. Nesse mundo imaginário, de criação "puramente subjetiva”, “a realidade é apenas um pretexto para formar o ambiente” onde os heróis “nascem, vivem, desaparecem e revivem sem dar contas a ninguém”.

O crítico ainda destaca: Macunaíma, por ser o “herói da nossa gente”, ou seja, dos brasileiros, “fala (...) uma língua que o autor imagina talvez que é o brasileiro, isto é, o português transplantado para o Brasil e modificado com as reações locais e pela fusão das raças que entraram na formação do tipo nacional.” Aníbal Fernandes sente falta de um glossário para facilitar a leitura dessa língua, mas admite: “o livro é divertido” e "acaba-se com saudades de Macunaíma quando o herói não acha mais graças nesta terra e cisma se deve ir morar no céu ou na ilha de Marajó...”. Dito isso, Aníbal Fernandes transcreve duas páginas inteiras do final

\footnotetext{
${ }^{7}$ A identificação do periódico e da data de publicação é feita por anotação manuscrita de Mário de Andrade, no recorte que se encontra no álbum R. 29 - Recortes de Mário de Andrade - IEB-USP. A identificação de autoria é feita por anotação manuscrita de Ascenso Ferreira no mesmo recorte, remetido por ele a Mário.
} 
do capítulo "Ursa Maior”, no intuito de dar ao leitor um exemplo da "técnica estranha e bizarra” de Mário de Andrade.

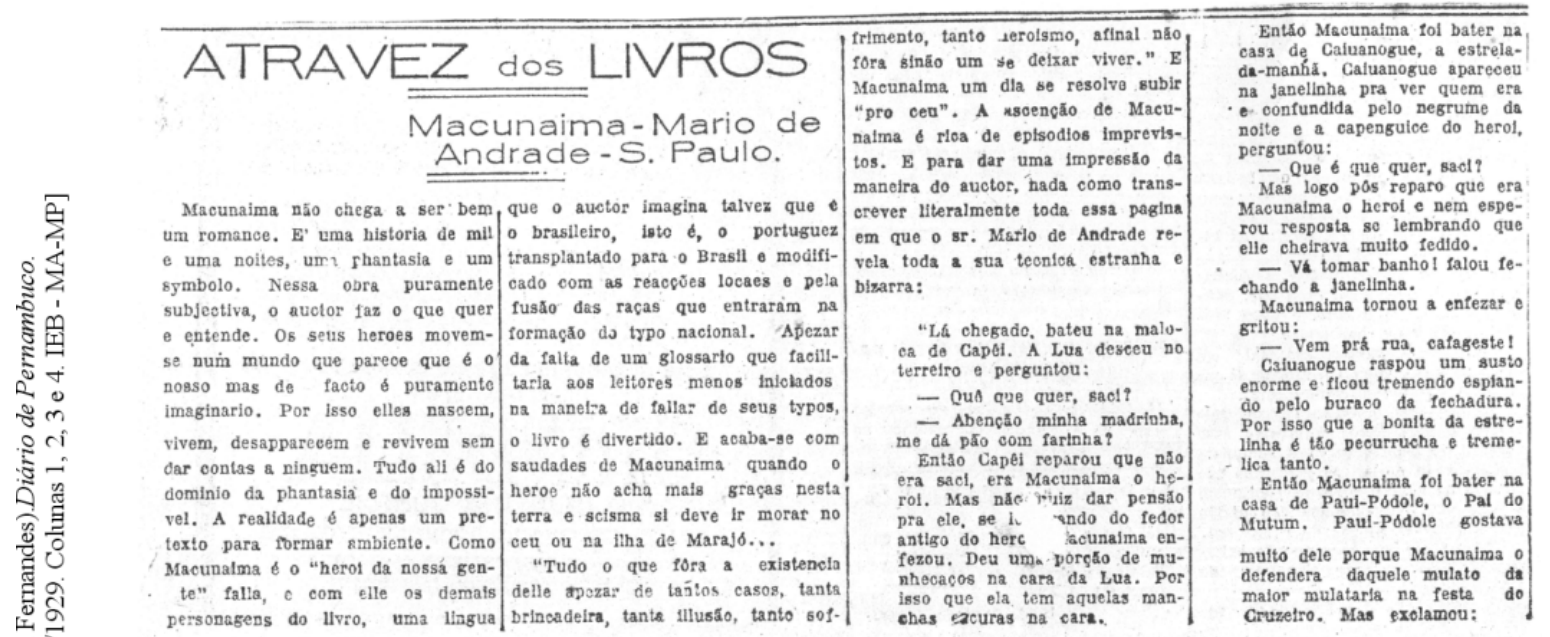

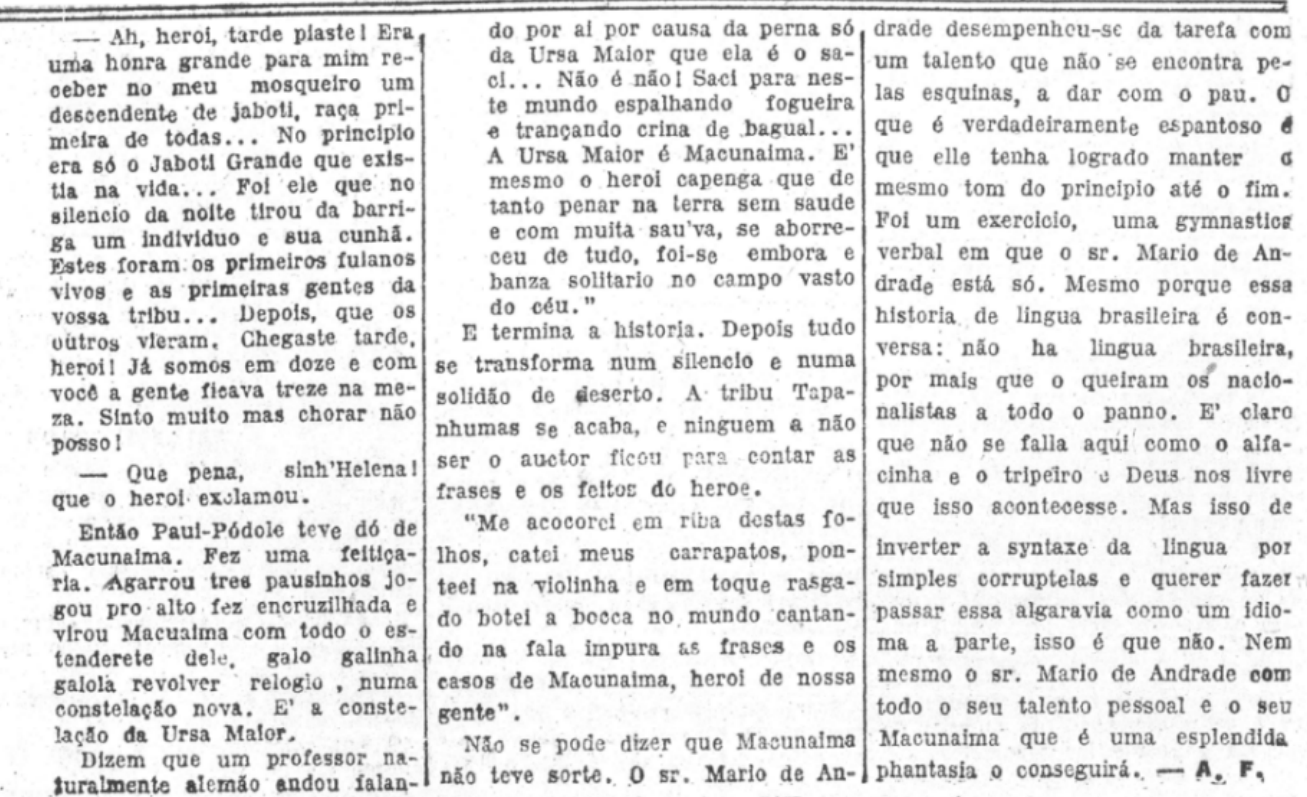

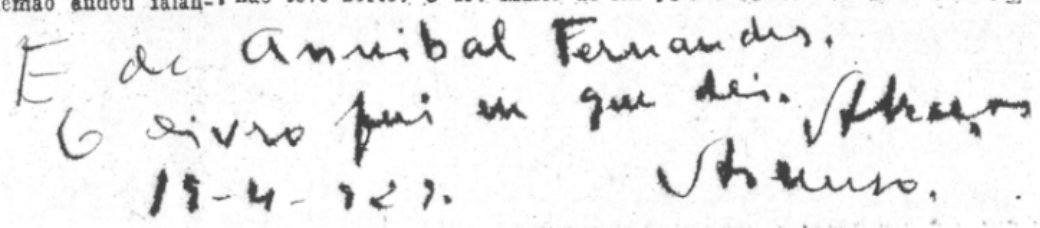

Após a transcrição do excerto, A. F. reconhece o talento incomum do artista que, de modo “verdadeiramente espantoso", lograra “manter o mesmo tom do princípio até o fim”, realizando “um exercício, uma ginástica verbal em que o sr. Mário de Andrade está só.” O 
patente elogio, no entanto, é corroído pela afirmação categórica emitida no desfecho da matéria: “essa história de língua brasileira é conversa: não há língua brasileira, por mais que o queiram os nacionalistas a todo o pano. É claro que não se fala aqui como o alfacinha e o tripeiro e Deus nos livre que isso acontecesse. Mas isso de inverter a sintaxe da língua por simples corruptelas e querer fazer passar essa algaravia como um idioma à parte, isso é que não. Nem mesmo o sr. Mário de Andrade com todo o seu talento pessoal e o seu Macunaíma que é uma esplêndida fantasia o conseguirá.”

\section{RAIDE DO SUBCONSCIENTE NACIONAL}

LIMA, Jorge de. “Todos cantam sua terra...”. In: Dois Ensaios. 1ª ed. Maceió (AL): Casa Ramalho, 1929, p. 86-138. ${ }^{8}$ Exemplar da Biblioteca de Mário de Andrade - IEB-USP, com dedicatória do autor.

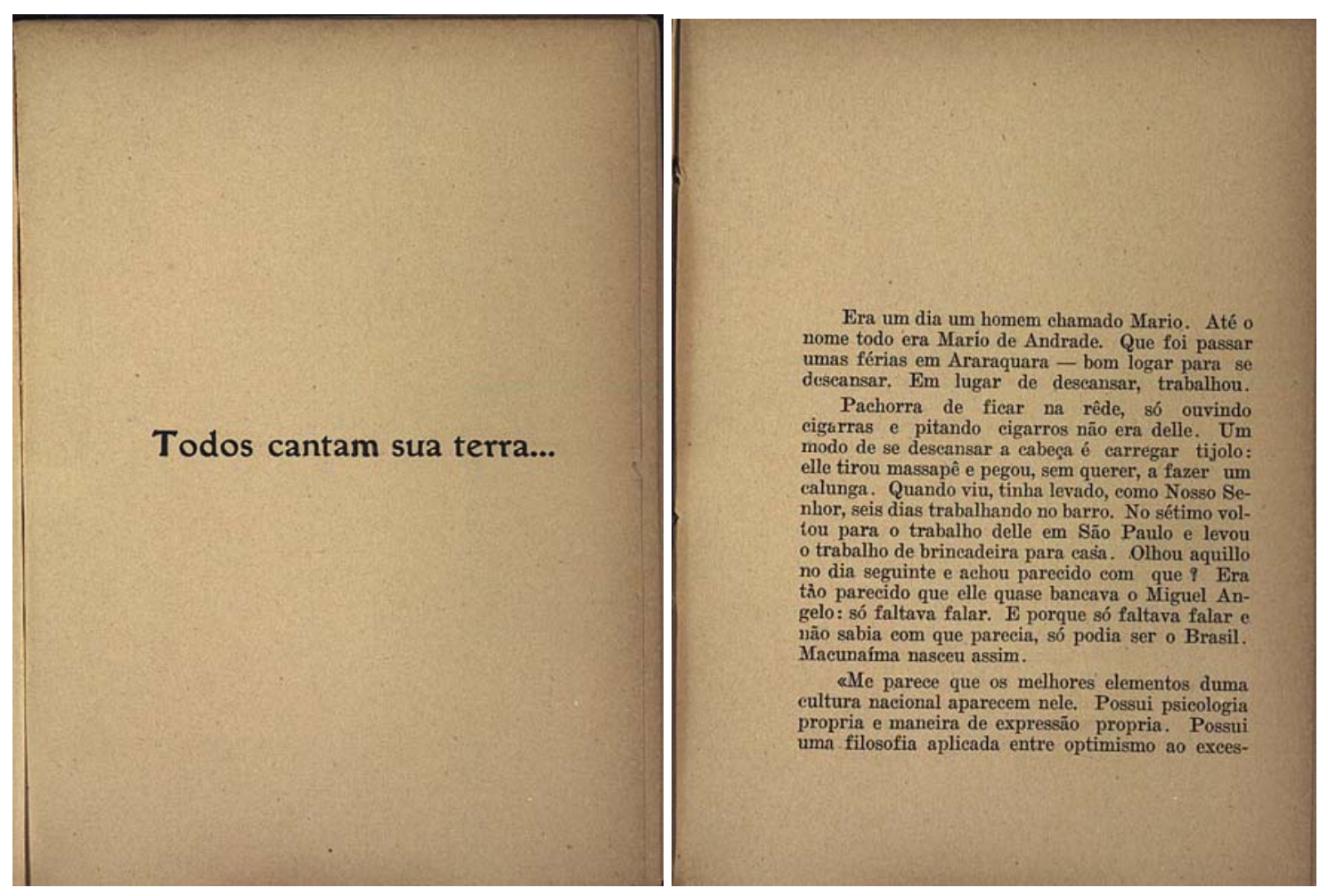

Dois ensaios, páginas 86 e 87.

\footnotetext{
${ }^{8}$ LimA, Jorge de. “Todos cantam sua terra...”. In: Dois Ensaios. $1^{\text {a }}$ ed. Maceió (AL): Casa Ramalho, 1929, p. 86138. Reeditado em 1934 ( $2^{\mathrm{a}}$ edição. Rio de Janeiro: Civilização Brasileira). Recolhido em Obras completas de Jorge de Lima. Rio de Janeiro: Aguilar, 1959, p. 1012-1038, v. I. Reproduzido, parcialmente, com o título de “Um raide do subconsciente nacional”, em ANDRADE, Mário de. Macunaíma. Edição crítica de Telê Porto Ancona Lopez, 1978.
} 
O ensaio “Todos cantam sua terra...”, de Jorge de Lima, é o primeiro documento da fortuna crítica de Macunaíma publicado em livro. Médico e político militante, o autor, quando lançou o volume Dois ensaios (1929), onde se encontra o texto em questão, vivia em Maceió e já havia publicado outras obras como poeta, romancista e ensaísta. Nessa época, Jorge de Lima estava envolvido intelectual e artisticamente com o projeto regionalista de Gilberto Freyre e seguidores, dentre esses o amigo José Lins do Rego. As idéias de Freyre, como veremos adiante, norteiam o ensaio, um tanto confuso e largamente digressivo, que examina o movimento modernista e a rapsódia de Mário de Andrade.

Na abertura, o ensaio noticia: Macunaíma fora criado durante umas férias de Mário de Andrade, num sítio em Araraquara, em seis dias, como um "trabalho de brincadeira”. Pronto o trabalho, o autor percebera que o brinquedo continha "os melhores elementos duma cultura nacional (...)”9, a despeito de o herói da história não ser “absolutamente brasileiro”10.

Retomando metáforas críticas de Tristão de Ataíde, para quem Macunaíma seria um retrato do Brasil e um coquetel de gêneros, Jorge de Lima concorda com a sentença do mesmo crítico, segundo a qual o herói é símbolo do "homo brasiliensis"11, cuja ausência de caráter Mário de Andrade haveria consagrado como traço distintivo. Nesse ponto, o poeta de "Essa negra Fulô” refere-se a outro texto de Tristão de Ataíde, em que o crítico católico considerava a América lusitana menos característica do que a América anglo-saxônica e a hispanoamericana, além de propensa a percorrer um caminho seguido, até então, “em direção oposta às suas realidades" ${ }^{12}$. Segundo Ataíde, informa Jorge de Lima, o modernismo tomara consciência dessa "ausência de Brasil nos antigos” e se esforçara para integrar a literatura brasileira “com as nossas realidades reais”. O escritor alagoano concorda também com isso e ainda admite, conforme Tristão, que o movimento desencadeado em 1922 incorria em erro grave ao criar "um convencionalismo modernista, uma brasilidade forçada".

O ensaio envereda em longa digressão, no intuito de demonstrar a “ausência de Brasil” nos escritores do passado. Essa falta torna-se critério para: a) repudiar o indianismo literário

\footnotetext{
${ }^{9}$ Jorge de Lima cita, copiado do artigo pioneiro de Tristão de Ataíde, um longo trecho do segundo prefácio de Mário a Macunaíma, identificando-o em nota de rodapé, de modo inexato, como "trecho da carta de Mário de Andrade a Tristão de Ataíde”.

${ }^{10}$ Expressão usada por Mário de Andrade, no segundo prefácio, para caracterizar o protagonista como personagem cuja amplitude semântica ultrapassa o referente brasileiro. Mário se congratula nesse prefácio por Macunaíma ser tão ou mais venezuelano do que brasileiro. Jorge de Lima cita o prefácio por intermédio do artigo de Tristão de Ataíde.

${ }^{11}$ Tristão de Ataíde, em seu ensaio, valeu-se da expressão latina "homo brasilicus" em vez de "homo brasiliensis”, adotada por Jorge de Lima.

${ }^{12}$ Jorge de Lima resenha idéias do artigo de Tristão de Ataíde, sem citar o texto nem indicar apropriadamente a fonte, limitando-se a informar que se tratava de material publicado no "jornalzinho da Ação Universitária Católica".
} 
de Gonçalves Dias e de José de Alencar, sob o argumento de que ambos haveriam concebido o indígena segundo modelos lusitanos; b) rechaçar o abolicionismo condoreiro de Castro Alves, pois o poeta baiano teria "elevado a espártaco" o negro, por meio do "pior romantismo do mundo que foi o de [Victor] Hugo"; c) lamentar a influência do condoreirismo na geração seguinte, de Martins Júnior, Tobias Barreto e Sílvio Romero, cuja poesia dita “científica” teria preservado o "lado ruim" de Castro Alves, o da poesia social, em detrimento do "lirismo tão fresco" de poemas como "Laço de fita” ou “Boa noite, Maria!”, de Espumas flutuantes. A origem da má retórica de toda essa "poesia excrescente e lambanceira” estaria, segundo observação de José Veríssimo endossada por Jorge de Lima, no gongorismo precoce do prefácio de Prosopopéia (1601), de Bento Teixeira, estilo que contaminara a literatura brasileira posterior. Nas palavras do crítico alagoano: "três séculos de gongorismo, e gongorismo reúno, que ainda dura hoje, capaz de projeção por muito tempo ainda.”

Desse modo, quase toda a literatura brasileira do passado é entendida como "literatura de imitação, de transposição quase”, em que os autores se deixaram levar pelas mais variadas "correntes estranhas, nocivas", de modo a desviar "o espírito brasileiro do achamento de sua expressão, de seus ritmos, de suas verdades.” Segundo Jorge de Lima, para evitar o nacionalismo intencional, o Brasil não deveria ser procurado, mas achado: "Não digo procura porque a procura implica uma intenção; falo achamento - que se teria alcançado talvez pelo caminho da nossa singeleza, da nossa brabeza virgem afastada completamente de qualquer imitação”.

Concluindo a argumentação sobre a “ausência de Brasil” em nossa literatura, o ensaísta sentencia: "as primeiras tentativas de expressão nacional foram assim todas elas falsas pelo exagero" ufanista e, embora o modernismo contivesse "muito de real”, sua intencionalidade prejudicara a expressão artística do Brasil ao praticar uma “campanha literária” favorável ao nacionalismo do tipo “custe o que custar”, de modo a incorrer em erro semelhante ao do passado literário e cair por vezes no ridículo.

O “achamento” do Brasil exigiria, pois, o abandono da intencionalidade nacionalista e da correspondente expressão carregada de exagero; exigiria também "trazer o homem brasileiro à sua realidade étnica, política e religiosa”, segundo o exemplo de Os sertões, em que Euclides da Cunha, vencendo o exagero, alcançara "uma expressão brasileira” e revelara "um pedaço da gente brasileira, um bocado bom do nosso mesticismo, do nosso misticismo e da nossa política”, três elementos que deveriam preocupar os intelectuais brasileiros contemporâneos, para além da literatura, e cuja revisão seria necessária e urgente. Isso porque, segundo Jorge de Lima, os intelectuais do passado, vivendo em situação de dependência, foram “obri- 
gados à traição”; exceção feita a Machado de Assis, tornaram-se áulicos, curvados ao poder em busca de sinecuras, e falsearam as questões.

O modernismo, diz o crítico, fora rechaçado pela burguesia, razão pela qual, "apesar dos pesares”, tornara-se “quase que o único movimento literário brasileiro curado de traição”, encontrando-se, portanto, em posição favorável para operar uma revisão de conceitos.

Ao espantar a burguesia, que tomara o movimento por "brincadeira de meninos, ou leseira de malucos”, os modernistas teriam sido obrigados ao isolamento e, por vezes, à prática da “poesia pura (...) separada de toda função áulica: isto é, diretamente social e política”. Embora separadas, as manifestações artísticas não seriam de todo independentes dos acontecimentos sociais e políticos, uma vez que eventos importantes dessa natureza "poderiam provocar também reações estéticas paralelas”. Levando isso em consideração, o artista deveria evitar a manifestação diretamente interessada, social e politicamente, mas o mesmo afastamento não seria tão necessário em relação à religião, pois, pressupõe o crítico, a arte, “às vezes, está tão pegada nela que a oração já é poesia”.

Então, Jorge de Lima considera necessário saber se os brasileiros constituem um povo místico, condição para que o elemento religioso (“misticismo”) tivesse validade nas manifestações artísticas. Asseverando que Macunaíma, resultante de pesquisas de Mário de Andrade, dá “a entender que o substrato desta nossa nação não tem caráter, é amoral e portanto irreligioso", Jorge de Lima se propõe a investigar a religiosidade dos brasileiros no "nosso jeito de ser católicos” e envereda em nova longa digressão.

Pergunta-se o ensaísta se o povo brasileiro é místico. Para responder, parte da observação da tendência desse povo para a "prática religiosa exterior, discursiva, oratória, literária”, cuja origem estaria no processo empregado pelos missionários na catequese dos indígenas. Segundo Jorge de Lima, “outros povos aceitaram o cristianismo num nível, num plano de civilização de preparo prévio que nos faltou”; os indígenas, antropófagos no “nível” cultural da “machadinha de pedra”, seriam “crianças grandes”, incapazes de compreender a religião. “Para gravar naquelas crianças grandes a palavra eterna”, os jesuítas teriam agido pragmaticamente, aplicando o processo “mais pedagógico, (...) de fazer o índio gostar de religião.” Para ilustrar tal processo, Jorge de Lima descreve a encenação de autos de José de Anchieta, seguidos de festanças em que "a indiaria embasbacada e depois excitada pelo sucesso da peça, caía num frevo carnavalesco de treme-terra, cadenciado a passo de siri-congado e ritmado de tambores, bumbos, caixas e saca-buchas. Era o suco. Em seguida três descargas de mosquetaria. Farta distribuição de espelhinhos e contas para os convivas, canivetinhos e estampas aos 
pajés, vivas a Portugal, vivas ao Brasil.” Desse modo, o indígena ter-se-ia afeiçoado à religião, preparando caminho para que o mesmo sucedesse com os africanos, considerados também como petizes, uma vez que o "nível” cultural dos adventícios escravizados seria, supostamente, análogo ao dos indígenas.

Entendendo que "nas crianças ninguém pode corrigir as criançadas da noite para o dia” e que “Jesus até gostava de criança”, o “inteligentíssimo missionário católico” fora complacente em relação a práticas heterodoxas - como a de virar de cabeça para baixo a imagem de um santo e de surrá-la com um galho para obter a concessão de um pedido -, fizera do templo católico uma espécie de “circo divino” e agira, a exemplo de São Francisco, como “jongleurs de Dieu! Palhaços do Senhor”, cuja linguagem seria a dos “poverellos”, uma linguagem universal entendida por todos: “Até os botocudos entendem. Os aimorés, os congos, os cabindas, os brasileiros de quando o Brasil amanhecia”.

Sedimentados “sem dúvida no subconsciente da nação”, diz o crítico, os atraentes ritos católicos se enriqueceram com a “colaboração das raças”, conforme José Lins do Rego notara nas práticas do catolicismo nordestino, destacadas no prefácio que o então futuro autor de Menino de engenho escrevera para o livro Poemas (1927), de Jorge de Lima.

Se o catolicismo do índio e do africano era precário, assim também era o dos adventícios europeus, gente "ruinzinha que doía (...) - o diabo que vinha da Renascença com os olhos de fogo sobre o Brasil.” Fundamentado nas cartas de Anchieta e de Manuel da Nóbrega, Jorge de Lima assevera que, exceção feita aos missionários católicos, os demais colonos comportavam-se de modo dissoluto e criminoso. Mas o relaxamento moral não os impedia de participar gostosamente de práticas devotas, como as procissões descritas por Martius [Viagens, obra só mencionada], Gilberto Freyre [excerto citado de Vida social do nordeste] ou Fernão Cardim [fragmento citado da obra Jesuítas do Brasil, do padre Luís Gonzaga Cabral]. Conforme o ensaísta, essas práticas marcadas por uma religiosidade sincrética ainda vigoravam nas procissões “por todo o Brasil, em que as autoridades que sustentam o pálio são as mais das vezes maçons-espíritas-católicos e a mulatinha que faz a Verônica é filha da negra-mina que tem um xangô perto da Igreja.” Jorge de Lima admite que essa religiosidade “não é catolicismo”, mas “um terreno preparado para o catolicismo nascer”; se não é religião, propriamente, “não deixa de ser um caráter (...) até gostoso, meio ingênuo e meio descarado.”

Na opinião de Jorge de Lima, a religiosidade sincrética é uma característica marcante dos brasileiros, mais até que “a pornografia que o Mário de Andrade acha tão nossa”. O ensaísta considera a obscenidade um tipo de manifestação do subconsciente de todos os povos, 
uma espécie de caduquice do espírito, que “em todo o mundo brota no doido, brota no delírio comum a muitas doenças, aparece todas as vezes que nós damos a palavra a ele [subconsciente].” Como exemplo da universalidade do "subconsciente sujo", Jorge de Lima cita a obra de Rabelais e os estudos de Berkeley Hill, Ferenczi e Freud. Agora, se do subconsciente provém “um despotismo de sujidades”, dele também se origina “uma porção de coisas bonitas”.

Perante essa dualidade, Jorge de Lima pergunta: “Como então encontrar a nossa expressão? Será descendo ao nosso subconsciente ou pesando as possibilidades ou medindo os degraus da nossa consciência, das forças voluntariosas do nosso caráter?”

Para responder, admite provisoriamente que o brasileiro se caracteriza pela falta de caráter, conforme Mário de Andrade postulara em Macunaíma, e passa a analisar a questão. Declara-se convencido de que “o brasileiro nasceu empelicado”, isto é, afortunado, pois sendo “um povo amassado de três barros ruins ainda não se esmigalhou”, resistindo à dissolução supostamente característica de seus elementos formadores. Embora provinda de africanos antropófagos, portugueses dissolutos, quando não criminosos, e de ameríndios entregues à luxúria, a gente brasileira "não consegue um recordezinho de criminalidade homicida" e "tem menos pervertidos sexuais que muito povo bom". Além disso, o brasileiro estaria "resistindo a quatro séculos de vermes, sezões, cachaça e doenças-do-mundo" e resolvendo os seus "problemas mais sérios não os resolvendo”. Segundo Jorge de Lima, o método de resistência do brasileiro é a indolência e o sexo: “Não está vendo que ninguém sai da rede para resolver problemas? Nós $0^{13}$ resolvemos dentro da rede mesmo. Dormindo com ele ou dormindo nele. $\mathrm{O}$ problema do negro foi assim: resolvido sexualmente." Para o poeta de "Essa negra Fulô", a "racinha” brasileira resulta da entredevoração dos três elementos formadores, e não como o movimento da antropofagia supunha ao propor que o índio devorasse o negro e o branco. No entanto, o entredevoramento ainda estaria em curso, de modo que seria impossível compreender os "problemas, finalidades, destinos" de "um povo provindo de raças choramingas [que] ainda não deu para berrar no meio do mundo.”

O ensaísta compara, então, a antropofagia, o “neo-indianismo realista” e o modernismo a um ovo gorado, entendendo a intencionalidade e o exagero nacionalista dessas correntes como razões para que elas fracassassem no esforço de captar a imagem ainda indefinida do brasileiro, bem como no de criar a respectiva expressão. Macunaíma, porém, seria “um ovo que deu asas”, pois, nessa obra, Mário de Andrade realizara com êxito a dupla empreitada.

\footnotetext{
${ }^{13}$ Silepse de número.
} 
Jorge de Lima compreende Macunaíma como uma espécie de “visão de aeroplano”, uma "fotografia tirada do alto", que “deixa a gente ver um pedação da nossa alma e da nossa terra” e consegue realizar "um bocado enorme da nossa expressão”. Confrontando Tristão de Ataíde e Mário de Andrade, o ensaísta concorda com o primeiro ao afirmar que Macunaíma é o Brasil e "o herói da brincadeira só pode ser o brasileiro”, a despeito da ausência dessa intenção por parte do autor. Agora, exatamente por ser a obra concebida como uma brincadeira, involuntariamente, ela realizara uma feliz imagem do Brasil e criara uma bem-sucedida expressão brasileira. Mário de Andrade se livrara da intencionalidade do nacionalismo literário e, sempre segundo Jorge de Lima, deixara “falar o seu subconsciente, que é uma parte do subconsciente coletivo do país”. Por isso e por ter sido escrito em seis dias, assevera o crítico, Macunaíma é “um raide do subconsciente nacional”, que outros haveriam tentado “desde Basílio e Durão até hoje”, mas só Mário conseguira cumprir, devido à “força” do artista, uma vez que "os raides dependem mais de força do que de vontade".

Excetuando a "Carta pras Icamiabas”, que seria a "única paulificância do livro”, Jorge de Lima considera que “o resto é a mais bonita das histórias”. "Mário Macunaíma”, isto é, o autor figurado na obra, a teria ouvido de um papagaio e a contara, por meio de seu subconsciente, com a "expressão e o encanto das histórias de mãe-preta” e com a beleza "que alemão não tem jeito de contar pra o mundo”.

A linguagem, suporte da história contada, é compreendida como "uma certa vitória do brasileiro falado sobre o português escrito” - uma conquista que Mário de Andrade compartilhava com o “gorado Modernismo”. Jorge de Lima, porém, sugere haver um diferença entre a conquista de Mário e a do movimento modernista. Com Macunaíma, Mário alcançara mais que a fabulação de um mito solar e o "aproveitamento simbólico desse mito para explicar o nosso falso brilho, 'bonito mas inútil’”; realizara “a expressão genuína [que] corre igualzinha com o genuíno das nossas realidades, com o característico das nossas faltas, do nosso eu enfim”. Depreende-se que a expressão lograda pelos demais modernistas ter-se-ia configurado ao crítico como linguagem inautêntica, pois, na linha de pensamento percorrida no ensaio, não corresponderia ao "genuíno de nossas realidades”, por forçar a nota nacionalista intencional.

Jorge de Lima sustenta que a língua de Macunaíma, apesar da teimosia de Mário em “provar a nossa ausência de caráter”, já é manifestação de caráter, na medida em que, como afirmara num passo anterior, o caráter coincide com a expressão, e que o próprio herói às vezes divisa possibilidades de sedimentação de caráter, exemplificadas na hesitação, antes de subir ao céu e tornar-se a Ursa Maior, entre viver na ilha de Marajó ou “morar na cidade da 
Pedra com o enérgico Delmiro Gouveia”. Não obstante isso, o crítico assinala que a resolução final do herói corresponde à triste verdade de que "nós [brasileiros] vivemos no mundo da lua, enquanto o estrangeiro se adapta a mais e mais no mundo da nossa Terra”.

Daí em diante, Jorge de Lima aparentemente abandona o assunto que, de Macunaíma, passa a ser o da necessidade de definição do brasileiro, associado à proposta de "uma literatura nova que sucedesse à atual”. Garante o ensaísta: sua sugestão não contém má vontade em relação ao estrangeiro, como ocorrera com o modernismo, levado ao “jacobinismo inútil” de um degenerado "brasileirismo de quero porque quero". Porém, a "preocupação do universal” deveria ser igualmente evitada, uma vez que “cosmopolitismo é indefinição” e "nós [brasileiros] precisamos antes de tudo de ser”, pois “o perigo da indefinição deveria amedrontar-nos tanto quanto amedronta o alemão de hoje quase afogado pelo judeu.”

Jorge de Lima cita Adolf Bartels (1862-1945), escritor alemão anti-semita, cujas palavras considera "tão oportunas que parecem escritas para a gente”. Segundo Bartels, os alemães deveriam permanecer fiéis à sua nacionalidade, sem dar ouvidos às "grandes palavras dos 'modernos'”, para que não se deixassem trivializar pela “nacionalidade ‘européia’”, nem abastardar "pela nação dos judeus, que agora é o inimigo real”; Bartels assinala que "toda a arte é e permanece nacional; quanto mais forte, mais nacional ela é” e que só pode ser literatura universal o que provém do "mais profundo ser" de um povo ${ }^{14}$.

Em nota de rodapé, Jorge de Lima afirma que “alemães, franceses, brasileiros pensam do mesmo modo" e, para corroborar a assertiva, transcreve alguns parágrafos de um ensaio de José Lins do Rego, a propósito de A bagaceira, em que o futuro autor de Menino de engenho cita Jacques Maritain - "les oeuvres les plus universeles et les plus humaines sont celles qui portent plus franchement la marque de leur patrie” - e louva o regionalismo de José Américo

\footnotetext{
${ }^{14}$ No corpo de seu ensaio, Jorge de Lima cita a seguinte passagem de História da literatura alemã, de Adolf Bartels: "Denn nur das Beste und das Besonderste eines jeden Volkes, das, was aus seinem tiefsten Wesen kommt, ist Weltliteratur und kann allen etwas sein, nicht das, was allen gemeinschaftlich ist." Em nota de rodapé, cita mais dois parágrafos da mesma obra: "Mit einem Wort: alle Kunst ist und bleibt national, ist um so stärker, je nationaler sie ist. [§] "Nein, du deutsches Volk, lasse dich nicht durch die großen Worte der 'Modernen' beirren, bleibe deinem germanischen Volkstum treu, reinige es, vertiefe es, halte es heilig! Wir wollen sein, wie wir sind, oder wir wollen nicht sein, wollen uns unser Deutschtum nicht durch 'Europäertum' verflachen und versimpeln, nicht durch das Iudentum, das jetzt der reale Feind ist, verfälschen und verderben lassen.” (Geschichte der deutschen Literatur, von Adolf Bartels. Verlag von George Westermann). Em tradução de Rodrigo Manz de Paula Ramos: "Pois apenas o melhor e o mais especial de cada povo, que vem do seu mais profundo ser, é literatura universal e pode significar algo para qualquer pessoa, não sendo tudo que é comum.” / "Em uma palavra: toda arte é e permanece nacional; quanto mais forte, mais nacional ela é. [§] Não, ó povo alemão, não te deixes desconcertar pelas grandes palavras dos 'modernos', permaneça fiel à tua nacionalidade germânica, purifique-a, aprofunde-a, tenha-a como divina! Nós queremos ser como somos ou então não queremos ser, não queremos que nossa nacionalidade alemã se trivialize pela nacionalidade 'européia' e seja abastardada e arruinada pela nação dos judeus, que agora é o inimigo real.”
} 
de Almeida, que não deixaria de ser universal, conforme Gilberto Freyre postulava que o regionalismo fosse.

O modo como Jorge de Lima articula essa nota de pé de página com o corpo do texto provoca a associação entre as idéias do autor alemão e as de José Lins do Rego, por sua vez escoradas em Gilberto Freyre. Depreende-se daí que, para o escritor alagoano, o nacionalismo anti-semita de Bartels estaria para a literatura alemã assim como, para a literatura brasileira, o regionalismo de Gilberto Freyre, assumido por José Lins como modelar. O poeta de "Essa negra Fulô”, então, indica de modo implícito o caminho gilbertiano como rota para "uma literatura nova”, que sucedesse o modernismo supostamente esgotado.

A literatura brasileira não deveria voltar ao passado para se renovar, pois isso significaria o retorno "ao retórico ruim ou ao gongorismo hugoano e científico”; deveria ir em frente, prosseguir do ponto alcançado pelo modernismo, cujo mérito seria o de ter-se aproximado de "um Brasil mais ou menos real” e, com exceção do grupo antropofágico, do "catolicismo, com as predominantes das três raças”. Esse avanço a partir do modernismo, conforme Jorge de Lima, já mostrava uma reação “anti-ANTI-SINTAXE” e “anti-ANTIGRAMATICAL em oposição ao desleixo que surgiu em alguns escritos, no começo [do modernismo]”, mas deveria evitar "todas aquelas coisas grandíloquas, empoladas, gongóricas, condoreiras, (...) a ufania do Brasil.” Para isso, seria necessário adotar na literatura o “tom natural de quem diz”, em vez da impostação afetada de quem canta. Assim, supõe o crítico, seria obtida a sinceridade e a simplicidade de que só o subconsciente é capaz, de modo que a literatura seria ouvida e ajudaria a consciência nacional a livrar-se do "perigo das saúvas”.

Considerando que "há saúva debaixo dos nossos alicerces” e que “muita [ação?; literatura?] formicida" foi utilizada inutilmente contra os "formigueiros", Jorge de Lima afirma que “ou o brasileiro deserta para o céu e vira estrela ou fica na terra e tem que virar tatu”, para concluir: os modernistas tentaram alcançar "alforria”, mas, cativos de símbolos ("Símboloestrela. Símbolo-tatu. Como símbolo-maracajá. Como símbolo-anta. Como símbolo-Brasil.”), pouquíssimos tiveram força "para arrebentar os ferros”. Com essas imagens um tanto obscuras, Jorge de Lima encerra o ensaio.

Um ano após o lançamento de Macunaíma, tornam-se escassos os pronunciamentos críticos sobre a obra. Entre 1930 e 1936, ano anterior ao da segunda edição da rapsódia andradiana, nossa pesquisa pôde recolher somente três matérias “novas”. Além dessas, há o registro de duas reeditadas: os artigos "Macunaíma - o herói sem nenhum caráter - de Mário de Andrade”, de Ronald Carvalho (Movimento: RJ, 01 de outubro de 1928), e "Brasilidade e di- 
namismo: a propósito do 'Macunaíma’ de Mário de Andrade”, de Ascenso Ferreira (Diário Nacional: SP, 28 de novembro de 1928). Consta que esse último foi republicado no mesmo Diário Nacional, na edição de 23 novembro de $1931^{15}$; como não localizamos esse documento, nada podemos dizer sobre possíveis modificações no texto. O artigo de Ronald de Carvalho foi recolhido em livro, no mesmo ano de 1931, com o título mudado para "Macunaíma, de Mário de Andrade” e algumas ligeiras alterações no texto ${ }^{16}$. Como as mudanças operadas nessa última versão incidem apenas na divisão de parágrafos e em pontuais acréscimos, substituições ou supressões de palavras, simples cosmética que em nada altera o conteúdo da primeira versão, já resenhada e discutida no primeiro capítulo deste estudo, seria inútil retomá-la aqui. Presumindo que Ascenso Ferreira haja mantido o texto original ou introduzido nele modificações superficiais, como as de Ronald de Carvalho, nada haveria a acrescentar ao que já foi examinado. Quanto aos dois textos reeditados, basta o registro de seus retornos à circulação. Detenhamo-nos, porém, nos documentos ainda não resenhados.

\section{CONTRA GRAÇA ARANHA}

Meyer, Augusto. “Macunaíma”. Correio de Povo: Porto Alegre, a. 36, no 153, p. 3, 01 de julho de 1930. Arquivo DZM.

No dia primeiro de julho de 1930, o jornal Correio do Povo, de Porto Alegre, estampa um pequeno artigo em que Augusto Meyer volta a tratar de Macunaíma, agora para cotejar a obra com Toda a América (1926), livro de poemas de Ronald de Carvalho. Mais exatamente, o crítico gaúcho compara imagens do Brasil e do povo brasileiro contidas nas duas obras.

Os poemas de Toda a América, segundo Meyer, conteriam a imagem de um "Brasil moço e satisfeito mostrando os dentes magníficos (...)”, correspondente à “mensagem otimista, higiênica, de professor de entusiasmo abstrato”, assumida por Ronald de Carvalho. O “tom largo de um profeta sem barbas nem arreganhos místicos”, adotado pelo poeta, é entendido pelo crítico como discurso vazio dedicado a uma “América cenográfica”, concebida de acordo com teorias hauridas de Graça Aranha.

\footnotetext{
${ }^{15}$ LOPEZ, Telê Porto Ancona. "Bibliografia sobre Macunaíma". In: ANDRADE, Mário de. Macunaíma. Edição crítica de Telê P. A. Lopez. Ed. cit., 1978.

${ }^{16}$ Carvalho, Ronald de. "Cadernos de imagens / 4 / Macunaíma, de Mário de Andrade”. In: Estudos Brasileiros. $1^{\mathrm{a}}$ ed. Rio de Janeiro: F. Briguiet, 1931, p. 151-152. Transcrito, com poucas modificações, de "Livros / Macunaíma - o herói sem nenhum caráter - de Mário de Andrade". Movimento: Rio de Janeiro, 01 de outubro de 1928, p. 21.
} 


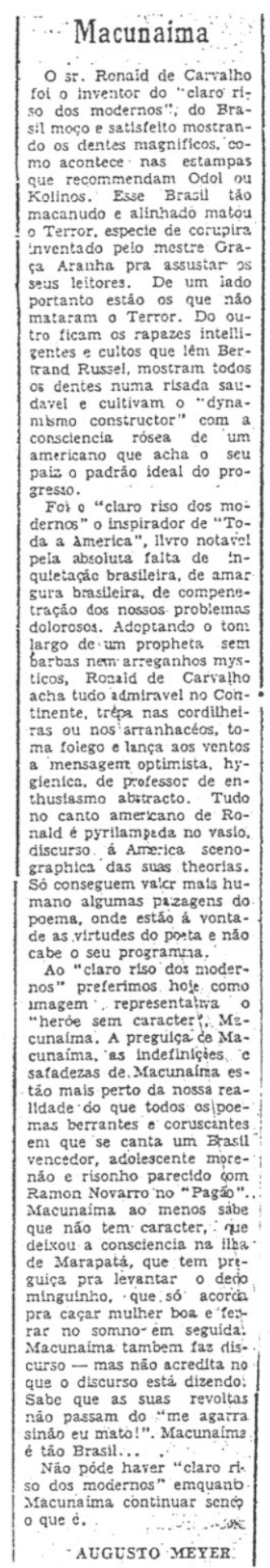

Segundo Meyer, Ronald de Carvalho realizara em Toda a América o programa nacionalista do autor de "O espírito moderno". O tom profético, o otimismo e a alegria entusiástica dos poemas são ironicamente associados à noção graciana de “dinamismo construtor” que, uma vez aplicada, resultara na criação da imagem de um Brasil distante da realidade, um Brasil "adolescente morenão e risonho parecido com Ramon Novarro no 'Pagão”,17. Essa imagem cinematográfica de um Brasil jovem e saudável corresponde à "consciência rósea de um americano que acha o seu país o padrão ideal do progresso.” Depreende-se dessa observação o vínculo estabelecido por Augusto Meyer entre a poesia de Ronald de Carvalho e a matriz evolucionista, associada à ideologia do progresso, e idealista do pensamento de Graça Aranha, que sobrepõe à realidade uma abstração teórica reputada por Meyer como vazia. Em decorrência desse vínculo, o livro Toda a América tornara-se "notável pela absoluta falta de inquietação brasileira, de amargura brasileira, de compenetração dos nossos problemas dolorosos”.

Para Augusto Meyer, a expressão “claro riso dos modernos”, atribuída a Ronald de Carvalho, sintetiza o nacionalismo idealista contido no livro Toda a América, cujos "poemas berrantes e coruscantes" cantam a imagem de “um Brasil vencedor”, na visão abstrata, otimista e ufana do país que, supostamente, derrotara o "terror" imaginado por Graça Aranha.

À imagem de país idealizado, oferecida pelo "claro riso dos modernos”, o crítico gaúcho prefere a que Mário de Andrade apresentara na figura do "herói sem nenhum caráter”. Em Macunaíma, o crítico reconhece uma “imagem representativa” do Brasil, sintetizada na inconsciência, na preguiça, na sensualidade libertina e na coragem do herói, que não passa de bravata a escamotear covardia. Para Augusto Meyer, as indefinições do herói preguiçoso, safado e autor de discursos, nos quais ele mesmo (o herói) não acredita,

\footnotetext{
${ }^{17}$ Ramon Novarro (1899-1968), cantor e ator mexicano de grande sucesso em Hollywood nas décadas de 1920 e de 1930. Estrelou vários filmes mudos e, já na fase sonora, musicais da MGM. O filme “The Pagan”, 1929, corresponde ao período de transição entre o cinema mudo e o sonoro.
} 
constituem uma imagem muito próxima, senão exata, da realidade do país: "Macunaíma é tão Brasil...”.

A afinidade espiritual de Augusto Meyer com o nacionalismo crítico de Mário de Andrade explicita-se na preferência dada a Macunaíma e no repúdio ao nacionalismo idealista de Ronald de Carvalho, inspirado em Graça Aranha: “Não pode haver 'claro riso dos modernos' enquanto Macunaíma continuar sendo o que é.”

\section{FOLCLORE INTELECTUAL}

Cascudo, Luís da Câmara. “Mário de Andrade”. Boletim de Ariel: Rio de Janeiro, a. 3, no 9, junho de 1934, p. 233-235. IEB-USP - MA-MP.

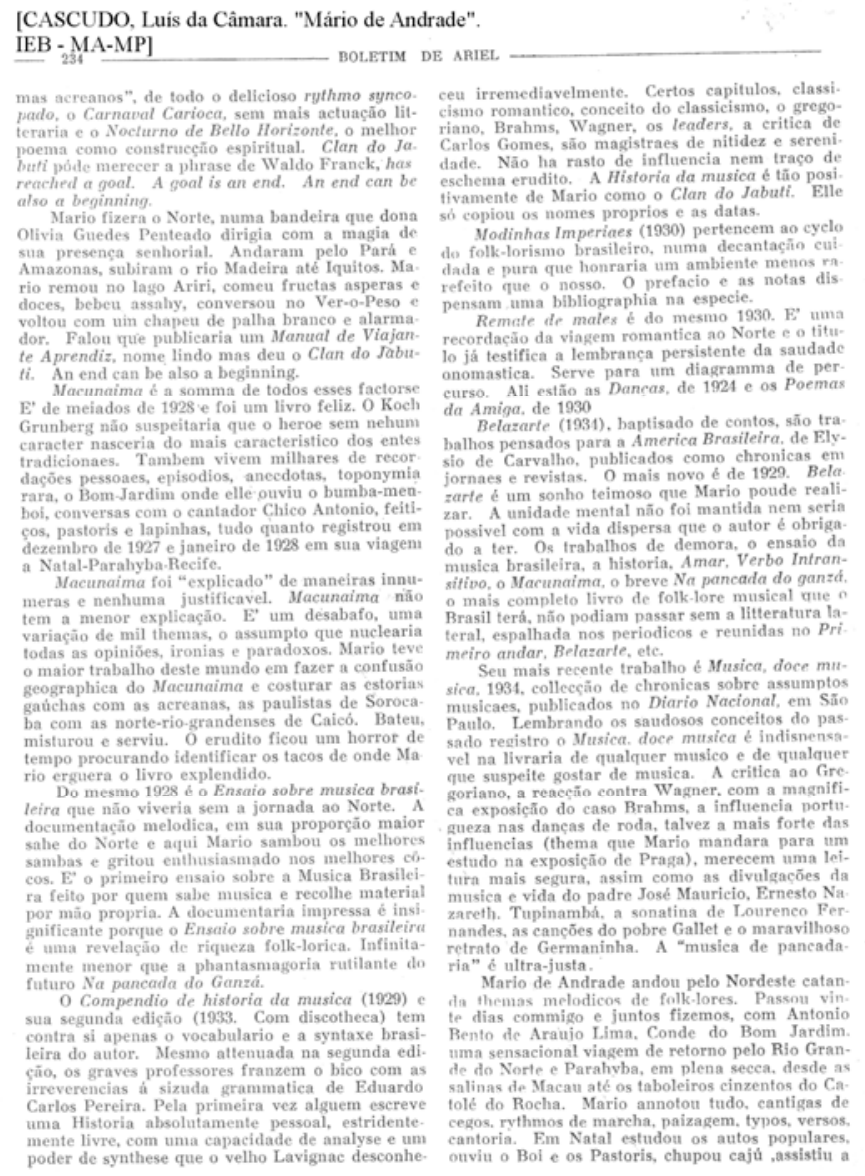

Luís da Câmara Cascudo dispensa apresentações. Como se sabe, o prolífero estudioso do folclore e Mário de Andrade foram amigos e compadres. A amizade, devido à distância que separava o natalense do paulistano, foi cultivada sobretudo por meio de cartas, trocadas entre 1924 e 1943, das quais só a correspondência ativa de Mário foi publicada ${ }^{18}$. Essa correspondência, corroborada por declarações de Câmara Cascudo, documenta a fecunda influência espiritual exercida mutuamente pelos amigos, que se conheceram pessoalmente em Natal na volta da viagem do "turista aprendiz” à Amazônia, empreendida entre maio e agosto de 1927. Os laços de amizade estreitaram-se durante a "viagem etnográfica” de Mário ao Nordeste, realizada entre dezembro de 1928 e fevereiro do ano seguinte.

\footnotetext{
${ }^{18}$ Andrade, Mário de. Cartas de Mário de Andrade a Luís da Câmara Cascudo. Introdução e notas de Veríssimo de Melo. Belo Horizonte/Rio de Janeiro: Itatiaia, 2000 (1ª̣ ed.: Villa Rica, 1991).
} 
No artigo “Mário de Andrade”, identificado acima, Câmara Cascudo traça um panorama da obra do escritor paulista, desde o primeiro livro até a produção recente e os projetos editoriais então em curso. As considerações sobre Macunaíma concentram-se em dois parágrafos do artigo, mas articulam-se ao que é dito antes.

Referindo-se à trajetória percorrida por Mário de Andrade até a publicação da rapsódia, Câmara Cascudo afirma: “Macunaíma é a soma de todos esses fatores”. Ao caracterizar esse trajeto, o escritor norte-rio-grandense destaca dentre os "fatores" a liderança de Mário no modernismo, na condição de autor de Paulicéia desvairada, cujo "Prefácio interessantíssimo" se tornara “dogma sistematizador do movimento", algo semelhante ao papel exercido no romantismo francês pelo prefácio escrito por Victor Hugo para o drama Cromwell. Outro fator fora A escrava que não é Isaura, um "discurso sobre algumas tendências da poesia modernista”, entendido como “a mais completa de todas as análises” dessa matéria até então aparecidas no cenário internacional. Com esse ensaio, Mário inaugurara a "era-de-ver para os modernistas”, isto é, dera início a uma fase em que o movimento superava certa ingenuidade dos primeiros tempos e passava a apresentar maior consciência crítica e artística. A “Carta aberta a Graça Aranha”, publicada pelo jornal carioca A Manhã, em 12 de janeiro de 1926, é assinalada como momento em que Mário decide divulgar sua discordância e rejeição quanto ao papel de “orientador de suprema importância” que o autor da Estética da vida ostentava em relação ao movimento modernista.

Cascudo também ressalta certas conquistas técnicas de Mário, despercebidas pela crítica, como a "associação de idéias por constelação", experimentada no poema "Flamingo", de Losango cáqui; destaca, ainda, os estudos de alemão e as leituras de Freud - contemporâneos da publicação dos contos de Primeiro andar, considerado pelo próprio autor como um livro desigual, uma vez que reunia “orientações díspares e opostas” - como aquisições intelectuais aproveitadas na composição de Amar, verbo intransitivo, "romance maciço e compacto que assustou muita gente”. Câmara Cascudo registra nos poemas de Clã do jabuti o aproveitamento artístico de material etnográfico estudado por Mário na leitura de autores como KochGrünberg, von den Steinen, Stradelli, Roquete Pinto e outros, mas, sobretudo, o escritor norterio-grandense considera Macunaíma como "explicação de livros sucessivos e antevisão do folclore intelectual de Mário de Andrade”.

Resumidamente, são esses os “fatores” somados em Macunaíma, obra a que Câmara Cascudo se refere com a expressão "folclore intelectual”, mas que não deve ser entendida como assimilação puramente livresca da cultura popular, uma vez que Mário de Andrade jun- 
tara à erudição a experiência colhida na viagem ao Norte (maio/agosto de 1927), em companhia de dona Olívia Guedes Penteado. Câmara Cascudo, porém, equivoca-se ao afirmar que Macunaíma também se aproveitara de contatos diretos de Mário de Andrade com manifestações folclóricas nordestinas, “em dezembro de 1927 e janeiro de 1928”, durante viagem a “Natal-Paraíba-Recife”. O escritor natalense é traído pela memória, pois tal viagem, de fato empreendida entre dezembro de 1928 e fevereiro de 1929, não poderia repercutir na rapsódia, publicada “em meados de 1928”, como informa precisamente o próprio Cascudo. Não obstante isso, em rápidas escalas na viagem de volta do Norte para São Paulo, em meados de 1927, Mário travou breve contato pessoal com a cultura popular nordestina e algo dessa experiência pôde ser aproveitado na redação definitiva da primeira edição de Macunaíma.

Deixemos de lado as observações concernentes às obras e projetos literários de Mário de Andrade posteriores a Macunaíma, que não são pertinentes ao escopo deste estudo, para fixar-nos no comentário da rapsódia tecido pelo folclorista ilustre. Segundo ele, "KochGrünberg não suspeitaria que o herói sem nenhum caráter nasceria do mais característico dos entes tradicionais”, esse último entendido como Makunaima, o herói mítico dos indígenas. Com essa consideração, Câmara Cascudo assinala a liberdade artística de Mário de Andrade perante a principal matriz narrativa geradora da rapsódia. Macunaíma resultara de um imenso trabalho em que Mário costurara as aventuras do herói caribe com “estórias” gaúchas, acreanas, paulistas, norte-rio-grandenses e de outras partes, numa intencional "confusão geográfica” cujo resultado seria uma espécie de “desabafo, uma variação de mil temas, (...) opiniões, ironias e paradoxos” que a crítica tentara explicar de inúmeras maneiras, mas "nenhuma justificável”, pois Macunaíma não teria qualquer explicação. Implicitamente, Câmara Cascudo se vale da noção de “coquetel”, empregada por Tristão de Ataíde em sua recepção crítica ao livro (“Macunaíma”. O Jornal: RJ, 09 de setembro de 1928), ao consignar que Mário de Andrade "bateu, misturou e serviu" uma obra erguida a partir de um enorme repertório de "tacos” da cultura popular brasileira. No entanto, ao contrário do crítico católico, que havia depreciado a obra disfarçadamente, Câmara Cascudo dá a ela o valor de um “livro esplêndido”.

\section{RECRIAÇÃO E INTERPRETAÇÃO}


Até a segunda edição de Macunaíma, há somente mais um escrito documentado na fortuna crítica da rapsódia: um artigo de Sérgio Buarque de Holanda.

\section{Holanda, Sérgio Buarque de. “O mito de Macunaíma”. O Espelho. Rio de Janeiro, no 6, p. $54-56$, setembro de $1935 .^{19}$}

Historiador, sociólogo, crítico literário e jornalista cuja reputação dispensa adjetivos, Sérgio Buarque de Holanda foi um intelectual de grande relevo no movimento modernista, quer como crítico, quer como diretor da revista Estética, ao lado de Prudente de Moraes, neto.

O objetivo precípuo de Sérgio Buarque com o artigo “O mito de Macunaíma” é o de oferecer aos leitores versões traduzidas por ele de três narrativas caribes protagonizadas pelo herói mítico Makunaima - chamado por Sérgio de "Macunaíma” -, duas delas ("Incêndio" e “As brigas de Macunaíma”) coligidas por Koch-Grünberg"20; a outra (“Macunaíma e Piá”), pelo pesquisador alemão Walter Roth ${ }^{21}$. Na perspectiva deste estudo, não nos interessam essas traduções, mas os comentários que as precedem e constituem valiosa, embora sucinta, contribuição de Sérgio Buarque de Holanda para a fortuna crítica da rapsódia de Mário de Andrade.

Segundo o então iminente autor de Raízes do Brasil, Mário de Andrade retirara do contexto mítico o protagonista da obra, bem como as respectivas peripécias, para realizar um “admirável (...) trabalho de recriação” e de “interpretação desse espírito mágico, que contrasta com a nossa civilização técnica, utilitária, mas que, apesar de tudo, ainda vive entre nós, sob mil formas intermediárias.” Sérgio Buarque observa haver em Macunaíma a contraposição do "homo divinans" ao "homo faber", entendida como esforço, inédito em "nossa literatura de imaginação", empreendido para a representação sugestiva do "substractum primitivo de nossa cultura”.

Ao referir-se ao trabalho de recriação, Sérgio Buarque tem como pressuposto o caráter artístico da obra de Mário, entendida como construção culta a partir da cultura popular. Agora, tal recriação, observa o articulista, implica uma interpretação da cultura brasileira, segundo a qual primitivismo e civilização se articulam de modo contraditório, uma vez que o "espírito mágico”, próprio do arcaísmo associado ao primeiro termo, sobrevive "sob mil formas inter-

\footnotetext{
${ }^{19}$ Documento não localizado pela pesquisa, mas transcrito em HoLANDA, Sérgio Buarque de. O espírito e a letra. Organização, introdução e notas: Antônio Arnoni Prado. São Paulo: Companhia das Letras, 1996, vol. I, p. 260-267.

${ }^{20}$ Op. cit.

${ }^{21}$ RoTH, Walter. "An inquiry into the animism and folk-lore of the Guyana indians”. In: Thirtieth Annual Report of the Bureau of American Ethnology. Washington: [?], 1915. Informação bibliográfica de Sérgio Buarque de Holanda.
} 
mediárias” no segundo, associado à modernidade configurada no país. Sérgio Buarque de Holanda, no entanto, não desenvolve essa observação crítica, nem propõe qualquer hipótese quanto ao possível sentido da interpretação andradiana da cultura brasileira observada por ele, Sérgio, em Macunaíma. 


\section{DESDOBRAMENTOS DE UM DIÁLOGO}

A primeira onda da fortuna de Macunaíma abrange a crítica pioneira, discutida no primeiro capítulo deste estudo, e os demais pronunciamentos dedicados à obra no período compreendido entre 1929 e 1936, que acabamos de resenhar. Aos treze documentos pioneiros, somam-se agora mais onze, sem contar as já mencionadas reedições, em 1931, dos artigos de Ronald de Carvalho e de Ascenso Ferreira, ambos de 1928. Dessas onze recepções, oito se concentram em 1929, ainda no intervalo de um ano desde o lançamento da rapsódia. Passado esse intervalo e antes do surgimento da segunda edição de Macunaíma (1937), ou seja, em sete anos, somente três críticas, publicadas respectivamente em 1930 (Augusto Meyer), 1934 (Câmara Cascudo) e 1935 (Sérgio Buarque de Holanda), estão documentadas, e nenhuma delas tem por objeto, propriamente, a análise da obra, embora contenham, como vimos, relevantes considerações sobre ela.

Os documentos resenhados na primeira seção deste segundo capítulo são outros desdobramentos do diálogo iniciado por Mário de Andrade e Tristão de Ataíde. Examinemos, então, esses escritos e vejamos se eles se acomodam ou não à "bitola crítica" estabelecida pelos interlocutores inaugurais da fortuna crítica de Macunaíma, no esforço de discernir as novas contribuições que trouxeram para a discussão da obra, distinguindo-as da reiteração de aspectos antes abordados pelos críticos pioneiros, isto é, os que se pronunciaram em 1928.

\section{GÊNERO E MATERIAL}

No período de 1929 a 1936, a crítica pouco acrescenta aos pronunciamentos pioneiros (1928) sobre a questão do gênero e do material. Quanto a esse último, o artigo de Luís da Câmara Cascudo ("Mário de Andrade”) indica, além de Koch-Grünberg, etnógrafos ${ }^{22}$ não detectados ou mencionados por críticos predecessores, supostamente compulsados por Mário de Andrade, sem, contudo, especificar as obras respectivas ou o que exatamente se aproveitara delas. Oswaldo Costa (“Moquém / II - Hors d’oeuvre”) destaca o nome de Amorim², tam-

\footnotetext{
${ }^{22}$ Edgard Roquete Pinto (1884-1954); Karl von den Steinen (1885-1929); Paul Max Alexander Ehrenreich (1855-1914); Wilhelm Schmidt (1868-1954); Krause (?); Kanike (?); Antônio Colbacchini (1881-1960); Ermanno Stradelli (1852-1926).

${ }^{23}$ Brandão de Amorim (1865-1926): Lendas em nheengatu e em português (1926).
} 
bém sem citar a obra, como etnógrafo de que Mário de Andrade se valera como fonte das lendas amazônicas que ele, Mário, haveria coligido em Macunaíma.

Ascenso Ferreira protestou contra o reducionismo implícito na observação de Oswaldo Costa. Para o poeta de Catimbó, Macunaíma seria muito mais que simples recolta daquele etnógrafo ou de outro qualquer, porque constituía um "maravilhoso sonho de mil e uma noites do Brasil”. Assim, repete o que dissera em sua recepção pioneira ("Brasilidade e dinamismo: a propósito do ‘Macunaíma’ de Mário de Andrade”. Diário Nacional: SP, 28 de novembro de 1928). Ascenso sintetiza nessa definição agora reutilizada os mesmos valores analisados no primeiro artigo: a importância do fantástico e do onírico como elementos decisivos de composição, por sua vez articulada pelo processo episódico, em que as peripécias são portadoras da particularidade nacional.

Como vimos, na "Resposta ao poeta de Catimbó", Oswaldo Costa se retrata quanto à redução denunciada por Ascenso, reiterando sua primeira avaliação de Macunaíma como “a Odisséia brasileira”. Com isso, Costa não repetia, propriamente, a si mesmo; antes, ecoava a comparação feita primeiro por Oswald de Andrade (In: "Esquema ao Tristão de Ataíde”. Revista de Antropofagia: SP, setembro de 1928). Embora eco, tal aproximação com a alta tradição rapsódica renova o convite para uma reflexão crítica sobre um possível diálogo entre $M a$ cunaíma e essa tradição literária ilustre. Mas não passa de um convite, pois a hipótese implícita na observação de Oswald de Andrade não foi desenvolvida, nem por ele, nem por Oswaldo Costa no artigo em foco, e ainda espera por um estudo sistemático que a investigue.

Seja como for, Oswaldo Costa e Luís da Câmara Cascudo contribuíram, mesmo que o tenham feito por suposição, para indicar fontes etnográficas que testemunham o imenso trabalho de pesquisa do imaginário brasileiro, transfigurado por Mário de Andrade em sua obra fontes em boa parte confirmadas mais tarde por M. Cavalcanti Proença em seu magistral Roteiro de Macunaíma (1955).

Quanto ao gênero, a crítica compreendida no período 1929-1936 também repete as profusas classificações pioneiras, com destaque para as verificadas no artigo atribuído a Mário de Andrade (“Macunaíma. O livro de Mário de Andrade”. Diário Nacional: SP, 07 de agosto de 1928) e no de Tristão de Ataíde (“Macunaíma”. O Jornal: RJ, 09 de setembro de 1928).

A classificação de "história”, adotada pelo próprio autor na primeira edição, é agora seguida por António de Alcântara Machado (“O modernismo da literatura de 1928”. A União: [Paraíba, PB], 31 de janeiro de 1929), Aníbal Fernandes (“Através dos livros / Macunaíma Mário de Andrade - S. Paulo”. Diário de Pernambuco: Recife, 18 de abril de 1929), Ascenso 
Ferreira (“Carta do poeta de Catimbó”. Revista de Antropofagia. 2ª Dentição. Diário de S. Paulo: SP, 19 de julho de 1929) e Jorge de Lima (“Todos cantam sua terra...”. In: Dois Ensaios. $1^{a}$ ed. Maceió, AL: Casa Ramalho, 1929).

António de Alcântara Machado especifica: a narrativa tem a "feição de história anônima formada através de gerações”, ou seja, Macunaíma, a “história”, mimetiza narrativas da cultura popular de transmissão oral, o que implica a idéia de rapsódia expedida na primeira recepção feita por Machado. A implícita idéia de rapsódia é reiterada na designação de “poema nacional”, também retomada daquela primeira recepção, em que chamara a atenção para a língua poética, musical, da obra de Mário. Como vimos no primeiro capítulo, a noção de "poema”, associada a Macunaíma, fora destacada por Ronald de Carvalho e Ascenso Ferreira, dentre os leitores pioneiros, mas partira de Mário de Andrade e fora divulgada por Tristão de Ataíde nas transcrições que seu artigo fizera de trechos dos prefácios “inéditos”. Quanto ao gênero da obra, Alcântara Machado, na sua segunda abordagem de Macunaíma, nada acrescentou ao que dissera na primeira ou às considerações dos demais críticos pioneiros sobre a questão.

Aníbal Fernandes, ao designar Macunaíma como "história”, indicou tratar-se de uma obra de gênero semelhante ao das narrativas seriadas de As mil e uma noites, em que o elemento maravilhoso se destaca. Assim, Aníbal Fernandes repercute a aproximação estabelecida primeiro por Nestor Vítor (“Macunaíma, o herói sem nenhum caráter”. O Globo: RJ, 08 de outubro de 1928), mas também apontada pelo conterrâneo Ascenso Ferreira em "Brasilidade e dinamismo...” (Diário Nacional: SP, 28 de novembro de 1928) e, agora, na "Carta do poeta de Catimbó”, onde Ascenso reitera tal analogia com o cuidado de ressaltar o aspecto genuinamente brasileiro das peripécias do herói.

Para Jorge de Lima, Macunaíma se afigurava como "a mais bonita das histórias, com encanto das histórias da mãe-preta”. Obviamente, a designação de "história” deve ser aqui entendida no sentido de narrativa anônima de transmissão oral, típica da cultura popular manifesta na atividade dos contadores de histórias, tais como a paradigmática “mãe-preta”. Nesse sentido, nada se acrescenta ao que já fora observado por João Pacheco (““'Macunaíma’ - Mário de Andrade - São Paulo”. Folha Acadêmica: RJ, 13 de setembro de 1928).

A definição de Macunaíma como um coquetel de gêneros, estabelecida por Tristão de Ataíde, é retomada implicitamente por Câmara Cascudo e explicitamente por Jorge de Lima, sem qualquer discussão. 
Entre 1929 e 1936, nenhum dos críticos documentados postulou a designação de "romance” para configurar o gênero da obra, hipótese muito discutida pela crítica pioneira e também por Mário de Andrade, como vimos no primeiro capítulo.

Augusto Meyer (“Macunaíma por Mário de Andrade”. Revista do Globo: Porto Alegre, janeiro de 1929) e Jorge de Lima (“Todos cantam sua terra...”) valeram-se da noção de “brincadeira”, utilizada nos prefácios “inéditos” citados por Tristão, mas, tais quais os críticos pioneiros que mencionaram tal noção, também não se detiveram para dela extrair qualquer conhecimento crítico mais significativo. Assim como em 1928, no período 1929-1936, a noção de "brincadeira”, associada ao gênero de Macunaíma, foi tratada pela crítica como mera sugestão geral do aspecto lúdico da narrativa.

Augusto Meyer associou a "brincadeira literária” ao registro humorístico ostensivo, considerado disfarce de uma possível sátira. Com isso, alinhou-se a Ascenso Ferreira, único entre os críticos pioneiros a referir-se a Macunaíma como sátira, exceto o próprio Mário de Andrade na primeiríssima recepção, a ele atribuída. Do texto de Augusto Meyer, depreende-se que, assim como Ascenso e Mário em seus respectivos artigos, não se vai além da noção habitual de sátira, compreendida como obra literária cuja intenção é a de castigar os costumes por meio do riso (“castigat ridendo mores”). Porém, ao observar que a brincadeira literária se impregnara da "amargura das grandes crises, quando o espírito não acha em torno a diretiva”, Meyer acrescenta um matiz enriquecedor à noção de sátira associada a Macunaíma, que poderia ser representado pela frase latina "risum in lacrimis vertit" ("transforma o riso em lágrimas”). Dentre os críticos da primeira edição de Macunaíma, somente Augusto Meyer percebeu, ou foi o único a externar, essa dimensão dolorosa contida na obra. Não obstante isso, Meyer hesitou em reconhecer inequivocamente a obra como uma sátira, uma vez que, em última análise, seria um "livro que não cabe em nenhuma classificação” quanto ao gênero, alinhando-se, nesse particular, com a mesma observação expedida por Augusto Frederico Schmidt (“A propósito de Macunaíma”. A Ordem: RJ, [dezembro?] 1928).

\section{TRABALHO ARTÍSTICO: ESTRUTURA, COMPOSIÇÃO E LINGUAGEM}

Augusto Meyer considerou Macunaíma inclassificável em virtude do aspecto compositivo paradoxal da obra, que lhe parecera, ao mesmo tempo, “muito largado e muito contido”. O crítico gaúcho não desenvolveu essa observação; no entanto, é lícito assimilá-la como hipótese crítica segundo a qual a narrativa seria articulada por meio de síntese dialética entre de- 
sordem e ordem compositiva. Ao aspecto "largado", associado ao pólo da desordem, corresponde, por exemplo, a "linguagem polpuda, às vezes com excesso intencional”. Nesse caso, Meyer se refere à linguagem experimental de Mário de Andrade, que desordenara os cânones acadêmicos para criar uma expressão artística original, no contexto do movimento modernista, então ainda em luta contra o passadismo acadêmico. Isso é claramente sugerido quando o crítico chama de “abridor” o trabalho artístico realizado em Macunaíma, e ao referir-se a Mário de Andrade como "campeão de boxe no ringue modernista”.

Depreende-se que o vocábulo "largado” corresponde também aos sentidos de solto, livre, desleixado, atrevido, arisco, desabusado e excessivo, todos eles compatíveis, sob a perspectiva do experimentalismo modernista, com a linguagem, o estilo e a estrutura compositiva inusitada de Macunaíma. Agora, segundo Augusto Meyer, o livro é “complexo, denso”. Desse modo, o aspecto "largado" do experimento literário não impede a contenção ordenadora, pois os elementos aparentemente desordenados da narrativa conectam-se numa exuberante rede de relações de interdependência e se convertem em estrutura cerrada, artisticamente impecável.

Augusto Meyer viu em Macunaíma uma obra inaugural. António de Alcântara Machado, em “O modernismo da literatura de 1928”, manifesta opinião análoga ao reconhecer a rapsódia andradiana como um “rasgão na nossa literatura”. Com essa metáfora, Machado sugere considerar a obra como ruptura histórica em relação à literatura do passado e como ponto de inflexão da vindoura. O autor de Brás, Bexiga e Barra Funda deixa patente que Macunaíma constituía um momento revolucionário no âmbito da literatura brasileira, uma "quebra de todos os limites” artísticos a que se acomodavam as manifestações literárias então prestigiadas pelo gosto acadêmico. Receptivo ao novo, Machado reconhece a importância dessa ruptura em virtude do valor alcançado na obra, quer como prosa poética, quer como construção artística. Como prosa poética, Mário estilizara a "fala suculenta do homem da terra”, com seu “estilo meio bárbaro e meio ingênuo”. Desde os poemas de Clã do jabuti, assinala Alcântara Machado, Mário de Andrade alcançara o registro de uma "voz" original, que incorpora "todos os sotaques” brasileiros, “sem preocupação nacionalista”, isto é, um estilo artístico cuja singular invenção pessoal, admirável pelo “vigor expressivo”, contém a particularidade socializadora de "todos os sotaques" nacionais e, por ser desprovida de intencionalidade nacionalista, se insere no “mundo inteiro”.

Machado assevera: Mário de Andrade, “como os índios do Mato Grosso (...), acredita que o Brasil seja todo o mundo”, uma vez que descrê “na existência da pátria e das pátrias”. 
Ao quebrar os limites regionais dissociadores e identificar o Brasil com o mundo, a "voz" manifesta em Macunaíma, sugere o crítico, alcançara o registro da particularidade nacional e, por meio dessa, da universalidade humana.

O referido feitio “meio ingênuo” do estilo se associa à semelhança descortinada pelo crítico entre a criação culta de Mário de Andrade e as criações da cultura popular, cujas tradições são preservadas na memória e atualizadas na transmissão oral, performance a que é inerente a inserção do ponto inventivo, indicador de marca individual, nos recontos das tradições anônimas.

Na noção de semi-ingenuidade estilística está implícita a de trabalho artístico consciente, por meio do qual a obra culta se apropria de características em geral atribuídas às manifestações da cultura popular, tais como a oralidade, a simplicidade, a sinceridade e a candura, mas também a malícia e a esperteza.

Com a indicação do perfil “meio bárbaro”, Alcântara Machado sugere que o estilo de Macunaíma, conscientemente, apropria-se do registro incorreto, rústico, grosseiro, também atribuído comumente a manifestações culturais populares, estranhas aos cânones do então considerado bom-gosto acadêmico, apreciador da norma culta e do recato "civilizado", para incorporá-lo como elemento nobre de criação artística. Com isso, depreende-se da análise do autor de Brás, Bexiga e Barra Funda, Mário de Andrade provocara a ruptura histórica logo acima referida; uma ruptura estilística e, em última análise, artística contra o elitismo então característico da literatura brasileira, carregada de preconceitos anti-populares, e em favor da inclusão dignificadora da linguagem e do repertório da cultura popular, transfigurados na práxis da arte culta.

Assim, por meio do material “meio bárbaro e meio ingênuo”, Mário lograra um estilo inventivo, cuja linguagem comportaria o dom da sensualidade sugestiva de "cor e cheiro", além de movimento coreográfico, em que os “períodos dançam, sapateiam, rebolam.” Invenção, vigor, linguagem sinestésica e coreográfica são propriedades estilísticas ressaltadas por Alcântara Machado para indicar o alto valor que atribuíra à prosa de Macunaíma .

A composição episódica (“anedótica”) e a feição lendária são apontadas como, respectivamente, práxis estruturadora da narrativa e recriação culta do imaginário popular, cujo valor como ficção, ajuíza Machado, iguala ou excede o alcançado enquanto prosa poética.

Quer como prosa (poética), quer como ficção, a revolução artística promovida por Mário de Andrade com a transcriação culta do material popular, em Macunaíma, segundo Alcântara Machado, descortinava um rico veio a explorar dali em diante, constituindo-se em refe- 
rência necessária aos artistas vindouros: uma espécie de ponto de inflexão da literatura brasileira.

Mário de Andrade, anonimamente, na primeiríssima recepção a Macunaíma, mostrou convicção da importância de seu livro, ao destacar a contribuição original que ele representava para a literatura brasileira. Como vimos, uma boa parte da crítica pioneira e, agora, a quase totalidade dos pronunciamentos do período 1929-1936 não hesitou em considerar a rapsódia como obra seminal, quer pela estrutura, quer como construção, quer como estilo e linguagem, quer pela inédita riqueza de significados inscritos na narrativa, em suma, como realização artística.

Aníbal Fernandes (“Macunaíma - Mário de Andrade - S. Paulo”. Diário de Pernambuco: Recife, 18 de abril de 1929), no período tratado neste capítulo, foi o único a censurar a obra abertamente, mas soube apreciar certas qualidades. A contribuição mais importante do crítico pernambucano consiste no reconhecimento da autonomia de Macunaíma. É o que se pode depreender da afirmação segundo a qual a narrativa circunscreve um "mundo que parece que é o nosso mas de fato é puramente imaginário” e, também, quando o crítico acentua o fato desse mundo imaginário pertencer ao “domínio da fantasia e do impossível”, sendo que a "realidade é apenas um pretexto para formar o ambiente”. Pouquíssimos tiveram essa percepção ou intuição da autonomia da obra entendida como arte, em sua pura dimensão de discurso ficcional. Dentre os críticos pioneiros, a noção de obra de arte autônoma está implícita só nos pronunciamentos de Ronald de Carvalho (“Macunaíma tem sabor das obras de invenção”) e de Ascenso Ferreira (“o livro olhado em conjunto apenas com o sentimento de arte”), mas nenhum deles chegou formulá-la. Tampouco a explicitaram os críticos do período agora estudado. Dentre todos esses, Aníbal Fernandes é o que mais próximo esteve de fazê-lo, na medida em que enfatizou a dimensão de pura fantasia investida na obra.

Quanto ao estilo, o jornalista pernambucano admira-se do "talento espantoso” com que Mário de Andrade sustentara “o mesmo tom do princípio ao fim”, realizando uma "verdadeira ginástica verbal”, metáfora que implica a noção de trabalho construtivo. Não obstante isso e seguindo as pegadas dos artigos pioneiros de Tristão de Ataíde e do escritor paraibano José Vieira (“Macunaíma, por Mário de Andrade, S. Paulo, 1928”. Vanguarda: [RJ?], 10 de dezembro de 1928), Aníbal Fernandes assinalou que o “exercício” lingüístico da rapsódia era uma experiência solitária de Mário de Andrade, e que esse esforço pretendia tornar aceitável uma “algaravia como um idioma à parte”. Lembremos Tristão a isolar a língua de Macunaíma como criação, em última análise, puramente individual de Mário de Andrade, embora expres- 
siva de uma espécie de "língua de candomblé”, considerada "barbaria” deplorável; lembremos, também, José Vieira a admitir diferenciação entre a língua dos brasileiros e a dos portugueses, mas a recusar validade à língua de Macunaíma, supostamente carregada de brasileirismo excessivo e carente de articulação sintática. Aníbal Fernandes, como dissemos, sugere reconhecer esforço construtivo na "ginástica verbal”, mas para negá-lo como experiência válida, pois não admite a existência de uma "língua brasileira”, a despeito da pretensão dos "nacionalistas a todo pano".

Jorge de Lima (“Todos cantam sua terra...”), ao reconhecer a linguagem de Macunaíma como "vitória do brasileiro falado sobre o português escrito", posicionou-se do lado oposto ao de Aníbal Fernandes. O poeta alagoano não só concebe a existência, mas a necessidade da "língua brasileira”, fundamentada na fala. Sem ela, diz ele, fora impossível à literatura realizar a “expressão brasileira”, pois a linguagem, destituída “das nossas realidades”, limitara-se a imitar padrões transpostos da Europa, desde Bento Teixeira até o modernismo, entendido esse como primeiro movimento habilitado a produzir uma linguagem expressiva das "nossas realidades reais”.

Em seu ensaio, Jorge de Lima enfatiza: o "gongorismo" contaminara a literatura brasileira do século XVII ao XIX e constituía ainda um perigo ao modernismo. Por "gongorismo" não se entende apenas a corrente literária seiscentista, mas um estilo semelhante ou, melhor, um modelo estilístico anistórico caracterizado pelo tom grandíloquo e altissonante de canto impostado, tal como ocorreria também, assinala o crítico, no condoreirismo social de Castro Alves e noutras manifestações literárias históricas em que se verificasse a presença de um certo “malabarismo palavroso" veiculado pelo "Velho Mundo".

Desde o barroco, o estilo recorrente na literatura brasileira distanciara-se da fala, em favor de uma linguagem falseada pelo exagero com que deformara a realidade nacional. Tal linguagem é chamada de “canto” para caracterizar o artificialismo de um estilo impostado, cujos exageros expressionais, via de regra, associar-se-iam ao pernicioso ufanismo brasileiro, intensificando o falseamento da realidade. A esse estilo “cantado”, Jorge de Lima opõe um outro, que seria uma espécie de "fala” ditada pelo subconsciente, entendida como estilo adequado à expressão válida do real. O modernismo conquistara esse registro, mas não cabalmente, por força do assumido nacionalismo intencional, sempre exposto à contaminação ufanista. Daí o juízo segundo o qual o modernismo haveria gorado. Por essa razão, impunha-se à literatura brasileira a assimilação das conquistas modernistas válidas e, a partir delas, a busca de novos caminhos. 
Jorge de Lima dá a entender que Macunaíma seria o paradigma para a literatura vindoura, pois vingara como alada expressão brasileira (“um ovo que deu asas”), destituída de intencionalidade. Mário de Andrade realizara “um bocado enorme de nossa expressão”, por meio da transposição do "brasileiro falado” para a linguagem literária escrita, de tal modo que “a expressão genuína corre igualzinha com o genuíno das nossas realidades, com o característico das nossas faltas, do nosso eu enfim”. Brasileira, sem nacionalismo proposital, a linguagem de Macunaíma evitara o tom de “cantor de melodrama” e o exagero ufanista programático; Mário estilizara a fala brasileira de tal modo que a língua coincidira com o caráter do herói sem nenhum caráter, por sua vez identificado com o do povo brasileiro. Jorge de Lima atribui esse sucesso não à vontade, mas à força criadora do artista, uma vez que, supostamente, $M a$ cunaíma seria manifestação do subconsciente de Mário de Andrade, entendido como "uma parte do subconsciente coletivo do país”. Assim, o crítico alagoano subscreve a hipótese de Tristão de Ataíde, segundo a qual o subconsciente de Mário de Andrade realizara, a despeito da vontade, um retrato do Brasil e do povo brasileiro. Porém, ao contrário do líder católico, que censurou Macunaíma pela língua “de candomblé” e pelo “estilo bárbaro”, considerados em última instância como aventura meramente pessoal do autor, Jorge de Lima, aparentemente, entendeu a língua e o estilo da rapsódia como expressão genuína dos referentes e idêntica a eles, além de modelo para a literatura brasileira sucessora do supostamente esgotado modernismo.

\section{FICĊ̃̃o E REALIDADE: A SALADA IDEOLÓGICA DE JORGE DE LIMA}

Assim como os pronunciamentos pioneiros, analisados no primeiro capítulo, os do período agora em discussão enfatizam a conexão entre literatura e elementos extraliterários, considerada evidente na obra. Nesse aspecto, mais uma vez, as críticas são tributárias do diálogo Mário de Andrade-Tristão de Ataíde, explicitado, como vimos, no polêmico artigo do segundo. Tal se observa na insistência com que os críticos do período 1929-1936 referiram-se à dimensão simbólica de Macunaíma, acatando, ao menos em parte, o argumento de Tristão, de que o artista, subconscientemente, havia construído com a obra e o herói, respectivamente, símbolos do Brasil e do povo brasileiro. Como pudemos observar, Jorge de Lima reconstitui em seu ensaio certas ponderações do escritor católico para ratificá-las, ao considerar o herói como símbolo do "homo brasiliensis" e a obra como um "raide do subconsciente nacional”, 
sem contudo compartilhar a avaliação de Ataíde, pois, em vez de censurar, louvou os resultados alcançados pelo artista.

A análise do escritor alagoano inspira-se na de Tristão, mas contém pressupostos ideológicos e apresenta uma conclusão cujas peculiaridades merecem consideração especial. Comecemos pelo fim. A conclusão do ensaio é fraturada, pois se formula em parte no corpo do texto, mas se completa em nota de rodapé: o modernismo levara a literatura brasileira a realizar-se como expressão nacional por meio da autêntica identidade alcançada entre a linguagem, as "nossas realidades” e o "nosso eu”, mas o movimento fracassara ao contaminar-se pelo nacionalismo intencional e ufanista. Macunaíma fora a mais alta realização do modernismo, evitara a intencionalidade nacionalista e superara o movimento, indicando o caminho considerado necessário à literatura brasileira, dali em diante, para que fosse genuína - o da afirmação da identidade brasileira. Porém, Mário de Andrade não chegara a tanto, por seu herói ser desprovido de caráter. Embora admitisse Macunaíma como uma "visão de aeroplano”, uma espécie de “fotografia tirada do alto" que corresponderia à efetiva indefinição de caráter do povo brasileiro, Jorge de Lima estabelece como imperativo à literatura sucessora do modernismo e de Macunaíma, exatamente, o combate a essa indefinição.

O paradigma, então, deixa de ser a obra de Mário de Andrade e se desloca para um modelo literário afirmativo do caráter nacional brasileiro que, em nota de rodapé, Jorge de Lima, citando José Lins do Rego, identifica com a proposta regionalista de Gilberto Freyre. O romance A bagaceira (1928), de José Américo de Almeida, é indicado como exemplo vivo desse novo paradigma, em que a singularidade nordestina representaria a particularidade nacional e se revestiria de universal interesse humano.

Contudo, para evitar a indefinição do cosmopolitismo, supostamente implícita na solução simbólica de Macunaíma, o nacional e o universal deveriam ser decorrências e não valores apriorísticos buscados intencionalmente.

Ora, Macunaíma, na condição de “raide do subconsciente nacional”, evitara o nacionalismo intencional para expressar com autenticidade o Brasil e o brasileiro, caracterizados pela indefinição correspondente ao processo ainda inconcluso de entredevoramento das raças formadoras; no entanto, a deserção do herói para o céu e sua transformação na Ursa Maior é interpretada como um mito astronômico, suporte simbólico para "explicar o nosso falso brilho, 'bonito mas inútil'”. Assim, Macunaíma seria explicação verídica da ausência de caráter do brasileiro, mas não seria a solução artística historicamente necessária, uma vez que o sentido da obra propenderia a perpetuar a indefinição como traço cultural distintivo da nacionalidade, 
sendo tal indefinição associada à noção de “cosmopolitismo”, por sua vez relacionada, suposta e implicitamente, ao símbolo contido na ascensão uraniana do herói.

Extrapolando o território literário, Jorge de Lima insiste na necessidade histórica de definição do caráter nacional brasileiro, que superasse a condição indecisa retratada em $M a$ cunaíma. Para tanto, em vez da atitude evasiva do herói sem nenhum caráter, que deserta para o céu (imagem do universal) deixando a terra (o Brasil) entregue à ação das saúvas (o estrangeiro), a sedimentação do caráter a ser promovida pela nova literatura exigiria, pelo que se depreende da argumentação do ensaísta, a rejeição da solução simbólica de Mário de Andrade, considerada, em última análise, universalizante, em favor de uma enérgica afirmação da peculiaridade regional, pois essa seria o legítimo suporte da naturalidade, da sinceridade e da simplicidade que, egressas do subconsciente, levariam a literatura a ajudar a consciência nacional a livrar-se do “perigo das saúvas”, isto é, daquilo que impede a consolidação da consciência e da identidade brasileira. Assim, para Jorge de Lima, o regionalismo de Gilberto Freyre deveria orientar a nova literatura e não o cosmopolitismo de Mário de Andrade, supostamente configurado no episódio em que Macunaíma substitui sem prejuízo a consciência perdida na Ilha de Marapatá pela de um hispano-americano.

Agora, talvez sem se dar conta, nem da contradição, nem da impropriedade em que incorria, o poeta de "Essa negra Fulô" sugere que a orientação gilbertiana seria análoga à do escritor alemão Adolf Bartels. Por suposto, o regionalismo anti-cosmopolita de Freyre estaria para o nacionalismo anti-semita germânico, que estigmatiza a minoria judaica como alteridade perigosa, como elemento estranho e ameaçador à suposta superioridade da "nacionalidade germânica” - noção racista, herdeira do gobinismo. Assim como a assimilação do povo judeu, no contexto ideológico da supremacia ariana, é entendido como ameaça de dissolução e enfraquecimento dos alemães, Jorge de Lima estigmatiza o estrangeiro, que se apropria do Brasil enquanto o brasileiro se aliena, como a alteridade perigosa à afirmação da identidade nacional.

O escritor alagoano não adota o implícito postulado da ideologia racista, segundo o qual a mestiçagem é condição de inferioridade, mas absorve a visceral xenofobia que a caracteriza, embora afirme o contrário disso ao declarar-se isento de qualquer resquício de “má vontade ao estrangeiro - dessa má vontade nortista jacobiníssima que parece vir ainda dos tempos das tremendas lutas coloniais com o estrangeiro, com o holandês, o francês, o espanhol e o português.” Para o ensaísta, a realidade étnica brasileira condiz com a mestiçagem de “um povo amassado de três barros ruins”, que, surpreendentemente, “ainda não se esmiga- 
lhou”, "não consegue um recordezinho de criminalidade homicida”, apresenta "menos pervertidos sexuais que muito povo bom” e “ainda tem virgens” e famílias. Ingenuamente ou não, Jorge de Lima incorre no ufanismo condenado por ele mesmo, ao exaltar essas supostas características morais como índice de certa superioridade do povo brasileiro em comparação com o germânico, uma vez que a Alemanha é o país indicado como exemplo de lugar de "povo bom”.

É também com a Alemanha que o Brasil é comparado sob a perspectiva da suposta necessidade histórica de afirmação da identidade cultural, baseada em pressupostos nacionalistas de inspiração xenófoba e racista, declarados abertamente no caso do pensamento germânico representado por Adolf Bartels e, disfarçadamente, no discurso de Jorge de Lima, que, como já dissemos, estabelece uma imprópria relação de analogia entre o nacionalismo de Bartels e o regionalismo de Gilberto Freyre. Há um momento, porém, em que Jorge de Lima explicita xenofobia e racismo grosseiramente ao referir-se ao "negro" como "estrangeiro pior que as bestas de carga”. Essa observação é suficiente para estabelecer fronteiras entre idéias de Gilberto Freyre e de Jorge de Lima. O segundo promove uma deformação da proposta regionalista do primeiro ao associá-la a ideais políticos e a ideologias racistas inexistentes nela.

Gilberto Freyre, a despeito do conservadorismo de seu pensamento, desde o início dos anos 1920, quando estudante de graduação da Universidade de Baylor, no Texas, e de pósgraduação na Universidade Colúmbia, em Nova Iorque, soube apreciar a "grande força espiritual representada pelos negros”24, contida na poesia do poeta norte-americano Vachel Lindsay $(1879-1931)^{25}$, com quem o então jovem pernambucano estabeleceu laços de amizade, e diferenciar as noções de raça e de cultura com as lições do professor alemão Franz Boas (18581942), ilustre antropólogo que ensinou o discípulo a considerar "o negro e o mulato no seu justo valor - separados dos traços de raça os efeitos do ambiente ou da experiência cultural”26, de modo a "discriminar entre os efeitos de relações puramente genéticas e os de influências

\footnotetext{
${ }^{24}$ FreYRE, Gilberto. Tempos mortos e outros tempos. Rio de Janeiro: José Olympio, 1975, p. 99.

${ }^{25}$ Em 1920, quando Gilberto Freyre e Vaquel Lindsay se conheceram, o poeta norte-americano estava no auge da fama, iniciada com a publicação de seu mais célebre poema (“General William Booth Enters Into Heaven”) no quarto número da revista Poetry, em 1913. A poesia de Lindsay inspira-se em ritmos populares, especialmente os afro-americanos, colhidos por ele em suas inúmeras perambulações pelo país. O poeta se apresentava em recitais por onde passava, em troca de comida e abrigo. Suas performances ficaram célebres pelo modo admirável como dizia seus poemas. Mais do que dizê-los, ele os modulava numa espécie de canto, acompanhado de instrumentos musicais, explorando ao máximo o ritmo e os demais elementos sonoros dos versos. A parte mais apreciada da produção poética de Lindsay, nos Estados Unidos, é exatamente aquela constituída por temas de fontes regionais, mas que traduzem valores e causas nacionais. Aliás, esse caráter da poesia de Lindsay - que de certo modo recupera o americanismo de Emerson e de Walt Whitman - foi o que mais contribuiu para despertar a admiração de Gilberto Freyre, sobretudo pelo que ela contém de assimilação da cultura negra.

${ }^{26}$ FrEYRE, Gilberto. Casa-grande \& senzala. 10ª ed. brasileira. Rio de Janeiro: José Olympio, 1961, p. XXXI.
} 
sociais, de herança cultural e de meio"27, conforme depoimento contido no prefácio à primeira edição de Casa-grande \& senzala.

A proposta artística e cultural de Jorge de Lima, então, incorpora o projeto de Gilberto Freyre, mas não pode ser confundido com ele, uma vez que também agrega elementos ideológicos estranhos a esse, de propensão nazifascista. Do escritor pernambucano, Jorge de Lima adota o critério regional, isto é, literatura e cultura deveriam voltar-se para a realidade brasileira expressa nas manifestações de valores locais e regionais, cujo resgate propiciaria o antídoto contra as falsificações do passado e as mistificações do presente, ensejando a afirmação da identidade nacional por meio de suas peculiaridades, em desfavor da descaracterização consubstanciada no nacionalismo ufanista intencional e da indefinição inerente ao cosmopolitismo, por sua vez compreendido como transposição inautêntica da modernidade representada pelos “Piaimãs do Ocidente”. Contra a alteridade estrangeira, Jorge de Lima propõe que a nova literatura deveria pautar-se pela expressão genuína da identidade brasileira, não como Macunaíma a haveria realizado, uma vez que a rapsódia registrara um momento de indefinição do caráter nacional com a imagem simbólica do herói sem nenhum caráter a evadir-se para o "mundo da lua”, mas como imagem realista de um caráter sedimentado "pelo caminho da nossa singeleza, da nossa brabeza virgem afastada completamente de qualquer imitação”, e no esforço de "trazer o homem brasileiro à sua realidade étnica, política e religiosa”.

Jorge de Lima idealiza esses três elementos, a despeito do postulado realismo regionalista. A realidade étnica brasileira, segundo ele, corresponde ao "mesticismo", processo de entredevoramento das "três raças" formadoras da nossa "racinha”. O diminutivo, que parece soar depreciativo, mostra-se também como expressão de afeto na medida em que o crítico entende esse processo como inconcluso, embora divise nele sinais de sedimentação de um caráter nacional, pois a "racinha” seria portadora de valores morais supostamente superiores aos de "muito povo bom”, bem como de uma suposta resistência orgânica, capaz de sobreviver a "quatro séculos de vermes, sezões, cachaça e doenças-do-mudo" e de resolver "o problema da verminose e da sífilis, sem guerra aos micróbios”, não fosse a intromissão de um programa sanitário norte-americano. Essa última observação sugere a hipótese de uma possível superioridade biológica do povo brasileiro. Jorge de Lima, assim, cai em contradição, uma vez que argumentara contra o nacionalismo intencional e ufanista para incorrer no mesmo, ao idealizar a mestiçagem brasileira e adotar tal idealização como um dos três elementos fundamentais de sua proposta para uma nova literatura, uma proposta afinada, apesar das deforma-

\footnotetext{
${ }^{27}$ Idem.
} 
ções, com o que mais tarde veio a ser conhecido como neo-realismo regionalista, de orientação gilbertiana.

Na construção da imagem do que seria o caráter nacional definido, em contraposição à de ausência de caráter contida na obra de Mário de Andrade, Jorge de Lima agrega à mestiçagem idealizada - cuja suposta superioridade moral e biológica se opõe à sensualidade desbragada e à fragilidade de Macunaíma, vítima das mais diversas moléstias - uma idealização da religiosidade do povo brasileiro.

Na interpretação do crítico, Macunaíma, cujo herói simbolizaria tal povo, dá “a entender que o substrato desta nossa nação não tem caráter, é amoral e portanto irreligioso”. Tal dedução decorre da perspectiva católica, similar à de Tristão de Ataíde, assumida como critério para aferir a religiosidade brasileira. Jorge de Lima, liminarmente, exclui a hipótese da religiosidade sincrética do herói sem nenhum caráter configurar uma imagem de religiosidade verdadeira. Apesar de admitir o "misticismo” brasileiro como manifestação sincrética, Jorge de Lima considera que o catolicismo, “enriquecido da colaboração das raças”, sedimentara no subconsciente da nação de tal modo que essa se inclinava decididamente para aquele: "Nas igrejas protestantes há sempre uma vazante de fiéis que faz dó (...). O templo católico é que se enche e anda sempre superlotado de manhã à noite. É uma enchente de circo. Circo divino”. O ensaísta recorre ao discurso apologético ao exaltar o catolicismo e considerar os missionários como “jograis divinos que Nosso Senhor mandou ao Brasil”. Note-se o efeito de sentido sugerido pela metonímia utilizada, em que a ação da Igreja católica romana se confunde com a ação da divindade pressuposta. Jorge de Lima escusa os desvios de ortodoxia da ação missionária sob o argumento da rusticidade dos “brasileiros de quando o Brasil amanhecia”, e elogia a inteligência dos padres que, a exemplo de Anchieta, foram complacentes com o comportamento dissoluto da colônia e souberam seduzi-la de tal modo que "todo mundo gostava da religião”. Com isso, assevera Jorge de Lima, o peculiar sincretismo religioso dos brasileiros não seria propriamente religião, mas impregnara-se tão profundamente de valores cristãos que constituíra um estágio preparatório “para o catolicismo nascer”.

Com essa postura, Jorge de Lima se aproxima da orientação do líder católico Tristão de Ataíde (“Macunaíma”. O Jornal: RJ, 09/09/1928), para quem Macunaíma deveria ser combatida na medida em que seria expressão da "barbaria dos nossos fermentos em ebulição”, caracterizada “pelo espírito das macumbas e pela volúpia da dissolução”. Ao defender a inclusão do misticismo sincrético tendente ao catolicismo como traço definidor do caráter nacional, em desfavor da suposta irreligiosidade de Macunaíma, o escritor alagoano pressu- 
põe o catolicismo como expressão última de uma espécie de evolucionismo místico, de caráter triunfalista, em que o cristianismo romano, por ação de um enérgico trabalho missionário, termina por se impor perante outras manifestações devotas, como a religiosidade grega antiga, o confucionismo, o budismo e o pensamento mítico, dito primitivo, de ameríndios e de "negros”, além de pairar acima de eventuais deformações ou desvios praticados por cristãos dissolutos, advindos da metrópole, por mais freqüentes ou graves que fossem.

Como se pode observar, Jorge de Lima não considera o catolicismo como imposição cultural estrangeira, mas como culminância de um processo evolutivo universal que, em toda parte, supostamente conduz o espírito do homem, seja qual for a sua cultura, à fé do cristianismo romano, implicitamente entendida como expressão da verdadeira religiosidade. Se cotejarmos tal apologia da universalidade do catolicismo à severa restrição feita ao cosmopolitismo, implicitamente atribuído a Macunaíma, conforme discutido anteriormente, surpreenderemos mais uma contradição no discurso do ensaísta, agora relativa à categoria da universalidade, admitida como válida para o elemento religioso vindo da Europa, na composição da imagem de um caráter bem definido do povo brasileiro, considerado como urgente necessidade histórica, mas inválida se referida à modernidade, também vinda da Europa, cuja transferência ao Brasil favoreceria a indefinição do caráter brasileiro, por força da ação dissolvente com que ameaçava a sedimentação da consciência nacional.

A rejeição da modernidade implica o repúdio do modelo de sociedade urbana e industrial, burguesa e capitalista então incipiente no Brasil, sobretudo em São Paulo. A análise de Jorge de Lima nem sequer menciona a descida de Macunaíma a São Paulo e o confronto do herói com a máquina, em que se insinua a crítica à reificação, associada à sociedade moderna, talvez porque o ensaísta não houvesse percebido essa instância de sentido que poderia ser aproveitada em favor de seu discurso contra a modernidade. Seja como for, o escritor alagoano vê esse modelo de modernidade como ameaça estrangeira à realidade política brasileira, terceiro termo de sua proposta para a sedimentação do caráter nacional. É o que se deduz de poucos elementos disseminados no discurso, que tergiversa sobre tal "realidade política” ao praticamente reduzi-la à questão do aulicismo supostamente praticado por escritores e intelectuais brasileiros, salvo raríssimas exceções como as de Machado de Assis e de autores modernistas - o primeiro, por sua peculiar disposição de espírito, “fechado na sua pobreza e na sua arte”; os segundos, pelo espanto e pelo descrédito com que a burguesia acolhera as produções do movimento, que, “por vezes”, praticara “a arte em si. (...) separada de toda função áulica: isto é, diretamente social e política”. 
Não obstante o louvor à prática modernista da “arte em si”, Jorge de Lima concede: “muitas vezes os acontecimentos sociais, políticos, provocando reações na massa, poderiam provocar também reações estéticas paralelas (não me animo a dizer correspondentes).” Como artista, Jorge de Lima mostrou-se sensível à idéia vanguardista de autonomia da arte, condenando qualquer manifestação direta de elementos do campo extraliterário, especialmente os sociais e políticos, excetuando-se o caso do misticismo. Como vimos, esse elemento é compreendido como essencial para a necessária definição do caráter brasileiro e se distingue pelo sincretismo religioso propenso ao catolicismo. Além disso, Jorge de Lima considera arte e religião como manifestações tão próximas uma da outra “que a oração já é poesia”. Se a religião pode ser incorporada à arte com maior naturalidade, o mesmo não é válido para as manifestações diretamente sociais e políticas. Mas o crítico admite como fato a "influência indireta” de tais manifestações e, nessa condição, as aceita no campo da arte. Resguardada essa condição, poder-se-ia supor válida uma "literatura social, religiosa, o que mais for." Nesse passo, em que o ensaio desenvolve uma reflexão sobre o terceiro elemento da proposta para o “achamento” do caráter brasileiro bem definido, a saber, a noção de "realidade política” nacional, o fio do raciocínio se parte, o discurso envereda na longa digressão sobre a religiosidade brasileira, apresentada e analisada no passo anterior deste estudo, deixando aquela noção obscura. Ao contrário do “mesticismo” e do “misticismo”, elementos claramente definidos, a noção de "realidade política” brasileira a integrar a proposta cultural e artística, sobretudo literária, de Jorge de Lima para o país só se insinua, discretamente, quando o autor caracteriza a "racinha” brasileira pela resistência, não só biológica, mas também social e política.

Conforme assevera Jorge de Lima, que, ressalte-se, além de clínico geral era médico sanitarista, os problemas sanitários do Brasil, “se Rockefeller não se mete no negócio”, resolver-se-iam “sem guerra aos micróbios”. O ensaísta se refere ao convênio firmado em 1923, entre o governo brasileiro e a Fundação Rockefeller, para um programa de erradicação de certas moléstias como a ancilostomíase (verminose ou “amarelão”), a febre amarela e a malária. A ação desse programa foi um marco histórico no combate a endemias no Brasil.

Como vimos, depreende-se do texto de Jorge de Lima a suposição de uma possível superioridade biológica dos brasileiros. Entende-se melhor, agora, que essa suposição traz implícito um raciocínio darwinista vulgar, segundo o qual os brasileiros sobreviventes às moléstias não combatidas por ação sanitária sistemática estariam a formar uma "racinha” depurada pela seleção natural, não fosse a intervenção estrangeira favorecer a sobrevivência, também, dos mais frágeis. Presume-se que os “quase quatro séculos” de ignorância e irresponsabilidade 
sanitária, se não foram suficientes para levar a cabo a constituição de uma "raça” depurada pelo processo de eugenia natural, ao menos o foram para forjar uma "racinha" dotada de notável resistência biológica. Há algo de irritação nas palavras com que Jorge de Lima assinala a cooperação da Fundação Rockefeller no combate às endemias, como se a entendesse como lamentável ingerência estrangeira nos assuntos nacionais ${ }^{28}$.

Recapitulando: com uma espécie de evolucionismo místico, Jorge de Lima justifica a sedimentação do catolicismo para o qual propenderia o sincretismo peculiar à religiosidade brasileira. A ação dos missionários fora eficaz porque inseminara o cristianismo no "subconsciente da nação”, tornando irreversível o processo que conduziria ao nascimento do autêntico catolicismo, entendida a metáfora genética como vocação mística que, messianicamente ("O Brasil espera um São Paulo que mande epístolas aos coríntios que os Anchietas prepararam”), Jorge de Lima anuncia como fator de sedimentação do caráter nacional, junto com o "mesticismo" e a "política brasileira”.

O crítico entende o sincretismo religioso característico do povo brasileiro, tal como transfigurado e expresso artisticamente em Macunaíma, como manifestação simbólica de irreligiosidade e de amoralidade de um povo sem nenhum caráter. Baseado nessa interpretação, Jorge de Lima considera inadequada a imagem de indefinição caracterológica, tal como a supõe contida na obra de Mário de Andrade, quer por não concordar com ela, pois entende o sincretismo místico brasileiro como um traço de caráter, certamente ainda indefinido, mas nitidamente propenso a sedimentar-se no catolicismo, quer por entender a sedimentação de um caráter bem definido como necessidade histórica, perante o avanço da modernidade estrangeira e cosmopolita sobre o Brasil.

Depreende-se que, para Jorge de Lima, o catolicismo, além de contribuir decisivamente para a definição do caráter nacional, estaria investido de valores espirituais contrapostos

\footnotetext{
28 “Os primeiros contatos entre médicos da Fundação Rockefeller e membros do governo brasileiro aconteceram a partir de 1916, com a vinda de comissões norte-americanas para avaliação do cenário de saúde nacional. Mas data do ano de 1923 o estabelecimento de convênio entre o governo brasileiro e a fundação, que fez uma dotação de recursos financeiros e garantiu a cooperação médico-sanitária e educacional para a implementação de programas de erradicação das endemias, um problema grave que afetava todo o país, sobretudo as regiões do interior, onde os trabalhos concentraram-se no combate à febre amarela e, mais tarde, à malária. Inicialmente atuando como coadjuvante junto aos serviços estaduais e municipais no combate a doenças como ancilostomíase, a Fundação Rockefeller ampliou sobremaneira sua participação e influência na área governamental de saúde pública, sobretudo a partir da década de 1930, combatendo a febre amarela. Essa doença foi considerada à época o maior desafio para a equipe norte-americana e contou, durante os anos 1930 e 1940, com um aparato organizacional ímpar na história de combate sistemático a uma endemia." Cf. LACERDA, Aline Lopes de. "Retratos do Brasil: uma coleção do Rockefeller Archive Center”. In: História, ciências, saúde - Manguinhos. Rio de Janeiro: set./dez. 2002, vol. 9, nำ 3, p. 625-645. ISSN 0104-5970.
} 
aos da modernidade, com o poder de resistir à ação deletéria do cosmopolitismo importado. Como vimos, Jorge de Lima subtrai o catolicismo ao que considera estrangeiro e cosmopolita.

Quanto ao "mesticismo”, em vez de metáfora genética, o ensaísta se vale de uma metáfora antropofágica - "Parece que as raças se entredevoraram” - para considerar o sexo como método de resolução do problema da diversidade étnica: “O problema do negro foi assim: resolvido sexualmente.” É importante distinguir tal metáfora antropofágica sexual da metáfora antropofágica cultural de Oswald de Andrade, que se associa à noção modernista de primitivismo crítico, enquanto a de Jorge de Lima se relaciona à noção de uma suposta resistência biológica, resultante de seleção natural e, por sorte, decorrente da mestiçagem das três "raças tristes”, formadoras do "empelicado" povo brasileiro. Vale repetir, "se Rockefeller não se mete no negócio" tal povo tenderia a resolver "o problema da verminose e da sífilis, sem guerra aos micróbios como fizemos a Abolição e a República sem guerra aos senhores e aos reis”.

Compreende-se, agora, que ao evolucionismo místico e ao biológico soma-se uma espécie de evolucionismo político, decorrente de uma suposta tradição histórica do povo brasileiro, de resolver "os nossos problemas mais sérios não os resolvendo.” O fio interrompido do discurso sobre a "realidade política” brasileira, terceiro elemento estruturador do caráter nacional sedimentado, deixara obscura essa noção. Com a analogia agora estabelecida entre o método tradicional de ação sanitária e de ação política, entende-se que essa, assim como aquela, caracteriza-se, segundo Jorge de Lima, pela inércia. Em tal concepção lateja o pressuposto ideológico da índole pacífica do povo brasileiro, característico do pensamento conservador das elites ameaçadas pelo processo de modernização então em curso no Brasil. Jorge de Lima interpreta a ascensão de Macunaíma ao céu como fuga lamentável, decorrente da ausência de caráter do herói. Daí a necessidade de afirmação enérgica do caráter nacional, pois a indefinição implica sucumbir ao estrangeiro, associado à modernização. No entanto, resistir à modernidade estrangeira ainda implica, no plano político interno, a práxis inercial com que as mudanças históricas se processariam, tradicionalmente, sem solução de continuidade, de modo a preservar o poder das elites tradicionais. Jorge de Lima deixa transparecer, apesar do modo sub-reptício adotado no discurso, sua aversão a transformações políticas drásticas, assim como se observa no texto do amigo José Lins do Rego, citado no ensaio, que manifesta indiretamente a mesma aversão ao comentar, a propósito de Sérgio Buarque de Holanda, que o então futuro autor de Raízes do Brasil andava “cheio de maus instintos de revolução”. Recordese que Jorge de Lima, filho de senhor de engenho, foi eleito deputado estadual, em 1926, pelo 
Partido Republicano de Alagoas, agremiação representativa dos interesses da oligarquia agrária local.

A frase "sem guerra aos senhores e aos reis" pode ser interpretada como uma divisa a pautar o comportamento político supostamente peculiar à índole brasileira, pró-católica e mestiça, e, assim, marcar o caráter nacional. Nessa espécie de evolucionismo político sem sobressaltos repercute o pensamento conservador característico do grupo regionalista, capitaneado por Gilberto Freyre, que via a sociedade agrária e patriarcal nordestina como portadora do traço definidor do caráter nacional.

Em suma, o ensaio de Jorge de Lima, mais do que uma análise de Macunaíma, contém uma crítica ao modernismo e esboça um programa não só para a literatura, mas também para a cultura e até para a política brasileira, mediante uma proposta de definição ou sedimentação da identidade nacional com base em três elementos formadores do espírito, do caráter e da consciência: a "realidade étnica, política e religiosa” do país. Como vimos, a concepção dessas noções, conforme o escritor alagoano as formula, é marcada por contradições, bem como por uma ideologia inspirada, sobretudo, em postulações de Tristão de Ataíde (catolicismo) e de Gilberto Freyre (regionalismo), embora essas se apresentem deformadas na síntese proposta pelo poeta de "Essa negra Fulô", em que ainda se misturam preconceitos cientificistas (evolucionismo vulgar), xenófobos e racistas (de influência nazifascista) com a inclinação política e social conservadora, de caráter oligárquico e patriarcal.

Sob a lente dessa espécie de salada ideológica, Jorge de Lima produziu a sua leitura de Macunaíma, em que os elogios escamoteiam o repúdio. O ensaísta louva a "expressão genuína” alcançada por Mário de Andrade, com a estilização da oralidade brasileira. Ao considerar a "expressão genuína” como equivalente ao "genuíno de nossas realidades”, Jorge de Lima mostra convicção de que Macunaíma constituía um "retrato do Brasil” e do "homo brasiliensis”. A imagem simbólica seria, na opinião do crítico, bem-ajustada ao referente extraliterário, embora não-intencional, uma vez que resultara de uma criação processada no subconsciente do artista, por sua vez partícipe do "subconsciente coletivo do país”: "um raide do subconsciente nacional”. Porém, à realidade sintetizada na imagem de ausência de caráter do brasileiro, concentrada nas "nossas faltas" ou naquilo que Tristão de Ataíde chamara "barbaria dos nossos fermentos em ebulição”, faltaria a dinâmica que conduziria à sedimentação do caráter moral, étnico e político nacional: a propensão ao catolicismo; a tendência da "racinha” evoluir para o branqueamento, a partir de "três barros ruins" e por meio da mestiçagem, bem como da seleção natural, com a eliminação gradual dos substratos étnicos mais atrasados: supostamen- 
te, o índio e o negro ${ }^{29}$; a inclinação acomodatícia, fundamentada na pressuposição de uma índole pacífica do povo brasileiro, com que, tradicionalmente, mudanças sociais e políticas, como “a Abolição e a República”, processar-se-iam “sem guerra aos senhores e aos reis”, sendo tal conservadorismo subentendido como força de resistência contra o perigo de dissolução do caráter e da consciência nacionais, representado pelo cosmopolitismo decorrente do avanço da modernização estrangeira no país.

Em última análise e nem sempre pelas mesmas supostas razões, deduz-se que Jorge de Lima tem opinião análoga à de Tristão de Ataíde, que viu em Macunaíma "o modelo do que devemos ‘combater’ em nós”. Comparado ao juízo severo do líder católico, que condenara a suposta “língua de candomblé” e a também suposta apologia da "barbaria”, Jorge de Lima mostra-se mais receptivo à rapsódia de Mário de Andrade, considerada um feito admirável como expressão artística da brasilidade, quer do ponto de vista da linguagem, quer da simbologia (a ausência de caráter) de que a linguagem é suporte. Agora, sob o argumento da necessidade histórica de sedimentação de um caráter nacional bem definido, cujo arcabouço é delineado com uma idealização do que considerou a "realidade" dos três elementos indicados por ele como decisivos para tal definição, Jorge de Lima propõe um programa para a literatura brasileira, que contribuísse para isso. Ao interpretar a ausência de caráter de Macunaíma como expressão de irreligiosidade e de cosmopolitismo, que implicaria ausência de consciência nacional, o escritor alagoano, conforme os pressupostos ideológicos investidos em seu projeto, não poderia, certamente, tomar a obra de Mário de Andrade, apesar de suas reconhecidas virtudes, como modelo.

Para a literatura brasileira conquistar “alforria” e, assim, contribuir para livrar a consciência nacional do "perigo das saúvas”, isto é, da dissolução decorrente da modernização estrangeira, uma nova orientação seria necessária: aquela inspirada no critério regional de Gilberto Freyre, embora modificado pelos pressupostos ideológicos enxertados por Jorge de Lima, no afã de configurar o que seriam para ele os traços definidores da realidade e da iden-

\footnotetext{
${ }^{29}$ Jorge de Lima não formula claramente, mas dá a entender que a mestiçagem e a dinâmica da seleção natural conduziria ao branqueamento do Brasil - ideologia racista muito em voga entre as elites das primeiras décadas do século XX. A adoção dessa ideologia pelo escritor alagoano é surpreendida na seguinte passagem do ensaio: "Não está vendo que ninguém [entre os brasileiros] sai da rede para resolver problemas? Nós o resolvemos dentro da rede mesmo. Dormindo com ele ou dormindo nele. O problema do negro foi assim: resolvido sexualmente. O americano-do-norte vai resolvê-lo de outro modo. Vamos ver se resolve!” O "branqueamento" opunha-se ao racismo segregacionista e era considerado por boa parte da elite como solução brasileira para o "problema do negro". No excerto denunciador, a rede é correlato objetivo do lugar social de onde Jorge de Lima se pronuncia: o espaço ocupado pelos senhores de engenho, com os quais o enunciador se identifica ao usar o pronome "nós". O verbo "dormir", por sua vez, é uma metáfora dupla: primeiramente, para a indolência aristocrática dos senhores, suposta como método eficaz de solução de problemas; em segundo lugar, para a generalizada prática sexual de senhores com as "negras", considerada método brasileiro para solucionar o "problema do negro".
} 
tidade brasileira, mas que resultam numa idealização filocatólica, racista, xenófoba e oligárquica.

\section{FICÇÃO EM TEMPO DE CRISE}

Os pronunciamentos da primeira onda da fortuna crítica de Macunaíma, geralmente, assinalam o esfuziante humorismo da narrativa, sem perceber a "nota dolorosa do livro", conforme a expressão de Augusto Meyer (A. M. “Macunaíma / por Mário de Andrade”. Revista do Globo, 01 de janeiro de 1929). Somente o crítico gaúcho descortinou na dimensão satírica da rapsódia o caráter trágico do destino do herói. Aliás, como revela o exame dos documentos, os críticos, excetuados Ascenso Ferreira e Augusto Meyer, sequer mencionaram a sátira como possível matiz do gênero de Macunaíma.

Dentre os pioneiros, somente Ascenso Ferreira observou haver na obra de Mário de Andrade um "espírito satírico”. Alguns deles, no entanto, sem explicitar ou atinar com a noção de sátira, constataram a presença de certas características ou de certos efeitos de sentido típicos do gênero nas análises que fizeram. Tristão de Ataíde, por exemplo, bem como os que o acompanharam na definição de Macunaíma como um “coquetel” de gêneros, tangenciou o sentido clássico antigo de sátira como miscelânea, isto é, mistura de prosa e verso. O mesmo Tristão, e seguidores, ao assinalar o registro crítico e humorístico do livro, aproximou-se também da noção de sátira, entendida como obra literária cuja função se define na tradicional divisa “castigat ridendo mores”, à qual, no entanto, só o poeta de Catimbó aludiu explicitamente.

Já no período em foco neste capítulo (1929-1936), o único pronunciamento a perfilar com o de Ascenso Ferreira, na hipótese de que Macunaíma seria uma sátira, é, exatamente, o recém-citado artigo de Augusto Meyer. Mas o crítico gaúcho vai além do pernambucano ao observar o humor não só como elemento de crítica risonha aos costumes, mas como máscara de uma intenção satírica nada divertida. Ao considerar demasiado o humor do livro, Meyer desconfiou da face ridente e distinguiu, sob ela, a face trágica que se revelava na narrativa, quando abordada sob a perspectiva temática da "procura da personalidade" brasileira. Meyer assinala: por um lado o herói "parece retratar a psicologia média do brasileiro, principalmente nos seus defeitos, por outro lado ele transcende qualquer realidade psicológica do momento e ganha proporções de símbolo, através da farsa”. Desse modo, o autor de Giraluz captou não só algo da particularidade do protagonista - imagem representativa do psiquismo (“médio”) 
nacional, válida para o momento histórico então vivenciado no país -, mas também da sua universalidade, na medida em que a mesma imagem constituiria um signo atemporal. Agora, quer como imagem particular, quer como universal, a personalidade do herói não é entendida como algo fixo, mas como um processo sempre inacabado, devido ao fato de Macunaíma ser incapaz de manter quaisquer “resoluções ordenadoras”, pois essas são todas destruídas perante a irresistível tendência à inércia e à dispersão. Assim, conclui Augusto Meyer, "Macunaíma é no fundo cousa alguma”, pois é um constante devir, sempre em crise de identidade. Essa fina observação leva o crítico a discernir que a crise representada na ficção, isto é, a procura frustrada da personalidade do herói, corresponde à ficcionalização da crise de identidade, particularmente do povo brasileiro, mas também, universalmente, da humanidade nos momentos de "grandes crises, quando o espírito não acha em torno a diretiva”. Com isso, Augusto Meyer foi o único a captar a "nota dolorosa” do livro de Mário de Andrade, cuja "leitura atenta” deixara “um vazio, um sentimento de falha”, não como realização artística, considerada impecável, mas pela amargura de que a obra se impregnara ao representar artisticamente a crise identitária. Contudo, para Meyer, o “sentido verdadeiro” da ficção permaneceria como enigma, que só poderia ser decifrado com distanciamento.

\section{FICÇÃO CONTRA FICÇÃO}

Como vimos na primeira parte deste capítulo, Augusto Meyer retornou à rapsódia de Mário de Andrade no artigo “Macunaíma” (Correio do Povo: Porto Alegre, 01/07/1930), para cotejar a imagem ficcional do Brasil contida na narrativa com a que fora sugerida pelos poemas de Toda a América, de Ronald de Carvalho, que o crítico gaúcho interpretou como tradução poética de idéias de Graça Aranha.

A contraposição das idéias nacionalistas de Graça Aranha, associadas aos poemas de Ronald de Carvalho, ao projeto de nacionalismo crítico de Mário de Andrade, realizado artisticamente em Macunaíma, constitui importante contribuição de Meyer para a discussão das diferentes concepções de arte, cultura e identidade nacional que se manifestavam no contexto de uma tumultuada adaptação do Brasil à modernidade. Graça Aranha não se pronunciou publicamente a propósito de Macunaíma, mas as idéias do autor de Canaã, como vimos ligeiramente no primeiro capítulo deste trabalho, interferiram na discussão crítica da obra e, assim, em torno dela, explicitou-se a significativa diferença de concepções de Mário de Andrade e de Graça Aranha sobre o Brasil, sua gente, sua cultura e sua arte, possivelmente implícita na rap- 
sódia. Mais adiante, examinaremos mais de perto essa questão; por ora, limitemo-nos a caracterizar as noções de Graça Aranha, contidas no ensaio "O espírito moderno”30, mas já presentes em escritos anteriores, às quais Augusto Meyer se refere em seu artigo.

Para o autor de Canaã, natureza e matéria não se confundem: a segunda é suporte da primeira. A natureza “está na matéria, na energia” (grifos meus), como princípio de realização: a natureza íntima da matéria é entendida como perpétuo movimento irracional, que a tudo muda a cada instante no mundo, “independente do espírito humano”. O homem, bem como o seu espírito, é um objeto adstrito à mesma lei de movimento e transformação.

Nessas considerações, insinua-se o pánta rê̂ (“tudo flui”) heraclítico, somado ao "tudo se transforma” de Lavoisier, como algo análogo à concepção graciana de “natureza”. Depreende-se vir de Heráclito, também, a idéia de unidade universal de todas as coisas. Apesar das decisivas diferenças existentes entre o conceito heraclíteo de "logos” e o de “integração”, do escritor brasileiro, ambos se aproximam na medida em que podem ser entendidos como princípios constitutivos daquela unidade. Para Heráclito, o "logos” é a essência ou substância de todas as coisas. Lei que rege a natureza e o homem e os liga entre si, o "logos” é, a um só tempo, a racionalidade e o ser do mundo, cuja unidade não resulta da harmonia, mas da tensão entre opostos, que não se anulam enquanto tais. Para Graça Aranha, ao contrário, todos os objetos constituintes da realidade harmonizam-se e integram-se fatalmente no "Todo universal”. Esse processo de síntese realiza-se "na profunda inconsciência, independente do espírito humano".

No entanto, embora objeto entre os objetos do universo, igualmente sujeito ao devir, o “espírito humano” pode conceber a si mesmo como integrado ao cosmo, isto é, à ordem universal, e, exatamente por isso, pode subtrair-se ao movimento irracional e fatal dos fenômenos inconscientes, entendido como essência ou natureza íntima de todas as coisas, para manifestar-se como movimento criador, consciente de si.

Nesse particular, em vez de Heráclito, ressoam nas idéias de Graça Aranha lições de seu professor Tobias Barreto sobre o evolucionismo cientificista do século XIX, especialmente o monismo de Haeckel, assimilado e diluído pelo aluno com o concurso de outras influências, dentre das quais o crítico Alfredo Bosi ${ }^{31}$ destacou as de Nietzsche e de Schopenhauer. Não nos interessa, aqui, especificá-las ou examiná-las para estabelecer com exatidão o lugar

\footnotetext{
30 ARANHA, Graça. “O espírito moderno”. In: TELES, Gilberto Mendonça. Vanguarda européia e modernismo brasileiro. 2ª ed. Petrópolis (RJ): Vozes, 1973, p. 188-202. As citações do ensaio de Graça Aranha são todas extraídas da edição indicada.

${ }^{31}$ Bosi, Alfredo. O pré-modernismo. 4⿳a ed. São Paulo: Cultrix, 1973, p. 109.
} 
delas no pensamento de Graça Aranha. Interessa-nos, porém, caracterizar as idéias do autor de Canaã, referidas no artigo de Augusto Meyer, que não devemos perder de vista. Além disso, este excurso sobre o pensamento de Graça Aranha será útil mais adiante, quando confrontarmos o projeto nacionalista desse escritor com o de Mário de Andrade, no contexto de um diálogo indireto estabelecido por intermédio de alguns documentos da fortuna crítica de Macunaíma, como é o caso do artigo do poeta de Giraluz.

A leitura do ensaio “O espírito moderno” permite entender o pensamento de Graça Aranha como uma construção ou, conforme suas próprias palavras, "uma abstração” cujo ponto de partida consiste na convicção do eterno e infinito devir irracional de todas as coisas, do próprio homem e de seu espírito. O espírito humano, no entanto, subtrai-se à irracionalidade ao tomar consciência do movimento que subjaz aos objetos do mundo. Essa consciência conduz ao conhecimento da unidade substancial do universo, entendido como integração cósmica de toda diversidade e multiplicidade. Sem esse conhecimento, o espírito humano se sujeita à natureza e torna-se cativo do "terror cósmico", uma vez que não vislumbra na realidade mais do que a sua fragmentação, sem nenhuma finalidade. Esse “terror”, segundo Graça Aranha, levara o homem a opor-se ao universo, a fugir da realidade e a deformá-la subjetivamente, sob a perspectiva do individualismo e do sentimentalismo característicos da cultura romântica, que persistia mesmo nas vanguardas artísticas européias e vigorava no Brasil, “um dos últimos refúgios do romantismo”. Do “terror cósmico” resultaria necessariamente o caráter de dissolução, destruição, tristeza e dor da cultura romântica.

Para Graça Aranha, o conhecimento da “unidade essencial e infrangível entre todos os seres”, que os harmoniza, equilibra e integra no "Todo universal”, é libertador e se identifica com o próprio universo ${ }^{32}$. Contudo, esse conhecimento não é puramente intelectual ou teorético. Supondo que "não se pode explicar cientificamente a substância”, Graça Aranha afirma: “todo o conhecimento do Universo é estético”. Tal conhecimento implica: a) contato sensível com o mundo exterior ao indivíduo; b) produção de sentimentos, emoções, intuições, idéias e pensamentos, por força desse contato; c) síntese espiritual desses produtos, por sua vez caracterizada como consciência ou conhecimento estético da integração; d) supressão do indivíduo com sua integração ao cosmo. A obra de arte, liberta do espírito romântico e imbuída do "espírito moderno”, é entendida como lugar privilegiado para a realização dessa síntese, capaz de suscitar no espectador um análogo sentimento de integração cósmica.

\footnotetext{
${ }^{32}$ Idem.
} 
O “espírito brasileiro”, segundo o autor de Canaã, sujeitava-se ao “terror cósmico”, pois não se libertara da imitação de e da submissão a modelos espirituais europeus, por sua vez subordinados à natureza e à tirania do "eu”. Daí decorreria o formato incaracterístico e romântico da cultura nacional - exemplificado em manifestações de lirismo ainda vigentes na atualidade (década de 1920), impregnadas de tristeza, pavor e subjetivismo sentimental -, uma cultura entorpecida pelo mascaramento da realidade. Esse espírito romântico e servil à cultura européia estaria em contradição com o Brasil, "terra árdega, que vive o poema da aspiração" a uma "verdadeira nacionalidade”.

Graça Aranha concebe a “civilização” configurada no país como "um esboço apenas sem tipo definido”. A cultura brasileira seria criada a partir do esforço de libertação daquela herança romântica paralisante e do procedimento mimético. Afinadas com o "espírito moderno”, a cultura e a arte brasileiras já estariam a superar o espírito do passado, associado à noção de “terror”, contrapondo ao caráter dissolvente desse o “dinamismo construtor” daquele, capaz de se sobrepor à matéria, vencer a natureza e, com isso, superar o "terror”. A cultura e a arte que se esboçavam no Brasil, imbuídas do "espírito moderno", estariam prestes a opor uma estratégia de ação e um método criativo, chamados respectivamente de "dinamismo construtor" e "objetivismo dinâmico", ao "subjetivismo passivo ou dinâmico" do passado e ainda do presente, de modo a expressar não mais o "Todo universal” subordinado ao indivíduo, mas “o movimento das coisas, que agem por suas próprias forças independentes do eu”, sendo esse “eu” integrado na "unidade essencial e infrangível [que há] entre todos os seres, os organismos, que por sua vez são órgãos do Todo universal”.

O individualismo, preparado pela cultura medieval européia e exaltado mais e mais desde o Renascimento, levara o “espírito humano” a fugir da realidade e a deformá-la, na medida em que a representava subjetivamente. A consideração objetiva da realidade fora uma conquista da "reação positiva", que substituíra a representação subjetiva pela "interpretação científica e unitária do Universo”. A literatura e a arte, porém, teriam permanecido cativas do subjetivismo, como atestaria o expressionismo e mesmo o lirismo de poetas como Appolinaire, Cocteau e Cendrars, ainda não emancipados da expressão sentimental.

O cubismo fora uma tentativa de libertação, mas incorrera no "erro" do "exclusivismo intelectual” ao buscar a representação pura dos objetos, "livre de todos os pormenores inúteis, tais como os aspectos, acidentes múltiplos e vários”. O cubismo, afirma Graça Aranha, remontara à filosofia platônica no esforço de fixar não a transitoriedade enganosa das coisas captadas pelos sentidos, mas “a quimera da verdade eterna” das formas. Em virtude de um 
suposto “idealismo transcendente”, os cubistas, “estes estranhos geômetras da arte”, haveriam rejeitado o subjetivismo dinâmico dos românticos impressionistas, caracterizado pelo idealismo individualista, sensorial e sentimental, para caírem na "mais intensa afirmação do subjetivismo”, uma espécie de subjetivismo estático, “para o qual os objetos só possuem a emoção que nós lhes damos com auxílio dos meios que nos fornecem nossa sensibilidade e nossa inteligência, e são imagens que só existem quando lhes prestamos atenção estrita, ou quando lhes atribuímos valor artístico.” Assim, para Graça Aranha, o cubismo não chegara a libertar a arte da tirania do "eu”, mas preparara o terreno para o que só o verdadeiro "espírito moderno" poderia realizar: a síntese integradora, a fusão do "sujeito pensante no objeto pensado”.

Para Graça Aranha, é por meio do “dinamismo construtor” e do “objetivismo dinâmico”, congeniais ao “espírito moderno”, que “a arte se liberta da natureza” e se universaliza.

Na perspectiva do "espírito moderno", a arte tem a função de, por meio da emoção estética, propiciar o conhecimento do universo, entendido como unidade essencial de todos os seres componentes do “Todo universal”. Graça Aranha compreende a arte como um fenômeno cujo ponto de partida está no contato sensível do artista com o que lhe é exterior. Esse contato, por sua vez, desencadeia um processo psicológico: o artista experimenta "sentimentos vagos, transcendentes”, que têm o poder de operar a “fusão do indivíduo no Universo”. O trabalho do artista consistiria na transposição dos mesmos sentimentos para a obra de arte, de tal modo que o trabalho artístico pudesse provocar sentimentos análogos nos espectadores e propiciar-lhes a mesma experiência de fusão essencial do indivíduo no universo. A essência da arte, segundo Graça Aranha, consiste na captação e transmissão de "sentimentos vagos, que nos levam à indiscriminação no todo infinito”.

Só o "espírito moderno" poderia ensejar que a arte pudesse assim se manifestar. Por meio do "objetivismo dinâmico", o artista captaria os "elementos gerais e universais” dos objetos: os seus componentes sensoriais "mais puros e mais intensos" e o perene movimento que constitui a essência de todos os seres; por intermédio do “dinamismo construtor”, o artista poderia ligar os objetos particulares e expressar a unidade que os integra ao "Todo universal”.

Ao tomar consciência da harmonia entre o homem e as forças da natureza, o "espírito moderno” possibilitaria a libertação do primeiro em relação às segundas. Graça Aranha admite que o “espírito moderno é uma abstração”, mas é por intermédio dessa abstração que a natureza é dominada e o homem pode, assim, deixar de imitá-la. Diz Graça Aranha: "Em vez de imitação, criação.” 
O “espírito moderno”, incorporado ao "espírito brasileiro”, exigia a libertação das cadeias que acorrentavam o país ao "terror", isto é, ao passado. Para tanto, a cultura e a arte brasileiras deveriam abandonar o individualismo sentimental, a imitação da natureza e também o academismo, entendido como entrave ao impulso criativo necessário à "emancipação espiritual" de nossa cultura, uma vez que o academismo favorecia "a cópia servil dos motivos artísticos ou literários europeus, exóticos, [que] nos desnacionaliza”; deveriam romper com o culto de uma tradição literária brasileira considerada escassa e incerta, senão irrelevante; deveriam, enfim, abandonar a atitude romântica que mantinha o "espírito brasileiro” em desacordo com a realidade do país. Segundo Graça Aranha, a literatura brasileira “vagueia entre o peregrinismo acadêmico e o regionalismo, falseando nesses extremos a sua força nativa e a sua aspiração universal.”

No Brasil, a civilização européia caldeara-se com outras culturas adventícias e com as autóctones e sofrera modificações determinadas pelo meio tropical. Não obstante essa mistura, segundo Graça Aranha, nenhuma herança espiritual fora legada pelos primitivos habitantes da terra, pois eles seriam, supostamente, “míseros selvagens rudimentares”.

Graça Aranha assevera que, embora o esboço de civilização verificado no Brasil não fosse exclusivamente europeu, "toda” a cultura brasileira ainda em formação procederia da européia. Essa matriz, porém, ter-se-ia aqui dissolvido por força não só de seu próprio espírito deletério, decorrente do individualismo, do subjetivismo e do sentimentalismo românticos seus característicos, mas também das injunções do ambiente e da "confluência das [outras] raças povoadoras do país”, de modo a configurar uma civilização "sem tipo definido”, um “ponto de partida para a criação da verdadeira nacionalidade”.

Agora, para escapar da condição de cópia européia e afirmar-se de modo original, a cultura brasileira não deveria retroceder ao primitivismo propalado por certos "escritores que no Brasil procuram dar de nossa vida a impressão de selvageria, de embrutecimento, de paralisia espiritual”. Tal atitude “seria um exercício de falsa literatura”. Graça Aranha não identifica os mencionados escritores, mas a admoestação tem endereço certo. Trata-se de uma alusão a Oswald de Andrade, cujo "Manifesto da poesia pau-brasil”33 fora publicado pelo jornal Correio da Manhã na edição de 18 de março de 1924, três meses antes de Graça Aranha ler o ensaio "O espírito moderno" em conferência pronunciada na Academia Brasileira de Letras

\footnotetext{
${ }^{33}$ ANDRADE, Oswald de. “Manifesto da Poesia Pau-Brasil”. In: Teles, Gilberto Mendonça. Op. cit., p. 203-208.
} 
(19 de junho de 1924) ${ }^{34}$. A censura velada, é importante assinalar, limita-se ao primitivismo defendido no manifesto de Oswald, que, de resto, contém várias propostas com as quais o pensamento de Graça Aranha até certo ponto coincide: o antiacademismo, a rejeição de modelos estéticos importados e da arte imitativa da natureza, a compreensão do dinamismo da vida e o esforço de construção da cultura brasileira por meio da síntese e da invenção artística; enfim, afinidades que justificam a inclusão de Oswald de Andrade entre os artistas brasileiros arrolados pelo ensaísta como representantes do esforço construtivo defendido na conferência.

Para criar “a nossa expressão própria”, seria necessário romper com as nossas "heranças espirituais”, mas sem cair na suposta incultura do primitivismo. Na doutrina de Graça Aranha, “a manumissão nacional” é uma conquista do espírito. Manifesto na cultura, o "espírito moderno" despontava no Brasil para libertá-lo do passado, do “terror”, do "eu” e do academismo, de modo a secar “os vales de lágrimas da tristeza romântica”, vencer a natureza e transfigurar os esforços pessoais “em uma força criadora, livre e construtora da nação”. Essa liberdade, bem entendida, significa a fusão do indivíduo “com essa terra exaltada e fascinante”, isto é, com o peculiar dinamismo do Brasil; significa, também, a destruição das "heranças espirituais” e da arte imitativa; significa, ainda, fazer da história uma tábua rasa sobre a qual “a força dinâmica do espírito moderno” haveria de criar “coisa própria” de valor universal. Livre do "terror cósmico" e afinado com o “espírito moderno”, por sua vez enérgico vencedor da natureza, o "espírito brasileiro" estaria a ponto de engendrar, com a expansão de sua alegria otimista, uma civilização característica, uma cultura original e uma arte de expressão própria; em suma, uma “verdadeira nacionalidade”.

O projeto nacionalista de Graça Aranha, para construir uma civilização original no Brasil e uma legítima cultura brasileira, entra, indiretamente, no debate acerca de Macunaíma não só por intermédio de Augusto Meyer, no cotejo das imagens do Brasil e do povo brasileiro contidas na rapsódia de Mário de Andrade com as estabelecidas nos poemas de Toda a América, de Ronald de Carvalho, mas, como vimos no primeiro capítulo deste estudo, pelo próprio Ronald de Carvalho, no artigo dedicado a Macunaíma ("Macunaíma - o herói sem nenhum caráter - de Mário de Andrade”. Movimento: RJ, 01 de outubro de 1928), cujas considerações são filtradas, em grande medida, por idéias de Graça Aranha.

\footnotetext{
${ }^{34}$ V. MARTins, Wilson. A crítica literária no Brasil. 2ª ed. Rio de Janeiro: Francisco Alves, 1983, p. 502, vol. I: "Note-se que, embora incluindo Oswald de Andrade entre os 'mil jovens espíritos sôfregos de demolição e construção’, a conferência de Graça Aranha não era apenas um manifesto contra a Academia - era também um manifesto contra a Poesia Pau-Brasil”.
} 
Agora, a mera evocação do autor de Canaã, quer na condição de filtro ideológico no artigo de Ronald Carvalho, quer como valor ideológico rechaçado por Augusto Meyer no artigo "Macunaíma” (Correio do Povo: Porto Alegre, 01 de julho de 1930), desperta uma suspeita: estariam as idéias de Graça Aranha contidas de algum modo em Macunaíma? Mário de Andrade repeliu publicamente as idéias do acadêmico rebelde na "Carta aberta a Graça Aranha” (A Manhã: RJ, de 12 de janeiro de 1926). Teria Mário estabelecido na rapsódia alguma interlocução com o autor de “O espírito moderno”? Na terceira parte deste capítulo, examinaremos a pertinência ou impertinência dessa hipótese. Seja como for, por interpostas pessoas, a fortuna crítica instaurou esse diálogo indireto, em que Augusto Meyer discerniu o confronto de duas imagens do Brasil, de seu povo e de sua cultura. Contra a visão teórica de Graça Aranha, subtendida nos poemas de Toda a América e entendida como ficção risonha e vazia, Meyer exibe Macunaíma como ficção representativa da dolorosa e problemática realidade brasileira. 


\section{MÁRIO E A CRÍTICA}

A pesquisa e organização da correspondência ativa de Mário de Andrade sobre Macunaíma e de outros pronunciamentos do autor sobre a mesma obra - em entrevistas, diário, crônicas e no prefácio “inédito” de Belazarte (1930) -, empreendida por Telê Porto Ancona Lopez $^{35}$, dá orientação indispensável não só ao estudo da fortuna crítica da rapsódia, observada na perspectiva do artista, mas também à investigação de depoimentos do autor, portadores de valor crítico sobre o seu próprio livro.

Como exemplo do segundo caso, merece destaque especial uma observação que enriquece a discussão sobre o gênero. Numa carta a Manuel Bandeira, de 12 de dezembro de 1930, Mário dá notícia do interesse da norte-americana Margaret Hollingsworth em traduzir Macunaíma para a língua inglesa, demonstrando receio de que ela não conseguisse "reproduzir a essência poema-herói-cômico, do livro”36. No entanto, Mário considera que a tradução talvez pudesse beneficiar o livro ao despi-lo de "certo lado excessivamente exteriormente brasileiro (...), porque muito secretamente o que me parece é que é uma sátira além de dirigível ao brasileiro em geral, de que mostra alguns aspectos característicos, escondendo os aspectos bons sistematicamente, o certo é que sempre me pareceu também uma sátira mais universal ao homem contemporâneo, principalmente sob o ponto-de-vista desta sem-vontade itinerante, destas noções morais criadas no momento de as realizar, que sinto e vejo tanto no

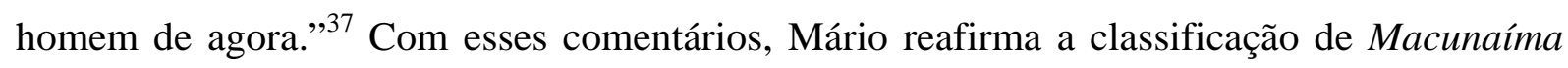
como sátira, a um só tempo nacional e universal, acrescentando que a condição de "poemaherói-cômico” participaria da “essência” genérica da obra.

Nesse sentido, não é ocioso supor a Batracomiomaquia como importante paradigma da "essência poema-herói-cômico” investida na composição de Macunaíma. Mário conhecia a “A guerra das rãs com os ratos”. Seus arquivos contêm um recorte do periódico A illustração brazileira (s/l., $\mathrm{n}^{\circ}$ 63, edição de 01 de janeiro de 1912), em que uma nota introdutória, contendo breve notícia da fortuna do poemeto que certa tradição atribuiu a Homero, precede a tradução desse em versos decassílabos brancos vertidos para o português, não diretamente do grego, mas de traduções italianas. Não há como honrar o nome do articulista e tradutor, pois não há identificação de autoria. Certamente, trata-se de um intelectual familiarizado com o

\footnotetext{
${ }^{35}$ Edição crítica de Macunaíma. Op. cit., 1997.

${ }^{36}$ BANDEIRA, Manuel (org.). Op. cit., p. 251-255. Também recolhido em MorAES, M. A. de. Op. cit., p. 473.

${ }^{37}$ Idem. Idem.
} 
modelo consagrado por Odorico Mendes. Os versos fluem com vivacidade nos decassílabos clássicos bem ritmados, predominantemente heróicos, e não falta o vezo odoriquiano de substituição de deuses gregos por romanos ou o toque de invenção lingüística, como se observa no neologismo "ratoranaguerra” e, sobretudo, nos nomes das personagens: Papapratos, Pannivoro, Trincafiambre, Grasnaforte, Patinhanalama etc. Mário, decerto, muito apreciara o poema, a julgar não só pela conservação do recorte em seus arquivos, mas por havê-lo destacado por inscrição manuscrita em sublinhadas letras garrafais: "Batraquiomaquia” (sic).

Da matéria introdutória à tradução do primeiro poema herói-cômico preservado da literatura ocidental $^{38}$, Mário assimilara que a essência de tal gênero consiste na mistura do estilo elevado da epopéia com estilo baixo, análogo ao da comédia, com intenção "burlesca e satírica”39; assimilara também uma lição de que se tornou para sempre convicto: “às composições de índole e de assuntos opostos convêm palavra e estilo também em tudo diferentes”40. Muitos anos depois, a propósito da acusação de Tristão de Ataíde quanto à "língua de candomblé” de Macunaíma, Mário, ao queixar-se em carta ao amigo Bandeira, faz um comentário em que ressoa nitidamente a lição do articulista e tradutor anônimo de "A batrachomyomachia”: “Achar que a língua do livro é de candomblé é injustiça. A língua foi justamente uma das preocupações minhas: sair da língua falada e chegar afinal na língua escrita. Se nas partes florestais isso aparece mais é porque estilo muda com assunto [grifo meu]." ${ }^{41}$

Da leitura do poemeto homérico, muitas outras lições provavelmente sedimentaram no espírito do jovem Mário de Andrade, então futuro autor de Macunaíma, narrativa em prosa poética que manifesta características inequívocas da "essência poema-herói-cômico" (para repetir a expressão usada pelo escritor na correspondência em que comentava o interesse de Margaret Hollingsworth em traduzir a rapsódia para o inglês): paródia de epopéia; mescla dos estilos alto e baixo; rebaixamento do sublime e elevação do grotesco. Enfim, entre muitas outras qualidades específicas: mistura de gêneros refundidos sob a perspectiva humorística e satírica; mescla sintetizada e atualizada artisticamente como imagem da “dolorosa (...) procu-

\footnotetext{
${ }^{38}$ A atribuição da Batracomiomaquia a Homero vem da Antiguidade e é uma tradição contestada desde essa mesma época. Em estudo recente, Fábio Possebom estima que o poema date do século II a.C. Trata-se de uma paródia da Ilíada, cujo registro elevado se mescla ao estilo baixo, associado à intenção humorística e à disposição satírica, em que deuses se queixam de aflições comezinhas, próprias a homens comuns, e heróis, com toda a pompa da empáfia épica, não são mais do que seres considerados vis: ratos e rãs. Cf.: HOMERO. Batracomiomaquia. Estudo e tradução de Fabricio Possebom. São Paulo: Humanitas-FFLCH/USP, 2003.

${ }_{39}$ S/A. "A batrachomyomachia / ou a guerra das rãs com os ratos / poemeto atribuído a Homero”. A illustração brazileira, s/l., nº 63, 01 de janeiro de 1912, p. 5. Recortes de Mário de Andrade. IEB-USP. ${ }^{40}$ Idem.

${ }^{41}$ Bandeira, Manuel (org.). Op. cit., p. 209-210. Também em Moraes, Marcos Antonio de (org.). Op. cit., p. 404. Carta a Bandeira: 10/09/1928.
} 
ra da personalidade״ ${ }^{42}$ nacional brasileira, tal como Augusto Meyer observara no artigo cuja leitura tivera o dom de reconduzir Mário de Andrade “aos pagos tristíssimos da alma do meu herói” ${ }^{43}$, devido à afinidade entre intenção do autor e compreensão do crítico, único a notar a face trágica sob a máscara risonha de Macunaíma, fina observação a ser discutida logo mais adiante.

Agora, na perspectiva do estudo da fortuna crítica da rapsódia, observada sob os critérios do artista, a consideração emitida no prefácio “inédito” de Belazarte (1930), de que a crítica brasileira, "no estado em que ela está”, parecia uma "inutilidade”, é sintoma do desgosto sofrido por Mário perante a recepção não só a Macunaíma, certamente, embora seja legítimo conjecturar que, conforme entendimento do escritor, a incompreensão com que boa parte da crítica recebera a rapsódia, considerada por ele, no mesmo prefácio, como “o meu melhor livro”, haja pesado mais para provocar o evidente sentimento de mágoa, mascarado na agressividade com que proclama a "inutilidade” da crítica. Contudo, nesse mesmo escrito, Mário assinala que tanto ataques quanto manifestações favoráveis a Macunaíma, bem como a releitura que fizera de sua própria obra, haviam despertado nele a opinião de que se tratava de uma “obra-prima que falhou”. A mesma opinião já se atesta no ano anterior, numa carta a Bandeira. Nesta, ao referir-se ao projeto do romance Café, a que dera início, Mário ressaltara: “tenho mais ou menos a convicção de que vou ratar, da mesma forma com que ratei Macunaíma - a obra-prima que não ficou obra-prima." 44

No prefácio a Belazarte não há mais que uma referência geral à recepção crítica à rapsódia. Tampouco na correspondência ativa de Mário há menção explícita a quaisquer pronunciamentos particulares da fortuna crítica da obra, publicados no período em evidência neste capítulo (1929-1936), exceto o primeiro artigo de Augusto Meyer, de 1929, e outro, de Prudente de Morais, neto, anterior a maio do mesmo ano, mas até hoje desconhecido ${ }^{45}$. Aliás, as remissões a críticas dedicadas ao livro, verificadas na epistolografia desse período, evocam somente, em que valha a exceção apontada, poucos escritos da fortuna pioneira, analisada no primeiro capítulo deste estudo.

\footnotetext{
${ }^{42}$ A. M. [Augusto Meyer]. "Macunaíma / por Mário de Andrade”. Revista do Globo: Porto Alegre, a. I, nº 1, janeiro de 1929. IEB-USP - MA-MP.

${ }^{43}$ FERNANDES, Lygia (org.). Op. cit., p. 75. Carta de Mário a Augusto Meyer: 02/12/1929.

${ }^{44}$ Bandeira, Manuel (org.). Op. cit., p. 227. Também em MorAes, Marcos Antonio de (org.). Op. cit., p. 427. Carta a Bandeira: 13/07/1929.

${ }^{45}$ Numa carta de Mário a Manuel Bandeira (11/05/1929), há referência a um artigo de Prudente de Moraes, neto, sobre a rapsódia. Ao compilar a correspondência ativa de Mário, referente à obra, Telê Porto Ancona Lopez destacou a existência desse artigo (“Dossier da Obra: Memória”. In: Macunaíma. Ed. cit., 1997, p. 506), obscuro até hoje. Como ele, há de haver outros; talvez outros mais, nem sequer registrados pelas pesquisas.
} 
São alusões, sobretudo, às críticas de Tristão de Ataíde e de João Ribeiro. Quanto à primeira, vimos como Mário, em 1928, opinara ao amigo Manuel Bandeira que Tristão ficara “em cima do muro” e não se decidira claramente sobre a obra. Não era bem isso, pois Tristão, de modo sub-reptício, mas inequívoco, tomara posição adversa a Macunaíma - postura fundamentada na perspectiva de militante católico conservador assumida contra o primitivismo expresso na obra, quer como linguagem brasileira experimental, quer como suposta apologia da “nossa barbaria”. Dois anos depois, ao mesmo amigo, Mário confidenciara sentir-se “ferido pela agressiva incompreensão com que os críticos, especialmente João Ribeiro, e especialissimamente Tristão, receberam Macunaíma, que juro que considero uma obra-prima ratada, mas que tenho a consciência de que é um livro notável. Um livro importante.”46 Já em 1935, Mário confessou, novamente a Manuel Bandeira: “não estava preparado pra receber tamanha ausência do que eu fiz dentro de João Ribeiro, foi uma surpresa que me machucou bastante. Mas também, e não me parece engano meu, a compreensão que João Ribeiro tinha de etnografia, e cultura variada dele, me fizeram imaginar que ele era um dos únicos que podiam compreender a significação mais profunda do meu livro, além do simples divertimento de reconto que teve e inda tem a maioria. A machucadura veio disso: duma esperança com muitas garantias que falhou de supetão. E pra ser franco, não me curei não. Não posso me conformar com essa incompreensão do velhinho (...)”47. No mesmo ano de 1935, ao filólogo Sousa da Silveira, Mário mostrou consciência de que a crítica de Tristão fora destruidora e ressaltou a opinião emitida por João Ribeiro, segundo a qual o livro seria “uma bobagem”48.

Como antecipamos, o artigo de Augusto Meyer ("Macunaíma / por Mário de Andrade”. Revista do Globo: Porto Alegre, a. I, n⿳ํㅡㄹ 1, janeiro de 1929) é a única crítica do período em foco neste capítulo comentada especificamente por Mário de Andrade em sua correspondência. Tendo como destinatário o próprio escritor gaúcho, Mário o saúda na qualidade de autor da crítica pequena no tamanho, mas “clarividente como nenhuma outra, uma síntese admirável cheia de verdades e duma fixação do tipo que me pareceu muito justa. Digo 'me pareceu', porque francamente, eu já nem sei bem direito o que é o meu safado herói. Sabia [grifo do autor], mas não sei mais. Me atrapalharam os comentários; e como a vagueza simbólica do filho do Uraricoera era bem elástica, cada qual me apresentava o seu Macunaíma dele. Achando o seu, tive o prazer de mais ou menos me achar pelo muito em que coincidimos, eu

\footnotetext{
${ }^{46}$ Bandeira, Manuel (org.). Op. cit., p. 263. Também em MoraEs, Marcos Antonio de (org.). Op. cit., p. 483. Carta de 12/01/1931.

${ }^{47}$ Idem, p. 349-350. Idem, p. 610. Carta a Manuel Bandeira: 26/01/1935.

${ }^{48}$ FeRnANDES, Lygia (org.). Op. cit., p. 165. Carta a Sousa da Silveira: 26/04/1935. Em rigor, João Ribeiro valeu-se da expressão “uma besteira", ressalvando que se tratava de "uma besteira de talento".
} 
na intenção, você na compreensão, e pude por isso voltar de novo aos pagos tristíssimos da alma do meu herói."

A elasticidade simbólica, observa Mário nesse depoimento, propiciara uma pluralidade de interpretações que o deixaram inseguro quanto ao significado do herói. Ressalte-se, porém: o autor reconhece na crítica de Meyer uma “fixação do tipo (...) muito justa”, em virtude da percepção de afinidade ou coincidência entre a intenção que orientara a composição caracterológica (in)definidora do protagonista e a compreensão demonstrada pelo crítico, que ensejara ao artista a possibilidade de "voltar de novo aos pagos tristíssimos da alma do meu herói." Cá está, provavelmente, a razão pela qual Mário considerou “clarividente como nenhuma outra” a crítica de Meyer.

Mais de uma vez, o autor de Macunaíma se queixou da incompreensão dos comentadores da rapsódia, que só viam nela a face divertida, conforme se refere na carta a Bandeira, em 26 de janeiro de 1935. Ali observara que os críticos, até então, haviam-se limitado ao reconhecimento da dimensão de "simples divertimento de reconto" e tinham sido incapazes de “compreender a significação mais profunda do meu livro”. Na primeira e na segunda partes deste capítulo, pudemos observar Augusto Meyer como o único crítico a descortinar, sob a face risonha, a máscara trágica de Macunaíma, ao compreender a saga do herói sem nenhum caráter sob o prisma temático da "busca da personalidade”. No périplo do protagonista, a autor de Giraluz captara “a nota dolorosa” do livro, identificando-a com a precariedade do herói, em perpétuo e contraditório devir, dotado de uma constituição espiritual caótica, incapaz de qualquer organização moral, a interagir com o meio por intermédio das pulsões do instinto sensual e do improviso.

Não é difícil demonstrar a coesão entre a interpretação de Meyer e a autocrítica de Mário concernente a esse aspecto decisivo em Macunaíma. A título de exemplo, veja-se o seguinte fragmento de carta a Ademar Vidal, de 20 de abril de 1929: "Sempre maginei fazer poema se ocupando do homem sem caráter nenhum, produto mesmo do caos humano, mexendo-se no abismo brasileiro, reflexo de elementos disparatados na arritmia gostosa a indicar o maravilhoso destino de nossa gente.” ${ }^{50} \mathrm{O}$ final dessa citação não nos deve iludir. O otimismo demonstrado se restringe a uma indicação de possibilidade futura, que poderia ou não realizar-se. Tal otimismo, que mais é esperança, não invalida, porém, a consciência crítica a pro-

\footnotetext{
${ }^{49}$ Idem, p. 75. Carta a Augusto Meyer: 02/12/1929.

${ }^{50}$ VIDAL, Ademar. "Mário de Andrade e o Nordeste". Revista do Livro, a. 10, n⿳ํㅜ31. Rio de Janeiro, 1967, p. 2728. Apud Andrade, Mário de. Macunaíma. Ed. crítica de Telê Porto Ancona Lopez. Op. cit., 1997, p. 505 (“Dossier da Obra: Memória / Considerações em cartas”).
} 
pósito do herói, que representaria, segundo Mário, “apenas o estado atual [“da raça que não é raça ainda”] fixado pela minha frágil imaginação.”51 Tal consciência pode ser claramente depreendida de uma importantíssima retrospecção de Mário, emitida vários anos após (16/02/1942), em missiva a Fernando Sabino: “(...) Macunaíma foi detestavelmente doloroso pra mim. Nos momentos mais anedóticos, mais engraçados do entrecho, eu não deixava de sofrer pelo meu herói, sofrer a falta de organização moral dele (do brasileiro, que ele satiriza), de reprovar o que ele estava fazendo contra a minha vontade. E quando no fim Macunaíma no ponto de se regenerar, fraqueja mais uma vez e prefere ir viver o brilho 'inútil' das estrelas, meus olhos se encheram de lágrimas. Se encheram e se encherão sempre.”52 Com isso, evidencia-se aquela afinidade crítica entre Mário de Andrade e Augusto Meyer, destacada anteriormente, que levou o segundo a discernir de modo ímpar a "nota dolorosa”, nas palavras do crítico gaúcho, contida em Macunaíma.

Mário não se pronunciou a propósito do segundo artigo de Meyer ("Macunaíma”. Correio de Povo: Porto Alegre, 01 de julho de 1930), mas não é despropositado conjecturar que não estaria em desacordo com ele, uma vez que pode ser visto como desdobramento lógico do primeiro, uma forma de exemplificar por contraste a imagem problemática de Brasil, contida em Macunaíma, com a imagem do mesmo país, mas edulcorada por Ronald de Carvalho, em Toda a América, por influência de Graça Aranha.

Pois bem, o exame do que chamamos primeira onda da fortuna crítica de Macunaíma, isto é, o conjunto de pronunciamentos conhecidos e publicados entre 1928 e 1936, permite observar como os discursos são comumente mediados por ideologias alheias ao campo especificamente artístico de uma obra literária, as quais servem de critério orientador para as análises e juízos expedidos.

Dentre essas ideologias, destacam-se sobretudo o nacionalismo metafísico de Graça Aranha, a antropofagia de Oswald de Andrade, o catolicismo de Tristão de Ataíde ${ }^{53}$ e o regionalismo de Gilberto Freyre. Até mesmo o verdeamarelismo de Plínio Salgado se entremostra, no artigo de Cândido Motta Filho ("Macunaíma”. Correio Paulistano: SP, 20/09/1928), como observamos no primeiro capítulo deste estudo. Todas elas se articulam em torno da questão nacional, elemento comum que as agrega e as distancia. Essas ideologias, manifestas explícita ou implicitamente nos pronunciamentos até agora investigados, confrontaram-se com o proje-

\footnotetext{
${ }^{51}$ Idem. Loc. cit., p. 506.

${ }^{52}$ SABINO, Fernando (org.). Cartas a um jovem escritor. $3^{\mathrm{a}}$ ed. Rio de Janeiro: Record, 1993, p. 29.

${ }^{53}$ Em rigor, o catolicismo não seria uma ideologia, mas uma religião; no exercício intelectual de Tristão de Ataíde, porém, a religião opera como ideologia sectária, ao menos nos escritos do período em que se circunscreve nosso objeto de estudo.
} 
to de nacionalismo crítico de Mário de Andrade, cuja expressão artística extrema se consubstancia em Macunaíma, conforme reconhecido pelo próprio autor, quando distinguiu tal obra como “coroamento" ${ }^{54}$ de uma fase indecisamente anunciada em Paulicéia desvairada e conscientemente construída desde então.

Já discutimos o diálogo estabelecido pelas correntes de pensamento representadas por Tristão de Ataíde, Oswald de Andrade, Gilberto Freyre e Plínio Salgado, os dois últimos por meio da análise de documentos de terceiros, como, respectivamente, o ensaio de Jorge de Lima e o artigo de Cândido Motta Filho. Resgatemos agora o projeto artístico e ideológico de Graça Aranha, confrontando-o ao de Mário de Andrade, tal como se realiza em Macunaíma, seguindo a hipótese sugerida pela análise do segundo artigo de Augusto Meyer ("Macunaíma”. Correio de Povo: Porto Alegre, 01/07/1930), de que a rapsódia de Mário conteria um diálogo com as propostas do autor de Canaã. Para isso, convém recuar ao momento em que, por intermédio da “Carta aberta a Graça Aranha” (1926), Mário de Andrade rompeu publicamente com o autor da Estética da vida.

Tal ruptura, no entanto, foi culminância de um processo de afastamento gradual em relação às idéias e posições do acadêmico rebelado; um processo de tomada de consciência do significado do projeto graciano sobre o qual Mário já manifestava discordância em sua correspondência pessoal, bem antes da publicação daquele documento ${ }^{55}$. Portanto, convém recuar um pouco mais no tempo, até uma mais antiga manifestação, embora de caráter privado, de restrições do escritor paulista ao ideário graciano. Em carta de 05 de agosto de 1923, Mário confidenciara a Bandeira: “Acho ridículo o preconceito da alegria do Graça. Também sou alegre. Digo mais: não só me penso, mas me sinto um homem muito feliz: porque para mim a dor cabe perfeitamente dentro do sentimento de felicidade.”56

Como ressaltou Augusto Meyer, em 1930, o mesmo “preconceito da alegria” levara Ronald de Carvalho a falsificar o Brasil e a sua gente nos poemas de Toda a América (1926), porque produzira uma imagem desprovida das mazelas e sofrimentos do país. Essa observação do crítico gaúcho põe em evidência a matriz ideológica graciana presente nos poemas de Ronald de Carvalho. À imagem de Brasil fundamentada nessa ideologia risonha, Meyer contrapôs a face trágica de Macunaíma.

\footnotetext{
${ }^{54}$ Correspondência de Mário de Andrade a Sousa da Silveira: 26/04/1935. In: FERNANDES, Lygia (org.). Op. cit., p. 164.

${ }_{55}$ A “Carta aberta a Graça Aranha” foi publicada em A Manhã : Rio de Janeiro, 12 de janeiro de 1926. Recolhida em livro: KoIfMAn, Georgina (org.). Cartas de Mário de Andrade a Prudente de Moraes, neto. Ed. cit., 1985, p. 185-190.

${ }^{56}$ BAndeira, Manuel (org.). Op. cit., p. 18-22. Também em Moraes, Marcos Antonio de (org.). Op. cit., p. 99. Essa última edição estabeleceu a data correta dessa correspondência de Mário a Bandeira: 05 de agosto de 1923.
} 
O sentimento trágico da vida, nas autocríticas de Mário de Andrade, associa-se ao tema do sacrifício, mas tal sentimento e tal temática associam-se também à peculiar noção andradiana de felicidade, de que a citada observação feita ao amigo Bandeira, no longínquo ano de 1923, dá testemunho. Desde essa época ou mesmo antes, conforme demonstrou Telê Ancona Lopez ${ }^{57}$, cristalizara-se no pensamento de Mário uma noção de felicidade derivada da miscigenação de elementos filosóficos epicuristas e taoístas com a sincera religiosidade que já hesitava em se dizer católica; uma noção de felicidade compreensiva do prazer e da dor.

Não se pode confundir com masoquismo a inclusão da dor no conceito andradiano de felicidade. Graça Aranha incorreu nesse erro, num discurso proferido em 07 de novembro de 1925, em louvor a Renato Almeida. Referindo-se depreciativamente ao primitivismo dos modernistas de São Paulo e, veladamente, ao de Mário de Andrade, Graça Aranha afirmara tratar-se de uma atitude romântica, "um estado mórbido de masoquismo [grifo do autor], que exige sofrer para se ter o gozo”, acrescentando: "E que maior sofrimento, mais delicioso, do que este de aviltar o espírito, rebaixando-o com ele o país, o quadro nacional? Masoquismo que nega a realidade da nossa ascensão para rebuscar o primitivo que passou, que não é mais o corpo dominante nesta química, em que se forma e transforma a nacionalidade, arte que só vê o tosco, o inacabado, e se engana quando não compreende que os resíduos africanos, os rudimentos selvagens, os desertos, a língua emaranhada, os jecas-tatus, os morros da Favela, tudo isto está no Brasil, mas não é todo o Brasil, nem o Brasil essencial. É o Brasil imobilizado.”58 O discurso de Graça Aranha implica a incompreensão do conceito de felicidade e a deformação da noção andradiana de primitivismo.

No pensamento de Mário, a felicidade comporta dor e prazer, mas aquela não é condição para esse. Ambos são realidades da vida, cuja felicidade, segundo a lição de Epicuro, consiste na sábia aceitação das coisas "com a medida e o critério dos benefícios e dos prejuízos, pois que, segundo as ocasiões, o bem nos produz o mal e, em troca, o mal, o bem”59. Assim, ainda segundo Epicuro, “pomos de lado muitos prazeres quando, como resultado deles, sofremos maiores pesares; e igualmente preferimos muitas dores aos prazeres quando, depois de longamente havermos suportado as dores, gozamos de prazeres maiores." ${ }^{60}$ É notável a coesão desses fragmentos do filósofo grego com a práxis sacrificial a que Mário de Andrade

\footnotetext{
${ }^{57}$ Lopez, Telê Porto Ancona. “Amazônia e utopia em Mário de Andrade”. In: América: ficção e utopias. São Paulo: Edusp, 1995.

58 "Cultura criadora / As novas correntes do pensamento brasileiro realizaram ontem uma festa em torno da personalidade do senhor Renato de Almeida / Discurso veemente e vibrante do senhor Graça Aranha”. Jornal do Brasil: Rio de Janeiro, 08 de novembro de 1925. Apud FrotA, Lélia Coelho (org.). Op. cit., p. 167.

59 “Antologia de textos de Epicuro”. In: Os pensadores. São Paulo: Abril Cultural, vol. V, 1973, p. 25.

${ }^{60}$ Idem.
} 
submete toda a sua produção. Como o maior prazer e a suprema felicidade, para o autor de Macunaíma, consistia em sentir-se socialmente útil, ele decidiu "sacrificar" a sua obra, o que significava desistir de qualquer pretensão de "ficar" para a história como grande autor de obras-primas, em favor de um trabalho útil para a atualidade histórica em que vivia.

Isso implicava, por um lado, converter seu trabalho à condição de "obra de circunstância”, em que a literatura se torna um modo de ação ou interação social atuante na realidade, com o perdão pela redundância; por outro lado, a necessidade de clara consciência quanto ao caráter problemático da atualidade histórica brasileira, de modo a orientar a práxis útil para o "amilhoramento" do homem, de acordo com a orientação humanista de fundo aristotélico (ideal ético-estético de arte) e cristão (o amor como valor universal), sempre presente nas cogitações andradianas sobre o papel da arte. ${ }^{61}$

O sacrifício, porém, no que diz respeito ao trabalho do artista, jamais significou que a obra de arte deixasse de ser o que é por natureza específica, mas, como fenômeno histórico, isso não implicava ser a arte sempre o retorno do mesmo; ao contrário, Mário é consciente de que o conceito de arte e a prática artística acompanham o dinamismo da história e se apresentam sob diversas formas que, em última instância, são diálogos com o mundo em que tais conceitos e práticas se inserem. Conforme assevera o próprio autor, em texto, provavelmente, de 1925: “A criação artística é uma realização de ideal que ultrapassa os dados concretos e o domínio físico das coisas. Na evolução estética do homem a gente vê o ideal se transformar e mudar não só pela influência histórica da época e do meio como do indivíduo também”62 (ressalte-se a ressonância taineana contida nessa observação).

Para Mário, por mais forte que fosse a individualidade do artista, quisesse ele ou não, sua obra exibiria de algum modo as marcas identitárias de seu tempo e lugar. A opção pela “arte de ação" ou "literatura de circunstância” corresponde à inserção consciente e voluntária do artista na história. O autor não invalida a possível opção pela “arte pura”, entendida como aquela que se esforça para realizar o "Belo (...) unicamente com os fatores formais dele”, mas a considera hedonística, tendente ao hermetismo, "um objeto de luxo restritíssimo pra elites mirins”, que não deixa de ter valor, embora seja pobre pois, desligada das instâncias da vida, despreza a dimensão expressiva e cognitiva da arte ${ }^{63}$.

\footnotetext{
${ }^{61}$ V. LOPEZ, Telê Porto Ancona. Ramais e caminho. Ed. cit., p. 242.

${ }^{62}$ ANDRADE, Mário de. Introdução à estética musical. Estabelecimento do texto, introdução e notas de Flávia Camargo Toni. São Paulo: Hucitec, 1995, p. 5.

${ }^{63}$ Idem, passim, p. 32.
} 
Mesmo quando de circunstância, a arte jamais deixa de ser arte se "supõe uma organização, uma técnica, uma disciplina que faz das obras uma manifestação encerrada em si mesma.” Nessa passagem, de um artigo sobre o romance L’Or (1925), de Blaise Cendrars, Mário ainda afirma: “A obra de arte é antes de mais nada uma organização fechada, em toda criação artística deve haver a intenção [grifo do autor] da obra de arte. Essa intenção é que a torna uma entidade valendo por si mesma, desrelacionada. Desrelacionada, não quero dizer que não possa ter intenções até práticas de moralização, socialização, edificação etc. quero dizer que se torna livre da percepção temporal vivida da sensação e do sentimento reais.”“4

Observa-se que a idéia de autonomia da obra de arte, sintonizada com as vanguardas e defendida nos escritos de reflexão estética, como A escrava que não é Isaura entre outros, não se dissocia da proposta também vanguardista de restabelecimento da conexão entre arte e vida que, na aparência, entra em contradição com a idéia de autonomia. Mário se inscreve entre os artistas de profunda convicção no caráter autônomo da arte, que se revela na "consciência da linguagem”, conforme demonstrado por João Luiz Lafetá ${ }^{65}$. Porém, a convicção dessa autonomia não leva Mário a romper o vínculo entre arte e vida. Para ele, arte não é fotografia da exterioridade do mundo, nem da interioridade do sujeito, mas uma construção resultante da necessidade de exteriorizar e comunicar certos conteúdos existenciais, deformados por meio de uma linguagem peculiar que os transforma em outros referentes, de caráter simbólico. No caso da arte literária, os referentes simbólicos têm a palavra como suporte e, como fim, a construção de um todo acabado, a obra de arte coincidente com a sua própria realização enquanto tal.

A obra de arte sintetiza numa peça (um quadro, uma escultura, uma sonata, um poema etc.) todo um processo que se inicia com a relação vital entre o artista e o mundo sensível no momento em que essa relação provoca o fenômeno da comoção, mais especificamente a comoção artística ou “lirismo”, como Mário também a chama, e que é despertada pelo sentimento de beleza. Num primeiro momento, esse sentimento é desligado da inteligência e consiste num "espanto imediato" 66 , atitude de pura contemplação, sem qualquer interesse ou necessidade prática. A sensação estética é uma espécie de "prazer deslumbrado"67, decorrente da interação sensível entre exterioridade e interioridade do artista, de modo que o belo "não resi-

\footnotetext{
${ }^{64}$ ANDRADE, Mário de. “L’Or”. In: Estética, no ${ }^{3}$. Rio de Janeiro: abr.-jun. de 1925. Apud: KoIfMAN, Georgina (org.). Op. cit., p. 113-114.

${ }^{65}$ LAFETÁ, João Luiz. “A consciência da linguagem”. In: 1930: A crítica e o modernismo. $2^{2}$ ed. São Paulo: Duas Cidades / Editora 34, 2000, p. 151-184.

${ }^{66}$ ANDRADE, Mário de. Introdução à estética musical. Op. cit., p. 15.

${ }^{67}$ Idem.
} 
de nem dentro da gente nem no mundo exterior porém na relação estabelecida entre essas duas entidades distintas"

Esse momento de puro lirismo, contudo, logo desperta a atenção, faculdade do intelecto que estabelece a mediação entre o "eu profundo" e a consciência. Por meio da atenção, a inteligência passa a agir de modo a coordenar as impulsões líricas, a traduzi-las e a organizálas numa linguagem específica, que, no caso da literatura, tem a palavra como suporte material. Dá-se, então, o trabalho artístico propriamente dito, que se completa com a construção voluntária de um todo acabado: a obra de arte em que deve ser imanente o poder de provocar comoções estéticas no receptor, análogas às experimentadas pelo artista. Nessa linha de pensamento e inspirado em suas leituras da revista francesa L'Esprit Nouveau ${ }^{69}$, Mário de Andrade formulou, em A escrava que não é Isaura, a definição segundo a qual "a obra de arte é uma máquina de produzir comoções”.

A metáfora mecânica encerra, obviamente, a noção de que a obra de arte é um artefato humano, não uma criação da natureza. Na hipótese de uma máquina perfeita, está implícita a necessidade de que cada parte do dispositivo esteja articulada às demais de modo a estruturar a unidade de um todo acabado, capaz de produzir de modo infalível ${ }^{70}$ o efeito para o qual foi construído. Essa unidade estruturada constitui a forma, que resulta dos meios empregados para a tradução das pulsões líricas e do modo como eles se combinam no trabalho construtivo da síntese artística, isto é, a criação de um todo "não direi mais homogêneo, não direi mais perfeito que o da natureza mas / DUMA OUTRA PERFEIÇÃO / DUMA OUTRA HOMOGENEIDADE. / A natureza existe fatalmente sem vontade própria. O poeta cria por inteligência, por vontade própria"71.

É enquanto forma que Mário de Andrade entende a autonomia da obra de arte. A sensação estética é uma síntese psicológica vital, pois é uma experiência humana que se dá na interioridade do sujeito a partir de sua relação com o mundo sensível. No artista, essa síntese desencadeia um processo de análise intelectual em que o espírito compara os objetos e os indica como universais. Esses são selecionados, combinados e organizados de modo a constituir outra síntese, que "permite criar todo um ambiente de realidades ideais onde sentimentos,

\footnotetext{
${ }^{68}$ Idem, p. 16.

${ }^{69}$ Maria Helena Grembecki (op. cit., p. 56) localizou a referida inspiração no artigo “Idées Personnelles”, assinado por Ozenfant e Jeanneret, no número 27 da revista (p. 291): “(...) on peut créer le tableau comme une machine. Le tableau est um dispositif destiné à nous émouvoir”.

${ }^{70}$ Em correspondência a Prudente de Moraes, neto, datada de 15/09/1925, Mário de Andrade observa: “Máquina (...), que quer dizer? Uma coisa que faz, que faz fatalmente, que não falha”. In: KoIFMAN, Georgina (org.). Op. cit., 1985, p. 105.

${ }^{71}$ A escrava... Op. cit., p. 237. Caixa-alta e grifos do autor.
} 
seres e coisas, belezas e defeitos se apresentam na sua plenitude heróica, que ultrapassa a defeituosa percepção dos sentidos”72. Tal síntese decorre do trabalho intelectual que consiste em dar forma à idealização, ou seja, em construir a obra de arte. Nesse processo, o artista se confronta com os seus materiais e os meios que lhes são próprios para torná-los sínteses artísticas materializadas das “realidades ideais". Esse trabalho exige do artista o conhecimento do material de sua arte e de sua respectiva técnica, meio pelo qual ele modula, articula e organiza a matéria-prima, transformando-a em obra acabada e autônoma.

Seleção, tradução, combinação e organização dos elementos sensíveis são atividades voluntárias do artista que constituem o processo de criação da obra de arte, ou seja, o trabalho inteligente e artesanal de constituição do objeto estético, entendido como "realidade do objeto que provoca sensações estéticas, mais ou menos o que se chama forma”73. Por meio do trabalho técnico do material a forma se perfaz. Essa noção de forma como ordenação acabada dos elementos sensíveis, isto é, a forma como o próprio objeto artístico estruturado e realizado em si, com seu poder de provocar comoções artísticas, foi formulada em texto provavelmente escrito em 1925 e só publicado em 1995, mas já estava implícita no "Prefácio interessantíssimo” (1922) e explícita em A escrava que não é Isaura (1925), permanecendo ao longo do tempo como um dos elementos unificadores do pensamento estético de Mário de Andrade.

A concepção andradiana de obra de arte como linguagem estruturada encontra seu limite na noção de arte pura, entendida como aquela que, em rigor, reduz-se ao desenvolvimento perfeito do material (técnica) e à beleza artística realizada unicamente com os elementos formais, dissociados de quaisquer outras determinações. Tal conceito só é possível desde que a beleza seja concebida como a finalidade da arte, o que, historicamente, só se verificaria de modo radical em certas correntes da arte moderna, a partir de sua origem remota, situada no Renascimento, antes do qual a arte era entendida sob outros critérios. Não que a beleza estivesse ausente de cogitações ou realizações artísticas anteriores ao Renascimento, mas porque, antes dele, a arte sempre esteve subsumida em finalidades práticas, utilitárias, quer de caráter mágico, quer religioso, quer social.

Períodos de transição, “em que uma determinada maneira artística de expressão se torna acadêmica” e o belo se coloca no centro da criação artística, abriram caminho para a manifestação da arte pura, essencialmente experimental e técnica, que dissocia o belo das noções de bem e de utilidade. Em A escrava que não é Isaura, Mário de Andrade observa que a mú-

\footnotetext{
72 “Prefácio...”. Op. cit., p. 65.

${ }^{73}$ ANDRADE, Mário de. Introdução à estética musical. Ed. cit., p. 17.
} 
sica fora a primeira a realizar a arte pura em obras de Bach, Mozart e Haydn; somente no século XX, outras artes a teriam realizado. Tendo a beleza como finalidade, certas correntes da arte moderna teriam produzido obras totalmente desinteressadas, sendo o desinteresse entendido como essencial no conceito de belo artístico. A arte pura, assim, dissocia o belo das instâncias da vida para realizá-lo como forma autônoma, auto-referente, cujo valor está em si mesma.

O autor de Macunaíma reconhece a importância das manifestações modernas de arte pura, pelo que contêm de valorização do material, da técnica e, em suma, da forma; chegou a entusiasmar-se com elas a ponto de acolher a concepção da arte como máquina, no sentido especificado anteriormente. Esse acolhimento, porém, não pode ser visto como integral. Mário entende que a arte possa ter a beleza por finalidade, mas, nesse caso, seria manifestação de um hedonismo só acessível a eruditos, uma vez que se tornaria uma espécie de "Arte de enigma, de chave, de maçonaria"74. Essa restrição à arte pura, formulada claramente em torno de 1925, já estava latente em 1922-1923, durante da redação de A escrava..., onde se encontra vigorosa condenação ao hermetismo e a defesa da idéia de arte como expressão, em que o belo seria o meio e a consequiência da manifestação artística, mas não o seu fim.

Para Mário de Andrade, a idéia de autonomia da arte é válida do ponto de vista de sua realização concreta como objeto organizado e criado pelo homem (o artista), isto é, enquanto forma independente da natureza e, quando acabada, liberta do próprio criador. Em uma carta a Manuel Bandeira, datada de 1925, Mário esclarece essa posição: “Quando eu digo [em A escrava...] que a obra de arte é inteiramente livre da natureza digo como obra de arte, isto é, manifestação objetiva, realidade já concreta. Isto não quer dizer que ela não tenha relação de criação e de organização partinte da relação entre homem e manifestação fenomenal quer física e exterior quer psicológica e interior, tudo manifestações naturais de que a obra de arte é a expressão"75.

No “Prefácio interessantíssimo”, Mário de Andrade já explicitara que entendia o belo artístico como convenção transitória, categoria histórica volúvel; em A escrava..., aduziu, vale repetir, que a beleza seria um meio e uma conseqüência, mas não deveria ser um fim. Segundo seu ponto de vista, a meta do trabalho construtivo da obra de arte moderna seria a de alcançar o "máximo de expressão", que resultaria da soma: máximo de lirismo + máximo de

\footnotetext{
${ }^{74}$ Introdução à estética musical. Ed. cit., p. 32.

${ }^{75}$ BAndeIRA, Manuel (org.). Op. cit., p. 74-78. Também em MorAes, Marcos Antonio de (org.). Op. cit., p. 208. Grifo do autor.
} 
crítica $^{76}$. O exercício da crítica se dá sobre o material, de acordo com as suas exigências, e sobre os seus meios de manifestação específicos, identificando-se com a práxis criativa que se perfaz na obra acabada. No entanto, esse trabalho que constitui a própria arte, considerada em si mesma, não se confunde com a sua finalidade, sob o risco de cair no formalismo materialista da arte pura (ou qualquer outro, como o formalismo intelectualista de Mallarmé, ou a arte pela arte dos parnasianos), que Mário admira, sabe apreciar, mas só admite, com restrições, na música, na medida em que ela pode ser considerada "a mais vaga e a menos intelectual de todas as artes”77, a que estaria mais livre da natureza e da perspectiva da arte mimética ou, melhor, “de relação”. Mário afirma que a música "se realiza por meio de Idéias musicais que só podem ser compreendidas musicalmente e não conscientemente como as outras artes que são artes de relação.”78 Reduzidas à arte pura, as “artes de relação” resultariam numa “Arte de grande pobreza" ${ }^{, 79}$.

Do ponto de vista do artista, mas não dos receptores, neles incluído o próprio artista ao contemplar o seu trabalho acabado, a finalidade da obra de arte moderna, segundo Mário de Andrade, consiste na expressão. Historicamente, atribuíra-se à arte finalidades diversas. Até o Renascimento, a arte sempre estivera submetida a uma destinação prática, quer reduzida ao artesanato de utensílios, quer dignificada como suporte de função mágica, religiosa ou social. Com o Renascimento, tem início o processo em que a realização da beleza passa a ser vista como finalidade da arte, perspectiva que levaria à concepção de arte como atividade do espírito, desinteressada e livre de qualquer utilidade relativa às instâncias imediatas da vida. No entanto, segundo Mário, também a partir do Renascimento, mas com origem remota enraizada no cristianismo, dá-se o despertar de outro valor histórico, que consiste na importância assumida pelo indivíduo, crescentemente considerado como núcleo do interesse humano. A valorização do indivíduo teria forçado o deslocamento da finalidade da arte, que passaria da beleza realizada na obra para a expressão do artista nela configurada, sendo a obra compreendida como manifestação do "gênio". Tal fenômeno se impõe sobretudo do romantismo em diante, levando, nos momentos mais agudos, a posições e manifestações artísticas de radical individualismo, que exalta elementos singulares do artista - sensações, emoções, sentimentos, fantasias, memórias, idéias, em suma, experiências vitais - com certa indiferença ou desprezo pela técnica no âmbito da forma. Assim, mais ou menos acentuadamente, a arte teria por fina-

\footnotetext{
${ }^{76}$ A escrava que não é Isaura. Ed. cit., p. 206.

${ }^{77}$ Idem, p. 256. Grifos do autor.

${ }^{78}$ Introdução à estética musical. Ed. cit., p. 50.

${ }^{79}$ Idem, p. 32.
} 
lidade ou a beleza ou a expressão do artista. Segundo Mário de Andrade, essas duas posições perante a arte coexistem, combinam-se, rivalizam e rechaçam-se na história posterior ao Renascimento. Mário de Andrade reconhece o valor e o vigor de ambas, quer nas manifestações passadas, quer nas atualizações suas contemporâneas, porém, mostra-se mais inclinado a aderir à que compreende a arte como expressão, considerada por ele como a tendência dominante na modernidade.

Em A escrava..., afirma-se que é a expressão, não a beleza, a finalidade da arte moderna. Tal afirmação pode parecer contraditória se a confrontarmos ao elogio à arte pura, contido na mesma obra. No entanto, é preciso observar que, se Mário de Andrade não limita a conquista da arte pura à música, considera um “erro grave”80 a sujeição de outras artes a ela, pois seria um esforço para realizar com outros materiais o que seria possível só com ritmos e sons sem relação com elementos que lhes são exteriores. Ou melhor, seria possível, mas estéril. Embora as artes possam se entrelaçar e procedam todas do mesmo tronco que, em última análise, é a vida, é necessário que cada uma corresponda à sua especificidade: “Cada arte no seu

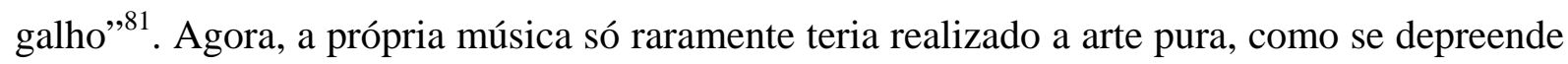
da seguinte observação contida em A escrava...: “O próprio Mozart, que para mim de todos os artistas de todas as artes foi quem melhor realizou a beleza insulada, sujeitou-a à expressão.”82

A publicação da Introdução à estética musical, em 1995, tornou mais claro o conceito andradiano de expressão. Uma vez melhor esclarecido, supomos que tal conceito ajudará a considerar de modo adequado a suposta contradição que consistiria no acolhimento de propostas aparentemente antagônicas no projeto artístico de Mário de Andrade, a saber: de autonomia da arte e de conexão dessa com a vida. Com isso, talvez seja possível entender sob uma perspectiva coesa e apropriada as noções andradianas de sacrifício, de "arte de ação" ou "literatura de circunstância”, de primitivismo e de nacionalismo crítico, possibilitando confrontar de modo adequado os projetos de Graça Aranha e de Mário de Andrade, sob a perspectiva daquela hipótese, sugerida por Augusto Meyer, de Macunaíma conter um certo diálogo com as idéias do autor de "O espírito moderno".

Assim sendo, lembre-se mais uma vez a fórmula contida em A escrava...: "máximo de lirismo e máximo de crítica para adquirir o máximo de expressão”83. Vimos que Mário considerara a expressão e não o belo como a finalidade da arte moderna, mas não se trata mais de

\footnotetext{
${ }^{80}$ A escrava... Ed. cit., p. 259.

${ }^{81}$ Idem, p. 265.

${ }^{82}$ Idem, p. 207.

${ }^{83}$ Idem, p. 206.
} 
expressão no sentido romântico de manifestação do gênio, descuidado quanto à dimensão propriamente artística de sua obra.

A Introdução à estética musical define expressão, genericamente, como "todas as coisas criadas pelo homem”84. Entretanto, a coisa (artística) criada implica necessariamente tudo aquilo que participou da ação criadora desde o primeiro momento de sua gênese: "a inspiração, a vontade, a crítica, elementos subjetivos” ${ }^{\nexists 5}$ etc. No caso da arte moderna, tal como a entende Mário de Andrade, não se trata mais de expressão da personalidade do artista, manifestação de qualquer individualidade, por mais genial que fosse; trata-se da interação entre sensibilidade individual e inteligência criadora, consciente do caráter artístico do trabalho voluntário que se manifesta na obra criada.

A expressão não pode mais ser entendida como manifestação do artista como homem, mas do homem enquanto artista consciente. Desse modo, a expressão passa a coincidir com a própria obra de arte, que implica lirismo e crítica: “a expressão implica além do sentimento ou da sensação que a origina, o conhecimento total da sensação ou do sentimento por meio da abstração e a vontade. Vontade livre que pode ser abandonada.” ${ }^{86}$ A comoção estética, inspiração ou lirismo, experiência existencial do artista, dá origem à expressão, mas essa só se perfaz ao se tornar "conhecimento total”, ou seja, quando a sensibilidade, trabalhada livremente pela inteligência, é abstraída do mundo sensível, idealizada e, assim, convertida em obra de arte, cada qual por meio de sua linguagem específica, o que implica os diferentes materiais e as respectivas técnicas, mediante as quais a obra de arte se objetiva como um todo acabado. $\mathrm{O}$ conceito andradiano de arte moderna como expressão é, de fato, muito diferente daquele sentido romântico. Trata-se de expressão entendida como totalidade idealizada, que converte a experiência sensível em um objeto criado livremente pelo homem e, portanto, forma independente da natureza e liberta do próprio criador: obra de arte autônoma, desinteressada e sem função utilitária.

Agora, é do ponto de vista do artista que a obra de arte moderna é entendida como expressão. Segundo Mário, é necessário verificar qual o significado da própria arte sob outra perspectiva. A Introdução à estética musical assinala: “A Arte embora não seja útil praticamente falando (...) é necessária porque é inerente ao homem e porque é conhecimento.»"87

\footnotetext{
${ }^{84}$ Introdução à estética musical. Ed. cit., p. 21.

${ }^{85}$ Idem.

${ }^{86}$ Idem, p. 24.

${ }^{87}$ Op. cit., p. 28.
} 
A essas duas necessidades da arte correspondem outras tantas finalidades: enquanto manifestação subjetiva, necessária porque inerente ao homem, a arte tem como finalidade a expressão desinteressada e livre, não propriamente da personalidade do artista, mas de uma criação espiritual dele, decorrente do “artefazer”; enquanto manifestação objetiva, porém, a arte tem por finalidade proporcionar um conhecimento virtual da vida ao receptor, necessário porque, afinal, também é inerente ao homem e corresponde à necessidade de prazer e de comunicação. No caso, trata-se da necessidade de prazer superior, espiritual, a que a obra de arte visa satisfazer por meio do belo artístico, diverso do belo natural. Quanto à comunicação, trata-se não só de um meio imprescindível de socialização, também considerado inerente ao homem, mas corresponde ainda à necessidade de conhecimento das "relações do ser humano com o mundo físico e o mundo metafísico.” ${ }^{88}$

O conhecimento proporcionado pela arte, Mário de Andrade especifica, é diverso do proporcionado pela ciência, entendido como abstrato e passivo, que se originaria da noção de "Verdade” relativa à realidade, digamos, material do mundo; é diverso também do conhecimento sob a perspectiva da "Moral”, considerado “de utilidade prática absolutamente ativo”, relacionado à noção de "Bem”: “A Arte se caracteriza pelo conhecimento virtual, intermediário entre a passividade do conhecimento científico e a atividade do conhecimento utilitário,

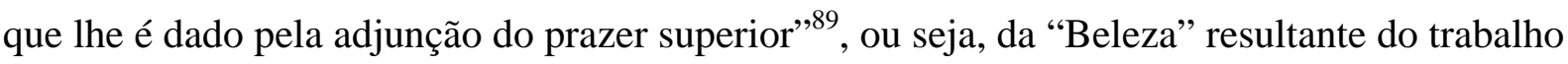
de organização da expressão.

O espectador, perante a "imediateza do Belo" acrisolado na obra de arte, desloca a expressão para o segundo plano, mas não a abstrai, pois é nela que o belo se estrutura e é por meio dela que se estabelece a relação entre a beleza e "a coisa conhecida”, uma relação, portanto, em que a forma acabada da obra de arte é suporte de um "conhecimento virtual da vida”. Virtual porque o objeto artístico, enfim, é uma idealização da vida, um produto do espírito que não se serve da vida para criar o "Belo", uma vez que esse, na concepção andradiana de arte moderna, repita-se, é um meio e pode ser uma conseqüência, mas não é o fim.

A arte, como manifestação subjetiva, tem como finalidade realizar a expressão desinteressada e livre, criada pelo espírito do artista. Como manifestação objetiva, porém, a finalidade da arte se define na relação da obra com o receptor e se justifica por atender à dupla necessidade dele: uma, imediata, é a de prazer superior; a outra, mediata, a de conhecimento. Embora conhecimento não real mas virtual da vida, sem interesse prático imediato para ela, a

\footnotetext{
${ }^{88}$ Idem, p. 24.

${ }^{89}$ Idem, p. 29.
} 
obra de arte tem o poder de nela agir. ${ }^{90}$ Talvez fosse melhor dizer interagir com a vida, idéia mais próxima do pensamento estético andradiano, pois não se trata só do poder da arte produzir vivas comoções no receptor, não iguais, mas análogas às experimentadas pelo artista; tratase também do poder de despertar a reflexão e, assim, virtual ou mediatamente, interferir na própria práxis viva do espectador (ou leitor) de arte enquanto público, no específico contexto cultural e social em que a chamada modernidade se impunha ao Brasil como manifestação histórica decisiva para a modelagem do país, segundo a noção de atualidade civilizacional que se expandia mundo afora.

Em suma, Mário de Andrade desloca a finalidade da arte moderna: do belo para a expressão, do ponto de vista do artista; na perspectiva do público, da expressão para o conhecimento virtual da atualidade, de que a expressão é suporte, ou seja, mediação útil à práxis vital e, portanto, interessada na vida e nos homens. Mário não nega modernidade às experiências de arte pura, mas, exceto a música, considera-as estéreis e prefere uma alternativa que, sem deixar de ser moderna, fosse fecunda. A arte pura se justificaria como legítimo fenômeno da fadiga intelectual no contexto da cultura européia, saturada de civilização, mas não no Brasil, cuja realidade era bem outra.

Mário desenvolvia essas reflexões no momento em que o país, sob a chamada República Velha, era ainda eminentemente rural e dominado por oligarquias representadas nos partidos republicanos regionais (estaduais); um país “arcaico” perante a modernização que sacudia as velhas estruturas econômicas, políticas e sociais. No Brasil, o processo de modernização levou ao esgotamento da República Velha e à rearticulação do poder ensejada pela revolução de outubro de 1930. Esta, por sua dinâmica histórica, redundou na centralização cada vez maior do poder, culminada em 1937 com o Estado Novo. A ditadura de Getúlio Vargas esmerou-se em superar a antiga cultura política regional, substituindo-a por um projeto de caráter nacional, populista, marcado pela acomodação das antigas oligarquias à nova situação - típico processo histórico de modernização conservadora.

Mário entendeu que a atualidade brasileira consistia na modernização do país em choque com o seu "primitivismo”, vocábulo aqui entendido em sentido bem específico, tal como se define numa carta de novembro ou dezembro de 1924, dirigida a Carlos Drummond de Andrade: “enquanto o brasileiro não se abrasileirar, é um selvagem. Os tupis nas suas tabas eram mais civilizados que nós nas nossas casas de Belo Horizonte e S. Paulo. Por uma simples razão: não há Civilização. Há civilizações. Cada uma se orienta conforme as necessida-

\footnotetext{
${ }^{90}$ Idem, passim, p. 29-30.
} 
des e ideais duma raça, dum meio e dum tempo. (...) Nós, imitando ou repetindo a civilização francesa, ou a alemã, somos uns primitivos, porque estamos ainda na fase do mimetismo [grifo meu]. Nossos ideais não podem ser os da França porque as nossas necessidades são inteiramente outras, nosso povo outro, nossa terra outra etc. Nós só seremos civilizados em relação às civilizações o dia em que criarmos o ideal, a orientação brasileira. Então passaremos da fase do mimetismo, pra fase da criação. E então seremos universais, porque nacionais.”"91

Num passo anterior da mesma correspondência, Mário caracteriza o seu peculiar nacionalismo: "não existe essa oposição entre nacionalismo e universalismo. O que há é mau nacionalismo: o Brasil pros brasileiros - ou regionalismo exótico. Nacionalismo quer simplesmente dizer: ser nacional. O que mais simplesmente ainda significa: Ser. Ninguém que seja verdadeiramente, isto é, viva, se relacione com o seu passado, com as suas necessidades imediatas práticas e espirituais, se relacione com o meio e com a terra, com a família etc., ninguém que seja verdadeiramente, deixará de ser nacional."92.

Assim, “desprimitivar o país”, contextualmente, significa libertá-lo do particularismo regional e da mera "macaqueação” estrangeira por meio do "abrasileiramento”: “O dia em que nós formos inteiramente brasileiros e só brasileiros a humanidade estará rica de mais uma raça, rica duma nova combinação de qualidades humanas."93

Para alcançar esse desígnio, segundo Mário formula em outra carta a Drummond, anterior à recém-citada, seria necessário “dar ao Brasil o que ele não tem e que por isso até agora não viveu, nós temos que dar uma alma ao Brasil e para isso todo sacrifício é grandioso, é sublime. E nos dá felicidade.”94 O Brasil não existira ainda como uma nação, por força do insulamento regional que o caracterizara política e culturalmente, até que a modernização então em curso criara as condições históricas de integração nacional do país.

Perante essa possibilidade e preocupado em discernir sua proposta daquilo que seria “mau nacionalismo”, Mário assume que "Ser” é “ser nacional”, ou seja, a identidade individual é definida pela identidade cultural socializada de uma nação, e que esse é o modo de um povo ${ }^{95}$ contribuir para o enriquecimento da humanidade. Orientado por tal "nacionalismo universalista”, rejeita o caminho da arte pura, que talvez lhe desse celebridade futura, e decide fazer de sua obra algo de útil e interessado nas instâncias momentâneas da vida, o que para o

\footnotetext{
${ }^{91}$ ANDRADE, Carlos Drummond de (org.). Op. cit., p. 15-16. Também em Frota, Lélia Coelho (org.). Op. cit., p. 70-71.

${ }^{92}$ Idem, p. 14-15. Idem, p. 70. Grifo do autor.

${ }^{93}$ Idem, p. 15. Idem, ibidem.

${ }^{94}$ Idem, p. 5. Idem, p. 51. Carta de 10/11/1924.

${ }^{95}$ Alternativamente, Mário talvez dissesse "uma raça”, mas a noção andradiana de raça é muito mais cultural do que biológica.
} 
autor de Macunaíma significou a opção por uma prática artística utilitária, engajada no trabalho interessado em “desprimitivar o país”, naquele sentido bem específico de retirá-lo da condição de simples reprodutor ou imitador de modelos estranhos e indiferentes às peculiaridades nacionais, alienadas no dinamismo do processo histórico de modernização. "Desprimitivar”, nesse contexto, significa “dar uma alma ao Brasil”, isto é, por meio do resgate crítico dos valores populares dispersos pelo país, contribuir para a construção da cultura nacional - orientação original, nova síntese enriquecedora da humanidade. ${ }^{96}$

Mário de Andrade viu no esforço de contribuir para “dar uma alma ao Brasil” uma espécie de sacrifício de si e de sua obra. De si, na medida em que converteria o individualismo personalista de uma voz individual, que aspirasse à “eternidade entre os homens da Terra”, em despersonalização socializante, propensa à realização de um ideal talvez longínquo, porém construído na práxis cotidiana, não como idealização sobreposta à realidade brasileira, mas como conhecimento crítico da mesma realidade, ajustado a ela e orientado para a sua definição como "entidade nacional”" ço implicava assumir o caráter transitório da literatura de circunstância, ou seja, criticamente afinada com a atualidade brasileira. Sacrifício, portanto, da própria obra, pois o valor estético é contaminado pelo interesse socializante, por sua vez orientado ideologicamente pelo nacionalismo crítico.

A conviç̧ão de que ao Brasil ainda incaracterístico como nação interessava a sua definição como tal e a decisão de trabalhar em prol desse interesse conduziu ao estudo do país. Para Mário de Andrade, tratava-se de colaborar com sua arte para a construção da identidade ou “entidade nacional” - expressão usada pelo autor nos prefácios “inéditos” de Macunaíma. Contudo, Mário entendera essa abstração, a despeito de seu fundamento metafísico, como categoria histórica, fundamentada no efetivo conhecimento da realidade viva, bem como na compreensão de seus traços culturais peculiares e na afirmação crítica de seus valores originais, mas universalmente válidos.

Como vimos no primeiro capítulo deste estudo, desde a época do "Prefácio interessantíssimo”, Mário de Andrade já asseverava ser o primitivismo o modo adequado e pertinente à expressão artística da modernidade; nos anos seguintes, acentua-se essa convicção, agora orientada energicamente pelo nacionalismo crítico com que o projeto estético se decide pela lite-

\footnotetext{
${ }^{96}$ Mário, comumente, confunde os conceitos de civilização e cultura, tomando um pelo outro e vice-versa.

${ }^{97}$ Andrade, Carlos Drummond de (org.). Op. cit., p. 6. FrotA, Lélia Coelho (org.). Op. cit., p. 51. Carta de 10 de novembro de 1924.

98 Expressão usada por Mário nos prefácios “inéditos” de Macunaíma.
} 
ratura de circunstância. Portanto, o primitivismo artístico seria a tática para alcançar o objetivo cultural estratégico, de caráter ideológico: “desprimitivar o país”.

Não há contradição nisso, pois “desprimitivar” significa, como vimos, superar o regionalismo fragmentador e o mero mimetismo da modernidade européia; significa criar a "orientação brasileira” por meio da síntese nacional de características culturais múltiplas, ainda dispersas, fragmentadas, contraditórias e indefinidas; significa, enfim, dar unidade, sentido e direção à experiência histórica, geográfica e cultural compreendida no processo de modernização então em curso no país. Nesse sentido, “desprimitivar” não se opõe ao primitivismo, tal como o entendeu Mário de Andrade. Lembre-se que, para ele, o índio na taba é civilizado, mas o brasileiro em suas cidades não o seria, pois o primeiro participa de uma identidade cultural tradicionalizada e viva enquanto o segundo carecia exatamente de identidade nacional. Lembre-se também da noção andradiana de primitivismo, estudada no primeiro capítulo deste trabalho, que não pode ser confundida com qualquer hipótese regressiva desde que Mário deixara bem claro que se tratava de ser, como artista moderno, primitivo "duma era nova"99.

Nesse sentido, tratava-se de restabelecer certa função prática da arte, de modo análogo ao que é típico de culturas ditas arcaicas, em que a arte, assim como as demais manifestações do espírito humano, é partícipe das instâncias da vida. O restabelecimento do vínculo entre arte e vida, porém, não se daria de acordo com o pensamento mágico das sociedades ditas primitivas, mas com o pensamento crítico, perquiridor consciente das exigências da sociedade, tal como essa se configurava no entrechoque da modernização com o substrato cultural do Brasil, onde remanescia muito de pensamento mítico e de experiência social, digamos, arcaica, em cujo âmbito a civilização tecnológica se sobrepunha como alteridade problemática.

Essa noção andradiana de primitivismo, procedimento fundamental do nacionalismo crítico, implica, portanto, estudo e conhecimento profundo da realidade brasileira historicamente configurada e expressa em suas múltiplas manifestações culturais, sobretudo as populares, bem como a consciência de seus problemas peculiares, para que a arte pudesse sintetizálos e, assim, se oferecesse como suporte ficcional útil à socialização daquele conhecimento e dessa consciência, de modo a contribuir, virtualmente, para o enriquecimento da humanidade por meio da “orientação brasileira”, ideal a construir e que, uma vez conquistado, libertaria o Brasil daquele primitivismo meramente mimético, empecilho à caracterização identitária, em prol do primitivismo criativo e atual (“de uma era nova”), favorável a essa mesma caracteri-

\footnotetext{
99 “Somos na realidade os primitivos duma era nova.” ANDRADE, Mário de. "Prefácio interessantíssimo”. Ed. cit., 1993, p. 74.
} 
zação. Importante frisar que não se trata de opor nacional e universal, nem arcaico e moderno, como aporias, mas como processo dialético cuja síntese crítica é artisticamente transfigurada sob a perspectiva de uma ideal “orientação brasileira” que não fosse apriorística, mas decorrente da realidade do país apreendida por intermédio de aturado estudo e reflexão. É nessa perspectiva que se configuram as noções de sacrifício e de literatura de circunstância, associadas ao experimentalismo artístico, nas cogitações estéticas de Mário de Andrade no período culminado com a composição e publicação de Macunaíma.

Conforme ressaltou Telê Porto Ancona Lopez ${ }^{100}$, desde 1924, Mário já associara primitivismo com a noção de obra de circunstância, marcada pela transitoriedade, então entendida como “divulgação da temática nacional” e suporte formal dessa temática, isto é, como linguagem experimental estilizadora da língua praticada no Brasil, que revelasse as constantes psicológicas do povo brasileiro; sistematização artística culta da oralidade, colhida nas manifestações da cultura popular e assimilada não como exemplo de exotismo ou de estupidez: "Não estou pitorescando o meu estilo nem muito menos colecionando exemplos de estupidez. O povo não é estúpido quando diz 'vou na escola’, 'me deixe’, 'carneirada’, 'mapear', ‘besta ruana’, ‘farra', 'vagão’, ‘futebol’. É antes inteligentíssimo nessa aparente ignorância porque sofrendo as influências da terra, do clima, das ligações e contatos com outras raças, das necessidades do momento e de adaptação, e da pronúncia, do caráter, da psicologia racial modifica aos poucos uma língua que já não lhe serve de expressão porque não expressa ou sofre essas influências e a transformará afinal numa outra língua que se adapta a essas influências. Então os escrevedores estilizam esse novo vulgar, descobrem-lhe as leis embrionárias e a língua literária, única que tem reconhecimento universal (aqui sinônimo de culto) aparece. Nessa estrada me meti. Sei que tudo está por fazer.”101

Em suma, o caráter experimental e de circunstância ao qual Mário converte consciente e energicamente sua obra literária, desde os idos de 1924 até 1931, conforme precisamente assinala Telê Porto Ancona Lopez ${ }^{102}$, associa-se à noção de primitivismo que, por sua vez, evoluíra desde a formulação contida no "Prefácio interessantíssimo" até circunscrever-se no âmbito ideológico do nacionalismo crítico, devotado à realização do ideal identitário. Mário se refere a tal projeto em que se engajara como se fora sacrifício, uma vez que o caráter especifica e exclusivamente estético da obra de arte, que, no limite teórico, consubstanciar-se-ia na

\footnotetext{
${ }^{100}$ Ramais e caminho. Ed. cit., p. 234.

${ }^{101}$ AnDrade, Carlos Drummond de (org.). Op. cit., p. 23-24. Também em FrOTA, Lélia Coelho (org.). Op. cit., p. 100-101. Carta a Carlos Drummond de Andrade: 18/02/1925.

${ }^{102}$ Ramais e caminho. Ed. cit., p. 234-237.
} 
noção moderna de arte pura, é rejeitado porque alienante, apesar de artisticamente válido. O sacrifício, portanto, significa a opção pela arte de compromisso ético-estético, participante na vida, como a dos “primitivos” de todas as épocas.

Agora, as reflexões teóricas de Mário de Andrade, mesmo nos momentos em que mais agudo se mostra o sentimento de contradição entre liberdade artística e função utilitária (social) da arte, jamais admitiram que essa fosse subsumida em qualquer esfera extra-artística social, política, religiosa, filosófica ou de quê mais -, pois deixaria de ser arte. Sem crítica e sem elaboração artística (forma) do material extraliterário não haveria arte de circunstância, “voltada para as necessidades do momento como contribuição social e estética”"103, mas uma pseudo-arte, ou obra "social de circunstância, circunstancial, pregação política sem objetivos artísticos” ${ }^{104}$, conforme agudamente discerniu Telê Ancona Lopez. Em um artigo de 1930, sobre o romance $O$ Quinze, de Rachel de Queiroz, Mário deixara claro, ainda segundo Telê, que a “adequação da eficácia estética à eficácia social da criação” deveria ocorrer sem permitir a dominação da primeira pela segunda; a práxis construtiva da arte, porém, não se orientaria no sentido da obtenção de efeito catártico, mas de "distanciamento, num sentido quase brechtiano”, que, em vez de entusiasmo, despertaria “no público o enfoque crítico”"105.

Ao escopo desta investigação da primeira onda da fortuna crítica de Macunaíma, pouco importa Mário não haja chegado, em algum momento de sua reflexão estética, a uma síntese teórica satisfatória que superasse a contradição arte pura e obra de circunstância - questão, aliás, esquadrinhada suficientemente por Telê Ancona Lopez, em Ramais e caminho, e João Luiz Lafetá, em 1930: A crítica e o modernismo ${ }^{106}$; basta a configuração do projeto estético que incorpora a elaboração ideológica do nacionalismo crítico, tal como Mário vivenciara dramaticamente a relação entre as duas esferas que este já longo excurso se esforçou para caracterizar: pólos de uma dialética problemática a realizar, por meio da linguagem experimental, do primitivismo e da literatura de circunstância, a conexão entre arte e vida e, assim, contribuir para a construção crítica da brasilidade, concebida como orientação de espírito original (nacional), enriquecedora da humanidade e, portanto, universalmente válida.

\footnotetext{
103 Idem, p. 240.

${ }^{104}$ Idem.

${ }^{105}$ Idem, passim, p. 240-241. Serve de suporte a essa certeira observação de Telê a análise crítica do artigo "Rachel de Queiroz”, de Mário de Andrade, publicado no Diário Nacional: São Paulo, 14 de setembro de 1930. Recolhido em Andrade, Mário de. Taxi e crônicas no Diário Nacional. Estabelecimento de texto, introdução e notas de Telê Porto Ancona Lopez. São Paulo: Duas Cidades/Secretaria de Cultura, Ciência e Tecnologia, 1976, p. 251-252.

${ }^{106}$ Op. cit., especialmente o capítulo “Ética e poética”, p. 187-224.
} 
Vimos qual o sentido preciso das noções andradianas de primitivismo e obra de circunstância e o quanto elas explicitam de consciência histórica, social, ética e estética; vimos também que as mesmas noções implicam estudo largo e profundo da realidade brasileira, sobretudo expressa nas manifestações da cultura popular; vimos ainda que o sentimento de sacrifício não pode jamais ser entendido, propriamente, como renúncia à arte, mas à "arte pura” ou totalmente desinteressada das instâncias da vida, posto que individualista e alienante. Tal renúncia redunda em sacrifício da perenidade, compreendida como valor supostamente possível pela realização de ao menos uma obra-prima, ou seja, aquela capaz de construir o belo artístico unicamente com seus elementos intrínsecos. Tal sacrifício implica a inserção da arte na atualidade histórica brasileira então contemporânea, considerada em seu devir, em favor da “adequação da eficácia estética à eficácia social da criação artística”, ressaltada por Telê Ancona Lopez, sem que o caráter socializante pudesse sobrepor-se ao artístico. Deriva daí o experimentalismo artístico assumido e a consciência de que, nessa linha, poderia errar e erraria muito. Agora, Mário concebe o erro não só como inevitável no processo, mas, sob a perspectiva do pragmatismo ético-estético, até mesmo como algo que pode ser voluntariamente acolhido no artefazer comprometido com as necessidades históricas (sobretudo sociais e culturais) do país, deduzidas de premissas documentadas e criticamente analisadas. Entenda-se bem: deduzidas e não preconcebidas, pois não se tratava de construir um ideal abstrato, por mais belo que fosse, e impô-lo à realidade brasileira, mas de acurada observação e aturado estudo dessa realidade viva, profusamente documentada, para daí formular, por meio do pensamento crítico e da práxis criadora, uma síntese interpretativa materialmente manifesta em obra de arte de interesse público, obra de circunstância que sacrifica as aspirações estéticas desinteressadas do que fosse extrínseco à arte ao trazer a vida para o seu interior, embora esteticamente reelaborada. Ressalte-se a justa observação de João Luiz Lafetá: “O engajamento, entretanto, ficava subordinado à literatura e devia dar-se dentro dela... ou então totalmente fora, nas obras de erudição e de estudo.”107

Se Mário de Andrade não resolveu satisfatoriamente a questão da legitimidade da transposição de elementos extrínsecos para o interior da obra de arte, se ele não percebeu, do ponto de vista teórico, como disse Antonio Candido em outro contexto, "que o externo [no caso, o social] importa, não como causa, nem como significado, mas como elemento que de-

\footnotetext{
${ }^{107}$ LAFETÁ, João Luiz. Op. cit., p. 219-220.
} 
sempenha um certo papel na constituição da estrutura, tornando-se, portanto, interno”"108, as investigações de Telê Ancona Lopez e de João Luiz Lafetá demonstram que faltou pouco para isso. Na composição da rapsódia, porém, ou de qualquer outra obra literária, Mário converteu de fato os elementos extraliterários em fatores estéticos, tornados, portanto, intrínsecos e atuantes "na constituição do que há de essencial na obra enquanto obra de arte”109.

Com esse excurso sobre o pensamento estético de Mário de Andrade, chegamos enfim ao ponto em que é possível explicitar claramente a diferença fundamental entre o projeto artístico e a correspondente ideologia nacionalista desse autor e os mesmos de Graça Aranha.

Após progressivo afastamento, Mário enfim rompera com o autor de Canaã mediante a “Carta aberta a Graça Aranha” (A Manhã: RJ, 12 de janeiro de 1926). Esse documento sintetiza e torna públicas as críticas confidenciadas na correspondência pessoal. Aliás, uma anterior manifestação pública de discordância deu-se em entrevista concedida a Viriato Correa para o jornal carioca A Noite, em 12 de dezembro de 1925 - estopim dos acontecimentos que levaram à produção da “Carta aberta...”. A matéria em que a entrevista se insere - “Assim falou / O Papa do Futurismo / COMO MÁRIO DE ANDRADE DEFINE A ESCOLA QUE

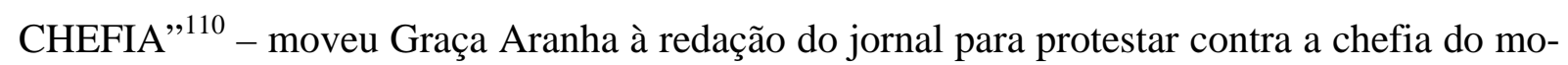
dernismo atribuída a Mário de Andrade, “porque a ‘chefia era dele [Graça Aranha]”"111. Mário tomara conhecimento do episódio por intermédio de Viriato Correia, conforme confidenciou a Carlos Drummond de Andrade na missiva em que informava haver-se “decidido a esculhambar o Graça”112.

Na “Carta aberta...”, Mário enumera as razões pelas quais os modernistas de todo o país, com raras exceções, ter-se-iam afastado do autor de "O espírito moderno”. O episódio ocorrido na redação de $A$ Noite é mencionado como exemplo do "erro de vaidade" em que Graça Aranha incorreria. Na pretensão de chefiar o movimento modernista, em vez de exercer a função de orientador, “sujeito de idéias largas, observando a época e condescendendo com o Modernismo tal como ela e ele são, espécie de Gourmont do Brasil, você [Graça Aranha] pela preocupação excessiva de si mesmo, pela estreiteza crítica a que essa preocupação o levou,

\footnotetext{
${ }^{108}$ CANDIDO, Antonio. “Crítica e sociologia”. In: Literatura e sociedade. $3^{3}$ ed. revista. Companhia Editora Nacional: São Paulo, 1973, p. 4. Grifos do autor.

${ }^{109}$ Idem, p. 5.

${ }^{110}$ Matéria reproduzida em: KoIfMAN, Georgina (org.). Cartas de Mário de Andrade a Prudente de Moraes, neto. Ed. cit., p. 145-150.

${ }^{111}$ Carta de Mário a Drummond, de 22 de dezembro de 1925, em: ANDRADE, Carlos Drummond de (org.). Op. cit., p. 62. Também recolhida em: FrOTA, Lélia Coelho (org.). Op. cit., p. 170.

${ }^{112}$ Idem. Idem, p. 171.
} 
está hoje sobrando em nosso despeito apenas como dogmático irritante, passador de pitos inda por cima indiscretos, e um modernista adaptado.”

Na observação crítica de Mário, obras como Malasarte (1911) ou a Estética da vida (1921) provariam a ignorância de Graça Aranha quanto ao modernismo, no período anterior à adesão do autor de Canaã ao movimento culminado na Semana de 22. Segundo Mário, após conviver com o jovens modernistas brasileiros, o escritor maranhense modificara suas concepções estéticas, sem jamais compreender de fato as correntes variadas, dispersas e até mesmo opostas, mas afinadas artisticamente com a atualidade, desenvolvidas no âmbito do modernismo.

Mário de Andrade distingue o ensaio “O espírito moderno” (1924) como evidência, quer do esforço de atualização das concepções artísticas de Graça Aranha, quer do fracasso dessa tentativa. O escrito polêmico, com que o pretenso líder do modernismo brasileiro marcara sua ruptura com a Academia Brasileira de Letras, documentaria, por exemplo, a incompreensão do cubismo. Em “O espírito moderno”, Graça Aranha julgara o cubismo a “mais intensa afirmação do subjetivismo, a oposição mais viva e mais profunda ao objetivismo dinâmico”"113; na "Carta aberta...”, Mário subentende esse juízo e o contraria ao afirmar ser o cubismo a justa realização do “objetivismo dinâmico na sua representação plástica mais integral”. Essa observação soa como escarninha acusação de equívoco, pois Graça Aranha considerara exatamente o “objetivismo dinâmico” como método criativo congenial ao "espírito moderno”, isto é, como procedimento artístico adequado à atualidade e à estratégia de ação, chamada de “dinamismo construtor”, devotada à construção da cultura e da identidade brasileira segundo a peculiar interpretação graciana da realidade, analisada na segunda seção deste capítulo.

Como vimos naquele passo, trata-se de uma interpretação fundamentada em pressupostos idealistas, no sentido de se apresentarem como puras idéias, puras abstrações, conforme admitiu o próprio autor em “O espírito moderno”. Liberto do “terror cósmico” decorrente da submissão à “natureza”, o “espírito brasileiro”, assimilando o “espírito moderno”, processaria a integração do “eu” no “Todo universal” para criar livre e alegremente a arte, a cultura e a civilização brasileiras, sem imitar formas e modelos do "Passado", como o supostamente dissoluto espírito romântico de procedência européia, bem como qualquer tradição histórica, política, social ou artística (essa associada ao academismo) local, uma vez que essa tradição seria inautêntica, desnaturada (desnacionalizadora) ou desprovida de valor. O espírito moder-

\footnotetext{
${ }^{113}$ TELES, Gilberto Mendonça (org.). Op. cit., p. 192.
} 
no brasileiro deveria, sobretudo, evitar a "incultura" do primitivismo, uma vez que "ser brasileiro não é ser selvagem, ser humilde, escravo do terror, balbuciar uma linguagem imbecil, rebuscar os motivos da poesia e da literatura unicamente numa pretendida ingenuidade popular, turvada pelas influências e deformações da tradição européia. Ser brasileiro é ver tudo, sentir tudo como brasileiro, seja a nossa vida, seja a civilização estrangeira, seja o presente, seja o passado. É no espírito que está a manumissão nacional, o espírito que pela cultura vence a natureza, a nossa metafísica, a nossa inteligência e nos transfigura em uma força criadora, livre e construtora da nação."

Na “Carta aberta...”, Mário denuncia a incompreensão do cubismo como prova do “desacordo enorme entre o nosso tempo e a sensibilidade” de Graça Aranha; outra prova disso seria a incompreensão “da essência primitivística de nossa época”, pois o autor de “O espírito moderno” desvirtuara a noção de primitivismo ao considerá-la apologia da regressão à selvageria e à “incultura”. Contudo, o maior erro de Graça Aranha, segundo o mesmo documento, não fora o de "se apresentar como moderno", mas o de se acreditar filósofo quando, em vez de filosofia, praticaria uma espécie de "filosofismo por demais lírico e alaridal que vem sendo a tiririca do pensamento brasileiro.” Tal prática redundara numa mistura confusa de idéias alheias, uma generalização afobada que se pretendia impor como orientação "representativa do Modernismo brasileiro” quando, na realidade, não poderia representar, nem a rica multiplicidade do movimento, nem o “brasileirismo”, pois a teorização de Graça Aranha “não sintetiza ou analisa ou procura discriminar os caracteres específicos do brasileiro e do Brasil, em vez cria e prega no seu idealismo incurável um brasileiro com Errata no rabo, talvez mais bonito não discuto, mais ideal porém, integrado no Cosmos e vivendo em perpétua Alegria. Quer impor a uma raça existente uma psicologia nova como si fosse possível a um homem criar ou apenas modificar com idéias a essência psicológica dum povo mesmo inda em formação ver o da gente. Não nego em você [Graça Aranha] o brasileirista. Pela ausência total de realidade mesmo sintética no ideal brasileiro que preconiza (e que poderia ser turco ou chim) nego que você [Graça Aranha] possa ser o tipo representativo do Brasileirismo.”

Ao estudarmos aspectos fundamentais do pensamento estético de Mário de Andrade, pudemos observar que, desde que fosse resultante de pesquisa, estudo, análise e síntese críticas da realidade, um “ideal” poderia ser orientação válida para a construção da autêntica cultura brasileira, cuja particularidade contribuiria de modo original para o enriquecimento da humanidade. Assim, o nacionalismo crítico, associado ao primitivismo entendido no sentido

\footnotetext{
${ }^{114}$ Idem, p. 199-200.
} 
andradiano, tática fundamental da estratégia universalista do projeto artístico e ideológico de Mário de Andrade, opõe-se ao nacionalismo de Graça Aranha não por esse ser “idealista”, posto que aquele, de certo modo, também era, mas porque o ensaio "O Espírito Moderno (...) em vez de ser, como devia pelo título e pela função, uma demonstração sintética das tendências mais gerais do espírito moderno que não pertence a você [Graça Aranha] porém ao mundo, é trabalho dogmático pregação de teorias pessoais que só tiveram eco fraco na obra de dois outros. Em vez de exposição crítica é litúrgica deficiente e tendenciosa porque toma por ponto de partida e de referência de juízo o Integralismo cósmico e o tal do Objetivismo dinâmico (...)"115. Em suma, a diferença fundamental entre os dois projetos consiste na natureza do idealismo de um e do outro. Ao ideal abstrato, síntese apriorística e subjetiva de Graça Aranha, contrapõe-se o ideal objetivo de Mário, síntese decorrente de análise e interpretação de tradições e valores historicamente contextualizados na documentação das mais diversas manifestações culturais do povo brasileiro.

Graça Aranha despreza a tradição e a cultura popular, nega qualquer valor às contribuições indígenas ou africanas e constrói um ideal anistórico por meio de noções metafísicas afastadas da realidade, como os conceitos de "terror cósmico”, em oposição ao de "alegria”, e de integração do "eu” no "todo universal”, em oposição ao de "individualismo", este supostamente resultante da submissão do "eu” à "natureza”.

Como bem identificou Mário de Andrade na "Carta aberta...”, o autor de “O espírito moderno" produzira um discurso ficcional mascarado em filosófico ("filosofismo por demais lírico e alaridal”) ao qual a realidade deveria se ajustar de modo procustiano. Com outras palavras, Mário reconhecera no discurso de Graça Aranha o caráter de ideologia abstrata, equivocada e dogmática, à qual é implícita a ilusão de, vale repetir, "modificar com idéias a essência psicológica dum povo mesmo inda em formação ver o da gente.”

Não haveria como essa ideologia convir à construção de uma legítima orientação para o país, para a sociedade e para a cultura nacional, posto que absolutamente desligada da realidade. Na perspectiva de Mário de Andrade, qualquer idealização, fosse teórica ou artística, haveria de se fundamentar nessa realidade observada nas mais diversas manifestações espirituais do Brasil, sobretudo da cultura popular, e investigada como processo histórico em que passado e presente dialogassem, no contexto da atualidade submetida à dinâmica da modernização que se expandia mundialmente desde os pólos de irradiação situados na Europa e nos Estados Unidos da América.

\footnotetext{
${ }^{115}$ ANDRADE, Mário de. “Carta aberta a Graça Aranha”. Op. cit.
} 
Por meio do nacionalismo crítico, associado ao primitivismo, haveria de ser construída a síntese desse diálogo, válida como orientação espiritual brasileira que enriquecesse a humanidade. Isso é dito publicamente por Mário de Andrade, desde ao menos 1925, em escritos como a carta a Joaquim Inojosa, reproduzida pelo Jornal do Commercio [Recife, PE] em 28 de dezembro desse ano. Nesse documento, Mário formula a sua concepção de nacionalismo universalista: “o Brasil pra ser civilizado artisticamente, entrar no concerto das nações que hoje em dia dirigem a Civilização da Terra, tem de concorrer para esse concerto com a sua parte pessoal, com o que o singulariza e individualiza, parte essa única que poderá enriquecer e alargar a Civilização.”116 A noção andradiana de primitivismo “de uma era nova”, como já vimos, explicita-se em A escrava que não é Isaura, poética modernista publicada no mesmo ano de 1925.

Em uma carta ao amigo Manuel Bandeira, de 26 de julho de 1925, Mário comenta o poema Raça, de Guilherme de Almeida, considerando-o equivocado quanto à imagem da realidade brasileira nele contida. Nesse comentário, Mário explicita o critério crítico de seu nacionalismo e a solução que encontrara para que esse fosse de fato representativo da realidade brasileira, no contexto de sua dinâmica e de sua atualidade histórica: “Ainda a respeito da Raça, eu tenho uma séria contradição a fazer pro poema do Gui [Guilherme de Almeida] sobre cuja admirabilidade já estamos entendidos é que quando ele chega no tronco da cruz, nós, os brasileiros, a evocação é muito convencional e passadista. Passadista no sentido de brasileiro que já passou. Esqueceu a realidade brasileira atual e evocou uma realidade brasileira em que a atual civilização e tendência civilizadoras das grandes cidades Rio, Recife, Belo Horizonte etc. e todo o Estado de São Paulo inteiramente automobilizado e eletrificado, não entram. A parte brasileira do poema, sob o ponto de vista ideal crítico de realidade brasileira [grifo meu] não corresponde à verdade, porém a uma convenção que se vai tornando exótica dentro do Brasil e que é regional, não duma só região, porém de regiões que não representam a realidade com que o Brasil concorre pra atual civilização universal. Porque essa concorrência se realiza com a parte progressista dum país, com o que nele é útil pra civilização e não com o que nele é exótico. Que não pode ser desprezado por nós, porém que é lícito à atualidade universal ignorar como parte representativa. Uma hábil mistura dessas duas realidades é a

\footnotetext{
${ }^{116}$ InOJOSA, Joaquim. O movimento modernista em Pernambuco. Rio de Janeiro, Ed. Guanabara, s.d., v. 2, p. 340. Apud MoraEs, Marcos Antonio de (org.). Op. cit., nota 79, p. 219.
} 
solução que pode realmente concretizar uma realidade brasileira que se possa dizer 'em marcha' [grifo meu]."117

Mário previra alguma reação ao ataque a Graça Aranha, que a “Carta aberta...” termina por chamar de “o maior blefe do Modernismo”. A previsão se confirma com o artigo "Modernismo e Modernistas / A Mário de Andrade”, de Teixeira Soares, publicado pelo jornal carioca $O$ Globo, edição de 25 de janeiro de 1926. Como resposta à crítica de Mário, Soares se esforça para assegurar a Graça Aranha a condição de pioneiro do modernismo nacional, escritor legitimamente brasileiro e pensador esclarecido para quem não haveria "uma idéia literária, social ou filosófica no mundo brasileiro em que (...) não tenha tocado”"118.

Teixeira Soares reconhece a “questão do 'brasileiro'” como centro da polêmica de Mário contra Graça Aranha e, identificando-se com esse na mesma incompreensão do primitivismo, entende essa noção de modo distorcido, pois a supõe emblemática de "um brasileiro primitivo, resignado, índio-preto”, que conduziria a "uma arte hu-hu-hu primata” quando seria preferível "uma arte brasileira e moderna, que seja um espetáculo alegre e colorido, onde existam banjos e tímpanos, palhaços e dançarinos, [trecho ilegível no documento] e corretores de Bolsa."119

No artigo “Meu despacho com Graça Aranha”, Mário de Andrade dá resposta a cada uma das objeções de Teixeira Soares, denuncia-as como desleal deformação do que dissera na “Carta aberta...” e reitera com fatos e argumentos as críticas expedidas nesse texto: “Afirmei que o brasileiro tipo 'Sejamos!' de Graça Aranha é um ideal sem essência psicológica nacional e tanto podia ser turco ou chim. Você [Teixeira Soares] imagina me contradizer falando que o brasileiro de Graça Aranha é o 'brasileiro sem anemia verminótica, brasileiro com escola pública e hospital, sanguíneo, musculoso, múltiplo e moderno.’ (...) Também nunca deixei de desejar essas coisas boas pra gente, apenas tento um brasileirismo tão essencialmente brasileiro que enriqueça a manifestação múltipla da humanidade com sua psicologia específica. (...) Quanto ao resto de sua frase: ‘e não o brasileiro primitivo, resignado, índio-preto’ e à ‘ar-

\footnotetext{
${ }^{117}$ BANDEIRA, Manuel (org.). Op. cit., p. 105-110. Também em MoRAEs, Marcos Antonio de (org.). Op. cit., p. 221.

${ }^{118}$ SOARES, Teixeira. "Modernismo e Modernistas / A Mário de Andrade”. O Globo: Rio de Janeiro, 25 de janeiro de 1926. Apud KoIfMAN, Georgina (org.) Op. cit., p. 240-244.

${ }^{119}$ Idem.
} 
te primata’ que você parece querer dar pra mim em oposição à boniteza do de vocês, isso não é mentira nem falsificação, é fosquinha (...)”.120

Teixeira Soares considerara as experiências poéticas de Mário de Andrade com a linguagem como "roupagem ao seu primitivismo”, sendo esse entendido como prática regressiva, além de ilegítima: “a gente deve fazer primitivismo com dados primitivos, e não primitivismo com dados modernos”, dissera Soares em sua réplica. Mário rechaça a assertiva como falsificação e demonstra que, quanto às suas experiências com a linguagem popular, não se poderia dissociar o primitivismo “duma era nova” da prática artística dita culta ou erudita, afinada com a atualidade: “Quanto à minha língua, ela pode pelo perfil se parecer com o linguajar caboclo, porém você está na obrigação, si não quiser falsificar, de reparar que não imito por diletantismo os caipiras porém busco estilizar os modismos sintáticos expressionais vocabulares passíveis de gramaticação.”121 Para Mário, vale frisar, trata-se de estilização artística, culta, da linguagem popular brasileira pesquisada, documentada e estudada previamente.

No desfecho de "Meu despacho com Graça Aranha”, Mário enumera algumas das principais críticas já por ele endereçadas publicamente ao autor de “O espírito moderno”, antes mesmo da divulgação da “Carta aberta...”: "Você não citou que eu já naquele tempo [das Crônicas de Malazarte] preferia o pensamento filosófico 'em que as verdades se organizam dos fatos'; que a Alegria de Graça Aranha '[ilegível] desumana'; que chamei de 'falso' como pensamento o tal capítulo [“A Perpétua Dor e a Perpétua Alegria”, de A estética da vida] admirado pelo ‘fluxo lírico’; que ataquei o ‘idealismo’ de Graça; que reconheci o direito da dor ao lado da alegria; que falei que Graça ‘corre a carreira da Ilusão’; que o chamei de ‘escamoteador de realidades’, ‘fogo de artifício’, tudo ataques diretos ou elogios com reverso.”’122

Quase duas décadas após essa polêmica, numa carta a Murilo Miranda (01/08/1943) em que Mário propõe à Revista Acadêmica, de que o destinatário era colaborador, a publicação da “Carta aberta a Graça Aranha” e de "Meu despacho com Graça Aranha” como exemplos de sua atividade como polemista, o signatário justifica tal seleção por considerar ambos os artigos como “muito importantes pra mim e pro Modernismo” ${ }^{\text {"123 }}$. Do ponto de vista deste estudo, esses textos se destacam, sobretudo, como importantes documentos para a investiga-

\footnotetext{
${ }^{120}$ ANDRADE, Mário de. "Meu Despacho com Graça Aranha”. A Manhã: Rio de Janeiro, 03 de fevereiro de 1926. Arquivo IEB-USP, Recortes de MA, Álbum 35. Texto reproduzido parcialmente em nota de Silviano Santiago para carta de Mário a Drummond, de 04 de fevereiro de 1926, em: FrOTA, Lélia Coelho (org.). Op. cit., p. 192-193.

${ }^{121}$ Idem. Idem.

${ }^{122}$ Idem. Grifos do autor.

${ }^{123}$ FERNANDES, Lygia (org.). Op. cit., p. 156.
} 
ção de Macunaíma ${ }^{124}$ em relação ao diálogo estabelecido pela fortuna crítica da rapsódia. Eles permitem supor que Mário, embora haja repelido a imagem de "brasileiro primitivo, resignado, índio-preto” supostamente defendida por ele segundo a caracterização caricata de Teixeira Soares, em Macunaíma, assumiria propositalmente parte do estereótipo para, a partir dele, compor a figura do "herói de nossa gente”, índio-preto da tribo tapanhumas. Também branco, o herói sintetiza a "hábil mistura” de arcaico e moderno para concretizar uma imagem artística da atualidade brasileira “em marcha”, solução teórica formulada naquela carta a Bandeira (26/07/1925), recém-citada, em que Mário comentara o poema Raça, de Guilherme de Almeida.

O diálogo de Mário de Andrade com Graça Aranha evidencia-se nos documentos aqui analisados de modo a configurar a nítida diferença entre os respectivos projetos em busca de uma identidade brasileira. No primeiro capítulo deste estudo, destacou-se a semelhança tópica entre aspectos das propostas nacionalistas de Mário de Andrade e de Gilberto Freyre. Algo análogo ocorre no confronto do projeto de Mário com o de Graça Aranha. O próprio Mário assinalou algumas vezes certas semelhanças que o atormentavam, pois poderiam confundir o seu nacionalismo crítico - ideologia articulada com a realidade histórica e eticamente compromissada - com o nacionalismo pseudometafísico do autor de “O espírito moderno” - ideologia abstrata, anistórica e fictícia (“filosofismo lírico e alaridal”), que a Mário repugnava por considerá-la também imoral. ${ }^{125}$

Em vista das evidências, é legítimo supor que Mário de Andrade transpôs seu diálogo com Graça Aranha, irônica e artisticamente, para o interior da rapsódia, mas de tal modo que o segundo talvez não haja percebido a ironia. Ao menos, é o que se pode depreender da leitura de um documento inédito: uma carta de Graça Aranha a Mário, de 27 de agosto de 1928, quando ambos já se haviam reconciliado - embora o destinatário preservasse as críticas e diferenças assentes na "Carta aberta...” e em “Meu despacho...”-, em que se lê o seguinte cumprimento pela publicação de Macunaíma:

\footnotetext{
${ }^{124}$ Silviano Santiago arrola o artigo "Modernismo e modernistas. A Mário de Andrade", de Teixeira Soares, como documento útil "para o debate sobre a gênese de Macunaíma e a questão do primitivismo." FrotA, Lélia Coelho (org). Op. cit., nota 18, p. 191.

${ }^{125}$ Em carta a Carlos Drummond de Andrade, de 27 de maio de 1925, Mário recusa o "conceito da vida tão imoral (veja bem que tenho a coragem de dizer imoral) da vida que prega o Graça [Aranha].” In: ANDRADE, Carlos Drummond de (org.). Op. cit., p. 37. Também em FrotA, Lélia Coelho (org). Op. cit., p. 128.
} 
23, praça Floriano,

Rio, 27 de agosto de 1928.

Mario de Andrade,

Grande admiração por “Macunaíma”. Admirei-lhe a maravilhosa fantasia, a força da criação, o ímpeto do movimento, o prodigioso dom de mentir, a audácia da magia, o dinamismo dos objetos e dos espíritos, a vida violenta, indiferente, a aplicação feliz das lendas, das expressões, dos cantos, dos fatos, a vastidão interior da poesia, a ligação dos mitos e dos costumes, a fusão das espiritualidades raciais, a fascinação do Amazonas e do Norte.

Por toda esta alegria, que V. me deu, um cordial abraço de

$$
\text { Graça Aranha }{ }^{126}
$$

Sob o impacto da leitura de Macunaíma na primeira hora da rapsódia, Graça Aranha, como leitor arguto, enumera qualidades reconhecidas e confirmadas por boa parte da fortuna crítica publicada no período compreendido entre 1928 e 1936. No entanto, assim como quase todos os críticos que se pronunciaram sobre o livro nesse intervalo de tempo, Graça Aranha distingue somente a máscara risonha da obra, provavelmente por sua leitura ser vincada pelos pressupostos de seu próprio projeto, como se evidencia na passagem em que louva "o dinamismo dos objetos e dos espíritos, a vida violenta, indiferente”, qualidades de fato pertinentes à rapsódia, mas não na perspectiva da teoria graciana, que as deforma pela aplicação de conceitos impertinentes, como o de "objetivismo dinâmico" ou de "dinamismo construtor", que pressupõem a integração do “eu” no "todo universal”, num consciente acordo do primeiro com o perpétuo movimento do segundo.

Para Graça Aranha, como observamos na análise de “O espírito moderno”, a integração cósmica, em vez de provocar o terror que levara à afirmação do individualismo romântico, em que o "eu” se escraviza à natureza ao buscar desligar-se dela, propiciaria a "alegria” inerente ao “espírito moderno”. A consciência da integração no cosmos, libertaria o “eu” que, por meio da cultura, em vez de imitar a natureza, passaria a criar, o que consistiria em impor à natureza o seu próprio dinamismo violento e indiferente. Tais postulados se associam à ideo-

\footnotetext{
${ }^{126}$ Carta de Graça Aranha a Mário de Andrade, 27/08/1928. Arquivo Mário de Andrade. Série: Correspondência de Mário de Andrade. Sub-série: Correspondência passiva. MA-C-CPL, nº 760. IEB-USP.
} 
logia do progresso, por sua vez articulada com o cientificismo europeu oitocentista, para compor a imagem de um "brasileiro sem anemia verminótica, brasileiro com escola pública e hospital, sanguíneo, musculoso, múltiplo e moderno”, para repetir as palavras já citadas de Teixeira Soares, correligionário ideológico de Graça Aranha, cujo ideal é, de fato, contrariado na imagem contida no refrão de Macunaíma: “pouca saúde e muita saúva os males do Brasil são”. No entanto, Graça Aranha se congratula pela “alegria” propiciada pela leitura da rapsódia. Ressalvada a hipótese de ser irônica, tal manifestação pode ser interpretada como índice de uma leitura incapaz de “compreender a significação mais profunda do meu livro, além do simples divertimento de reconto que teve e inda tem a maioria”127, para lembrar as palavras de Mário ao lamentar-se com o amigo Bandeira sobre a incompreensão dos críticos em relação à rapsódia, em 1935, já quase no fim do período até aqui em foco (1928-1936).

Não é despropositado imaginar que haja ocorrido a Graça Aranha, ao ler Macunaíma, algo semelhante ao que Mário aponta como leitura deformada do escritor maranhense em relação ao poema "Danças”"128 : "Graça querendo fazer do brasileiro um tipão alegre por... teoria filosófica e integração no Todo Infinito com uma incompreensão inteirinha do homem brasileiro que ele não observou, contrariando a psicologia natural desse homem, fazendo da alegria um preconceito a ponto de ver alegria nas minhas 'Danças' tão tristes e tão doloridas, qual! não tenho tempo pra ler essas coisas, qualquer livro de regionalista besta dá mais documentos verdadeiros."

Os documentos analisados permitem legitimar a hipótese segundo a qual Macunaíma contém, entre suas múltiplas instâncias de sentido, um certo diálogo com o projeto nacionalista de Graça Aranha, conforme sugerido pelo artigo de Augusto Meyer - "Macunaíma”. Correio de Povo: Porto Alegre, 01 de julho de 1930 -, um dos poucos críticos da fortuna de $M a$ cunaíma, até aqui estudada, a discernir o caráter satírico da obra e o único, dentre esses, a ter convicção de que o riso se converte em lágrimas quando a face risonha é criticamente despida e sob ela se revela a face trágica, reverso irônico da risonha imagem identitária graciana ${ }^{130}$.

\footnotetext{
${ }^{127}$ BAndeIRA, Manuel (org.). Op. cit., p. 349-350. Também em MorAEs, Marcos Antonio de (org.). Op. cit., p. 610. Carta a Manuel Bandeira: 26/01/1935.

${ }^{128}$ Composto em 1924 e incluído no livro Remate de Males, 1930.

129 BAndeIRA, Manuel (org.). Op. cit., p. 74-78. Também em MorAes, Marcos Antonio de (org.). Op. cit., p. 205-206. Carta a Manuel Bandeira: 07/05/1925.

${ }^{130}$ A correspondência de Mário de Andrade dá farto testemunho da radical diferença entre o seu projeto nacionalista e o de Graça Aranha. Cf. Cartas a Manuel Bandeira: 05/08/1923; 10/10/1924; 19/11/1924; 22/11/1924; 18/04/1925; 07/05/1925; 24/06/1925. A Carlos Drummond de Andrade: post. 10/11/1924; 27/05/1925; 23/08/1925; post. 07/12/1925; 22/12/1925; 01/01/1926. A Prudente de Morais, neto: 04/12/1924; 16/12/1924; ?/06/1925; 15/09/1925.
} 


\section{EPÍLOGO}

Na oportunidade da segunda edição de Macunaíma (1937), Brito Broca comenta: "Publicado há cerca de dez anos, quando ainda estavam em foco as polêmicas modernistas, esse livro quase não teve repercussão”. ${ }^{1}$ Na perspectiva sociológica destacada por Silviano Santiago $^{2}$, de fato, a repercussão de Macunaíma, no contexto do precário mercado de bens culturais do final da década de 1920 no Brasil, é modestíssima: oitocentos exemplares para uma população de aproximadamente trinta e cinco milhões de habitantes, majoritariamente iletrada, quando não analfabeta, a circular num período de nove anos (1928-1936). Santiago, então, adverte: “a mera apreciação crítico-descritiva do material jornalístico ou ensaístico sobre um (ou qualquer) livro modernista”3 arrisca-se a deformar a verdadeira dimensão do impacto de obras como Macunaíma, se não considerar o âmbito da específica realidade histórica e, particularmente, cultural do país.

Para evitar esse perigo, é importante lembrar que as condições de produção e de distribuição da edição príncipe de Macunaíma podem ser caracterizadas a traços largos: a tiragem foi custeada e distribuída pelo autor. Estava-se muito aquém das possibilidades geradas pela tardia instalação da indústria cultural no país, consolidada somente a partir do final dos anos 1960. No contexto da implantação da modernidade capitalista, industrial e urbana, Mário de Andrade, assim como a maior parte dos escritores modernistas, patrocinava a edição de suas obras literárias. Não há expectativa de que a literatura seja rentável; os meios de subsistência do autor provêm de outras fontes, como, no caso de Mário de Andrade, o magistério e o jornalismo. Quanto a Macunaíma e outros livros publicados às suas expensas, a correspondência do autor testemunha o desinteresse pecuniário em relação a essas obras. Numa carta a Augusto Meyer (28 de fevereiro de 1932), por exemplo, Mário enfatiza: “Jamais fiz literatura pra ganhar dinheiro. (...) o meu prazer no caso, só é ser lido.”4

Essa mesma carta ao crítico gaúcho explicita o empenho pessoal de Mário na distribuição da obra e, ao mesmo tempo, dá idéia do minguado interesse de livreiros e, portanto, de

\footnotetext{
1 “A epopéia de um herói sem nenhum caráter. A reedição de Macunaíma, de Mário de Andrade”. A Gazeta: São Paulo, 25 de fevereiro de 1937. FCL-CEDOC. Cf.: p. 159-162 do Anexo.

2 "A trajetória de um livro". In: ANDRADE, Mário de. Macunaíma, o herói sem nenhum caráter. Edição crítica de Telê P. A. Lopez (coord.). Ed. cit., 1997, p. 184.

${ }^{3}$ Idem, p. 182.

${ }^{4}$ FernANDES, Lygia (org.). Mário de Andrade escreve cartas a Alceu, Meyer e outros. Ed. cit., p. 100.
} 
leitores em relação à rapsódia: "Resolvi enviar dez exemplares do Macunaíma pra você fazer deles o que quiser. A Livraria do Globo não aceita livros em consignação, e creio que não quer mais Macunaímas. Inda quando foi da publicação do Remate de Males, lembrei a ela si não queria mais alguns exemplares do Macunaíma cuja edição está quasi acabada, não recebi resposta, e siquer acusação dos dois exemplares amostra do Remate enviados, como ela pede.”5 Além de autor e patrocinador, o artista se torna distribuidor da obra, interessado nela não como mercadoria, mas como bem cultural ávido de leitores. Apropriando-nos de noções marxistas, diríamos que o artista estava interessado não no valor de troca, mas no virtual valor de uso espiritual do livro.

Decerto, Mário se encarregou pessoalmente da distribuição de Macunaíma em São Paulo. Em outras cidades, quando não entabulou negociações com livreiros, por meio postal, apelou para a amizade de Augusto Meyer (Porto Alegre), Carlos Drummond de Andrade (Belo Horizonte) e Prudente de Moraes, neto (Rio de Janeiro), entre outros que se incumbiram da exposição e venda em livrarias, bem como da alocação do livro em bibliotecas públicas.

Na ausência de outros registros, a repercussão da obra junto ao público anônimo pode ser medida vagamente pelo que disse Mário na recém-citada carta a Meyer: a tiragem da primeira edição de Macunaíma levara quatro anos para “quasi” se esgotar. Outros cinco transcorreram, portanto, com a obra fora de mercado, até que a editora José Olympio publicasse os mil exemplares da segunda edição (1937). Perante tais números, fica evidente não ser o mercado de bens culturais a instância de legitimação da obra, pois, no período em foco, esse mercado é imponderável.

Somente após a consolidação da indústria cultural no Brasil, desde o fim da década de 1960, o mercado se torna um componente capaz de decidir, ao menos do ponto de vista estritamente mercadológico, o sucesso de uma obra literária, como é o caso do romance $O$ meu pé de laranja lima (1968), de José Mauro de Vasconcelos, que, parafraseando José de Alencar, brilhou por um tempo, pelo sucesso editorial, para depois se apagar, carente de prestígio crítico. Na transição do século XX para o XXI, o fenômeno Paulo Coelho demonstra o inequívoco poder da indústria cultural e do mercado globalizado como instância de legitimação da obra literária e reconhecimento oficial do artista, malgrado a crítica. Esses exemplos são índices notáveis da profissionalização do trabalho artístico, proporcionado pela formação de um mercado para a literatura. Na época em discussão, a profissionalização do escritor como artista era improvável.

\footnotetext{
${ }^{5}$ Idem, p. 99.
} 
O fenômeno de popularização experimentado por Macunaíma em tempo mais recente não deve, portanto, ofuscar um fato: junto ao "grande público” (se assim podemos chamá-lo), nos idos das décadas de 1920 e 1930, a repercussão da rapsódia é quase irrelevante.

A quase ausência de público leitor de literatura, sobretudo a modernista, obriga o artista a cuidar da divulgação do livro junto aos seus pares. Mário remete algumas dezenas de exemplares da rapsódia a intelectuais como Alceu Amoroso Lima, Ascenso Ferreira, João Ribeiro, Jorge de Lima, Luís da Câmara Cascudo, Manuel Bandeira, Pedro Nava e Sérgio Buarque de Holanda, para citar alguns poucos.

No campo da vida intelectual letrada, Mário estabeleceu uma prodigiosa rede de comunicação, dialogando intensamente com seus pares, quer por meio epistolar, quer por intermédio de crítica jornalística, quer, enfim, por sua intervenção direta na produção e na crítica de bens culturais em circulação no país. Os numerosos interlocutores privilegiados de Mário, consignados na vasta correspondência, são, eles mesmos, produtores desses bens e os leitores especialmente almejados para Macunaíma.

A expectativa maior do artista se concentra na recepção de sua obra no espaço público, e também no privado, em que se movia a inteligência brasileira. Antes do lançamento da rapsódia, mesmo temendo incompreensão, como observamos em citada carta a Drummond ${ }^{6}$, Mário de Andrade evidencia o anseio de ressonância crítica. Este desejo se realizou. A crítica não se omitiu, pronunciando-se profusamente. No entanto, o artista sofreu o desgosto de ver confirmada, em grande parte e segundo o seu ponto de vista, a conjecturada incompreensão.

Se a repercussão junto ao público anônimo é desprezível, não se pode subestimar o impacto da obra junto ao público diferenciado, constituído de formadores de opinião, quase todos militantes assíduos no jornalismo dos maiores centros urbanos do país, onde e quando o jornal ocupava a primeira posição como suporte para a circulação de idéias.

Agora, segundo Silviano Santiago, o “meio jornalístico da época [decênios de 1920 e 1930]” padecia de flagrante "pobreza intelectual”’ . Supondo correta essa observação, torna-se mais significativa ainda a primeira onda de recepção crítica a Macunaíma, uma vez que a quantidade documentada de pronunciamentos sobre a edição príncipe da rapsódia sobreleva até mesmo a recebida por muitos lançamentos literários hodiernos, sob o auspício de editoras de peso, em época de pleno vigor da indústria cultural. Das vinte e quatro recepções recebidas

\footnotetext{
${ }^{6}$ ANDRADE, Carlos Drummond de (org.). Op. cit., p. 105. Carta de 20 de fevereiro de 1927. Também recolhida em Frota, Lélia Coelho (org.). Op. cit., p. 278.

${ }^{7}$ SAntiago, Silviano. "A trajetória de um livro”. In: ANDRAde, Mário de. Macunaíma. Ed. crítica de Telê P. A. Lopez. Ed. cit., 1997, p. 187.
} 
entre 1928 e 1936, treze foram publicadas em cinco meses, entre o lançamento do livro, em 26 de julho de 1928, e dezembro desse mesmo ano; outras sete, no espaço de tempo limitado a um ano, desde o lançamento da obra, foram divulgadas em periódicos de cinco estados: São Paulo, Rio de Janeiro, Pernambuco, Paraíba e Rio Grande do Sul. Nesse mesmo período de um ano, surge, ainda, o primeiro ensaio de maior fôlego sobre a rapsódia, no livro Dois ensaios (1929), de Jorge de Lima, publicado em Maceió.

Mais importante que a quantidade e a difusão geográfica, porém, é a qualidade dos pronunciamentos, cujos autores são reconhecidos como representantes dos mais refinados círculos da inteligência nacional, no âmbito histórico em que se circunscreve este estudo.

Evidentemente, a importância da primeira onda da fortuna de Macunaíma deve-se, antes de qualquer outra consideração, ao valor crítico intrínseco aos pronunciamentos. Contudo, não se deve desprezar a reputação dos autores, cuja fama, decerto, deveria atrair um número significativo de leitores para as matérias assinadas por eles.

É importante ressaltar a importância da imprensa como suporte da instância de legitimação da obra no período estudado: exceto o ensaio “Todos cantam sua terra...”, de Jorge de Lima, a divulgação e discussão do livro de Mário de Andrade deu-se por meio de veículos periodistas - resenhas, artigos e ensaios em revistas e, sobretudo, jornais. O corpus estudado evidencia certas características próprias do gênero, ou seja, da crítica literária em jornal: a brevidade, o caráter informativo, a síntese crítica e o juízo de valor fundamentado na opinião, geralmente, polêmica.

O exame da documentação demonstra que ela não pode ser definida como exemplo de crítica impressionista, no sentido atribuído por João Luís Lafetá a autores como João do Rio, Coelho Neto, Graça Aranha, Carlos de Laet e Agripino Grieco, entre outros ${ }^{8}$. No corpus, não há exemplo da linguagem decorativa, de eloqüência fácil, como diz Lafetá, com que a crítica impressionista, perante a obra a comentar, enreda em divagações suscitadas pela sensibilidade diletante. Em vez disso, os textos estudados revelam um viés claramente militante.

A fortuna crítica em causa difere ainda da crítica impressionista na medida em que a opinião expedida não resulta mais do gosto e do livre jogo entre a sensibilidade e a inteligência do receptor (o crítico) - jogo centrado mais no sujeito do que no objeto do discurso. As críticas colecionadas são, nitidamente, voltadas para o seu objeto. Se este não pode ser analisado extensamente, devido às limitações impostas pela mídia, as matérias comumente se apresentam como sínteses sugestivas de uma reflexão maior.

\footnotetext{
8 “O impressionismo e o ecletismo”. In: 1930: a crítica e o modernismo. Ed. cit., 2000, p. 61-67.
} 
Geralmente, os pronunciamentos analisam de modo sumário certos aspectos da obra considerados como fundamentais, de modo que os recortes analíticos suportem razoavelmente os juízos de valor, que variam de acordo com os diversos pressupostos estéticos assumidos pelos críticos.

Em casos como as recepções assinadas por Tristão de Ataíde e Nestor Vítor, as matérias ultrapassam o caráter de crítica literária jornalística, a despeito da mídia, e se apresentam como ensaios curtos que se esforçam para dar suporte aos juízos por meio de argumentos construídos no decorrer da análise estética, impregnada de elementos ideológicos, como insistiremos mais adiante.

Perseguindo uma hipótese de Silviano Santiago, este estudo se esforçou por demonstrar que a primeira onda da fortuna crítica de Macunaíma constitui um diálogo de múltiplas vozes, balizado pela discussão travada entre Tristão de Ataíde e Mário de Andrade, por intermédio da primeira recepção crítica da obra, assinada por Tristão, posto que a primeiríssima (“Macunaíma. O livro de Mário de Andrade”. Diário Nacional: São Paulo, 07 de agosto de 1928) é, mais propriamente, um depoimento do autor, mascarado em crítica anônima.

Mário remetera a Tristão o texto dos dois prefácios esboçados para Macunaíma, informando a decisão de não publicá-los. Em carta, Mário anunciara que enviaria os originais “num manuscrito terrível e a lápis”9 . É possível que isso haja ocorrido, pois o próprio Tristão assinala, na sua recepção à rapsódia, que tinha “em mãos (...) os originais desses dois prefácios”. Nessa hipótese, eles teriam sido devolvidos a Mário, pois esses originais foram conservados por ele em seus arquivos, que integram o acervo do IEB-USP. Outra hipótese: Mário os copiara a mão ou a "Manuela" e os remetera. Neste caso, a suposta cópia dos prefácios seria bem próxima dos manuscritos originais preservados. Ao confrontar as citações contidas no ensaio de Tristão com a transcrição publicada dos prefácios ${ }^{10}$ e com os fac-símiles publicados dos manuscritos ${ }^{11}$, notam-se modificações irrelevantes operadas pelo líder católico, incidindo predominantemente na pontuação, exceto a que substitui o vocábulo “moralizante” por "amoralizante”, numa passagem anotada no corpus ${ }^{12}$. Não há elementos para garantir a veracidade dessa última hipótese, pois não há registro de tal cópia. Consultado, o Instituto Moreira Sales, em Petrópolis (RJ), que conserva o Arquivo Alceu Amoroso Lima, informa por intermédio da

\footnotetext{
${ }^{9}$ FeRnANDES, Lygia (org.). 71 cartas de Mário de Andrade. Ed. cit., p. 32. Carta a Alceu Amoroso Lima, 19 de maio de 1928.

${ }^{10}$ BATISTA, Marta Rossetti, Lopez, Telê Porto Ancona e LiMA, Yone Soares. Brasil: $1^{o}$ tempo modernista 1917/29. São Paulo: IEB-USP, 1972, p. 289-295.

${ }^{11}$ ANDRADE, Mário de. Macunaíma, o herói sem nenhum caráter. Edição crítica de Telê Porto Ancona Lopez (coord.). Ed. cit., 1997.

${ }^{12}$ Cf. nota 20, p. 16 do Anexo.
} 
pesquisadora Maria da Guia que as supostas cópias não se encontram no acervo. Assim, o que se conhece dos prefácios, até a publicação deles em 1972, é a transcrição de fragmentos no corpo da recepção crítica a Macunaíma assinada por Tristão de Ataíde ${ }^{13}$.

Ao contrapor sua análise e interpretação da rapsódia a declarações de Mário, contidas nos prefácios, Tristão, como crítico literário de prestígio no país, socializou seu diálogo com o autor e, com isso, logrou tornar sua matéria o ponto de referência fundamental para o debate sobre a obra não só no período em foco, como pudemos verificar nesta tese, mas, provavelmente, ao longo de toda a primeira fase da recepção crítica a Macunaíma, que se estende até 1954, ano que antecede a primeira edição póstuma de Macunaíma (Martins, 1955) e a publicação do primeiro grande estudo da rapsódia, empreendido por M. Cavalcanti Proença (Roteiro de Macunaíma).

O exame do corpus evidencia que o diálogo Tristão-Mário definiu o repertório crítico verificado em pronunciamentos subseqüentes da primeira onda da fortuna, que se estende até 1936. Os documentos atestam a reiteração dos problemas abordados pelo diálogo inaugural nas demais recepções investigadas: a questão do material, do gênero, do método ou estrutura de composição, do estilo, da língua e da (in)caracterização do protagonista, bem como da possível simbologia da obra e do herói - tudo isso associado ao conceito de nacionalismo, tema nuclear do grande debate em busca de um projeto para o Brasil, em vigor no período investigado: 1928-1936, respectivamente, pródromos da Revolução de Outubro (1930) e da instalação do Estado Novo (1937).

Assim, a fortuna crítica da edição príncipe de Macunaíma, além de contribuir para a compreensão estética da obra, mostra-se como recorte do diálogo em que se manifestam vários dos mais influentes projetos artísticos, culturais e, até mesmo, sociais e políticos para o país, antes da vitória e imposição da via getulista. Nesse sentido, o corpus estudado interessa como repositório de notáveis leituras de Brasil, manifestas no processo de transição da República Velha para o período Vargas, associado à dinâmica da modernização. A documentação contribui para o estudo das ideologias nacionalistas que estavam na base de quase todos os projetos em discussão naquele momento histórico decisivo para o país, pois a análise permite surpreender, de modo nítido, matizes e variantes de influentes correntes nacionalistas então em pauta.

\footnotetext{
${ }^{13}$ No corpus, anotamos as diferenças entre as transcrições de Tristão e os textos publicados em BATISTA, Marta Rossetti, LoPEZ, Telê Porto Ancona e LiMA, Yone Soares. Brasil: $1^{o}$ tempo modernista - 1917/29. São Paulo: IEB-USP, 1972, p. 289-295. O confronto também se fez com os manuscritos dos prefácios por intermédio de fac-símiles publicados em ANDRADE, Mário de. Macunaíma, o herói sem nenhum caráter. Edição crítica de Telê Porto Ancona Lopez (coord.). Ed. cit., 1997.
} 
A discriminação das contribuições individuais de cada crítico, bem como de suas concordâncias e desacordos, evidencia que, a partir do diálogo inaugural, as demais vozes se alinham de acordo com a inclinação judicativa favorável ou desfavorável à inusitada experiência artística de Macunaíma quando de seu advento. Os juízos estéticos antagônicos coincidem com o antagonismo de dois campos ideológicos em que se digladiam os dispersos projetos nacionalistas aqui estudados.

De um lado, entusiastas como Raul Bopp recomendam a leitura do livro, considerado “a maior obra nacional”"14; do lado oposto, embora reconhecendo nela alguns aspectos admiráveis, repudiam a obra os seguidores da linha de Tristão. Vimos como Mário, num primeiro momento, julgou que o crítico católico ficara “em cima do muro”, para depois refletir melhor e convencer-se de que ele fora, de fato, adverso.

Os dois partidos coincidem claramente na abordagem reiterada dos tópicos sumariados atrás, sobre os quais nem sempre divergem. Há uma zona menos nítida em que os opostos se aproximam. Mesmo pronunciamentos francamente desfavoráveis reconhecem, com restrições, qualidades merecedoras de admiração, louvor ou ao menos atenção, em virtude da relevância de uma ou outra questão suscitada pela rapsódia. A mais destruidora das recepções (a de João Ribeiro), que considera o livro “uma asneira”, concede algo ao louvar a "facilidade comunicativa de alegria e desenfado” do estilo e ao destacar a originalidade de Mário perante o material folclórico aproveitado.

Seja como for, a recepção crítica à edição príncipe de Macunaíma, unanimemente, reconhece a importância da obra como paradigma estético do movimento modernista, quer para saudá-la como grande realização artística, verdadeiro divisor de águas no contexto da literatura brasileira, quer para desqualificá-la como obra de arte, em decorrência de inépcia do autor, deficiência da estética ou por suposta contaminação de elementos extra-literários considerados nocivos e contra os quais seria necessário lutar.

João Pacheco, António de Alcântara Machado, Oswald de Andrade, Ronald de Carvalho, Ascenso Ferreira, Augusto Meyer, Oswaldo Costa (Tamandaré), Luís da Câmara Cascudo e Sérgio Buarque de Holanda integram o grupo francamente favorável. Todos são intelectuais ligados ao movimento modernista, alguns deles desde a primeira hora. Mas a documen-

\footnotetext{
${ }^{14}$ MANFREDiNI, Jurandyr. "Et tout finit par des chansons... O epílogo. O papel construtor da antropofagia. Um autógrafo de Crisnamurti. Raul Bopp. O Brasil canibal.” Gazeta do Povo: Curitiba (PR), 02 de setembro de 1928. Arquivo Gazeta do Povo. O que há de mais importante nessa matéria é a transcrição da carta de Raul Bopp, citada por Oswald de Andrade em sua recepção a Macunaíma ("Esquema ao Tristão de Ataíde". Revista de Antropofagia: São Paulo, a. I, no 5, setembro de 1928, p. 3). Exposição de propostas centrais do movimento antropofágico, a carta de Bopp contém breve, embora entusiástica, menção a Macunaíma.
} 
tação revela ásperas divergências no interior do movimento e nítidos sinais de ruptura. Nesse sentido, destacam-se as críticas de Oswaldo Costa, para quem, em 1929, o modernismo seria um fenômeno datado e já encerrado. De fato, nesse ano culmina o processo de fragmentação do movimento que abrigara tendências tão díspares sob a palavra de ordem da revolução estética, ela mesma caracterizada pela dispersão de múltiplas correntes da vanguarda artística internacional.

Em torno de 1930, encerra-se o ciclo propriamente modernista, não só conforme consenso mais recente da crítica e da história literária brasileira, mas de acordo com a consciência das próprias gerações que vivenciaram essa transição histórico-estética. Assinale-se que as observações de Oswaldo Costa não são escoteiras, haja em vista outras postulações, como a de Jorge de Lima, para quem o modernismo gorara, além de se haver esgotado. Mário de Andrade ironiza essa opinião, na crônica “Táxi: Ortografia II”: “Ultimamente desiludidos consigo mesmo os invejosos por não termos produzido uma obra-prima como Dom Segundo Sombra, alguns modernistas (vejam o segundo dos Dois ensaios de Jorge de Lima) deram pra falar mal do movimento. 'Não fizeram nada!' ‘É preciso ser antimoderno!' (Não reparando que isto é se tornar 'up-to-date'). Os benefícios do Modernismo foram enormes e fecundos.”15 Não obstante o elogio ao movimento vanguardista e a convicção de seu caráter seminal, depreende-se do verbo flexionado no pretérito perfeito que, também para Mário, já era possível falar do modernismo no passado.

Os sinais inequívocos de dissolução do modernismo coincidem com o próprio processo de expansão do movimento. Ao mesmo tempo em que se ampliava por diversos quadrantes do país, a partir dos núcleos de São Paulo e do Rio de Janeiro, ele se atomizava em correntes sectárias.

O corpus evidencia a desagregação do modernismo, também, ao dar testemunho da ruptura entre Mário e Oswald, preconizada no ensaio de Tristão de Ataíde e, certamente, estimulada por esse escrito. A discordância de Mário em relação à antropofagia torna-se pública com a “indiscrição necessária” de Tristão e provoca a resposta indignada de Oswald, que não só denuncia e repudia os preconceitos do líder católico como estende, de modo cifrado, o ataque ao "proprietário” de Macunaíma ao justificar a "posse” ou apropriação antropofágica da rapsódia, atitude imitada por Oswaldo Costa (Tamandaré), como vimos no Capítulo I. A segunda crítica de António de Alcântara Machado (“O modernismo da literatura de 1928”. A

\footnotetext{
${ }^{15}$ Andrade, Mário de. Táxi e crônicas no Diário Nacional. Estabelecimento de texto, introdução e notas de Telê Porto Ancona Lopez. São Paulo: Duas Cidades / Secretaria da Cultura, Ciência e Tecnologia, 1976, p. 167168. Crônica publicada em 08 de dezembro de 1929.
} 
União: [Paraíba, PB], 31 de janeiro de 1929) espicaça o grupo antropófago ao solidarizar-se com Mário, a quem atribui o provocativo epíteto de “Miramar do Modernismo”.

O pronunciamento de Ronald de Carvalho, por sua vez, deixa entrever a corrente capitaneada por Graça Aranha, cujas idéias servem de filtro ideológico para a apreciação da rapsódia pelo poeta de Toda a América. Vimos como Augusto Meyer (“Macunaíma”. Correio de Povo: Porto Alegre, 01 de julho de 1930) sugeriu haver em Macunaíma a contraposição entre o nacionalismo abstrato de Graça Aranha e o nacionalismo crítico de Mário de Andrade. Perseguindo a sugestão de Meyer, a reconstituição do processo que culminou na ruptura evidenciada na "Carta aberta a Graça Aranha” e, especialmente, em "Meu despacho com Graça Aranha” demonstra claramente que a rapsódia contém um diálogo irônico de Mário com as imagens de Brasil e de povo brasileiro idealizadas pelo autor de "O espírito moderno" e adotadas por seus seguidores ou simpatizantes.

Sérgio Buarque de Holanda, em 1926, já comentara as rupturas no interior do movimento, no artigo "O lado oposto e os outros lados”16, em que escritores como Graça Aranha, Ronald de Carvalho e Guilherme de Almeida, chamados de “acadêmicos 'modernizantes'”, são posicionados do "lado oposto" do modernismo autêntico. Para Sérgio, em última análise, esses autores mostravam "pontos de contato bem visíveis" com a corrente de pensamento liderada por Tristão de Ataíde, na medida em que projetavam em seus escritos o mesmo ideal de "criação de uma elite de homens, inteligentes e sábios, embora sem grande contato com a terra e com o povo”, empenhada na construção "bem-intencionada” de uma ordem social, que disciplinasse o caos nacional de acordo com modelos importados, "senão do outro mundo, pelo menos do Velho Mundo.”

No mesmo artigo, Sérgio Buarque se vale da expressão "Ideologias do construtivismo" para caracterizar a proposta de "construção” do Brasil, "panacéia abominável”, segundo ele, fundamentada na “ordem” a ser estabelecida por “uma elite de homens inteligentes e sábios”, capaz de civilizar o país, livrando-o da "barbaria dos nossos fermentos em ebulição", nas palavras de Tristão de Ataíde ao se referir com nítido preconceito e intolerância às múltiplas vozes da cultura popular, transfiguradas artisticamente em Macunaíma de modo a dignificálas e dar a elas lugar privilegiado em manifestação literária culta. A atitude refratária de Tristão coincide com sua militância de líder católico, diretor do Centro Dom Vital, de orientação conservadora. Argutamente, Sérgio Buarque aproxima tal orientação daquela representada por

\footnotetext{
${ }^{16}$ Publicado na Revista do Brasil: São Paulo, 15 de outubro de 1926, p. 9-10. Apud HolANDA, Sérgio Buarque de. O espírito e a letra. Organização, introdução e notas: Antônio Arnoni Prado. São Paulo: Companhia das Letras, 1996, vol. I, p. 224-228.
} 
Graça Aranha, Ronald de Carvalho, Renato Almeida e Guilherme de Almeida: os “acadêmicos 'modernizantes"”.

Agora, valendo-nos de uma observação aguda de Antonio Candido, citada no Capítulo $\mathrm{I}^{17}$, podemos considerar o verdeamarelismo como variante da orientação liderada por Graça Aranha e, portanto, também próxima da linha de Tristão. Isso se evidencia na recepção crítica de Cândido Motta Filho a Macunaíma, que ratifica e endurece as censuras de Ataíde, demonstrando explícita afinidade com o espírito conservador. Ao repudiar a imagem contida em $\mathrm{Ma-}$ cunaíma, considerada repugnante por reduzir o povo brasileiro à face “canalha” de sua condição mestiça, incivilizada e incapaz de qualquer ordenação, Cândido Motta Filho evidencia pressupostos estético-ideológicos do verdeamarelismo de Menotti del Picchia, Plínio Salgado et alii, vertente nacionalista do modernismo que se fundamenta num suposto espírito gregário e receptivo dos tupis, subjacente à suposta boa índole do povo brasileiro. Este, como se observa no Manifesto do verdeamarelismo ou da escola da anta, teria aceito a cultura cristã européia sob o primado do sentimento de integração, de “colaboração coletiva” orquestrada por “todas as instituições conservadoras”, em cujo âmbito processar-se-ia a construção nacional e a renovação do Brasil.

Os críticos veteranos, João Ribeiro e Nestor Vítor, também repudiaram a rapsódia, igualmente fundamentados em pressupostos estéticos e ideológicos conservadores, mas abertamente posicionados fora do modernismo. Supostamente de dentro, mas também alinhado a posições adversas distingue-se, ainda, o ensaio de Jorge de Lima, que ratifica as formulações de Tristão de Ataíde aproximando-as da orientação representada por Gilberto Freyre - outra vertente importante do conservadorismo a se manifestar (indiretamente) na fortuna crítica em questão.

Tristão de Ataíde, Cândido Motta Filho, Nestor Vítor, João Ribeiro, Olívio Montenegro, Augusto Frederico Schmidt, Aníbal Fernandes e Jorge de Lima constituem o grupo adverso a Macunaíma. Nestor Vítor e João Ribeiro representam gerações anteriores e se pronunciam de fora da esfera modernista, os demais são contemporâneos, como é o caso de Tristão, também posicionado à margem, embora na tangente do movimento, ou partícipes da vanguarda a expressar dissensões.

Em última instância, os pronunciamentos adversos se inscrevem na perspectiva preconizada em parte por Tristão de Ataíde, em parte por Graça Aranha, em parte por Gilberto Fre-

\footnotetext{
${ }^{17}$ SoUZA, Antonio Candido de Mello e. "Literatura e cultura de 1900 a 1945”. In: Literatura e sociedade. Ed. cit., 1973, p. 122.
} 
yre - três matrizes do espectro ideológico conservador manifestos direta ou indiretamente na primeira onda da fortuna crítica.

Em contraste ao "lado oposto”, Sérgio Buarque indica a opção pela atitude de resistência, seguida por escritores como Oswald de Andrade, Prudente de Moraes, neto e António de Alcântara Machado, representantes do modernismo autêntico. Embora distinga Mário de Andrade como o "melhor poeta brasileiro", Sérgio faz objeção ao que considera "pontos fracos nas suas [de Mário] teorias”: “quase todos onde elas coincidem com as idéias de Tristão de Ataíde”. Se essa suposta coincidência estiver correta, é importante considerar que a recepção adversa de Tristão a Macunaíma evidencia suficientemente o afastamento de Mário em relação às posições defendidas pelo líder católico. Seja como for, o grupo de resistência a que se refere Sérgio Buarque também “rachou”.

Agora, o próprio Mário de Andrade demonstra consciência de que Macunaíma representava o “coroamento” de uma fase ${ }^{18}$. Lembre-se António de Alcântara Machado a repercutir exatamente a mesma convicção de a rapsódia resultar do processo criativo, que passava por Amar, verbo intransitivo e Clã do jabuti ${ }^{19}$, orientado para a realização de um peculiar projeto nacionalista para a arte e para a cultura do país, e que alcançara um ápice não só na trajetória do autor, mas também no movimento modernista, bem como se constituíra num marco importante da literatura brasileira - opinião, aliás, compartilhada por todos os simpatizantes.

Em já citada missiva a Drummond (28 de fevereiro de 1928) ${ }^{20}$, Mário considerou Macunaíma como ponto de chegada do "brasileirismo de estandarte”. Não seria mais preciso insistir na questão do nacionalismo, pois o trabalho "pró-brasilidade complexa e integral (coisa que não se resume como tantos imaginaram no trabalho da linguagem)" a que resolvera dedicar a vida se impusera, surpreendentemente, com certa facilidade. Certamente, Mário se refere à generalização da perspectiva nacionalista nas cogitações das mais importantes correntes ideológicas engajadas no processo de modelagem do país, no contexto histórico da modernização incipiente, mas vigorosa e irreversível. Contudo, é sempre necessário ter em vista que o generalizado nacionalismo comportava posturas não raro antagônicas.

\footnotetext{
${ }^{18}$ Fernandes, Lygia (org.). Mário de Andrade escreve cartas a Alceu, Meyer e outros. Ed. cit., 1968, p. 164, Carta a Sousa da Silveira, 26 de abril de 1935.

${ }^{19}$ MACHADO, António de Alcântara. “O modernismo da literatura de 1928”. A União: [Paraíba, PB], 31 de janeiro de 1929. IEB-USP - MA-MP. Em nota para o segundo prefácio de Macunaíma, Mário estabelece a seguinte equação: “Amar, Verbo Intransitivo + Clan do Jaboti = Macunaíma”. Cf.: BATISTA, Marta Rossetti, et alii.Op. cit., 1972, p. 295.

${ }^{20}$ ANDRADE, Carlos Drummond de (org.).Op. cit., 1982. p. 130. Também em FroTA, Lélia Coelho (org.).Op. cit., 2002, p. 321. Carta de 28 de fevereiro de 1928.
} 
Ao associar a rapsódia ao "brasileirismo de estandarte”, Mário a concebe como exemplo máximo de sua proposta estética de “arte de ação” ou “literatura de circunstância”, disposta a "sacrificar” a "arte pura” em favor da função socializante da arte, de utilidade prática para a vida, no caso: a de servir de suporte para o conhecimento virtual, por imagens, da realidade brasileira, interpretada segundo a perspectiva do nacionalismo crítico andradiano que, artisticamente, problematiza a mistura contraditória de arcaico e moderno verificada no Brasil naquela quadra, conforme Sérgio Buarque de Holanda ${ }^{21}$ bem observou, no calor da hora. Tal mistura fora preconizada teoricamente por Mário de Andrade - na carta a Bandeira (26 de julho de 1925$)^{22}$ em que comentara o caráter inatual do nacionalismo contido no poema Raça, de Guilherme de Almeida - como provável solução para que o modernismo representasse a realidade do país “em marcha”, de modo que o dinamismo das imagens correspondesse à dinâmica da formação da identidade nacional, ou seja, à afirmação da particularidade brasileira que enriquecesse o processo histórico universal da contemporânea marcha da “civilização”.

Ao admitir Macunaíma como coroamento da fase nacionalista “de estandarte”, Mário a reconhece como a mais radical realização artística de sua proposta de "arte de ação" ou "literatura de circunstância”, na vertente do nacionalismo crítico e universalista. A recepção de Tristão de Ataíde, e as de seus seguidores, destacou esse aspecto como fator de desequilíbrio estético, pela carga de elementos extraliterários supostamente carreados para a obra. Além de estranhos à arte, esses elementos configurariam uma visão pessimista, equivocada e nociva do Brasil e de sua gente, que deveria ser combatida. Como vimos, os simpatizantes discordaram dessa avaliação e exaltaram a rapsódia como obra notável por sua integridade e alta qualidade artística, além de imagem literária bem-ajustada ao referente extraliterário.

Perante esse choque de opiniões, Mário de Andrade, uma vez mais, enseja a compreensão do problema: como "arte de ação” ou "literatura de circunstância”, Macunaíma se embebe na realidade brasileira, filtra criticamente os profusos documentos colhidos da cultura popular, assimila o processo criativo dessa cultura tradicional e reinventa o material estudado em síntese artística dessa realidade, isto é, em imagem construída de acordo com a proposta de integração entre arte e vida - vertente modernista escolhida por Mário de Andrade, em desfavor da vertente oposta da vanguarda, representada pela noção de “arte pura”. A recepção crítica à primeira edição de Macunaíma levara Mário de Andrade a refletir sobre a obra e,

\footnotetext{
${ }^{21}$ Holanda, Sérgio Buarque de. “O mito de Macunaíma”. O Espelho. Rio de Janeiro, nº 6, p. 54-56, setembro de 1935. Recolhido em HolAndA, Sérgio Buarque de. O espírito e a letra. Organização, introdução e notas: Antônio Arnoni Prado. São Paulo: Companhia das Letras, 1996, vol. I, p. 260-267.

${ }^{22}$ Moraes, Marcos Antonio de (org.). Op. cit., 2001, p. 221.
} 
certamente, contribuíra para a decisão de emendá-la. Tal disposição já se anuncia claramente em 1928, ao confidenciar a Manuel Bandeira: "Se Macunaíma algum dia tiver a honra duma segunda edição acho que refundo aquilo.”23 Em 1930, ao mesmo amigo, reafirma: “estou convencido que carreguei a mão, e tirava o mesmo efeito com menos coisas imorais. (...) palavra de honra que ia tentar reescrever Macu. (...) quanta coisa eu mudava.”24 Por ocasião da proposta de Margaret Richardson Wollingsworth, de tradução de Macunaíma para a língua inglesa, Mário auspiciou a possibilidade de o livro ganhar com a tradução, que o enxugaria de certos excessos de "brasileirismo”, de modo a acentuar o aspecto universalista.

Não obstante essas observações, é necessário contrapor a elas a concomitante consciência de que a rapsódia se constituíra na "mais artística das minhas obras”25. Na carta a Alceu Amoroso Lima (Tristão de Ataíde), de 19 de maio de 1928, já manifestara a mesma opinião, de modo mais esclarecedor: “Às vezes tenho a impressão de que [Macunaíma] é a única obrade-arte, de deveras artística, isto é, desinteressada que fiz na minha vida. No geral meus atos e trabalhos são muito conscientes por demais pra serem artísticos. Macunaíma não.”26 Como vimos, Tristão não entendeu assim a rapsódia, ao destacar o que lhe parecera sobreposição do caráter simbólico, de crítica social, ao estético. Curiosamente, Ataíde inverte o argumento de Mário ao asseverar que a simbologia carregada de crítica seria manifestação involuntária do subconsciente ou inconsciente do artista. Jorge de Lima adota uma variante dessa interpretação ao afirmar que Macunaíma, escrito em seis dias, seria um "raide do subconsciente”.

Conforme discutido no Capítulo II, Mário associara o elemento crítico, no âmbito de sua proposta de "literatura de circunstância” ou “arte de ação”, não só ao caráter voluntariamente socializante da obra de arte, entendida, do ponto de vista do interesse público, como conhecimento virtual útil a interagir com a vida contemporânea (primitivismo “de uma era nova”), historicamente configurada e "em marcha” no Brasil e no mundo, mas também ao intrínseco processo de construção formal, em que a obra de arte se explicita, do ponto de vista do artista, como “forma” ou “expressão”. Esta noção, como observamos no Capítulo II, implica a conversão do elemento extraliterário em material reelaborado criticamente pelo trabalho artístico, isto é, em imagem construída por intermédio de uma linguagem específica, no caso,

\footnotetext{
${ }^{23}$ Bandeira, Manuel (org.). Op. cit., p. 207. Também em MorAes, M. A. de (org.). Op. cit., p. 402 . Carta de 29 de agosto de 1928. Mário se refere, especificamente, à descrição dos amores de Macunaíma e Ci na rede.

${ }^{24}$ Idem, p. 254. Idem, p. 474. Carta de 12 de dezembro de 1930.

${ }^{25}$ Andrade, Carlos Drummond de (org.).Op. cit., 1982. p. 136. Também em Frota, Lélia Coelho (org.).Op. cit., 2002, p. 339. Carta de 15 de outubro de 1928. Grifo do autor.

${ }^{26}$ FERnANDES, Lygia (org.). 71 cartas de Mário de Andrade. Ed. cit., p. 31.
} 
a literária. Para Mário, a crítica é um procedimento inerente ao processo de seleção, combinação e elaboração artística do material.

É importante frisar a consciência artística de Mário para evitar uma interpretação equivocada de suas palavras na missiva a Alceu Amoroso Lima, quando considerara Macunaíma “a única obra-de-arte, de deveras artística, isto é, desinteressada que fiz na minha vida”, uma vez que não seria consciente “por demais”. Não se deve entender por isso que a rapsódia seria uma manifestação do subconsciente do autor, como fez Jorge de Lima, radicalizando a sugestão de Tristão de Ataíde que, ao considerar Macunaíma como tal (“em grande parte”), interpretou a obra como expressão do substrato primitivo e degradado do povo brasileiro, mas que em última instância seria projeção de uma imagem do "totalismo nacional (...) de fato só dele [Mário de Andrade]”, insinuando com essa observação que a carapuça da "barbaria dos nossos fermentos em ebulição”, contida no livro e a ser combatida, se ajustaria sobretudo ao autor da rapsódia “pessimista”. Tristão investe contra Macunaíma na medida em que a imagem de brasilidade percebida na linguagem e no suposto sentido simbólico do livro entra em choque com um projeto nacional de arte, cultura e sociedade bem diverso, pois amparado em visão ideológica carregada de preconceitos e intolerância em relação ao substrato cultural popular, dito primitivo, valorizado na rapsódia.

Na esteira de Tristão de Ataíde, Jorge de Lima considera Macunaíma, escrita em seis dias, manifestação do subconsciente de Mário de Andrade, entendido como "uma parte do subconsciente coletivo do país", de modo a constituir-se em um "raide do subconsciente nacional”. O poeta de “Essa negra Fulô” parece elogiar a experiência estética inovadora de Mário, ao reconhecê-la como conquista de uma legítima "expressão nacional”, quer como linguagem artística, quer como imagem bem-ajustada aos referentes: o Brasil e os brasileiros. No entanto, o elogio tem a função de anestésico retórico para obscurecer o repúdio ao modelo de brasilidade consubstanciado na rapsódia, em favor do preconizado por Gilberto Freyre, embora matizado pela peculiar salada ideológica de Jorge de Lima, caracterizada no Capítulo II.

É preciso enfatizar o equívoco, se não falsificação, de críticos como Jorge de Lima ou Tristão de Ataíde quando supõem Macunaíma como um ditado do subconsciente, escrito em seis dias de “possessão” criativa. Como Mário adverte a Bandeira: “não é possível esquecer todo o preparo formidavelmente grande anterior (e posterior, como em Paulicéia, de que também cortei muita coisa), que permitiu essa declanchação”27, isto é, o desencadeamento do

\footnotetext{
${ }^{27}$ BANDEIRA, Manuel (org.). Op. cit., p. 293. Também em MoraEs, M. A. de (org.). Op. cit., p. 519. Carta de 16 de agosto de 1931.
} 
processo criativo de Macunaíma, cuja primeira redação se perfez em seis dias de entusiasmo artístico, segundo o próprio autor. Uma carta de Mário a Henriqueta Lisboa, de 30 de janeiro de 1942, esclarece melhor tal questão: “O Macunaíma e quase a infinita maioria dos meus poemas 'dirigidos' foram escritos em estado de possessão preparada. Como assunto, a própria Paulicéia, mas sem saber que estava preparando. Depois, principiei fazendo isto voluntariamente. Quero dizer: eu provoco o estado de poesia. Esses em geral, por isso que dirigidos, são os poemas mais remanejados. Às vezes entre a primeira e a versão definitiva são mais dois poemas irmãos que o mesmo poema."28

Mário entende o “estado de poesia”, inspiração, “lirismo” ou “comoção estética” como ponto de partida da “expressão”, que só se perfaz na obra de arte acabada, a qual, por sua vez, implica “a inspiração, a vontade, a crítica, elementos subjetivos” ${ }^{29}$, entre outros que participam do processo criativo do artista consciente. O comentário feito a Henriqueta Lisboa desmistifica qualquer tentativa de, para bem ou para mal, incluir Macunaíma no rol de obras cuja criação decorresse de estados psíquicos alterados e/ou dissolventes, como sugeriu Nestor Vítor, para mal, ao associar Macunaíma ao “dionisismo” dadá-freudiano, ou Oswaldo Costa (Tamandaré), para bem, ao elogiar a “parte bode” de Mário de Andrade, realizada, segundo Costa, de modo admirável na rapsódia.

O minucioso estudo empreendido por Telê Porto Ancona Lopez, na sua terceira edição crítica de Macunaíma (1996), enriquecida pela perspectiva da pesquisa genética, testemunha profusamente a inquietação artística de Mário de Andrade, traduzida no processo de preparação, escritura e laboriosas reescrituras da obra. Para Mário, Macunaíma é exemplo máximo de seus “poemas dirigidos”, noção associada à de “arte de ação” ou "literatura de circunstância”, coroamento da fase nacionalista "de estandarte”, e, a um só tempo, a "mais artística das minhas obras”, isto é, exemplo máximo de obra de arte desinteressada, realização mais próxima da "arte pura” de que fora capaz e que exigira incansável trabalho intelectual de elaboração artística. Essa consciência se explicita, ainda, num comentário feito a Manuel Bandeira: “A importância está na coisa em si, ou por outra: a coisa pode viver por si. Porém a quem lê o Quixote e percebe além da coisa em si, tudo o que ela traz de representações ideais, esse tem

\footnotetext{
${ }^{28}$ PALÚ, Pe. Lauro (org.). Querida Henriqueta. Cartas de Mário de Andrade a Henriqueta Lisboa. Rio de Janeiro, José Olympio, 1990, p. 74. Grifos do autor.

${ }^{29}$ Introdução à estética musical. Ed. cit., p. 21.
} 
um gozo muito infinitamente maior. (...) Macunaíma vive por si, porém possui um caráter que é justamente o de não ter caráter.”30

Dessa linha de raciocínio, obviamente, depreende-se a convicção da autonomia do herói e de suas peripécias, respectivamente, como personagem e narrativa de ficção: a "coisa em si”, pura obra de arte realizada como fenômeno de linguagem. Simultaneamente, desvela-se a consciência da conexão entre arte e vida operada em Macunaíma, uma vez que a obra conteria certas “representações ideais”: uma síntese poética de conclusões a que Mário chegara sobre os brasileiros e os valores nacionais, entendidos como incaracterísticos, mas portadores de sintomas de uma cultura nacional: "Sempre maginei fazer poema se ocupando do homem sem caráter nenhum, produto mesmo do caos humano, mexendo-se no abismo brasileiro, reflexo de elementos disparatados na arritmia gostosa a indicar o maravilhoso destino de nossa gente. Poema-síntese que teve alongamentos além da minha vontade diretora. (...) Macunaíma saltando com todos os desesperos da raça que não é raça ainda, mas se preparando para ser estupenda raça nos fixados caracteres. Quando quando? Não sabemos que o mistério do sempre grave amanhã não deixa brecha para se saber seguro. Macunaíma, Macunaíma apenas o estado atual fixado pela minha frágil imaginação. (...)”31, isto é, “literatura de circunstância” em que a imagem artística realizada na “expressão”, enquanto forma, dialoga com referentes extraliterários. Esse diálogo por imagens, potencialmente, comunica-se ao público como conhecimento virtual de valor prático para a vida (primitivismo...), de modo a interagir com a realidade brasileira “em marcha” (... “de uma era nova”). Segundo Mário de Andrade, é importante frisar, Macunaíma explicita a imagem artística de "sintoma de cultura nacional” (segundo prefácio), resultante de suas pesquisas e reflexões, bem como de sua imaginação.

Mário de Andrade considerou Macunaíma, ao menos no período aqui estudado, como ponto culminante de sua obra, quer como exemplo de arte pura, quer como de ação, uma vez que, para ele, a rapsódia lograra realizar "da arte e da vida um sistema de vasos comunicantes”, como se lê numa importante passagem do segundo prefácio a Macunaíma, omitida pela recepção crítica de Tristão. O estudo da primeira onda da fortuna crítica da rapsódia dá a ver que essa culminância na trajetória da obra artística pessoal de Mário de Andrade coincide com o ápice do movimento modernista brasileiro, no momento em que os esforços de renovação estética, associados a projetos nacionalistas de modelagem do país, completam a trajetória de

\footnotetext{
${ }^{30}$ Bandeira, Manuel (org.). Op. cit., p. 175-178. Também em MoraEs, M. A. de (org.). Op. cit., p. 363. Carta de 07 de novembro de 1927.

${ }^{31}$ VIDAL, Ademar. "Mário de Andrade e o Nordeste". Revista do Livro, a. 10, ํㅜ 31. Rio de Janeiro, 1967, p. 2728. Apud AndRADE, Mário de. Macunaíma. Ed. crítica de Telê Porto Ancona Lopez. Ed cit., 1997, p. 505-506 (“Dossier da Obra: Memória / Considerações em cartas").
} 
fragmentação em posições estético-ideológicas sectárias, de modo a assinalar aproximadamente o ponto em que o ciclo histórico do modernismo propriamente dito se encerra.

O estudo da fortuna da edição príncipe de Macunaíma evidencia que a instância de legitimação da obra, no período, encontra-se na esfera da crítica literária jornalística em que se movia a vida intelectual letrada do país. Todos os pronunciamentos, mesmo os adversos, agregam elementos valiosos para a compreensão estética do livro, inaugurando linhas de pesquisa posteriormente desenvolvidas ou ainda à espera de quem delas se ocupe. O corpus ainda revela que os juízos estéticos não se dissociam de valores ideológicos das mais importantes correntes nacionalistas então contemporâneas. Todos os que se pronunciaram de modo desfavorável à experiência artística inusitada de Macunaíma seguem orientações representadas sobretudo por Tristão de Ataíde, Graça Aranha e Gilberto Freyre, adeptos de projetos culturais e sociais para o Brasil que se inscrevem no âmbito da chamada "modernização conservadora”, fundamentados no pressuposto ideológico de “ordem”. Do lado em que se encontram os discursos favoráveis, há representantes do pensamento conservador, como é o caso de Luís da Câmara Cascudo, orientações que não podem ser confundidas com propensões ideológicas revolucionárias - as críticas de António de Alcântara Machado ou de Augusto Meyer - e perspectivas simpatizantes de soluções radicais, à esquerda, como se verifica na recepção de Oswald de Andrade. O que há de comum nelas é o reconhecimento de Macunaíma, sobretudo, como fato estético de capital importância para a literatura brasileira, a despeito ou até mesmo em virtude de valores ideológicos de que a linguagem fosse suporte.

A fortuna crítica da edição príncipe de Macunaíma enseja o reconhecimento das principais correntes estéticas em vigor no período (1928-1936): modernismo “academizante” denominação dada por Sérgio Buarque de Holanda para a corrente liderada por Graça Aranha e aqui alargada para comportar o espectro ideológico também conservador a que se associam as variantes representadas por Tristão de Ataíde, Gilberto Freyre ou Plínio Salgado, resguardadas as diferenças entre elas - em oposição ao modernismo de "resistência”, propugnado pelo mesmo Sérgio Buarque como alternativa à direção indicada pelo conservadorismo.

Em vez de projetos elitistas impostos de cima para ordenar os debaixo, ou seja, “civilizar” o "caos” nacional em que ainda subsistiriam elementos considerados pejorativamente "primitivos”, o modernismo de resistência dignifica esses elementos, dedica-se a estudar as contribuições culturais populares para entendê-las e aprender com elas que o suposto "caos” nacional talvez fosse índice de uma outra ordem, resultante da mistura, adaptação e acomodação, certamente contraditórias, de múltiplos sedimentos culturais, sobretudo provenientes dos 
substratos formadores fundamentais - o branco português, o negro africano e o ameríndio "da cor de bronze novo" -, aos quais se agregaram contribuições de novos adventícios, como os italianos, espanhóis, alemães, sírio-libaneses e japoneses, dentre imigrantes de outras nacionalidades menos afluentes, a modular o processo histórico universal de modernização capitalista.

Do ponto de vista do modernismo de resistência, particularmente o que se manifesta no projeto andradiano por intermédio das noções de nacionalismo crítico e literatura de circunstância (primitivismo “de uma era nova”) consubstanciadas em Macunaíma, a identidade cultural brasileira é entendida não como idealização abstrata, dissociada da realidade, cuja função seria a de garantir as elites conservadoras no controle da modernização, mas como síntese concreta (artística) dessa identidade - processo dinâmico deduzido de observação profusa e análise refletida -, portadora de valores contrapostos à reificação dos homens e à padronização das sociedades nacionais, decorrentes da expansão do capitalismo internacional.

A propósito da recepção crítica a Macunaíma, Mário de Andrade assinala, no prefácio “inédito” de Belazarte (1930): “Alguns me compreenderam; e os que me atacaram ou puderam estimar na minha obra o que havia nela de estimável, me fizeram bem. Não renego o meu milhor livro. Mas o odeio.”32 Tal “ódio” se esclarece na autocrítica do autor, segundo a qual a sua criação fracassara: “Depois que escrevi o poema herói-cômico de Macunaíma e o li, meu desespero foi enorme ante a obra-prima que falhou. O filão era de obra-prima porém o faiscador servia só pra cavar uns brilhantinhos de merda.”33 Esta observação evidencia: a opinião do criador foi afetada, sobretudo, pelos pronunciamentos críticos adversos que fizeram da tópica da obra-prima falhada um leitmotiv na autocrítica de Mário.

Aparentemente, o artista elide o contrapeso representado pelas críticas favoráveis, sobretudo as elaboradas por também artistas como António de Alcântara Machado, Ascenso Ferreira, Oswald de Andrade e Augusto Meyer, cujas avaliações se aproximam do que hoje é consensual: Macunaíma seria perfectível, não fosse a morte precoce de Mário de Andrade, mas, uma vez perfeita como ficou, a rapsódia, desde o esclarecedor Roteiro de Macunaíma (1955), de M. Cavalcanti Proença, merece a reputação de paradigma do modernismo de resistência, admirável trabalho de recriação e interpretação do substrato popular da cultura brasileira em contraste e confronto (para usar a expressão de Euclides da Cunha) com o avanço da chamada civilização moderna e as acomodações conservadoras a esse processo. Enfim, notá-

\footnotetext{
32 “Considerações no prefácio inédito de Belazarte: 1930”. In: ANDRADE, Mário de. Macunaíma, o herói sem nenhum caráter. Edição crítica de Telê Porto Ancona Lopez (coord.). Ed. cit., 1997. p. 527.

${ }^{33}$ Idem.
} 
vel como obra de arte literária, “das mais originais da nossa literatura”, conforme preconizara o próprio Mário de Andrade no depoimento mascarado em primeiríssima recepção crítica a Macunaíma. 


\section{BIBLIOGRAFIA}

A. de A. M. [Antônio de Alcântara Machado]. “Um poeta e um prosador / Mário de Andrade - Macunaíma - São Paulo - 1928”. Revista de Antropofagia: São Paulo, a. I, nº 5, setembro de 1928, p. 4. Edição fac-similar. São Paulo: Abril / Metal Leve, 1975.

A. F. [Aníbal Fernandes]. “Através dos livros / Macunaíma - Mário de Andrade - S. Paulo”. Diário de Pernambuco: Recife, 18 de abril de 1929ํㅗㄴ IEB-USP - MA-MP.

A. M. [Augusto Meyer]. “Macunaíma / por Mário de Andrade”. Revista do Globo: Porto Alegre, a. I, $\mathrm{n}^{\mathrm{o}}$ 1, janeiro de 1929. IEB-USP - MA-MP.

Andrade, Carlos Drummond de (org.). A lição do amigo: cartas de Mário de Andrade a Carlos Drummond de Andrade. Rio de Janeiro: José Olympio, 1982.

ANDRADE, Mário de. “A escrava que não é Isaura”. In: Obra imatura. 2ª̣ ed. São Paulo: Martins / Brasília: INL-MEC, 1972.

ANDRADE, Mário de. “A Raimundo Moraes”. In: Táxi e crônicas no Diário Nacional. Op. cit., 1976.

Andrade, Mário de. “L’Or”. In: Estética, nº 3. Rio de Janeiro: abr.-jun. de 1925. Apud: KOIFMAN, Georgina (org.). Op. cit., p. 113-114.

Andrade, Mário de. “Modernismo e ação”. Jornal do Commercio: Recife, 24 de maio de 1925. In: AzEVÊDo, Neroaldo Pontes de. Modernismo e regionalismo (Os anos 20 em Pernambuco). João Pessoa: Secretaria de Educação e Cultura da Paraíba, 1984, p. 223-225.

\footnotetext{
${ }^{1}$ Identificação de periódico e data de publicação por anotação de Mário de Andrade no recorte que se encontra no álbum R. 29 do IEB - Recortes de Mário de Andrade. Identificação de autoria por anotação de Ascenso Ferreira, que remeteu o recorte a Mário.
} 
Andrade, Mário de. “Prefácio interessantíssimo”. In: Paulicéia desvairada, 1a ed. 1922. Apud: Andrade, Mário de. Poesias completas. Edição crítica de Diléa Zanotto Manfio. Belo Horizonte / Rio de Janeiro: Villa Rica, 1993.

Andrade, Mário de. Aspectos da literatura brasileira. 5ª̣ ed. São Paulo: Martins, 1974.

Andrade, Mário de. Cartas de Mário de Andrade a Luís da Câmara Cascudo. Introdução e

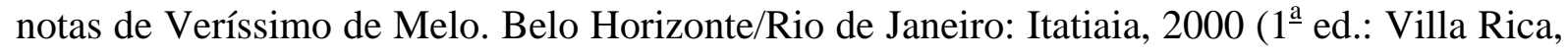
1991).

Andrade, Mário de. Correspondente contumaz: cartas a Pedro Nava, 1925-1944. Edição preparada por Fernando da Rocha Peres. Rio de Janeiro: Nova Fronteira, 1982.

ANDRADE, Mário de. Introdução à estética musical. Estabelecimento do texto, introdução e notas de Flávia Camargo Toni. São Paulo: Hucitec, 1995.

Andrade, Mário de. Macunaíma. Edição crítica de Telê Porto Ancona Lopez. Ilustrações de Pedro Nava. Rio de Janeiro: Livros Técnicos e Científicos / São Paulo: Secretaria da Cultura, Ciência e Tecnologia, 1978.

ANDRADE, Mário de. Macunaíma, o herói sem nenhum caráter. Edição crítica de Telê Porto Ancona Lopez (coord.). $2^{\underline{a}}$ ed., $1^{\underline{a}}$ reimp. Madri etc.: ALLCA XX / São Paulo: Scipione, 1997. Coleção Arquivos, 6. (1ª̣ ed. Paris: ALLCA XX / Brasília: CNPq, 1988; 2ª ed., 1996).

Andrade, Mário de. O banquete. São Paulo: Duas Cidades, 1977.

ANDRADE, Mário de. O turista aprendiz. $1^{\underline{a}}$ ed. Estabelecimento de texto, introdução e notas de Telê Porto Ancona Lopez. São Paulo: Duas Cidades / Secretaria Ciência, Cultura e Tecnologia, 1976 ( $2^{\underline{a}}$ ed., 1983).

Andrade, Mário de. Poesias completas. Edição crítica de Diléa Zanotto Manfio. Belo Horizonte / Rio de Janeiro: Villa Rica, 1993. 
Andrade, Mário de. Taxi e crônicas no Diário Nacional. Estabelecimento de texto, introdução e notas de Telê Porto Ancona Lopez. São Paulo: Duas Cidades/Secretaria de Cultura, Ciência e Tecnologia, 1976.

Andrade, Oswald de. “Esquema ao Tristão de Ataíde”. Revista de Antropofagia: São Paulo, a. I, nº 5, setembro de 1928, p. 3. Edição fac-similar. São Paulo: Abril / Metal Leve, 1975.

Andrade, Oswald de. “Manifesto da poesia pau-brasil”. In: TELEs, Gilberto Mendonça. Op. cit., p. 203-208.

AnTELO, Raúl. Na ilha de Marapatá. São Paulo: Hucitec; Brasília: MINC/Pró-Memória/INL, 1986.

ArAnHA, Graça. “O espírito moderno”. In: Teles, Gilberto Mendonça. Op. cit., 1973.

Assis, Machado de. "Notícia da atual literatura brasileira / Instinto de nacionalidade”. In: . Obra completa. Rio de Janeiro: Aguilar, 1962, p. 801-809, vol. III. Ensaio publicado originalmente no periódico Novo Mundo, edição de 24 de março de 1873.

AtAíDE, Tristão de [Alceu Amoroso Lima]. “Macunaíma”. O Jornal: Rio de Janeiro, 09 de setembro de 1928. FBN - Periódicos.

AzevÊdo, Neroaldo Pontes de. Modernismo e regionalismo (Os anos 20 em Pernambuco). João Pessoa: Secretaria de Educação e Cultura da Paraíba, 1984.

BAndeIRA, Manuel (org.). Cartas de Mário de Andrade a Manuel Bandeira. Rio de Janeiro: Simões, 1958.

BARreto, Lima. Triste fim de Policarpo Quaresma. Apresentação de Ivan Teixeira. Cotia (SP): Ateliê Editorial, 2004.

Batista, Marta Rossetti (org.). Cartas a Anita Malfatti. São Paulo: Forense Universitária, 1989. 
Batista, Marta Rossetti, Lopez, Telê Porto Ancona e LimA, Yone Soares. Brasil: $1^{\underline{o}}$ tempo modernista - 1917/29. São Paulo: IEB-USP, 1972.

BosI, Alfredo. O pré-modernismo. $4^{\mathrm{a}}$ ed. São Paulo: Cultrix, 1973.

CAMARgo, Suzana. Macunaíma - ruptura e tradição. São Paulo: Massao Ohno/João Farkas editores, 1977.

CAMPOS, Haroldo de. “Morfologia de Macunaíma”. Correio da Manhã: Rio de Janeiro, 26 de novembro de 1967.

CAMPOS, Haroldo de. Morfologia do Macunaíma. São Paulo: Perspectiva, 1973. Coleção Estudos, 19.

CARvalho, Ronald de. “Cadernos de imagens / 4 / Macunaíma, de Mário de Andrade”. In: Estudos Brasileiros. 1a ed. Rio de Janeiro: F. Briguiet, 1931. Transcrito, com poucas modificações, de "Livros / Macunaíma - o herói sem nenhum caráter - de Mário de Andrade”. Movimento: Rio de Janeiro, 01 de outubro de 1928, p. 21.

CAscudo, Luís da Câmara. "Mário de Andrade”. Boletim de Ariel: Rio de Janeiro, a. 3, nº 9, junho de 1934, p. 233-235. IEB-USP - MA-MP.

CASCUDO, Luís da Câmara. Dicionário do folclore brasileiro. $2^{\underline{a}}$ ed. Rio de Janeiro: INL, 1962, 2 vol.

CHAMIE, Mário. Intertexto: escrita rapsódica - ensaio de leitura produtora. São Paulo: Práxis, 1970.

CostA, Oswaldo. "Resposta a Ascenso Ferreira”. Revista de Antropofagia. $2^{\underline{a}}$ Dentição. Diário de S. Paulo: São Paulo, 19 de julho de 1929, p. 12. Edição fac-similar. São Paulo: Abril / Metal Leve, 1975. 
Coutinho, Afrânio e SousA, J. Galante de (diretores). Enciclopédia da literatura brasileira. $2^{\underline{a}}$ ed. rev., ampl., atual. e il. sob a coordenação de Graça Coutinho e Rita Moutinho. São Paulo: Global Editora; Rio de Janeiro: Fundação Biblioteca Nacional/DNL: Academia Brasileira de Letras, 2001, 2 vol.

DimAs, Antônio. “Um manifesto guloso”. In: FrEYRE, Gilberto. Manifesto regionalista. $7^{\mathrm{a}}$ ed. Organização e apresentação de Fátima Quintas. Recife: Massangana, 1996.

EPICURO. “Antologia de textos de Epicuro”. In: Os pensadores. São Paulo: Abril Cultural, vol. V, 1973.

FERnANDES, Lygia (org.). 71 cartas de Mário de Andrade. Rio de Janeiro, São José, s.d.

FERnANDEs, Lygia (org.). Mário de Andrade escreve. Cartas a Alceu, Meyer e outros. Rio de Janeiro: Editora do Autor, 1968.

FERreirA, Ascenso. “Brasilidade e dinamismo / a propósito do 'Macunaíma’ de Mário de Andrade”. Diário Nacional: São Paulo, 28 de novembro de 1928. IEB-USP - CAP-MP. Republicado no mesmo jornal: 23 de novembro de 1931.

Ferreira, Ascenso. "Carta do poeta de Catimbó”. Revista de Antropofagia. $2^{\underline{a}}$ Dentição. Diário de S. Paulo: São Paulo, 19 de julho de 1929, p. 12. Edição fac-similar. São Paulo: Abril / Metal Leve, 1975.

FErreira, Delson Gonçalves (org.). Cartas de Mário de Andrade a Rosário Fusco. Belo Horizonte, 1977, inédito. Apud ANDRADE, Mário de. Macunaíma o herói sem nenhum caráter. Ed. crítica de Telê Porto Ancona Lopez (org.). Op. cit., 1997, p. 499.

FradiQue, Mendes (pseudônimo de José Madeira de Freitas). História do Brasil pelo método confuso. Isabel Lustosa (org.). São Paulo: Companhia das Letras, 2004.

FreYre, Gilberto. Casa-grande \& senzala. 10aㅡ ed. brasileira. Rio de Janeiro: José Olympio, 1961. 
FrEYre, Gilberto. Manifesto regionalista. $7^{\text {aa }}$ ed. Organização e apresentação de Fátima Quintas. Recife: Massangana, 1996.

FrEYRE, Gilberto. Tempos mortos e outros tempos. Rio de Janeiro: José Olympio, 1975.

Frota, Lélia Coelho (org.). Carlos e Mário: correspondência entre Carlos Drummond de Andrade - inédita - e Mário de Andrade. Apresentação e notas às cartas de Mário de Andrade: Carlos Drummond de Andrade; prefácio e notas às cartas de Carlos Drummond de Andrade: Silviano Santiago. Rio de Janeiro: Bem-Te-Vi, 2002.

GonzÁlez, Mario M. “Macunaíma”. In: A saga do anti-herói. São Paulo: Nova Alexandria / Embaixada de Espanha, 1994.

HeRÁCLITO. In: Os pré-socráticos. São Paulo: Abril Cultural, Os pensadores, vol. I, 1973.

Holanda, Sérgio Buarque de. “O mito de Macunaíma”. O Espelho. Rio de Janeiro, nº 6, p. 54-56, setembro de 1935. Recolhido em HolandA, Sérgio Buarque de. O espírito e a letra. Organização, introdução e notas: Antônio Arnoni Prado. São Paulo: Companhia das Letras, 1996, vol. I, p. 260-267.

HolANDA, Sérgio Buarque de. O espírito e a letra. Organização, introdução e notas: Antônio Arnoni Prado. São Paulo: Companhia das Letras, 1996, 2 vol.

Homero. Batracomiomaquia. Estudo e tradução de Fabricio Possebom. São Paulo: Humanitas-FFLCH/USP, 2003.

InOJOSA, Joaquim. O movimento modernista em Pernambuco. Rio de Janeiro, Ed. Guanabara, s.d., v. 2, p. 340. Apud Moraes, Marcos Antonio de (org.). Op. cit., nota 79, p. 219.

J. P. [João Pacheco]. “Bibliografia / 'Macunaíma' - Mário de Andrade - São Paulo”. Folha Acadêmica: Rio de Janeiro, 13 de setembro de 1928, p. 484. IEB-USP - MA-MP. 
Kolfman, Georgina (org.). Cartas de Mário de Andrade a Prudente de Moraes, neto: 192436. Rio de Janeiro: Nova Fronteira, 1985.

LACERDA, Aline Lopes de. "Retratos do Brasil: uma coleção do Rockefeller Archive Center”. In: História, ciências, saúde - Manguinhos. Rio de Janeiro: set./dez. 2002, vol. 9, nº 3, p. 625-645. ISSN 0104-5970.

LAFETÁ, João Luiz. 1930: A crítica e o modernismo. 2ª̣ ed. São Paulo: Duas Cidades / Editora 34, 2000.

LIMA, Jorge de. “Todos cantam sua terra...”. Dois ensaios. 1ª ed. Maceió (AL): Casa Ramalho, 1929, p. 86-138. Exemplar com dedicatória do autor a Mário de Andrade. Biblioteca IEBUSP. Reeditado em 1934 (2 $2^{\underline{a}}$ edição. Rio de Janeiro: Civilização Brasileira). Recolhido em Obras completas de Jorge de Lima. Rio de Janeiro: Aguilar, 1959, p. 1012-1038, v. I. Reproduzido, parcialmente, com o título de "Um raide do subconsciente nacional”, em ANDRADE, Mário de. Macunaíma. Edição crítica de Telê Porto Ancona Lopez. Op. cit., 1978.

Lopez, Telê Porto Ancona. Mário de Andrade: ramais e caminho. São Paulo: Duas Cidades, 1972.

LoPEz, Telê Porto Ancona. Macunaíma: a margem e o texto. São Paulo: Secretaria Cultura, Esporte e Turismo / Hucitec, 1974.

LoPEz, Telê Porto Ancona. "Bibliografia sobre Macunaíma”. In: AndRAdE, Mário de. Macunaíma. Edição crítica de Telê Porto Ancona Lopez, ed. cit., 1978.

LOPEZ, Telê Porto Ancona. “Introdução”. In: AndRADE, Mário de. Macunaíma. Edição crítica de Telê P. A. Lopez, ed. cit., 1978.

Lopez, Telê Porto Ancona. “Amazônia e utopia em Mário de Andrade”. In: América: ficção e utopias. São Paulo: Edusp, 1995. 
Machado, António de Alcântara. “O modernismo da literatura de 1928”. A União: [Paraíba, $\mathrm{PB}^{2}$ ], 31 de janeiro de 1929. IEB-USP - MA-MP.

MARTins, Wilson. A crítica literária no Brasil. 2ª ed. Rio de Janeiro: Francisco Alves, 1983, 2 vol.

MedEIROS, Sérgio (org.). Makunaíma e Jurupari: cosmogonias ameríndias. São Paulo: Perspectiva, 2002.

Mello e Souza, Antonio Candido de. “Crítica e sociologia”. In: Literatura e sociedade. $3^{\text {a }}$ ed. revista. Companhia Editora Nacional: São Paulo, 1973.

Mello e SouzA, Antonio Candido de. “Literatura e cultura de 1900 a 1945”. In: Literatura e sociedade. $3^{\mathrm{a}}$ ed. revista. São Paulo: Editora Nacional, 1973.

Mello e SouzA, Gilda de. O tupi e o alaúde: uma interpretação de Macunaíma. São Paulo: Duas Cidades, 1979.

Melo, Veríssimo de (org.). Cartas de Mário de Andrade a Luís da Câmara Cascudo. Belo Horizonte/Rio de Janeiro: Itatiaia, 2000. (1ª ed.: Belo Horizonte/Rio de Janeiro: Itatiaia, Villa Rica, 1991).

Meyer, Augusto. "Macunaíma”. Correio de Povo: Porto Alegre, a. 36, nº 153, p. 3. 01 de julho de 1930. Arquivo DZM.

Montenegro, Olívio. “Mário de Andrade”. In: O romance brasileiro. $2^{\underline{a}}$ ed. Rio de Janeiro: José Olympio, 1953, p. 199-214. Na 1ª ed., de 1938, não havia o capítulo dedicado a Mário de Andrade.

Moraes, Marcos Antonio de (org.). Correspondência Mário de Andrade \& Manuel Bandeira. $2^{\underline{a}}$ ed. São Paulo: Edusp/IEB-USP, 2001 (1ª ed., 2000).

\footnotetext{
${ }^{2}$ No recorte que se encontra no álbum R.27 do IEB - Recortes de Mário de Andrade -, há uma anotação de Mário de Andrade que identifica a data de publicação, o periódico e a cidade, Paraíba, depois chamada João Pessoa.
} 
MotTA FiLHo, Cândido. “As leituras da semana / Literatura / Macunaíma - Mário Moraes de Andrade - São Paulo - 1928”. Correio Paulistano: São Paulo, 20 de setembro de 1928. IEBUSP - CAP-MP.

O. M. [Olívio Montenegro]. "Livros novos / Macunaíma - Romance - Mário de Andrade - S. Paulo - 1928”. Periódico não identificado, [Recife ${ }^{3}$ ], s/d. IEB-USP - MA-MP.

Palú, Pe. Lauro (org.). Querida Henriqueta. Cartas de Mário de Andrade a Henriqueta Lisboa. Rio de Janeiro, José Olympio, 1990.

RIBEIRO, Darcy. “Liminar / Macunaíma”. In: AndRADE, Mário de. Macunaíma. Edição crítica de Telê Porto Ancona Lopez (coord.). Op. cit., p. XVIII.

RIBEIRO, João. “Crônica literária / Macunaíma - herói sem nenhum caráter - por Mário de Andrade”. Jornal do Brasil: Rio de Janeiro, 31 de outubro de 1928, p. 10. IEB-USP - CAPMP. Recolhido em Os Modernos. Rio de Janeiro: ABL, 1952, p. 81-84, vol. IX das Obras completas de João Ribeiro. Reproduzido em ANDRADE, Mário de. Macunaíma. Edição crítica de Telê Porto Ancona Lopez. Rio de Janeiro: Livros Técnicos e Científicos / São Paulo: Secretaria da Cultura, Ciência e Tecnologia, 1978.

RiBeiro, João. O folclore. Rio de Janeiro: (?), 1919. Apud CASCudo, Luís da Câmara. Dicionário do folclore brasileiro. $2^{\mathrm{a}}$ ed. Rio de Janeiro: INL, 1962, p. 137, vol. 1.

S/A [Mário de Andrade]. "Macunaíma. O livro de Mário de Andrade”. Diário Nacional: São Paulo, 07 de agosto de 1928. IEB-USP - CAP-MP.

S/A [Ronald de Carvalho]. "Livros / Macunaíma - o herói sem nenhum caráter - de Mário de Andrade”. Movimento: Rio de Janeiro, 01 de outubro de 1928, p. 21. FBN - Periódicos. Recolhido em Carvalho, Ronald de. "Cadernos de imagens / 4 / Macunaíma, de Mário de Andrade”. In: Estudos Brasileiros. 1ํㅡㄹ ed. Rio de Janeiro: F. Briguiet, 1931, p. 151-152. Reedita-

\footnotetext{
${ }^{3}$ No verso do recorte, que se encontra no álbum R.29 do IEB - Recortes de Mário de Andrade -, há indícios de que a cidade de Recife seja o local da publicação.
} 
do em: Rio de Janeiro: MEC / Nova Aguilar, 1976, p. $143-144$.

S/A. "A batrachomyomachia / ou a guerra das rãs com os ratos / poemeto atribuído a Homero”. A illustração brazileira, s/l., nº 63, 01 de janeiro de 1912, p. 5. Recortes de Mário de Andrade. IEB-USP.

SABINO, Fernando (org.). Cartas a um jovem escritor. 3ª ed. Rio de Janeiro: Record, 1993.

SANTIAgo, Silviano. “A trajetória de um livro”. In: AndRADE, Mário de. Macunaíma, o herói sem nenhum caráter. Edição crítica de Telê Porto Ancona Lopez (coord.). Op. cit., p. 185. Esse ensaio, com o título mudado para "História de um livro”, foi recolhido em SANTIAGO, Silviano. Nas malhas da letra. São Paulo: Cia. das Letras. 2ª ed. Rio de Janeiro: Rocco, 2002.

SCHMIDT, Augusto F. “A propósito de 'Macunaíma””. A Ordem: Rio de Janeiro, [dezembro?] de 1928, p. 34-38. IEB-USP - CAP-MP.

SouzA, Eneida Maria de. A pedra mágica do discurso. $2^{2}$ ed. revista e ampliada. Belo Horizonte: Ed. UFMG, 1999.

TAMANDARÉ [Oswaldo Costa]. “Moquém / II - Hors d'oeuvre”. Revista de Antropofagia. $2^{\underline{a}}$ Dentição. Diário de S. Paulo: São Paulo, 14 de abril de 1929, p. 6. Edição fac-similar. São Paulo: Abril / Metal Leve, 1975.

TAMANDARÉ [Oswaldo Costa]. “Moquém / III - Entradas”. Revista de Antropofagia. 2a Dentição. Diário de S. Paulo: São Paulo, 24 de abril de 1929, p. 10. Edição fac-similar. São Paulo: Abril / Metal Leve, 1975.

TELEs, Gilberto Mendonça. Vanguarda européia e modernismo brasileiro. $2^{\mathrm{a}}$ ed. Petrópolis (RJ): Vozes, 1973. 
VidAl, Ademar. “Mário de Andrade e o Nordeste”. Revista do Livro, a. 10, nº 31. Rio de Janeiro, 1967, p. 27-28. Apud Andrade, Mário de. Macunaíma. Ed. crítica de Telê Porto Ancona Lopez. Op. cit., 1997, p. 505 (“Dossier da Obra: Memória / Considerações em cartas”).

VIEIRA, José. “Livros novos / Macunaíma, por Mário de Andrade, S. Paulo, 1928”. Vanguarda: [Rio de Janeiro ${ }^{4}$ ], 10 de dezembro de 1928. IEB-USP - MA-MP.

VíTOR, Nestor. “Macunaíma, o herói sem nenhum caráter”. O Globo: Rio de Janeiro, 08 de outubro de 1928. FBN - Periódicos. Recolhido em VÍTOR, Nestor. “Os de Hoje / Mário de Andrade / Macunaíma”. Obra crítica de Nestor Vítor. Rio de Janeiro: MEC / Fundação Casa de Rui Barbosa, 1973, v. II, p. 360-365. [1ª ed. 1938].

\footnotetext{
${ }^{4}$ No verso do recorte, que se encontra no álbum R.29 do IEB - Recortes de Mário de Andrade -, há indícios de que a cidade do Rio de Janeiro seja o local da publicação.
} 
José de Paula Ramos Jr.

\section{A $\mathbf{N}$ E X O}

Tese de doutoramento

“A fortuna crítica de Macunaíma: primeira onda (1928-1936)”

Área: Literatura Brasileira

Departamento de Letras Clássicas e Vernáculas

Faculdade de Filosofia, Letras e Ciências Humanas

Universidade de São Paulo

Orientadora

Profa. Dra. Therezinha Apparecida Porto Ancona Lopez

\section{SÃO PAULO}

2006 


\section{SUMÁRIO}

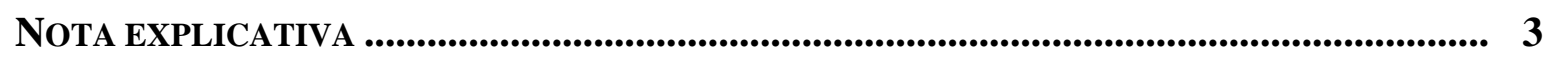

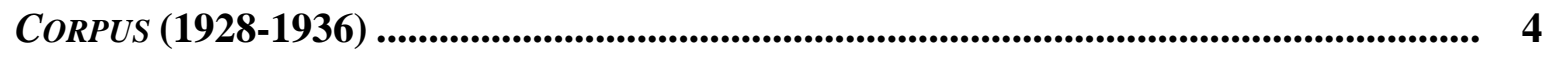

MATÉRIA AGREGADA: DOCUMENTOS, TEXTOS E NOTAS (1937-1954) ........................... 153

ORDENAÇÃO CRONOLÓGICA (1928-1954) ............................................................ 279

77 ANOS DE FORTUNA CRÍTICA DE MACUNAÍMA NO BRASIL (1928-2005) ........................ 286 ÍNDICE DA DOCUMENTAÇÃO

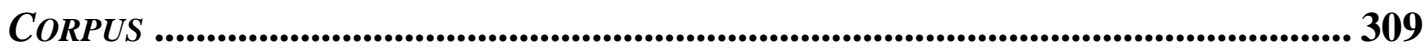

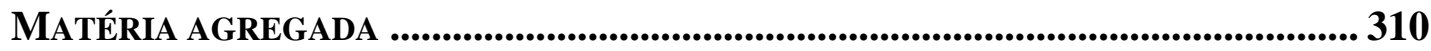




\section{NOTA EXPLICATIVA}

A documentação relativa ao período circunscrito entre 1928 e 1936 constitui o corpus da tese “A fortuna crítica de Macunaíma: primeira onda (1928-1936)”.

Este Anexo, porém, acolhe ainda pronunciamentos críticos sobre a rapsódia de Mário de Andrade publicados até 1954. Como “matéria agregada”, esta documentação se oferece a futuros estudos macunaímicos.

De 1928 a 1954, os documentos aqui coligidos foram localizados, copiados, conferidos e reproduzidos em arquivos de imagens digitalizadas e de textos transcritos (com atualização ortográfica) e anotados. As fontes primárias de alguns não foram localizadas pela pesquisa, no entanto, eles cá estão por intermédio de fontes secundárias que os recolheram. Não há registros de publicações nos anos de 1932, 1933, 1936, 1941, de 1947 a 1952 e 1954.

Acrescenta-se, por fim, a este Anexo a fortuna crítica de Macunaíma, de 1928 a 2005, em separata de vasta pesquisa inédita de Diléa Zanotto Manfio - sobre a fortuna crítica de Mário de Andrade -, preparada com a nossa colaboração.

\section{CONVENÇõES}

BDFSP: Banco de dados Folha de S. Paulo.

CAP-MP: Arquivo Carlos Alberto Passos - matéria em periódicos.

DZM: Arquivo particular da Profa. Dra. Diléa Zanotto Manfio.

FBN: Fundação Biblioteca Nacional.

FCL-CEDOC: Fundação Cásper Líbero - Centro de Documentação.

IEB-USP: Instituto de Estudos brasileiros - Universidade de São Paulo

MA-MP: Arquivo Mário de Andrade - matéria em periódicos. 


\section{CORPUS}

(1928 - 1936) 
1928 
[Diário Nacional. São Paulo, 07/08/1928. IEB - CAP-MP]

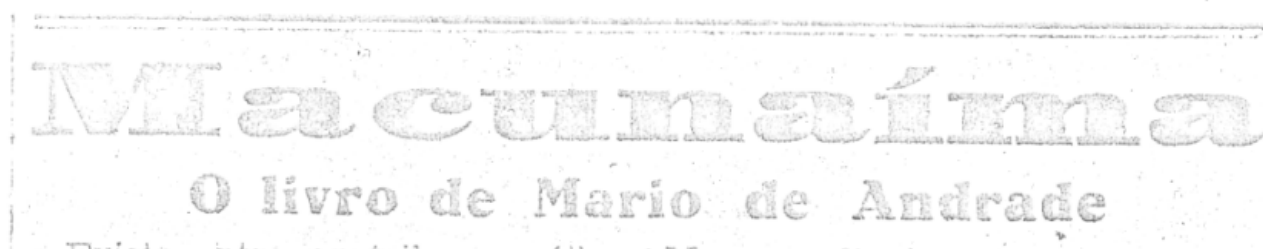

Existe entre as tribus caraibas I Mas un dia, a yara dum Iagõa do extremo norte da Amazonia, um encanta o heroe, ele se atira nacyclo de tradicões soore um heroe gua e os bichos da agua the rouchamado Macunaima. Essas tradi- bam de novo o talisman que ainda c5os lendarias foram reveladas por Koch-Griinjercr na sua obra monuInental, "Vom Roroima zum Oriroco". Aproveitando-se dos trabalhos de Hoch-Grüberg, Mario de Andrade teve a idéa clum romance em que satirisa certes defeitos do brusilciro. D'ai o titulo: "Macunaíma, o heroo sem nenhum caracter".

Como as tradiçoes cyclices sobre Macunaima sĩo em número diminuto, o autor se aproveita de cutras lendas brasileiras, fazendoas passar com o mesmo herve. Macuntima, depois da infancia passada no mocambo ratal, consegue amar a rainia das Amazonas e se torna por isso, imperador do Mato-Virgem. Forêm a esposa, dosgostosa com a morte do filho, abandona o imperador e vai para - ceu convertida numa estrela. Deixa ao espúso como lembranca uma muraquita, que da faliciade. Porem, o heroe a porde e, por varias circunstancias, o talisman va: parar nas nàos dum regatao, Venceslau Pietro Pietra, este enriauece por effeito do talisman e ven morar em S. Paulo. Macunaimer, tendo conhecimento do caso, vem a. S. Paulo buscar a pedra. A parte central do livro passa-se toda cm S. Putlo e Pio. Depois de muitas lutas curiosas, o heroe consegue rehaver a muiraguita e parte de novo para a terra natal. Mare so cacontra a solidio do deserto porgue a tribu morrera toda numa cidemia. Macunaima inda ve monerem os dois manos delle, com os quzes vicra para s. Peuto. Sozinio, o heroe vive enfarado e incapaz de organizar coisa alguma. o fazia viver feliz. O heroe procura rearir, porem lhe falta caracter para reorganizar a vida. M ıcunaima desgosta-se para sempre da terra, planta o cipó-escada e vai para o céo onde o Pai do Mutum (o Cruzeiro), a quem Macunaima defendera em s. Paulo, converte-o na constelação da Ursa Maior.

os casos tão curiosos que o heroe vivel estariam perdidos da memoria humana se näo fosse no fim da vida Macunaima ter-se acamaradado com um pagagaio aruai muito falador a quem contara tudo. E é com a scena de encontro entre o papagaio e o autor que o romance acaba.

E' um livro cheio de historias, onde o autor reuniu tambem copiosamente manifestaçōes de costumes, supersticões, proverbios, modismos vocabulares, frases-feitas e cacoetes brasileiros. E' uma san tira um pouco crua para poder cair nas müos de qualquer yessoa.

Eis os titulos dos capitulos: Macunaima; Maioridade; Ci, Mäi do Mato: Boiuna Luna; Piaimü; A Francesa e o Gigante; Macumba Vei, o Sol; Carta prás Icamiabas; Paui-Pódole; As tres Normalistas; A. Velha Ceinci; Teque-teque, Chupinzäo e a Injustiça dos Homens; A Piolhenta do Jiguê; Muiraquitâ; A. Pacuera de Oibê; Urariccera; Ursa Maior; Epilogo.

Este livro de Mario de Andrade ê uma das obras mais originaes da nossa literatura. Foi editada no "Estabelecimento Graphico Eugenio Cupolo" e apresenta um excellente aspecto typographico. Opportunamente, na seçĩo "Bibliogra" phia", sealysaremog o liyro.

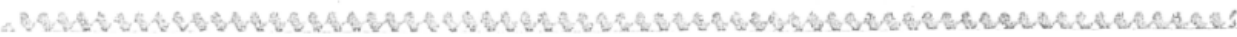




\section{Macunaíma. O livro de MÁrio de ANDrade}

S/A [Mário de Andrade]. "Macunaíma. O livro de Mário de Andrade”. Diário Nacional: São Paulo, 07 de agosto de $1928^{1}$. IEB-USP - CAP-MP.

Existe, entre as tribos caraíbas ${ }^{2}$ do extremo norte da Amazônia, um ciclo de tradições sobre um herói chamado Macunaíma. Essas tradições lendárias foram reveladas por KochGrünberg na sua obra monumental, Vom Roraima zum Orinoco. Aproveitando-se dos trabalhos de Koch-Grünberg, Mário de Andrade teve a idéia dum romance em que satiriza certos defeitos do brasileiro. Daí o título: “Macunaíma, o herói sem nenhum caráter”.

Como as tradições cíclicas sobre Macunaíma são em número diminuto, o autor se aproveita de outras lendas brasileiras, fazendo-as passar com o mesmo herói. Macunaíma, depois da infância passada no mocambo natal, consegue amar a rainha das Amazonas e se torna[,] por isso, imperador do Mato-Virgem. Porém a esposa, desgostosa com a morte do filho, abandona o imperador e vai para o céu convertida numa estrela. Deixa ao esposo como lembrança uma muiraquitã, que dá felicidade. Porém, o herói a perde e, por várias circunstâncias, o talismã vai parar nas mãos dum regatão, Venceslau Pietro Pietra. Este ${ }^{3}$ enriquece por efeito do talismã e vem morar em S. Paulo. Macunaíma, tendo conhecimento do caso, vem a S. Paulo buscar a pedra. A parte central do livro passa-se toda em S. Paulo e Rio. Depois de muitas lutas curiosas, o herói consegue reaver a muiraquitã e parte de novo para a terra natal. Mas só encontra a solidão do deserto porque a tribo morrera toda numa epidemia. Macunaíma inda vê morrerem os dois manos dele, com os quais viera para S. Paulo. Sozinho, o herói vive enfarado e incapaz de organizar coisa alguma. Mas um dia, a iara dum lagoão encanta o herói; ele se atira nágua e os bichos da água lhe roubam de novo o talismã que ainda o fazia viver feliz. $\mathrm{O}$ herói procura reagir, porém lhe falta caráter para reorganizar a vida. Macunaíma desgosta-se

\footnotetext{
${ }^{1}$ Em “A trajetória de um livro” Silviano Santiago aventa a hipótese de ser Mário de Andrade o autor do artigo. In: ANDRADE, Mário de. Macunaíma, o herói sem nenhum caráter. Edição crítica coordenada por Telê Porto Ancona Lopez. $2^{\mathrm{a}}$ ed., $1^{\mathrm{a}}$ reimp. Madrid: ALLCA XX; São Paulo: Scipione, 1997, p. 182-193. Coleccíon Archivos, 6. Esse ensaio foi recolhido em SANTIAGO, Silviano. Nas malhas da letra. São Paulo: Cia. das Letras. p. 124-139. $2^{\mathrm{a}}$ ed. Rio de Janeiro: Rocco, 2002, p. 145-163, com o título mudado para "História de um livro". Assumimos como correta a hipótese do crítico mineiro.

${ }^{2}$ No jornal, lê-se "caráibas". Os dicionários registram “caraíbas” ou "caribes”, vocábulos de origem tupi usados não no sentido de "homem branco", "feiticeiro" ou "coisa sagrada", mas como designações com as quais europeus do século XVI referiam-se a vários grupos étnicos indígenas, de mesma família lingüística e dispersos desde as Antilhas até o extremo norte do Brasil. Cf. Dicionário Houaiss eletrônico.

${ }^{3}$ No jornal, lê-se “(...) o talismã vai parar nas mãos dum regatão, Venceslau Pietro Pietra, este enriquece (...)”. Para maior clareza e coesão sintática, mudamos a pontuação.
} 
para sempre da terra, planta o cipó-escada e vai para o céu onde o Pai do Mutum (o Cruzeiro), a quem Macunaíma defendera em S. Paulo, converte-o na constelação da Ursa Maior.

Os casos tão curiosos que o herói viveu estariam perdidos da memória humana se não fosse no fim da vida Macunaíma ter-se acamaradado com um papagaio aruaí muito falador a quem contara tudo. E é com a cena de encontro entre o papagaio e o autor que o romance acaba.

É um livro cheio de histórias, onde o autor reuniu também copiosamente manifestações de costumes, superstições, provérbios, modismos vocabulares, frases feitas e cacoetes brasileiros. É uma sátira um pouco crua para poder cair nas mãos de qualquer pessoa.

Eis os títulos dos capítulos: Macunaíma; Maioridade; Ci, Mãe do Mato; Boiúna Luna; Piaimã; A Francesa e o Gigante; Macumba; Vei, a ${ }^{4}$ Sol; Carta pras Icamiabas; Pauí-Pódole; As três Normalistas ${ }^{5}$; A Velha Ceiuci; Teque-teque, Chupinzão e a Injustiça dos Homens; A Piolhenta do Jiguê; Muiraquitã; A Pacuera de Oibê; Uraricoera; Ursa Maior; Epílogo.

Este livro de Mário de Andrade é uma das obras mais originais da nossa literatura. Foi editada no “Estabelecimento Gráfico Eugênio Cupolo” e apresenta um excelente aspecto tipográfico. Oportunamente, na seção “Bibliografia”, analisaremos o livro.

S/A [Mário de Andrade]

\footnotetext{
${ }^{4}$ No jornal, lê-se: “o Sol”. Em Macunaíma, Mário de Andrade nomeia a divindade solar, Vei, no gênero feminino.

${ }^{5}$ Episódio suprimido por Mário de Andrade na 2ª edição de Macunaíma (1937).
} 
[O Jornal. Rio de Janeiro, 09/09/1928. Colunas 1, 2, 3 e 4. FBN - Periódicos]

\section{VIDA LITERARIA}

\section{Macunalma}

Ton commotter unit salincreblio

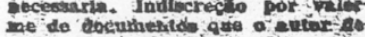

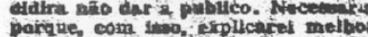
parque, com itoo, espllicarel melbo protelie = s cantasiatas.

Tratase ato nitimo livro do

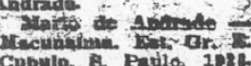

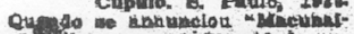

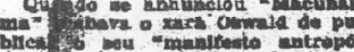

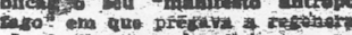

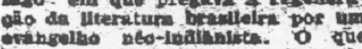

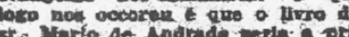

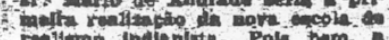

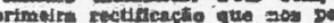
melttem os preshelos Ineditos, gy

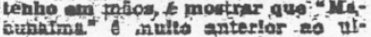
cutiafme is nutes anterlor - a dndracie, que passeta actualmente o Eeu Inailantamo pela belra do

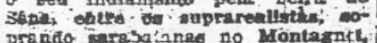
Jeborkdo. Kachiri., no Fouguets. iando entrowetia : Nouvolies It de 195 o nto-Indiandemo pati. annos antes. A primeira verelio fol

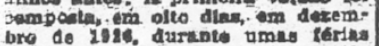
bro do 1928, duranto umis terika que o autor pusaava - "no melo Ararnquara" As dates qun we oncontran no ort

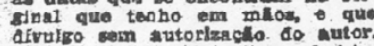
aivulio quaro que flque bema clara enih clr cymalancls. pars o. Ilvro. Achau a prlimelra ingurfaclente o segrundo muffelente da mails. O primeiro por ter sida emquanta ella the appareila como

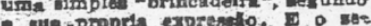
rundo, encripto em minico deste revno, depolt de Rnao o Itro. -

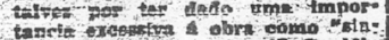

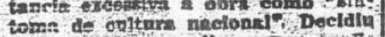

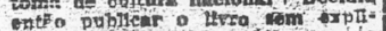

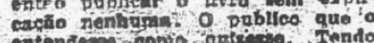
ontendor porim, millos por eirc"n-

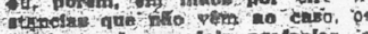
erighanes desses -dolin profacloy. paro is para entender in intencto do nato co para entender a tivral-o de quat. gror inilnuacto do plaglo, - roanibos os documentes.

\section{Then so atria thin}

Abto allow, parim, vastoe var.

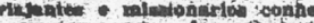

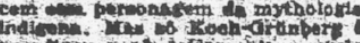

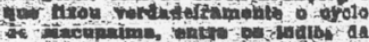

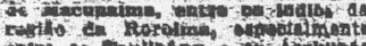

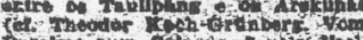

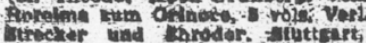
196. no rolum 20 as obs 8

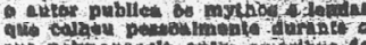

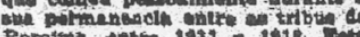
obrath de atatse 1921 o 1916.

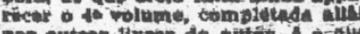
por outros livros do dutat, of otwe

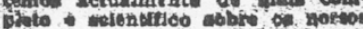
istiser ate).

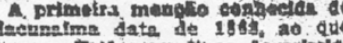

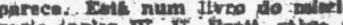

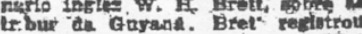
essa elgurz como sendo un "Bot De modo ot on miselonarios ptotentahtes, nil tritauoebes da Biblia

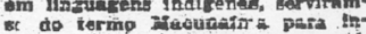
dicar a Dotu. . O mestra qua os ptio niciros misestomatou jesulíns risetrivia, porém, um srande entrano. cume um osplitito da bom o ulm o crimarar

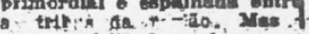

como cuplrito do mal, conno ombus tolro, trapacista enrededor sis - "O nome do mals elovado horro da tribu, Makunaima, contem como

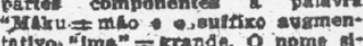
tativo "Ima" = Erapde. O nome almaflearla, portanto - o srakide ao - caractor nefanto e 1ntrífrante que to occuparin com o har 00 . vasunarma o main importento on. tre os irmitok. A flo se Junitam ors

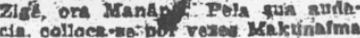

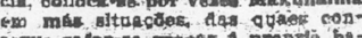
holice on tras, f um crande magleo. Flle fies T no corres do lliro, antilo, restaIra a autor, uma por ume an nven turas de Kacunating a seve Jrmhor. ram com o termo Tuphan, trovalo. Fru IrT रo male -yotho. Makuns tma, como todom eates hier6es triqua variam allas de terbu in tribu.
Wortunns, especialmente. Os tracos macr-parirt do noelso wertio.

cme tre as evențuras de Makunssuas lutas com o glgante anthropopharo Plaimi a wue mudhar. E Artinbers da is todo ose cyclo mytholostco umk siciniricachio astral, As oppoulgkio ontre o sol a a lun, ontro multo ethnolotos.

ar. Marlo e Andrada vamos encontrar como

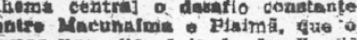
cusos ugit allaw a Lenda das. "Imul

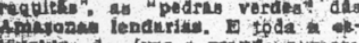
teuctur $d_{1}$ ivro erande numet

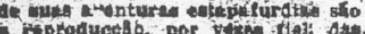

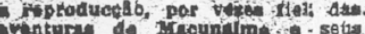
forlos om aum lita com a orfe

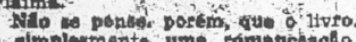
ormplesmente yme tomanceasho it teamento males coriplori, com Hario tudo o que tem telto $:$ si. Mario do Andirade, no sula buser

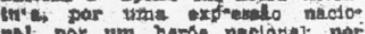
nal; por um herbo naclonal; por Qu ollo duta fazer, como consta primetramente do prefacio que asmo Intelo da abria.

"O que me intefensou por siadesembro As 1916. - "I01 Ineontektavelmente a prececupacajo om mall que posat a entidade niado polejar muito verietiques umi colse me parece que certa: a brapalavra ceracter não dotermipo Em ves, antendo a ontidade pal. quica permenente, ue manilfestando exterior, no costrumes, na scsas bem eomo no mal." Bm outros povos,

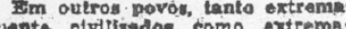
manto primitivos, entro of tranceroh, os mexicanos on on forubses. ve tra Eezes, por eivillzaçíno proprja, nos cario, nos pelo perrigo norte-ampri uma etvilisaéro primitlve. Man n68 trấ temos nadn disso. I thi, retes equo encontro umis nota a mar $\operatorname{sem}$ advertsndo - - tirar Toda rgikg. un 0 -eutor no contente to now negar caracier pajcholosd ols ésthetleo, nexa-nod tambem todo ratracos nessimintas, roalmente fnlupchjertivos, oomo. - " desanreen enitura verdidesfra, o improvinio. Ralta ne menso etnleo nan tamplian

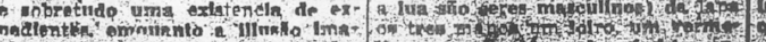

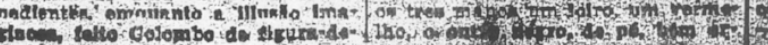


[O Jornal. Rio de Janeiro, 09/09/1928. Colunas 5, 6, 7 e 8. FBN - Periódicos]

\begin{tabular}{|c|c|c|c|}
\hline 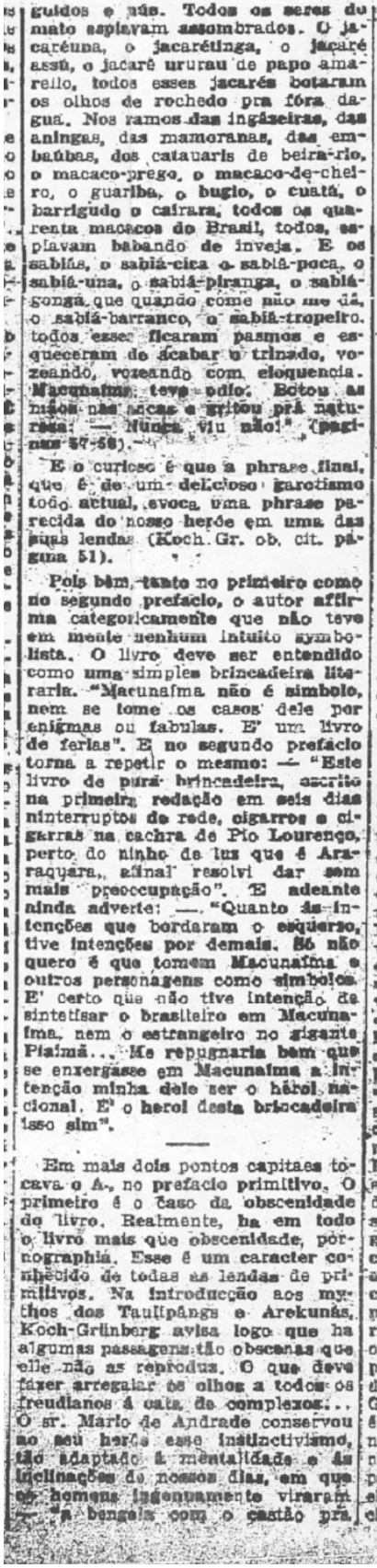 & 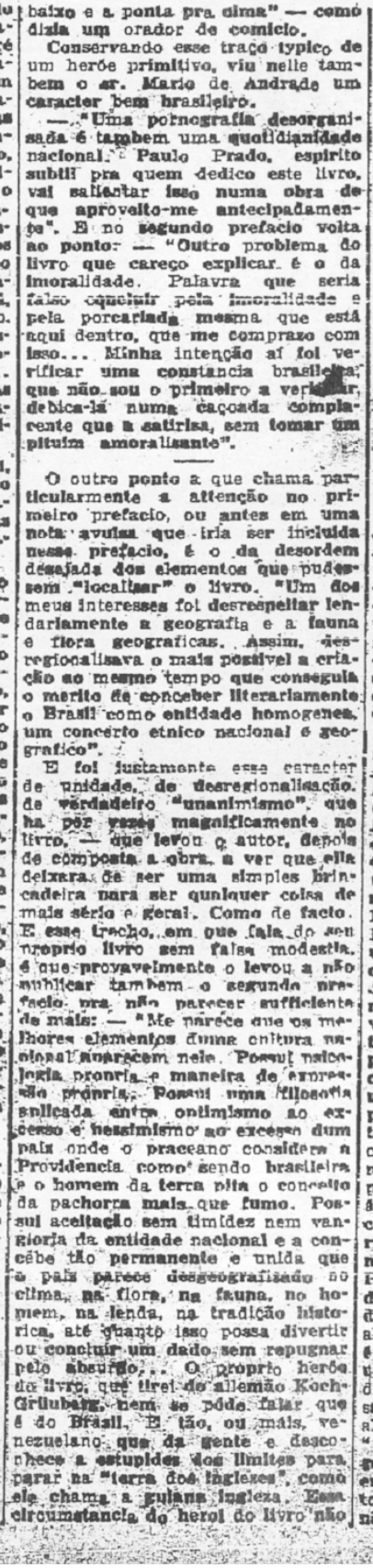 & 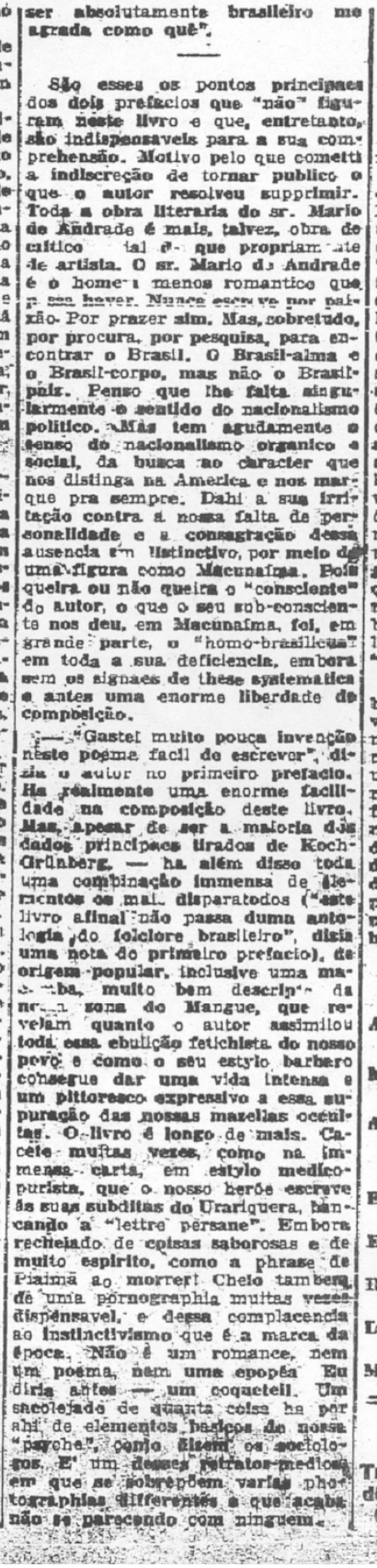 & 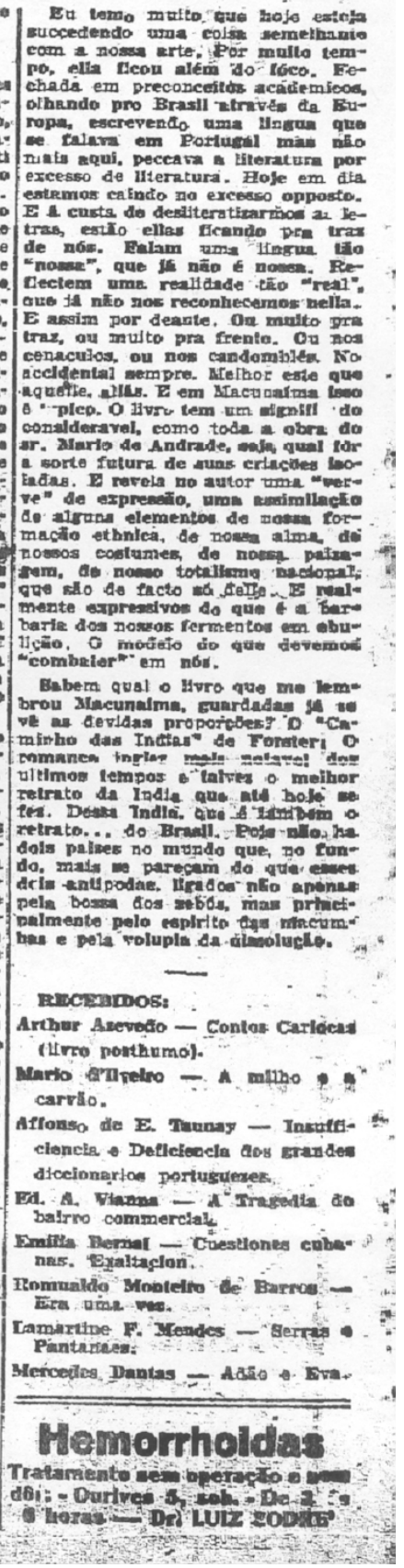 \\
\hline
\end{tabular}




\section{MacunAímA}

ATAíDE, Tristão de [Alceu Amoroso Lima]. "Macunaíma”. $O$ Jornal: Rio de Janeiro, 09 de setembro de 1928. FBN - Periódicos.

Vou cometer uma indiscrição necessária. Indiscrição por valer-me de documentos que o autor decidira não dar a público. Necessária porque, com isso, explicarei melhor uma obra que, de outra forma, se prestaria a interpretações as mais fantasistas.

Trata-se do último livro do sr. Mário de Andrade.

Mário de Andrade - Macunaíma. Est. Gr. E. Cupolo. S. Paulo, 1928.

Quando se anunciou Macunaíma, acabava o xará Oswald de publicar o seu "manifesto antropófago" em que pregava a regeneração da literatura brasileira por um evangelho neoindianista. O que logo nos ocorreu é que o livro do sr. Mário de Andrade seria a primeira realização da nova escola do realismo indianista. Pois bem, a primeira retificação que nos permitem os prefácios inéditos, que tenho em mãos, é mostrar que Macunaíma é muito anterior ao último manifesto do sr. Oswald de Andrade, que passeia atualmente o seu indianismo pela beira do Sena, entre os surrealistas, soprando zarabatanas no Montagnet, bebendo caxiri ${ }^{6}$ no Fouquet's e dando entrevistas às Nouvelles Littéraires.

É de 1928 o neo-indianismo paulista. Macunaíma, porém, é de dois anos antes. A primeira versão foi composta, em oito dias ${ }^{7}$, em dezembro de 1926, durante umas férias que o autor passava - "no meio de mangas, abacaxis, cigarras de Araraquara". A versão definitiva é de 28-12-26 a 13-1-27. São essas as datas que se encontram no original que tenho em mãos, e que divulgo sem autorização do autor. Quero que fique bem clara essa circunstância. $\mathrm{O}$ autor "arrependeu-se” dos dois prefácios que compôs para o livro. Achou o primeiro insuficiente e o segundo suficiente demais. O primeiro por ter sido escrito antes da obra pronta, e enquanto ela lhe aparecia como uma simples "brincadeira", segundo a sua própria expressão. E o segundo, escrito em março deste ano, depois de findo o livro - talvez por ter dado uma importância excessiva à obra como "sintoma de cultura nacional". Decidiu então publicar o livro sem explicação nenhuma. O público que o entendesse como quisesse. Tendo eu, porém, em

\footnotetext{
${ }^{6}$ No jornal, lê-se "Kachiri”.

${ }^{7}$ Segundo prefácio que Mário de Andrade escreveu para Macunaíma, mantendo-o inédito, e que Alceu Amoroso Lima teve em mãos, a obra foi escrita em seis dias: "Este livro de pura brincadeira, escrito na primeira redação em seis dias ininterruptos de rede, cigarros e cigarras na chácara de Pio Lourenço, perto do ninho de luz que é Araraquara...”. No entanto, num fragmento de manuscrito da rapsódia, pertencente ao IEB-USP - USP, Mário registrou entre 16 e 23 de dezembro de 1926 o período de composição da obra. Oito dias, portanto.
} 
mãos por circunstâncias que não vêm ao caso, os originais desses dois prefácios, e parecendome ambos indispensáveis, não só para entender a intenção do autor, como para livrá-lo de qualquer insinuação de plágio, - resolvo transcrever alguns trechos de ambos os documentos.

Antes disso, porém, vamos ver o que é Macunaíma. Há muito que os viajantes e missionários conhecem essa personagem da mitologia indígena. Mas só Koch-Grünberg é que fixou verdadeiramente o ciclo de Macunaíma, entre os índios da região de Roraima, especialmente entre os taulipangues e os arecunas ${ }^{8}$ (cf. Theodor Koch-Grünberg, Vom Roroima zum Orinoco, 5 vols. Verl. Strecker und Shröder. Stuttgart, 1924. É no volume 2 da obra que o autor publica mitos e lendas que colheu pessoalmente durante a sua permanência entre as tribos de Roraima, entre 1911 e 1918 . Esta obra, de que creio falta ainda aparecer o $4^{\circ}$ volume, completada aliás por outros livros do autor, é o que temos atualmente de mais completo e científico sobre os nossos indígenas).

A primeira menção conhecida de Macunaíma data de 1868, ao que parece. Está num livro do missionário inglês W. H. Brett, sobre as tribos da Guiana. Brett registrou essa figura como sendo um "Ser invisível, todo bondade e grandeza”. De modo que os missionários protestantes, nas traduções da Bíblia em linguagens indígenas, serviram-se do termo Macunaíma para indicar Deus. O mesmo que os missionários jesuítas fizeram com o termo Tupã, trovão. Havia, porém, um grande engano. Macunaíma não era de forma alguma um espírito do bem e sim o contrário. A sua importância era primordial e espalhada entre todas as tribos da região. Mas como espírito do mal, como embusteiro, trapacista e enredador. Eis o que nos informa Koch-Grünberg: - “O nome do mais elevado herói da tribo, Makunaíma, contém como partes componentes a palavra 'Maku' = mau e o sufixo aumentativo 'ima' = grande. O nome significaria, portanto - 'o grande malvado’, o que bem corresponde ao caráter nefasto e intrigante desse herói... Em todas as lendas que se ocupam com o herói, é Makunaíma o mais importante entre os irmãos. A ele se juntam ora Zigê ora Manãpe. Pela sua ausência, coloca-se por vezes Makunaíma em más situações, das quais consegue safar-se graças à própria habilidade ou graças à esperteza do seu irmão mais velho. Makunaíma, como todos esses heróis tribais, é um grande mágico. Ele transmuta homens em animais, ou vice-versa, ora por punição, ora por simples malvadez”. (ob. cit., p. 5). E no correr do livro, então, registra o autor, uma por uma, as aventuras de Macunaíma e seus irmãos, que variam aliás de tribo a tribo, embora sempre conservando traços comuns, especialmente os traços psicológicos desse antepassado do sacipererê do nosso sertão.

\footnotetext{
${ }^{8}$ No jornal, lê-se “(...)Taulipang e os Arekunás (...)”, nessa e em outras ocorrências.
} 
Entre as aventuras de Makunaíma figuram, em muitas lendas, as suas lutas com o gigante antropófago Piaimã e sua mulher. E Grünberg dá a todo esse ciclo mitológico uma significação astral, de oposição entre o sol e a lua, segundo a interpretação corrente entre muitos etnólogos.

Pois bem, no livro do sr. Mário de Andrade vamos encontrar como tema central o desafio constante entre Macunaíma e Piaimã, que o autor liga aliás à lenda das “muiraquitãs”, as “pedras verdes” das Amazonas lendárias. E toda a estrutura do livro e grande número de suas aventuras estapafúrdias são a reprodução, por vezes fiel, das aventuras de Macunaíma e seus irmãos, em suas lutas com o ogro ${ }^{9}$ Piaimã.

Não se pense, porém, que o livro é simplesmente uma romanceação de lendas amazônicas. É coisa infinitamente mais complexa, como aliás tudo que tem feito o sr. Mário de Andrade, na sua busca ansiosa e capital em nossa literatura, por uma expressão nacional, por um herói nacional, por uma cultura nacional. Vamos ver o que ele quis fazer, como consta primeiramente do prefácio que escreveu no início da obra.

“O que me interessou por Macunaíma” - escrevia ele então em dezembro de 1926 "foi incontestavelmente a preocupação em que vivo de trabalhar e descobrir o mais que possa a entidade nacional dos brasileiros. Ora, depois de pelejar muito verifiquei uma coisa me parece que certa: o brasileiro não tem caráter... E com a palavra caráter não determino apenas uma realidade moral, não. Em vez, entendo a entidade psíquica permanente, se manifestando por tudo, nos costumes, na ação exterior, no sentimento, na língua, na História, na andadura, tanto no bem como no mal."10

Em outros povos, tanto extremamente civilizados como extremamente primitivos, entre os franceses, os mexicanos ou os iorubas ${ }^{11}$, encontra ele essa personalidade que falta ao brasileiro. Nos franceses, por civilização própria, nos mexicanos pelo perigo norte-americano, nos iorubas ${ }^{12}$, pelos restos de uma civilização primitiva. Mas nós não temos nada disso. E aí, registra o autor alguns traços tão fortes que encontro uma nota à margem advertindo: - "tirar

\footnotetext{
${ }^{9}$ No jornal, lê-se: "ogre”.

${ }^{10}$ Na transcrição de BATISTA, Marta Rossetti et alii. Brasil: 1 o tempo modernista - 1917/29 - documentação. São Paulo: Instituto de Estudos Brasileiros - USP, 1972, p. 289: “(...) uma coisa que parece certa (...)”, em desacordo com o fac-símile que registra a mesma forma da transcrição de Tristão; na passagem “(...) não determino apenas uma realidade moral não em vez entendo a entidade psíquica permanente, se manifestando por tudo, nos costumes, na ação exterior no sentimento na língua na História na andadura, (...)”, em Brasil: 1o tempo modernista - 1917/29, respeita a pontuação que se verifica no fac-símile, enquanto a transcrição de Tristão intervém e a modifica.

${ }^{11}$ No jornal, lê-se: "jorubas".

${ }^{12}$ Idem.
} 
toda essa parte; não ir tanto às do cabo"13. É que o autor, não contente de nos negar caráter psicológico ou estético, nega-nos também todo caráter moral. Mas entre alguns traços pessimistas, realmente injustos, registra outros perfeitamente objetivos, como - “o desapreço à cultura verdadeira, o improviso, a falta de senso étnico nas famílias e sobretudo uma existência de expedientes, enquanto a ilusão imaginosa, feito Colombo de figura-de-proa, busca com olhos eloqüentes na terra um eldorado que não pode existir mesmo, entre panos de chãos e climas igualmente bons e ruins, dificuldades macotas que só a franqueza de aceitar a realidade poderia atravessar". ${ }^{14}$

Foi pensando em tudo isso que lhe caiu sob os olhos o livro do alemão. E lendo as aventuras do saci dos arecunas, verificou que Macunaíma era um herói - "surpreendentemente sem caráter”. Ora, isso coincidia exatamente com os resultados a que chegara em suas divagações pessimistas sobre os brasileiros. E lembrou-se então de aproveitar Macunaíma.

Para quem lê o livro a conclusão evidente é que Macunaíma é o brasileiro de hoje, como Venceslau Pietro Pietra, nome paulistano do gigante Piaimã, é o imigrante. É fácil encontrar numerosos trechos em que as alusões são transparentes. Cito apenas um. É quando o nosso herói, tendo sabido que a sua muiraquitã perdida está em S. Paulo, em poder do gigante Piaimã, resolve largar das margens do Uraricoera para vir correr mundo atrás da pedra encantada, que lhe permitirá reaver a sua Ci perdida. O primeiro cuidado do herói foi se aliviar da consciência.

— "No outro dia Macunaíma pulou cedo na ubá e deu uma chegada até a foz do rio Negro pra deixar a consciência na ilha de Marapatá. Deixou-a bem na ponta dum mandacaru de dez metros, pra não ser comida pelas saúvas”. E veio, juntamente, com os irmãos Araguaia arriba. Um dia, querendo tomar banho, e com medo das piranhas do rio, encontrou "numa lapa bem no meio do rio uma cova cheia dágua... Mas a água era encantada porque aquele buraco na lapa era marca do pézão do Sumé, do tempo em que andava pregando o evangelho de Jesus pra indiada brasileira. Quando o herói saiu do banho estava branco loiro e de olhos azuizinhos, água lavara o pretume dele”. Quando os irmãos viram aquilo também quiseram virar brancos. Primeiro entrou o Jiguê, mas - “a água já estava muito suja da negrura do herói

\footnotetext{
${ }^{13}$ Em BATISTA, Marta Rossetti et alii. Op. cit., loc. cit.: "Tirar toda esta parte e talvez não ir tanto às do cabo.” No fac-símile, idem.

${ }^{14}$ Em BATiSTA, Marta Rossetti et alii. Op. cit., loc. cit.: “(...) o desapreço à cultura verdadeira, o improviso, a falta de senso étnico nas famílias. E sobretudo uma existência (improvisada) no expediente (?) enquanto a ilusão imaginosa feito Colombo de figura-de-proa busca com olhos eloquentes na terra um Eldorado que não pode existir mesmo, entre panos de chãos e climas igualmente bons e ruins, dificuldades macotas que só a franqueza de aceitar a realidade, poderia atravessar." No fac-símile, idem, exceto o vocábulo "eldorado”, grafado em minúsculas.
} 
e por mais que Jiguê esfregasse feito maluco, atirando água pra todos os lados, só conseguiu ficar da cor do bronze novo”. Quando Manape foi tomar banho, só havia um pouco dágua no fundo e - "Manape conseguiu molhar só a palma dos pés e das mãos. Por isso ficou negro bem filho da tribo Tapanhumas. Só que as palmas das mãos e dos pés dele são vermelhas por terem se limpado na água santa”. E os três irmãos, num quadro magnífico de expressão literária, em ritmo poético bárbaro, de grande efeito, aparecem então como um símbolo transparente do Brasil:

— "E estava lindíssimo na Sol (o sr. Mário de Andrade feminiza sempre o Sol, quando na mitologia amazônica tanto o Sol como a lua ${ }^{15}$ são seres masculinos) da lapa os três manos um loiro um vermelho outro negro, de pé bem erguidos e nus. Todos os seres do mato espiavam assombrados. O jacareúna o jacaretinga o jacaré-açu o jacaré-ururau de papo amarelo, todos esses jacarés botaram os olhos de rochedo pra fora dágua. Nos ramos das ingazeiras das aningas das mamoranas das embaúbas dos catauaris de beira-rio o macaco-prego o macacode-cheiro o guariba o bugio o cuatá o barrigudo o coxiú o cairara, todos os quarenta macacos do Brasil, todos, espiavam babando de inveja. E os sabiás, o sabiacica o sabiapoca o sabiaúna o sabiapiranga o sabiagongá que quando come não me dá, o sabiá-barranco o sabiá-tropeiro, todos esses ficaram pasmos e esqueceram de acabar o trinado, vozeando, vozeando com eloqüência. Macunaíma teve ódio. Botou as mãos nas ancas e gritou pra natureza: - Nunca viu não!” (páginas 57-58).

E o curioso é que a frase final, que é um delicioso garotismo todo atual, evoca uma frase parecida do nosso herói em uma das suas lendas (Koch-Gr., ob. cit., página 51).

Pois bem, tanto no primeiro como no segundo prefácio, o autor afirma categoricamente que não teve em mente nenhum intuito simbolista. O livro deve ser entendido como uma simples brincadeira literária. "Macunaíma não é símbolo, nem se tome os casos dele por enigmas ou fábulas. É um livro de férias”. E no segundo prefácio torna a repetir o mesmo: “Este livro de pura brincadeira, escrito na primeira redação em seis dias ininterruptos de rede, cigarros e cigarras na chácara de Pio Lourenço, perto do ninho de luz que é Araraquara, afinal resolvi dar sem mais preocupação"16. E adiante ainda adverte: - "Quanto às intenções que bordaram o esquerzo ${ }^{17}$, tive intenções por demais. Só não quero é que tomem Macunaíma e outros personagens como símbolos. É certo que não tive intenção de sintetizar o brasileiro em

\footnotetext{
${ }^{15}$ T. de A. grafa "Sol” com maiúscula inicial, mas escreve "lua” com minúscula.

${ }^{16}$ Em BAtista, Marta Rossetti et alii. Op. cit., lê-se “...chacra...” e "ninho da luz”, assim como no fac-símile.

17 "Scherzo": brincadeira; música: peça em estilo ligeiro e vivaz.
} 
Macunaíma, nem o estrangeiro no gigante Piaimã... Me repugnaria bem que se enxergasse em Macunaíma a intenção minha dele ser o herói nacional. É o herói desta brincadeira isso sim”.

Em mais dois pontos capitais tocava o A. no prefácio primitivo. O primeiro é o caso da obscenidade do livro. Realmente, há em todo o livro mais que obscenidade, pornografia. Esse é um caráter conhecido de todas as lendas de primitivos. Na introdução aos mitos taulipangues e arecunas, Koch-Grünberg avisa logo que há algumas passagens tão obscenas que ele não as reproduz. O que deve fazer arregalar os olhos a todos os freudianos à cata de complexos... O sr. Mário de Andrade conservou no seu herói esse instintivismo, tão adaptado à mentalidade e às inclinações de nossos dias, em que os homens ingenuamente viraram - "a bengala com castão pra baixo e a ponta pra cima” - como dizia um orador de comício.

Conservando esse traço típico de um herói primitivo, viu nele também o sr. Mário de Andrade um caráter bem brasileiro.

- "Uma pornografia desorganizada é também uma ${ }^{18}$ cotidianidade nacional. Paulo Prado, espírito sutil para quem dedico este livro, vai salientar isso numa obra ${ }^{19}$ de que aproveito-me antecipadamente”. E no segundo prefácio volta ao ponto: - “Outro problema do livro que careço explicar é o da imoralidade. Palavra que seria falso concluir pela imoralidade e pela porcariada mesma que está aqui dentro, que me comprazo com isso... Minha intenção aí foi verificar uma constância brasileira que não sou o primeiro a verificar, debicá-la numa caçoada complacente que a satiriza sem tomar um pitium moralizante”20.

O outro ponto a que chama particularmente a atenção no primeiro prefácio, ou antes em uma nota avulsa que iria ser incluída nesse prefácio, é o da desordem desejada dos elementos que pudessem "localizar" o livro. "Um dos meus interesses foi desrespeitar lendariamente a geografia e a fauna e flora geográficas. Assim, desregionalizava o mais possível a criação ao mesmo tempo que conseguia o mérito de conceber literariamente o Brasil como entidade homogênea ${ }^{21}=$ um concerto étnico nacional e geográfico”.

\footnotetext{
${ }^{18}$ Em BAtistA, Marta Rossetti et alii. Op. cit., p. 290: “(...) também da cotidianidade (...)”. Assim também o facsímile.

${ }^{19}$ Trata-se de PRADO, Paulo. Retrato do Brasil: Ensaio sobre a tristeza brasileira. São Paulo: Duprat Mayença, 1928.

${ }^{20}$ No jornal, lê-se “... pituim amoralizante”. No manuscrito de Mário, p. 6, lê-se “... pitium moralizante”. Pituim e pitium são variantes lingüísticas que significam mau odor, catinga, fedor. Aqui, a transcrição errônea do manuscrito não traz problema, mas, quando escreve "amoralizante" em vez de "moralizante", Tristão de Ataíde deforma - voluntária ou involuntariamente? - o discurso de Mário de Andrade, dando-lhe sentido oposto. No entanto, é possível que o engano tenha sido do tipógrafo. Cf.: ANDRADE, Mário de. Macunaíma o herói sem nenhum caráter. Ed. crítica de Telê Porto Ancona Lopez, 1997, p. 467: fac-símile de manuscrito de Mário de Andrade para o segundo prefácio.

${ }^{21}$ No jornal, lê-se “...entidade homogênea, um concerto étnico nacional e geográfico”. Em vez de vírgula, o facsímile (Ed. crítica cit., 1997) registra o sinal de igualdade.
} 
E foi justamente esse caráter de unidade, de desregionalização, de verdadeiro "unanimismo”, que há por vezes magnificamente no livro - que levou o autor, depois de composta a obra, a ver que ela deixara de ser uma simples brincadeira para ser qualquer coisa de mais séria e geral. Como de fato. E esse trecho, em que fala de seu próprio livro sem falsa modéstia, é que provavelmente o levou a não publicar também o segundo prefácio pra não parecer suficiente demais: - "Me parece que os melhores elementos duma cultura nacional aparecem nele. Possui psicologia própria e maneira de expressão própria. Possui uma filosofia aplicada entre otimismo ao excesso e pessimismo ao excesso dum país onde o praciano ${ }^{22}$ considera a Providência como sendo brasileira e o homem da terra pita o conceito da pachorra mais que fumo. Possui aceitação sem timidez nem vanglória da entidade nacional e a concebe tão permanente e unida que o país parece desgeografizado no clima, na flora, na fauna, no homem, na lenda, na tradição histórica, até quanto isso possa divertir ou concluir um dado sem repugnar pelo absurdo... O próprio herói do livro, que tirei do alemão Koch-Grünberg, nem se pode falar que é do Brasil. É tão, ou mais, venezuelano que da gente e desconhece a estupidez dos limites para parar na "terra dos ingleses”, como ele chama a Guiana Inglesa ${ }^{23}$. Essa circunstância do herói do livro não ser absolutamente brasileiro me agrada como quê”.

São esses os pontos principais dos dois prefácios que “não” figuram neste livro e que, entretanto, são indispensáveis para a sua compreensão. Motivo pelo que cometi a indiscrição de tornar público o que o autor resolveu suprimir. Toda a obra literária do sr. Mário de Andrade é mais, talvez, obra de crítico social do que propriamente de artista. O sr. Mário de Andrade é o homem menos romântico que possa haver. Nunca escreve por paixão. Por prazer sim. Mas, sobretudo, por procura, por pesquisa, para encontrar o Brasil. O Brasil-alma e o Brasil-corpo, mas não o Brasil-país. Penso que lhe falta singularmente o sentido do nacionalismo político. Mas tem agudamente o senso de nacionalismo orgânico e social, da busca ao caráter que nos distinga na América e nos marque para sempre. Daí a sua irritação contra a nossa falta de personalidade e a consagração dessa ausência em distintivo, por meio de uma figura como Macunaíma. Pois queira ou não queira o "consciente” do autor, o que o seu subconsciente nos deu, em Macunaíma, foi, em grande parte, o “homo-brasilicus” em toda a sua deficiência, embora sem os sinais de tese sistemática e antes uma enorme liberdade de composição.

\footnotetext{
${ }^{22}$ No jornal, lê-se "praceano”. Na transcrição de BATISTA, Marta Rossetti et alii, bem como no fac-símile da página 2 do manuscrito (Ed. crítica cit., 1997, p. 459), lê-se: “(...) dum país bem onde o praceano (...)”.

${ }^{23}$ No jornal, lê-se "guiana inglesa”, em letras minúsculas.
} 
- “Gastei muito pouca invenção neste poema fácil de escrever”, dizia o autor no primeiro prefácio. Há realmente uma enorme facilidade na composição deste livro. Mas, apesar de ser a maioria dos dados principais tirados de Koch-Grünberg - há além disso toda uma combinação imensa de elementos os mais disparatados (“este livro afinal não passa duma antologia do folclore brasileiro”, dizia uma nota do primeiro prefácio), de origem popular, inclusive uma macumba, muito bem descrita da nossa zona do Mangue, que revelam quanto o autor assimilou toda essa ebulição fetichista do nosso povo e como o seu estilo bárbaro consegue dar uma vida intensa e um pitoresco expressivo a essa supuração das nossas mazelas ocultas. O livro é longo demais. Cacete muitas vezes como na imensa carta, em estilo médicopurista, que o nosso herói escreve às suas súditas do Uraricoera, bancando a "lettre pérsane”24. Embora recheado de coisas saborosas e de muito espírito, como a frase de Piaimã ao morrer! Cheio também de uma pornografia muitas vezes dispensável, e dessa complacência ao instintivismo que é a marca da época. Não é um romance, nem um poema, nem uma epopéia. Eu diria antes - um coquetel ${ }^{25}$. Um sacolejado de quanta coisa há por aí de elementos básicos de nossa "psyche”, como dizem os sociólogos. É um desses retratos médios, em que se sobrepõem várias fotografias diferentes e que acaba não se parecendo com ninguém.

Eu temo muito que hoje esteja sucedendo uma coisa semelhante com a nossa arte. Por muito tempo, ela ficou além do foco. Fechada em preconceitos acadêmicos, olhando pro Brasil através da Europa, escrevendo uma língua que se falava em Portugal mas não mais aqui, pecava a literatura por excesso de literatura. Hoje em dia estamos caindo no excesso oposto. E à custa de desliteratizarmos as letras, estão elas ficando pra trás de nós. Falam uma língua tão “nossa”, que já não é nossa. Refletem uma realidade tão “real”, que já não nos reconhecemos nela. E assim por diante. Ou muito pra trás, ou muito pra frente. Ou nos cenáculos, ou nos candomblés. No acidental sempre. Melhor este que aquele, aliás. E em Macunaíma isso é típico. O livro tem um significado considerável como toda obra do sr. Mário de Andrade, seja qual for a sorte futura de suas criações isoladas. E revela no autor uma "verve” de expressão, uma assimilação de alguns elementos de nossa formação étnica, de nossa alma, de nossos costumes, de nossa paisagem, de nosso totalismo nacional, que são de fato só dele. E realmente expressivos do que é a barbaria dos nossos fermentos em ebulição. O modelo do que devemos “combater” em nós.

\footnotetext{
${ }^{24}$ Alusão ao romance epistolar Lettres persanes, 1721, de Montesquieu.

${ }^{25}$ No jornal, lê-se “coqueteil”.
} 
Sabem qual o livro que me lembrou Macunaíma, guardadas já se vê as devidas proporções? O Caminho das Índias de Forster. O romance inglês mais notável dos últimos tempos e talvez o melhor retrato da Índia que até hoje se fez. Dessa Índia, que é também o retrato... do Brasil. Pois não há dois países no mundo que, no fundo, mais se pareçam do que esses dois antípodas, ligados não apenas pela bossa dos zebus, mas principalmente pelo espírito das macumbas e pela volúpia da dissolução.

TRISTÃO DE ATAÍDE 


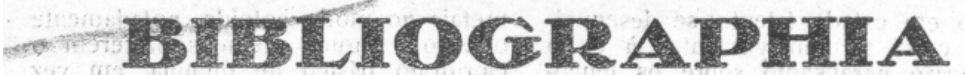

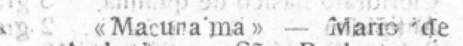
0. Andradie. Sä́o Paulo.

O sr. Mario des Andrade contou uma historia p'ra gente grande, da mesma maneira que elle poderia chamar uma porção de gurys que estavam jogando guide, e sapecar uma daquellas, historias compridas que continuam no dia seguinte. A gente gosa tanto essas historias que fica damnadio quando se interrompe, então eu não ine lembro quando eu era mais menor e finha o sa Cotinho pira me contar historias?

$O$ sr. Mario de Andrade ganhou de todo o pessoal que andou contando historia nestes ultimos tempos, ganhou delle mesmo $\rightarrow$ é a mais linda de todas ellas "Macunaima" que quando se arrota lembra-se da "Paulicéa" (Chi) os pautistas devem estar queimados com aquella carta).

com aquella carta). caracter, o heroe da nossa gente Não brinca commigo não que meu patrono é Obatalá

S.erá que Macuinaima soinos nós todos? deixem de tapeacão pessoal qué ás vezes" a génté nằ, póde cuizer que não.

Eu contieço um cabra que só pensa em brincar, outro só mente outro só embrulha e outro só ri quando se conta ... unía vez uma moça vinha, num trern e... quá quá quá pois não e todos esses, (e que baita turma) são Macumaima.

Agora, ás vezes se pansa no «eu» completamente abstracto (apezar de uns psychologos dizerem que é impossivel) então sim Macunaima cae fóra e fiza um bamba, de mojo que... O bicho está bem retratado até os tres adiviahas não falton, $A$ xingação que - Wencesláu Pietro Pietra levou é typico,

$\mathrm{O}$ norte viru a cabeca do sr. Mario de Andrade. Aqualle passeio delle no Amazonas rendeu, tudo se aproveitou até o negocio de deixar a consciencia na itha de Marapatá...

E' a historia do folk-lore e dos ditos populares quer coisa melhor que as nossas falas que ensinam o que os outros sabios estão estudando para saber, veja-se: - "Quem é bom jâ nasce feito" (Mendel, Morgan etc). "Quem tiver mulher bonita e egua eaxita que não leve ellas na cidadia porque fioa sem mulher e a egua caxita desapriarece de noite...» (Freud etc.

São dessas coisas assim que o livro está cheio e anda tão esprarramado tudo isso e uninguem aproveita.
O snr. Mario de Andrade fez um grande trabalho de construcção mesmo "Macunaima » fechou o tempo.

A vacea victoria entrou por uma porta e sahiu por outra quem quizer que conte outra.

$$
\text { J. P. : }
$$

"Luc Durlain - L'Outre Europe. (Mosco: et sa foi). Parts rope. 1928 .

Luc Durtain é talvez o mais interessante dos chronistas de viagem Jornalista nomade, viajando sempre a procura de factos novos, dá-nos agora as suas impressões da Russia.

E' muito difficil escrever sem paixão sobre a Russia.

O drama ciessa nacionalidade existe latente em todos os paizes, dahi a parcialidade dos juizos que sobre ella se formain. Elatretanto podemos affirmar que Luc Durtain fugiu tanto quainto possivel á regra, e deu-nos quanto possivel a

Semcellente fivro de impressoes.

Sem a preoccupação de louvar ou combater as instituições sovieticas, Durtain expoz em synthese minuciosa os aspectos mais palpitantes da nova Russia.

A impressão que se tem com a leitura desse livro é uma impressão de equilibrio Durtain não critica, nâo affirma isto é bom aquillo é máo. affirma isto é bom, aquillo é máo. juncto complexo a Russia viva, objectiva, afogando todas as miserias das 


\section{“MACUnAímA” - Mário de ANdRAde - SÃo PAUlo}

J. P. [João Pacheco]. “Bibliografia / 'Macunaíma' - Mário de Andrade - São Paulo”. Folha Acadêmica: Rio de Janeiro, 13 de setembro de 1928, p. 484. IEB-USP MA-MP.

O sr. Mário de Andrade contou uma história pra gente grande, da mesma maneira que ele poderia chamar uma porção de guris que estavam jogando gude, e sapecar uma daquelas histórias compridas que continuam no dia seguinte. A gente goza tanto essas histórias que fica danado quando se interrompe, então eu não me lembro quando eu era mais menor e tinha o sa Cotinho pra me contar histórias?

O sr. Mário de Andrade ganhou de todo o pessoal que andou contando história nestes últimos tempos, ganhou dele mesmo - é a mais linda de todas elas Macunaíma que quando se arrota lembra-se da Paulicéia $^{26}$ (Chi! Os paulistas devem estar queimados com aquela $\left.\operatorname{ta}^{27}\right)$.

— Eu sou Macunaíma, o herói sem caráter, o herói da nossa gente.

Não brinca comigo não que meu patrono é Obatalá ${ }^{28}$.

Será que Macunaíma somos nós todos? Deixem de tapeação pessoal que às vezes a gente não pode dizer que não.

Eu conheço um cabra que só pensa em brincar, outro só mente outro só embrulha e outro só ri quando se conta... uma vez uma moça vinha, num trem e... quá quá quá pois não e todos esses (e que baita turma) são Macunaíma.

Agora, às vezes se pensa no “eu” completamente abstrato (apesar de uns psicólogos dizerem que é impossível) então sim Macunaíma cai fora e fica um bamba, de modo que... O bicho está bem retratado até os três adivinhas não faltou. A xingação que o Venceslau Pietro Pietra levou é típico.

O norte virou a cabeça do sr. Mário de Andrade. Aquele passeio dele no Amazonas ${ }^{29}$ rendeu, tudo se aproveitou até o negócio de deixar a consciência na ilha de Marapatá...

\footnotetext{
${ }^{26}$ Referência ao livro Paulicéia desvairada, de Mário de Andrade.

${ }^{27}$ Referência à “Carta pras Icamiabas”, capítulo IX de Macunaíma.

${ }^{28}$ No mito ioruba, é a divindade criadora. Também chamado Oxalá. Na religiosidade afro-brasileira, é, sincreticamente, associado a Jesus Cristo.
} 
É a história do folclore e dos ditos populares quer coisa melhor que as nossas falas que ensinam o que os outros sábios estão estudando para saber, veja-se: — “Quem é bom já nasce feito” (Mendel, Morgan etc.). “Quem tiver mulher bonita e égua caxita que não leve elas na cidade porque fica sem mulher e a égua caxita desaparece de noite...” (Freud etc.).

São dessas coisas assim que o livro está cheio e anda tão esparramado tudo isso e ninguém aproveita.

O sr. Mário de Andrade fez um grande trabalho de construção mesmo: Macunaíma fechou o tempo.

A vaca vitória entrou por uma porta e saiu por outra quem quiser que conte outra.

J. P. [JOÃO PACHECO]

\footnotetext{
${ }^{29}$ Referência à viagem de Mário de Andrade ao norte do Brasil, em 1927, relatada em ANDRADE, Mário de. $O$ turista aprendiz. Estabelecimento de texto, introdução e notas de Telê Porto Ancona Lopez. $1^{\mathfrak{a}}$ ed. São Paulo: Duas Cidades / Secretaria Ciência, Cultura e Tecnologia, 1976.
} 
[Cândido Mota Filho. Correio Paulistano. São Paulo, 20/09/1928. IEB - CAP-MP]

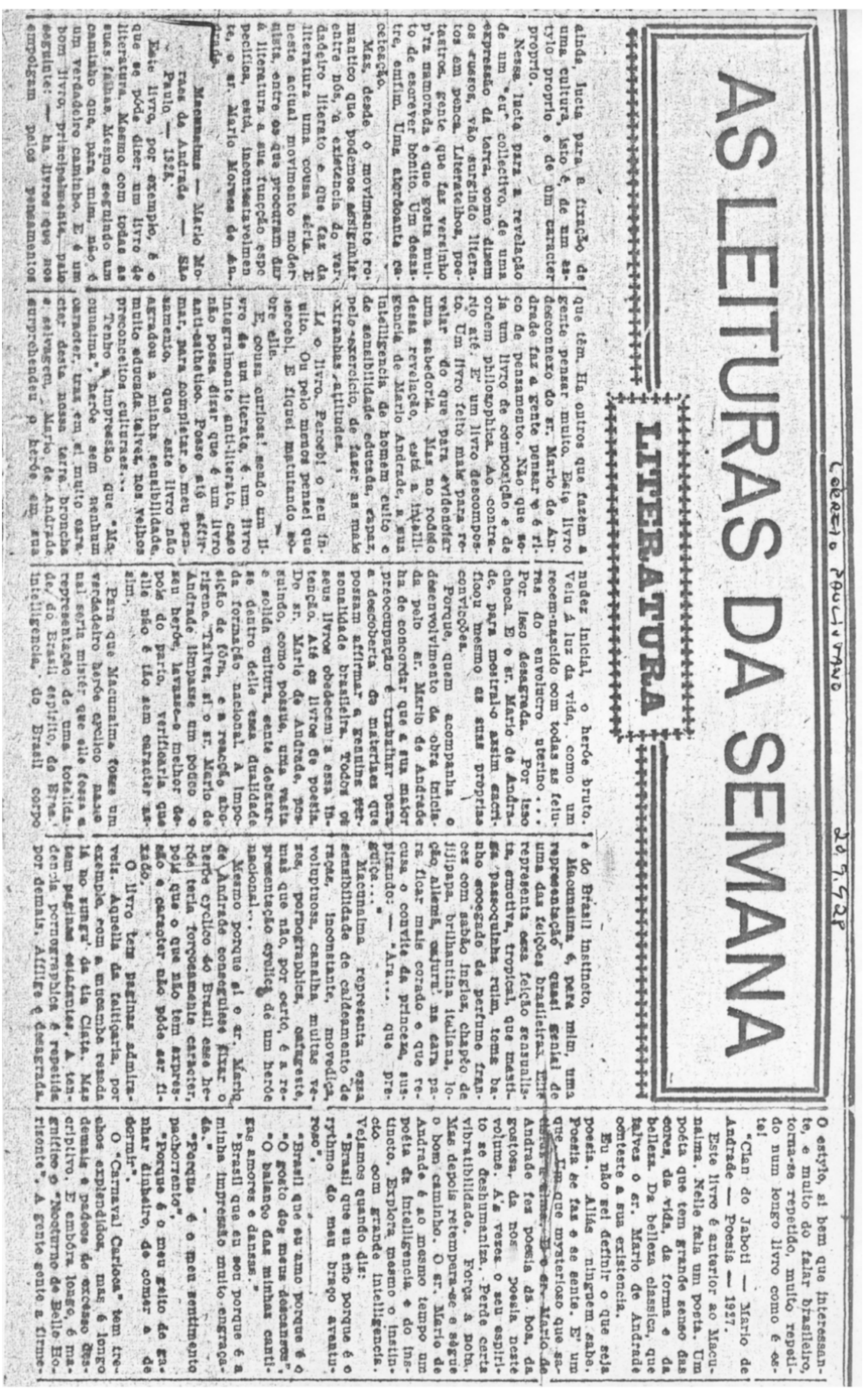




\title{
Macunaíma - MÁrio Moraes de ANdrade - SÃo PAUlo - 1928
}

\author{
MotTA FilHo, Cândido. “As leituras da semana / Litera- \\ tura / Macunaíma - Mário Moraes de Andrade - São \\ Paulo - 1928”. Correio Paulistano: São Paulo, 20 de se- \\ tembro de 1928. IEB-USP - CAP-MP.
}

Este livro, por exemplo, é o que se pode dizer um livro de literatura. Mesmo com todas as suas falhas. Mesmo seguindo um caminho que, para mim, não é um verdadeiro caminho. E é um bom livro, principalmente pelo seguinte: - há livros que nos empolgam pelos pensamentos que têm. Há outros que fazem a gente pensar muito. Este livro desconexo do sr. Mário de Andrade faz a gente pensar e é rico de pensamento. Não que seja um livro de composição e de ordem filosófica. Ao contrário até. É um livro descomposto. Um livro feito mais para revelar do que para evidenciar uma sabedoria. Mas, no rodeio dessa revelação, está a inteligência de Mário de Andrade, a sua inteligência de homem culto e de sensibilidade educada, capaz, pelo exercício, de fazer as mais estranhas atitudes.

Li o livro. Percebi o seu intuito. Ou pelo menos pensei que percebi. E fiquei matutando sobre ele.

E, cousa curiosa! sendo um livro de um literato, é um livro integralmente antiliterato, caso não possa dizer que é um livro antiestético. Posso até afirmar, para completar o meu pensamento, que este livro não agradou a minha sensibilidade, muito educada, talvez, nos velhos preconceitos culturais...

Tenho a impressão que Macunaíma, herói sem nenhum caráter, traz em si muito caráter desta nossa terra bronca e selvagem. Mário de Andrade surpreendeu o herói em sua nudez inicial, o herói bruto. Veio à luz da vida, como um recém-nascido com todas as feiúras do invólucro uterino... Por isso desagrada. Por isso choca. E o sr. Mário de Andrade, para mostrá-lo assim[,] sacrificou mesmo as suas próprias convicções.

Porque, quem acompanha o desenvolvimento da obra iniciada pelo sr. Mário de Andrade há de concordar que a sua maior preocupação é trabalhar para a descoberta de materiais que possam afirmar a genuína personalidade brasileira. Todos os seus livros obedecem a essa intenção. Até os livros de poesia. Do sr. Mário de Andrade, possuindo, como possui, uma vasta e sólida cultura, sente debater-se dentro dele essa dualidade da formação nacional. A 
imposição de fora, e a reação aborígine. Talvez, se o sr. Mário de Andrade limpasse um pouco o seu herói, lavasse-o melhor depois do parto, verificaria que ele não é tão sem caráter assim.

Para que Macunaíma fosse um verdadeiro herói cíclico nacional seria mister que ele fosse a representação de uma totalidade do Brasil espírito, do Brasil inteligência, do Brasil corpo e do Brasil instinto.

Macunaíma é, para mim, uma representação quase genial de uma das feições brasileiras. Ele representa essa feição sensualista, emotiva, tropical, que mastiga paçoquinha ruim, toma banho sossegado de perfume francês com sabão inglês, chapéu de jijipapa, brilhantina italiana, loção alemã, cajuru na cara para ficar mais corado e que recusa o convite da princesa, suspirando: - “Ara... que preguiça...”

Macunaíma representa essa sensibilidade de caldeamento de raças, inconstante, movediça, voluptuosa, canalha muitas vezes, pornográfica, cafajeste, mas que não, por certo, é a representação cíclica de um herói nacional...

Mesmo porque se o sr. Mário de Andrade conseguisse fixar o herói cíclico do Brasil esse herói teria forçosamente caráter, pois que o que não tem expressão e caráter não pode ser fixado.

O livro tem páginas admiráveis. Aquela da feitiçaria, por exemplo, com a macumba rezada lá no zungu da tia Ciata. Mas tem páginas estafantes. A tendência pornográfica é repetida por demais. Aflige e desagrada. O estilo, se bem que interessante, e muito do falar brasileiro, torna-se repetido, muito repetido num longo livro como é este!

[CÂNDIDO] MOTTA FILHO 
[Cópia reduzida de ed. fac-similar

\section{UM POETA E UM PROSADOR}

MANUEL DE ABREU Substância - Rio de Janei ro -1928 .

Uma das poesias podia dar o título do livro: Are you ready? Porque Substância é um jôgo de tenis entre autor - leitor. As bolas vêm violentamente, sem parar, num bate-pula danado. Nem tempo para respirar a gente tem.

Tudo é mais ou menos dêste geito:

Sinto em mim uma Cidade
jardiņs
lirismo da minha
raça os arranha-céus da ilusão
piscam
na via-lactea das vidraçàs
arrabaldes
debalde!

debalde!

E tomem bola.

Nesse fớu e nêsse arrojo não é di. ficil descobrir talento'e sensibilidade.

A poesia de Mánuel de Abreu não possue colorido brasileiro algum. E' internacional. Europea talvez seja mais certo. Cousa que hoje em dia e entre nós cơnstitue originalidade. $\mathrm{E}$ quem sabe qualidade. Porque afinal de contas sempre é meihor tomar um expresso-interuacional da que o mixto de São Pedro do Carirí. Leva onde se queira. Inclusive á própria terra em gue a gente nasceu.

MARIO DE ANDRADE Macunaíma - São Paulo 1928.

A's vezes a gente em literatura pede a Deus que apareça um livro bom só para poder dizer aos autores de livros maus: Assim è que vecềs deviam ter feito.

Macunaima tem ésses dois valores é um livro bom (não sei se já repararaṃ na fôrça que há nessa palavra: parece um tiro de canhão) è um livro oportuno. E' o bcin oportuno portanto. Chegou na hora. Veiu pôr no seu devido pé a famigerada brasilidade atrás da qual correm suados e errados desde muitos anos o: escritores dêste Brasil tão imenso mas tão arraial ainda.

Há que tempo Machrdo de Assis dizia por outras palavras que ser escritor brasileiro não \& tãc simplesmente cantar o índio e bolar numa paisagem ipês em flor. $O$ Brasil não é isso só. Ou melhor: o Brasil não é isso. Qualquèr estrangeiro é cøpaz de fazer um romance muito bem feitinho com personagens desta terra movendo-se nesta terra. Agora o romance da terra só um brasileiro pode $\epsilon$ screver. $\mathrm{E}$ há de escrever passando alêm do visivel e do palpável. Não se contentar com ıquilo que a terra oferece e mete pelos lhos da gente a dentro. Mas sofrer o of rimento da terra, gozar o gôzo da erra, rir o riso da terra, viver a vida da terra.

Só êste refrão de Macunaíma - Ai! que preguiça!... - vale como brasilidade mais do que tocias as ruazinhas de arrabalde, todos os tutús de feijão, morenas de chita e tal que enchem os versos dos nossos curumins contemporâneos.
Paulo Prado em conversa costuma caçoar dessa mania que muito novo (ou pretendente a tar) tem de gritar esmurrando o peito: Fu sou brasileiro! Eu sou brasileiro! Ea é que sou o verdadeiro brasileiro! Burrice, moco. Se você é brasileiro näo precisa gritar que é: a gente vê logo.

Mario de Andrade dos que não gritam nem fazem questão de parecer. Pois êle é ainda que não queira.

Macunaíma tem tanta moleza, tanta senvergonhice, tanta basófia bem nossas e talvez só nossas que dá vontade da genté se estirar nas páginas dêle como numa rêde e balanço vai balanço vem se abandonar e se esquecer naquela gostosura.

Rapsódia nacionar icom o.r bem ro lado) de lendas, de anedotas, de cheiros. de tudo. A língur então é a mais poética possivel. Parece uma música. $O$ violão sempre acompanhando.

E o mais bonito é que Mario se mostra inteirinho no. livro (o que acontece em todos os que publica aliás). Poucas vezes tenho visto tamanha falta de respeito humano. Há páginas em que a gente se contem para não disparar com o autor: Saia daí, diabo: Como êle mesmo fêz no Amar; verbo intransitivo.

Percebe-se claramente que Mario ama o heroi a tal pontn. que quer ser o heroi. Mas é bom que a gente o desiluda. Mario é um pedacinho do heroi.

O heroi somos nós todos juntos. Até eu, porque não? 


\section{Um Poeta e UM Prosador}

A. de A. M. [António de Alcântara Machado]. "Um poeta e um prosador / Mário de Andrade - Macunaíma São Paulo - 1928”. Revista de Antropofagia: São Paulo, a. I, n 5 , setembro de 1928, p. 4. Edição fac-similar. São Paulo: Abril / Metal Leve, 1975.

\section{(...)}

Mário de Andrade — Macunaíma — São Paulo — 1928.

Às vezes a gente em literatura pede a Deus que apareça um livro bom só para poder dizer aos autores de livros maus: Assim é que vocês deviam ter feito.

Macunaíma tem esses dois valores: é um livro bom (não sei se já repararam na força que há nessa palavra: parece um tiro de canhão) e é um livro oportuno. É o bom oportuno portanto. Chegou na hora. Veio pôr no seu devido pé a famigerada brasilidade atrás da qual correm suados e errados desde muitos anos os escritores deste Brasil tão imenso mas tão arraial ainda.

Há que tempo Machado de Assis dizia por outras palavras que ser escritor brasileiro não é tão simplesmente cantar o índio e botar numa paisagem ipês em flor. O Brasil não é isso só. Ou melhor: o Brasil não é isso. Qualquer estrangeiro é capaz de fazer um romance muito bem feitinho com personagens desta terra movendo-se nesta terra. Agora[,] o romance da terra só um brasileiro pode escrever. E há de escrever passando além do visível e do palpável. Não se contentar com aquilo que a terra oferece e mete pelos olhos da gente a dentro. Mas sofrer o sofrimento da terra, gozar o gozo da terra, rir o riso da terra, viver a vida da terra.

Só este refrão de Macunaíma - Ai! que preguiça!... - vale como brasilidade mais do que todas as ruazinhas de arrabalde, todos os tutus de feijão, morenas de chita e tal que enchem os versos dos nossos curumins contemporâneos.

Paulo Prado em conversa costuma caçoar dessa mania que muito novo (ou pretendente a tal) tem de gritar esmurrando o peito: Eu sou brasileiro! Eu sou brasileiro! Eu é que sou o verdadeiro brasileiro! Burrice, moço. Se você é brasileiro não precisa gritar que é: a gente vê logo.

Mário de Andrade é dos que não gritam nem fazem questão de parecer. Pois ele é ainda que não queira. 
Macunaíma tem tanta moleza, tanta sem-vergonhice, tanta bazófia bem nossas e talvez só nossas que dá vontade da gente se estirar nas páginas dele como numa rede e balanço vai balanço vem se abandonar e se esquecer naquela gostosura.

Rapsódia nacionar (com o r bem rolado) de lendas, de anedotas, de cheiros, de tudo. A língua então é a mais poética possível. Parece uma música. O violão sempre acompanhando.

E o mais bonito é que Mário se mostra inteirinho no livro (o que acontece em todos os que publica aliás). Poucas vezes tenho visto tamanha falta de respeito humano. Há páginas em que a gente sê contém para não disparar com o autor: Saia daí, diabo. Como ele mesmo fez no Amar, verbo intransitivo.

Percebe-se claramente que Mário ama o herói a tal ponto que quer ser o herói. Mas é bom que a gente o desiluda. Mário é um pedacinho do herói. O herói somos nós todos juntos. Até eu, porque não?

A. DE A. M. [ANTÓNIO DE ALCÂNTARA MACHADO] 


\section{SCHEMA AO TRISTAOO DE ATHAYDE}

[Cópia reduzida de ed. fac-similar São Paulo: Abril / Metal Leve, 1975.]

Saberá vocé que pelo desenvolvimento logico de minha pesquiza, "o Brasil é unx grilo te seis milhōes de kilometros, talhado ein Tordesilhas. Pelo que ainda o iustincto antropofagico de nosso povo se prolonga até a secçào livre dós jortacs, ficando bem como symbolo de uma consciencia juridica nativa de um lado a tei das doze- taboas sobte uma caravella e. do outro uma banana. Da mesma maneira nós todos com o padre Cicero á frente somos catholicos romanos. Romanos por causa do centuriāo das procissóes. Nấ foi inutil vermos de ollos do creanca a vig-lactea das semanas santas cmparcdadas com o soldado e a legiāo, atfaz da cruz. 0 Christianismo absorvemol-o. Se naol Trazia dois graves arsumentos, Jesu's filho do totem e da tribu, O mator tranco da historia no patriarcadó Chamar São José de patiarca e ironia. 0 patriarcado erigído pelo catolicismo com o espiritosanto como totem, ì annunciaçâo etc. Dona Sebastlana vae putar de gana! Mas o facto e que ha tambem a antropofagia trazida em pessoa na communhäo. Este ff o meu corpo, Hoc est corpus meum. $O$ Brasil indio nāo podia delxar de, adoptar um deus filho só da màe que, alem disso, satisfazia plenamente gulas atavicar. Catolicos romanos:

0 facto do grilo bistorico, (donde sahirá, revendo-se o nomadismo antepior, a veridica legislaçâo patria) aftirma como pedra do direito antropofagico o seguinte: A POSSE CONTRA A PHOPHIEDADE. Como prova humata de que isso esta certo é que nunca houve duvida sobre a legitima acclamaçäo de Casanova (a posse) contra Menetau (a propriedade). Isso nos Eslaxtus Unitos foi significado ainda ultimamente pela defcza do Rodoloho Vulentino, produzida pela gravidade de Mencken. Tinha maico mais razão de ganhar dinheiro do yue os sabios qu 'vivem analysando encarros e tirando botōes dos narizes dos bebès. Muito mais! Porque afinal é preciso se pesar a onda de gozo romantico quie elle despejou sobre os milhöes de vidas das senhoras dos caixas e dos burocratas. Issó é que é importante.

No Brasil chegámos a maravilha do crear o DiREITo costuMEIRo TI-TRADICIONAL. $z$ quando a gente

\section{Oswald de Andrade}

fala que o divorcio existe eir Portu gal desde 1910, respondem: - act nāo é preciso tratar dessias cogitaçóe porque tem um juiz tim Piracicapiass que anulia tudo quanto é casamento ruime, $E^{\prime}$ só ir lá. Ou cntāo, o Uruguay Prompto: A fussia póde ter equipar do a tamilia natural a legal c supprimido a herança. Nós já tizemos tudo isso. Filho de padre so tem dado sort entre nós. $\mathbf{L}$ quanto íl herança, os tiinos pöen mesmo tóra!

Ura, o gue para $\mathrm{mim}$, estraga o. Oc cidente, é a placenta juridica en que se envolve o homen uesde o acto de amor que, alıas, nada tem que ver com a concepça. Wilhos do totem! juo Lspirito santo! 1sso sım! Como aqui viva o Brasil:

Mas vanios a lautos. Sahiram dol livros puramente untropolagicos. Ma ro cscreveu a nossa Unyssea e creou cuma tacapada o tatroe eyctico e por cincoenta annos o kirotin poetico nacional. Antonio de Nicantara Machialo deu uma cousa tao gustosa e profund como a secçá livre da Estado.

\section{NOTA -}

A secção livre do Fistado á a campo onde se debatem con tesouras D. Chiquinha Dell'osso e b. Maria F. Brandâo, A Grecia tinha ne sues escolas de philosophia. Nós témos as de córte.

Ha hömens, meu caro, no Brasil nove Acabo de conheer Filgard San ches, lente de philosophia do direito na Faculdade da Balida. Un homern fecundante. E estupenda. Outros são a mocidade de Martinetli e Oulrus Arranha Céos. Daquil Enuardo Pellegrini, Paulo Mendes e Americo Portugal. E Fuul Bopp? Ex um colossol A elle devo immenso! A rede telegraphica mais possante da verdade brasileira. Fis urn trecho de carta sua a proposito da fundação que ora tentamos de um Club de Antropofagia e de uma grande festa que proponho vara a vespera de 12 de Outubro. $E^{*}$ uma curta a Jurandyr Manfredini, de Curftyba, publicada a 2 de Setembro na Gazeta do Povo, dali. Depois de detalhar os argumentos do srilo - base do direito patrio eil-o que diz: "Comemas o" resio do Territorio. isso!
Alni está a licăo do nosso Direito. De remos nos plasmar ncssas origens historicas.

Revisão da relizižo. O nosso povo ten um temperamento supcrsicioso, relígioso. Nầ contrariemos. Vamos crear a santoral brasileira: Nossa Senhora das Cobras, Santo Antonio das Mocas Tristes, tudo isso.... Admittir a nacumba e a missia do gallo. Tudo no fondo è a mesmn cousa. $O$ instincto acima de tudo, $O$ indio como expressão maxima. Educação de selva. Sensibilidade aprendendo com a terra, o Anor naturai frira da civilizaçầ, apparatosa e polpuda: Indio siöples: instinetivo. (Sis comia o forte).

E' a communhăo adoptada por todas as religióes. $O$ indio commungava a carne viva; real. $O$ catholicismo inštituio mesma cousis, porém acovardou-se, mascarando o nosso symbolio. Veja só que vigor: -- Iá vem a nossa comida plilandol E a "comida" dizia: come essa carne porque vae sentir nella 0 gosto dn sangue dos teus antepassados.

(Sú comiam os fortes). Hans Staden salvou-se porque chorous. 0 elub de Anthropophugia quer agregar todos os elementos serrios. Precisamos rever tudo - o idioma o direito de propriedade, a familia, a hecessidade do divorcio - , uscrever como se fala, sinceridade maxima

(O) macuntaima á a maior obra nacional. Voeé preceisa lêr. Macunaima em estado de ebulição. Depois isso cồa-se. Toma festim moderado, com saldo a favor). Vamns fazer um levantamento topographico da" moral brasileira, a lunda sexualidade do nosso povo. Vumos rever a historià, daqui e da Europa. Festejar a dia 11 de Outubro, o ultimo dia dis America livre, pura, descolombisata, encantada e bravia".

Quanto ao equiveso de se pensar que eu quero é a tainga, affirmo provarei que todo progresso rcal humano ed patrimonio do homem antropofagico (Galileu, Fulton etc.). De resto, Bernardi .Shaw ja disse:. Está mais proximo do homem natural quem come caviar com gosto de que quem se abstem de alcool por principio. $E^{\prime}$ 


\section{EsqueMA Ao TRISTÃo de ATAÍDE}

ANDRADE, Oswald de. "Esquema ao Tristão de Ataíde”. Revista de Antropofagia: São Paulo, a. I, $\mathrm{n}^{-0}$ 5, setembro de 1928, p. 3. Edição fac-similar. São Paulo: Abril / Metal Leve, 1975.

Saberá você que pelo desenvolvimento lógico de minha pesquisa, o Brasil é um grilo de seis milhões de quilômetros, talhado em Tordesilhas. Pelo que ainda o instinto antropofágico de nosso povo se prolonga até a seção livre dos jornais, ficando bem como símbolo de uma consciência jurídica nativa de um lado a lei das doze tábuas sobre uma caravela e do outro uma banana. Da mesma maneira nós todos com o padre Cícero à frente somos católicos romanos. Romanos por causa do centurião das procissões. Não foi inútil vermos de olhos de criança a via-láctea das semanas santas emparedadas com o soldado e a legião, atrás da cruz. O Cristianismo absorvemo-lo. Se não! Trazia dois graves argumentos. Jesus filho do totem e da tribo. O maior tranco da história no patriarcado! Chamar São José de patriarca é ironia. O patriarcado erigido pelo catolicismo com o espírito-santo como totem, a anunciação etc. Dona Sebastiana vai pular de gana! Mas o fato é que há também a antropofagia trazida em pessoa na comunhão. Este é o meu corpo, Hoc est corpus meum. O Brasil índio não podia deixar de adotar um deus filho só da mãe que, além disso, satisfazia plenamente gulas atávicas. Católicos romanos.

O fato do grilo histórico, (donde sairá, revendo-se o nomadismo anterior, a verídica legislação pátria) afirma como pedra do direito antropofágico o seguinte: A POSSE CONTRA A PROPRIEDADE. Como prova humana de que isso está certo é que nunca houve dúvida sobre a legítima aclamação de Casanova (a posse) contra Menelau (a propriedade). Isso nos Estados Unidos foi significado ainda ultimamente pela defesa de Rodolfo Valentino, produzida pela gravidade de Mencken. Tinha muito mais razão de ganhar dinheiro do que os sábios que vivem analisando escarros e tirando botões dos narizes dos bebês. Muito mais! Porque afinal é preciso se pesar a onda de gozo romântico que ele despejou sobre os milhões de vidas das senhoras dos caixas e dos burocratas. Isso é que é importante.

No Brasil chegamos à maravilha de criar o DIREITO COSTUMEIRO ANTITRADICIONAL. E quando a gente fala que o divórcio existe em Portugal desde 1910, respondem: - aqui não é preciso tratar dessas cogitações porque tem um juiz em Piracicapiassu 
que anula tudo quanto é casamento ruim. É só ir lá. Ou então, o Uruguai! Pronto! A Rússia pode ter equiparado a família natural à legal e suprimido a herança. Nós já fizemos tudo isso. Filho de padre só tem dado sorte entre nós. E quanto à herança, os filhos põem mesmo fora!

Ora, o que para mim estraga o Ocidente é a placenta jurídica em que se envolve o homem desde o ato de amor que, aliás, nada tem que ver com a concepção. Filhos do totem! Do Espírito Santo! Isso sim! Como aqui! Viva o Brasil!

Mas vamos a fatos. Saíram dois livros puramente antropofágicos. Mário escreveu a nossa Odisséia e criou duma tacapada o herói cíclico e por cinqüenta anos o idioma poético nacional. António de Alcântara Machado deu uma coisa tão gostosa e profunda como a seção livre do Estado.

NOTA -

A seção livre do Estado é o campo onde se debatem com tesouras D. Chiquinha Dell’Osso e D. Maria F. Brandão. A Grécia tinha as suas escolas de filosofia. Nós temos as de corte.

Há homens, meu caro, no Brasil novo. Acabo de conhecer Edgar Sanches, lente de filosofia do direito na Faculdade da Bahia. Um homem fecundante. E estupendo. Outros são a mocidade de Martinelli e Outros Arranha-Céus. Daqui! Eduardo Pellegrini, Paulo Mendes e Americo Portugal. E Raul Bopp? É um colosso! A ele devo imenso! A rede telegráfica mais possante da verdade brasileira. Eis um trecho de carta sua a propósito da fundação que ora tentamos de um Club de Antropofagia e de uma grande festa que proponho para a véspera de 12 de Outubro. É uma carta a Jurandyr Manfredini, de Curitiba, publicada a 2 de Setembro na Gazeta do Povo, dali. Depois de detalhar os argumentos do grilo - base do direito pátrio heilo que diz:

“Comemos o resto do Território. Aí está a lição do nosso Direito. Devemos nos plasmar nessas origens históricas.

Revisão da religião. O nosso povo tem um temperamento supersticioso, religioso. Não contrariemos. Vamos criar a santoral brasileira: Nossa Senhora das Cobras, Santo Antônio das 
Moças Tristes, tudo isso... Admitir a macumba e a missa do galo. Tudo no fundo é a mesma coisa. O instinto acima de tudo. O índio como expressão máxima. Educação de selva. Sensibilidade aprendendo com a terra. O amor natural fora da civilização, aparatosa e polpuda. Índio simples: instintivo. (Só comia o forte).

É a comunhão adotada por todas as religiões. O índio comungava a carne viva, real. O catolicismo instituiu a mesma coisa, porém acovardou-se, mascarando o nosso símbolo. Veja só que vigor: — Lá vem a nossa comida pulando! E a “comida” dizia: come essa carne porque vai sentir nela o gosto do sangue dos teus antepassados.

(Só comiam os fortes). Hans Staden salvou-se porque chorou. O club de Antropofagia quer agregar todos os elementos sérios. Precisamos rever tudo - o idioma, o direito de propriedade, a família, a necessidade do divórcio —-, escrever como se fala, sinceridade máxima.

(O Macunaíma é a maior obra nacional. Você precisa ler. Macunaíma em estado de ebulição. Depois isso côa-se. Toma festim moderado, com saldo a favor). Vamos fazer um levantamento topográfico da moral brasileira, a funda sexualidade do nosso povo. Vamos rever a história, daqui e da Europa. Festejar o dia 11 de Outubro, o último dia da América livre, pura, descolombizada, encantada e bravia”.

Quanto ao equívoco de se pensar que eu quero é a tanga, afirmo e provarei que todo progresso real humano é patrimônio do homem antropofágico (Galileu, Fulton etc.). De resto, Bernard Shaw já disse: Está mais próximo do homem natural quem come caviar com gosto de que quem se abstém de álcool por princípio. É isso!

OSWALD DE ANDRADE 
[Rio de Janeiro, 01/10/1928. FBN - Periódicos]

des. Continuanclo mais tarde as suas se modifica. A temperatura desce a $36^{\circ}, 6$ observações, descobriu certas tendencias e pendorcs nessa relação. Dediconse então á anatomia do cerebro, de que se tornou emerito dissecador, esuguanto tirava ousadas conclusōes para a sua theoria, que ganhava mundo c obtinha - maior exito scientifico. F: certo que pouco ficou da phrenologia, hojs aban conada, nas foi um tos caninhos abertos ás doutrinas das localisaçōes cerebraes. Por outro lado foi Gall que chamou a attençào para as differenças indivduaós, "moptrando que ellas dependem antes de tulo da estructura innata, diriamos hoje, da hereditaricdade".

\section{PINTURA}

\section{CHAGALL ILLUSTRADOR DE} LA FONTAINE

No $4^{\circ}$ fasciculo dos Cohicrs d"Art reproduzem-se varias gravuras das que Chagal acaba de iazer para illustrar as fabulas de I.a Fontaine. Dellas disse René Schwov: "O universo das fahulas de Chagall $\dot{e}$ un universo de contos de fadas, em que os séres sú vivem pelo mysterio de um "complot" de còres. Como o de La Fontaine evita todo peso graças á inserção de un mundo num outro, cujas expressōes deliciosas compōem a unidade. A pintura e a poesia se juntam assim, menos pela transposição de nma realidade literaria sobre - plano cla plastico, do que por uma certa Tigeireza de espirito e de teclunica. numa technica difierente."

\section{LIVROS}

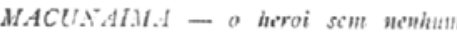
caracter - de Mlario de Andrade

Macumaima é o heróe do cyclo americano. $E^{*}$ unia força pura da cosmogonia precolumbiana, acima, ou melhor, fóra do ben: e do mal. Macunaima transcende o espaço e o tempo. Suas dimensões exccten a realidade. Por isso, elle constituc um espectaculo permanente, que se alimenta da substancia universal, e que se desloca em planos espaciaes e temporaes, sem correspouclencia nas séries mathematicas en que se move o homem.

Mactunainta é una aggregação de elcmentos, uma conjugaçăo de energias que . fazem, apesar do set involucro anthropomorphico, um indice da especie, uma concentração de todos os valores da especie humana, no set estado essencial. E' um mytho de vontade e imaginaçã̃o, onde se cncontram, no seu dynamismo potencial, to- las as volições peculiarcs a cada um do seres que se integram nos limites da collectividade. Macusaima não tem limites, a pāo ser aquelles que elle proprio se impōe, quando tangencia o mundo phenomenal.

Tomando-o como ponto de referencia, conseguiu Mario de Andrade tirar uma força organica desse cáos de elementos formadores de Mucunaima. Mario de Andrade projucton o Brasil nessa Pigura, pelo menos um dos Brasil que ajudam a situar as difierentes imagens do nosso complexo nacional.

O aviso de Mario de Ankirade parece ronico. Afacuncima năo podcria ter nenhum caracter, pois, sendo illimitado, $n$ ha cstí sujeito ís contingencias. $\Sigma$ é, justamentc, essa auscncia de caracter que the dá um granie caracter sobre-humano, em que se reflecten, no tumulto da sua appa. rente indisciplina, as energias elementares. Ltcicupeína ri da verdade e do erro. Salta sobre todas as medidas. Pelo menos Alacunaima de Mario de Andrade que, lunge de ser a "peor dos homens", nấ ć bom nem mau, porque a sua regra escaja completamente ans numeros.

Ifacuncima tem o sabor das obras de invençio. $\mathrm{F}$, sem duvida, pela deflagração da alegria que transmitte, pelo dynarismo violento que nos communica, o tnelhor dos pocmas de Mario de Andradc.

\section{"RETRATO DO BRASIL", DE} PAULO PRADO

Apparecerá ainda este mez o lirro de Paulo Prado, Retrato do Brasil, de cujo post-scriptum publicamos um trecho neste uumero. Por elle, terí visto o lei tor ds intençues geracs do trabalhó, que é un ensaio sobre a tristeza brasileira, atiribuida a duas grandes influencias, actuardo poderosamemte no poroamenii, e 12 e croluçăo da colonia: sensualidad. e aubictío dio ouro, Mais tarde, outros factores vicram preponderar, de correntes dos desvarios do mal romantico. Por essa these se fixa o “caso brasileiro", nas suas varias modalidades. ac tempo e 110 espaco, através de um li. ro solidamente construido c pensado com sggurança, que permittem ao autor os seus conhecimentos de historia e a sua acuidade critica. Porque Paulo Prado é daquelles que procuram no ensinamento do passadn descobrir a orienta cio que deve clirigir o futuro, as leis sociologicas que o deterninarão. Já en Paulistica caracterizon essa tendencia, mais definida agora neste livro, feito com grande audacia, não cvitando o Autor desenvolver o seu pensamento e chegar ás conclusōes, por mais dolorosas extremas que sejam as exigencias do raciociuio. Paulo Prado é o historiador moderno, como noderno é o selt espirito c a stu expressão artistica. Fo clle um dos grandes elementos da Se- mana de Arte Moderna, que se rsalizou gloriosamente, em São Paulo, em 1922, e tem sido sempre um magnifico companheiro nesta campanha dc rejuvenescimento do Brasil, para a sua salvação.

Agora, consagra Paulo Prado a mais carinhosa assistencia á "Sociedade $\mathrm{Ca}$. pistrano de Abreu", que preside, para fazel-a um centro activo de intellectualiklade, en que os estudos de historia não serăo inocuas pesquizas de documentos, nem dilletantismo de escritore falhados, mas contribuiçōes uteis á vida brasileira, a exemplo do Retrato do Brasil, cujo apparecimento é ansiosamente csperato e do qual MOVIMENTO apresenta, cm primeira mão, uma das -uas paginas suggestivas.

\section{"JÉSUS CHRIST" DE LEEONCE DE GRANDMAISON}

Cón o titulo Jéras Christ, sa Personne, son Message, ses Preuves, acaua de ser publicada, em dois rolumes alentados, a obra do Padre Léonce de Grandmaison, um dos maiores escriterca catholicos da França fallecido ha cerca de um anno. Publicon, ha 15 annos, o Dictionnaire apologétique de la Foi catholique. Na sua nova obra, agora apparecida, divide os volumes ent livros, contendo o $1^{\text {n, }}$, tres, consagrados respectivamente á descripção, do meio evang?lico e á apresentaçăo da mensagem de Christo. São estudos largos e de rasta erudição, sendo o prineiro delles considerado como uma "verdacleira introducçåo á literatura evangelica." O $2^{\circ}$ tomo é tambem dividicio en 3 livros, que tratam succes. sivabantc da ftara de Chrisus, das suas obras e do estabelecimento da religião c alguns dos seus testimunhos através da Historia. O $2^{\circ}$ tomo é coltsiclerado como a parte, en que o Atttor fixa o grande debat., do seculo XIX, sobre o problema de Jesus, nos seus multiplos aspectos, historico, philosophico e nais do que tudo humano. Esie trabalho, cujo apparacimento anuunciamos, é considerado como uma das ohras fundamentaos da literaturh catholica, nos ultimos tempos.

\section{TEXTOS DE DIREITO INTER-} NACIONAL

A casa Dalloz de Paris, acaba de publicar o Recueil de Textes de Droit International Public, organizado pelos srs. Louis Le Fur e Georges Chklaver, em duas partes. A primeira reproduz alguns dos textos mais conhecidos, na historia do direito das gentes, no passado: Confucius. a Tregua e a Paz de Deus, Santa Thomaz de Aquino, Vitoria, Suarez, Grotius, Vatel, Rousseau, Kant, as Capitulações romanas, a Santa Alliança e varios projectos de Declaração de Direitos e lieveres dos Fistados.

[Ronald de Carvalho] 


\section{Macunaíma - o Herói SEM NenHum CARÁter - de MáRio de ANDRAde}

S/A [Ronald de Carvalho]. "Livros / Macunaíma - o herói sem nenhum caráter - de Mário de Andrade”. Movimento: Rio de Janeiro, 01 de outubro de 1928, p. 21. FBN - Periódicos. Recolhido em CARVALHO, Ronald de. "Cadernos de imagens / 4 / Macunaíma, de Mário de Andrade”. In: Estudos Brasileiros. $1^{\mathrm{a}}$ ed. Rio de Janeiro: F. Briguiet, 1931, p. 151-152. Reeditado em:

Aguilar, 1976, p. 143-144.

. Rio de Janeiro: MEC / Nova

Macunaíma é o herói do ciclo americano. É uma força pura da cosmogonia précolombiana, acima, ou melhor, fora do bem e do mal. Macunaíma transcende o espaço e o tempo. Suas dimensões excedem a realidade. Por isso, ele constitui um espetáculo permanente, que se alimenta da substância universal, e que se desloca em planos espaciais e temporais, sem correspondência nas séries matemáticas em que se move o homem.

Macunaíma é uma agregação de elementos, uma conjugação de energias que o fazem, apesar do seu invólucro antropomórfico, um índice da espécie, uma concentração de todos os valores da espécie humana, no seu estado essencial. É um mito de vontade e imaginação, onde se encontram, no seu dinamismo potencial, todas as volições peculiares a cada um dos seres que se integram nos limites da coletividade. Macunaíma não tem limites, a não ser aqueles que ele próprio se impõe, quando tangencia o mundo fenomenal.

Tomando-o como ponto de referência, conseguiu Mário de Andrade tirar uma força orgânica desse caos de elementos formadores ${ }^{30}$ de Macunaíma. Mário de Andrade projetou o Brasil nessa figura, pelo menos um dos Brasil que ajudam a situar as diferentes imagens do nosso complexo nacional.

O aviso de Mário de Andrade parece irônico. Macunaíma não poderia ter nenhum caráter, pois[,] sendo ilimitado, não está sujeito às contingências. E é, justamente, essa ausência de caráter que lhe dá um grande caráter sobre-humano, em que se refletem, no tumulto da sua aparente indisciplina $^{31}$, as energias elementares. Macunaíma ri da verdade e do erro. Salta sobre todas as medidas. Pelo menos o Macunaíma de Mário de Andrade que ${ }^{32}$, longe de ser o

\footnotetext{
${ }^{30}$ No texto recolhido em livro (1931), lê-se "geradores” em vez de "formadores”.

${ }^{31}$ Idem, lê-se “(...) no tumulto de aparente indisciplina (...)”.

${ }^{32}$ Idem, supressão. Lê-se: “(...). Salta sobre todas as medidas. Longe de ser (...)”.
} 
“pior dos homens”, não é bom nem mau, porque a sua regra escapa completamente aos núme$\operatorname{ros}^{33}$.

Macunaíma tem sabor das obras de invenção. É, sem dúvida, pela deflagração da alegria que transmite, pelo dinamismo violento ${ }^{34}$ que nos comunica, o melhor ${ }^{35}$ dos poemas de Mário de Andrade.

S/A [RONALD DE CARVALHO]

\footnotetext{
${ }^{33}$ Idem, acréscimo: “(... números), aos nossos números diferenciais.”

${ }^{34}$ Idem, acréscimo: “(... violento) e espontâneo (...)”.

${ }^{35}$ Idem, acréscimo: “(...o melhor), o mais puro (...)”.
} 
[O Globo. Rio de Janeiro, 08/10/1928. FBN - Periódicos]

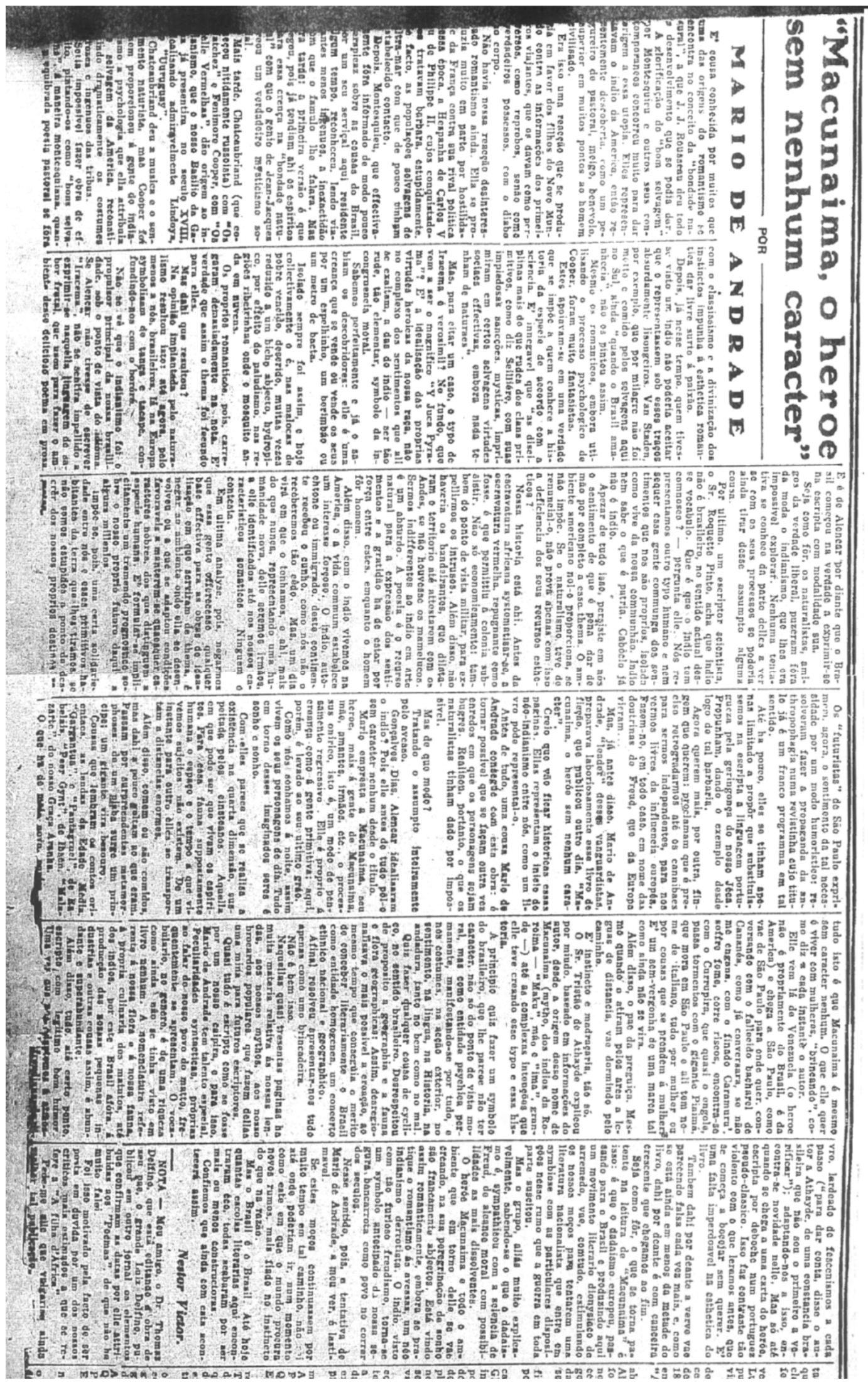




\section{MACUNAÍMA, O HERÓI SEM NENHUM CARÁTER}

VÍTOR, Nestor. "Macunaíma, o herói sem nenhum caráter”. O Globo: Rio de Janeiro, 08 de outubro de 1928. FBN - Periódicos. Recolhido em VíTOR, Nestor. "Os de Hoje / Mário de Andrade / Macunaíma”. Obra crítica de Nestor Vítor. Rio de Janeiro: MEC / Fundação Casa de Rui Barbosa, 1973, v. II, p. 360-365. [1 $1^{\underline{a}}$ ed. 1938].

É cousa conhecida por muitos que uma das origens do romantismo se encontra no conceito da "bondade natural”, a que J. J. Rousseau deu todo o desenvolvimento que se podia dar.

A glorificação do "bom selvagem” por Montesquieu e outros seus contemporâneos concorreu muito para dar origem a essa utopia. Eles representavam o índio da América, então recentemente descoberta, como um pegureiro de pastoral, meigo, benévolo, superior em muitos pontos ao homem civilizado.

Era isso uma reação que se produzia em favor dos filhos do Novo Mundo contra as informações dos primeiros viajantes, que os davam como perversos, como réprobos, senão como verdadeiros possessos, com o diabo no corpo.

Não havia, nessa reação desinteressada, romantismo ainda. Ele se produzia muito em parte por hostilidade da França contra sua rival política dessa época, a Espanha de Carlos V ou de Filipe II, cujos conquistadores tratavam bárbara, estupidamente, de fato, as populações selvagens de ultramar com que de pouco tinham estabelecido contato.

Depois, Montesquieu, que efetivamente fora informado de modo pouco perspicaz sobre as cousas do Brasil, por um seu serviçal aqui residente algum tempo, reconheceu, lendo viajantes menos ingênuos, a inexatidão com que o fâmulo lhe falara. Mas, era tarde: a primeira versão é que pegou, pois já tendiam aí os espíritos para essa crença na "bondade natural" com que o gênio de Jean-Jacques criou um verdadeiro misticismo social.

Mais tarde, Chateaubriand (que começou nitidamente rousseauísta ${ }^{36}$ ) com os Os Natchez e Fenimore Cooper, com Os Pele-Vermelhas, dão origem ao indianismo, que o nosso Basílio da Gama já pressentira no século XVIII, idealizando admiravelmente Lindóia, no $U$ raguai.

\footnotetext{
${ }^{36}$ No jornal, lê-se “russoísta”, forma modificada para “rousseauísta” na publicação em livro.
} 
Chateaubriand deu a música e o sentimento naturista, mas Cooper foi quem proporcionou à gente do indianismo a psicologia que ela atribuía ao selvagem da América, reconstituindo dramaticamente os costumes ferozes e ingênuos das tribos.

Seria impossível fazer obra de efeito, pintando-os como “bons selvagens”, à maneira montesquiana, quando a equilibrada poesia pastoral se fora com o classicismo, e a divinização dos instintos impunha à estética romântica dar livre surto à paixão.

Depois, já nesse tempo, quem tivesse visto um índio não poderia aceitar que o representassem sob esses traços absurdamente lisonjeiros. Hans Staden ${ }^{37}$, por exemplo, que por milagre não foi morto e comido pelos selvagens aqui no Sul, ainda "quando o Brasil amanhecia”, não os pintou assim.

Mesmo os românticos, embora utilizando o processo psicológico de Cooper, foram muito fantasistas.

Estes apoiavam-se em uma verdade que se impõe a quem conhece a história da espécie de acordo com a ciência. É inegável que “as disciplinas mais do que rudes dos clãs primitivos” como diz Seillière, “com suas impiedosas sanções, místicas, imprimiram, em certos selvagens virtudes sociais efetivas, embora nada tenham de naturais”.

Mas, para citar um caso, o tipo de Iracema é verossímil? No fundo, que vem a ser o magnífico “I-Juca-Pirama”? É a idealização das próprias virtudes heróicas da nossa raça, não no complexo dos sentimentos que ali se exaltam, a das do índio - ser tão rude, tão elementar, símbolo da incongruência moral.

Sabemos perfeitamente e já o sabiam os descobridores: ele é uma criança que se vende ou vende os seus por um espelhinho, um berimbau ou um metro de baeta.

Isolado sempre foi assim, e hoje coletivamente o é, nas malocas de pobre vencido, descrido, muitas vezes reduzido a um bicho abjeto, hidrópico, por efeito do paludismo, nas regiões ribeirinhas onde o mosquito anda em nuvens.

Os próprios românticos, pois, carregaram demasiadamente na nota. É verdade que assim o tema foi fecundo para eles.

Mas daí que resultou?

Na opinião implantada pelo naturalismo resultou isto: até agora, pelo menos a nós brasileiros, lá na Europa simbolizam de tanga e tacape, confundindo-nos com o bororo.

\footnotetext{
${ }^{37}$ No jornal, lê-se “Van Staden”.
} 
Não se vê que o indianismo foi o principal propulsor da nossa brasilidade, sob o ponto de vista do idioma. Se Alencar não tivesse de escrever Iracema, não se sentira impelido a exprimir-se naquela linguagem de sabor frutal, que usou para fazer o ambiente desse delicioso poema em prosa. E é de Alencar por diante que o Brasil começou na verdade a exprimir-se na escrita com modalidade sua.

Seja como for, os naturalistas, amigos da verdade liberal, puseram fora da moda o indianismo, que lhes era impossível explorar. Nenhuma tentativa se conhece da parte deles a ver se com os seus processos se poderia ainda tirar desse assunto alguma cousa.

Por último, um escritor cientista, o Sr. Roquete Pinto, acha que índio não é brasileiro, no sentido atual desse vocábulo. Que é que o índio tem conosco? - pergunta ele. Nós representamos outro tipo humano e nem sequer essa gente comunga dos sentimentos que nos são próprios, isolada como vive da nossa comunhão. Índio nem sabe o que é pátria. Caboclo já não é índio.

Apesar de tudo isso, persiste em nós o sentimento de que é pena dar de mão por completo a esse tema. O ambiente americano no-lo proporciona, se não impõe. Se o naturalismo teve de renunciá-lo, não prova apenas com isso a deficiência dos seus recursos estéticos?

Nossa história está aí. Antes da escravatura africana sistematizar-se, a escravatura vermelha, repugnante como fosse, é que permitiu a colônia subsistir. Não só economicamente; também do ponto de vista militar, para expelirmos os intrusos. Além disso, não haveria os bandeirantes, que dilataram o território até entestarem com os Andes, se não houvesse os mamelucos. Sermos indiferentes ao índio em arte é um absurdo. A poesia é o recurso natural para a expressão dos sentimentos e a gratidão há de estar por força entre estes, enquanto o homem for homem.

Além disso, com o índio vivemos na América, e a vida comum estabelece um interesse forçoso. O índio, autóctone ou imigrado, deste continente recebeu o cunho, como nós não o receberemos tão cedo. Mas, um dia virá em que o tenhamos, e aí, mais do que nunca, representando uma humanidade nova, dele seremos irmãos, a ele identificados até nos nossos característicos somáticos. Ninguém o contesta.

Em última análise, pois, negarmos que essa gente oferecesse qualquer base efetiva para as obras de idealização em que serviram de tema, é negar ao ambiente onde ela se desenvolveu ou a que se adaptou condições favoráveis a manterem-se quaisquer caracteres nobres, 
dos que distinguem a espécie humana. É formular-se implicitamente um tremendo ${ }^{38}$ prognóstico sobre o nosso próprio futuro daqui a alguns milênios.

Impõe-se, pois, uma certa solidariedade entre nós e esses primitivos habitantes da terra que lhes tiramos, se não somos estúpidos a ponto de descrer dos nossos próprios destinos remotos.

Os “futuristas” de São Paulo exprimem, agora, o sentimento da tal necessidade por um modo humorístico: resolveram fazer a propaganda da antropofagia numa revistinha cujo título já é um franco programa em tal sentido.

Até há pouco, eles se tinham apenas limitado a propor que substituíssemos na escrita a linguagem portuguesa pela geringonça do nosso jeca. Propunham, dando o exemplo desde logo de tal barbaria.

Agora querem mais, por outra, fingem que querem: proclamam que é preciso retrogradarmos até os canibais para sermos independentes, para nos vermos livres da influência européia. Fazem-no, em todo caso, em nome das doutrinas de Freud, que da Europa vieram...

Mas, já antes disso, Mário de Andrade, líder ${ }^{39}$ desses vanguardistas, preparava laboriosamente esse livro de ficção, que publicou outro dia, Macunaíma, o herói sem nenhum caráter.

Creio que vão ficar históricas essas páginas. Elas representam o início do neoindianismo entre nós, como um livro pode representá-lo.

Antes de tudo, uma cousa Mário de Andrade consegue com esta obra: é tornar possível que se façam outra vez enredos em que os personagens sejam bugres. Realizou, portanto, o que os naturalistas tinham dado por impossível.

Mas de que modo?

Tratando o assunto inteiramente pelo avesso.

Gonçalves Dias, Alencar idealizaram o índio? Pois ele antes de tudo pô-lo sem caráter nenhum desde o título.

Mário empresta a Macunaíma, seu herói, mais à gente de Macunaíma, mãe, amantes, irmãos, etc., o processo onírico, isto é, um modo de pensamento regressivo. Ele é próprio à criança como à gente primitiva; aqui, porém, é levado ao seu último grau.

\footnotetext{
${ }^{38}$ No texto em livro, supressão. Lê-se: “(...). É formular-se prognóstico sobre (...)”.

${ }^{39}$ No jornal, lê-se “leader”, forma inglesa substituída pela portuguesa “líder” na publicação em livro.
} 
Como nós sonhamos à noite, assim vivem os seus personagens de dia. Tudo em torno desses imaginados seres é sonho e sonho.

Com eles parece que se realiza a existência na quarta dimensão suspeitada pelos einsteinianos ${ }^{40}$. Aquela em que pode ser que vivam os espíritos. Para essa fauna supostamente humana o espaço e o tempo a que vivemos sujeitos não existem. De um instante para outro eles se transportam a distâncias enormes.

Além disso, comem ou são comidos, mas daí a pouco voltam ao que eram. Passam por surpreendentes metamorfoses: de um piaba surge um príncipe; um gigante vira besouro.

Cousas que lembram os contos orientais, as lendas da Idade Média, Gargantua e Pantagruel, de Rabelais, Peer Gynt, de Ibsen, Malasarte, do nosso Graça Aranha.

O que há de mais novo, porém, em tudo isso é que Macunaíma é mesmo sem caráter nenhum. O que ele quer é viver com mulheres, "brincando”, como diz a cada instante o autor.

Ele vem lá de Venezuela (o herói não é propriamente do Brasil, é da América) e chega a São Paulo, como vai de São Paulo para onde quer, conversando com o falecido bacharel de Cananéia, como já conversara, se não me engano, com o finado Caramuru; sofre fome, corre riscos, encontra-se com o Currupira, que quase o engole, passa tormentos com o gigante Piaimã, que mora em São Paulo e ali tem nome de italiano, tudo por mulher ou por cousas que se prendem à mulher. É um sem-vergonha de uma marca tal como ainda não se vira.

Além disso, o pai da preguiça. Mesmo quando o atiram pelos ares a léguas de distâncias, vai dormindo pelo caminho.

É instinto e madraçaria, tão-só.

O Sr. Tristão de Ataíde explicou por miúdo, baseado em informações do autor, desde a origem desse nome de Macunaíma (mito, dos índios da Roraima - “Maku”, mau e “ima”, grande -) até as complexas intenções que ele teve criando esse tipo e essa história.

A princípio quis fazer um símbolo do brasileiro, que lhe parece não ter caráter, não só do ponto de vista moral, mas como entidade psíquica permanente, manifestando-se por tudo, e nos costumes, na ação exterior, no sentimento, na língua, na História, na andadura, tanto no bem como no mal.

Quis fazer qualquer cousa de cíclico, no sentido brasileiro. Desrespeitou de propósito a geografia e a fauna e flora geográficas. Assim, desregionalizava o mais possível a criação, ao

\footnotetext{
${ }^{40}$ No jornal, lê-se “einsteanos”, forma mudada para “einsteinianos” na publicação em livro.
} 
mesmo tempo que conseguia o mérito de conceber literariamente o Brasil como entidade homogênea, um concerto étnico nacional e geográfico.

Afinal, resolveu apresentar-nos tudo apenas como uma brincadeira.

Não é bem isso.

Naquelas quase trezentas páginas há muita matéria relativa às nossas lendas, aos nossos mitos, aos nossos brocardos populares, que fazem delas uma mina para futuros escritores.

Quase tudo é escrito como se fosse por um nosso caipira, e para isso, Mário de Andrade tem talento especial. Peculiaridades sintáticas, próprias ao falar do nosso povo do mato, freqüentemente se apresentam. O vocabulário, no gênero, é de uma riqueza como ainda não se tinha visto em livro nenhum. A nomenclatura referente à nossa fauna, à própria culinária dos matos, até dos índios, por este Brasil afora, à produção das nossas pequenas indústrias e outras cousas assim, é abundante e superabundante.

Além disso, tudo até certo ponto, escrito com legítimo bom humor. Uma vez que nos adaptemos à atmosfera fedorenta, bem freudiana do livro, lardeado de fescenismos a cada passo ("para dar conta”, disse o autor a Ataíde, “de uma constância brasileira que não sou o primeiro a verificar”); adaptando-nos a isso, encontra-se novidade nele. Mas só até quando se chega a uma carta do herói, escrita por deboche num português pseudoclássico ${ }^{41}$. Isso faz contraste tão violento com o que lêramos antes, que se começa a bocejar sem querer. É uma falta imperdoável na estética do livro.

Também daí por diante a verve vai parecendo falsa cada vez mais, e, como se está ainda em menos da metade do livro, daí por diante é com canseira crescente que chegamos ao fim.

Seja como for, o que se torna patente na leitura de Macunaíma é isso: é que o dadaísmo europeu, passando para o Brasil e produzindo aqui um movimento literário dionisíaco de arremedo, vai, contudo, estimulando os nossos moços para tentarem uma literatura nacionalista que entre em simbiose com as particulares disposições nesse rumo que a guerra em toda parte suscitou.

Mas o grupo, aliás muito explicavelmente, sabendo-se o que o dadaísmo é, simpatizou com a ciência de Freud, de alcance moral com possibilidades as mais dissolventes.

O herói Macunaíma e todo o ambiente que em torno dele se vai criando, na sua peregrinação de sonho são francamente abjetos. Está vindo assim romanticamente, embora se pra-

\footnotetext{
${ }^{41}$ No jornal, lê-se “pseudo-clássico”.
} 
tique o romantismo às avessas, um neo-indianismo derrotista. $\mathrm{O}$ índio, visto com tão furioso freudismo, torna-se um símbolo antecipado da nossa segura bancarrota como povo no correr dos séculos.

Nesse sentido, pois, a tentativa de Mário de Andrade, a meu ver, é lastimável.

Se estes moços continuassem por muito tempo em tal caminho, não sei até onde poderiam ir, num momento como este em que o mundo procura novos rumos, mais fiado no instinto, do que na razão.

Mas o Brasil é o Brasil. Até hoje quantas escolas literárias aqui encontraram eco, todas acabaram por ser mais ou menos construtoras.

Confiemos que ainda com esta acontecerá assim. 
[João Ribeiro. Jornal do Brasil. Rio de Janeiro, 31/10/1928. IEB - CAP-MP] qualquer coordenação.

Sô uma cousa transpira desse montão de palha incendlada é o fumo que revela um fogo interior, occulto e ardente.

Mario de Andrade - - Macunaima (S. Paulo). Viriato Corrêa - Novellas asperas (Rio). Affons: Ha, todavia, no acervo paginas de rele ro: a distinccão da lingua fallada $e$ a escripta, a macumba, as historias popila res de animaes, a geographia inconsequenres de animaes, a geographia inconsequenque é ainda a nossa, cheia le multiplas rens do Nilo e dos diamantes

Costa - Gallicismos e não gallicismos (Rio). Conc cas mil e uma riquezas ineditas.

da cahirá em ridiculez inevitavel. Năoti-

MaCUNATMa - Heroe sem nenhum 'ou brincadeira como the chama o autor, se caracter - Por Mario de Andra- gundo as palavras releridas por um dos de (S. Paulo).

Estive com a historia de Macunaina quasf um mez, tentando a leitura seguida continua. Mas, pude sorvelo aos poucos. atre an paginas que offer tuanti, do a proposito e do desproposito. ousag lucongruentes, em qua se descrere cousas iacong? se. incomprebenstvel, absirio, mixto de . boclo, do negro e do branco. 0 lirro parece muito mals retratar os enbustes de Malasartes (que é uma ep. ronta mediterranea das aventurag do astato tiysses), do que a

Cona ama Macunaima

Conkecemos o de Macunatma cono noclosa sua prectosa collect

Este couto em seus fundamentoz par

Eece ao cyclo dos dous irmōos que appar teace ao colo dos defor ir com onl varias tradleors untversaes (Abst * Calm, Romelo do le propria mãe que eran ellhos do sol desde propria matre materno propóm rocurar desdegentor ingltivo andando para 0ezte. sa progetutas as aventuras dezza jornada ma rarilhosa e afinal vảo os berces a perar no raricosa aluar metamorohose. jlacuraima e a constellacão das Pleiales e perna que perdera um delles numa das sung arentupordera um delles numa das

, Porma o cinto do Orion.

Eols, um mytho astronomico que nâo assigiala no céo o logar da Ursa maicr, o alli, sem ordem que não ha, como se fosse uma collectanea ou selecta de excerptos

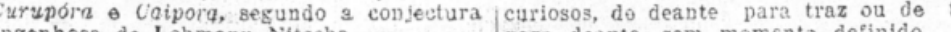

No livro, romance (e

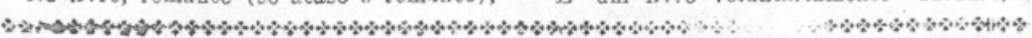
póde

do talento para enganar os mancista as analogias com o conto indige existem.

e a Ifacunama fosse um llvro de es. téa, a autor nos causaria pena como a de proximo hospede de manicomio.

Para nós é evidente que o autor, ainda contra a sua propria critica, quiz-nos nin. tar o bomem brasileiro, indolente, mas as tuto (em poucas cousas, na politiea, nor exemplo) sem caracter defiuide perturba. do pela heterogeneidade de gens elementos formativos, ignorante mas audaz, pobre mas fanfarrấo de liberalidades, presum.do como a mosca do cache, vassalo arcotando soberania... que reptgnam eutre si como disparates.

Macuuaima é tolo e astuto, instructivo. (utem escaparco a todes as de niços ethnicas e anthropologlcas. A sua mals logica é a đa magia.

Tessa infindavel mistura de idéas e ce falta de ldéas, de verdade e de taita de vernos, é difficil e para nós in inoscivzi, deeco brir o fio ja meada ou um leit motif que Itio seja o estribllho:

ue of a melbor ecoressão do Macunativia. Concluir-se-á dessa

Vão acreditamos, e por varias razôa . Fin primeirn lezar Mario do Anfrude e capaz do uma azueira. mas seutnre uma as ueira de talento.

En segundo logar, oespirtio, o humour, a graça trauspira em todas as paginas: lendo-o rimonos. criamos bom sangue e agra. decemos ao eutor a sua lacilidade commu. seria um synjolo e sería falso, orque afinal somos uns pobres diabos cheios de intersoes benovolas a arcar com nosso injorts terrestre incomquinstavel. Ha muitos defeitos no livro de Mario do Andrade, a concupiscencia de termos empis serdadefros a ficticios de pura invenção, extra-regionalismos discordantes, ibsurios ineffaveis.

Jas, se o livro è isso mesmo? -

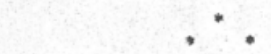




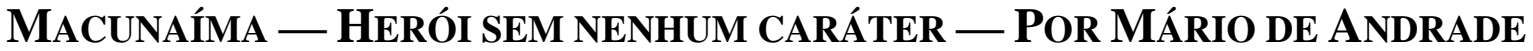

\author{
RIBEIRO, João. “Crônica literária / Macunaíma - herói sem ne- \\ nhum caráter - por Mário de Andrade”. Jornal do Brasil: Rio de \\ Janeiro, 31 de outubro de 1928, p. 10. IEB-USP - CAP-MP. Re- \\ colhido em Os Modernos. Rio de Janeiro: ABL, 1952, p. 81-84, \\ vol. IX das Obras completas de João Ribeiro. Reproduzido em \\ Andrade, Mário de. Macunaíma. Edição crítica de Telê Porto \\ Ancona Lopez. Rio de Janeiro: Livros Técnicos e Científicos / \\ São Paulo: Secretaria da Cultura, Ciência e Tecnologia, 1978.
}

Estive com a história de Macunaíma quase um mês, tentando a leitura seguida e contínua. Mas, pude sorvê-lo aos poucos, entre desgostoso e interessado, ao grado das páginas que ofereciam aspectos novos, antigos na balbúrdia cronológica de tutti quanti, do a propósito e do despropósito.

Macunaíma é um conglomerado de coisas incongruentes, em que se descreve o tipo de um Malasartes indiano, aborígine, incompreensível, absurdo, misto de toda a ciência folclórica e tríplice, do caboclo, do negro e do branco.

O livro parece muito mais retratar os embustes de Malasartes (que é uma epigonia mediterrânea das aventuras do astuto Ulisses), do que a figura do Macunaíma da lenda amazônica.

Conhecemos o conto de Macunaíma como no-lo refere Th. Koch-Grünberg na sua preciosa coleção dos India-nermaerchen sob o n⿳0 28.

Este conto em seus fundamentos pertence ao ciclo dos dous irmãos que aparecem em várias tradições universais (Abel e Caim, Rômulo e Remo) e quase sempre nas lendas americanas são gêmeos. Sabendo da própria mãe que eram filhos do Sol, desde o ventre materno propõem procurar o progenitor fugitivo andando para oeste. São muitas as aventuras dessa jornada maravilhosa e afinal vão os heróis a parar no céu em singular metamorfose. Macunaíma é a constelação das Plêiades e a perna que perdera um deles numa de suas aventuras, forma o cinto do Orion.

É pois um mito astronômico que não corresponde à conclusão do livro que lhe assinala no céu o lugar da Ursa Maior, correlata aos mitos do Saci e do Curupóra e Caipora, segundo a concepção engenhosa de Lehmann Nitsche. 
No livro, romance (se acaso é romance), ou brincadeira como lhe chama o autor, segundo as palavras referidas por um dos nossos críticos ${ }^{42}$, íntimo confidente do romancista, as analogias com o conto indígena são muito apagadas e quase não existem.

O autor urdiu um livro original, utilizando materiais conhecidos das nossas tradições, e se não conseguiu dar harmonia ao conjunto, em todo caso concertou o mais que pôde idéias e noções objecionáveis e contraditórias em si mesmas.

Parece mesmo que cultivou essa incongruência fundamental de ajuntar cousas que repugnam entre si como disparates.

Macunaíma é tolo e astuto, instrutivo, brutal, sensualíssimo, sem a moral de hoje nem a de ontem, escapando a todas as definições étnicas e antropológicas. A sua arte principal primitiva e mais verídica ou mais lógica é a da magia.

Nessa infindável mistura de idéias e de falta de idéias, de verdade e de falta de verdade, de vida solar e de pesadelos noturnos, é difícil, e para nós impossível, descobrir o fio da meada ou um leit motif que não seja o estribilho:

— Ai! que preguiça!

que é a melhor expressão do Macunaíma.

Concluir-se-á dessa breve exposição que o livro é um desastre?

Não acreditamos, e por várias razões.

Em primeiro lugar Mário de Andrade é capaz de uma asneira, mas sempre uma asneira respeitável. E, nesse caso, uma asneira de talento.

Em segundo lugar, o espírito, o humour, a graça transpira em todas as páginas: lendo-o rimo-nos, criamos bom sangue e agradecemos ao autor a sua facilidade comunicativa de alegria e desenfado.

Não há maior delícia que $\mathrm{a}^{43}$ de ler, aqui e ali, sem ordem que não há, como se fosse uma coletânea ou seleta de excertos curiosos, de diante para trás ou de trás para diante, sem momento definido.

É um livro voluntariamente bárbaro, primevo, espécie de fragmentos desconexos que escaparam e foram reunidos por um comentador reduzido à inépcia de qualquer coordenação.

Só uma cousa transpira desse montão de palha incendiada, é o fumo que revela um fogo interior, oculto e ardente.

\footnotetext{
${ }^{42}$ Referência a Tristão de Ataíde (Alceu de Amoroso Lima).

${ }^{43}$ No jornal, lê-se: "Não há maior delícia que o de ler...”.
} 
Há, todavia, no acervo[,] páginas de relevo: a distinção da língua falada e da escrita, a macumba, as histórias populares de animais, a geografia inconseqüente que é ainda a nossa, cheia de múltiplas origens do Nilo e dos diamantes da Garça e das mil e uma riquezas inéditas.

Contudo se essa brincadeira for repetida cairá em ridiculez inevitável. Não se pode abusar do talento para enganar os tolos.

Se a [obra] Macunaíma fosse um livro de estréia, o autor nos causaria pena como a de um próximo hóspede de manicômio.

Para nós é evidente que o autor, ainda contra a sua própria crítica, quis-nos pintar o homem brasileiro, indolente, mas astuto (em poucas cousas, na política, por exemplo) sem caráter definido, perturbado pela heterogeneidade de seus elementos formativos, ignorante mas audaz, pobre mas fanfarrão de liberalidades, presumido como a mosca do coche, vassalo arrotando soberania...

Mas isso seria um símbolo e seria falso, porque afinal somos uns pobres-diabos ${ }^{44}$ cheios de intenções benévolas a arcar com nosso império terrestre inconquistável.

Há muitos defeitos no livro de Mário de Andrade, a concupiscência de termos tupis verdadeiros e fictícios de pura invenção, extra-regionalismos discordantes, e absurdos inefáveis.

Mas, se o livro é isso mesmo?

JOÃO RIBEIRO

\footnotetext{
${ }^{44}$ No jornal, sem hífen.
} 
[Diário Nacional. São Paulo, 28/11/1928. IEB - CAP-MP]

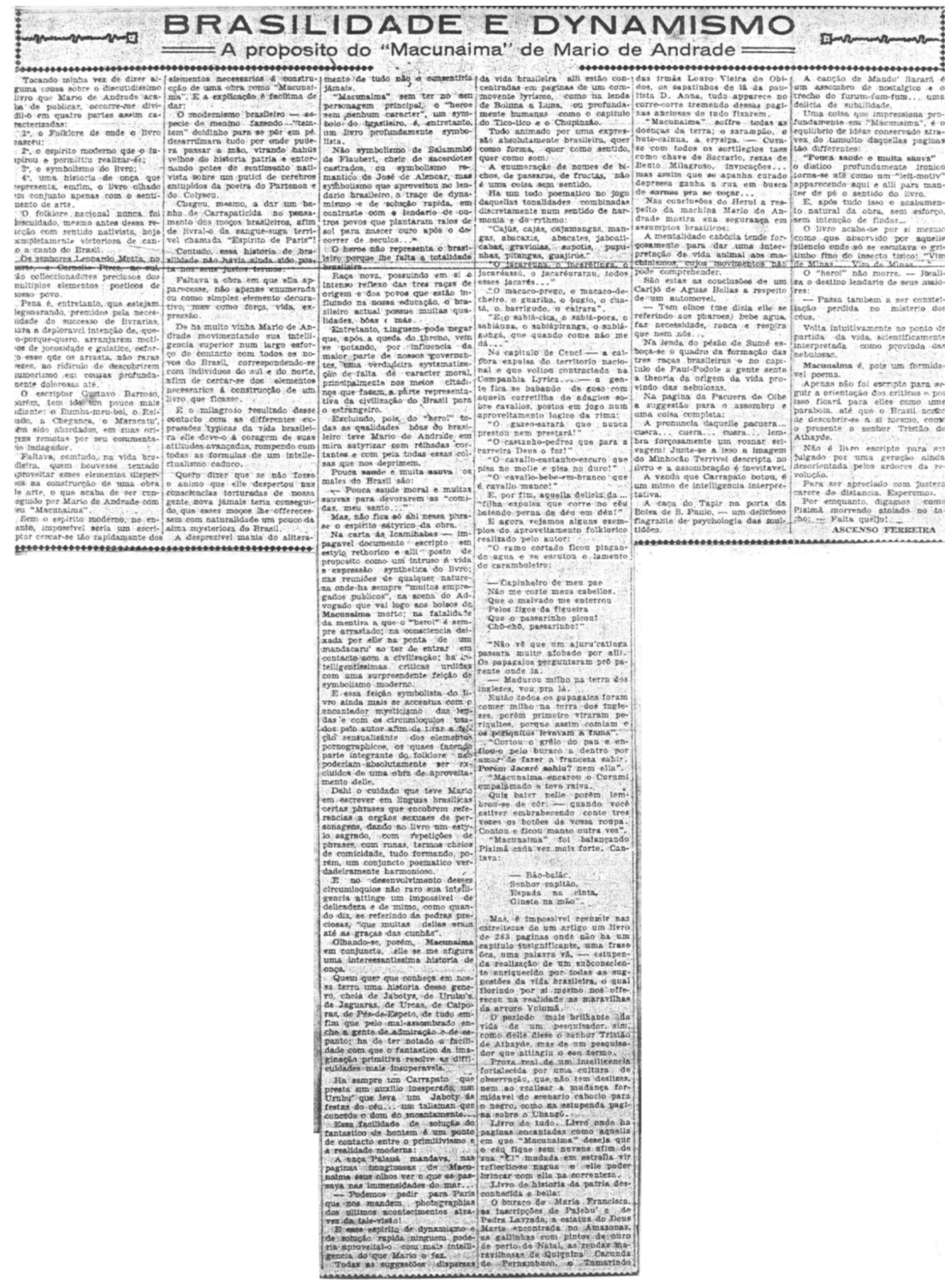




\section{BRASILIDADE E DINAMISMO A PROPÓSITO DO “MACUNAÍMA” DE MÁRIO DE ANDRADE}

FERreira, Ascenso. "Brasilidade e dinamismo / a propósito do 'Macunaíma' de Mário de Andrade”. Diário Nacional: São Paulo, 28 de novembro de 1928. IEB-USP - CAP-MP. Republicado no mesmo jornal em 23 de novembro de 1931.

Tocando minha vez de dizer alguma cousa sobre o discutidíssimo livro que Mário de Andrade acaba de publicar, ocorre-me dividi-lo em quatro partes assim caracterizadas:

$1^{\underline{a}}$. o Folclore de onde o livro nasceu;

$2^{\underline{a}}$. o espírito moderno que o inspirou e permitiu realizar-se;

$3^{\mathrm{a}}$. o simbolismo do livro;

4⿳亠口冋. uma história de onça, que representa, enfim, o livro olhado em conjunto apenas com o sentimento de arte.

O folclore nacional nunca foi descuidado, mesmo antes dessa reação com sentido nativista, hoje completamente vitoriosa de canto a canto do Brasil.

Os senhores Leonardo Motta, no norte, e Cornélio Pires, no sul, são colecionadores preciosos dos múltiplos elementos poéticos de nosso povo.

Pena é, entretanto, que estejam degenerando, premidos pela necessidade do sucesso de livrarias, para a deplorável intenção de, quero-porque-quero, arranjarem motivos de jocosidade e gaiatice, esforço esse que os arrasta, não raras vezes, ao ridículo de descobrirem humorismo em cousas profundamente dolorosas até.

O escritor Gustavo Barroso, porém, tem ido um pouco mais adiante: o Bumba-meuboi, o Reisado, a Chegança, o Maracatu têm sido abordados, em suas origens remotas por seu comentário indagador.

Faltava, contudo, na vida brasileira, quem houvesse tentado aproveitar esses elementos dispersos na construção de uma obra de arte, o que acaba de ser conseguido por Mário de Andrade com o seu Macunaíma.

Sem o espírito moderno, no entanto, impossível seria um escritor cercar-se tão rapidamente dos elementos necessários à construção de uma obra como Macunaíma. E a explicação é facílima de dar.

O modernismo brasileiro — espécie de menino fazendo "tem-tem” doidinho para se por em pé, desarrumara tudo por onde pudera passar a mão, virando baús velhos de história 
pátria e entornando potes de sentimento nativista sobre um potici ${ }^{45}$ de cérebros entupidos da poeira do Partenon e do Coliseu.

Chegou, mesmo, a dar um banho de carrapaticida no pensamento dos moços brasileiros, a fim de livrá-lo da sanguessuga terrível chamada “Espírito de Paris”!

Contudo, essa história de brasilidade não havia ainda sido posta nos seus justos termos.

Faltava a obra em que ela aparecesse, não apenas enumerada ou como simples elemento decorativo, mas como força, vida, expressão.

De há muito vinha Mário de Andrade movimentando sua inteligência superior num largo esforço de contato com todos os novos do Brasil, correspondendo-se com indivíduos do sul e do norte, a fim de cercar-se dos elementos necessários à construção de um livro que ficasse.

E o milagroso resultado desse contato com as diferentes expressões típicas da vida brasileira ele deve-o à coragem de suas atitudes avançadas, rompendo com todas as fórmulas de um intelectualismo caduco.

Quero dizer que se não fosse o ânimo que ele despertou nas consciências torturadas de nossa gente nova jamais teria conseguido que esses moços lhe oferecessem com naturalidade um pouco da alma misteriosa do Brasil.

A desprezível mania do aliteramento [sic] de tudo não o consentiria jamais.

Macunaíma, sem ter no seu personagem principal, o “herói sem nenhum caráter”, um símbolo do brasileiro, é, entretanto, um livro profundamente simbolista.

Não simbolismo de Salambô, de Flaubert, cheio de sacerdotes castrados, ou simbolismo romântico de José de Alencar, mas simbolismo que aproveitou no lendário brasileiro o traço de dinamismo e de solução rápida, em contraste com o lendário de outros povos que plantaram raios de sol para nascer ouro após o decorrer dos séculos...

O herói não representa o brasileiro porque lhe falta a totalidade brasileira.

Raça nova, possuindo em si o intenso reflexo das três raças de origem e dos povos que estão influindo na nossa educação, o brasileiro atual possui muitas qualidades, boas e más.

Entretanto, ninguém pode negar que, após a queda do trono, vem se notando, por influência da maior parte de nossos governantes, uma verdadeira sistematização de falta de caráter moral, principalmente nos meios citadinos que fazem a parte representativa da civilização do Brasil para o estrangeiro.

\footnotetext{
45 “Potici”: grande quantidade. Regionalismo brasileiro, nordestino e nortista.
} 
Excluindo, pois, do "herói” todas as qualidades boas do brasileiro, teve Mário de Andrade em mira satirizar com relhadas cortantes e com peia todas essas coisas que nos deprimem.

Pouca saúde e muita saúva os males do Brasil são:

— Pouca saúde moral e muitas saúvas para devorarem as “comidas, meu santo...”

Mas, não fica só aí nessa frase o espírito satírico da obra.

Na carta às Icamiabas - impagável documento escrito em estilo retórico e ali posto de propósito como um intruso à vida e expressão sintética do livro; nas reuniões de qualquer natureza onde há sempre “muitos empregados públicos”, na cena do Advogado que vai logo aos bolsos de Macunaíma morto; na fatalidade da mentira a que o "herói” é sempre arrastado; na consciência deixada por ele na ponta de um mandacaru ao ter de entrar em contato com a civilização; há inteligentíssimas críticas urdidas com uma surpreendente feição de simbolismo moderno.

E essa feição simbolista do livro ainda mais se acentua com o encantador misticismo das lendas e com os circunlóquios usados pelo autor a fim de tirar a feição sensualizante dos elementos pornográficos, os quais fazendo parte integrante do folclore não poderiam absolutamente ser excluídos de uma obra de aproveitamento dele.

Daí o cuidado que teve Mário em escrever em línguas brasílicas certas frases que encobrem referências a órgãos sexuais de personagens, dando ao livro um estilo sagrado, com repetições de frases, com runas, termos cheios de comicidade, tudo formando, porém, um conjunto poemático verdadeiramente harmonioso.

E no desenvolvimento desses circunlóquios não raro sua inteligência atinge um impossível de delicadeza e de mimo, como quando diz, se referindo às pedras preciosas, "que muitas delas eram até as graças das cunhãs”.

Olhando-se, porém, Macunaíma em conjunto, ele se me afigura uma interessantíssima história de onça.

Quem quer que conheça em nossa terra uma história desse gênero, cheia de Jabotis, de Urubus, de Jaguaras, de Urcas, de Caiporas, de Pés-de-Espeto, de tudo enfim que pelo malassombrado enche a gente de admiração e de espanto, há de ter notado a facilidade com que o fantástico da imaginação primitiva resolve as dificuldades mais insuperáveis.

Há sempre um Carrapato que presta um auxílio inesperado, um Urubu que leva um Jaboti às festas do céu... um talismã que concedeu o dom do encantamento. 
Essa facilidade de solução do fantástico de ontem é um ponto de contato entre o primitivismo e a realidade moderna:

A onça Palauá mandava, nas páginas imaginosas de Macunaíma, seus olhos ver o que se passava nas imensidades do mar...

- Podemos pedir para Paris que nos mandem fotografias dos últimos acontecimentos através da televisão!

E esse espírito de dinamismo e de solução rápida ninguém poderia aproveitá-lo com mais inteligência do que Mário o fez.

Todas as sugestões dispersas da vida brasileira ali estão concentradas em páginas de um comovente lirismo, como na lenda de Boiúna a Luna, ou profundamente humanas, como o capítulo do Tico-tico e o Chupinzão.

Tudo animado por uma expressão absolutamente brasileira, quer como forma, quer como sentido, quer como som.

A enumeração de nomes de bichos, de pássaros, de frutas, não é uma coisa sem sentido.

Há um todo poemático no jogo daquelas tonalidades combinadas discretamente num sentido de harmonia e de ritmo:

“Cajus, cajás, cajamangas, mangas, abacaxis, abacates, jaboaticabas [sic], graviolas, sapotis, pupunhas, pitangas, guajirus”.

“O jacareúna, o jacaretinga, o jacaré-açu, o jacareurarau, todos esses jacarés...”

“O macaco-prego, o macaco-de-cheiro, o guariba, o bugio, o cuatá, o barrigudo, o cairara”.

“E o sabiacica, o sabiapoca, o sabiaúna, o sabiá-piranga, o sabiá-gongá, que quando come não me dá...”

No capítulo de Ceuci - a caipora expulsa do território nacional e que voltou contratada da Companhia Lírica... - a gente fica se babando de gozo com aquela carretilha de adágios sobre cavalos, postos em jogo num aproveitamento lógico da rima:

“O gázeo-sarará que nunca prestou nem prestará!”

“O castanho-pedrês que para a carreira Deus o fez!”

“O cavalo-castanho-escuro que pisa no mole e pisa no duro!”

“O cavalo-bebe-em-branco que é cavalo manco!”

E, por fim, aquela delícia da "filha expulsa que corre no céu batendo perna de déu em déu!” 
E agora vejamos alguns exemplos do aproveitamento folclórico realizado pelo autor:

“O ramo cortado ficou pingando água e se escutou o lamento do caramboleiro:

- Capinheiro de meu pai

Não me corte meus cabelos,

Que o malvado me enterrou

Pelos figos da figueira

Que o passarinho picou!

Chô-chô, passarinho!”

"Não vê que um ajurucatinga passara muito afobado por ali. Os papagaios perguntaram pro parente onde ia.

— Madurou milho na terra dos ingleses, vou pra lá.

Então todos os papagaios foram comer milho na terra dos ingleses, porém primeiro viraram periquitos, porque assim comiam e os periquitos levavam a fama”.

"Cortou o grelo do pau e enfiou-o pelo buraco a dentro por amor de fazer a francesa sair. Porém Jacaré saiu? Nem ela”.

"Macunaíma encarou o Curumi empalamado e teve raiva.

Quis bater nele porém lembrou-se de cor: — quando você estiver embrabecendo conte três vezes os botões de vossa roupa. Contou e ficou manso outra vez".

“Macunaíma foi balançando Piaimã cada vez mais forte. Cantava:

— Bão-balão

Senhor capitão,

Espada na cinta,

Ginete na mão”.

Mas, é impossível resumir nas estreitezas de um artigo um livro de 283 páginas onde não há um capítulo insignificante, uma frase oca, uma palavra vã, - estupenda realização de um subconsciente enriquecido por todas as sugestões da vida brasileira, o qual florindo por si mesmo nos ofereceu na realidade as maravilhas da árvore Volomã.

O período mais brilhante da vida de um pesquisador, sim, como dele disse o senhor Tristão de Ataíde, mas de um pesquisador que atingiu o seu termo. 
Prova real de uma inteligência fortalecida por uma cultura de observação, que não tem deslizes, nem ao realizar a mudança formidável do cenário caboclo para o negro, como na estupenda página sobre o Xangô.

Livro de tudo. Livro onde há páginas encantadas como aquela em que Macunaíma deseja que o céu fique sem nuvens a fim de sua "Ci” mudada em estrela vir refletir-se nágua e ele poder brincar com ela na correnteza.

Livro de história da pátria desconhecida e bela.

O buraco de Maria Francisca, as inscrições de Pajeú e de Pedra Lavrada, a estátua do Deus Marte encontrada no Amazonas, as galinhas com pintos de ouro de perto de Natal, as rendas maravilhosas de Quiquina Cacunda de Pernambuco, o Tamarindo das irmãs Louro Vieira de Óbidos, os sapatinhos de lã da paulista D. Ana, tudo aparece no corre-corre tremendo dessas páginas ansiosas de tudo fixarem.

Macunaíma sofre todas as doenças da terra: o sarampão, o bute-calnua ${ }^{46}$, a erisipa. Cura-se com todos os sortilégios tais como chave de Sacrário, rezas de Bento Milagroso, invocações... mas assim que se apanha curado depressa ganha a rua em busca de sarnas pra se coçar...

Nas conclusões do herói a respeito da máquina Mário de Andrade mostra sua segurança em assuntos brasílicos:

A mentalidade cabocla tende forçosamente para dar uma interpretação de vida animal aos maquinismos, cujos movimentos não pode compreender.

São estas as conclusões de um Carijó de Águas Belas a respeito de um automóvel.

— Tem olhos (me dizia ele se referindo aos faróis), bebe água, faz necessidade, ronca e respira que nem nós...

Na lenda do pezão de Sumé esboça-se o quadro da formação das três raças brasileiras e no capítulo de Pauí-Pódole a gente sente a teoria da origem da vida provindo das nebulosas.

Na página da Pacuera de Oibê a sugestão para o assombro é uma coisa completa:

A pronúncia daquele pacuera... cuera... cuera... lembra forçosamente um rosnar selvagem! Junte-se a isso a imagem do Minhocão Terrível descrita no livro e a assombração é inevitável.

A venda que Carrapato botou é um mimo de inteligência interpretativa.

\footnotetext{
${ }^{46}$ O vocábulo "bute”, no Nordeste brasileiro, indica de modo jocoso qualquer doença. No contexto da enumeração de patologias, pode ser essa a sua acepção. A expressão “bute-calnua” nos é desconhecida, mas, como "bute”, também no Nordeste, indicava uma dermatite que acometia os escravos, talvez a locução conjugue patologia e terapêutica.
} 
A caça do Tapir na porta da Bolsa de S. Paulo — um delicioso flagrante de psicologia das multidões.

A canção de Mandú Sarará é um assombro de nostálgico e o trecho do furun-funfum... uma delícia de sutilidade.

Uma coisa que impressiona profundamente em Macunaíma é o equilíbrio de idéias conservado através do tumulto daquelas páginas tão diferentes.

"Pouca saúde e muita saúva” o dístico profundamente irônico torna-se até como um "leitmotiv” aparecendo aqui e ali para manter de pé o sentido do livro.

E, após tudo isso[,] o acabamento natural da obra, sem esforço, sem intenção de findar...

O livro acaba-se por si mesmo como que absorvido por aquele silêncio onde só se escutava o gritinho fino do inseto tísico: “Vim de Minas, vim de Minas”.

O herói não morre. - Realiza o destino lendário de seus maiores:

— Passa também a ser constelação perdida no mistério dos céus.

Volta intuitivamente ao ponto de partida da vida, cientificamente interpretada como provinda das nebulosas.

Macunaíma é, pois[,] um formidável poema.

Apenas não foi escrito para seguir a orientação dos críticos e por isso ficará para eles como uma parábola, até que o Brasil acabe de descobrir-se a si mesmo, como o pressente o senhor Tristão de Ataíde.

Não é livro escrito para ser julgado por uma geração ainda desorientada pelos ardores da revolução.

Para ser apreciado com justeza carece de distância. Esperemos.

Por enquanto, digamos como Piaimã morrendo atolado no tacho: — Falta queijo! 


\section{Livres NovOS $\because-$ Macunaima, por Mario de LIVIOS NOVOS .. Mndratede, S. Paulo. 1928}

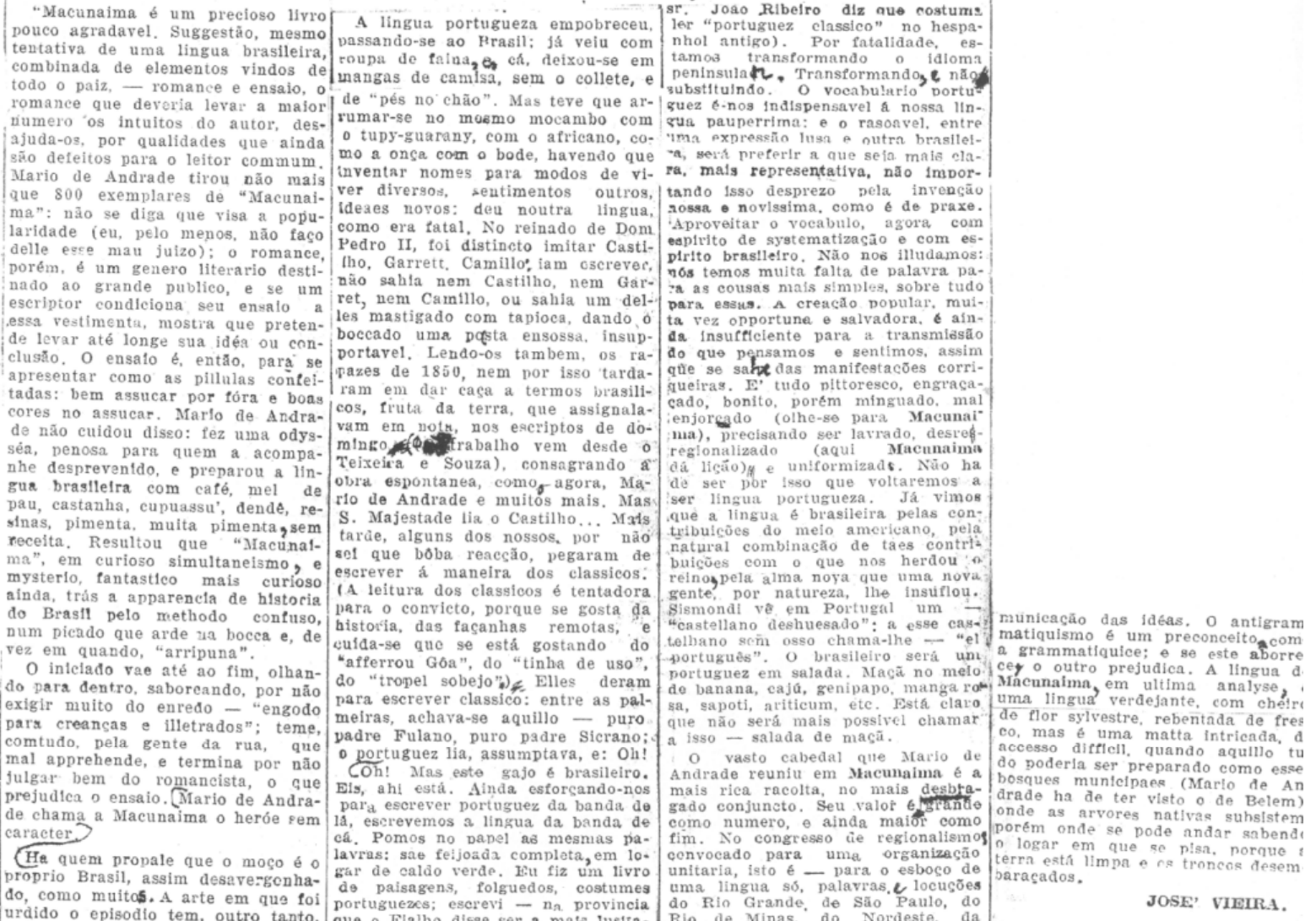

do, como muitos. A arte em que foi por que se lhe dêm palmas, logo que Mas eu não ribanceira do autor. minar a ficcấo, onde, aliás, exaa or é independente, como, o creaalém do mais, por ser um dos bem brincadeira de umas tradicōes, barbudas que estavam abusando das que me limitar ao ensaio, Tenho que me limitar ao ensaio, que é Brasil empalemedo de estrangelris. mo.

Mario de Andrade não se colloc somente entre os quo enxergam as differencas da lingua falada e escripta no Brasil, comparada com a
outra, que aqui desembarcou prote gida, que agui desembarcou protegantes; faz mais: enfileira-se com os que propugnam a differenoiaçăo ajudanđo o phenomeno ordinarlo. ucontece vale já por bravura (entre nós é isso), porquanto o frequente tem sido uma cegueira in hoa von ao ñ̃o manatiace oreguiçisa, qua tuguezes distingulu-se da lingua dos tespanhoes, como tinha de ser; ungua dos brasileiros differencia-se da lingua portugueza: ora! faz de cnnta que não 6 , nega-se que seja, chega-se a ñ̃o crer, mesmo, no laefo, para não se desagradar ao dr.
Julio. da Academia de Os portuguezes som de Sclencias. convem, mas, por dentro, riem do colonfalismo inconsclente, ou imbe-
₹il. senđ̃o safadote.

que o Flatho disse ser a malô lusttana de todas; lia, na occastao. numa
quinta, debaixo de velhos carvalhos acolhedores, o mesnio Fialho, lia cal mals adequado. No Brasil. Mario de Alencar achou a "linguagem aportyllezada não sendo attingir o es. trasiletra: entre pertugueze ninguem tro. Marto de Andrade o outros abrastAnado obsbulos nascla os no Bras!l por cima de vocabulos nascidos e ereados em tugueza ê portuguez por adaptação
como serdi brasilefro a quando of nalonallzarmos, como se fez em portugal, na coordenaçáo e nacionaliza. so de lusitanlemo. ora por excesso de brasileirismo. Vala-se bem: a nåo está nas palavres em s1, está no sentido novo que lhes damos, na dis. ve, a que nĩo imprimimos mals bre tudo por impossibibilidade pgychologlea, a ordem portukueza maracteristica; nos achegd indios ou africanos, com ob neoloxismos formados na convivencia das varias racas: nos
cacoetes de expressa, de que nenu
Ruy - Machado se 11 vraram - 1nao tudo pelo vielo physico, pela - complexidade humant, smnim nosso drama nacional. A base da llpgua brasileira tem, todavia, que ser a lingua portugueza no que ella possue de unlversal, da mesma sorte qu, portuguez so organizou sobre all-
cerce hespanhol. (Conta-se que o eninsula ta - a as cousas ina falta de palavra pa. Insucficiente para a transmlassã que que pensamos e sentimos, assin cado, ma), precisando ser larrado, desreg. cá liçáo) y e unfformizads. Nüo ha que a lingua ê brasileira pelas conmatural buicues com o que nos herdou gente, por natureza, the insuflou. Sismondi vê em Portugal um
"castellano deshuesado": a e esse cas telhano scm osso chama-line - - el. portuguez em salada. Maca no meto sa, sapoti, aritieum etc Fst́́ clato que não será mais possiv

o vasto cabedal que Mario de mais rica racolta, no mais desbtacomo numero, e ainda maior como unitaria, isto e - para o esboso de do Rio Grande. de São Paulo, do Amazonla, etc. se encontrem e prestern servicos em toda a parte, Esca a mensagem do ensalo, não contando o folk-lore. Conclamaçáo de intubia valente, no cume do morMario de Andrade teria reito alnda melhor, a meu vêr, não fosse tãc ta que poz no mesmo plano uma esganda philologica. Destrancezando - romance, desacademizando o esmodo que anarchisou $\&$ destrufu quando queria construlr. Sabe-se que Mario de Andrade pretendeu atordoar o ouvido habltuado as memanchar a casa branca da serra, vantar outra mals forte 0 mais nossa, com madeiras do Para. Mas botou so o material no terreno, evitando um trabalho architectonleo, certo que transitorio, porem pue morar debalxo de um tecto, e pelo facto tempos em tempos, não se ha de
ficar apanhando sol e ohuva, a olhar para as telhas, para os tijolos.
para os calbros e rlpas, apenas para os calbros e ripas, apenas comprehender o que está no llivro. seu 18 de malo. tão opportuno. attinglar uma coisa que e de todas rlos, a de todas as epocas e palzes: qualquer lingua, em qualquer ins, como Instrunento de com
Ideas, O antigram ce o outro prejudica. A lingua d uma lingua verdejante, com chétri JOSE' VIEIRA.

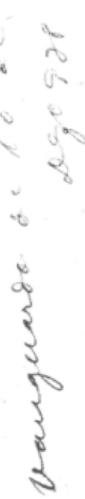

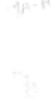




\section{MACUNAÍMA, POR MÁRIO DE ANDRADE}

VIEIRA, José. “Livros novos / Macunaíma, por Mário de Andrade, S. Paulo, 1928”. Vanguarda: [Rio de Janeiro ${ }^{47}$ ], 10 de dezembro de 1928. IEB-USP - MA-MP.

Macunaíma é um precioso livro pouco agradável. Sugestão, mesmo tentativa de uma língua brasileira, combinada de elementos vindos de todo o país, - romance e ensaio, o romance que deveria levar a maior número os intuitos do autor, desajuda-os, por qualidades que ainda são defeitos para o leitor comum. Mário de Andrade tirou não mais que 800 exemplares de Macunaíma: não se diga que visa a popularidade (eu, pelo menos, não faço dele esse mau juízo); o romance, porém, é um gênero literário destinado ao grande público, e se um escritor condiciona seu ensaio a essa vestimenta, mostra que pretende levar até longe sua idéia ou conclusão. O ensaio é, então, para se apresentar como as pílulas confeitadas: bem açúcar por fora e boas cores no açúcar. Mário de Andrade não cuidou disso: fez uma odisséia, penosa para quem a acompanhe desprevenido, e preparou a língua brasileira com café, mel de pau, castanha, cupuaçu, dendê, resinas, pimenta, muita pimenta, sem receita. Resultou que Macunaíma, em curioso simultaneísmo, e mistério, fantástico mais curioso ainda, traz ${ }^{48}$ a aparência de história do Brasil pelo método confuso, num picado que arde na boca e, de vez em quando, “arripuna”.

O iniciado vai até o fim, olhando para dentro, saboreando, por não exigir muito do enredo - "engodo para crianças e iletrados"; teme, contudo, pela gente da rua, que mal apreende, e termina por não julgar bem do romancista, o que prejudica o ensaio. Mário de Andrade chama a Macunaíma o herói sem nenhum caráter.

Há quem propale que o moço é o próprio Brasil, assim desavergonhado, como muitos. A arte em que foi urdido o episódio tem, outro tanto, por que se lhe dêem palmas, logo que estejamos na ribanceira do autor. Mas eu não tenho espaço para examinar a ficção, onde, aliás, o criador é independente, como criador, além do mais, por ser um dos bem aparecidos desmancha-prazer, na brincadeira de umas tradições barbudas que estavam abusando das liberalidades do usocapião. Tenho que me limitar ao ensaio, que é o remédio ou veneno curativo para o Brasil empalemado de estrangeirismo.

\footnotetext{
${ }^{47}$ No verso do recorte, que se encontra no álbum R.29 do IEB-USP - Recortes de Mário de Andrade -, há indícios de que a cidade do Rio de Janeiro seja o local da publicação.

${ }^{48}$ No jornal, lê-se "trás".
} 
Mário de Andrade não se coloca somente entre os que enxergam as diferenças da língua falada e escrita no Brasil, comparada com a outra, que aqui desembarcou protegida por Nossa Senhora dos Navegantes; faz mais: enfileira-se com os que propugnam a diferenciação, ajudando o fenômeno ordinário. Neste problema, enxergar o que acontece vale já por bravura (entre nós é isso), porquanto o freqüente tem sido uma cegueira de boa vontade, comodidade preguiçosa, quando não lucrativa. A língua dos portugueses distinguiu-se da língua dos espanhóis, como tinha de ser; a língua dos brasileiros diferencia-se da língua portuguesa: ora! faz de conta que não é, nega-se que seja, e chega-se a não crer, mesmo, no fato, para não se desagradar ao dr. Júlio, da Academia de Ciências. Os portugueses gostam, porque lhes convém, mas, por dentro, riem do colonialismo inconsciente, ou imbecil, senão safadote.

A língua portuguesa empobreceu, passando-se para o Brasil; já veio com roupa de faina, e, cá, deixou-se em mangas de camisa, sem o colete, e de “pés no chão”. Mas teve que arrumar-se no mesmo mocambo com o tupi-guarani, com o africano, como a onça com o bode, havendo que inventar nomes para modos de viver diversos, sentimentos outros, ideais novos: deu noutra língua, como era fatal. No reinado de D. Pedro II, foi distinto imitar Castilho, Garrett, Camilo: iam escrever não saia nem Castilho, nem Garrett, nem Camilo, ou saía um deles mastigado com tapioca, dando o bocado uma pasta insossa, insuportável. Lendo-os também, os rapazes de 1850, nem por isso tardaram em dar caça a termos brasílicos, fruta da terra, que assinalavam em nota, nos escritos de domingo (o trabalho vem desde o Teixeira e Sousa), consagrando a obra espontânea, como agora, Mário de Andrade e muitos mais. Mas S. Majestade lia o Castilho... Mais tarde, alguns dos nossos, por não sei que boba reação, pegaram de escrever à maneira dos clássicos. (A leitura dos clássicos é tentadora para o convicto, porque se gosta da história, das façanhas remotas, e cuida-se que se está gostando do "aferrou Goa”, do "tinha de uso”, do "tropel sobejo”[)]. Eles deram para escrever clássico: entre as palmeiras, achava-se aquilo - puro padre Fulano, puro padre Sicrano; o português lia, assuntava, e: Oh! Oh! Mas este gajo é brasileiro. Eis, aí está. Ainda esforçando-nos para escrever português da banda de lá, escrevemos a língua da banda de cá. Pomos no papel as mesmas palavras: sai feijoada completa, em lugar de caldo verde. Eu fiz um livro de paisagens, folguedos, costumes portugueses; escrevi: - na província que o Fialho disse ser a mais lusitana de todas; lia, na ocasião, numa quinta, debaixo de velhos carvalhos acolhedores, o mesmo Fialho, lia o Camilo; acumulei o vocabulário local mais adequado. No Brasil, Mário de Alencar achou a "linguagem aportuguesada”, não sendo atingir o estilo, onde estava, antes, a modalidade brasileira; entre portugueses, ninguém hesitou nem se enganou; e está certo. 
Mário de Andrade e outros abrasileiradores exageram e erram na obstinação com que buscam botar vocábulos nascidos no Brasil por cima de vocábulos nascidos e criados em Portugal. Muitíssimo da língua portuguesa é portuguesa por adaptação, como serão brasileiros quando os nacionalizarmos, como se fez em Portugal, na coordenação e nacionalização que está tardando, ora por excesso de lusitanismo, ora por excesso de brasileirismo. Veja-se bem: a diferença fundamental da língua não está nas palavras em si, está no sentido novo que lhes damos, na disposição em que elas ficam na frase, a que não imprimimos mais, sobretudo por impossibilidade psicológica, a ordem portuguesa característica; nos achegos índios ou africanos, com os neologismos formados na convivência de várias raças; nos cacoetes de expressão, de que nem Rui e Machado se livraram - influindo tudo pelo meio físico, pela maior complexidade humana, enfim, pelo ritmo brasileiro e americano do nosso drama nacional. A base da língua brasileira tem, todavia, que ser a língua portuguesa no que ela possui de universal, da mesma sorte que o português se organizou sobre alicerce espanhol. (Conta-se que o sr. João Ribeiro diz que costuma ler "português clássico" no espanhol antigo). Por fatalidade, estamos transformando o idioma peninsular. Transformando, e não substituindo. O vocabulário português é-nos indispensável à nossa língua paupérrima; e o razoável, entre uma expressão lusa e outra brasileira, será preferir a que seja mais clara, mais representativa, não importando isso desprezo pela invenção nossa e novíssima, como é de praxe. Aproveitar o vocábulo, agora com espírito de sistematização e com espírito brasileiro. Não nos iludamos: nós temos muita falta de palavra para as coisas mais simples, sobretudo para essas. A criação popular, muita vez oportuna e salvadora, é ainda insuficiente para a transmissão do que pensamos e sentimos, assim que se saiu das manifestações corriqueiras. É tudo pitoresco, engraçado, bonito, porém minguado, mal-enjorcado ${ }^{49}$ (olhe-se para Macunaíma), precisando ser lavrado, desregionalizado (aqui Macunaíma dá lição) e uniformizado. Não há de ser por isso que voltaremos a ser língua portuguesa. Já vimos que a língua é brasileira pelas contribuições do meio americano, pela natural combinação de tais contribuições com o que nos herdou o reino, pela alma nova que uma nova gente, por natureza, lhe insuflou. Sismondi vê em Portugal um “castellano deshuesado"; a esse castelhano sem osso chama-lhe — "el português”. O brasileiro será um português em salada. Maçã no meio de banana, caju, jenipapo, manga-rosa, sapoti, $\operatorname{ariticum}^{50}$, etc. Está claro que não será mais possível chamar a isso — salada de maçã.

\footnotetext{
49 “Mal-enjorcado”. Regionalismo: mal-composto.

50 “Ariticum”: mesmo que araticum, vocábulo que designa árvores e arbustos frutíferos do Brasil; designação comum à graviola e à fruta-do-conde entre outras subespécies.
} 
O vasto cabedal que Mário de Andrade reuniu em Macunaíma é a mais rica recolta ${ }^{51}$, no mais desbragado conjunto. Seu valor é grande como número, e ainda maior como fim. No congresso de regionalismo, convocado para uma organização unitária, isto é — para o esboço de uma língua só, palavras e locuções do Rio Grande, de São Paulo, do Rio, de Minas, do Nordeste, da Amazônia, etc., se encontrem e prestem serviços em toda a parte, como componentes de um todo. Essa a mensagem do ensaio, não contando o folclore. Conclamação de inúbia valente, no cume do morro, assoprando para a redondeza. Mário de Andrade teria feito ainda melhor, a meu ver, não fosse tão levado pelo partidarismo ${ }^{52}$ modernista, que pôs no mesmo plano uma estética revolucionária e uma propaganda filológica. Desfrancesando o romance, desacademizando o estilo, desarticulou a sintaxe, de um modo que anarquizou e destruiu quando queria construir. Sabe-se que foi isso feito voluntariamente, que Mário de Andrade pretendeu atordoar o ouvido habituado às melodias enternecedoras, que quis desmanchar a casa branca da serra, feita de pinheiro europeu, para levantar outra mais forte e mais nossa, com madeiras do Pará. Mas botou só o material no terreno, evitando um trabalho arquitetônico, certo que transitório, porém necessário, porque a gente tem que morar debaixo de um teto, e pelo fato de ter de vir um prefeito Passos de tempos em tempos, não se há de ficar apanhando sol e chuva a olhar para as telhas, para os tijolos, para os caibros e ripas, apenas amontoados no chão. Não é não ${ }^{53}$ compreender o que está no livro.

O que não se deve ocultar é que o seu 13 de maio, tão oportuno, atingiu uma coisa que é de todas escolas, de todos os credos literários, e de todas as épocas e países: uma ordem lógica, indispensável a qualquer língua, em qualquer instante, como instrumento de comunicação de idéias. O antigramatiquismo é um preconceito como a gramatiquice; e se este aborrece, o outro prejudica. A língua de Macunaíma, em última análise, é uma língua verdejante, com cheiro de flor silvestre, rebentada de fresco, mas é uma mata intrincada, de acesso difícil, quando aquilo tudo poderia ser preparado como esses bosques municipais (Mário de Andrade há de ter visto o de Belém), onde as árvores nativas subsistem, porém onde se pode andar sabendo o lugar em que se pisa, porque a terra está limpa e os troncos desembaraçados.

JOSÉ VIEIRA

\footnotetext{
${ }^{51}$ No jornal, lê-se “racolta”.

${ }^{52}$ No jornal, lê-se "pardidarismo". Erro tipográfico.

${ }^{53}$ No arquivo de recortes de Mário de Andrade, pertencente ao IEB-USP, o exemplar do artigo de José Vieira contém correções manuscritas (feitas por Mário de Andrade?). Nessa passagem, o vocábulo "não" foi escrito sobre a palavra impressa, quase ilegível. Provavelmente, lia-se “mão” em vez de "não” - o que seria evidente erro tipográfico.
} 
[O. M. (Olivio Montenegro). Periódico não identificado.

$\mathrm{S} / 1$ (Recife), s/d. Colunas 1 a 5. IEB - MA-MP]

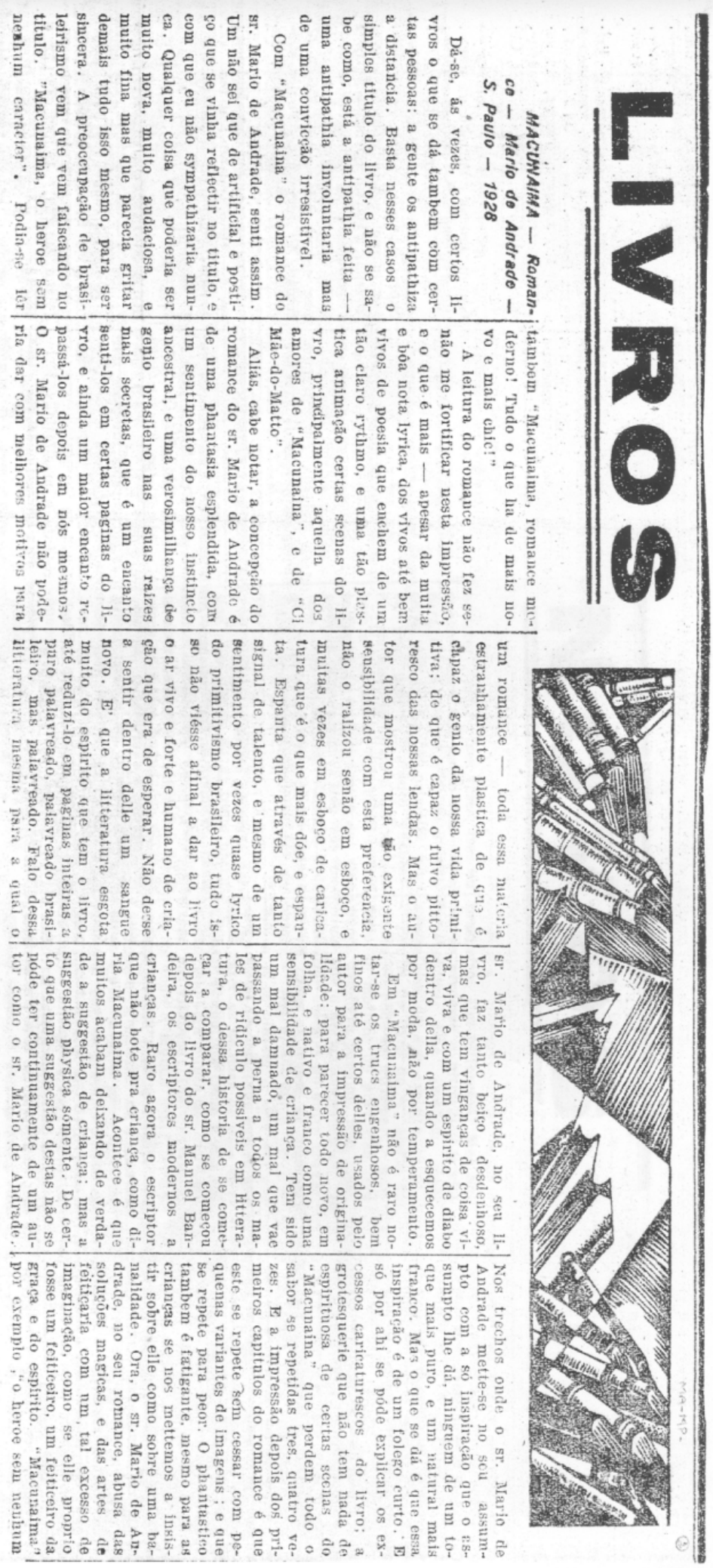


[O. M. (Olívio Montenegro). Periódico não identificado. $\mathrm{S} / 1$ (Recife), s/d. Colunas 6 e 7. IEB - MA-MP]
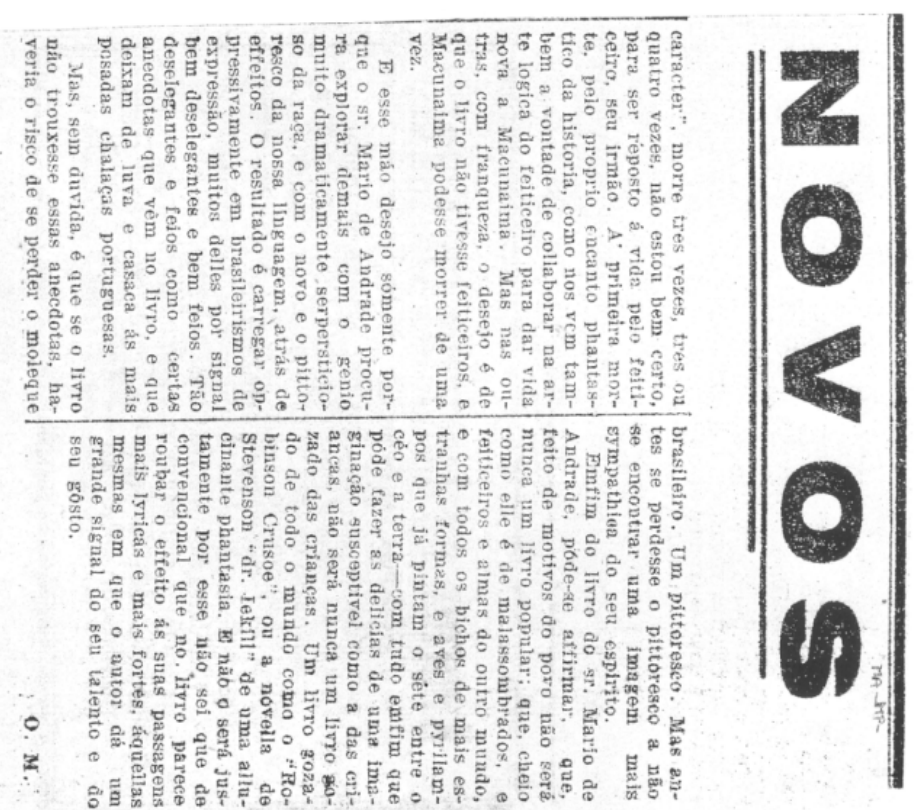


\section{MACUNAÍMA — ROMANCE - MÁRIO DE ANDRADE}

O. M. [Olívio Montenegro]. "Livros novos / Macunaíma - Romance - Mário de Andrade - S. Paulo - 1928”. Periódico não identificado, [Recife ${ }^{54}$ ], s/d. IEB-USP - MA-MP.

Dá-se, às vezes, com certos livros o que se dá também com certas pessoas: a gente os antipatiza à distância. Basta nesses casos o simples título do livro, e não se sabe como, está a antipatia feita - uma antipatia involuntária mas de uma convicção irresistível.

Com Macunaíma, o romance do sr. Mário de Andrade, senti assim. Um não sei quêe $^{55}$ de artificial e postiço que se vinha refletir no título, e com que eu não simpatizaria nunca. Qualquer coisa que poderia ser muito nova, muito audaciosa, e muito fina mas que parecia gritar demais tudo isso mesmo, para ser sincera. A preocupação de brasileirismo vem que vem faiscando no título. Macunaíma, o herói sem nenhum caráter. Podia-se ler também “Macunaíma, romance moderno! Tudo o que há de mais novo e mais chic!”

A leitura do romance não fez senão me fortificar nesta impressão, e o que é mais - apesar da muita e boa nota lírica, dos vivos até bem vivos de poesia que enchem de um tão claro ritmo, e uma tão plástica animação certas cenas do livro, principalmente aquela dos amores de Macunaíma e de Ci Mãe-do-Mato.

Aliás, cabe notar, a concepção do romance do sr. Mário de Andrade é de uma fantasia esplêndida, com um sentimento do nosso instinto ancestral, e uma verossimilhança de gênio brasileiro nas suas raízes mais secretas, que é um encanto senti-los em certas páginas do livro, e ainda um maior encanto repassá-los depois em nós mesmos. O sr. Mário de Andrade não poderia dar com melhores motivos para um romance - toda essa matéria estranhamente plástica de que é capaz o gênio da nossa vida primitiva; de que é capaz o fulvo pitoresco das nossas lendas. Mas o autor que mostrou uma tão exigente sensibilidade com esta preferência; não o realizou ${ }^{56}$ senão em esboço, e muitas vezes em esboço de caricatura que é o que mais dói, e espanta. Espanta que através de tanto sinal de talento, e mesmo de um sentimento por vezes quase lírico do primitivismo brasileiro, tudo isso não viesse afinal a dar ao livro o ar vivo e forte e humano de criação que era de esperar. Não desse a sentir dentro dele um sangue novo.

\footnotetext{
${ }^{54}$ No verso do recorte, que se encontra no álbum R.29 do IEB-USP - Recortes de Mário de Andrade -, há indícios de que a cidade de Recife seja o local da publicação.

55 No jornal, lê-se “que”, sem o acento.

${ }^{56}$ No jornal, lê-se “ralizou” - evidente erro tipográfico.
} 
É que a literatura esgota muito do espírito que tem o livro, até reduzi-lo em páginas inteiras a puro palavreado, palavreado brasileiro, mas palavreado. Falo dessa literatura mesma para a qual o sr. Mário de Andrade, no seu livro, faz tanto beiço desdenhoso, mas que tem vinganças de coisa viva, viva e com um espírito de diabo dentro dela, quando a esquecemos por moda, não por temperamento.

Em Macunaíma não é raro notar-se os truques ${ }^{57}$ engenhosos, bem finos até certos deles, usados pelo autor para a impressão de originalidade: para parecer todo novo, em folha, e nativo e franco como uma sensibilidade de criança. Tem sido um mal danado, um mal que vai passando a perna a todos os males de ridículo possíveis em literatura, o dessa história de se começar a comparar, como se começou depois do livro do sr. Manuel Bandeira, os escritores modernos a crianças. Raro agora o escritor que não bote pra criança, como diria Macunaíma. Acontece é que muitos acabam deixando de verdade a sugestão de criança; mas a sugestão física somente. De certo que uma sugestão destas não se pode ter continuamente de um autor como o sr. Mário de Andrade. Nos trechos onde o sr. Mário de Andrade mete-se no seu assunto com a só inspiração que o assunto lhe dá, ninguém de um toque mais puro, e um natural mais franco. Mas o que se dá é que essa inspiração é de um fôlego curto. E só por aí se pode explicar os excessos caricaturescos do livro; a grotesquerie que não tem nada de espirituosa de certas cenas do Macunaíma, que perdem todo o sabor se repetidas três, quatro vezes. E a impressão depois dos primeiros capítulos do romance é que este se repete sem cessar com pequenas variantes de imagens; e que se repete para pior. O fantástico também é fatigante, mesmo para as crianças se nos metemos a insistir sobre ele como sobre uma banalidade. Ora, o sr. Mário de Andrade, no seu romance, abusa das soluções mágicas, e das artes de feitiçaria com um tal excesso de imaginação, como se ele próprio fosse um feiticeiro, um feiticeiro da graça e do espírito. Macunaíma, por exemplo, “o herói sem nenhum caráter”, morre três vezes, três ou quatro vezes, não estou bem certo, para ser reposto à vida pelo feiticeiro, seu irmão. À primeira morte, pelo próprio encanto fantástico da história, como nos vem também a vontade de colaborar na arte lógica do feiticeiro para dar vida nova a Macunaíma. Mas nas outras, com franqueza, o desejo é de que o livro não tivesse feiticeiros, e Macunaíma pudesse morrer de uma vez.

E esse mau desejo somente porque o sr. Mário de Andrade procura explorar demais com o gênio muito dramaticamente supersticioso da raça, e com o novo e o pitoresco da nossa linguagem, atrás de efeitos. O resultado é carregar opressivamente em brasileirismos de ex-

\footnotetext{
${ }^{57}$ No jornal, lê-se “trucs”.
} 
pressão, muitos deles por sinal bem deselegantes e bem feios. Tão deselegantes e feios como certas anedotas que vêm no livro, e que deixam de luva e casaca às mais pesadas chalaças portuguesas.

Mas, sem dúvida, é que se o livro não trouxesse essas anedotas, haveria o risco de se perder o moleque brasileiro. Um pitoresco. Mas antes se perdesse o pitoresco a não se encontrar uma imagem mais simpática do seu espírito.

Enfim[,] do livro do sr. Mário de Andrade, pode-se afirmar que, feito de motivos do povo, não será nunca um livro popular; que, cheio como ele é de mal-assombrados ${ }^{58}$, e feiticeiros e almas do outro mundo, e com todos os bichos de mais estranhas formas, e aves e pirilampos que já pintam o sete entre o céu e a terra - com tudo enfim que pode fazer as delícias de uma imaginação suscetível como a das crianças, não será nunca um livro gozado das crianças. Um livro gozado de todo o mundo como o Robinson Crusoe, ou a novela de Stevenson Dr. Jekill de uma alucinante fantasia. E não o será justamente por esse não sei quê de convencional que no livro parece roubar o efeito às suas passagens mais líricas e mais fortes, àquelas mesmas em que o autor dá um grande sinal do seu talento e do seu gosto.

O. M. [OLÍVIO MONTENEGRO]

\footnotetext{
${ }^{58}$ No jornal, lê-se “malassombrados”.
} 

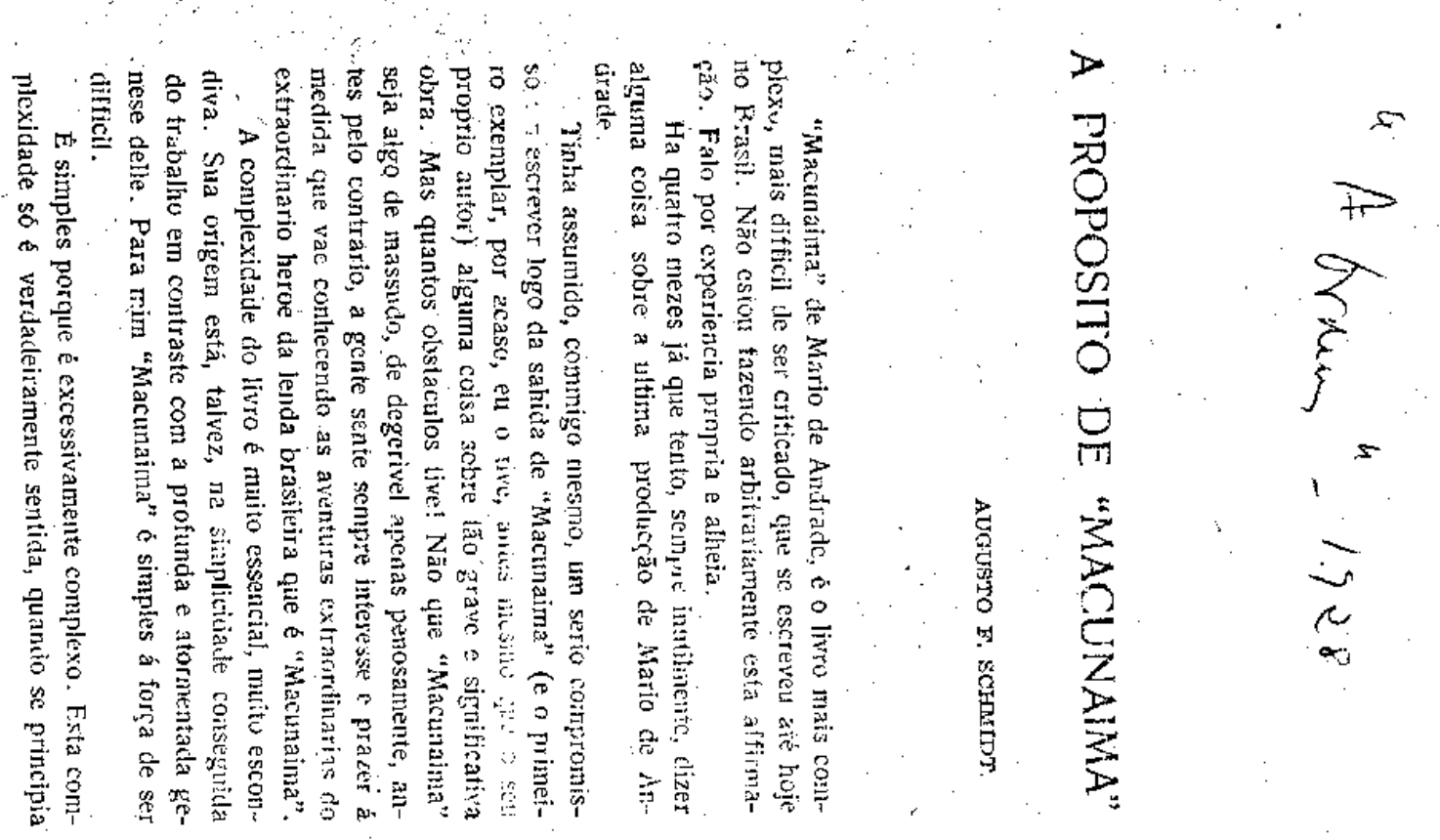

$\stackrel{\$}{\$}$

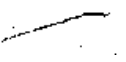

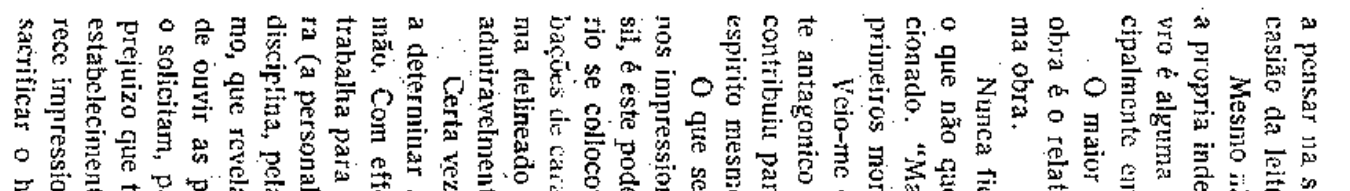

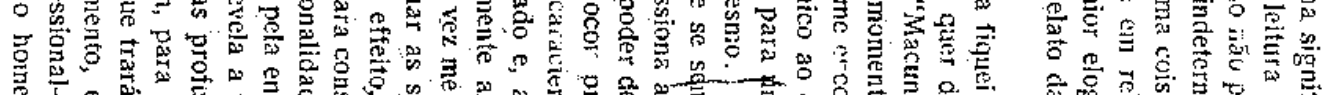

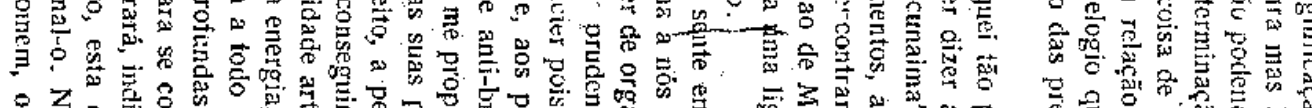

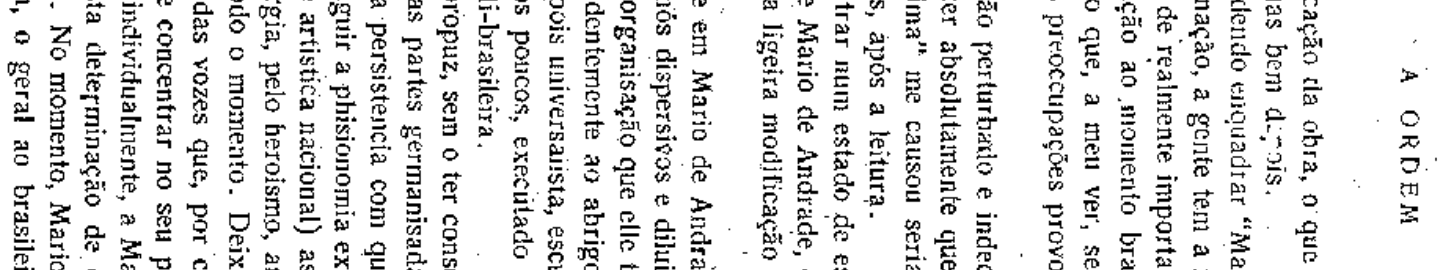

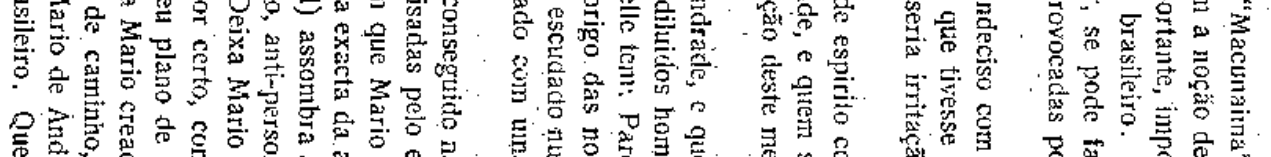

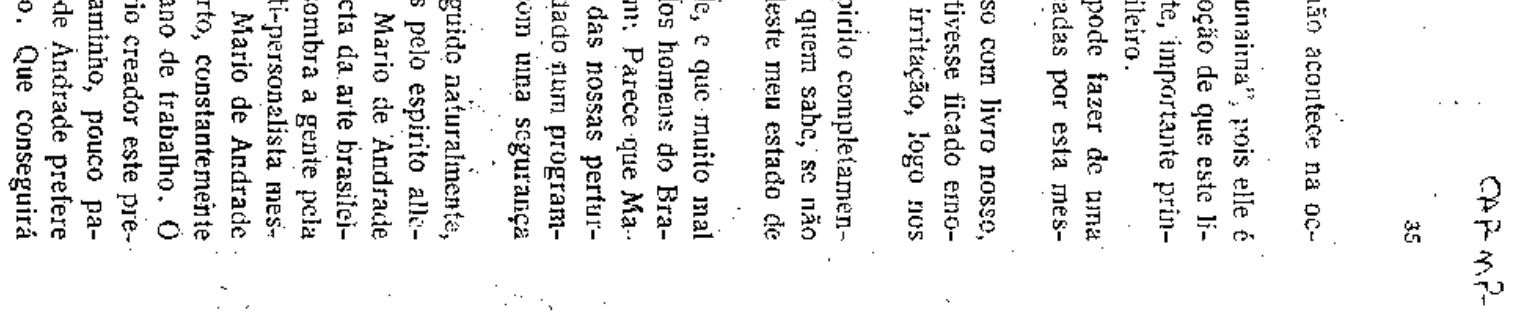


[A Ordem. Rio de Janeiro, 1928. IEB - CAP-MP」

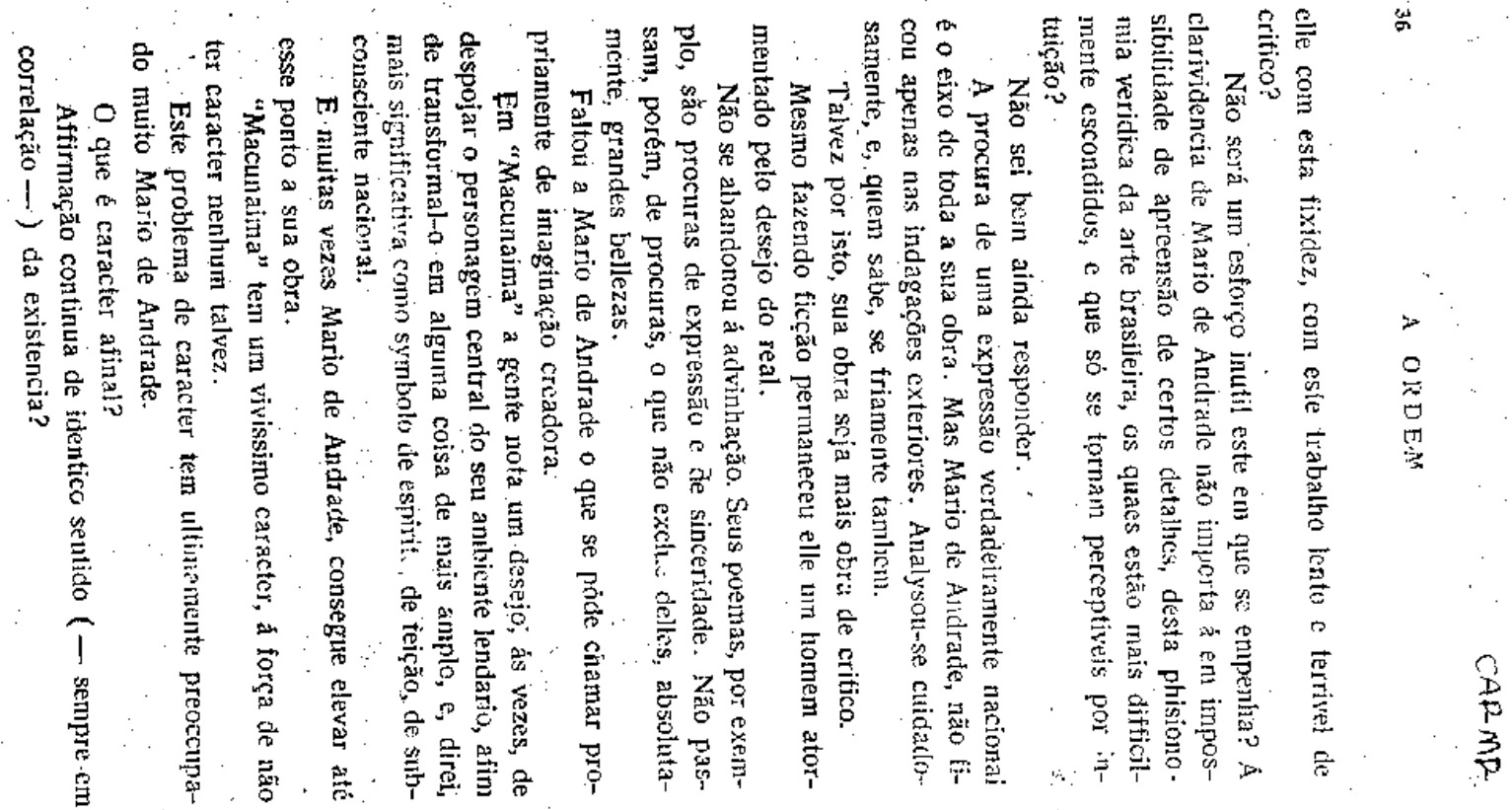

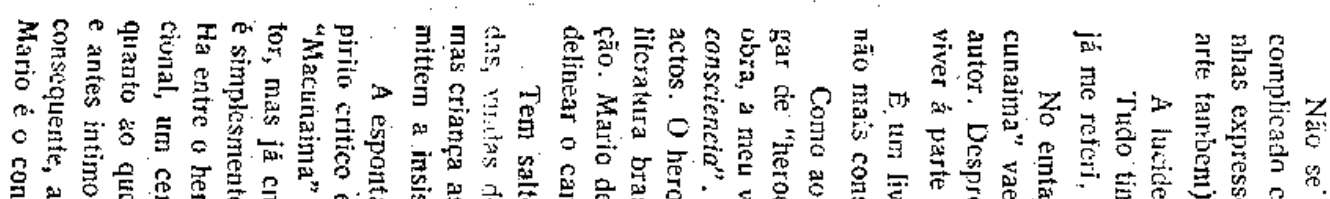

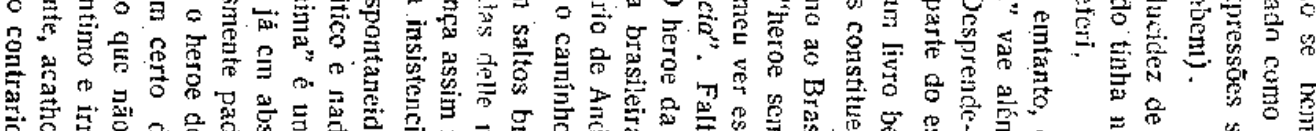

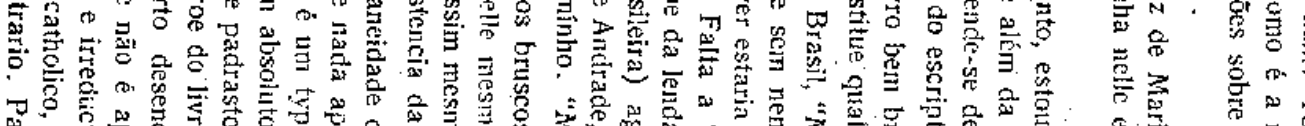

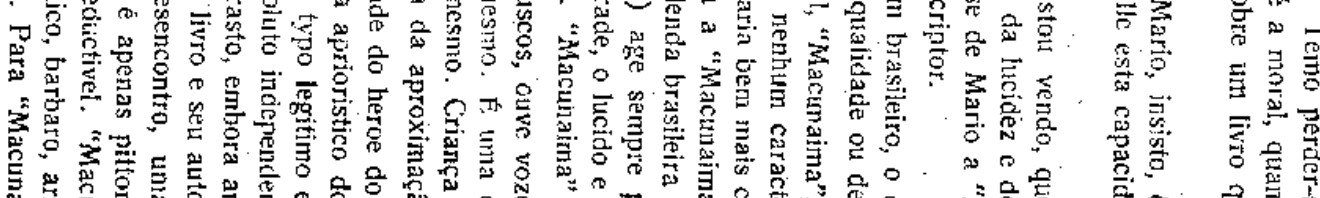

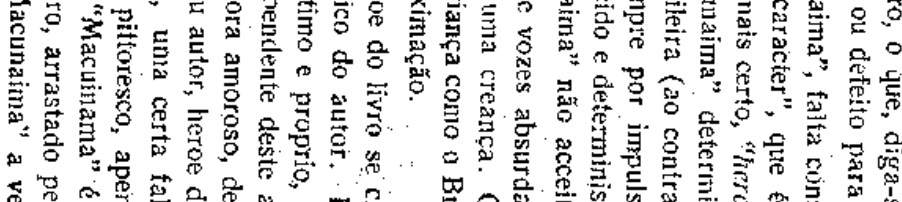

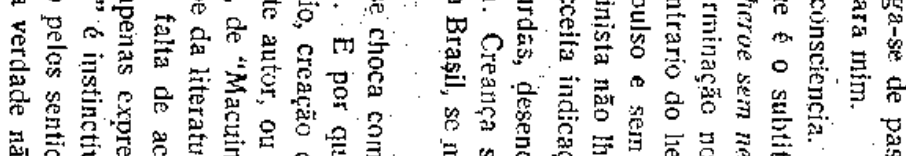

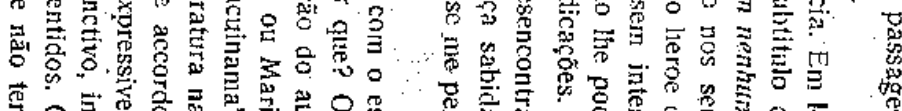

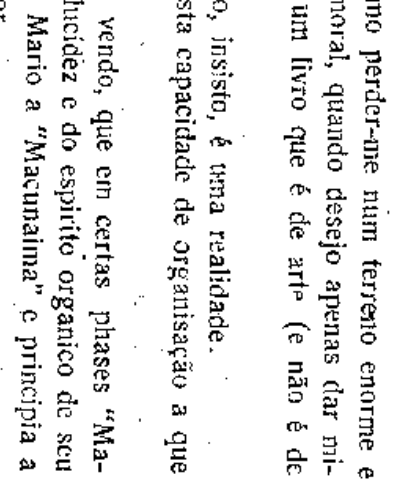
$\frac{8}{5}$ (2)

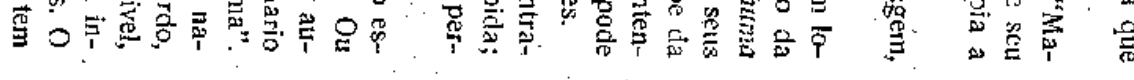


$\lfloor$ A Ordem. Rio de Janeiro, 1928. IEB - CAP-MP」

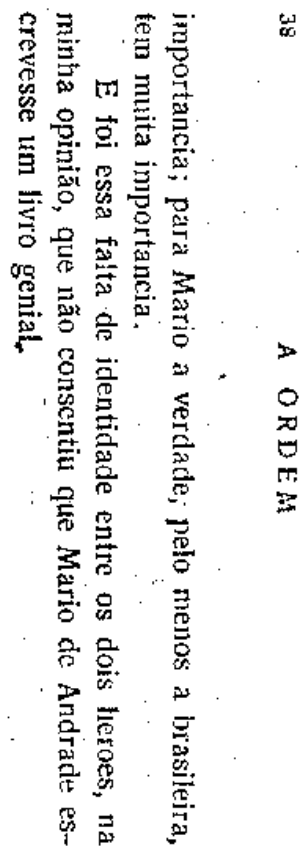




\section{A PROPÓSITO DE MACUNAÍMA}

SCHMIDT, Augusto F. “A propósito de Macunaíma”. A Ordem: Rio de Janeiro, [dezembro?] de 1928, p. 34-38. IEB-USP - CAP-MP.

Macunaíma, de Mário de Andrade, é o livro mais complexo, mais difícil de ser criticado, que se escreveu até hoje no Brasil. Não estou fazendo arbitrariamente esta afirmação. Falo por experiência própria e alheia.

Há quatro meses já que tento, sempre inutilmente, dizer alguma coisa sobre a última produção de Mário de Andrade.

Tinha assumido, comigo mesmo, um sério compromisso em escrever logo da saída de Macunaíma (e o primeiro exemplar, por acaso, eu o tive antes mesmo que o seu próprio autor) alguma coisa sobre tão grave e significativa obra. Mas quantos obstáculos tive! Não que $M a-$ cunaíma seja algo de massudo, de digerível apenas penosamente, antes pelo contrário, a gente sente sempre interesse e prazer à medida que vai conhecendo as aventuras extraordinárias do extraordinário herói da lenda brasileira que é Macunaíma.

A complexidade do livro é muito essencial, muito escondida ${ }^{59}$. Sua origem está, talvez, na simplicidade conseguida do trabalho em contraste com a profunda e atormentada gênese dele. Para mim “Macunaíma” é simples à força de ser difícil.

É simples porque é excessivamente complexo. Esta complexidade só é verdadeiramente sentida quando se principia a pensar na significação da obra, o que não acontece na ocasião da leitura mas bem depois.

Mesmo não podendo enquadrar Macunaíma, pois ele é a própria indeterminação, a gente tem a noção de que este livro é alguma coisa de realmente importante, importante principalmente em relação ao momento brasileiro.

O maior elogio que, a meu ver, se pode fazer de uma obra é o relato das preocupações provocadas por esta mesma obra.

Nunca fiquei tão perturbado e indeciso com livro nosso, o que não quer dizer absolutamente que tivesse ficado emocionado. Macunaíma me causou séria irritação, logo nos primeiros momentos, após a leitura.

\footnotetext{
${ }^{59}$ No periódico, lê-se “escondiva”. Erro tipográfico.
} 
Veio-me encontrar num estado de espírito completamente antagônico ao de Mário de Andrade, e[,] quem sabe, se não contribuiu para uma ligeira modificação deste meu estado de espírito mesmo.

O que se sente em Mário de Andrade, e que muito mal nos impressiona a nós dispersivos e diluídos homens do Brasil, é este poder de organização que ele tem. Parece que Mário se colocou prudentemente ao abrigo das nossas perturbações de caráter pois universalista, escudado num programa delineado e, aos poucos, executado com uma segurança admiravelmente anti-brasileira.

Certa vez me propus, sem o ter conseguido naturalmente, a determinar as suas partes germanizadas pelo espírito alemão. Com efeito, a persistência com que Mário de Andrade trabalha para conseguir a fisionomia exata da arte brasileira (a personalidade artística nacional) assombra a gente pela disciplina, pela energia, pelo heroísmo, anti-personalista mesmo, que revela a todo o momento. Deixa Mário de Andrade de ouvir as profundas vozes que, por certo, constantemente o solicitam, para se concentrar no seu plano de trabalho. O prejuízo que trará, individualmente, a Mário criador este pré-estabelecimento, esta determinação de caminho, pouco parece impressioná-lo. No momento, Mário de Andrade prefere sacrificar o homem, o geral ao brasileiro. Que conseguirá ele com esta fixidez, com este trabalho lento e terrível de crítico?

Não será um esforço inútil este em que se empenha? À clarividência de Mário de Andrade não importa a impossibilidade ${ }^{60}$ de apreensão de certos detalhes, desta fisionomia verídica da arte brasileira, os quais estão mais dificilmente escondidos, e que só se tornam perceptíveis por intuição?

Não sei bem ainda responder.

A procura de uma expressão verdadeiramente nacional é o eixo de toda a sua obra. Mas Mário de Andrade, não ficou apenas nas indagações exteriores. Analisou-se cuidadosamente, e, quem sabe, se friamente também.

Talvez por isto, sua obra seja mais obra de crítico.

Mesmo fazendo ficção permaneceu ele um homem atormentado pelo desejo do real.

Não se abandonou à adivinhação. Seus poemas, por exemplo, são procuras de expressão e de sinceridade. Não passam, porém, de procuras, o que não exclui deles, absolutamente, grandes belezas.

\footnotetext{
${ }^{60}$ No periódico, lê-se “(...) não importa à em impossibilidade (...)”. Erro tipográfico.
} 
Faltou a Mário de Andrade o que se pode chamar propriamente de imaginação criadora.

Em Macunaíma a gente nota um desejo; às vezes, de despojar o personagem central do seu ambiente lendário, a fim de transformá-lo em alguma coisa de mais amplo, e, direi, mais significativa como símbolo de espírito, de feição, de subconsciente nacional.

E muitas vezes Mário de Andrade consegue elevar até esse ponto a sua obra.

Macunaíma tem um vivíssimo caráter, à força de não ter caráter nenhum talvez.

Este problema de caráter tem ultimamente preocupado muito Mário de Andrade.

O que é caráter afinal?

Afirmação contínua de idêntico sentido (— sempre em correlação —) da existência?

Não sei bem. Temo perder-me num terreno enorme e complicado como é a moral, quando desejo apenas dar minhas expressões sobre um livro que é de arte (e não é de arte também).

A lucidez de Mário, insisto, é uma realidade.

Tudo tinha nele esta capacidade de organização a que já me referi.

No entanto, estou vendo que, em certas fases, Macunaíma vai além da lucidez e do espírito orgânico de seu autor. Desprende-se de Mário a Macunaíma e principia a viver à parte do escritor.

É um livro bem brasileiro, o que, diga-se de passagem, não mais constitui qualidade ou defeito para mim.

Como ao Brasil, Macunaíma, falta consciência. Em lugar de "herói sem nenhum caráter”, que é o subtítulo da obra, a meu ver estaria bem mais certo, “herói sem nenhuma consciência”. Falta a Macunaíma determinação nos seus atos. O herói da lenda brasileira (ao contrário do herói da literatura brasileira) age sempre por impulso e sem intenção. Mário de Andrade, o lúcido e determinista não lhe pode delinear o caminho. Macunaíma não aceita indicações.

Tem saltos bruscos, ouve vozes absurdas, desencontradas, vindas dele mesmo. É uma criança. Criança sabida; mas criança assim mesmo. Criança como o Brasil, se me permitem a insistência da aproximação.

A espontaneidade do herói do livro se choca com o espírito crítico e nada apriorístico do autor. E por quê? Ou Macunaíma é um tipo legítimo e próprio, criação do autor, mas já em absoluto independente deste autor, ou Mário é simplesmente padrasto, embora amoroso, de Macunaíma. Há entre o herói do livro e seu autor, herói da literatura nacional, um certo de- 
sencontro, uma certa falta de acordo, quanto ao que não é apenas pitoresco, apenas expressível [sic], e antes íntimo e irredutível. Macunaíma é instintivo, inconseqüente, acatólico, bárbaro, arrastado pelos sentidos. O Mário é o contrário. Para Macunaíma a verdade não tem importância; para Mário a verdade, pelo menos a brasileira, tem muita importância.

E foi essa falta de identidade entre os dois heróis, na minha opinião, que não consentiu que Mário de Andrade escrevesse um livro genial.

AUGUSTO F. SCHMIDT 
1929 


\section{A C U N A I M A \\ por Mafilo de Amphade}

$M$

ACLNAIMA" d: Mario de Andrado a livro que não cathe em nenhuma dassificacâo. Aliás vesto nonto bem raracido com o seu autor. complexo, deliso, muito largado e muito contido ao mesmo tempo. Será uma satyra? Por vezes foi essa a intençāo escondida. Mas läo se podle negar que ha lumor demais no Ilvro para tanto. Si Macunaima, o heroe sem caracter, parece retratar a psychologia media do brasileiro, principalmente nos seug defeitos, por outro lado elle transeende qualquer realidade psychologica do 'momento e ganha proporçōes de symbolo, atrayés da farça. Mesma porque Macunaima é no fundo cousa alguma. A nota dolorosa deste livro tằo ingular está na procura da personalidade. Macunatma tende a ser, nunca fol. Elle traz o imperativo da presuiça. a indifterença moral. a tendencia $\dot{A}$ dispersão. Todas as suas re. tolngões ordenadoras se quebran contra a inercin a o jequismo. Esquece tudn por uma liora de animali. date.

Póde-se, portanto, dizer que a brincadelra literaria intitulada "Macunaima" se impregnou de amargura, a amargura das grandes crises, quando o espirito não acha em torno a directiva. $O$ aue fica da leitura at. tenta é um vasio, um sentimento de falha. Não como arte, está claro, porque poucos livros de Mario justificam tão bem o seu masoetismn de abridor, de campeão de box no ring modernista. Escripto uumo linguagem polpuda, as vezes com excesso intencional, domina a gente. $\mathbf{E}$ ' que se pede. Mas o sentido verdadeiro ainda precisa de distaneia.

A. $\boldsymbol{M}$.

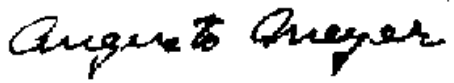




\title{
MACUNAÍMA \\ POR MÁRIO DE ANDRADE
}

\author{
A. M. [Augusto Meyer]. "Macunaíma / por Mário \\ de Andrade”. Revista do Globo: Porto Alegre, a. \\ I, $\mathrm{n}^{\mathrm{o}}$ 1, janeiro de 1929. IEB-USP - MA-MP.
}

Macunaíma de Mário de Andrade é livro que não cabe em nenhuma classificação. Aliás neste ponto bem parecido com o seu autor. Complexo, denso, muito largado e muito contido ao mesmo tempo. Será uma sátira? Por vezes foi essa a intenção escondida. Mas não se pode negar que há humor demais no livro para tanto. Se Macunaíma, o herói sem caráter, parece retratar a psicologia média do brasileiro, principalmente nos seus defeitos, por outro lado ele transcende qualquer realidade psicológica do momento e ganha proporções de símbolo, através da farsa. Mesmo porque Macunaíma é no fundo cousa alguma. A nota dolorosa deste livro tão singular está na procura da personalidade. Macunaíma tende a ser, nunca foi. Ele traz o imperativo da preguiça, a indiferença moral, a tendência à dispersão. Todas as suas resoluções ordenadoras se quebram contra a inércia e o jequismo. Esquece tudo por uma hora de animalidade.

Pode-se, portanto, dizer que a brincadeira literária intitulada Macunaíma se impregnou de amargura, a amargura das grandes crises, quando o espírito não acha em torno a diretiva. $\mathrm{O}$ que fica da leitura atenta é um vazio, um sentimento de falha. Não como arte, está claro, porque poucos livros de Mário justificam tão bem o seu magnetismo de abridor, de campeão de box no ring modernista. Escrito numa linguagem polpuda, às vezes com excesso intencional, domina a gente. É o que se pede. Mas o sentido verdadeiro ainda precisa de distância.

A. M. [AUGUSTO MEYER] 
[A União. Paraíba, 31/01/1929. Colunas 1, 2, 3 e 4. IEB - MA-MP]

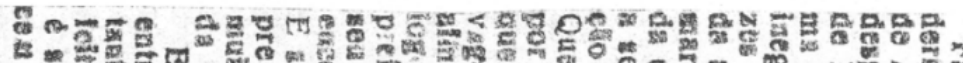

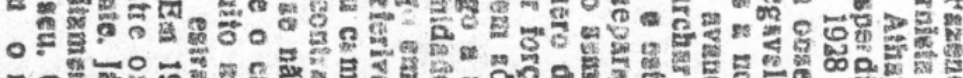

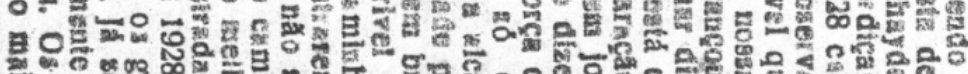

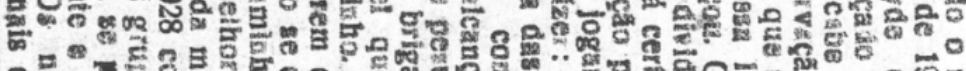

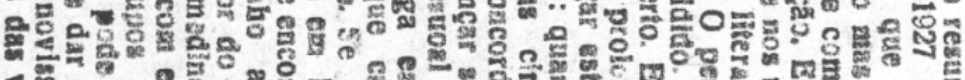

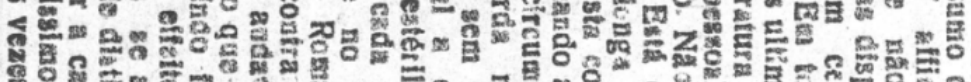

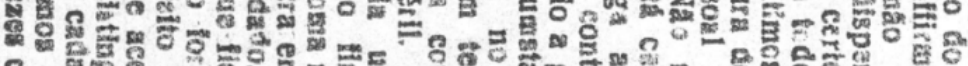

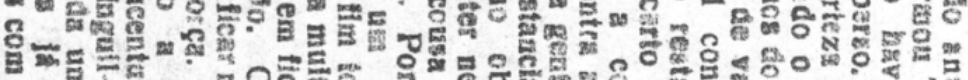

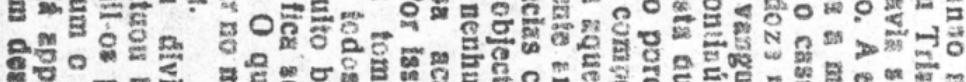

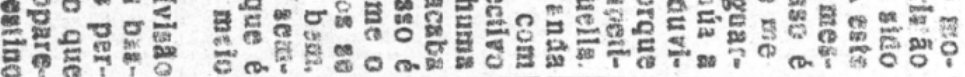

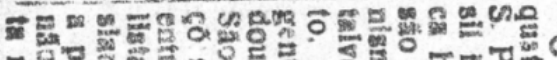

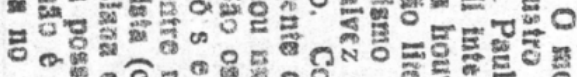

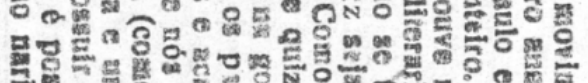

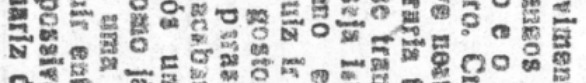

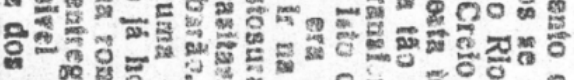
을

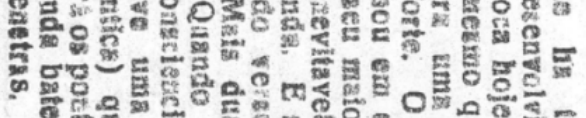
m

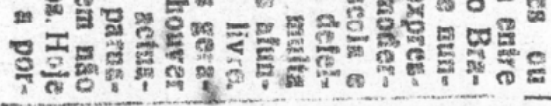

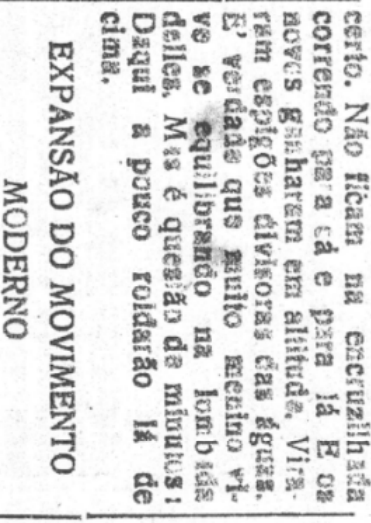

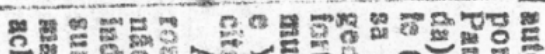

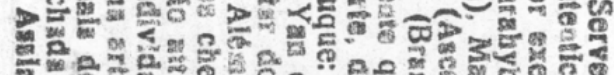

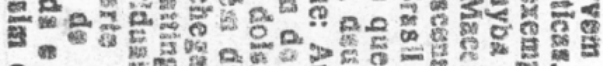

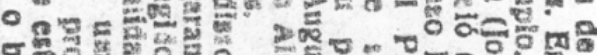

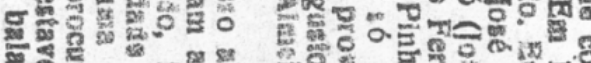

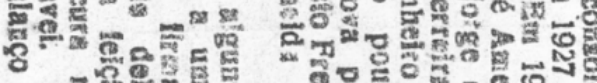

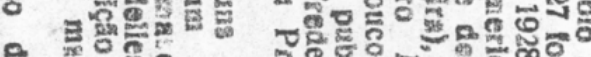

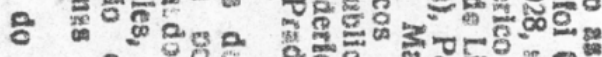

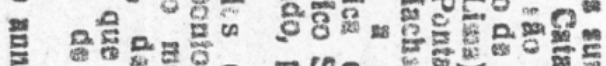
5 "

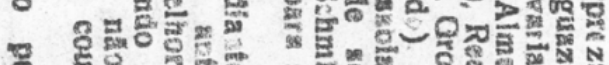

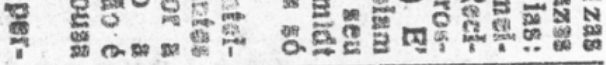

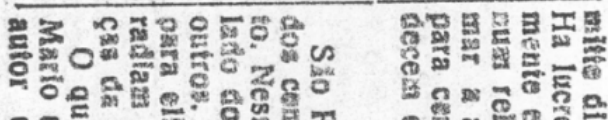

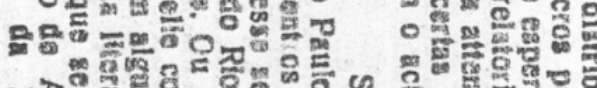
굴

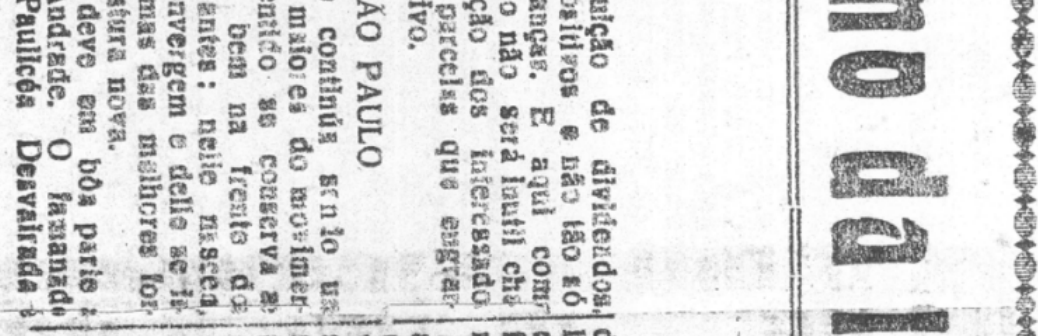

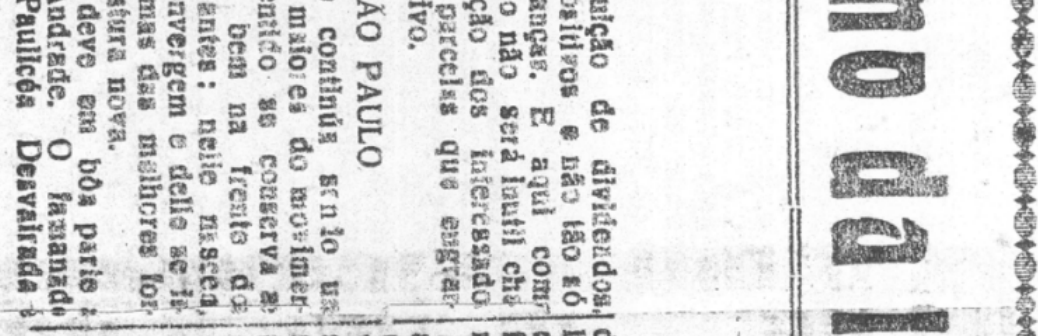


\A União. Paraiba, 31/01/1929. Colunas 5, 6, 7 e 8. IEB - MA-MP」

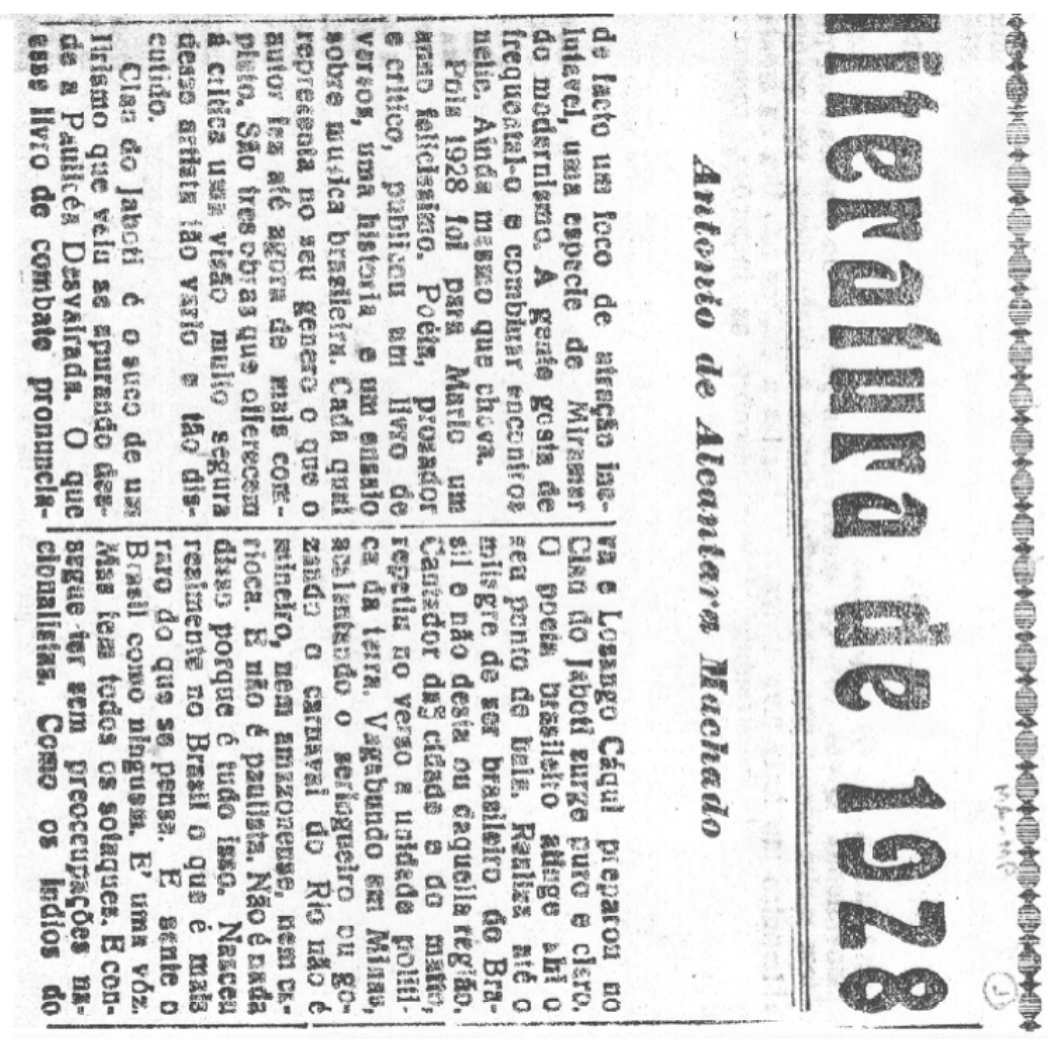

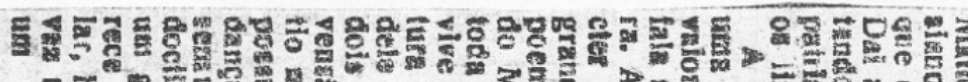

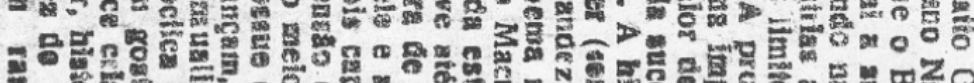

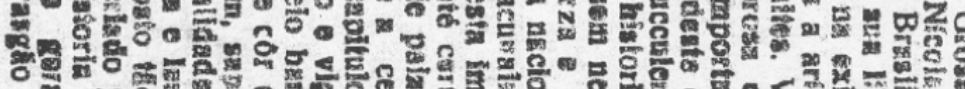

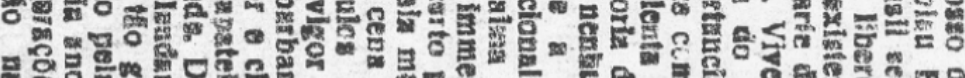

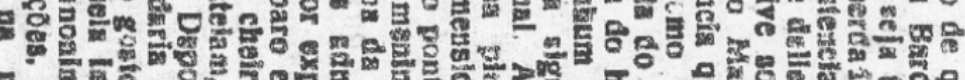

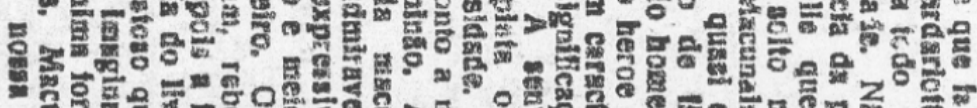

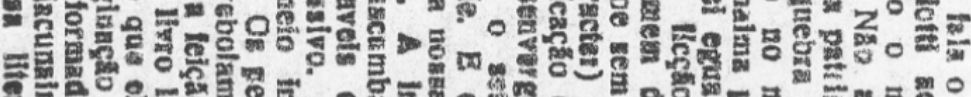

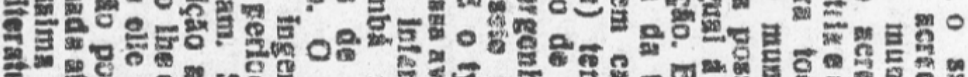

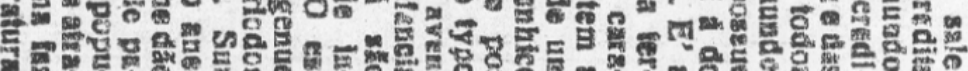

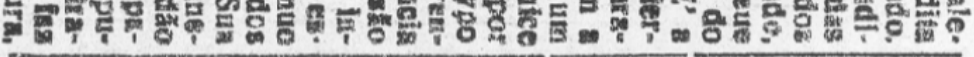

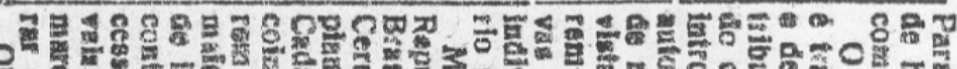
일

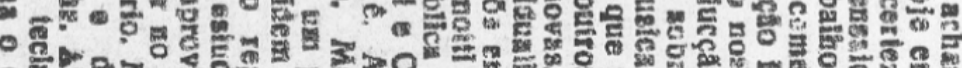
을

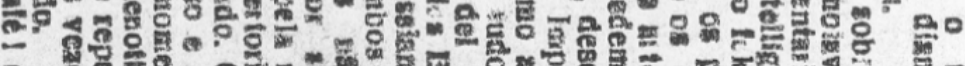
₹ 至 \%

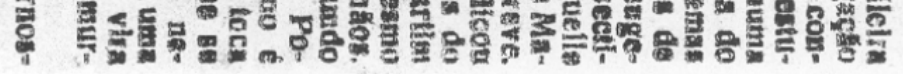




\section{O Modernismo dA Literatura de 1928}

MACHAdo, António de Alcântara. "O modernismo da literatura de 1928”. A União: [Paraíba, $\mathrm{PB}^{61}$ ], 31 de janeiro de 1929. IEB-USP - MA-MP.

Fazendo o resumo do ano modernista de 1927[,] afirmou Tristão de Ataíde que não havia sido desperdiçado mas disperso. A este de 1928 cabe com certeza a mesma observação. Em todo o caso é inegável que nos últimos doze meses a nossa literatura de vanguarda avançou. O pessoal continua a marchar dividido. Não resta dúvida e está certo. Está certo porque a separação prolonga a competição sem jogar esta contra aquela. Quero dizer: quando a gente anda por força das circunstâncias com quem só concorda no objetivo vago a alcançar sem ter nenhuma afinidade pessoal a cousa acaba logo em briga estéril. Por isso é preferível que cada um tome o seu caminho. Se no fim todos se encontrarem em Roma muito bem. E se não se encontrarem fica sempre o caminho andado. O que é muito melhor que ficar no meio da estrada medindo força.

Em 1928[,] com efeito[,] a divisão entre os grupos se acentuou bastante. Já se pode distingui-los perfeitamente e dar a cada um o que é seu. Os novíssimos já aparecem o mais das vezes com destino certo. Não ficam na encruzilhada correndo para cá e para lá. E os novos ganharam em altitude. Viraram espigões divisores ${ }^{62}$ das águas. É verdade que muito menino vive se equilibrando na lombada deles. Mas é questão de minutos. Daqui a pouco roldarão ${ }^{63}$ lá de cima.

\section{EXPANSÃO DO MOVIMENTO MODERNO}

O movimento que há três ou quatro anos se desenvolvia entre S. Paulo e o Rio toca hoje o Brasil inteiro. Creio mesmo que nunca houve nesta terra uma expressão literária tão forte.

\footnotetext{
${ }^{61}$ No recorte que se encontra no álbum R. 27 do IEB - Recortes de Mário de Andrade -, há uma anotação de Mário que identifica a data de publicação, o periódico e a cidade, Paraíba, depois chamada João Pessoa.

${ }^{62}$ No jornal, lê-se "divisoras".

63 "Roldarão": em vez de "rolarão" - possível erro tipográfico. Há a possibilidade de ser um neologismo inventado, supostamente, a partir do substantivo "roldão", que conjuga os significados de "desordem" e "precipitação". Augusto de Campos, em "Jaguadarte", faz uso desse neologismo em sua transcriação do poema "Jabberwocky", de Lewis Carroll: "Era briluz. As lesmolisas touvas / Roldavam e relviam nos gramilvos". In: CARROLL, Lewis. Aventuras de Alice. Tradução e organização de Sebastião Uchoa Leite. $3^{\underline{a}}$ ed. São Paulo: Summus, 1980, p. 147.
} 
O modernismo se transformou em escola e talvez seja isto o seu maior defeito. Como era inevitável muita gente quis ir na onda. E se afundou na gostosura do verso livre. São os parasitas. Mais duas gerações e acabarão. Quando houver entre nós uma consciência atualista (como já houve uma parnasiana e uma romântica) quem não a possuir entregará os pontos. Hoje não é possível ainda bater a porta no nariz dos penetras.

Servem de consolo as surpresas autênticas. Em 1927 foi Cataguases por exemplo. Em 1928 são várias: Paraíba (José Américo de Almeida), Maceió (Jorge de Lima), Recife (Ascenso Ferreira), Ponta Grossa (Brasil Pinheiro Machado). $\mathrm{E}^{64}$ gente que só poucos a sabiam forte, deu prova pública de seu muque: Augusto Frederico Schmidt e Yan de Almeida Prado, para só citar dois.

Além disso[,] alguns dos dianteiros chegaram a um ponto antes não atingido, firmando melhor a individualidade deles, dando a sua arte uma feição que não é mais de procura mas de cousa achada e estável.

Assim[,] o balanço do ano permite distribuição de dividendos. Há lucros positivos e não tão somente esperanças. E aqui[,] como num relatório[,] não será inútil chamar a atenção dos interessados para certas parcelas que engrandecem o ativo.

\section{SÃo PAULO}

São Paulo continua sendo um dos centros maiores do movimento. Nesse sentido[,] se conserva ao lado do Rio bem na frente dos outros. Ou antes: nele nascem, para ele convergem e dele se irradiam algumas das melhores forças da literatura nova.

O que se deve em boa parte a Mário de Andrade. O famanado autor de Paulicéia Desvairada é de fato um foco de atração inelutável, uma espécie de Miramar do modernismo. A gente gosta de freqüentá-lo e combinar encontros nele. Ainda mesmo que chova.

Pois 1928 foi para Mário um ano felicíssimo. Poeta, prosador e crítico, publicou um livro de versos, uma história e um ensaio sobre música brasileira. Cada qual representa no seu gênero o que o autor fez até agora de mais completo. São três obras que oferecem à crítica uma visão muito segura desse artista tão vário e tão discutido.

Clã do Jabuti ${ }^{65}$ é o suco de um lirismo que veio se apurando desde a Paulicéia Desvairada. O que este livro de combate prenunciava ${ }^{66}$ e Losango Cáqui preparou[,] no Clã do

\footnotetext{
${ }^{64}$ No jornal, lê-se "É".

${ }^{65}$ No jornal, lê-se “Clan do Jaboti”, grafia usada na primeira edição da obra.
} 
Jabuti surge puro e claro. O poeta brasileiro atinge aí o seu ponto de bala. Realiza até o milagre de ser brasileiro do Brasil e não desta ou daquela região. Cantador da cidade e do mato, repetiu no verso a unidade política da terra. Vagabundo em Minas, acalentando o seringueiro ou gozando o carnaval no Rio não é mineiro, nem amazonense, nem carioca. E não é paulista. Não é nada disso porque é tudo isso. Nasceu realmente no Brasil o que é mais raro do que se pensa. E sente o Brasil como ninguém. É uma voz. Mas tem todos os sotaques. E consegue ter sem preocupações nacionalistas. Como os índios do Mato Grosso[,] de que fala o salesiano Nicola Bardarlotti[,] acredita que o Brasil seja todo o mundo. Daí a sua liberdade. Não acreditando na existência da pátria e das pátrias[,] a arte dele quebra todos os limites. Vive solto no mundo.

A prosa do Macunaíma possui uma importância quase igual à do valor deste como de ficção. É a fala suculenta do homem da terra. A história do herói sem caráter (sem nenhum caráter) tem a grandeza e a significação de um poema nacional. A sem-vergonhice ${ }^{67}$ de Macunaíma pinta o sete por toda esta imensidade. E o tipo vive até certo ponto a nossa aventura de país meninão. A infância dele e a cena da macumba são dois capítulos admiráveis de invenção e vigor expressivo. O estilo meio bárbaro e meio ingênuo possui cor e cheiro. Os períodos dançam, sapateiam, rebolam. Sua sensualidade. Depois[,] a feição anedótica e lendária do livro lhe dão um gosto tão gostoso que ele parece criado pela imaginação popular, história anônima formada através de gerações. Macunaíma faz um rasgão na nossa literatura. Para achar o tesouro[,] é preciso de hoje em diante passar por ele com certeza.

(...)

\footnotetext{
${ }^{66}$ No jornal, lê-se "pronunciava”.

${ }^{67}$ No jornal, lê-se "senvergonhice”.
} 
[Tamandaré (Oswaldo Costa). Revista de Antropofagia.

$2^{\circledR}$ Dentição. In: Diário de S. Paulo. São Paulo, 14/04/1929,

p. 6. Edição fac-similar. São Paulo: Abril / Metal Leve, 1975]

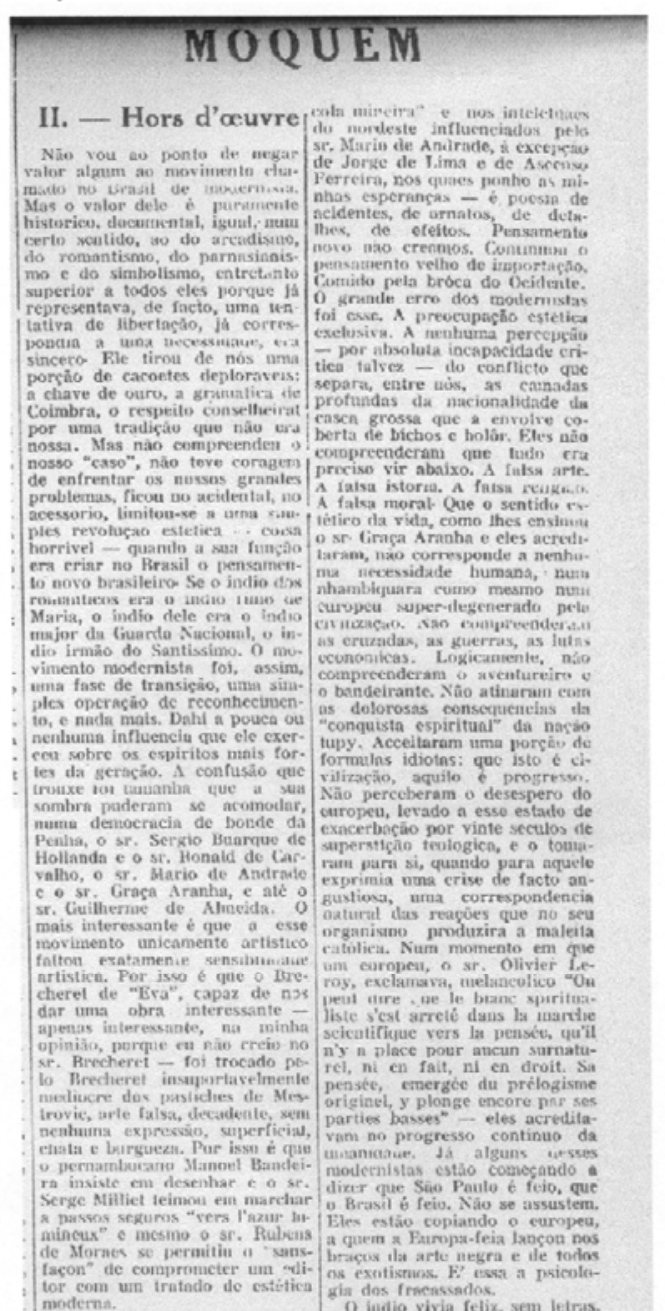

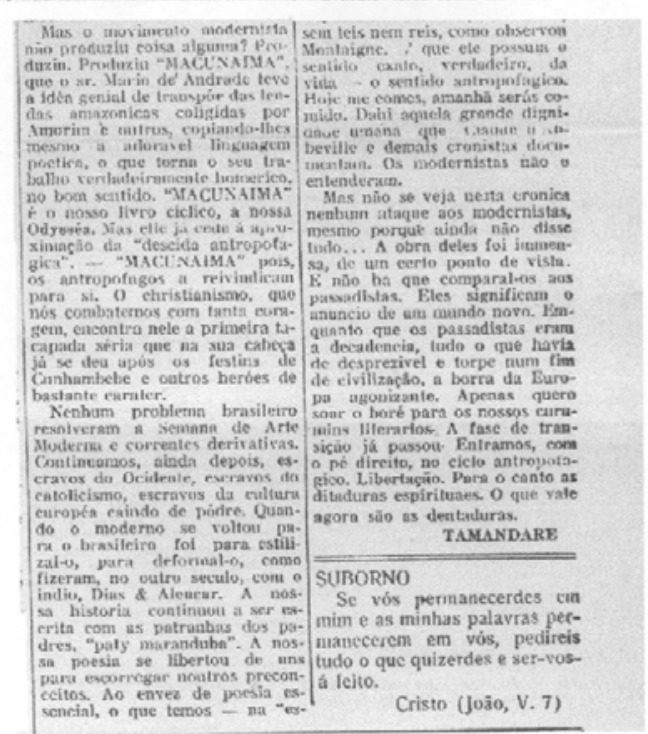




\section{MOQUÉM}

\section{II. - Hors d'oeuvre}

TAMANDARÉ [Oswaldo Costa]. "Moquém / II - Hors d'oeuvre”. Revista de Antropofagia. $2^{\underline{a}}$ Dentição. Encarte do Diário de S. Paulo: São Paulo, 14 de abril de 1929, p. 6. Edição fac-similar. São Paulo: Abril / Metal Leve, 1975.

Não vou ao ponto de negar valor algum ao movimento chamado no Brasil de modernista. Mas o valor dele é puramente histórico, documental, igual, num certo sentido, ao do arcadismo, do romantismo, do parnasianismo e do simbolismo, entretanto superior a todos eles porque já representava, de fato, uma tentativa de libertação, já correspondia a uma necessidade, era sincero. Ele tirou de nós uma porção de cacoetes deploráveis: a chave de ouro, a gramática de Coimbra, o respeito conselheiral por uma tradição que não era nossa. Mas não compreendeu o nosso "caso", não teve coragem de enfrentar os nossos grandes problemas, ficou no acidental, no acessório, limitou-se a uma simples revolução estética - coisa horrível - quando a sua função era criar no Brasil o pensamento novo brasileiro. Se o índio dos românticos era o índio filho de Maria, o índio dele era o índio major da Guarda Nacional, o índio irmão do Santíssimo. O movimento modernista foi, assim, uma fase de transição, uma simples operação de reconhecimento, e nada mais. Daí a pouca ou nenhuma influência que ele exerceu sobre os espíritos mais fortes da geração. A confusão que trouxe foi tamanha que à sua sombra puderam se acomodar, numa democracia de bonde da Penha, o sr. Sérgio Buarque de Holanda ${ }^{68}$ e o sr. Ronald de Carvalho, o sr. Mário de Andrade e o sr. Graça Aranha, e até o sr. Guilherme de Almeida. O mais interessante é que a esse movimento unicamente artístico faltou exatamente sensibilidade artística. Por isso é que o Brecheret de "Eva”, capaz de nos dar uma obra interessante - apenas interessante, na minha opinião, porque eu não creio no sr. Brecheret - foi trocado pelo Brecheret insuportavelmente medíocre dos pastiches de Mestrovic, arte falsa, decadente, sem nenhuma expressão, superficial, chata e burguesa. Por isso é que o pernambucano Manoel Bandeira insiste em desenhar e o sr. Serge Milliet teimou em marchar a passos seguros “vers l'azur lumineux” e mesmo o sr. Rubens de Moraes se permitiu o “sans façon” ${ }^{69}$ de comprometer um editor com um tratado de estética moderna.

\footnotetext{
${ }^{68}$ Na revista, lê-se "Hollanda".

${ }^{69}$ Na Revista, lê-se: "sansfaçon".
} 
Mas o movimento modernista não produziu coisa alguma? Produziu. Produziu Macunaíma, que o sr. Mário de Andrade teve a idéia genial de transpor das lendas amazônicas coligidas por Amorim e outros, copiando-lhes mesmo a adorável linguagem poética, o que torna o seu trabalho verdadeiramente homérico, no bom sentido. Macunaíma é o nosso livro cíclico, a nossa Odisséia. Mas ele já cede à aproximação da “descida antropofágica”. - Macunaíma[,] pois, os antropófagos a reivindicam para si. O cristianismo, que nós combatemos com tanta coragem, encontra nele a primeira tacapada séria que na sua cabeça já se deu após os festins de Cunhambebe e outros heróis de bastante caráter.

Nenhum problema brasileiro resolveram a Semana de Arte Moderna e correntes derivativas. Continuamos, ainda depois, escravos do Ocidente, escravos do catolicismo, escravos da cultura européia caindo de podre. Quando o moderno se voltou para o brasileiro foi para estilizá-lo, para deformá-lo, como fizeram, no outro século, com o índio, Dias \& Alencar. A nossa história continuou a ser escrita com as patranhas dos padres, "paty maranduba” ${ }^{, 70}$. A nossa poesia se libertou de uns para escorregar noutros preconceitos. Ao invés de poesia essencial, o que temos - na "escola mineira" e nos intelectuais do nordeste influenciados pelo sr. Mário de Andrade, à exceção de Jorge de Lima e de Ascenso Ferreira, nos quais ponho as minhas esperanças - é poesia de acidentes, de ornatos, de detalhes, de efeitos. Pensamento novo não criamos. Continuou o pensamento velho de importação. Comido pela broca do Ocidente. O grande erro dos modernistas foi esse. A preocupação estética exclusiva. A nenhuma percepção - por absoluta incapacidade crítica talvez - do conflito que separa, entre nós, as camadas profundas da nacionalidade da casaca grossa que a envolve coberta de bichos e bolor. Eles não compreenderam que tudo era preciso vir abaixo. A falsa arte. A falsa história. A falsa religião. A falsa moral. Que o sentido estético da vida, como lhes ensinou o sr. Graça Aranha e eles acreditaram, não corresponde a nenhuma necessidade humana, num nhambiquara como mesmo num europeu super-degenerado pela civilização. Não compreenderam as cruzadas, as guerras, as lutas econômicas. Logicamente, não compreenderam o aventureiro e o bandeirante. Não atinaram com as dolorosas conseqüências da "conquista espiritual” da nação tupi. Aceitaram uma porção de fórmulas idiotas: que isto é civilização, aquilo é progresso. Não perceberam o desespero do europeu, levado a esse estado de exacerbação por vinte séculos de superstição teológica, e o tomaram para si, quando para aquele exprimia uma

\footnotetext{
70 "Paty" é forma arcaizante de "patim", no sentido de pequeno pátio ou patamar, como, por exemplo, ocorre no topônimo Paty do Alferes, cidade do Estado do Rio de Janeiro. "Maranduba" - do tupi, "mora’nduwa" - é regionalismo que, no Nordeste e no Norte do Brasil, significa "mentira" ou "história inverossímil". Desse modo, a expressão teria o sentido de "pátio da mentira" - variante da forma popular "pátio dos milagres".
} 
crise de fato angustiosa, uma correspondência natural das reações que no seu organismo produzira a maleita católica. Num momento em que um europeu, o sr. Olivier Leroy, exclamava, melancólico “Ou peut dire que le branc spiritualiste s'est arreté dans la marche scientifique vers la pensée, qu'il n’y a place pour aucun surnaturel, ni en fait, ni en droit. Sa pensée, emergée du prélogisme originel, y plonge encore par ses parties basses” - eles acreditavam no progresso contínuo da humanidade. Já alguns desses modernistas estão começando a dizer que São Paulo é feio, que o Brasil é feio. Não se assustem. Eles estão copiando o europeu, a quem a Europa-feia lançou nos braços da arte negra e de todos os exotismos. É essa a psicologia dos fracassados.

O índio vivia feliz, sem letras, sem leis nem reis, como observou Montaigne. É que ele possuía o sentido exato, verdadeiro, da vida - o sentido antropofágico. Hoje me comes, amanhã serás comido. Daí aquela grande dignidade humana que Claude d’Abeville e demais cronistas documentam. Os modernistas não o entenderam.

Mas não se veja nesta crônica nenhum ataque aos modernistas, mesmo porque ainda não disse tudo... A obra deles foi imensa, de um certo ponto de vista. E não há que comparálos aos passadistas. Eles significam o anúncio de um mundo novo. Enquanto que os passadistas eram a decadência, tudo o que havia de desprezível e torpe num fim de civilização, a borra da Europa agonizante. Apenas quero soar o boré para os nossos curumins literários. A fase de transição já passou. Entramos, com o pé direito, no ciclo antropofágico. Libertação. Para o canto as ditaduras espirituais. O que vale agora são as dentaduras.

TAMANDARÉ [OSWALDO COSTA] 
LA. F. (Aníbal Fernandes).Diário de Pernambuco.

Recife, 18/04/1929. Colunas 1, 2, 3 e 4. IEB - MA-MP]
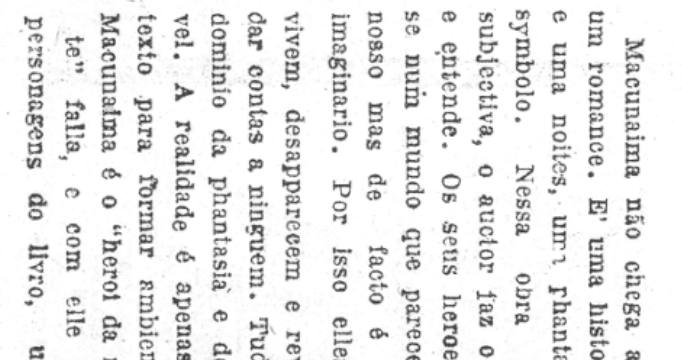

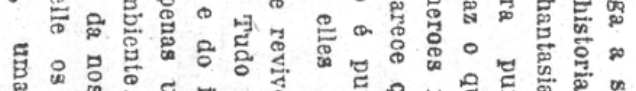

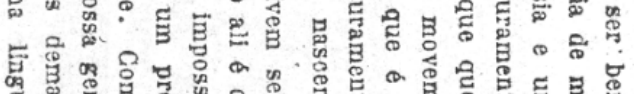

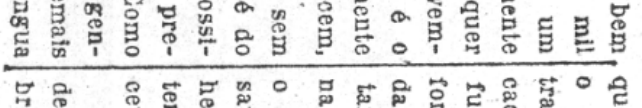

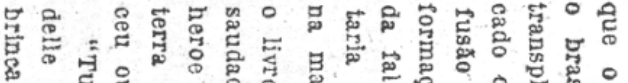

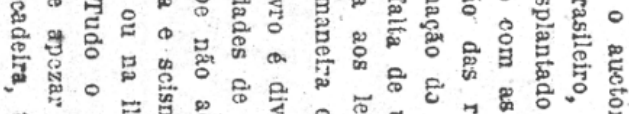

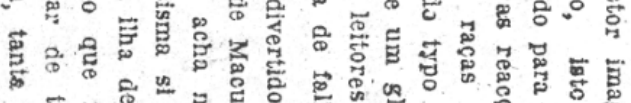

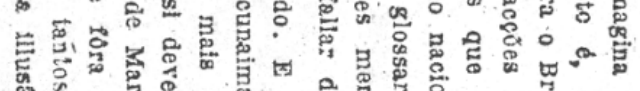

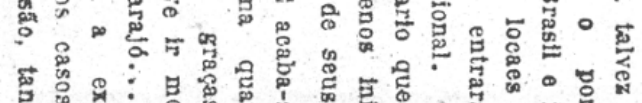

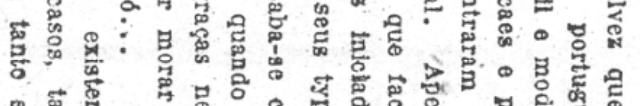

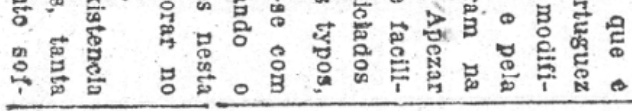

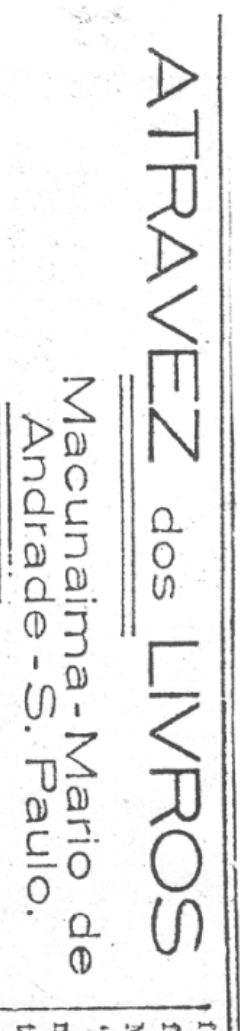

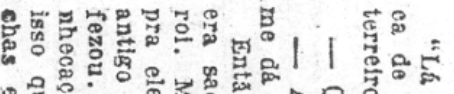

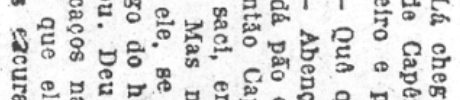

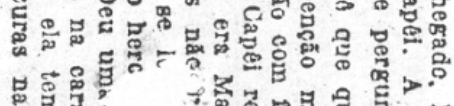

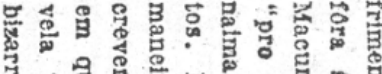

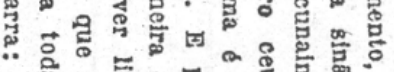

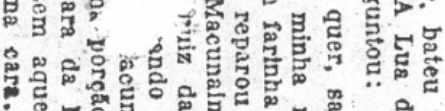

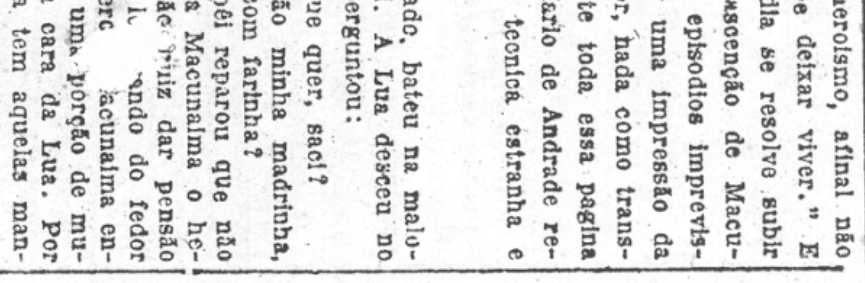

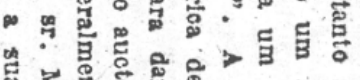

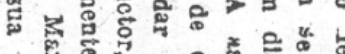

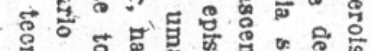

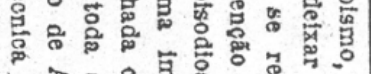

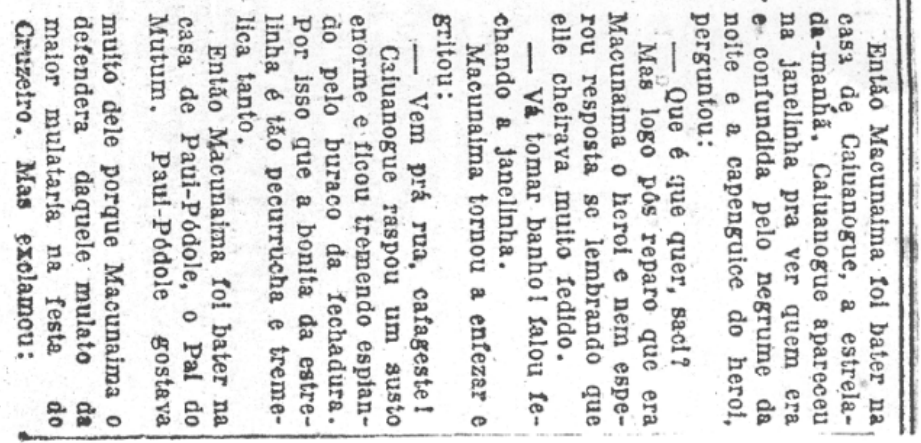


A. F. (Anibal Fernandes)Diário de Pernambuco

Recife, 18/04/1929. Colunas 5, 6e 7. IEB - MA-MP]

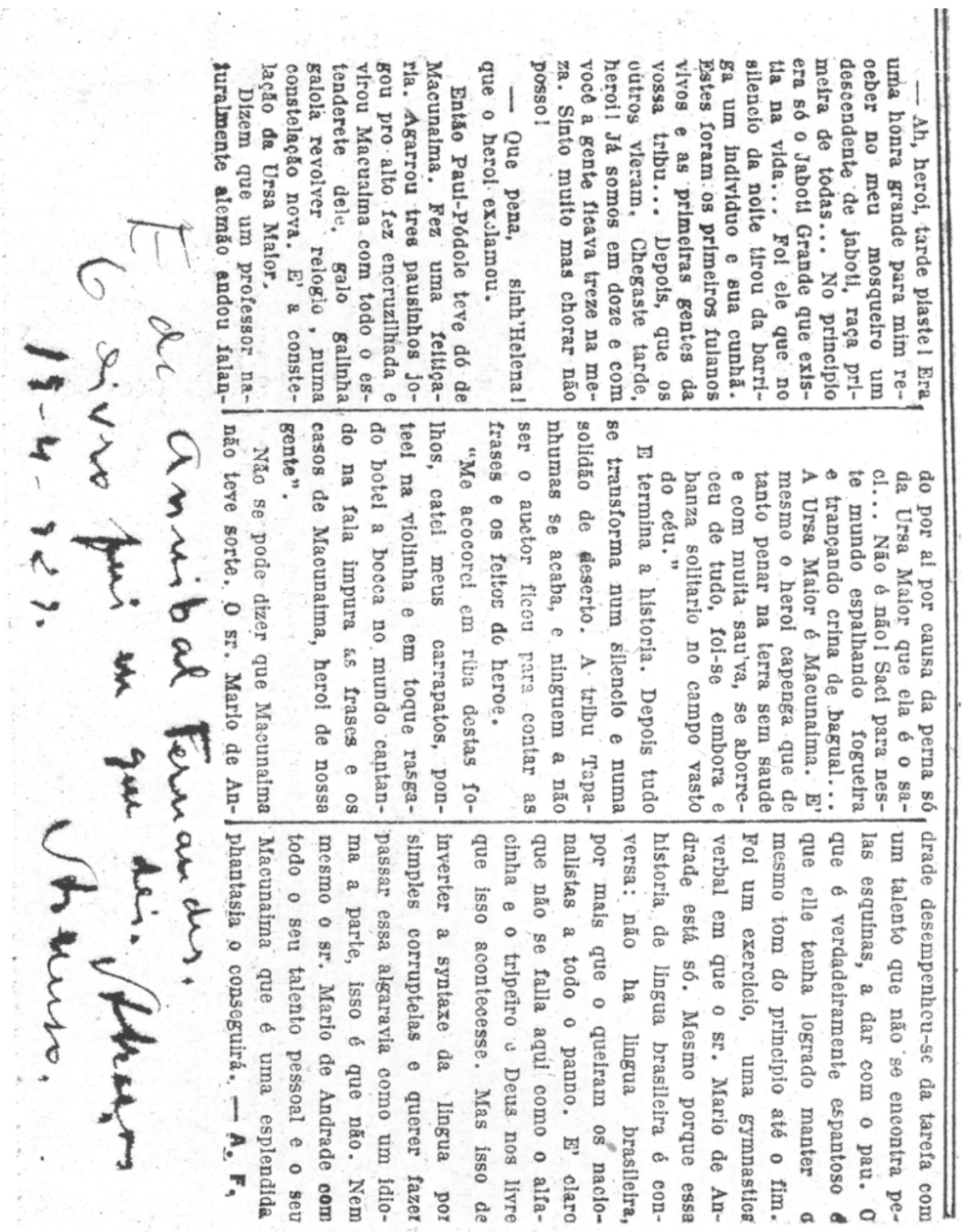




\section{Macunaíma - Mário de Andrade — S. Paulo}

A. F. [Aníbal Fernandes]. "Através dos livros / Macunaíma Mário de Andrade - S. Paulo”. Diário de Pernambuco: Recife, 18 de abril de $1929^{71}$. IEB-USP - MA-MP.

Macunaíma não chega a ser bem um romance. É uma história de mil e uma noites, uma fantasia e um símbolo. Nessa obra puramente subjetiva, o autor faz o que quer e entende. Os seus heróis movem-se num mundo que parece que é o nosso mas de fato é puramente imaginário. Por isso eles nascem, vivem, desaparecem e revivem sem dar contas a ninguém. Tudo ali é do domínio da fantasia e do impossível. A realidade é apenas um pretexto para formar o ambiente. Como Macunaíma é o "herói da nossa gente”, fala, e com ele os demais personagens do livro, uma língua que o autor imagina talvez que é o brasileiro, isto é, o português transplantado para o Brasil e modificado com as reações locais e pela fusão das raças que entraram na formação do tipo nacional. Apesar da falta de um glossário que facilitaria aos leitores menos iniciados na maneira de falar de seus tipos, o livro é divertido. E acaba-se com saudades de Macunaíma quando o herói não acha mais graças nesta terra e cisma se deve ir morar no céu ou na ilha de Marajó...

“Tudo o que fora a existência dele apesar de tantos casos tanta brincadeira tanta ilusão tanto sofrimento tanto heroísmo, afinal não fora sinão um se deixar viver»72. E Macunaíma um dia se resolve subir “pro céu”. A ascensão de Macunaíma é rica de episódios imprevistos. E para dar uma impressão da maneira do autor, nada como transcrever literalmente toda essa página em que o sr. Mário de Andrade revela toda a sua técnica estranha e bizarra:

“Lá chegado bateu na maloca de Capei. A Lua desceu no terreiro e perguntou:

— Quê que quer, saci?

— Abenção minha madrinha, me dá pão com farinha?

\footnotetext{
${ }^{71}$ Identificação de periódico e data de publicação por anotação de Mário de Andrade no recorte que se encontra no álbum R. 29 - Recortes de Mário de Andrade - IEB-USP. Identificação de autoria por anotação de Ascenso Ferreira, que remeteu o recorte a Mário.

${ }^{72}$ Neste Corpus, as citações de Macunaíma serão sempre corrigidas, quando for necessário, conforme a primeira edição da rapsódia. Neste caso, de acordo com a p. 276. No jornal, lê-se: "Tudo o que fora a existência dele apesar de tantos casos, tanta brincadeira, tanta ilusão, tanto sofrimento, tanto heroísmo, afinal não fora sinão um se deixar viver.”
} 
Então Capei reparou que não era saci não, era Macunaíma o herói ${ }^{73}$. Mas não quis dar pensão pra ele, se lembrando do fedor antigo do herói. Macunaíma enfezou. Deu uma porção de munhecaços na cara da Lua. Por isso que ela tem aquelas manchas escuras na cara.

Então Macunaíma foi bater na casa de Caiuanogue, a estrela-da-manhã. Caiuanogue apareceu na janelinha pra ver quem era e confundida pelo negrume da noite e a capenguice do herói, perguntou:

- Que $^{74}$ é que quer, saci?

Mas logo pôs reparo que era Macunaíma o herói e nem esperou resposta se lembrando que ele cheirava muito fedido. ${ }^{75}$

— Vá tomar banho! falou fechando a janelinha.

Macunaíma tornou a enfezar e gritou: ${ }^{76}$

— Vem pra rua, cafajeste!

Caiuanogue raspou um susto enorme e ficou tremendo espiando pelo buraco da fechadura. Por isso que a bonita da estrelinha é tão pecurrucha e tremelica tanto. ${ }^{77}$

Então Macunaíma foi bater na casa de Pauí-Pódole, o Pai do Mutum. Pauí-Pódole gostava muito dele porque Macunaíma o defendera daquele mulato da maior mulataria na festa do Cruzeiro. Mas exclamou:

— Ah, herói, tarde piaste! Era uma honra grande $\mathrm{pra}^{78}$ mim receber no meu mosqueiro um descendente de jabuti, raça primeira de todas... No princípio era só o Jabuti Grande que existia na vida... Foi ele que no silêncio da noite tirou da barriga um indivíduo e sua cunhã. Estes foram os primeiros fulanos vivos e as primeiras gentes da vossa tribo... Depois, que os outros vieram. Chegaste tarde, herói! Já somos em doze e com você a gente ficava treze na mesa. Sinto muito mas chorar não posso!

— Que pena, sinh’Helena! que o herói exclamou.

Então Pauí-Pódole teve dó de Macunaíma. Fez uma feitiçaria. Agarrou três pauzinhos jogou pro alto fez encruzilhada e virou Macunaíma com todo o estenderete dele, galo galinha gaiola revólver relógio, numa constelação nova. É a constelação da Ursa Maior. ${ }^{79}$

Dizem que um professor naturalmente alemão andou falando por aí por causa da perna só da Ursa Maior que ela é o saci... Não é não! Saci inda ${ }^{80}$ pára neste mundo espalhando fo-

\footnotetext{
${ }^{73}$ No jornal, lê-se “(...) não era saci, era Macunaíma”.

${ }^{74}$ No jornal, lê-se “Quê".

${ }^{75}$ No jornal, este parágrafo não é destacado como tal, constituindo extensão do anterior.

${ }^{76}$ Idem.

${ }^{77}$ Idem.

${ }^{78}$ No jornal, lê-se “para”.

${ }^{79}$ No jornal, este parágrafo não é destacado como tal, constituindo extensão do anterior.
} 
gueira e trançando crina de bagual... A Ursa Maior é Macunaíma. É mesmo o herói capenga que de tanto penar na terra sem saúde e com muita saúva, se aborreceu de tudo, foi-se embora e banza solitário no campo vasto do céu.”

E termina a história. Depois tudo se transforma num silêncio e numa solidão de deserto. A tribo Tapanhumas se acaba, e ninguém a não ser o autor ficou para contar as frases e os feitos do herói.

"Me acocorei em riba destas folhas, catei meus carrapatos, ponteei na violinha e em toque rasgado botei a boca no mundo cantando na fala impura as frases e os casos de Macunaíma, herói de nossa gente”.

Não se pode dizer que Macunaíma não teve sorte. O sr. Mário de Andrade desempenhou-se da tarefa com um talento que não se encontra pelas esquinas, a dar com o pau. O que é verdadeiramente espantoso é que ele tenha logrado manter o mesmo tom do princípio até o fim. Foi um exercício, uma ginástica verbal em que o sr. Mário de Andrade está só. Mesmo porque essa história de língua brasileira é conversa: não há língua brasileira, por mais que o queiram os nacionalistas a todo o pano. É claro que não se fala aqui como o alfacinha e o tripeiro e Deus nos livre que isso acontecesse. Mas isso de inverter a sintaxe da língua por simples corruptelas e querer fazer passar essa algaravia como um idioma à ${ }^{81}$ parte, isso é que não. Nem mesmo o sr. Mário de Andrade com todo o seu talento pessoal e o seu Macunaíma que é uma esplêndida fantasia o conseguirá.

\footnotetext{
${ }^{80}$ No jornal, lê-se “Saci pára neste mundo (...)”.

${ }^{81}$ No jornal, lê-se “a parte”, sem crase.
} 
[Tamandaré (Oswaldo Costa).

Revista de Antropofagia. $2^{\complement}$ Dentição.

In: Diário de S. Paulo. São Paulo, 24/04/1929, p. 10.

Edição fac-similar. São Paulo: Abril / Metal Leve, 1975] Pag. 10

\section{MOQUEM}

HII - Entradas

Não tinha ainda terminado a te quando o sr. Mario de Anfrade veiu de taxi em meu auzilio, apoiando a minha tése. lestemunho do sr. Mario de Andrade. $c$ valioso e insuspeitissimontos de politica literaria. Pel coragem com que se confessa en publico. Pela réiva de que estâ possuido conita os antropofagos. Literato brasiteiro - diz ele, con muita justiça - oitenta e cinco essa deslavada ignorancia, que laz a gente confundir tudo, é que em sido a causa de vivermos no comadrismo mais certo, mais saladinho, mais fatigante, quand os assuntos deste liundio sáo intgentes e de importancia tapracresuenta Mario. Como vê, não faço senão repetir, con as palavras do poeta, o que aqui passado. Foi isso exatamente que histe: ansencia do Univero, como diria o padre Vieira sobretudo a sua ausencia do Brasil, como dizemos nós, antro pofagos. Me diga o sr. Mario de Andrade que assunto co mundo ram os modernos Pois nẫo continu os modernos. Poir tuấ, concomadrismo indecente, valorizando mediocridades, como si um artista fosse café ou assucar cristal, trocando elogios, importando bobagens, misturando Uidocoveram por exemplo, Ronald de Carvatho e Guilherme de Almeida, que o sr. Mario de Andrade nâo se do e porque Antonio de Alcan-

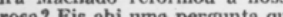
prosa? embora dificil de responder. terato brasileiro é um ignoranaro. De facto. Confunde turlo drade quer uma prova9 Faça um Arace católico que é. Elogios de enecmenda a Navarro da Costa. Foguetes á poesia bôbalhona de guem na madeira. Corresponden cia amorosa com o que ha de mediocre na inteletualidade do Brasil inteiro. Zumbaias a A cantara Machado e outras bexigas da nossa meninada serelepe de Cataguazes. Toda essa confusão e esse comadrismo, de quem a culpa Ora, quem se baba diante dos pastiches cretinos de Brecheret isse muito bem Fosca. Ouer destaca, na exposicão de Anita - que nela havia de ruim, o Lazaro. Quem baralha monumenta coin alegorico. asneira grossa que fez, em tempo, as delicias de profissẫo embora grande realismo em pintura, comete por isso a patada de ele giar um pintamonos pensand que o debochava. Quem se orgulha de imitar Bilac e Vicente Carvalho, o que temos de peior vergónha de chamar de infalivel, por simples camaradagem, o gosto artistico do sr. Guilherme de Almeida, que póde ter ou ter
tido outros gostos, não contesto, tido outros gostos, nas
mas esse nunca teve.

Quem na mesima hora toca orgia na egreja de Santa EfigeCHADO. Quem andou por ahi distribuindo receitas de lirismo moderno. (Lá está na ESCRAVA "Dei-vos uma receita. Não falei na proporçáo dos ingredientes. gina - "a impulsão lirica e elgina - a impulsão lirica é li-
vre, imdependente de nós, independe de nossa inteligencia" e
logo dá marcha-ré, escrevendo que "pos discursos atuaes é a intefigencia que pronuncia o tenho"nas evolucốes sem covardia que guem volta para atraz" e voltou, em terceira, para o Pequenino Morto. Quem classificou de fiAlberto de Oliveira no que, aliás. certou porque o farmaceutico é sso mesino - poeta de ouvido. Quem faz discursos ao sr. GoCardim, credo! deus literatos não somos. E' o sr. Mario de Andrade, o cerebro mais confuso da critica contemdo alemão, segundo os rapazes do alemáo, segundo os rapazes ha da literatura nacional, segundo o sr. Menotti Del Picchia, por signal tâo horrivelmente

O sr. Mario de Andrade é con" iberdade", por isso mesmo a sinceridade e a liberdade da decida antropofagica são o diabo.... Podem entornar o caldo do Amorim... Assim, adeus mutirão de sabença da rua Lopes Chaves, ro! Adeus Catagnazes! Adeus. adeus.

E é tambem contra a origina, ele que dizia, quando ainda podia cair em transe para compốr MACUNAIMA, que "a e, de que se faz cavalo de batalha contra nós é desejo legiEuclides, Galileu, Newton e Einstein e nas artes Sofocles, Dante, Cervantes, Gonçalves Dias, Edschmidt", puxa!

Mario de Andrade tem, poranto, razão quando, com invular coragern, resolve abrir o peio aos amigos e bater nele com orça, destiando o seu rosario leiro é mesmo o que ele é: oitenta e cinco por cento ignorantão. Confunde tudo. Como deixei provado. E é inutil, como continuo a perguntar: em sete anos que resultou para nós Não gostei, porém, das amarguras que Mario pôz no seu mingau. Mingau não queremos, Ma-
rio. Queremos amor. Aquele amor gostosissimo que você boou nas estrófes do CABO MACHADO. Mas sem o incenso do côro de Santa Efigenia. Com a pimenta de MACUNAIMA, com que você queimou os beiços gu losos da Santa Made Igreja. TAMANDARE' 


\section{MOQUÉM}

\section{III - ENTRADAS}

TAMANDARÉ [Oswaldo Costa]. “Moquém / III - Entradas”. Revista de Antropofagia. $2^{\underline{a}}$ Dentição. Encarte do Diário de $S$. Paulo: São Paulo, 24 de abril de 1929, p. 10. Edição fac-similar. São Paulo: Abril / Metal Leve, 1975.

Não tinha ainda terminado a crítica do movimento modernista quando o sr. Mário de Andrade veio de táxi ${ }^{82}$ em meu auxílio, apoiando a minha tese. O testemunho do sr. Mário de Andrade é valioso e insuspeitíssimo. Pela sua autoridade em assuntos de política literária. Pela coragem com que se confessa em público. Pela réiva de que está possuído contra os antropófagos. Literato brasileiro — diz ele, com muita justiça — oitenta e cinco por cento é um ignorantão. E essa deslavada ignorância, que faz a gente confundir tudo, é que tem sido a causa de vivermos no comadrismo mais curto, mais safadinho, mais fatigante, quando os assuntos deste mundo são inumeráveis e os do Brasil são urgentes e de importância tamanha, acrescenta Mário. Como se vê, não faço senão repetir, com as palavras do poeta, o que aqui disse aos leitores no domingo passado. Foi isso exatamente que condenei no movimento modernista: a sua ausência do Universo, como diria o padre Vieira, e sobretudo a sua ausência do Brasil, como dizemos nós, antropófagos. Me diga o sr. Mário de Andrade que assunto do mundo e que assunto do Brasil resolveram os modernos. Pois não continuamos a confundir tudo, num comadrismo indecente, valorizando mediocridades, como se um artista fosse café ou açúcar cristal, trocando elogios, importando bobagens, misturando Uidobro com Unamuno? Que espírito novo trouxeram à nossa poesia, por exemplo, Ronald de Carvalho e Guilherme de Almeida, que o sr. Mário de Andrade não se cansa de enaltecer, e como, quando e porque António de Alcântara Machado reformou a nossa prosa? Eis aí uma pergunta que desejaria não ver sem resposta, embora difícil de responder. Literato brasileiro é um ignorantão. De fato. Confunde tudo. A-qui-qui. O sr. Mário de Andrade quer uma prova? Faça um exame de consciência, como bom católico que é. Elogios de encomenda a Navarro da Costa. Foguetes à poesia bobalhona de Augusto Frederico Schmidt, peguem na madeira. Correspondência amo-

\footnotetext{
${ }^{82}$ Referência à crônica “Táxi: casa de pensão”. Diário Nacional: São Paulo, 11 de abril de 1929. Reunida em AndRAdE, Mário de. Táxi e crônicas no Diário Nacional. Estabelecimento de texto, introdução e notas de Telê Porto Ancona Lopez. São Paulo: Duas Cidades/Secretaria de Cultura, Ciência e Tecnologia, 1976, p. 83.
} 
rosa com o que há de medíocre na intelectualidade do Brasil inteiro. Zumbaias a Alcântara Machado e outras bexigas da nossa Barra Funda literária. Conselhos tendenciosos à meninada serelepe de Cataguases. Toda essa confusão e esse comadrismo, de quem a culpa? Ora, quem se baba diante dos pastiches cretinos de Brecheret - arte de Saint Sulpice, como disse muito bem Fosca. Quem destaca, na exposição de Anita, o que nela havia de ruim, o Lazaro. Quem baralha monumental com alegórico, asneira grossa que fez, em tempo, as delícias de S. Paulo. Quem não sabe[,] crítico de profissão embora, o que seja grande realismo em pintura, e comete por isso a patada de elogiar um pintamonos pensando que o debochava. Quem se orgulha de imitar Bilac e Vicente de Carvalho, o que temos de pior na nossa poesia. Quem o se envergonha de chamar de infalível, por simples camaradagem, o gosto artístico do sr. Guilherme de Almeida, que pode ter ou ter tido outros gostos, não contesto, mas esse nunca teve.

Quem na mesma hora toca órgão na igreja de Santa Efigênia e se confessa no "Cabo Machado”83. Quem andou por aí distribuindo receitas de lirismo moderno. (Lá está na Escra$v a^{84}$ : “Dei-vos uma receita. Não falei na proporção dos ingredientes. Será.”) Quem escreve numa página - “a impulsão lírica é livre, independente de nós, independe de nossa inteligência” e logo dá marcha-ré, escrevendo que "nos discursos atuais é a inteligência que pronuncia o tenho-dito”. Quem hoje afirma que "nas evoluções sem covardia ninguém volta para atrás” e voltou, em terceira, para o Pequenino Morto. Quem classificou de finíssimo o ouvido de poeta do sr. Alberto de Oliveira, no que, aliás, acertou porque o farmacêutico é isso mesmo poeta de ouvido. Quem faz discursos ao sr. Gomes Cardim, credo! Não somos nós, antropófagos, que graças a deus literatos não somos. É o sr. Mário de Andrade, o cérebro mais confuso da crítica contemporânea - o Virgílio Maurício do alemão, segundo os rapazes do Conservatório, o Nilo Peçanha da literatura nacional, segundo o sr. Menotti Del Picchia, por sinal tão horrivelmente complicado quanto ele.

O sr. Mário de Andrade é contra “o preconceito da sinceridade” e contra “o preconceito da liberdade”, por isso mesmo... A sinceridade e a liberdade da decida antropofágica são o diabo... Podem entornar o caldo do Amorim... Assim, adeus mutirão de sabença da rua Lopes Chaves, primaz do modernismo brasileiro. Adeus Cataguases! Adeus, adeus.

E é também contra a originalidade, ele que dizia, quando ainda podia cair em transe para compor Macunaíma, que “a procura do novo, da originalidade, de que se faz cavalo de

\footnotetext{
${ }^{83}$ Referência ao poema “Cabo Machado”, do livro O losango cáqui. Cf. AndRADE, Mário de. Poesias completas. Edição crítica de Diléa Zanotto Manfio. Belo Horizonte: Villa Rica, 1993, p. 144.

${ }^{84}$ Alusão ao ensaio A escrava que não é Isaura, 1925. Reunido em ANDRADE, Mário de. Obra imatura. $2^{\underline{a}}$ ed. São Paulo: Martins / Brasília: INL, 1972, p. 195-300.
} 
batalha contra nós é desejo legítimo que nas ciências produziu Euclides, Galileu, Newton e Einstein e nas artes Sófocles, Dante, Cervantes, Gonçalves Dias, Edschmidt”, puxa!

Mário de Andrade tem, portanto, razão quando, com invulgar coragem, resolve abrir o peito aos amigos e bater nele com força, desfiando o seu rosário fusco de culpas. Literato brasileiro é mesmo o que ele é: oitenta e cinco por cento ignorantão. Confunde tudo. Como deixei provado. E é inútil, como continuo a perguntar: em sete anos que resultou para nós da Semana de Arte Moderna?

Não gostei, porém, das amarguras que Mário pôs no seu mingau. Mingau não queremos, Mário. Queremos amor. Aquele amor gostosíssimo que você botou nas estrofes do "Cabo Machado”. Mas sem o incenso do coro de Santa Efigênia. Com a pimenta de Macunaíma, com que você queimou os beiços gulosos da Santa Madre Igreja.

TAMANDARÉ [OSWALDO COSTA] 
[Revista de Antropofagia. $2^{\underline{a}}$ Dentição.

In: Diário de S. Paulo. São Paulo, 19/07/1929, p. 12.

Edição fac-similar. São Paulo: Abril / Metal Leve, 1975]

Pag. 12

\section{carta do poeta de "Catimbo"}

Recife, 2 de julho de 1929.

Meu caro Oswaldo Costa.

Recebi sua carta amiga e apresso-me em respondel-a:

$\mathrm{O}^{*}$ programma antropofago é, na sua orientação profundamente nativista, o meu programma já ésbocado em "Catimbó".

A minha solidariedade, pois, com Vocês, seria fatal em vista da unidade de pensamentos, e mais que isso: - da unidade de sentimentos.

Quebra, portanto, dessa solidariedade não será dizer-lhe, afim de evitar explorações, que aquella minha admiração pelo alto espirito orientador desse "Moquem n. 2" não importa em solidariedade total com todos os pensamentos nelle contidos.

Assim, eu não posso dar minha solidariedade ao que Você diz. sobre o "Macunaima", chamando-o de lendas amazonicas colligidas por Amorim e copiadas na sua adoravel linguagem pelo autor.

Nâo.

"Macunaima" é um maravilhoso sonho de mil e uma noites do Brasil.

Não sảo sómente lendas brasileiras o que Você encontra naquellas paginas encantadas!

Pelo contrario: o espirito nordestino passou o pensamento do autor no papo, e, por isso talvez, Vocês do Sul, não tenham podido bem interpretal-o.

Feitas essas consideracôes que me dita o dever de ser sincero commigo mesmo, espero que Você terá a lealdade de publical-as nas mesmas paginas da Revista que tão generosamente me acolheu.

Gratissimn, assigno-me

seu do coraçâo

ASCENSO FERREIRA. 


\section{CARTA DO POETA DE “CATIMBÓ”}

Ferreira, Ascenso. "Carta do poeta de Catimbó”. Revista de Antropofagia. $2^{\underline{a}}$ Dentição. Encarte do Diário de S. Paulo: São Paulo, 19 de julho de 1929, p. 12. Edição facsimilar. São Paulo: Abril / Metal Leve, 1975.

Recife, 2 de julho de 1929.

Meu caro Oswaldo Costa.

Recebi sua carta amiga e apresso-me em respondê-la:

O programa antropófago é, na sua orientação profundamente nativista, o meu programa já esboçado em Catimbó.

A minha solidariedade, pois, com Vocês, seria fatal em vista da unidade de pensamentos, e mais que isso: - da unidade de sentimentos.

Quebra, portanto, dessa solidariedade não será dizer-lhe, a fim e evitar explorações, que aquela minha admiração pelo alto espírito orientador desse “Moquém n. 2" não importa em solidariedade total com todos os pensamentos nele contidos.

Assim, eu não posso dar minha solidariedade ao que Você diz sobre o Macunaíma, chamando-o de lendas amazônicas coligidas por Amorim e copiadas na sua adorável linguagem pelo autor.

Não.

Macunaíma é um maravilhoso sonho de mil e uma noites do Brasil.

Não são somente lendas brasileiras o que Você encontra naquelas páginas encantadas!

Pelo contrário: o espírito nordestino passou o pensamento do autor no papo, e, por isso talvez, Vocês do Sul, não tenham podido bem interpretá-lo.

Feitas essas considerações que me dita o dever de ser sincero comigo mesmo, espero que Você terá a lealdade de publicá-las nas mesmas páginas da Revista que tão generosamente me acolheu.

Gratíssimo, assino-me

Seu de coração 
[Revista de Antropofagia. $2^{\natural}$ Dentição.

In: Diário de S. Paulo. São Paulo, 19/07/1929, p. 12.

Edição fac-similar. São Paulo: Abril / Metal Leve, 1975]

resposta a Ascenso Ferreira

A sua carta, Ascenso, não tem rão no Epstein - que eu reagi nenhuma razão de ser. $\hat{\mathrm{E}}$ uma car-ן de tacape em punho. Você mesta de sentimento, coisa para além mo acha que o espirito do Moda antropofagia, e que eu desco- quem N. 2 foi "altamente oriennheco, gracas a Freud, a Jesus tador". E então?

de Pirapora e a Echú. Nesse ponto - veja o perigo de certas generosidates - você se põe de acordo com esse cretino do Carlos Drumond, para quem "toda literatura nẩo vale uma boa amisade"... Eu gosto de você, Ascenso, porque você tem talento, porque você é um grande poeta, porque você escreveu alguns dos mais gostosos poemas brasileiros que até hoje tenho lido. Mas se um dia você ficasse burro e tésse para imitar Bilac e Vicente de Carvalho - como - Mario de Andrade - eu deixaria de querer bem a você e não teria outro remedio senão devorar o anigo com a maior feroci. dade possivel. Mario se colocou - na posição de mestre diante de vocês, que ele considera dicipu los e maternalmente aconselha com a brandura mais catolica deste mundo. Ora, que vocês devem a ele? Que deve você? Que deve o Jorge de Lima? Que deve o Jorge Fernandes? Nada. Pelo contrario, é a vocês que ele deve tudo. E' de vocês que vem a força que ele exibe aqui no sul, reclanisticamente. Mario é o cosmeti\% da poesia nordestina. Ora eu refiro a cabeleira revolta e despenteada do "Catimbó", da "Nega Fulô" e daquele serelepe "Sã̃o Paulo que não sei não". Para mim toda a obra de Mario nâo vale o Inacio da Catingueira. Você não está de acordo?

Foi contra essas atitudes bestas do autor de Eserava que não é Isaura - que vocês encontra-

Como poeta, Mario tem realmente coisas deliciosas. E' quando ele se esquece que é professor do Conservatorio, que escreveu um Compendio de Historia de Musica, que faz critica profissional atravez de estampas e de Art Vivant, e deixa ou não consegue deixar de explodir dentro dele o negro bom que ele quer inutilmente esconder por medo da Santa Madre Igreja. E esse samba - como observou Oswaldo de Andrade - que faz gostosas certas coisas dele. $\mathrm{Na}$ obra dele, portanto, si não me interessa a parte doutoral, pedante, falsamente erudita, a parte do branco ipócrita do côro de Santa Efigenia, me interessa a parte-bode, que é ás vezes de uma riqueza inegualavel. 0 que lastimo, exatamente, é que Mario recalque $o$ bode. Quanto ao mais - Macunaima inclusive. que elogiei ao ponto mesmo de reivindical-o para o movimento antropofagico, dizendo que ele era a Odisséa brasileira - está certissimo. Não discuto.

Nenhuma razão, desse mollo, assiste ao seu desabafo sentimental, meu querido Ascenso. Ele serviu, entretanto, para firmar a sua solidariedade com a Antropofagia, onde você foi recebido com a satisfação que merece o seu grande talento. Dê por mim uma tacapada séria na Ácademia Pernambucana e disponha de seu velho

OSWALDO COSTA

\section{revista de antropofagia,}




\section{RESPOSTA A ASCENSO FERREIRA}

Costa, Oswaldo. "Resposta a Ascenso Ferreira”. Revista de antropofagia. $2^{\underline{a}}$ Dentição. Encarte do Diário de S. Paulo: São Paulo, 19 de julho de 1929, p. 12. Edição fac-similar. São Paulo: Abril / Metal Leve, 1975.

A sua carta, Ascenso, não tem nenhuma razão de ser. É uma carta de sentimento, coisa para além da antropofagia, e que eu desconheço, graças a Freud, a Jesus de Pirapora e a Exu. Nesse ponto - veja o perigo de certas generosidades - você se põe de acordo com esse cretino do Carlos Drummond, para quem “toda a literatura não vale uma boa amizade”... Eu gosto de você, Ascenso, porque você tem talento, porque você é um grande poeta, porque você escreveu alguns dos mais gostosos poemas brasileiros que até hoje tenho lido. Mas se um dia você ficasse burro e desse para imitar Bilac e Vicente de Carvalho - como o Mário de Andrade eu deixaria de querer bem a você e não teria outro remédio senão devorar o amigo com a maior ferocidade possível. Mário se colocou na posição de mestre diante de vocês, que ele considera discípulos e maternalmente aconselha com a brandura mais católica deste mundo. Ora, que vocês devem a ele? Que deve você? Que deve o Jorge de Lima? Que deve o Jorge Fernandes? Nada. Pelo contrário, é a vocês que ele deve tudo. É de vocês que vem a força que ele exibe aqui no sul, reclamisticamente. Mário é o cosmético da poesia nordestina. Ora, eu prefiro a cabeleira revolta e despenteada do "Catimbó", da "Nega Fulô" e daquele serelepe "São Paulo que não sei não”. Para mim[,] toda a obra de Mário não vale o Inácio da Catingueira. Você não está de acordo?

Foi contra essas atitudes bestas do autor de Escrava que não é Isaura - que vocês encontrarão no Epstein - que eu reagi de tacape em punho. Você mesmo acha que o espírito do Moquém N. 2 foi “altamente orientador”. E então?

Como poeta, Mário tem realmente coisas deliciosas. É quando ele se esquece que é professor do Conservatório, que escreveu um Compêndio de História da Música, que faz crítica profissional através de estampas e de Art Vivant, e deixa ou não consegue deixar de explodir dentro dele o negro bom que ele quer inutilmente esconder por medo da Santa Madre Igreja. É esse samba - como observou Oswald de Andrade - que faz gostosas certas coisas dele. Na obra dele, portanto, se não me interessa a parte doutoral, pedante, falsamente erudita, a parte do branco hipócrita do coro de Santa Ifigênia, me interessa a parte-bode, que é às vezes 
de uma riqueza inigualável. O que lastimo, exatamente, é que Mário recalque o bode. Quanto ao mais - Macunaíma inclusive, que elogiei ao ponto mesmo de reivindicá-lo para o movimento antropofágico, dizendo que ele era a Odisséia brasileira - está certíssimo. Não discuto.

Nenhuma razão, desse modo, assiste ao seu desabafo sentimental, meu querido Ascenso. Ele serviu, entretanto, para firmar a sua solidariedade com a Antropofagia, onde você foi recebido com a satisfação que merece o seu grande talento. Dê por mim uma tacapada séria na Academia Pernambucana e disponha de seu velho

OSWALDO COSTA [TAMANDARÉ] 
BIBLIOTECA IEB - USP

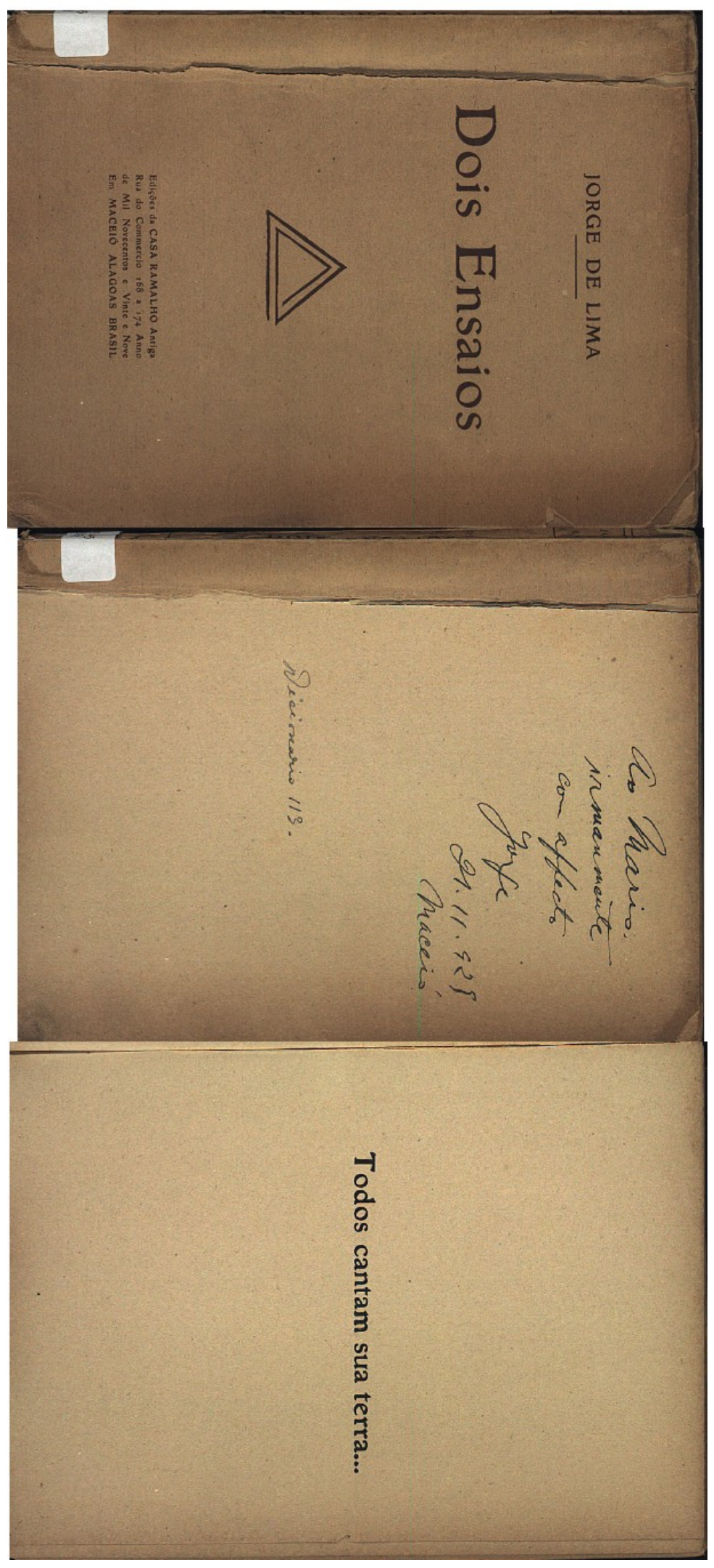




\section{TODOS CANTAM SUA TERRA... ${ }^{85}$}

LIMA, Jorge de. “Todos cantam sua terra...”. In: Dois Ensaios. 1aㅡ ed. Maceió, AL: Casa Ramalho, 1929, p. 86138. $2^{\underline{a}}$ edição, Rio de Janeiro: Civilização Brasileira, 1934. Recolhido em: Obras completas de Jorge de Lima. Rio de Janeiro: Aguilar, 1959, p. 1012-1038, v. I. Reproduzido, parcialmente, com o título de "Um raide do subconsciente nacional”, em ANDRADE, Mário de. Macunaíma. Edição crítica de Telê Porto Ancona Lopez. Rio de Janeiro: Livros Técnicos e Científicos / São Paulo: Secretaria da Cultura, Ciência e Tecnologia, 1978.

Era um dia um homem chamado Mário. Até o nome todo era Mário de Andrade. Que foi passar umas férias em Araraquara - bom lugar para se descansar. Em lugar de descansar, trabalhou.

Pachorra de ficar na rede, só ouvindo cigarras e pitando cigarros não era dele. Um modo de se descansar a cabeça é carregar tijolo: ele tirou massapé e pegou, sem querer, a fazer um calunga. Quando viu, tinha levado, como Nosso Senhor, seis dias trabalhando no barro. No sétimo voltou para o trabalho dele em São Paulo e levou o trabalho de brincadeira para casa. Olhou aquilo no dia seguinte e achou parecido com quê? Era tão parecido que ele quase bancava o Miguel Ângelo: só faltava falar. E porque só faltava falar e não sabia com que parecia, só podia ser o Brasil. Macunaíma nasceu assim.

"Me parece que os melhores elementos duma cultura nacional aparecem nele. Possui psicologia própria e maneira de expressão própria. Possui uma filosofia aplicada entre otimismo ao excesso e pessimismo ao excesso dum país onde o praciano ${ }^{86}$ considera a Providência como sendo brasileira e o homem da terra pita o conceito da pachorra mais que fumo. Possui aceitação sem timidez nem vanglória da entidade nacional e a concebe tão permanente e unida que o país parece desgeografizado no clima, na flora, na fauna, no homem, na lenda, na tradição histórica, até quanto isto possa divertir ou concluir um dado sem repugnar pelo absurdo... O próprio herói do livro, que tirei do alemão Koch-Grünberg, nem se pode falar que é do Brasil. É tão, ou mais, venezuelano que da gente e desconhece a estupidez dos limites para

\footnotetext{
${ }^{85}$ As citações e notas feitas pelo autor serão identificadas como "Nota de J. de L.”.

${ }^{86}$ No livro, lê-se “praceano”.
} 
parar na 'terra dos ingleses', como ele chama a Guiana Inglesa. Essa circunstância do herói do livro não ser absolutamente brasileiro me agrada como quê...”87

Agarrou tudo. Ofereceu ao Paulo Prado que tinha um retrato ${ }^{88}$, para ver se não se parecia mesmo. De fato, se parecia, porque não se parecia. Então era mesmo o Brasil. Mandou o calunga ao Tristão:

“O livro é longo demais. Cacete muitas vezes, como na imensa carta, em estilo médico-purista, que o nosso herói escreve às suas súditas do Urariquera, bancando a 'lettre persane’. Embora recheado de coisas saborosas e de muito espírito, como a frase de Piaimã ao morrer! Cheio também de uma pornografia muitas vezes dispensável, e dessa complacência ao instintivismo que é a marca da época. Não é um romance, nem um poema, nem uma epopéia. Eu diria antes - um coquetel. Um sacolejado de quanta coisa há por aí de elementos básicos de nossa 'psyche', como dizem os sociólogos. É um desses retratos-médios, em que se sobrepõem várias fotografias diferentes e que acaba não se parecendo com ninguém.

Eu temo muito que hoje esteja sucedendo uma coisa semelhante com a nossa arte. Por muito tempo, ela ficou além do foco. Fechada em preconceitos acadêmicos, olhando pro Brasil através da Europa, escrevendo uma língua que se falava em Portugal mas não mais aqui, pecava a literatura por excesso de literatura.

Hoje em dia estamos caindo no excesso oposto. E à custa de desliteratizarmos as letras, estão elas ficando pra trás de nós. Falam uma língua tão 'nossa', que já não é nossa. Refletem uma realidade tão 'real', que já não nos reconhecemos nela. E assim por diante. Ou muito pra trás, ou muito pra frente. Ou nos cenáculos[,] ou nos candomblés. No acidental sempre. Melhor este que aquele, aliás. ${ }^{89}$

E em Macunaíma isso é típico. O livro tem um significado considerável, como toda obra do Sr. Mário de Andrade, seja qual for a sorte futura de suas criações isoladas. E revela no autor uma 'verve’ de expressão, uma assimilação de alguns elementos de nossa formação étnica, de nossa alma, de nossos costumes, de nossa paisagem, de nosso totalismo nacional, que são de fato só dele. E realmente expressivos do que é a barbaria dos nossos fermentos em ebulição. O modelo do que devemos ‘combater’ em nós.”

\footnotetext{
${ }^{87}$ Nota de J. de L.: “Trecho da carta de Mário de Andrade a Tristão de Ataíde.” Nesta e em outras passagens do ensaio, Jorge de Lima cita o artigo "Macunaíma", de Tristão de Ataíde, publicado em O Jornal: Rio de Janeiro, 09 de setembro de 1928. O trecho de Mário, citado por J. de L., não pertence a uma carta, mas a dois excertos do quarto parágrafo do segundo prefácio, transcritos do texto de Tristão. Cf.: p. 17 deste Corpus.

${ }^{88}$ Alusão ao livro de PRADO, Paulo. Retrato do Brasil. São Paulo: Duprat Mayença, 1928.

${ }^{89}$ Este parágrafo, bem como o anterior e o próximo, na edição de $O$ Jornal, são períodos integrados em um só parágrafo.
} 
Depois assuntando melhor, olhando devagar, reparando bem, Tristão de Ataíde viu que era a cara mesma do Brasil, escarrada e cuspida:

“O Sr. Mário de Andrade é o homem menos romântico que possa haver. Nunca escreve por paixão. Por prazer sim. Mas, sobretudo, por procura, por pesquisa, para encontrar o Brasil. O Brasil-alma e o Brasil-corpo, mas não o Brasil-país. Penso que lhe falta singularmente o sentido do nacionalismo político. Mas tem agudamente o senso do nacionalismo orgânico e social, da busca ao caráter que nos distinga na América e nos marque pra sempre. Daí a sua irritação contra a nossa falta de personalidade e a consagração dessa ausência em distintivo, por meio de uma figura como Macunaíma. Pois queira ou não queira o 'consciente' do autor, o que o seu subconsciente nos deu, em Macunaíma, foi, em grande parte, o 'homo brasiliensis ${ }^{90}$ em toda a sua deficiência, embora sem os sinais de tese sistemática e antes uma enorme liberdade de composição.”

Esses pedaços que eu acabo de transcrever de Tristão são todos de um estudo ótimo publicado em rodapé do O Jornal por ocasião do aparecimento do livro Macunaíma. Não sei quando foi, o mesmo ilustre crítico em artigo também ótimo para a A. U. C. a respeito das nossas realidades e dos nossos fins diz sobre as diretrizes do povo brasileiro umas coisas tão agudas e tão salutares que eu desejaria botar aqui se tivesse ainda o jornalzinho da Ação Universitária Católica.

Citando Okakura Kakuso que dizia “a Ásia é una”, ele vê a América tríplice. América anglo-saxônica. Hispano-americana. Luso-americana. Fatores demográficos, geográficos e sobretudo espirituais limitam as três Américas. Nós somos a menos característica.

A primeira caminha para o tecnicalismo democrático.

A segunda para o socialismo. A terceira caminhará para a imitação de qualquer das duas. Do mesmo modo como caminhou até hoje em direção oposta às suas próprias realidades. Acha Tristão de Ataíde que a literatura brasileira moderna, apesar de tudo, enxergou qualquer cousa às claras. Pois que deu fé que estava em erro. Que se esquecera do Brasil, que se expressava numa língua que não era a fala do povo, que enveredara por terras de Europa e lá se perdera, com o mundo do Velho Mundo. Trabalho deu a esse movimento literário atual, a que chamam de moderno, trazer a literatura brasileira ao ritmo da nacionalidade, isto é, integrá-la com as nossas realidades reais. Mais ou menos isso falou o grande crítico. Assim como falou no novo erro em que caiu esta literatura atual criando um convencionalismo moder-

\footnotetext{
${ }^{90}$ Em O Jornal, lê-se "homo brasilicus".
} 
nista, uma brasilidade forçada, quase tão errada quanto a sua imbrasilidade. Em tudo isso está certo Tristão.

Houve de fato ausência de Brasil nos antigos, hoje parece que há Brasil de propósito nos modernos. Porque nós não poderíamos com sinceridade achar Brasil no índio que Alencar isolou do negro, cedendo-lhe as qualidades lusas, batalhando por um abolicionismo literário do índio que nos dá a impressão de que o escravo daqueles tempos não era o preto, era o autóctone. O mesmo se deu com Gonçalves Dias em que o índio entrou com o vestuário de penas pequeno e escasso demais para disfarçar o que havia de Herculano no escritor.

Os seus versos mais brasileiros e mais populares como:

"Minha terra tem palmeiras

onde canta o sabiá,”

nos dão a impressão inversa da desejada pelo poeta: que ele cantando os sabiás não se esquecera de Coimbra.

Não havia realidade nesta literatura. Como não havia no negro de Castro Alves elevado a espártaco e servido do pior romantismo do mundo que foi o de Hugo.

Esse romantismo social, fácil, palavroso, como um meeting político, como um discurso republicano, ou uma estirada acadêmica, poderia ter tido suas realizações políticas. Poéticas não! Estragou o motivo que era o negro, do mesmo modo que os indianistas estragaram o índio. É por isso que em Castro Alves o poeta interessante ficou no lirismo do "Laço de Fita”, no "Boa-Noite".

Não era somente o estilo que era condoreiro nos poetas desta fase literária: os motivos eles os elevavam à altura do vôo das rapinas.

Faltou por exemplo a Castro Alves a justeza de um Baudelaire amando e cantando as suas paixões, os seus motivos com o tamanho que eles tinham realmente; enquanto Joana Duval ficou sempre para o poeta das Flores do Mal o veneno; "la négresse satanique”, à banalíssima Eugênia Câmara não bastavam asas de condor, o poeta deu-lhe asas de anjo; cair-lhe aos pés era até ficar de pé:

“Gravitar, para ti é levantar-se

Cair-te às plantas é ficar de pé.”

A propósito é bom lembrar umas amostrazinhas do poeta.

O poeta abolicionista:

"Arranca este peso das costas do Atlante

Levanta o madeiro dos ombros de Deus!” 
O poeta da República:

"República! vôo ousado

Do homem feito condor!

Raio de aurora inda oculto

Que beija a fronte ao Tabor.”

O poeta social:

"Quebre-se o cetro do papa,

Faça-se dele uma cruz,

A púrpura sirva aos pobres

Pra cobrir os ombros nus.”

“Já que a terra estacou na órbita imensa

Já que tudo mentiu, a glória! a crença!

A liberdade! a Cruz!”

O poeta épico:

"Nós que somos a raça eleita do futuro,

O filho que o Senhor amou qual Benjamim,

Que faremos de nós... se é tudo falso, impuro,

Se é mentira o progresso! e o erro não tem fim!

Não! clamemos bem alto à Europa, ao globo inteiro!

Gritemos - liberdade - em face da opressão!

Ao tirano dizei - tu és um carniceiro!

És um crime de bronze - escreva-se a canhão!”

O mais interessante é que aos jovens de sua geração e mesmo aos que se sucederem a ela, era justamente o lado ruim do poeta, essa poesia excrescente e lambanceira em oposição ao lirismo tão fresco do "Boa Noite, Maria!” o que mais encantava. A esse latão agarrou-se tempos depois Martins Júnior, no Recife, dizendo-se inventor de poesia científica. Apesar de que o culpado desse esparramo martinesco foi mesmo o Tobias Barreto - um homem que não chegou a ser nem filósofo, nem poeta, nem cientista como pretendia.

A ela aderiram alguns rapazes como o Sílvio Romero que apesar de versificar estiradas levemente sociais, políticas e históricas, não conseguiu nem mesmo o que o Martins Júnior conseguira com semelhantes despropósitos:

"Comte pôde, estóico, escalar o alevantado monte

Deixando embaixo Kant, Simon, Burdin, Turgot,

Newton e Cordorcet e Leibnitz, voou

Ele para as alturas mágicas da glória, 
Após ter arrancado ao pélago da História

A vasta concha azul da ciência social!”

O grande crítico que foi José Veríssimo anota, não me lembro se na sua História da Literatura Brasileira ou se nos seus Estudos de Literatura, que a nossa primeira manifestação literária (por sinal ruim como quê) era gongórica antes do gongorismo: o prefácio da Prosopopéia de Bento Teixeira.

Temos mais de três séculos de gongorismo, e gongorismo reúno, que ainda dura hoje, capaz de projeção por muito tempo ainda.

Góngora nos dá a impressão dum gigante de prole liliputiana ${ }^{91}$.

Só ele foi grande. Mas peganhento que nem visgo. Só a gripe que da Espanha veio também com o mesmo tamanho, com o mesmo contágio e os mesmos estragos.

Portugal vizinho, pagou sério tributo: era um campo preparado, como dizem os médicos. Houve livros que se chamaram: Syntagma comparística, Crisol seráfico, Amplidão verbênica, Luminescências alcandóricas, Desmaios de maio em sombras do Mondego, e outras pepineiras. Pegaria por sem dúvida o Brasil a moléstia da Península. Deixou marcas bem fundas em Antônio de Sá e Eusébio de Matos, na Escola Baiana enfim, em que a poética pábula do "Boca do Inferno" é exemplo claro, para culminar em virulência e gravidade nos condoreiros que se agravaram da pior imitação importada como a do Lamartine e do Hugo.

Essa literatura de imitação, de transposição quase, era tão fácil, que o bom autor de $I$ racema e péssimo escritor de outras coisas esqueceu para a felicidade do José Américo de Almeida a seca, com as maiores páginas que lhe poderia dar, esqueceu o negro derrancado de surra e de tronco, esqueceu até o ódio ao português que lhe havia humilhado a família e exterminado mesmo alguns membros ascendentes, (parece), para ver só o índio a quem presenteou com uma literatura de abolicionista, recheada de palavras bem-soantes. Foi buscar o gaúcho a quinhentas léguas de distância, para escrever dois tomos de coisas falsas, mandou buscar da corte as suas “Divas” e as suas “Lucíolas” para encher alguns volumes de sensaborias e passou por cima do seu sertão caboclo e de seus brejos matutos ali a dois passos de distância, com o seu ritmo fatal de desespero e de fartura. Embelecado na conversa fiada do filosofismo fútil de sua época botou num livro que se lê com interesse aos 13 anos a má compreensão que se tinha do missionário catequista no Brasil. Aquele Loredano d’O Guarani transparece o que

\footnotetext{
${ }^{91}$ No livro, lê-se “liliputeana”.
} 
romancista aprendeu em folhetos franceses: laicismo, animosidade anti-religiosa que não fizeram do Alencar nem um anticatólico, nem um anti-sobrenaturalista, nem um evolucionista, nem nada. ${ }^{92}$ Apenas um anticlerical.

O que é muito pouco para um homem que não queria ser ignorante.

$E^{93}$ que foi contagiado como quase todos de seu tempo pelo malabarismo palavroso que do Velho Mundo veiculava um semicultismo. Nós sempre nos curvamos ao magnetismo das palavras, ao imperativo da ressonância vocabular. A introdução do positivismo no Brasil começou com a sedução que a palavra Matemática impunha a certos espíritos que nada entendiam de Matemática e pregaram um positivismo de oitiva com a expressão comum de lugares banais: o regime normal, a anarquia mental, a ordem é fator de progresso, os mortos governam os vivos, as pátrias brasileiras, a integração do proletariado, etc.

Esta gíria influiu por muito tempo antes da República e depois, nos que separam a Igreja do Estado, nos abolicionistas, nos nossos políticos, oradores, críticos e filosofozinhos de meia-tigela. E foi querendo reagir contra a influência positivista mais retórica do que mesmo positiva, que o Sílvio Romero propunha uma fórmula inócua do evolucionismo spenceriano, que sem a força dos conceitos retóricos do positivismo, necessitaria como necessitou da oratória do polemista para fazer de seu estudo Doutrina contra doutrina uma detestável estirada sonora. Correntes estranhas, nocivas, desviaram o espírito brasileiro do achamento de sua expressão, de seus ritmos, de suas verdades.

Não digo procura porque a procura implica uma intenção; falo: achamento - que se teria alcançado talvez pelo caminho da nossa singeleza, da nossa brabeza virgem afastada completamente de qualquer imitação. Os poetas que cantaram as aves que aqui gorjeiam e a terra encantada, mimoso jardim de fada, do mundo todo invejada, que o mundo não tem igual, levariam essa literatura ao mais bocó dos jacobinismos. Isso é que se poderia chamar um brasileirismo além de falso, intencional. O que põe em relevo o brasileirismo da nossa literatura de hoje que pode ter muito de intencional, mas em compensação tem muito de real.

\footnotetext{
${ }^{92}$ Nota de J. de L.: "Também no Brasil a lenda teve curso e deixou vestígios no romance, no drama, e aqui e ali, na crítica e na História; mormente na história de fancaria, retalhada a corte de tesoura e cerzida à pressa para as escolas ginasiais. Por vezes a jesuitofobia lindava com a inconsciência do escritor tão radicalmente ignaro das cousas da Companhia que nem sequer a casca lhes salvaguardava ao menos, e disparava em anacronismos e anomalias de expressão incontestavelmente caricatas. Baste por todos o exemplo de José de Alencar, que não hesitou em escrever um drama tão diretamente sobre o assunto, que tem por título Os Jesuítas, e no qual o reitor do colégio da Companhia, uma das personagens principais da peça é... (risum teneatis!): Frei Luiz!” (P. Luís Gonzaga Cabral S. J., Jesuítas no Brasil, p. 35).

93 No livro, lê-se "E” - possível erro tipográfico.
} 
As primeiras tentativas de expressão nacional foram assim todas elas falsas pelo exagero.

Muito antes de o poeta das Primaveras garantir que nas “débeis cordas da lira” havia de fazer “a terra rainha” "no seu trono de beleza”, o Sebastião da Rocha Pita dizia a mesma coisa em estilo e intenção que haviam de perdurar desde 1730 em tanta gente ufanada do Brasil, do seu céu[,] do seu sol e das suas estrelas que são sempre postos em concorrência com os soizinhos e as estrelinhas vagabundas dos outros. Aqui havia no céu um despotismo de coisas ótimas, porque propositalmente "a mão da natureza esmerou-se em quanto tinha”. Era natural que cem anos antes do Casimiro, o fogoso fazendeiro baiano, autor da História da América Portuguesa escrevesse: “em nenhuma outra região se mostra o céu mais sereno, nem madruga mais bela aurora; o sol em nenhum outro hemisfério tem os raios mais dourados, as estrelas são as mais benignas e se mostram sempre alegres, é enfim o Brasil o terreal Paraíso descoberto em que influem benignos astros.”

Da mesma forma que os nossos primeiros literatos cantaram a terra, os nossos poetas e escritores de hoje querem expressar o Brasil numa campanha literária de “custe o que custar”. Surgiram no começo verdadeiros manifestos, verdadeiras paródias ao Casimiro e ao Gonçalves Dias: “Todos dizem a sua terra, também vou dizer a minha.” E do norte, do sul, do sertão, do brejo, de todo o país brotaram grupos, programas, proclamações modernistas brasileiras, umas ridículas à beça ${ }^{94}$. Ninguém melhor compreendeu, adivinhou mesmo, previu o que se ia dar, botando o preto no branco, num estudo apenso ao meu primeiro livro de poesia em 1927, do que o meu amigo José Lins do Rego. Me desculpem, mas eu não posso deixar de dar a palavra ao meu amigo:

"Ninguém em poesia diz a outro: eu vou fazer a Ilíada, ou um poema à Bahia. O poema é que entra dentro do poeta e o domina. Ou ele escreve ou perde o poema. Verifica-se o mesmo com esta história de poesia modernista no Brasil. Vemos todo dia um novo gritando: eu vou fazer a poesia nova do meu país. A gente vai atrás do ruído, e não encontra nada. Não se descobre poesia, como se fosse fórmula de remédio, com esforço de paciência. Ela tem de vir pelas suas próprias forças. Aquela receita de Pascal, que em fé é tão ativa expressão, parece que não se fez para negócios de arte. Em poesia a graça tem de chegar ${ }^{95}$ como em S. Genest, que sem procurar se situou na mais ${ }^{96}$ viva realidade. Ela não faz barulho para conquistar, tem os passos mansinhos do ladrão imperceptível do verso de Claudel. Foi por isso que o se-

\footnotetext{
${ }^{94}$ No livro, lê-se “a bessa”.

${ }^{95}$ No livro, lê-se “chagar”. Erro tipográfico.

${ }^{96}$ No livro, lê-se “masi”. Erro tipográfico.
} 
nhor Sérgio Buarque de Holanda, agudo como o diabo, disse uma vez que essa história de arte brasileira 'não nascerá da nossa vontade, surgirá muito mais provavelmente da nossa indiferença'. Sérgio Buarque quis com isso tocar no esforço e messianismo de certa gente que a toda força procura criar uma arte nacional, como se fosse tão fácil criar uma arte. Aí Sérgio Buarque de Holanda pensou bem - esse curioso rapaz em que J. J. Gomes Sampaio descobriu um caraterzinho bem ruim e que anda cheio de maus instintos de revolução.”

Dois anos depois é o mesmo protesto de Tristão de Ataíde: “esse modernismo intencional não vale nada!” Entretanto nós precisamos achar a nossa expressão que é o mesmo que nos acharmos.

E parece que o primeiro passo para o achamento é procurar trazer o homem brasileiro à sua realidade étnica, política e religiosa.

Essa expressão falhou em tantas tentativas: O Uraguay, O Caramuru, Os Timbiras, $A$ Confederação dos Tamoios, O Colombo, O Guarani e todo o Castro Alves épico, político ou social. Quando o exagero cedeu um momento e a nossa realidade foi entrevista por um homem de gênio, Euclides da Cunha, nós tivemos Os Sertões que vencendo mesmo o empolado da linguagem escancaram uma expressão brasileira, um pedaço da gente brasileira, um bocado bom do nosso mesticismo, do nosso misticismo e da nossa política.

Mesticismo, misticismo e política brasileiros são coisas que nos deviam preocupar mais do que literatura.

Porque precisam de revisão mais do que tudo. Principalmente a política. Mas a gente deve ver a dependência em que vive o intelectual brasileiro geralmente pobre, incapaz num país em que pouquíssima gente lê, de viver do que escreve, a gente deve ver que aqui os clérigos de Benda $^{97}$ são todos[,] por força das coisas, obrigados à traição.

Nos lugares pequenos os médicos fazem tudo, arrancam dente, passam receita, tiram meninos a ferro e receitam gotinhas para os olhos, senão morrem de fome.

Este Brasil é um país pequeno. Se o sujeito não trair a cleresia, está fatalmente perdido.

Ainda não vi país em que os intelectuais se preocupassem mais com política do que aqui. É verdade que não se contando com os idealistas da abolição, com os parlamentaristas do primeiro e do segundo império, muitos destes sem talento, a preocupação política do nosso intelectual é a preocupação que é a de se render ao profissional político, espiar a maré, dedicar

\footnotetext{
${ }^{97}$ Alusão ao livro La trahison des clercs (1927), do escritor francês Julien Benda (1867-1956).
} 
livros e escrever louvores a ele, para cavar suas sinecurazinhas, e cavar uma Câmara que é a suprema aspiração do intelectual brasileiro.

Essa Câmara vai depois ser mantida à custa do maior avacalhamento do mundo. O termo avacalhamento até surgiu lá.

Já se tornou sabedoria popular essa coisa de que "sujeito inteligente é sujeito safado, sem caráter, etc.” Águia é tanto o sujeito brilhante que pode ir a Haia, como o fazedor de contos-do-vigário que freqüenta a delegacia.

Quando os militares proclamaram a República e uma semicultura positivista estragou a nova instituição de dísticos tolinhos, os nossos poetas eram puros “clérigos” de dedos calejados na contagem de sílabas parnasianas, os nossos filósofos eram também puros clérigos fascinados pelo monismo, pela Clotilde, pelo pitecantropo em que viam sujeito maior que Deodoro. O que não empatou esses clérigos de aderirem à República e dedicarem à "pátria amada” os hinos, as canções, uma literatura tão insossa e paradoxalmente tão palavrenta e tão engraçada quanto a poesia social, épica e abolicionista de Castro Alves. Conta-se que por ocasião do feito histórico do Generalíssimo, estando o senhor Medeiros e Albuquerque em Lisboa, tirou o retrato montado a cavalo e de barrete frígio.

A gente sem querer se lembra duma descoberta do Veríssimo: "Bento Teixeira fica sendo, não só o primeiro em data dos poetas brasileiros, mas o patriarca dos nossos engrossadores literários. Bento foi, (conclui o crítico) de ambos os modos progenitor fecundíssimo de incontável prole.”

Desta paternidade nem sei como escapou um sujeito medroso e tímido como o grande Machado de Assis que passou a vida clérigo, fechado na sua pobreza e na sua arte. Quase que o único movimento literário brasileiro curado de traição foi o atual, apesar dos pesares. A gente deve salvar logo o Oswaldo [sic] de Andrade que dedicou seu Primeiro caderno de poesia ao doutor Júlio Prestes, mas numa época em que o homem não era ainda manda-chuva.

Um grande descrédito junto à burguesia livrou providencialmente de traição o Modernismo de hoje. O mal era antigo e viera da Península em que os reis ao lado dos bobos tinham poetas efetivos e oficiais. Do Reino ${ }^{98}$ passou naturalmente à Colônia.

Aqui tudo quanto foi capitão-mor, donatário, senhor de engenho, governador e outros manda-chuvas bancaram os heróis. "Desde as suas primeiras manifestações (diz José Veríssimo) a poesia e depois toda a espécie de literatura, inspirou-se grandemente aqui daqueles motivos, e foi consideravelmente áulica. Aulicismo, arcadismo, gongorismo foram sempre

\footnotetext{
${ }^{98}$ No livro, lê-se “No Reino” - erro tipográfico.
} 
aliás traços característicos das letras portuguesas.” Era fatal que o costume viesse do Império para a República em que poetas, jornalistas e até meetingueiros conseguiram tudo.

Com o parnasianismo brasileiro, sete séculos de rimas, de métricas e de verborréia tinham $^{99}$ culminado na impersonalidade e na impassibilidade da finada escola literária. Era natural que a reação intensa produzida pelo modernismo espantasse o burguês. E espantou.

Intencionalmente ou desintencionalmente, o caso é que espantou. Em São Paulo - uma terra que o brasileiro já se acostumou a chamar terra de finos e de gente do trinque, o Mário de Andrade passou por maluco e mais do que esse pequeno prejuízo, foi dispensado de professor de música pelos papais de suas discípulas.

Isto num Estado que se presume da gente mais decente, onde há conde e bandeirante como bala. Nos outros Estados menos felizes o modernismo é considerado brincadeira de meninos, ou leseira de malucos. E quando o sujeito não é nem uma coisa, nem outra, e já maduro aparece com um poeminha qualquer, a burguesia, o vulgo, toda a gente o rebaixa à idade e à insanidade que há nas creches e nos hospícios.

O sujeito caía dos queixos, quando ouvia dizer que Manuel Bandeira, por exemplo, era homem de seus quarenta anos e sisudo de verdade. Em uma célebre excursão pelos Estados, a declamadora dona Ângela Vargas, se queria ter boas casas, o que era de seu especial agrado, tinha de dizer toda viagem o "Caçador de Esmeraldas” e outras coisas assim. Aliás o queridíssimo poeta da "A Missão de Purna”, havia escrito oportunamente em outros tempos, que a senhora Ângela Vargas “era a própria poesia”. A “própria poesia brasileira” viu com os próprios olhos naquela famosa excursão quanto era estimada por todos e quanto foi xingado por toda a gente o futurismo dos modernistas. Foram estes obrigados a um isolamento, a um fechamento que nunca se observou em poetas de nenhuma época, nos Tobias e nos Castros das noitadas célebres do Santa Isabel nem nos parnasianos declamáveis e colaboradores obrigados de todos os álbuns de poesia, do Brasil.

Fizeram por vezes assim os modernistas, intencionalmente ou desintencionalmente, poesia pura. A arte (a arte em si) parece que devia estar pois separada de toda função áulica: isto é, diretamente social e política. Não tenho coragem de dizer independente, pois que muitas vezes os acontecimentos sociais, políticos, provocando reações na massa, poderiam provocar também reações estéticas paralelas (não me animo a dizer correspondentes).

O mesmo não se dá com a religião, mais de perto da arte, às vezes, tão pegada nela que a oração já é poesia. Certa arte de fundo místico poderá fazer indiretamente a religião,

\footnotetext{
${ }^{99}$ No livro, lê-se “tinha”.
} 
assim[,] influir na massa. Mas esta influência parece melhor da religião mesma. Se essa influência indireta é um fato[,] teremos então literatura social, religiosa, o que mais for. Só assim. As pesquisas de Mário de Andrade, as estrepolias de Macunaíma, o depoimento do subconsciente danado de sincero, do herói de Mário, parece dão a entender que o substrato desta nossa nação não tem caráter, é amoral e portanto irreligioso. O que leva a gente a olhar o nosso jeito de ser católicos e saber com que olhos Roma nos olha. Mesmo para melhorar. Não sei se nós somos de verdade um povo místico. Mas místico mesmo. É preciso ver. Verdadeiramente clérigos em religião creio que não somos. A gente sai da religião como sai da arte, como sai de casa para cair com gosto na rua. Há é uma tendência no brasileiro à prática religiosa exterior, discursiva, oratória, literária, dos beiços para fora. Por isso talvez é que o brasileiro procura mais as ordens seculares que as monásticas em que o espírito de renúncia, de recolhimento mais se nota.

Não derivará daí o assalto das mediocridades aos nossos seminários? A gente não quer melindrar os pensadores, mas a intromissão dos seculares ou dos clérigos leigos na política é traição e da roxa. A política requer uma descida. E o católico devia ser a Santa Sé. E parece que onde houver esse hibridismo político-religioso é necessário que haja um Bispo de Olinda para botar as coisas nos seus lugares. A nossa maneira de ser católicos é outra coisa que pede meditação.

Como será que nós somos inquietos?

Parece que os outros povos amam a Deus e nós gostamos de Deus. Nós gostamos muito de Nosso Senhor. Um dia nós fomos catecúmenos. Os outros povos aceitaram o cristianismo num nível, num plano de civilização de preparo prévio que nos faltou. Cristo veio nas caravelas para o Brasil. A humildade d’Ele desceu à brabeza do indígena. Desceu, desceu, até o indígena compreender ${ }^{100}$. Os outros povos tinham muita coisa, tinham o pecado. O índio nem o pecado tinha.

Os missionários[,] que pregam no Oriente, encontram o amarelo forrado de Confúcio. Para Cristo é um passo. Os catequistas da Índia desalojam facilmente Buda de dentro do povo

\footnotetext{
${ }^{100}$ Nota de J. de L.: Desceu. desceu, desceu. Desceu até o indígena compreender. No litoral de hoje subiu, subiu, subiu.

Subiu aos homens inteligentes. É próprio desta religião católica acomodar-se a todos omnium ingenuo accommodatam. A rudes e intelectuais religio siquidem Christi sua profunditate philosophis, sua simplicitate rudibus apprime accommodatur. Pode estar como aquele gênio de Aladim, dentro de dez páginas do catecismo como pode superar as obras dos santos, doctrina christiano - catholica legitimis intellectus humani aspirationibus optime respondet porque é uma suma, como disse Santo Tomás.

Para ver-se a Synopsis Theologiae Dogmaticae, ad mentem S. Thomae Aquinatis hodiernis moribus accomodata - TANQUEREY.
} 
dos marajás. Mas o menino Jesus que São Cristóvão Colombo passou no mar para as Américas veio encontrar no Brasil o homem da machadinha de pedra.

Um sujeito de entendimento pode estar apedrejando um missionário, furando os olhos dele, e pepinando o corpo todo para judiar bem dele, e muitas vezes antes de acabar o serviço, o camarada está é vencido pelo mártir, convertido, mudado e até com vontade de ser pepinado também.

A história dos catequistas do Oriente está cheia destes casos. Os meus conterrâneos caetés que devoraram um bispo e mais quarenta cristãos, comiam sem conversão nenhuma tantos bispos aparecessem. Abriam a carcaça dum cristão como um menino abre um boneco, sem virar boneco.

Era um trabalho para o santo Anchieta se fazer compreender. Era um trabalho como aquele que Livingstone - o pioneiro protestante, desenvolvia nas margens do Zambeze, no coração da África, entre makololos e bazinkas. Conta-se que este inglês ${ }^{101}$ chegou uma tarde em Chonuane, a grande aldeia do chefe negro Sechele. Aí parou e vendo que o chefe era inteligente, tão inteligente que aprendeu todo o alfabeto num dia, resolveu ficar entre aquele povo que talvez compreendesse a doutrina inteiramente inacessível aos bakhalas e morumbuas por ele deixados no caminho. E começou a pregação.

Depois de dois dias o pessoal estava na mesma. Depois de três, na mesma. Depois de uma semana: ainda na mesmíssima. Aí o chefe Sechele falou como homem prático, conhecedor do povo que governava: “Pai Livingstone, isto não dá resultado. Vou mandar surrar o pessoal a couro de rinoceronte, e você verá como a coisa agora vai!”

Anchieta só faltou passar o seu pessoal também nas embiras, porque tudo ele fazia para gravar naquelas crianças grandes a palavra eterna. E o processo mais prático, mais pedagógico, não era fazer o índio compreender a religião, era fazer o índio gostar da religião. Havia uma intenção montessórica nos processos do padre. De cinqüenta léguas em torno afluíam aimorés e tamoios para assistirem a um auto dele. O Mistério de Jesus por ele composto e representado pelos índios da missão foi um sucesso de arromba entre a bugraria. Como só homens representavam no palco improvisado no meio do mato, um índio aparecia fantasiado de Nossa Senhora, enquanto outros representavam anjos, diabos, Nero, Júpiter, Guaixara, Saravana, S. Sebastião, S. Lourenço, o Cão Grande, o Gavião... Ninguém não ficava surpreso de ver Saravana de braços dados com a Virgem. Nos bastidores São Sebastião cachimbava ao lado de Júpiter. Os versos tupis soavam cadenciados, as deixas eram atendidas em cima da

\footnotetext{
${ }^{101}$ David Livingstone (1813-1873) era, na verdade, explorador e missionário escocês.
} 
bucha. Anchieta autor, ponto e contra-regra, dirigia as cenas. E no fim, vencidos os diabos, os imperadores, os maus espíritos da floresta, a indiaria embasbacada e depois excitada pelo sucesso da peça, caía num frevo carnavalesco de treme-terra, cadenciado a passo de siricongado e ritmado de tambores, bumbos ${ }^{102}$, caixas e saca-buchas. Era o suco. Em seguida três descargas de mosquetaria. Farta distribuição de espelhinhos e contas para os convivas, canivetinhos e estampas aos pajés, vivas a Portugal, vivas ao Brasil. Todo o mundo gostava da religião.

O índio havia preparado o terreno religioso para o negro. Este foi chegando e sem precisar dos autos interessantes de Anchieta que em força eram tão fortes como os processos do chefe Sechele, foi logo gostando da religião.

Ainda era a semente fecunda do inteligentíssimo missionário católico. Os futuros paisjoões foram gostando mesmo das procissões, da água-benta, das missas cantadas, do sacristão ${ }^{103}$, do seu ${ }^{104}$ Vigário. Mas se encontrasse Pascal, não gostava, não. Me digam uma coisa: não era natural que o brasileiro vendo a demora ou o indeferimento que qualquer santo opusesse a uma petição sua, botasse o santo de cabeça para baixo ou surrasse com galho de pinhão-roxo o São Benedito tão enfeitadinho de fitas do oratório?

O padre via aquilo e deixava passar.

Aquela gente não era o grego, não era o coríntio, não era o gálata, não era o tessalônico, não era o chinês, não era o puritano. Não se podia prender aquela gente a epístola nem a pistola. Nem como S. Paulo, nem como Argall. Aquela gente era criança.

E nas crianças ninguém pode corrigir as criançadas da noite para o dia. Nós ainda somos crianças também em catolicismo. Não pensem que eu estou desgostoso com isso. Não estou, não. Jesus até gostava era das crianças.

Os escribas, os doutores do templo, Ele verificou que sabiam muito pouco. As crianças é que sabiam tudo. Que missão difícil, que foi a missão entre crianças, confiada aos missionários brasileiros! Os templos religiosos no Brasil são ainda hoje atestados do esforço catequista daqueles tempos. Nas igrejas protestantes há sempre uma vazante de fiéis que faz dó, é uma vazante de conferência literária. O templo positivista do Rio de Janeiro nem por ser da humanidade e achar-se entre população mais densa e mais instruída, não arranja pessoal nem para o banco da música.

\footnotetext{
102 No livro, lê-se "bombos".

${ }^{103}$ No livro, lê-se "sãochristão".

${ }^{104}$ No livro, lê-se "sêo".
} 
O templo católico é que se enche e anda sempre superlotado de manhã à noite. É uma enchente de circo. Circo divino. Quem não tiver alma de compreender o circo, não tem aquela sabedoria das crianças de que Jesus gostava. Enquanto o teatro muda e Pirandello passará, como Ibsen passou, o circo é o mesmo e há de ser sempre o mesmo. São Francisco deixou de ser trovador para ser “jongleur”, como se chamou a si e a seus companheiros, assim mesmo em francês.

Jongleurs de Dieu! Eram os palhaços de Nosso Senhor. Os que têm dançado em grelhas quentes. Os que têm sido pasto nas arenas romanas a tigres e a leões. Os que foram crucificados de cabeça para baixo, como São Pedro. Os que fingem de boêmios para não parecerem santos, como o buon Filipo Neri.

A linguagem universal dos “Jongleurs” é a linguagem universal dos poverellos que até o irmão lobo, os irmãos bichos compreendem. Até os botocudos entendem. Os aimorés, os congos, os cabindas, os brasileiros de quando o Brasil amanhecia entenderam todos esses jograis divinos que Nosso Senhor mandou ao Brasil.

Os autos de Anchieta, as procissões, as santas missões sedimentaram por sem dúvida no subconsciente da nação. Mas o que desceu no subconsciente voltou de lá enriquecido da colaboração das raças.

Como olhariam os pascais esse nosso catolicismo?

Em notas apensas aos meus Poemas José Lins do Rego já escrevia que “um interessante ensaio por escrever-se seria sobre o catolicismo que o nordestino encheu de notas tão pessoais nas novenas, nos terços, nas procissões do mato, nos quartos de defunto, nas pagas de promessas, e em tantos outros atos que dizem fortemente duma gente crédula em que as forças de criação acusam uma admirável riqueza.”

É injustiça olhar somente o catolicismo do negro e do índio. A imigração lusa que entrou nesta terra, já é chapa a gente dizer, era ruinzinha que doía. Os outros ádvenas não eram melhores: piratas, ladrões - o diabo que vinha da Renascença com os olhos de fogo sobre o Brasil.

Eu não concordo com todas as coisas bonitas que o meu amigo Paulo Prado botou no seu Retrato do Brasil, mas não posso deixar de aceitar entre muita coisa certa este pedaço: “a essa verdadeira pandemia só escaparam duas classes de colonos: os padres da Companhia e os parasitas sedentários da burocracia metropolitana. Estes pela estupidez vegetativa dos governos coloniais, capitães-mores, fidalgotes, desembargadores, ouvidores, bispos, toda a complicada máquina administrativa que já começara a sugar a energia do velho Portugal. Aqueles, 
pelo derivativo da fé missioneira, em que no desenfreamento das paixões do Novo Mundo o jesuíta representou o poder moderador, o elemento de cultura moral, de exaltado misticismo com que aqui chegaram os primitivos missionários de Coimbra e Évora.” O resto não prestava para nada. A própria autoridade dos padres era impotente para conter a safadeza de seus compatriotas. As cartas de Anchieta e de Nóbrega ao Rei repetiam-se de reclamações, de queixas, quanto ao descalabro, à vida sem-vergonha e criminosa de toda a gente.

Os padres tinham de fechar os olhos bem fechados ao primitivismo inocente do índio e ao relaxamento incurável do colono.

Faltava a este a limpeza moral do puritano que construiu os Estados Unidos; faltava aos missionários o laicismo violento e armado (o que lhes estava em oposição à regra) dos pioneiros ingleses, dum Argall por exemplo que impunha, a bala, obediência às autoridades religiosas, assiduidade obrigatória aos cultos, reverência integral à Bíblia e aos ensinamentos da Igreja. Senão, não tinha conversa: era emigrar para o outro mundo e prestar contas ao diabo.

Martius em seu livro Viagens aparecido em 1818 conta a surpresa que lhe causou uma procissão do Senhor do Bonfim, na Bahia. Não seria, por certo[,] menos pitoresca do que as de Olinda que o senhor Gilberto Freyre descreve em seu estudo Vida social do Nordeste: "os Nossos Senhores de longos olhos de queixa e cachos de cabelo preto, as Nossas Senhoras dolorosas; o bispo sob o baldaquino, num passo lento e doce, como se a rua fosse um quarto de doente; os anjinhos; as tristes figuras de Adão e Eva; meninos sarapintados de borrões de tinta para fingir sangue virgem dos mártires de Marrocos; o papa-angu com a sua corneta e o seu chicote, enfrentando as pitombadas dos moleques gingadores; o governador e altos funcionários atrás do pálio; senhoras ostentando vestidos de seda grossa, a saia arrastando, a renda preta da mantilha caindo atrás; indivíduos vestidos de Morte, tangendo matracas de jacarandá diante dos andores; fanáticos meio nus com o sangue não de mentira, mas de verdade, a espirrar vivo e quente do dorso retalhado a caco de vidro e a pingar na rua quando a procissão parava diante dum nicho.” O testemunho de Fernão Cardim lembrado pelo Padre Luís Gonzaga Cabral em sua bela obra Jesuítas no Brasil ainda é mais curioso que as duas precedentes:

“Trouxemos no navio, diz Cardim, uma relíquia do glorioso S. Sebastião, engastada em um braço de prata... Uma das oitavas à tarde se fez uma célebre festa. O sr. Governador, com os mais portugueses fizeram um lustroso alardo de arcabuzaria, e assim juntos, com seus tambores, pífanos e bandeiras foram à praia. O Padre Visitador, com o mesmo Governador e os principais da terra nos embarcamos numa grande barca; nela se armou um altar e alcatifou 
a tolda com um pálio por cima; acudiram algumas vinte canoas bem esquipadas. Entre eles vinha Martim Afonso, comendador de Cristo, índio antigo Abaeté e Moçacara, scilicet grande cavaleiro e valente que ajudou muito os Portugueses na tomada deste Rio. Desembarcando, viemos em procissão até à Misericórdia com a relíquia debaixo do pálio; as varas levaram os da Câmara, cidadãos principais, antigos e conquistadores daquela terra.

Estava um teatro à porta da Misericórdia, com uma tolda de uma vela, e a santa relíquia se pôs sobre um rico altar, enquanto se representou um devoto diálogo do martírio do santo, com coro e várias figuras muito ricamente vestidas; e foi asseteado um moço atado a um pau; causou este espetáculo muitas lágrimas de devoção e alegria a toda a cidade, por representar muito ao vivo o martírio do santo, nem faltou mulher que viesse à festa. Era para ver uma dança de meninos índios, o mais velho seria de oito anos, todos nuzinhos, pintados de certas cores aprazíveis, com seus cascavéis nos pés e braços, pernas, cinta e cabeças com várias invenções de diademas de penas, colares e braceletes; parece-me que se os viram nesse reino, que andaram todo o dia atrás deles. Foi a mais aprazível dança, que destes meninos cá vi. Chegados à Igreja foi a santa relíquia colocada no sacrário, para consolação dos moradores que assim o pediram.”

É tudo tão pitoresco quanto a descrição que Paul Marcoy nos dá da procissão do Senhor dos Tremores de Terras em Cuzco. Estas práticas correspondem a um passado não muito longínquo, mas hoje ainda encontradas por todo o Brasil, em que as autoridades que sustentam o pálio são as mais das vezes maçons-espíritas-católicos e a mulatinha que faz a Verônica é filha da negra-mina que tem um xangô perto da Igreja.

Falar verdade, isto não é catolicismo, mas é um terreno preparado para o catolicismo nascer. O Brasil espera um São Paulo que mande epístolas aos coríntios que os Anchietas prepararam. Mas, se isto não é religião, não deixa de ser um caráter. Isto caracteriza a nossa gente. Imprime um caráter até gostoso, meio ingênuo e meio descarado.

Caracteriza mais do que a pornografia que o Mário de Andrade acha tão nossa.

Mas basta abrir um livro genuinamente francês como La vie très horrifique du grand Gargantua para a gente se convencer que o subconsciente de qualquer povo é um fedorento fundo de quintal: 
“I’ay (respondit Gargantua) par longue \& curieuse ${ }^{105}$ experience inuenté un moyen de me torcher le cul, le plus seigneurial, le plus excellent, le plus expedient que jamais ${ }^{106}$ feut $\mathrm{vu}^{107}$."

Eu não posso continuar a citação mesmo neste francês tão velho quanto o Brasil. A invenção de Gargantua é todo o capítulo XIII do $1^{\underline{0}}$ volume das Obras de Rabelais, e dá conta muito minuciosamente da maneira curiosa de se provocar "la volupté mirificque laquelle facilement est communicquée au boyau culier \& aultres intestines, iusques à la region du coeur \& du cerveau.”

O subconsciente de qualquer raça é este gâtisme do paulificante Courbon. Este subconsciente sujo em todo o mundo brota no doido, brota no delírio comum a muitas doenças, aparece todas as vezes que nós damos a palavra a ele. Tenha a palavra o senhor subconsciente do francês, do inglês, do checo-eslovaco, do brasileiro.

E se preparem os ouvidos para receber uma porção de coisas bonitas e um despotismo de sujidades.

Berkeley Hill (Anal-Erotic in the Religion, Philosophy and Character, 1827), Ferenczi (Z. f. Psychoanalysis) e muitos outros e acima deles o buzinadíssimo doutor Freud procuraram explicar com muito exagero e com muita chicana mas com alguma verdade, como fica, como se transforma, como aparece e reaparece o complexo anal-erótico, no menino da primeira infância, no adulto alienado ou não. Isto é um assunto até interessante, tratado com habilidade pelo pesquisador judeu da psicanálise, mas estragado por alguns médicos que[,] por meio de circunlóquios, de metáforas, de literatura ruim, quiseram fazer autodidatismo tão comum nos nossos médicos escrevedores. Nem um assunto tão antiestético, tão antiliterário como este do "Complexo anorretal ${ }^{108 ،}$ escapou à sanha de certos estupradores da literatura brasileira.

Como então encontrar a nossa expressão?

Será descendo ao nosso subconsciente ou pesando as possibilidades ou medindo os degraus da nossa consciência, das forças voluntariosas do nosso caráter?

Nós nos caracterizamos pois pela falta de caráter, como um delinqüente na polícia teria a sua caderneta de identificação mais facilmente reconhecível se além de sua impressão digital tivesse o retrato com a ausência de um olho ou de uma orelha.

\footnotetext{
105 No livro, lê-se "curiense”.

${ }^{106}$ No livro, lê-se "iamais”.

${ }^{107}$ No livro, lê-se “veu”.

${ }^{108}$ No livro, lê-se "ano-rectal”.
} 
Todo dia me convenço que o brasileiro nasceu empelicado: Nosso senhor gosta da gente, “Jesus nasceu na Bahia”. Ora veja como um povo amassado de três barros ruins ainda não se esmigalhou. Uma gente formada de antropófagos bantos, de criminosos lusos, sem pena de morte, sem casas correcionais, sem esterilização, sem júri, não consegue um recordezinho de criminalidade homicida. Os únicos casos cinematografáveis é o pessoal estrangeiro que faz. Um povo provindo de raças choramingas ainda não deu para berrar no meio do mundo. Uma gente em que a negra era prostituída sistematicamente pelos senhores, em que o índio segundo o testemunho de Gabriel Soares (entre muitos) era incestuoso, pederasta, sodomita "tão luxurioso que não há pecado de luxúria que não cometa”; em que os costumes do portuga conforme asseverava o Padre Simão de Vasconcelos "vinham a ser quase como os dos índios”, em que a gente melhorzinha que era mesmo o bandeirante paulista, dele escrevia Montoya - “las mujeres de buen parecer, casadas, solteras o gentiles, el dueño las encerraba consigo en un aposento, con quien pasaba las noches al modo que un cabrón en un corral ${ }^{109}$ de cabras”; essa gente tem menos pervertidos sexuais que muito povo bom. A Alemanha, por exemplo. Este povo ainda tem virgens, este povo ainda tem famílias. Um povo de cujas mulheres o gabola do Pyrard disse coisas sujas, e Dellon escrevia:

“Je ne scay si le libertinage est aussi grand par tout le Brésil, qu’il l’est dans la ville de San Salvador. Les femmes les plus qualifiées, et celles qui passent pour avoir quelques vertus, n'y font point de scrupule de parer leurs esclaves avec beaucoup de soin, afin de les mettre en état de vendre plus cher les infames plaisirs qu'elles donnent, elles partagent ensuite le malheureux profit de la débauche de ces prostituées: en sorte que l'on peut dire avec justice, que la pudeur est presque entièrement bannie de cette ville, et que le vice $\mathrm{y}$ règne souverainement.” (Cit. por Southey.)

Pois este povo cede o negócio como se cede uma concessão de estrada de ferro, ao balcânico, ao polaco ou ao russo, um negócio para que tínhamos vocação colonial. Esta tradição, felizmente nem o modernismo nem a antropofagia, nem o neo-indianismo realista quis nos seus manifestos. Nem cafetinas ${ }^{110}$. Nem tupinambás pederastas. Donde se conclui que o modernismo escapou também duma outra espécie de exagero. Eu não tenho procuração de meu amigo Graça Aranha para defender o menino e as raças tristes. Esse modernismo gorou como tudo tem gorado no Brasil, isso é até um caráter do nosso ovo. Não é erro do tipógrafo, não; quero dizer ovo mesmo. Parece que nem tudo está goro. Esse Macunaíma, por exemplo,

\footnotetext{
${ }^{109}$ No livro, lê-se “curral”.

${ }^{110}$ No livro, lê-se "caftinas".
} 
é um ovo que deu asas. Mas eu ainda quero dizer que esta racinha está resistindo a quatro séculos de vermes, sezões, cachaça e doenças-do-mundo. E se Rockefeller não se mete no negócio, não é que nós íamos resolvendo o problema da verminose e da sífilis, sem guerra aos micróbios como fizemos a Abolição e a República sem guerra aos senhores e aos reis?

Falam agora com mais insistência do que nunca em antropofagia. Em antropofagia de índio. É preciso ver quem é o antropófago. Dentro do índio estarão o português e o preto? Ou os dois primeiros estarão dentro do último? Ou terá sido o português quem comeu os dois antropófagos? Parece que as raças se entredevoraram. Que se estão entredevorando ainda. Criando problemas, finalidades, destinos impossíveis de ser compreendidos hoje.

Nós não sabemos aonde vamos bater.

Resolvemos os nossos problemas mais sérios não os resolvendo. O problema chega e espera que nós, como os outros povos, avancemos nele.

Não está vendo que ninguém sai da rede para resolver problemas? Nós o[s] resolvemos dentro da rede mesmo. Dormindo com ele[s] ou dormindo nele[s]. O problema do negro foi assim: resolvido sexualmente. O americano do Norte vai resolvê-lo de outro modo. Vamos ver se resolve!

Mas, desde um poder de tempo que eu quero falar no Mário. Mas vou é falando de outras coisas sem querer, arrastado na corrente da concatenação das coisas.

Mas era um dia um moço chamado Mário. Que foi passar umas férias em Araraquara. Chegou lá pegou tinta para brincar.

Foi botando uns pinguinhos dela entre duas folhas de papel e espremendo para ver o que dava. A gente faz isso e outros brinquedos de tinta, quando a gente tem força de descer à criança. Quando se acaba, vai-se ver com que se parece. Às vezes o borrão chega a se parecer com gente.

A tinta vermelha do tinteiro do subconsciente do Mário deu um borrão parecido com o Brasil: Macunaíma. Deu uma coisa pelo menos desintencionalmente brasileira, sem a cor verde propositada de certo nacionalismo literário. Ele realizou uma feição da terra e do povo, sem querer. O que é uma felicidade.

Tristão de Ataíde disse dele: “Não se pense, porém, que o livro é simplesmente uma romanceação de lendas amazônicas. É coisa infinitamente mais complexa, como aliás tudo o que tem feito o sr. Mário de Andrade, na sua busca ansiosa e capital em nossa literatura, por uma expressão nacional[, por um herói nacional] ${ }^{111}$, por uma cultura nacional.” Mário diz de

\footnotetext{
${ }^{111}$ Expressão omitida no livro de J. de Lima.
} 
si próprio: "Só não quero é que tomem Macunaíma e outros personagens como símbolos. É certo que não tive intenção de sintetizar o brasileiro em Macunaíma, nem o estrangeiro no gigante Piaimã... Me repugnaria bem que se enxergasse em Macunaíma a intenção minha dele ser o herói nacional. É o herói desta brincadeira, isso sim.”

É isso mesmo, Mário. A brincadeira é o Brasil: o herói da brincadeira só pode ser o brasileiro. É verdade que nem o livro sintetiza o Brasil nem o herói sintetiza o brasileiro. E é verdade também que quanto mais a pessoa tiver ânsia de um herói e de uma expressão nacional, menos os consegue. Quando Mário deixou falar o seu subconsciente[,] que é uma parte do subconsciente coletivo do país, conseguiu um bocado enorme da nossa expressão. Escreveu um livro grosso em seis dias. Um raide do subconsciente nacional.

O herói deixa de ser portanto o Macunaíma para ser o próprio Mário. Outros em todos os tempos têm tentado a viagem, desde Basílio e Durão até hoje.

Mas esse pessoal não tinha os motores e as asas de Mário e os raides dependem mais de força do que de vontade.

Aquela gente usava o carro de boi, que, se não encrenca nunca, também não atinge. $\mathrm{O}$ raide de seis dias foi bom, a fotografia tirada do alto deixa a gente ver um pedação da nossa alma e da nossa terra: “o desapreço à cultura verdadeira, o improviso, a falta de senso étnico nas famílias e sobretudo uma existência de expedientes, enquanto a ilusão imaginosa, feito Colombo de figura de proa, busca com olhos eloqüentes na terra um eldorado que não pode existir mesmo, entre panos de chãos e climas igualmente bons e ruins, dificuldades macotas que só a fraqueza de aceitar a realidade poderia atravessar.” É uma visão de aeroplano que esses panos de chão, de terras igualmente boas e ruins nos dão da nossa realidade. Enquanto outros andarilhos da nossa literatura se perderam na maloca do índio ou na senzala do negro e foram comidos ou desapareceram com eles, Mário viu tudo, chegou são e salvo e mandou o seu subconsciente contar uma história que tem a expressão e o encanto das histórias de mãepreta e o pitoresco das coisas que um Caminha contasse em carta às icamiabas da terra. Porque aquela carta em "estilo médico-purista” como lhe chama Tristão é a única paulificância do livro.

O resto é a mais bonita das histórias:

Era uma feita Mário de Andrade da tribo Tapanhumas que fica na margem direita do Uraricoera. Vai[,] escutou um dia a fala do aruaí que lhe contou uma história esquecida dos homens. A ave tinha "uma fala muito mansa, muito nova, muito! que era canto e que era cachiri com mel-de-pau, que era boa e possuía a traição das frutas desconhecidas do mato”. Má- 
rio Macunaíma ouviu aquilo do papagaio e foi contando pra gente uma história bonita que alemão não tem jeito de contar pra o mundo.

“No fundo do mato-virgem nasceu Macunaíma herói da nossa gente. Era preto retinto e filho do medo da noite. Houve um momento em que o silêncio foi tão grande escutando o murmurejo do Uraricoera que a índia tapanhumas pariu uma criança feia. Essa criança é que chamaram de Macunaíma.”112

Do mesmo modo que a nossa tradição literária é portuguesa ou francesa, a nossa linguagem escrita é verdadeiramente lusa. Foi esse modernismo nosso que tentou com certo resultado botar na escrita alguma coisa da fala brasileira, do nosso caráter de dizer. Este caráter é a língua de Macunaíma - o herói sem caráter. Foi ele mesmo que, enquanto esperava a muiraquitã perdida, “aproveitava a espera se aperfeiçoando ${ }^{113}$ nas duas línguas da terra, o brasileiro falado e o português escrito”. A expressão de Mário, não há dúvida que é uma certa vitória do brasileiro falado sobre o português escrito. E esta é uma vitória comum ao gorado modernismo. Que houve afetação literária em Alencar apesar de toda a sua vocação revolucionária, não há dúvida que houve. Ora, a coisa mais dolorosa que há é a derrocada de uma tradição, mesmo quando a tradição é falsa e não nos pertence, como esta da nossa linguagem literária escrita. E não há dúvida que Mário de Andrade ou António de Alcântara Machado ou João Alphonsus e outros escrevem um bocado bom de brasileiro falado. Macunaíma não é apenas fabulação de mito solar, aproveitamento simbólico deste mito para explicar o nosso falso brilho, "bonito mas inútil”,[, é muito mais do que isso, mas muito! A expressão genuína corre igualzinha com o genuíno das nossas realidades, com o característico das nossas faltas, do nosso eu enfim. Mário teima em provar a nossa ausência de caráter.

Mas o próprio herói tem olhos às vezes para ver as possibilidades, as exceções que vão sedimentando em caráter. Quando ele se viu só no mundo, sem Jiguê que ele transformara na sombra leprosa, sem Iriqui, sem Maanape ${ }^{114}$, sem Capei, nem $\mathrm{Ci}$, nem ninguém, sem muiraquitã, sem gente para brincar, mentir e fazer estrepolias, ele pensou (antes de ir para o Céu virar na Ursa Maior), “pensou na ilha de Marajó. Um momento pensou mesmo em morar na

\footnotetext{
${ }^{112}$ Nota de J. de L.: Isso do nome de Macunaíma não ser brasileiro é bem nacional. Aqui o sujeito não é menos caboclo por chamar-se Rondon nem menos brasileiro se chamando Varnhagen, nem é mais brasileiro o Febrônio Índio do Brasil - um marquês de Sade mulato tatuando meninos e fazendo coisas de estrangeiro.

Por questão de nome o Assis Brasil tomaria o lugar do Washington, o Roquete se demitiria do Museu e o Coelho não seria grego nunca. Tradição! Desde o começo, as paraguaçus se chamam catarinas e os pretos henriquedias.

${ }^{113}$ Em Dois ensaios, 1929 (p. 130), lê-se “(...) perfeiçoando (...)”. Recuperamos a citação segundo a $1^{\text {a }}$ edição de Macunaíma (p. 137).

${ }^{114}$ Idem (p. 131), lê-se "Manaape".
} 
cidade da Pedra com o enérgico Delmiro Gouveia, porém lhe faltou ânimo. Pra ${ }^{115}$ viver lá, assim como tinha vivido era impossível. Até era por causa disso mesmo que não achava mais graça na Terra... Tudo o que fora a existência dele apesar de tantos casos tanta brincadeira tanta ilusão tanto sofrimento tanto heroísmo, afinal não fora senão um se deixar viver; e pra parar na cidade do Delmiro ou na ilha de Marajó que são desta Terra carecia de ter um sentido. E ele não tinha coragem pra uma organização. Decidiu:

“- Qual o quê!... Quando urubu está de caipora o de baixo caga no de cima, este mundo não tem jeito mais e vou pro céu.”

Aí fica uma tristeza que é uma verdade. Os Delmiros desta Terra são raros e os próprios irmãos os matam. Então o estrangeiro vai tomando o lugar dos Delmiros. O único camarada que no conto do Mário não se transforma em estrela é o estrangeiro, é Venceslau Pietro Pietra.

Assim, nós vivemos no mundo da lua, enquanto o estrangeiro se adapta a mais e mais no mundo da nossa Terra.

Que estrangeiro mais bêsta já houve que o negro?

Veio na corda, viveu no tronco, morreu na enxada; pior que as bestas de carga.

Este estrangeiro pior que as bestas de carga é o maior problema dos Estados Unidos.

E parece que os Piaimãs do Ocidente não são assim aquelas bestas de carga.

Nesta minha fala não tem nenhum jacobismo nem resquício algum de má vontade ao estrangeiro - dessa má vontade nortista jacobiníssima que parece vir ainda dos tempos das tremendas lutas coloniais com o estrangeiro, com o holandês, o francês, o espanhol e o português. Não tem não.

Alguém já advertiu que esse brasileirismo de quero porque quero iria degenerar num jacobinismo inútil, numa bazófia fofa, numa preocupação infantil de marca registrada nacional.

Mas é preciso observar também que a preocupação do universal, o cuidado de posar para o resto do mundo é uma preocupação mais fofa ainda. Cosmopolitismo é indefinição.

E nós precisamos antes de tudo de ser.

Só assim interessaríamos aos outros.

Poesia a Whitman, a Cocteau, teatro a Pirandello, política fascista, tudo isso é universal, tem a força do universal, mas indefine o brasileiro. Pirandello é universal, mas é também siciliano da gema. Mistral escreveu em dialeto.

\footnotetext{
${ }^{115}$ Em Dois ensaios, 1929, lê-se “Para”; em Macunaíma (1ª edição, p. 277), “Pra”.
} 
O perigo da indefinição deveria amedrontar-nos tanto quanto amedronta o alemão de hoje quase afogado pelo judeu.

As melhores forças da Alemanha clamam pelo seu nacionalismo, pela sua expressão. Para lembrar uma obra entre muitas bastaria o grande livro de Adolf Bartels - História da literatura alemã:

"Denn nur das Beste und das Besonderste eines jeden Volkes, das, was aus seinem tiefsten Wesen kommt, ist Weltliteratur und kann allen etwas sein, nicht das, was allen gemeinschaftlich ist.” Isto está na página 680. E em todo o livro há coisas iguais e tão oportunas que parecem escritas para a gente. ${ }^{116}$

A tendência de uma literatura nova que sucedesse à atual, como se tem observado no ritmo de tantas outras poderia por acaso ser a volta ao nosso classicismo, se considerarmos nossos clássicos as produções portuguesas escritas por brasileiros, a partir da Prosopopéia até os primeiros românticos. Seria um ressuscitamento do retórico, do gongórico espanhol, do seiscentismo português.

Volta ao classicismo, o modernismo atual efetuou num outro sentido: voltou a um Brasil mais ou menos real que até aos últimos românticos não existiu. Voltou em muitos modernos, (excetuando o grupo antropofágico), ao catolicismo, com as predominantes das 3 raças. Não poderá voltar nunca ao retórico ruim ou ao gongorismo hugoano e científico, porque aquela escrófula romântica como a chama Proudhon é mesmo do tamanho de uma besteira. No seio deste modernismo já se opera uma reação anti-ANTI-SINTAXE, anti-

\footnotetext{
${ }^{116}$ Nota de J. de L.: "Mit einem Wort: alle Kunst ist und bleibt national, ist um so stärker, je nationaler sie ist.

"Nein, du deutsches Volk, lasse dich nicht durch die grossen Worte der 'Modernen' beirren, bleibe deinem germanischen Volkstum treu, reinige es, vertiefe es, halte es heilig! Wir wollen sein, wie wir sind, oder wir wollen nicht sein wollen uns unser Deustchtum nicht durch 'Europäertum' verflachen und versimpeln, nicht durch das Iudentum, das jetzt der reale Feind ist, verfälschen und verderben lassen.” Pág. 682 - (Geschichte der deutschen Literatur, von Adolf Bartels. Verlag von George Westermann).

Alemães, franceses, brasileiros pensam do mesmo modo: "O romance todo de José Américo de Almeida nos dá vontade de riscar página por página. Não há um canto no meu volume por onde não tivesse andado a ponta do meu lápis guloso. Andaram a propósito dele a esconder o seu caráter de livro regional. No entanto, não vejo no Brasil livro mais de sua Terra que o seu.

Ele é todo do seu país. Agora é preciso tomar o regionalismo como o entendeu o arguto pensador nordestino Sr. Gilberto Freyre. Ser regional, sendo universal. Foi no seu ensaio sobre a pintura no Nordeste que ele pôs às claras esse seu ponto de vista. Chama-se aí a atenção dos artistas brasileiros para o intenso da nossa vida e da nossa paisagem.

E com Maritain a gente chega a ver que 'les oeuvres les plus universeles et les plus humaines sont celles qui portent plus franchement la marque de leur patrie.”

Nenhum mais marcado pelo sofrimento e pelo pitoresco de sua terra que esse livro de José Américo de Almeida, e nenhum mais cheio de tão fundo interesse humano. Caso idêntico ao de Thomas Hardy: "Suas obras não parecem somente trazer o selo inglês, porém mais claro ainda, estampado sobre o selo o carimbo de Essex, com a data". Entretanto, esse Thomas Hardy, cuja obra é quase toda enraizada no canto onde ele nasceu, é "o autor da obra de ficção mais universalmente humana que a Inglaterra produziu neste último século”. (Trecho de um ensaio sobre José Américo de Almeida, por José Lins do Rego.)
} 
ANTIGRAMATICAL em oposição ao desleixo que surgiu em alguns escritos, no começo. Nós não temos um passado literário comprido (como têm os italianos, para citar só um povo), que nos endosse qualquer mudança no presente, pela volta a ele, renascimento dele, pela volta de sua expressão estilística ou substancial. A nossa tradição estilística, de galho deu na terra boa em que se plantando dá tudo, apenas garranchos.

Nós não temos transformações sociais ou políticas marcantes, revolucionárias, populares, grandes que provoquem como na Itália (para conservar o exemplo) que desde 1870 vem dando paralelamente a cada transformação social ou política, nacionalistas, imperialistas, regionalistas, moralistas, imoralistas e amoralistas, veristas, individualistas, socialistas, espiritualistas, intuitivistas, futuristas, relativistas e os neoclassicistas de hoje.

Parece que estamos num ponto em que o caminho é ir para a frente sem ter vergonha do bocadinho de nada que (faz de conta) já construímos.

Para voltar, nós voltaríamos a todas aquelas coisas grandíloquas, empoladas, gongóricas, condoreiras, tão longes da terra, no tempo em que os homens cantavam as estrelas da pátria, os sabiás das palmeiras, a ufania do Brasil.

“Quem canta, os seus males espanta.” Mas a gente não deve espantar os males, cantando, para esquecê-los. Mesmo há males que por mais que a gente cante nunca os espanta, nunca chega a abafar os gritos desses males.

Por que em vez de cantar não falamos?

Não dizemos? A gente devia conservar em tudo o mesmo tom da linguagem falada. Mas parece que, quando pegamos o lápis para escrever, é como se fôssemos escrever em pauta musical, o que dá ao escritor brasileiro um jeitão afetado de cantor de melodrama.

Complicamos a voz, atravessamos a fala quando escrevemos. E para agüentar a atenção e o gosto desse público de recital, temos que mostrar mesmo uma literatura de cenários e de carpintaria de acordo com o esganiçamento e a complicação do autor não, do ator.

E o tom dessa literatura devia ser o tom natural de quem diz.

De quem diz tudo, com essa sinceridade, com essa simplicidade, com essa espontaneidade que só do subconsciente mesmo.

Dizer para a consciência ouvir.

E livrar do perigo das saúvas esta consciência nacional.

O estribilho de Macunaíma era: "Pouca saúde e muita saúva os males do Brasil são.” Quando o herói quis descer para São Paulo, deu uma chegadinha até a boca do rio Negro, foi 
na Ilha de Marapatá, vigiou um mandacaru bem grande e pendurou na ponta a consciência para as saúvas não comerem. Quando voltou, deu outra chegadinha no mandacaru da Ilha de Marapatá.

\section{Cadê consciência?}

“Jacaré achou? nem ele. Então o herói pegou na consciência dum hispanoamericano ${ }^{117}$ botou na cabeça e se deu bem da mesma forma. ${ }^{118 ،}$

Não há dúvida que há saúva debaixo dos nossos alicerces.

Contra os formigueiros se tem ensaiado muita formicida em vão. Ou o brasileiro deserta para o céu e vira estrela ou fica na terra e tem que virar tatu.

Veja que a gente sem querer vai inventando símbolos. Símbolo-estrela. Símbolo-tatu. Como símbolo-maracajá. Como símbolo-anta. Como símbolo Brasil. Quando se pensa que se está forro é quando se está cativo de verdade.

Entretanto do mesmo jeito que o Alencar foi um abolicionista literário do índio e o Castro, do negro, o modernista tentou a sua alforria.

Mas, questão de força, bem poucos tiveram muque para rebentar os ferros.

Porque soltar os pés do tronco para meter a cabeça na canga é ficar mais preso ainda. Preso pela cabeça. Agora, cortar a cabeça para se libertar da canga ou para provar que isso de literatura não vale nada é até bancar o suicida - o das declarações que a gente, todo dia, lê nos jornais.

JORGE DE LIMA

\footnotetext{
${ }^{117}$ Em Macunaíma (1ª edição, p. 249), lê-se “hispanoamericano”, sem hífen.

${ }^{118}$ Em Dois ensaios, 1929, lê-se “(...) e se deu da mesma forma”. Falha de transcrição.
} 
1930 
[Correio do Povo. Porto Alegre, 01/07/1930, a. 36, nº 153, p. 3. Arquivo DZM]

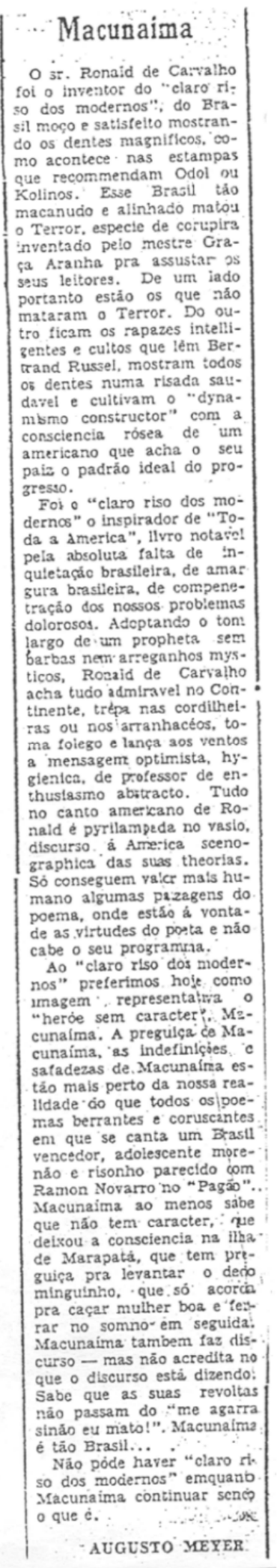




\section{Macunaíma}

Meyer, Augusto. "Macunaíma”. Correio de Povo: Porto Alegre, a. 36, $\mathrm{n}^{0}$ 153, p. 3.01 de julho de 1930. Arquivo DZM.

O sr. Ronald de Carvalho foi o inventor do "claro riso dos modernos”, do Brasil moço e satisfeito mostrando os dentes magníficos, como acontece nas estampas que recomendam Odol ou Kolinos. Esse Brasil tão macanudo e alinhado matou o Terror, espécie de curupira ${ }^{119}$ inventado pelo mestre Graça Aranha pra assustar os seus leitores. De um lado portanto estão os que não mataram o Terror. Do outro ficam os rapazes inteligentes e cultos que lêem Bertrand Russel, mostram todos os dentes numa risada saudável e cultivam o "dinamismo construtor” com a consciência rósea de um americano que acha o seu país o padrão ideal do progresso.

Foi o “claro riso dos modernos” o inspirador de Toda a América, livro notável pela absoluta falta de inquietação brasileira, de amargura brasileira, de compenetração dos nossos problemas dolorosos. Adotando o tom largo de um profeta sem barbas nem arreganhos místicos, Ronald de Carvalho acha tudo admirável no Continente, trepa nas cordilheiras ou nos arranha-céus, toma fôlego e lança aos ventos a mensagem otimista, higiênica, de professor de entusiasmo abstrato. Tudo no canto americano de Ronald é pirilâmpeda ${ }^{120}$ no vazio, discurso à América cenográfica das suas teorias. Só conseguem valor mais humano algumas passagens do poema, onde estão à vontade as virtudes do poeta e não cabe o seu programa.

Ao "claro riso dos modernos" preferimos hoje como imagem representativa o "herói sem caráter”, Macunaíma. A preguiça de Macunaíma, as indefinições e safadezas de Macunaíma estão mais perto da nossa realidade do que todos os poemas berrantes e coruscantes em que se canta um Brasil vencedor, adolescente morenão e risonho parecido com Ramon Novarro no "Pagão"121. Macunaíma ao menos sabe que não tem caráter, que deixou a consciência na ilha de Marapatá, que tem preguiça pra levantar o dedo minguinho, que só acorda pra caçar mulher boa e ferrar no sono em seguida. Macunaíma também faz discurso - mas não acredi-

\footnotetext{
${ }^{119}$ No jornal, lê-se “corupira”.

${ }^{120}$ No jornal, lê-se "pyrilampeda”.

${ }^{121}$ Ramon Novarro (1899-1968), cantor e ator mexicano de grande sucesso em Hollywood nas décadas de 1920 e de 1930. Estrelou vários filmes mudos e, já na fase sonora, musicais da MGM, entre os quais conta-se o filme “The Pagan”, 1929.
} 
ta no que o discurso está dizendo. Sabe que as suas revoltas não passam do "me agarra senão eu mato!”. Macunaíma é tão Brasil...

Não pode haver “claro riso dos modernos” enquanto Macunaíma continuar sendo o que é.

AUGUSTO MEYER 
1931 


\section{MACUnAímA, DE MÁRIo de ANDRADE}

CARVAlHO, Ronald de. "Cadernos de imagens / 4 / Macunaíma, de Mário de Andrade”. In: Estudos Brasileiros. $1^{\underline{a}}$ ed. Rio de Janeiro: F. Briguiet, 1931, p. 151-152. Transcrito de "Livros / Macunaíma - o herói sem nenhum caráter - de Mário de Andrade”. Movimento: Rio de Janeiro, 01 de outubro de 1928, p. 21. Reeditado em:

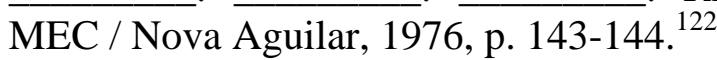

$$
\text { Rio de Janeiro: }
$$

${ }^{122}$ A edição em livro, de 1931, apresenta algumas mudanças de pontuação e divisão de parágrafos, bem como algumas supressões ou acréscimos já assinalados: p. 34-35 deste volume. 


\section{BRASILIDADE E DINAMISMO A PROPÓSITO DO “MACUNAÍMA” DE MÁRIO DE ANDRADE}

FERREIRA, Ascenso. "Brasilidade e dinamismo: a propósito do 'Macunaíma' de Mário de Andrade”. Diário Nacional, São Paulo, 23 de novembro de 1931. Transcrito do Diário Nacional, edição de 28 de novembro de 1928. ${ }^{123}$.

${ }^{123}$ A existência deste documento, não localizado pela pesquisa, é assinalada por Telê Porto Ancona Lopez na seção "Bibliografia sobre Macunaíma". In: ANDRADE, Mário de. Macunaíma. Edição crítica de Telê Porto Ancona Lopez. Op. cit., 1978. Ver o texto desse ensaio de Ascenso Ferreira, versão publicada em 1928: p. 48-55 deste volume. 
1934 
[Cascudo, Luís da Câmara. "Mário de Andrade".

Boletim de Ariel: Rio de Janeiro, a. 3, n 9 , jun. 1934, p. 233-235.

IEB - MA-MP] BOLETIM DE ARIEL

\section{$M A R I O D E$}

O primeiro livro de Mario, Ha uma gotta de sangue em cada poema, é de 1917 e constitue rari dade bibliographica. Livro dos 24 annos. Poesia romantica sobre a guerra de 14. A guerra não, mas o resultado espiritual da guerra. Era o que elle me dizia ser o comecinho pobre. E nem assignou. Deu um Mario Sobral em vez do nome.

Paulicéa Desvairada é de 1922, escripto de de zenıro a dezembro de 1920-21. Nós estamos lon ge. Ninguem se lembra mais da Semana de Arte Moderna, da Klaxon, do furor litterario paulista. da repercussão. Tambem não se disse que Paulicéa foi verdadeiramente o indice de todas as actividades e o prefacio virou dogma systematizador do movimento. Até o comparavam ao de Cromwell. Havia muita ingenuidade naquelle desvai rismo mas o autor mergulhou, brusco, numa livra rada cotejadora. Paulicéa Desvairada tivéra o condão inicial de desarticular a armadura poetica $e$ andava identificando peça a peça, mostrando procedencia e preco pela tarifa alfandegaria. Aquil lo (fue reinava em Rio-S. Paulo era soldo-de-anno dos armazens francezes. Paulicéa foi uma reacção de bom-senso sem pensar que o possuisse.

A escrava que não é Isaura appareceu em 1925 e é a Paulicéa Desvairada sem a funccão poetica. F.' o prefacio virado discurso sobre algumas tendencias da poesia modernista. Apezar de publicado em 25 o ensaio é do anno anterior. Sahiu logo em janeiro de 25, inaugurando a era-de-ver para os modernistas. A Escrava era a Poesia c Mario alinhava a classificação de suas algemas e formulas de libertação. Era a substituição da ordem intellectual pela ordem subconsciente, o pampsychismo poetico, a preconização da rapidez, du synthese, a idéa kodac, o real-expressivo antes do ideal-bonito. Para muitos o Escrava era uma inversão demoniaca de todos os venerandos valo. res poeticos desde Horacio até Bilac. Mario resistiu, sozinho, ao embate porque a Escrava, muito gabada, foi pouco entendida. Recordo-me da surpresa dos argentinos quando thes mandei o livro. Não havia em parte alguma do Mundo trabalho semelhante. Era a mais completa de todas as analy ses da poesia modernista. As tendencias, as influencias, as opiniões, a dispersão reaccionaria do movimento que, atacando as escolas, ia fundand, uma, tiveram uma palavra de justa e segura com prehenção critica e divulgadora. Havia, natural mente, deformacão inconsciente porque Mario re flectia leituras estrangeiras e accommodava-as a si-mesmo. Obrigava pernas e braços a tomarem a extensâo de sua mentalidade. O ensaio, até hojc. senhores doutores, não encontrou parecença com outro.

Foi em 1926, na Manhâ, do Rio, a 12 de Janeiro, que Mario enderecou a desnorteadora Carta aberta a Graça Aranha, explicando a discordancia entre

\section{ANDTRDE}

os dois e fixando a imposicão de personalidade pre tendida pelo primeiro. Foi outro tempo-quente. Graça Aranha, seductor e envolvente, estava convencido, possivelmente sem sentir a propria con vicção mas enrolado nella, que tinha um papel orientador de suprema importancia especialmente para os paulistas, prolatores do modernismo.

Em fevereiro de 1925 sacode o Losango Cáqui, poeminhas batidos quatro annos antes e ageitados posteriormente. Vem o Alto, a Toada da esquina. a Parada, photos do voluntariado militar. E' o ca bo Machado bandeira-do-Brasil. Neste momento Mario conseguiu um puzzle que o orgulhou varios mezes. E' o Flamingo, associação de idéas por constellacão. A critica não deu pela brida. Nem olhou o Flamingo.

1926 ainda deu Primeiro andar, contos daqui - dalém. Era no fim do anno e Mario estudava o allemão, lia Freud e trabalhava num romance de exame e cirurgia a viennense. Primeiro andar. reune contos de orientacões dispares e oppostas. Mario andou sempre em cima ou abaixo do nivel. Nunca direitinho nelle. Basta ler Conto do Natal, Gallo que não cantou e a Historia sem data, que elle disse ter sido plagiado do Avatar de Theophilo Gautier mas, avisado depois do crime, achava o plagio melhor que o original e deixava.

Amar, verbo intransitivo é de 1927 . Mario escrevel-o de 23 a 24 . O romance massico e compacto assustou muita gente. Foi o mais ignorado dos livros. Um critico e dos maiores, disse que aquillo era o elogio de Freud quando parece justamente o inverso. Applicou-se o methodo para a educacão sexual, sommando os resultados e contra. producencias que não compensavam a fama. Deste Amar, verbo intransitivo, ha uma adantação para o americano com o titulo de Fraulein, por Margaret Richardson Hollingsworth.

No morrer de 27, Mario publicou Clan do Jabuti. Roquette Pinto dera-lhe o gosto pela indiaria e o poeta da Paulicéa, o romancista allemão do Amar, voltou a ler ethnologos, especialmente o claro Koch Grumberg, no Vom Roruima zum Orinoco e Unter den Naturvolkern Zentral-Brasiliens, e mesmo os anteriores, von den Steinen, Ehrenreich, Schmidt, Krause. Kanike, posteriores, o padre Colbacchini, o conde de Stradelli. Das aparas de im vressão ia ficando muito material aproveitado. Clan do Jabuti é a explicacão de livros successivos e ante visão do folk-lore intellectual de Mario de Andrade. A toada do Pai do Mato é dos indios Parecis e em Roquette Pinto Mario encontrou, para sentir e popularizar, o Nozan ná (phonogramma 11. 14.597) assim como o episodio da india cama latô com o Pai do Matto que ella julga ser um ariti. Está a estoria do piá que foi para o céu levado por uma andorinha, thema recolhido por Koch Grunber@. Para não perder as reminiscencias modernistas (!) é que Mario juntou ao lado dos "dois poe- 


\section{[CASCUDO, Luís da Câmara. "Mário de Andrade". IEB - MA-MP] BOLETIM DE ARIEL}

mas acreanos", de todo o delicioso rythmo syncopado, o Carnaval Carioca, sem mais actuação litteraria e o Nocturno de Bello Horizonte, o melhor poema como construccão espiritual. Clan do Jabuti póde merecer a phrase de Waldo Franck, has reached a goal. A goal is an end. An end can be also a beginning.

Mario fizera o Norte, numa bandeira que dona Olivia Guedes Penteado dirigia com a magia de sua presenca senhorial. Andaram pelo Pará e Amazonas, subiram o rio Madeira até Iquitos. Mario remou no lago Ariri, comeu fructas asperas e doces, bebeu assahy, conversou no Ver-o-Peso voltou com uin chapeu de palha branco e alarmador. Falou quie publicaria um Manual de Viajante Aprendiz, nome lindo mas deu o Clan do Jabuti. An end can be also a beginning.

Macunaima é a somma de todos esses factorse E' de meiados de 1928 e foi um livro feliz. O Koch Grunberg não suspeitaria que o heroe sem nehum caracter nasceria do mais caracteristico dos entes tradicionaes. Tambem vivem milhares de recor dacões pessoaes, episodios, anecdotas, toponymia rara, o Bom-Jardim onde elle ouviu o bumba-men boi, conversas com o cantador Chico Antonio, feiticos, pastoris e lapinhas, tudo quanto registrou em dezembro de 1927 e janeiro de $1928 \mathrm{em}$ sua viagem a Natal-Parahyba-Recife.

Macunaima foi "explicado" de maneiras innumeras e nenhuma justificavel. Macunaima não tem a menor explicacão. E' um desabafo, uma variação de mil themas, o assumpto que nuclearia todas as opiniões, ironias e paradoxos. Mario teve o maior trabalho deste mundo em fazer a confusão geographica do Macunaima e costurar as estorias gaúchas com as acreanas, as paulistas de Soroca ba com as norte-rio-grandenses de Caicó. Bateu, misturou e serviu. O erudito ficou um horror de tempo procurando identificar os tacos de onde $\mathrm{Ma}$ rio erguera o livro explendido.

Do mesmo 1928 é o Ensaio sobre musica brasileira que não viveria sem a jornada ao Norte. A documentacão melodica, em sua proporção maior sahe do Norte e aqui Mario sambou os melhores sambas e gritou enthusiasmado nos melhores côcos. E' o primeiro ensaio sobre a Musica Brasileira feito por quem sabe musica e recolhe material por mão propria. A documentaria impressa é insi gnificante porque o Ensaio sobre musica brasileira è uma revelação de riqueza folk-lorica. Infinitamente menor que a phantasmagoria rutilante do futuro Na pancada do Ganzá.

o Compendio de historia da musica (1929) e sua segunda edicão (1933. Com discotheca) tem contra si apenas o vocabulario e a syntaxe brasileira do autor. Mesmo attenuada na segunda edicão, os graves professores franzem o bico com as irreverencias á sizuda grammatica de Eduardo Carlos Pereira. Pela primeira vez alguem escreve uma Historia absolutamente pessoal, estridente mente livre, com uma capacidade de analyse e um poder de synthese que o velho Lavignac desconhe- ceu irremediavelmente. Certos capitulos, classi cismo romantico, conceito do classicismo, o gregoriano, Brahms, Wagner, os leaders, a critica de Carlos Gomes, são magistraes de nitidez e sereni dade. Não ha rasto de influencia nem traço de eschema erudito. A Historia da musica é tão positivamente de Mario como o Clan do Jabuti. Elle só copiou os nomes proprios e as datas.

Modinhas Imperiaes (1930) pertencem ao cyclo do folk-lorismo brasileiro, numa decantação cui dada e pura que honraria um ambiente menos ra refeito que o nosso. O prefacio e as notas dis pensam uma bibliographia na especie.

Remate de males é do mesmo 1930. E' uma recordacão da viagem romantica ao Norte e o titulo já testifica a lembranca persistente da saudade onomastica. Serve para um diagramma de percurso. Ali estão as Dancas, de 1924 e os Poemas da Amiga, de 1930

Belazarte (1934), baptisado de contos, são trabalhos pensados para a America Brasileira, de Elysio de Carvalho, publicados como chronicas em jornaes e revistas. O mais novo é de 1929. Bela. zarte é um sonho teimoso que Mario poude realizar. A unidade mental não foi mantida nem seria possivel com a vida dispersa que o autor é obrigado a ter. Os trabalhos de demora, o ensaio da musica brasileira, a historia, Amar, Verbo Intransitivo o Macunaima, o breve Na pancada do ganzá, o mais completo livro de folk-lore musical que o Brasil terá, não podiam passar sem a litteratura lateral, espalhada nos periodicos e reunidas no Primeiro andar, Belazarte, ete.

Seu mais recente trabalho é Musica, doce muica 1934, colleccão de chronicas sobre assumptos musicaes, publicados no Diario Nacional, em São Paulo Lembrando os saudosos conceitos do passado registro o Musica. doce musica é indisnensavel na livraria de qualquer musico e de 'qualquer cue suspeite gostar de musica. A critica ao Gregoriano, a reacção contra Wagner, com a magnifica exposicão do caso Brahms, a influencia portugueza nas dancas de roda, talvez a mais forte das influencias (thema que Mario mandara para um estudo na exposição de Praga), merecem uma leitura mais segura, assim como as divulgacões da musica e vida do padre José Mauricio, Ernesto Nazareth. Tupinambá, a sonatina de Lourenco Fernandes, as cancões do pobre Gallet e o maravilhoso retrato de Germaninha. A "musica de pancadaria" é ultra-justa.

Mario de Andrade andou pelo Nordeste catanda themas melodicos de folk-lores. Passou vinte dias commigo e juntos fizemos, com Antonio Bento de Arauio Lima, Conde do Bom Jardim. uma sensacional viagem de retorno pelo Rio Grande do Norte e Parahyba, em plena secca, desde as salinas de Macau até os taboleiros cinzentos do Catolé do Rocha. Mario annotou tudo, cantigas de cegos, rythmos de marcha, paizagem, typos, versos, cantoria. Em Natal estudou os autos populares, ouviu o Boi e os Pastoris, chupou cajú ,assistiu a 
[CASCUDO, Luís da Câmara. "Mário de Andrade" IEB - MA-MP]

Cheganca e fechou o corpo, num catimbó do Alecrim, com mestre Germano que é protegido por Xa ramundi e as Tres Meninas da Saia Verde sob cuja egide Mario pôde atravessar todas as aguas correnles e paradas, frias e ardentes, arma de fogo não acerta, cachorro perde o faro, faca amolga e guarda-civil fica zarolho para não o enxergar. De tanto andar atraz de Bumba-meu-boi e zambez, pegou um appellido de Doutor do Boi, e, nas ruas, os homens do povo apontavam-no sorridentes: - "aquel. le é o doutor que veio de São Paulo estudá o Boi..." E era mesmo. Em Parahyba, e, antes do Bom Jardim, feudo de Antonio Bento, ouviu Chico Antonio cantar o Boi Tungão, as emboladas de ganzá, um desespero de novidade rythmica, um encanto de desenho melodico simples e de inesqueciveis effeitos. Levou para S. Paulo receitas de bolos e oracỗes fortes, alguns kilos de versos, uma colleccão de gaitas usadas nos Caboclinhos e creio que um zabumba dum maracatú pernambucano, desses de estourar ouvidos.

Todo este material infinito está sendo intelligentemente aproveitado. A intelligencia vae ao par do ciume com que elle communica o avanço da empreza. Na pancada do ganzá nós teremos uma surpresa para os estudiosos da Musica Brasileira. V'amos ver o contacto do brasileiro com os mais distantes povos. Uma phrase inteira da Marselhe $z a$ está nos Congos e a entrada do Boi é inteirinha uma musica slava.

No meio de tudo isto correm anecdotas que eu não quero contar. Esse homem dos sete instrumentos, apparentemente desorganizado, é o mais technico, cauto, disciplinado dos brasileiros. Amigo de dossier, de livro-de-nota, de apontamento em caderno proprio, com indice remissivo, catalogando o que lê para achar quando quizer.

Tsara diz que a ausencia do methodo é um methodo e muito mais sympathico. Mario tem o melhor dos methodos, o methodo da intelligencia e da sensibilidade.

Luiz da Camara Cascudo

Está sendo relida a tradução da Moll Flanders, de Daniel de Foe, devida á penna de Marcel Schwob. E livro que bastaria para dar uma grande reputação ao autor, se elle não houvesse escripto o Robinson, esse heroico manual de energia ingleza. E póde dizer-se que a notoriedade do Robinson suffocou injustamente a reputação deste admiravel romance de costumes, que, en tonalidade menos carregada, faz pensar nos melhores romances picarescos da velha Espanha Moll Flanders, soberbo retrato de corpo inteiro, reflecte toda umápoca soluen bo refrato aventurasa e turbulenta da baixa sociedade ingleza. Fo chra lue respira intenso realismo e vale por muitas synopses historicas de excavadores ertaditos. São vario decennios da existencia de uma mulher perdida, que casa cinco vezes e uma dellas com o irmão, na pratica de um incesto involuntario que os romancistas tanto explorariam mais tarde: Canaillo no Olho de Vidro, Eça de Queiroz nos Maias e até o nosso Heitor Marçal na Sinhá Dona. Faz-se depois gatuna, é deportada para a Virginia, finalmente enriquece e morre nas melhores relacões espirituaes com o Creador. Admiravel no livro, segundo Marcel Schwob, é "a verdade núa dos sentimentos e das accões".
- Gonzague Truc, numa collecção consagrada aos mestres do pensamento religioso, analysa o classicismo de Bossuet. Attraido pelos homens e coisas do grande seculo francez, Truc já dedicou um forte ensaio a ma dame de Maintenon e agora põe em fóco a robustez de idéas, a cultura theologica, a expressão mascula, tudo o due empresta um coracter de eternidade aos sernões, que en presta um caracter de eternidade aos sermós, ás prégón for es Franca.

- Pierre Abraham, autor de La Physique au Théâtre, desperta no momento grande interesse entre os conrades gaulezes. As revistas de vanguarda estampam-lhe as produções em sitio de relevo. A proposito de um seu volume sobre Balzac accentuaram os outros criticos que elle desentranhou innumeras novidades do mais explorado dos assumptos, lançando luz nova em muitas reentrancias da obra do prodigioso creador de almas.

- Está sendo publicado em França o theatro completo de Sardou. Quê? Pois esse velho machinador de melodramas impressionantes, dado pelos confrades modernos como sendo apenas forte em carpintaria theatral, ainda a dade das Lettras. dade das Lettras.

- Le Fantôme del Midi, de Noel Vindry, evoca os roubos mysteriosos feitos, em pleno dia, num palacio provençal. Será uma incursão de espiritos inattingiveis ou estarão em jogo, mais prosaicamente, cidadãos affeitos a alliviar e a desmobiliar a casa do proximo? Um arguto solucionador de enigmas policiaes encarrega-se de desvendar mais esta complicação. Trata-se, ao que accentúa o proprio autor, de um "romance-problema".

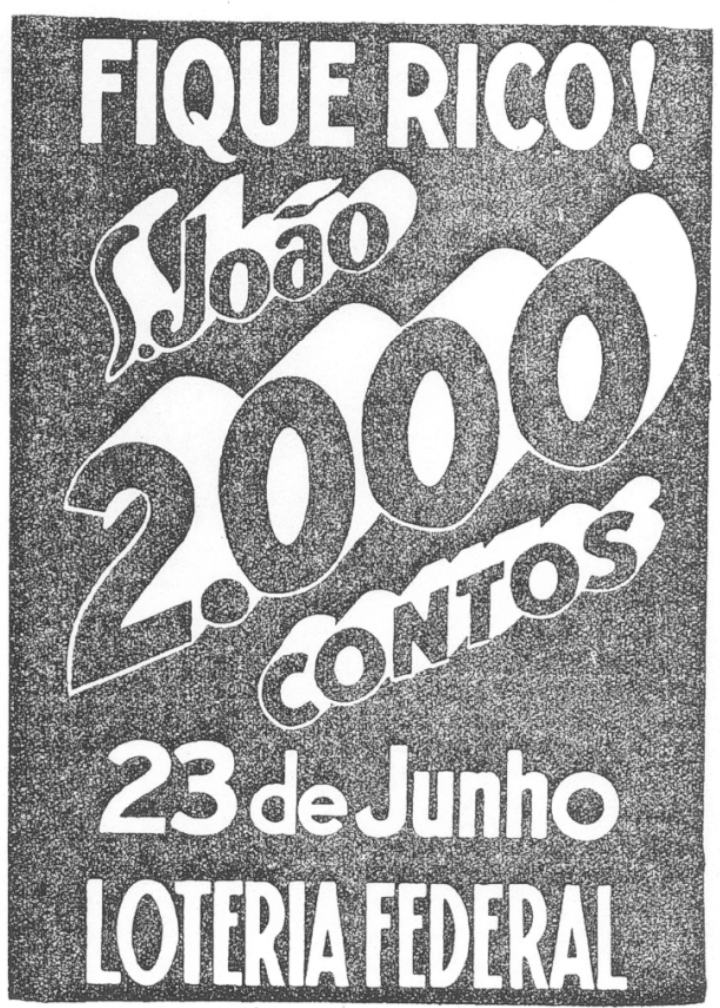




\section{MÁRIO DE ANDRADE}

CAscudo, Luís da Câmara. "Mário de Andrade". Boletim de Ariel: Rio de Janeiro, a. 3, nº 9, junho de 1934, p. 233-235. IEBUSP - MA-MP.

O primeiro livro de Mário, Há uma gota de sangue em cada poema, é de 1917 e constitui raridade bibliográfica. Livro dos 24 anos. Poesia romântica sobre a guerra de 14. A guerra não, mas o resultado espiritual da guerra. Era o que ele me dizia ser o comecinho pobre. E nem assinou. Deu um Mário Sobral em vez do nome.

Paulicéia desvairada é de 1922, escrito de dezembro a dezembro de 1920-21. Nós estamos longe. Ninguém se lembra mais da Semana de Arte Moderna, da Klaxon, do furor literário paulista, da repercussão. Também não se disse que Paulicéia foi verdadeiramente o índice de todas as atividades e o prefácio ${ }^{124}$ virou dogma sistematizador do movimento. Até o comparavam ao de Cromwell $^{125}$. Havia muita ingenuidade naquele desvairismo mas o autor mergulhou, brusco, numa livrarada cotejadora. Paulicéia desvairada tivera o condão inicial de desarticular a armadura poética e andava identificando peça a peça, mostrando procedência e preço pela tarifa alfandegária. Aquilo que reinava em Rio-S. Paulo era soldo-de-ano dos armazéns franceses. Paulicéia foi uma reação de bom-senso sem pensar que o possuísse.

A escrava que não é Isaura apareceu em 1925 e é a Paulicéia desvairada sem a função poética. É o prefácio virado discurso sobre algumas tendências da poesia modernista. Apesar de publicado em 25 o ensaio é do ano anterior. Saiu logo em janeiro de 25, inaugurando a era-de-ver para os modernistas. A Escrava era a Poesia e Mário alinhava a classificação de suas algemas e fórmulas de libertação. Era a substituição da ordem intelectual pela ordem subconsciente, o pampsiquismo poético, a preconização da rapidez, da síntese, a idéia kodac, o real-expressivo antes do ideal-bonito. Para muitos o Escrava era uma inversão demoníaca de todos os venerandos valores poéticos desde Horácio até Bilac. Mário resistiu, sozinho, ao embate porque a Escrava, muito gabada, foi pouco entendida. Recordo-me da surpresa dos argentinos quando lhes mandei o livro. Não havia em parte alguma do Mundo trabalho semelhante. Era a mais completa de todas as análises da poesia modernista. As tendências, as influências, as opiniões, a dispersão reacionária do movimento que, atacando as escolas, ia fun-

\footnotetext{
${ }^{124}$ Referência ao “Prefácio Interessantíssimo”, de Paulicéia desvairada.

${ }^{125}$ Referência ao prefácio de Victor Hugo ao seu drama Cromwell, de 1827.
} 
dando uma, tiveram uma palavra de justa e segura compreensão crítica e divulgadora. Havia, naturalmente, deformação inconsciente porque Mário refletia leituras estrangeiras e acomodava-as a si mesmo. Obrigava pernas e braços a tomarem a extensão de sua mentalidade. O ensaio, até hoje, senhores doutores, não encontrou parecença com outro.

Foi em 1926, na Manhã, do Rio, a 12 de Janeiro, que Mário endereçou a desnorteadora Carta aberta a Graça Aranha, explicando a discordância entre os dois e fixando a imposição de personalidade pretendida pelo primeiro. Foi outro tempo-quente. Graça Aranha, sedutor e envolvente, estava convencido, possivelmente sem sentir a própria convicção mas enrolado nela, que tinha um papel orientador de suprema importância especialmente para os paulistas, prolatores do modernismo.

Em fevereiro de 1926 sacode o Losango cáqui, poeminhas batidos quatro anos antes e ajeitados posteriormente. Vem o “Alto”, a “Toada da esquina”, a "Parada”126, fotos do voluntariado militar. É o cabo Machado ${ }^{127}$ bandeira-do-Brasil. Neste momento Mário conseguiu um puzzle que o orgulhou vários meses. É o "Flamingo" "128, associação de idéias por constelação. A crítica não deu pela brida. Nem olhou o "Flamingo".

1926 ainda deu Primeiro andar, contos daqui e dalém. Era no fim do ano e Mário estudava o alemão, lia Freud e trabalhava num romance de exame e cirurgia ao vienense. Primeiro andar reúne contos de orientações díspares e opostas. Mário andou sempre em cima ou abaixo do nível. Nunca direitinho nele. Basta ler “Conto do Natal”, “Galo que não cantou” e a "História com data”" ${ }^{29}$, que ele disse ter sido plagiado do Avatar de Teófilo Gautier mas, avisado depois do crime, achava o plágio melhor que o original e deixava.

Amar, verbo intransitivo é de 1927. Mário escreveu-o de 23 a 24. O romance maciço e compacto assustou muita gente. Foi o mais ignorado dos livros. Um crítico, e dos maiores, disse que aquilo era o elogio de Freud quando parece justamente o inverso. Aplicou-se o método para a educação sexual, somando os resultados e contraproducências que não compensavam a fama. Deste Amar, verbo intransitivo, há uma adaptação para o americano com o título de Fräulein, por Margaret Richardson Hollingsworth.

\footnotetext{
126 “Alto”, “Toada da esquina” e “Parada” são poemas de Losango cáqui, 1926. In: AndRADE, Mário de. Poesias completas. Op. cit., p. 133, 157 e 149, respectivamente.

${ }^{127}$ Referência ao poema “Cabo Machado”, de Losango cáqui. Idem, p. 144.

${ }^{128}$ Referência ao poema "Flamingo”, de Losango cáqui. Idem, p. 142.

129 “Conto do Natal”, “Galo que não cantou” e a "História com data” são contos de Primeiro andar, 1926, recolhidos em ANDRADE, Mário de. Obra imatura. Op. cit., p. 49, 88 e 130, respectivamente. Na revista, lê-se "História sem data”, em vez de "História com data”, nítida confusão de Cascudo com o título do livro de contos de Machado de Assis - Histórias sem data (1884) -, parodiado por Mário de Andrade em seu conto.
} 
No morrer de 27, Mário publicou Clã do jabuti. Roquette Pinto dera-lhe o gosto pela indiaria e o poeta da Paulicéia, o romancista alemão do Amar, voltou a ler etnólogos, especialmente o claro Koch-Grünberg, no Vom Roraima zum Orinoco e Unter den Naturvolkern Zentral-Brasiliens, e mesmo os anteriores, von den Steinen, Ehrenreich, Schmidt, Krause, Kanike, posteriores, o padre Colbacchini, o conde de Stradelli. Das aparas de impressão ia ficando muito material aproveitado. Clã do jabuti é a explicação de livros sucessivos e antevisão do folclore intelectual de Mário de Andrade. A “Toada do Pai-do-Mato”130 é dos índios Parecis e em Roquette Pinto Mário encontrou, para sentir e popularizar, o Nozan ná (fonograma $\mathrm{n}^{\mathrm{o}}$ 14.597) assim como o episódio da índia camalalô com o Pai-do-Mato que ela julga ser um ariti ${ }^{131}$. Está a estória do piá que foi para o céu levado por uma andorinha, tema recolhido por Koch-Grünberg. Para não perder as reminiscências modernistas (!) é que Mário juntou ao lado dos “dois poemas acreanos"132, de todo o delicioso ritmo sincopado ${ }^{133}$, o "Carnaval Carioca”134, sem mais atuação literária e o "Noturno de Belo Horizonte”135, o melhor poema como construção espiritual. Clã do jabuti pode merecer a frase de Waldo Franck, has reached a goal. A goal is an end. An end can be also a beginning.

Mário fizera o Norte, numa bandeira que dona Olívia Guedes Penteado dirigia com a magia de sua presença senhorial. Andaram pelo Pará e Amazonas, subiram o rio Madeira até Iquitos. Mário remou no lago Ariri, comeu frutas ásperas e doces, bebeu açaí, conversou no Ver-o-Peso e voltou com um chapéu de palha branco e alarmador. Falou que publicaria um Manual de viajante aprendiz, nome lindo mas deu o Clã do jabuti. An end can be also a beginning.

Macunaíma é a soma de todos esses fatores. É de meados de 1928 e foi um livro feliz. O Koch-Grünberg não suspeitaria que o herói sem nenhum caráter nasceria do mais característico dos entes tradicionais. Também vivem milhares de recordações pessoais, episódios, anedotas, toponímia rara, o Bom-Jardim onde ele ouviu o bumba-meu-boi, conversas com o cantador Chico Antônio, feitiços, pastoris e lapinhas, tudo quanto registrou em dezembro de 1927 e janeiro de 1928 em sua viagem a Natal-Paraíba-Recife.

\footnotetext{
130 “Toada do Pai-do-Mato” é poema de Clã do jabuti. In: Andrade, Mário de. Poesias completas. Op. cit., p. 191.

131 “Ariti”: possivelmente, o mesmo que “aritauá” ou “aratauá”, nome indígena para uma espécie de pássaro de plumagem preta e amarela.

132 “Dois poemas acreanos: I. Descobrimento; II. Acalanto do seringueiro”. Clã do jabuti. In: ANDRADE, Mário de. Poesias completas. Op. cit., p. 203.

133 “Ritmo sincopado” é o nome de uma das partes em que se divide o livro Clã do jabuti. Op. cit., p. 190-202.

134 “Carnaval Carioca” é título de um poema longo, que figura no livro Clã do jabuti. Op. cit., p. 163-173.

135 “Noturno de Belo Horizonte” é título de outro poema longo do livro Clã do jabuti. Op. cit., p. 178-189.
} 
Macunaíma foi “explicado” de maneiras inúmeras e nenhuma justificável. Macunaíma não tem a menor explicação. É um desabafo, uma variação de mil temas, o assunto que nuclearia todas as opiniões, ironias e paradoxos. Mário teve o maior trabalho deste mundo em fazer a confusão geográfica do Macunaíma e costurar as estórias gaúchas com as acreanas, as paulistas de Sorocaba com as norte-rio-grandenses de Caicó. Bateu, misturou e serviu. O erudito ficou um horror de tempo procurando identificar os tacos de onde Mário erguera o livro esplêndido.

Do mesmo 1928 é o Ensaio sobre música brasileira que não viveria sem a jornada ao Norte. A documentação melódica, em sua proporção maior sai do Norte e aqui Mário sambou os melhores sambas e gritou entusiasmado nos melhores cocos. É o primeiro ensaio sobre a Música Brasileira feito por quem sabe música e recolhe material por mão própria. A documentaria impressa é insignificante porque o Ensaio sobre música brasileira é uma revelação de riqueza folclórica. Infinitamente menor que a fantasmagoria rutilante do futuro $\mathrm{Na}$ pancada do ganzá.

O Compêndio de história da música (1929) e sua segunda edição (1933. Com discoteca) tem contra si apenas o vocabulário e a sintaxe brasileira do autor. Mesmo atenuada na segunda edição, os graves professores franzem o bico com as irreverências à sisuda gramática de Eduardo Carlos Pereira. Pela primeira vez alguém escreve uma História absolutamente pessoal, estridentemente livre, com uma capacidade de análise e um poder de síntese que o velho Lavignac desconheceu irremediavelmente. Certos capítulos, classicismo romântico, conceito do classicismo, o gregoriano, Brahms, Wagner, os leaders, a crítica de Carlos Gomes, são magistrais de nitidez e serenidade. Não há rasto de influência nem traço de esquema erudito. A Historia da música é tão positivamente de Mário como o Clã do jabuti. Ele só copiou os nomes próprios e as datas.

Modinhas imperiais (1930) pertencem ao ciclo do folclorismo brasileiro, numa decantação cuidada e pura que honraria um ambiente menos rarefeito que o nosso. O prefácio e as notas dispensam uma bibliografia na espécie.

Remate de males é do mesmo 1930. É uma recordação da viagem romântica ao Norte e o título já testifica a lembrança persistente da saudade onomástica. Serve para um diagrama de percurso. Ali estão as Danças, de 1924 e os Poemas da Amiga, de 1930

Belazarte (1934), batizado de contos, são trabalhos pensados para a América Brasileira, de Elysio de Carvalho, publicados como crônicas em jornais e revistas. O mais novo é de 
1929. Belazarte é um sonho teimoso que Mário pôde ${ }^{136}$ realizar. A unidade mental não foi mantida nem seria possível com a vida dispersa que o autor é obrigado a ter. Os trabalhos de demora, o ensaio da música brasileira, a história, Amar, Verbo Intransitivo, o Macunaíma, o breve Na pancada do ganzá, o mais completo livro de folclore musical que o Brasil terá, não podiam passar sem a literatura lateral, espalhada nos periódicos e reunidas no Primeiro andar, Belazarte, etc.

Seu mais recente trabalho é Música, doce música, 1934, coleção de crônicas sobre assuntos musicais, publicados no Diário Nacional, em São Paulo. Lembrando os saudosos conceitos do passado registro o Música, doce música é indispensável na livraria de qualquer músico e de qualquer que suspeite gostar de música. A crítica ao Gregoriano, a reação contra Wagner, com a magnífica exposição do caso Brahms, a influência portuguesa nas danças de roda, talvez a mais forte das influências (tema que Mário mandara para um estudo na exposição de Praga), merecem uma leitura mais segura, assim como as divulgações da música e vida do padre José Maurício, Ernesto Nazareth, Tupinambá, a sonatina de Lourenço Fernandes, as canções do pobre Gallet e o maravilhoso retrato de Germaninha. A “música de pancadaria” é ultra-justa.

Mário de Andrade andou pelo Nordeste catando temas melódicos de folclores. Passou vinte dias comigo e juntos fizemos, com Antônio Bento de Araújo Lima, Conde do Bom Jardim, uma sensacional viajem de retorno pelo Rio Grande do Norte e Paraíba, em plena seca, desde as salinas de Macau até os tabuleiros cinzentos do Catolé do Rocha. Mário anotou tudo, cantigas de cegos, ritmos de marcha, paisagem, tipos, versos, cantoria. Em Natal estudou os autos populares, ouviu o Boi e os Pastoris, chupou caju, assistiu a Chegança e fechou o corpo, num catimbó do Alecrim, com mestre Germano que é protegido por Xaramundi e as Três Meninas da Saia Verde sob cuja égide Mário pôde atravessar todas as águas correntes e paradas, frias e ardentes, arma de fogo não acerta, cachorro perde o faro, faca amolga e guardacivil fica zarolho para não o enxergar. De tanto andar atrás de Bumba-meu-boi e zambez ${ }^{137}$, pegou um apelido de Doutor do Boi, e, nas ruas, os homens do povo apontavam-no sorridentes: — “aquele é o doutor que veio de São Paulo estudá o Boi...”. E era mesmo. Em Paraíba, e, antes do Bom Jardim, feudo de Antônio Bento, ouviu Chico Antônio cantar o Boi Tungão, as emboladas de ganzá, um desespero de novidade rítmica, um encanto de desenho melódico

\footnotetext{
${ }^{136}$ Na revista, lê-se “poude”.

${ }^{137}$ Mesmo que "Zambê". Grande tambor e, por, metonímia, o baile popular de Norte e Nordeste do Brasil, em que o instrumento figura com destaque. Cf. CASCUDO, Luís da Câmara. Dicionário do folclore brasileiro. $2^{\mathrm{a}}$. ed. Rio de Janeiro: INL / MEC, 1962, v. II, p. 791/2.
} 
simples e de inesquecíveis efeitos. Levou para S. Paulo receitas de bolos e orações fortes, alguns quilos de versos, uma coleção de gaitas usadas nos Caboclinhos e creio que um zabumba dum maracatu pernambucano, desses de estourar ouvidos.

Todo este material infinito está sendo inteligentemente aproveitado. A inteligência vai ao par do ciúme com que ele comunica o avanço da empresa. Na pancada do ganzá nós teremos uma surpresa para os estudiosos da Música Brasileira. Vamos ver o contato do brasileiro com os mais distantes povos. Uma frase inteira da Marselhesa está nos Congos e a entrada do Boi é inteirinha uma música eslava.

No meio de tudo isto correm anedotas que eu não quero contar. Esse homem dos sete instrumentos, aparentemente desorganizado, é o mais técnico, cauto, disciplinado dos brasileiros. Amigo de dossier, de livro-de-nota, de apontamento em caderno próprio, com índice remissivo, catalogando o que lê para achar quando quiser.

Tsara diz que a ausência do método é um método e muito mais simpático. Mário tem o melhor dos métodos, o método da inteligência e da sensibilidade.

LUÍS DA CÂMARA CASCUDO 
1935 

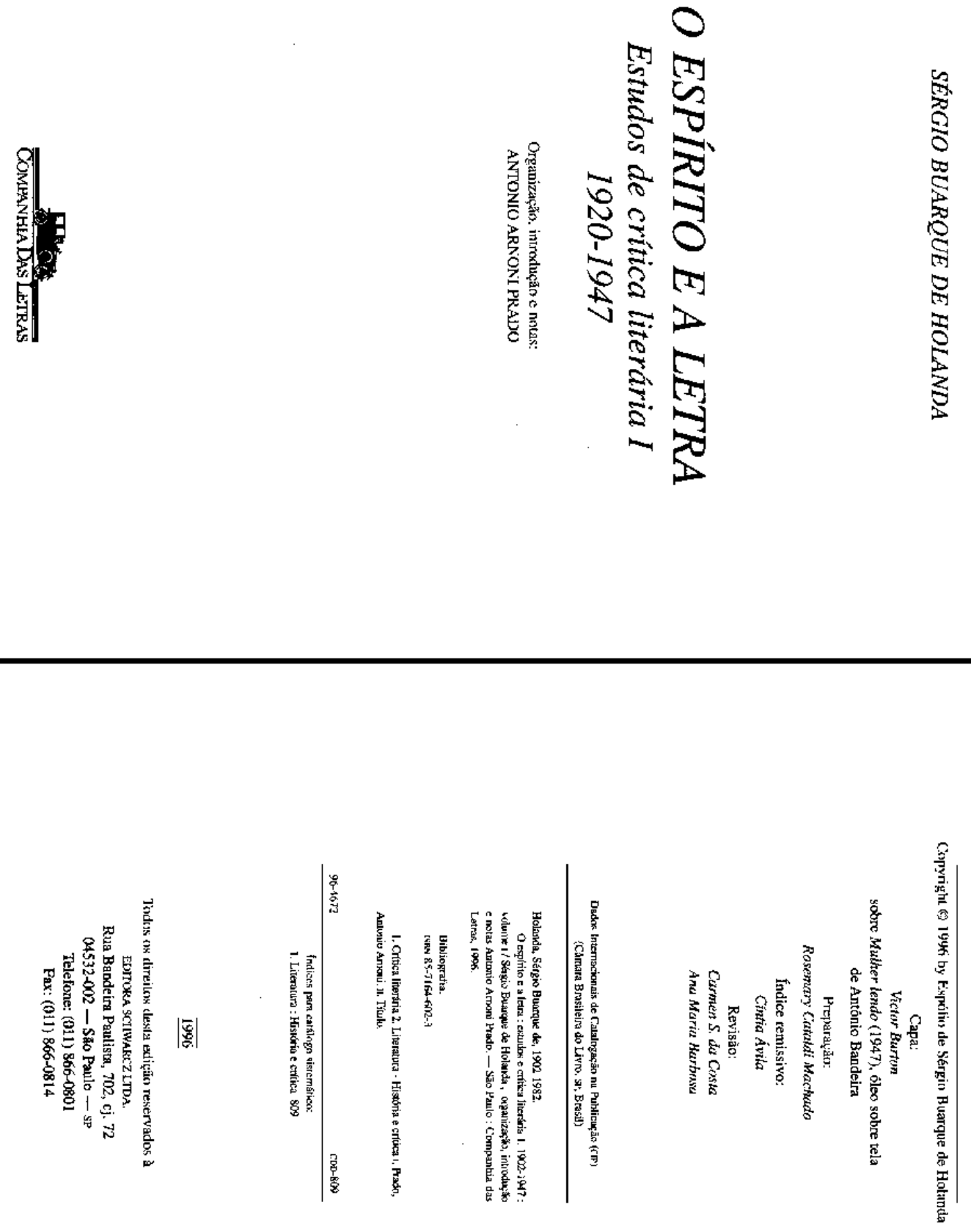


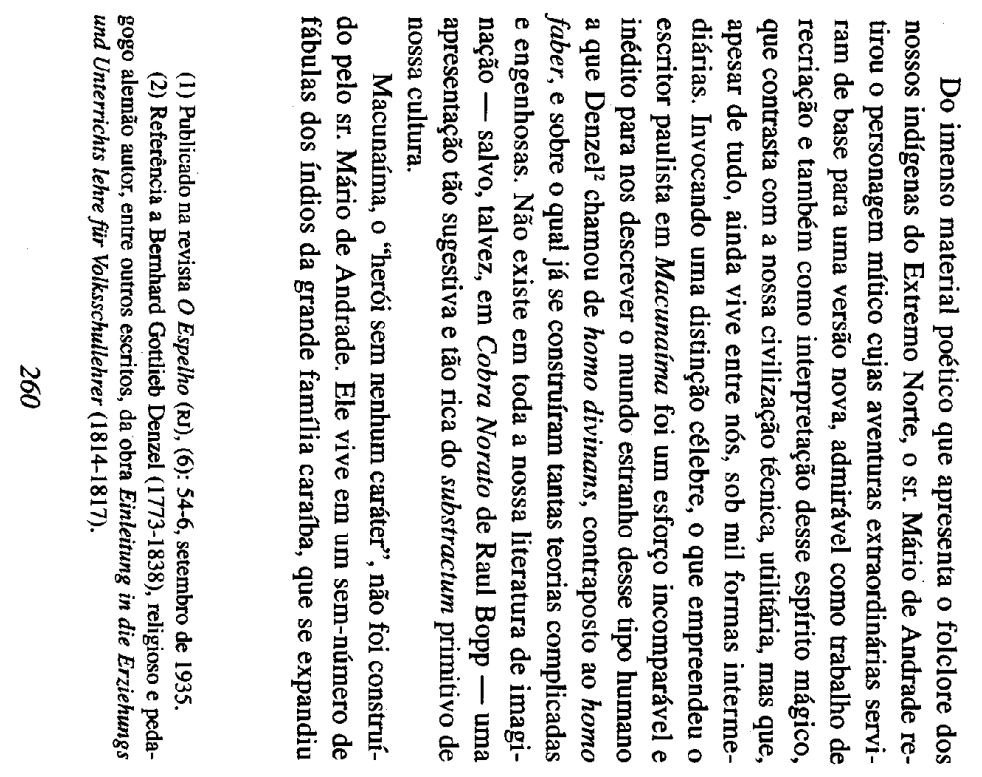

苗
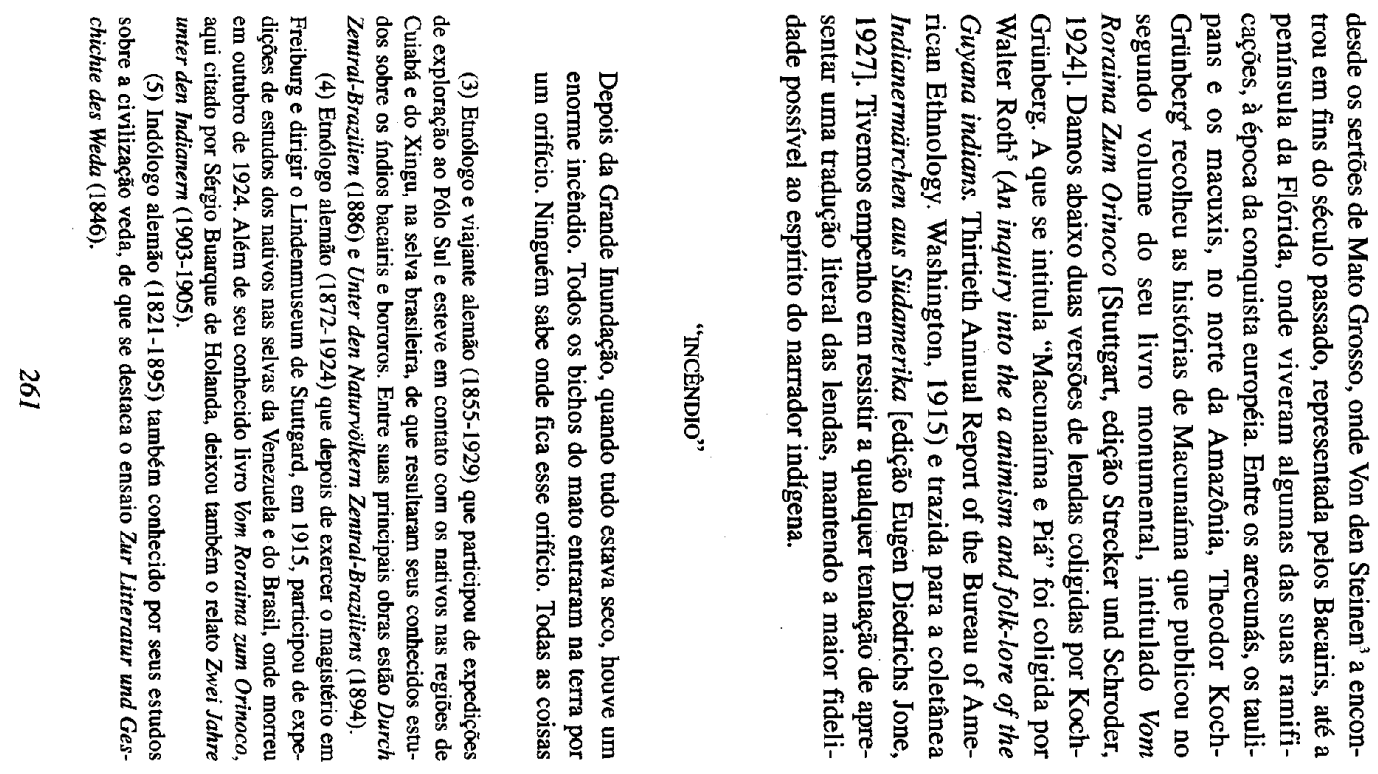


\section{O Mito de Macunaíma}

HolandA, Sérgio Buarque de. "O mito de Macunaíma". $O$ Espelho. Rio de Janeiro, $\mathrm{n}^{\circ}$ 6, p. 54-56, setembro de 1935. ${ }^{138}$ Recolhido em HolandA, Sérgio Buarque de. $O$ espírito e a letra. Organização, introdução e notas: Antônio Arnoni Prado. São Paulo: Companhia das Letras, 1996, vol. I, p. 260-267. ${ }^{139}$

Do imenso material poético que apresenta o folclore dos nossos indígenas do Extremo Norte, o sr. Mário de Andrade retirou o personagem mítico cujas aventuras extraordinárias serviram de base para uma versão nova, admirável como trabalho de recriação e também como interpretação desse espírito mágico, que contrasta com a nossa civilização técnica, utilitária, mas que, apesar de tudo, ainda vive entre nós, sob mil formas intermediárias. Invocando uma distinção célebre, o que empreendeu o escritor paulista em Macunaíma foi um esforço incomparável e inédito para nos descrever o mundo estranho desse tipo humano a que Den$\mathrm{zel}^{140}$ chamou de homo divinans, contraposto ao homo faber, e sobre o qual já se construíram tantas teorias complicadas e engenhosas. Não existe em toda a nossa literatura de imaginação - salvo, talvez, em Cobra Norato de Raul Bopp - uma apresentação tão sugestiva e tão rica do substractum primitivo de nossa cultura.

Macunaíma, o "herói sem nenhum caráter”, não foi construído pelo sr. Mário de Andrade. Ele vive em um sem-número de fábulas dos índios da grande família caraíba ${ }^{141}$, que se expandiu desde os sertões de Mato Grosso, onde Von den Steinen ${ }^{142}$ a encontrou em fins do século passado, representada pelos Bacairis, até a península da Flórida, onde viveram algumas das suas ramificações, à época da conquista européia. Entre os arecunás, os taulipans e os

\footnotetext{
${ }^{138}$ Documento não localizado pela pesquisa.

${ }^{139}$ Nota de Antônio Arnoni Prado (identificado por “AAP” nas citações seguintes): Publicado na revista O Espelho (RJ), (6): 54-6, setembro de 1935.

${ }^{140}$ Nota de AAP: Referência a Bernhard Gottlieb Denzel (1773-1838), religioso e pedagogo alemão autor, entre outros escritos, da obra Einleitung in die Erziehungs und Unterrichts lehre für Volksschullehrer (1814-1817).

${ }^{141}$ Cf. nota 2, p. 7, deste Corpus.

${ }^{142}$ Nota de AAP: Etnólogo e viajante alemão (1855-1929) que participou de expedições de exploração ao Pólo Sul e esteve em contato com os nativos nas regiões de Cuiabá e do Xingu, na selva brasileira, de que resultaram seus conhecidos estudos sobre os índios bacairis e bororos. Entre suas principais obras estão Durch ZentralBrazilien (1886) e Unter den Naturvölkern Zentral-Braziliens (1894).
} 
macuxis, no norte da Amazônia, Theodor Koch-Grünberg ${ }^{143}$ recolheu as histórias de Macunaíma que publicou no segundo volume do seu livro monumental, intitulado Vom Roraima Zum Orinoco [Stuttgart, edição Strecker und Schroder, 1924]. Damos abaixo duas versões de lendas coligidas por Koch- Grünberg. A que se intitula "Macunaíma e Piá” foi coligida por Walter Roth ${ }^{144}$ (An inquiry into the a animism and folk-lore of the Guyana indians. Thirtieth Annual Report of the Bureau of American Ethnology. Washington, 1915) e trazida para a coletânea Indianermärchen aus Südamerika [edição Eugen Diedrichs Jone, 1927]. Tivemos empenho em resistir a qualquer tentação de apresentar uma tradução literal das lendas, mantendo a maior fidelidade possível ao espírito do narrador indígena.

\section{"INCÊNDIO"}

Depois da Grande Inundação, quando tudo estava seco, houve um enorme incêndio. Todos os bichos do mato entraram na terra por um orifício. Ninguém sabe onde fica esse orifício. Todas as coisas se queimaram — os homens, os morros, as pedras... Os rios secaram. E é por isso que, ainda hoje, se encontram grandes pedaços de carvão pela terra. Macunaíma fabricou homens novos com cera. Mas todos se derreteram ao calor do sol. Então fez homens de barro. Ao sol eles se endureceram. Então ele os transformou em gente.

\section{“MACUNAÍMA E PIÁ”}

Há muito tempo existiu uma mulher que ficou grávida, por artes do Sol, de duas crianças gêmeas, Macunaíma e Piá. Certo dia, ainda no ventre de sua mãe, assim lhe falou Piá: "Saiamos a visitar nosso pai. Mostraremos o caminho. Apanha para nós todas as flores bonitas que enxergares pela estrada”. Imediatamente ela se ergueu e partiu rumo a oeste, a fim de ir ver seu esposo.

Durante a viagem, como fosse colhendo as flores que encontrava às margens do caminho, ela tropeçou, caiu e machucou-se. Isso aborreceu as duas crianças, que ainda não tinham nascido. E ficaram tão zangadas que mais tarde, quando a mãe lhes perguntou por onde devia

\footnotetext{
${ }^{143}$ Nota de AAP: Etnólogo alemão (1872-1924) que depois de exercer o magistério em Freiburg e dirigir o Lindenmuseum de Stuttgard, em 1915, participou de expedições de estudos dos nativos nas selvas da Venezuela e do Brasil, onde morreu em outubro de 1924. Além de seu conhecido livro Vom Roraima zum Orinoco, aqui citado por Sérgio Buarque de Holanda, deixou também o relato Zwei Jahre unter den Indianern (1903-1905).

${ }^{144}$ Nota de AAP: Indólogo alemão (1821-1895) também conhecido por seus estudos sobre a civilização veda, de que se destaca o ensaio Zur Litteratur und Geschichte des Weda (1846).
} 
seguir, negaram-se a ensinar. Sucedeu, assim, que errou de direção e finalmente, cansada e com os pés magoados, chegou a uma casa estranha. Pertencia a Konoboarú, a rã de tempestade, mãe de um jaguar. Quando a mulher, exausta da viagem, descobriu onde estava, disse à velha que lamentava ter chegado àquele lugar, pois muito ouvira contar sobre a maldade de seu filho. Então a dona da casa teve pena dela. Convenceu-lhe de que não tivesse receio e escondeu-a no pote de fazer caxiri, que cobriu com a tampa. De tarde, quando o jaguar chegou, pôs-se a fungar de um lado para o outro e a exclamar: "Mamãe, sinto cheiro de alguém. Quem está aqui?”. Conquanto a mãe respondesse que não havia ninguém em casa, o jaguar assim mesmo não se deu por satisfeito. Tratou ele próprio de procurar e acabou espiando dentro da vasilha, onde descobriu a aterrorizada criatura.

Matou a pobre mulher, encontrou as duas crianças, que ainda não tinham nascido, e mostrou-as à mãe dele. “Deves tomar conta das crianças e sustentá-las”, disse-lhe. Ela embrulhou os pequenos em um manto de algodão a fim de aquecê-los e notou, no dia seguinte, que já tinham começado a crescer. Na outra manhã estavam bem maiores e, com o crescimento de todos os dias, dentro de um mês já eram como adultos. Então a mãe do jaguar falou que podiam usar arco e flecha e que deveriam atirar no mutum, pois fora ele — dizia - o matador de sua mãe.

Na manhã seguinte puseram-se a caminho o Piá e Macunaíma, que entraram a alvejar os mutuns. Não havia dia em que não matassem dessas aves. E como pensassem em dar cabo de todas elas, disse-lhes então o mutum que o matador de sua mãe não fora nenhum animal de sua raça e sim o jaguar. E narrou-lhes todas as particularidades da morte. Os dois moços ficaram muito zangados quando ouviram isso, pouparam o pássaro e disseram à velha, quando chegaram de mãos vazias à casa, que o mutum lhes tomara as flechas. Isso naturalmente não era verdade, mas um simples pretexto. Eles próprios tinham escondido as flechas no mato e pretendiam fazer armas novas e mais poderosas. Quando essas armas ficaram prontas, fizeram um esconderijo em uma árvore e, quando o jaguar passou por baixo, alvejaram-no e mataramno. Depois voltaram para casa e mataram também a mãe do jaguar.

Os dois moços seguiram então o seu caminho e chegaram por fim a um mato de algodoeiros, no meio do qual havia uma casa. Nela morava uma mulher muito velha, que em verdade era uma rã, e ali instalaram sua residência. Todos os dias iam à caça e, ao regresso, encontravam regularmente uma porção de mingau de mandioca que tinha preparado a dona da casa. “Isso é extraordinário”, observou Piá ao seu irmão, “não há aqui nenhum campo e, no entanto, vê a quantidade de mandioca que nos dá a velha! Precisamos observá-la!” 
No dia seguinte, em vez de ir à caça, foram ao mato, a pequena distância da casa, e esconderam-se por detrás de uma árvore, de onde podiam espiar o que sucedia lá dentro. Viram então que a velha rã tinha uma mancha branca nos ombros; repararam que, quando ela se curvava e coçava essa mancha, saía por ali a farinha de mandioca. Voltando à casa, recusaram a comida de costume, agora que sabiam a sua origem. Na manhã seguinte colheram uma porção de algodão dos arbustos vizinhos e espalharam-no pelo chão. Como a velha perguntasse para que servia aquilo, responderam eles que lhe preparavam uma cama bonita e macia. Muito contente, ela sentou-se imediatamente em cima. Mal, porém, se tinha sentado, os moços puseram fogo no algodão. A pele da velha ficou tão horrivelmente queimada que tomou o aspecto encarquilhado e áspero que ainda hoje apresenta.

Macunaíma e Piá continuaram a viagem a fim de irem ao encontro de seu pai, e chegaram logo à casa do Tapir, onde permaneceram três dias. No terceiro dia voltou o Tapir e pareceu-lhes muito liso e roliço. Os moços bem queriam saber o que tinha ele comido. Por isso seguiram os seus rastros até que encontraram uma ameixeira. Sacudiram a árvore com tamanha força que caíram todas as frutas, maduras e verdes, esparramando-se pelo chão. Quando o Tapir chegou no dia seguinte, ficou muito zangado. Voltou rapidamente para casa, deu muita pancada nos dois e foi-se embora correndo, para o mato. Os moços decidiram então segui-lo, acompanhando-o durante alguns dias. Por fim alcançaram-no. Então Piá recomendou a Macunaíma que passasse adiante, espantasse o Tapir para o seu lado e, enquanto isso, fosse preparando uma flecha de arpão. No caminho, porém, Macunaíma embaraçou-se no cordão e ficou sem uma perna.

Nas noites claras ainda podem ser vistos no céu — lá está o Tapir (Hyades), acolá Macunaíma (Orion) e mais embaixo sua perna cortada (a cinta de Orion).

\section{“AS BRIGAS DE MACUNAÍMA”}

Quando Macunaíma ainda era muito pequeno, passava todas as noites chorando e pedia à mulher de seu irmão mais velho que o levasse para fora de casa. Lá fora ele queria por força agarrá-la para se deitar com ela. A mãe dele fazia menção de levá-lo, mas ele nada de deixar. Então dizia à nora que carregasse a criança para fora de casa. Esta o conduzia a uma pequena distância, mas ele implorava que fosse ainda mais adiante. Então a mulher ia com Macunaíma mais adiante, para trás do morro. Macunaíma ainda era muito pequeno. Mas quando ali chegava virava homem e deitava-se com ela. Assim fazia ele sempre com a mu- 
lher, servindo-se dela todas as vezes em que seu irmão saía para a caça. Mas o irmão de nada sabia. Em casa Macunaíma era uma criança. Fora, virava logo homem.

O irmão mais velho apanhava as fibras do carauá a fim de fazer um laço para a anta. Disse que tinha encontrado o rastro recente de uma anta e queria colocar o laço no caminho por onde ia passar o bicho. Macunaíma pediu um laço também para ele, mas o irmão mais velho não quis dar, e disse:

— Para quê? Menino não brinca com laço. É só para gente que sabe lidar com essas coisas.

Mas o pequeno era teimoso e queria obter por força o laço. E tornava a pedir todos os dias. Afinal lhe deu o irmão mais velho um pouco de fibra de carauá, e perguntou à mãe:

— Para que esse menino quer laço?

O irmão mais velho tinha encontrado o rastro recente da anta e queria botar ali o laço. Então o pequeno falou à mãe:

- A anta não vai cair no laço dele!

E pôs o seu laço, que fez com as fibras de carauá, em um caminho antigo, por onde já não passava nenhuma anta. O irmão mais velho já tinha armado o seu laço.

No outro dia Macunaíma disse à mãe que fosse ver se tinha caído alguma anta em seu laço. Lá estava uma. A mãe voltou e disse que a anta já tinha morrido. Então o menino falou à mãe que dissesse ao irmão mais velho para tirar a anta e cortá-la. Ela precisou dizer isso duas vezes porque o irmão não queria acreditar. E falou:

— Eu sou mais velho e não há nenhuma anta em meu laço. Por que razão haveria no laço desse menino?

Macunaíma falou à sua mãe:

— Diga-lhe que leve a mulher dele para que carregue a carne.

Quando o irmão tinha partido em companhia da mulher, a fim de cortar a anta, Macunaíma disse à mãe que não devia ir junto. E quando o irmão tinha cortado a anta, Macunaíma disse à mãe para lhe avisar que trouxesse o animal inteiro para casa; ele próprio queria distribuir a carne. Mas o irmão mais velho não lhe quis dar nenhum pedaço de carne, pois era muito criança. Então levou toda a carne para casa e deu os intestinos da anta para o menino. Este ficou muito zangado.

O irmão mais velho percebeu que Macunaíma andava fazendo das suas com a mulher dele. Saiu a caçar, mas voltou do meio do caminho a fim de espreitar o menino. Esperou junto ao lugar para onde a mulher tinha o hábito de ir sempre com Macunaíma. Então ela chegou 
com o menino no colo. Quando estavam atrás do morro, ela pôs a criança no chão. Então Macunaíma virou homem. E crescia até não poder mais. (O menino era muito gordo.) Pegou a mulher e deitou-se com ela. O irmão viu tudo. Agarrou um pedaço de madeira e deu uma sova bem dada em Macunaíma.

Mas Macunaíma começou a ficar farto dessa vida. E disse à mãe: "Mamãe, quem levará a casa ao cume da montanha alta?”.

E disse ainda:

— Fecha os olhos! Diga esta frase: “Quem leva a casa ao cume da montanha?”.

Quando a mãe fechou os olhos, Macunaíma disse:

— Fica ainda mais um pouquinho de olhos fechados.

Então ele levou a casa e todas as plantas, bananeiras e outras, para o cume da montanha. Depois disse:

— Abre os olhos!

Quando ela abriu os olhos, já estava tudo no alto da montanha.

Então ela jogou lá embaixo uma casca de banana com um pedacinho da fruta, porque o irmão de Macunaíma e sua família não tinham de que comer — o pequeno carregara tudo. Macunaíma perguntou:

— Por que isso?

— Seu irmão está com fome, respondeu ela.

Então o menino disse:

— Faz para eles a bebida caxiri.

Durante o dia a mãe deu alguns nós em uma corda de fibra de meriti, a fim de preparar o caxiri, e jogou a corda para o filho, lá embaixo.

Aí o menino falou à sua mãe:

- Diz, mamãe, quem levará a casa, de novo, para baixo. Fecha os olhos e diz essas palavras: “Quem leva a casa de novo para baixo?”. Assim fez ela. Então o menino disse:

— Deixa os olhos fechados, ainda um pouquinho. - E pôs a casa de novo, lá embaixo, em um lugar diferente, perto da residência de seu irmão. Trouxe então o irmão com sua família à sua casa, no cume da montanha. Mas o irmão estava muito magro. Dançaram e o irmão ficou bêbedo e caiu. Macunaíma riu-se, pois ele estava muito magro e todos os seus ossos apareciam, mesmo os do traseiro. Então o irmão comeu muito e ficou de novo gordo.

Certo dia o irmão ia com os outros irmãos a caçar e deixou sua esposa em casa com o menino e a mãe. A mãe foi ver as plantações e Macunaíma ficou só em casa com a mulher. 
Transformou-se em uma pulga de areia para fazê-la rir. A princípio ela não se riu. Então ele se transformou em um homem, com o corpo coberto de feridas, para fazê-la rir. Pois o que ele queria era abrandá-la mais um pouco. Aí a mulher começou a rir. Macunaíma caiu em cima dela e deitaram-se os dois. O irmão mais velho soube de tudo, mas fez de conta que não sabia. Pois só pensava na fome que tinha tido e além disso não podia passar sem seu irmãozinho. Por isso mesmo resolveu não brigar nunca mais com ele. Então morreu a mãe deles no lugar chamado "Pai da Tocandira” ou Murazapombo. A casa da mãe chama-se Araliamaintepe. É uma montanha.

SÉRGIO BUARQUE DE HOLANDA 


\title{
MATÉRIA AGREGADA
}

\section{DOCUMENTOS, TEXTOS E NOTAS}

\author{
(1937-1954)
}


2ª edição de Macunaíma 
[Rio Magazine. Rio de Janeiro, $\mathrm{n}^{\circ}$ 8, s/d (1937). IEB - MA-MP]

\title{
A Lingua de Macunaima
}

\author{
Nunes Pereira
}

Como Pecr Gynt, na féerie de Henrik Ibsen, Macunaima, na historia, de Mario de Andrade, fala uma lingua de extraordinaria vitalidade, essencialmente nacicnal.

Figura mítica, qua a tcdo instante se mcvimenta, desgeografisando-se, entre os aspetcs mais diversos do Brasil, Macunai$m a$ tem de servir-se das formas dialetais da sua terra, sempre com desassombro s exat dâo, por vezes com imprudencia e perversidade, desde o emprego dos nomes-feios, das bocages, dcs xingamento3 de garoto-boca-suja, ás expressóes, saborosamente tipicas, novissimas, de sua criação, quando pinta ou define ou descreve uma figura, uma atitude, um carater, uma cena.

Eis aí o que tcrna, em grande parte. inacessivel e dificil, ás meninas e aos rapazes que só lêm francês, português ou slang, já não direi a obra, mas alguns dos seus trechos, dos seus capitulos, das suas bólas.

Ibsen, tambem, rebelado contra as formas conservadoras, estaticas, impermeaveis, em que o norueguês tendia a cristalzar-se, sem que o oxigenassem as inovaçōes dialetais, as pecul aridades da linguagem do p:vo, tomou ao proprio povo uma das suas figuras - a mais irrequieta, a mais pitoresca, a mais irreverente - a a exiblu aos seus contemporanecs com o coração, o cerebro e a boca che'03, não sćmente de versos maravilhosos, mas da opulencia dialztal, que fascina por suas rusticidades primitivas $e$ pir 3 uas requintadas delicadezas

- poema do gen'o que escreveu Brand S Jean-Gabriel Borkmann, como um rio. daguas tumultucsas e selvagens, impeliu o noruezuês para essa marcha incessante, que vitalisa, através do tempo e do espaço, uma verdadeira lingua nacional. No Brasil, os escritores que a isso se abalançaram, á falta de folego, para não dizer á falta de brasilidade, nâo conseguiram ir além dos romances, dos contos, das histcrias, dos poemas regionalistas. Só Mario de Andrade, cujo espirito incescantemente se alarga e se ronova, em redcr de todos os obstaculos, como as ccrrentes aéreas e as correntes marinhas, só Mario de Andrade desdobrou á minh v'sta o panorama espetacular da lingua brasileira.

Em Macunaima ele nos revela, ao mesmo tempo, a dialetologia do indio, do negro, do português de - importaçăo, do gaúcho e do nordestino, do homem da brenha amazonica e do mocinho carioca, do paulista e do cabeça-chata.

Pela primeira vez, com espanto e despeito dcs lexicografos, dos gramaticos e dos folk-loristas, um escritor destes exquisitos pōe de parte a lingua de Camós, de Laudelino e de Aloysio, para nos contar. no brasileiro falado, a infsncia, os amores, as lutas, as mentiras, as fantasias, as lendas de um Heroe da nossa tribu "preto e ret'nto, filho do medo da ncite".

Fisa porfomance de Mario de Andra¿3, para mim e para um grupz que o estuda tanto quanto o admira, essa perfcmance representa um dos aspetos mais interessantes da obra que ded cou ao Irmãa de Peer Gynt.

Porque (é preciso explicar sempre um porque) nấc é só o trabalho de colec:onar mod'smos, anexins, idiotismos, cacofonias e neologismos, com caracteris- ticos deste ou daquele brasile:ro, do Norte. do Centro ou do Sul, que avulta da histcria a que me estou referindo, e sim o poder de utilisar todo esse material para traduzir as expressões da ps c: logia complexissima de um Heróe sem nenhum carater...

Tambem essa fol uma das mais notaveis perfomances de Ibsen com c seu Peer Gynt - um tipo da Mitologia escandinava, habil em prcezas, em façanhas de toda especie, das que só uma divindade ou um mistificadcr conzeguem realizar ou simplesmente imaginar.

Como se vê náo fớ apenas o fato de Mario de Andrade ter tornado o brasileiro falado brasileiro escrito, que dá á sua obra situação d ferente, entre os demais autores.

Foi aquele pcder, tão divino e tão humano, que levou Ibsen a fazer de um simples rascal, para me servir de um cpiteto de Shaw, como Peer Gynt, uma figura autent'camente nacional.

Nunes Pereira, nosso colaborador, está preparando um ensaio sobre "Macunaima", ensaio que talvez seja lançado ao mesmo tempo que a $2 .^{\circ}$ edição do grande livro de Mario de Andrade. Nesse ensaio são estudadas as relações entre ○ "Peer Gynt" e "Macunaima", tendo, ainda Nunes $\mathrm{Pe}$ reira organisado um vocabulario de todos os termos brasileiros de que se serve o escriptor paulista. 


\section{A língua de Macunaíma}

PereirA, Nunes. “A língua de Macunaíma”. Rio Magazine: Rio de Janeiro, $\mathrm{n}^{\mathrm{o}}$ 8, s/d [1937 ${ }^{1}$. IEB-USP - MAMP.

Como Peer Gynt, na féerie de Henrik Ibsen, Macunaíma, na história² , de Mário de Andrade, fala uma língua de extraordinária vitalidade, essencialmente nacional.

Figura mítica, que a todo instante se movimenta, desgeografisando-se, entre os aspectos mais diversos do Brasil, Macunaíma tem de servir-se das formas dialetais da sua terra, sempre com desassombro e exatidão, por vezes com imprudência e perversidade, desde o emprego dos nomes-feios, das bocagens ${ }^{3}$, dos xingamentos de garoto-boca-suja, às expressões, saborosamente típicas, novíssimas, de sua criação, quando pinta ou define ou descreve uma figura, uma atitude, um caráter, uma cena.

Eis aí o que torna, em grande parte, inacessível e difícil, às meninas e aos rapazes que só lêem francês, português ou slang, já não direi a obra, mas alguns dos seus trechos, dos seus capítulos, das suas bólas ${ }^{4}$.

Ibsen, também, rebelado contra as formas conservadoras, estáticas, impermeáveis, em que o norueguês tendia a cristalizar-se, sem que o oxigenassem as inovações dialetais, as peculiaridades da linguagem do povo, tomou ao próprio povo uma das suas figuras - a mais irrequieta, a mais pitoresca, a mais irreverente - e a exibiu aos seus contemporâneos com o coração, o cérebro e a boca cheios, não somente de versos maravilhosos, mas da opulência dialetal, que fascina por suas rusticidades primitivas e por suas requintadas delicadezas.

O poema do gênio que escreveu Brand e John Gabriel Borkman ${ }^{5}$, como um rio, de águas $^{6}$ tumultuosas e selvagens, impeliu o norueguês para essa marcha incessante, que vitaliza, através do tempo e do espaço, uma verdadeira língua nacional.

\footnotetext{
${ }^{1}$ Nota editorial no fim do artigo permite supor que date de 1937, pouco antes da publicação da $2^{a}$ edição de $M a-$ cunaíma.

${ }^{2}$ Grifo do autor.

${ }^{3}$ No periódico, lê-se "bocages".

${ }^{4}$ Grifo do autor. Os dicionários não registram a forma "bólas”. Pode ser uma gíria de época ou talvez uma forma alternativa de "bólax" (vocábulo que designa uma planta sul-americana). Nessa última hipótese, o vocábulo seria uma metonímia do que é típico dessa região e esta, por sua vez, metáfora da linguagem eivada de "brasileirismo".

${ }^{5}$ Dramas de Henrik Ibsen: Brand, 1866, e John Gabriel Borkman, 1896. No periódico, lê-se "Jean-Gabriel Borkmann".

${ }^{6}$ No periódico, lê-se “daguas”.
} 
No Brasil, os escritores que a isso se abalançaram, à falta de fôlego, para não dizer à falta de brasilidade, não conseguiram ir além dos romances, dos contos, das histórias, dos poemas regionalistas.

Só Mário de Andrade, cujo espírito incessantemente se alarga e se renova, em redor de todos os obstáculos, como as correntes aéreas e as correntes marinhas, só Mário de Andrade desdobrou à minha vista o panorama espetacular da língua brasileira.

Em Macunaíma ele nos revela, ao mesmo tempo, a dialetologia do índio, do negro, do português de importação, do gaúcho e do nordestino, do homem da brenha amazônica e do mocinho carioca, do paulista e do cabeça-chata.

Pela primeira vez, com espanto e despeito dos lexicógrafos, dos gramáticos e dos folcloristas, um escritor destes esquisitos põe de parte a língua de Camões, de Laudelino ${ }^{7}$ e de Aloysio $^{8}$, para nos contar, no brasileiro falado ${ }^{9}$, a infância, os amores, as lutas, as mentiras, as fantasias, as lendas de um herói da nossa tribo "preto retinto e filho do medo da noite”10.

Essa performance de Mário de Andrade, para mim e para um grupo que o estuda tanto quanto o admira, essa performance representa um dos aspetos mais interessantes da obra que dedicou ao irmão de Peer Gynt.

Porque (é preciso explicar sempre um porque) não é só o trabalho de colecionar modismos, anexins, idiotismos, cacofonias e neologismos, com característicos deste ou daquele brasileiro, do Norte, do Centro ou do Sul, que avulta da história ${ }^{11}$ a que me estou referindo, e sim o poder de utilizar todo esse material para traduzir as expressões da psicologia complexíssima de um herói sem nenhum caráter...

Também essa foi uma das mais notáveis performances de Ibsen com o seu Peer Gynt um tipo da mitologia ${ }^{12}$ escandinava, hábil em proezas, em façanhas de toda espécie, das que só uma divindade ou um mistificador conseguem realizar ou simplesmente imaginar.

Como se vê não foi apenas o fato de Mário de Andrade ter tornado o brasileiro fala$d o^{13}$ brasileiro escrito, que dá à sua obra situação diferente, entre os demais autores.

Foi aquele poder, tão divino e tão humano, que levou Ibsen a fazer de um simples ras$\mathrm{cal}^{14}$, para me servir de um epíteto de Shaw ${ }^{15}$, como Peer Gynt, uma figura autenticamente nacional.

\footnotetext{
${ }^{7}$ Alusão ao filólogo e dicionarista Laudelino Freire.

${ }^{8}$ Alusão, talvez, ao escritor naturalista Aluísio Azevedo.

${ }^{9}$ Grifo do autor.

${ }^{10}$ No periódico, lê-se "preto e retinto, filho do medo da noite".

${ }^{11}$ Grifo do autor.

${ }^{12}$ No periódico, lê-se “Mitologia”, com maiúscula inicial.

${ }^{13}$ Grifo do autor.
} 
Nunes Pereira, nosso colaborador, está preparando um ensaio sobre Macunaíma, ensaio que talvez seja lançado ao mesmo tempo que a $2^{2}$ edição do grande livro de Mário de Andrade. Nesse ensaio são estudadas as relações entre o Peer Gynt e Macunaíma, tendo, ainda Nunes Pereira organizado um vocabulário de todos os termos brasileiros de que se serve o escritor paulista. ${ }^{16}$

NUNES PEREIRA

${ }^{14}$ Idem. Em francês, patife ou velhaco.

${ }^{15}$ George Bernard Shaw, 1850-1956.

${ }^{16}$ Esse estudo anunciado de Nunes Pereira não foi encontrado pela pesquisa. 
A Gazeta: São Paulo, 25/02/1937.

Fundação Cásper Líbero - CEDOC]

\section{A epopéa de um heróe sem nenhum caracter \\ A reedição de "Macunaima", de Mario Andrade}

wlo ha nada mais artiticlal, no fundo, lizar uma porçlo de espalhatatos lltedo que o desinteresse pela literatura affe- rarios e a sus obra prias pasoou, pars ctado por certos intellectuaes. Esse de- muitos, como mails uma molecagem do sinteresse os leva, ds veses, a descrer homem que escrevis os versos de "Re-
inteiramente dos processos literarios pa- mates de Males" e "Lossngo Kaki". Hoje. ra exprimir a verdade da vida, e esfor- apparecendo em seguada edictóto (Tivraria sar-se por crear uma werie de valores Jos Olympio) "Macunatima merece ser

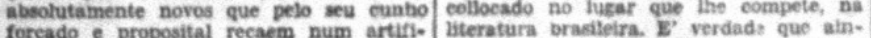
corsado e proposital recaem num artir. cialismo muito peor ainda. iteratura brasitetra. E' verdad? que aincoisa do Marto Andrade postico e antitura, mass o despreas dos "poncifs", dos pathico, mas o conjunto é natural, escionaes nato implica o desdem e scepticismo com que alguns escriptores, ats disciplinas novidade, procuram demolir expressto. O atan exagzerado de fugtr de certas praxes acaba por constitul tambem uma praxe, uma norma: o desejo de crear um estylg differente que $\cos$ estylo: a intençlo sempre visivel de dicer as cousas de uma maneira anti-litesnobismo que acabam por afastar o eseriptor da sua obra. Só receiam o couvencionalismo os que, pela formachio intellectual, se sentem ameacados por elle.
Um escriptor sincero e humano deve escrever como pensa sem a preoceupacelo. de fazer 0 moderno ou fazer 0 antigo. de fugir do estylo ou de cahir na literatura. A vertadeira arte incorporada vida e em funcecalo desta, dispenasa os masuas proprias creaçós. as proprias creapbes. mente aympathia.

O Iivro constitue, por assim diser, ums mythologin earicatural do nosso poro. Reagindo contra as sugfestors din mentalidade europea - os modelos esirangerros em nossos rounances, Marno Andrade

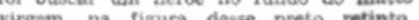
ringe panhumas

Como heroe mythologica, Macunaima náo se localla no tempo nem no espaco. Vae do norte para sui, de leste pars oes-
le, da floresto amazonica para a na $\mathrm{L}$ ero Eadero. Esta em toda parte, como alma da terra e da race. Suas aventuras reproduzm o folk-Jore brasleiro, as poss as mantiss, a nowsos escoctes, of nosfundo de e nidicutos, e tambena lova a realiar arandes colsas que nos bermos

E. Ai. que presuiça

E sistir muttas veses, do methor tac de uma obra do sr. Mario Andrade Fol elle um dos rebentos mais revolucionarios surgidos na famosa Semana da Arte Moderna. Escreveu toda sorte de poemas kaleidoscopios, procurando achincalhar tudo que cheirava " "feito", o "preyarado". o "usado", classificados com rotulo geral de passadismo.

Arranjou uma escrava que náo era Isaura so para fazer pirraca a Bernardo Guimaráes e um indis que náo era Pery, ineileira e seris capaz de cousas muito peores para banir o postico em nossa peores para

B que resultou de tudo isso? Resultou que sua escrava sem ser Isaura tornou-se menos Imana e mais irritante do que a do saudoso Bernardo Guimarấes - que a sua fala brasileira parecen mais estranha a os brasileiros que as protuberancias lexicas do sr. Coetho Netto 1. que trouxe ene ainda sos nossos dade nessers movimentos, a impressfeer. que quem nfo sente os nho vire na su creacio, mas que se colloca por detrax della, como si estivesse a atirar petardos numa multidao e esperar os effeitos, rindo de gozo comsitgo mesmo.

Entretanto, si tal feitio sensivel a printpio na obra do escriptor, ainda hoje e manifesta, nilo podemos deixar de Alatinguir na actividade creadors do sr. Marno de Andrade, um momento felin. momento notavel, em que as voses espontaneas - Illuminadas do seu espirito mador. E' "Macunaima ". Publicado ba ceren te des annos, quanids ainda estavam en 1000 as polemicas modernistas. esue ivro quasi nío leve repercusalio.
o sr. Marlo Andrade acabava de rea-

quando já estava prestos a alcaxçal-o. O autor desperta no seu heróe todas as a gente.

-Macunsima" é a vislo allucinada do reverso da medatha que esquecemos de co e convencional o Braesl academieo, urado dessa Hteratura contra a gual \%. Mario Andrade tanto imprecara naouelle tempo.

A carta de Mscunnima is Amaromas e ima satyra deliciosa e tafvez uma da melhores cousas do livro.

Outros trechas que nos seria diffici? aspectos mais typicos. E nma poes is st. tresuando resina, uma poesia sos

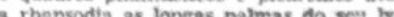

ismo tropical.
Para tornar o tivo mais acoessivel o r. Mario Andrade devia collocar no fim benas empregados.

alva de tudo ounto obra que se recernastico, E o Mario de Andrade, que com seu ar de diletante parece nfo wi: coe livmo toda a adhesto do seu expirito din ma sensibilidade. - R. B.

\section{"Um violine na sombra..."}

Versos de Guilherme de Figueiredo

O m. Qutherme Firuetredo abre sen 


\section{A EPOPÉIA DE UM HERÓI SEM NENHUM CARÁTER}

B. B. [Brito Broca]. "A epopéia de um herói sem nenhum caráter. A reedição de Macunaíma, de Mário de Andrade”. A Gazeta: São Paulo, 25 de fevereiro de 1937. FCL-CEDOC.

Não há nada mais artificial, no fundo, do que o desinteresse pela literatura afetado por certos intelectuais. Esse desinteresse os leva, às vezes, a descrer inteiramente dos processos literários para exprimir a verdade da vida, e esforçar-se por criar uma série de valores absolutamente novos que pelo seu cunho forçado e proposital recaem num artificialismo muito pior ainda.

Não devemos acreditar muito na literatura, mas o desprezo dos "poncifs"," dos "clichés” batidos, das fórmulas convencionais não implica o desdém e ceticismo com que alguns escritores, atacados de novidade, procuram demolir a disciplina e a harmonia dos meios de expressão. O afã exagerado de fugir de certas praxes acaba por constituir também uma praxe, uma norma; o desejo de criar um estilo diferente que consista afinal numa ausência absoluta de estilo; a intenção sempre visível de dizer as coisas de uma maneira antiliterária redunda numa afetação e num esnobismo que acabam por afastar o escritor da sua obra. Só receiam o convencionalismo os que, pela formação intelectual, se sentem ameaçados por ele. Um escritor sincero e humano deve escrever como pensa sem a preocupação de fazer o moderno ou fazer o antigo, de fugir do estilo ou de cair na literatura. A verdadeira arte incorporada à vida e em função desta dispensa os manifestos e fala pela espontaneidade de suas próprias criações.

Já não é a primeira vez que nos ocorrem essas considerações diante de uma obra do sr. Mário de Andrade. Foi ele um dos rebentos mais revolucionários surgidos na famosa Semana da Arte Moderna. Escreveu toda sorte de poemas caleidoscópios, procurando achincalhar tudo que cheirava o "feito”, o “preparado”, o “usado”, classificados com o rótulo geral de passadismo.

\footnotetext{
${ }^{17}$ Banalidades.
} 
Arranjou uma escrava que não era Isaura ${ }^{18}$ só para fazer pirraça a Bernardo Guimarães e um índio que não era Peri ${ }^{19}$, inventou uma gramatiquinha de fala brasileira e seria capaz de coisas muito piores para banir o postiço em nossa literatura.

E que resultou de tudo isso? Resultou que a sua escrava sem ser Isaura tornou-se menos humana e mais irritante do que a do saudoso Bernardo Guimarães e que a sua fala brasileira pareceu mais estranha aos brasileiros que as protuberâncias léxicas do sr. Coelho Neto. E o que trouxe ele ainda aos nossos olhos foi uma certa falta de sinceridade nesses movimentos, a impressão de que quem não sente e não vive na sua criação, mas que se coloca por detrás dela, como se estivesse a atirar petardos numa multidão e esperar os efeitos, rindo de gozo consigo mesmo.

Entretanto, se tal feitio sensível a princípio na obra do escritor ainda hoje se manifesta, não podemos deixar de distinguir na atividade criadora do sr. Mário de Andrade um momento feliz, momento notável em que as vozes espontâneas e iluminadas do seu espírito triunfavam de todo o esnobismo reformador. É Macunaíma. Publicado há cerca de dez anos, quando ainda estavam em foco as polêmicas modernistas, esse livro quase não teve repercussão.

O sr. Mário de Andrade acabava de realizar uma porção de espalhafatos literários e a sua obra-prima passou, para muitos, como mais uma molecagem do homem que escrevia os versos de Remate de males e Losango cáqui. Hoje, aparecendo em segunda edição (Livraria José Olympio), Macunaíma merece ser colocado no lugar que lhe compete, na literatura brasileira. É verdade que ainda encontramos nessas páginas alguma coisa do Mário de Andrade postiço e antipático, mas o conjunto é natural, espontâneo e cheio de viva e fremente simpatia.

O livro constitui, por assim dizer, uma mitologia caricatural do nosso povo. Reagindo contra as sugestões da mentalidade européia e os modelos estrangeiros em nossos romances, Mário de Andrade foi buscar um herói no fundo do mato virgem, na figura desse preto retinto, filho do medo da noite com a índia tapanhumas.

Como herói mitológico, Macunaíma não se localiza no tempo nem no espaço. Vai do norte para o sul, de leste para oeste, da floresta amazônica para rua Líbero Badaró. Está em toda parte, como a alma da terra e da raça. Suas aventuras reproduzem o folclore brasileiro, as nossas manias, os nossos cacoetes, os nossos defeitos e ridículos, e também o fundo de ingenuidade e bravura que nos leva a realizar grandes coisas sem sabermos.

\footnotetext{
${ }^{18}$ Referência ao livro A escrava que não é Isaura (1925), poética modernista de Mário de Andrade, cujo título parodia o do romance A escrava Isaura (1875), de Bernardo Guimarães, no ano comemorativo do cinqüentenário dessa obra representativa do romantismo.

${ }^{19}$ Possível alusão a Macunaíma, herói da obra homônima de Mário de Andrade.
} 
— Ai, que preguiça!

É o estribilho com que Macunaíma entremeia as suas aventuras e que o faz desistir muitas vezes do melhor bocado, quando já estava prestes a alcançá-lo.

O autor desperta no seu herói todas as vozes inconscientes e recalcadas da nossa gente.

Macunaíma é a visão alucinada do reverso da medalha que esquecemos de procurar na face de um Brasil formalístico e convencional, o Brasil acadêmico, saturado dessa literatura contra a qual o sr. Mário de Andrade tanto imprecava naquele tempo.

A carta de Macunaíma às Amazonas é uma sátira deliciosa e talvez uma das melhores coisas do livro.

Outros trechos que nos seria difícil citar aqui revivem o brasileiro nos seus aspectos mais típicos. E uma poesia sã, tressuando resina, uma poesia bárbara, nativa, indígena estende sobre os quadros fantásticos e picarescos ${ }^{20}$ dessa rapsódia as longas palmas do seu lirismo tropical.

Para tornar o livro mais acessível, o sr. Mário de Andrade devia colocar no fim um glossário dos termos dialetais e indígenas empregados.

Macunaíma é uma obra que se ressalva de tudo quanto o autor tem feito de pernóstico. E o sr. Mário de Andrade, que com seu ar de diletante parece não viver as suas criações artísticas, deu a esse livro toda a adesão do seu espírito e da sua sensibilidade.

B. B. [BRITO BROCA]

\footnotetext{
${ }^{20}$ No jornal, lê-se “picaremos”. Erro tipográfico.
} 


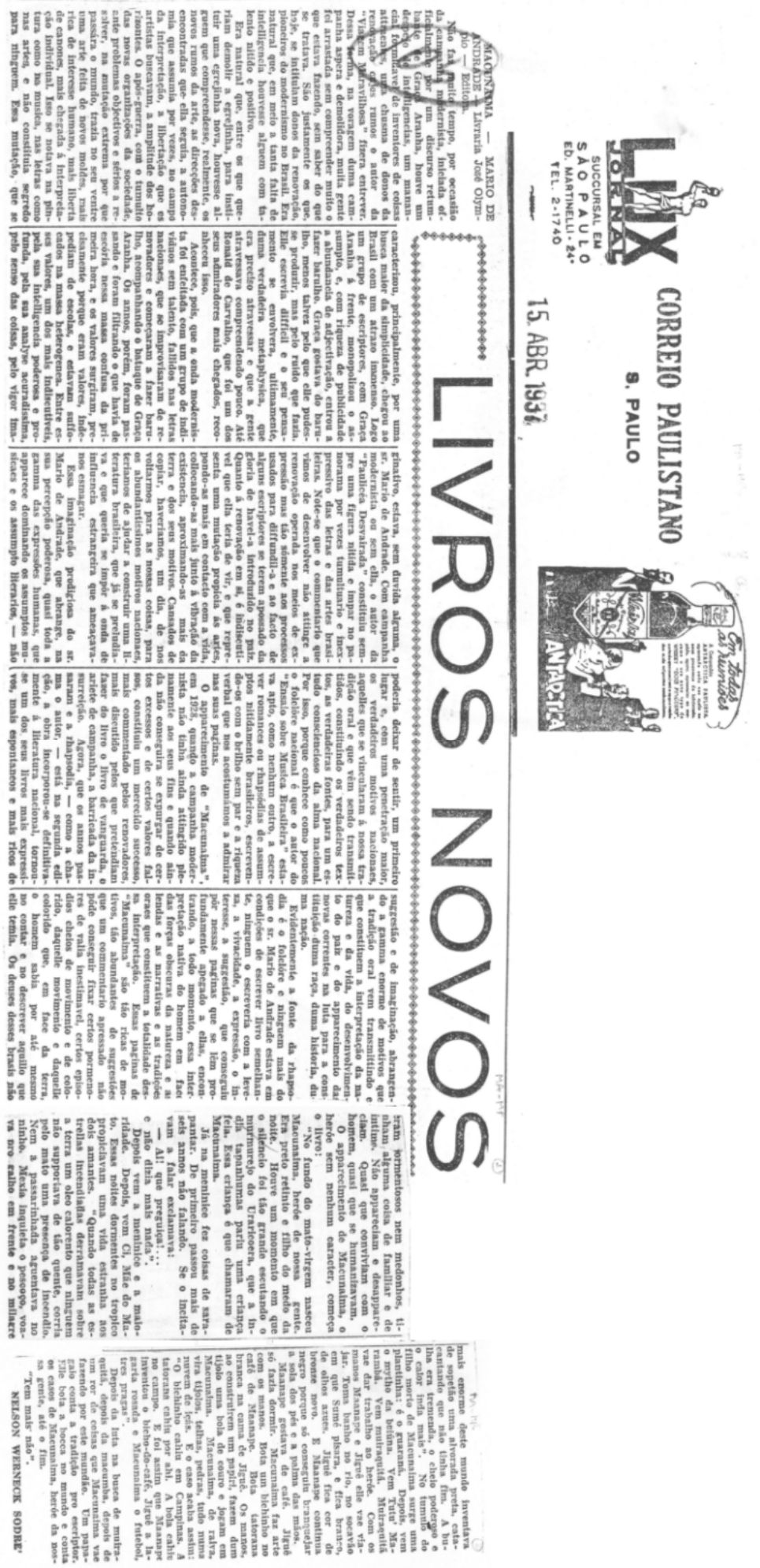




\section{MACUNAÍMA - MÁRIo de ANDRAdE - LiVRARIA JosÉ OlyMPIo EdiTORA}

SODRÉ, Nelson Werneck. "Livros novos / Macunaíma - Mário de Andrade - Livraria José Olympio Editora”. Correio Paulistano: São Paulo, 15 de abril de 1937. IEB-USP - MA-MP.

Não faz muito tempo, por ocasião da campanha modernista, iniciada oficialmente por um discurso retumbante de Graça Aranha, houve um despejo de inteligências, um manancial formidável de inventores de coisas atraentes, uma chusma de donos da renovação cujos rumos o autor da Viagem maravilhosa ${ }^{21}$ fizera entrever. Dessa forma, na voragem duma campanha áspera e demolidora, muita gente foi arrastada sem compreender muito o que estava fazendo, sem saber do que se tratava. São justamente os que, hoje, se intitulam donos da renovação, pioneiros do modernismo no Brasil. Era natural que, em meio a tanta falta de inteligência[,] houvesse alguém com talento nítido e positivo.

Era natural que, entre os que queriam demolir a igrejinha, para instituir uma igrejinha nova, houvesse alguém que compreendesse, realmente, os novos rumos da arte, as direções desencontradas que ela seguia, a autonomia que assumia por vezes, no campo da interpretação, a libertação que os artistas buscavam, a amplitude dos horizontes. O após-guerra, com o tumulto das novas organizações da sociedade, ante problemas objetivos e sérios a resolver, na mutação extrema por que passara o mundo, trazia no seu ventre uma arte feita de novos moldes, mais rica de interesse humano, mais liberta de cânones, mais chegada à interpretação individual. Isso se notava na pintura como na música, nas letras como nas artes, e não constituía segredo para ninguém. Essa mutação, que se caracterizou, principalmente, por uma busca maior da simplicidade, chegou ao Brasil com um atraso imenso. Logo um grupo de escritores, com Graça Aranha à frente, monopolizou o assunto e, com riqueza de publicidade e abundância de adjetivação, entrou a fazer barulho. Graça gostava do barulho, menos talvez pelo que ele pudesse produzir, mas pelo ruído que fazia. Ele escrevia difícil e o seu pensamento se envolvera, ultimamente, duma verdadeira metafísica, que era preciso atravessar e que a gente atravessava compreendendo pouco. Até Ronald de Carvalho, que foi um dos seus admiradores mais chegados, reconheceu isso.

Acontece, pois, que a onda modernista foi enfeitada com um grupo de indivíduos sem talento, falidos nas letras nacionais, que se improvisaram de renovadores e começaram a fazer

\footnotetext{
${ }^{21}$ Romance de ArAnHA, Graça. A viagem maravilhosa. Rio de Janeiro / Paris: Garnier, 1929.
} 
barulho, acompanhando o batuque de Graça Aranha. Os anos, porém, foram passando e foram filtrando o que havia de escória nessa massa confusa da primeira hora, e os valores surgiram, precisamente porque eram valores, independiam de escolas, e estavam sufocados na massa heterogênea. Entre esses valores, um dos mais indiscutíveis, pela sua inteligência poderosa e profunda, pela sua análise acuradíssima, pelo senso das coisas, pelo vigor imaginativo, estava, sem dúvida alguma, o sr. Mário de Andrade. Com campanha modernista ou sem ela, o autor da Paulicéia desvairada constituiu sempre uma figura nítida e ímpar no panorama por vezes tumultuário e inexpressivo das letras e das artes brasileiras. Note-se que o comentário que vimos de desenvolver não atinge a renovação operada nos meios de expressão mas tão somente aos processos usados para difundi-la e ao fato de alguns escritores se terem apossado da glória de havê-la introduzido no país. Quanto à renovação em si, é indiscutível que ela teria de vir, e que representa uma mutação propícia às artes, pondo-as mais em contato com a vida, colocando-as mais junto à vibração da existência, aproximando-as mais da terra e dos seus motivos. Cansados de copiar, haveríamos, um dia, de nos voltarmos para as nossas coisas, para os abundantíssimos motivos nacionais, teríamos de ajudar a construir uma literatura brasileira, que já se preludiava e que queria se impor à onda de influência estrangeira que nos ameaçava esmagar ${ }^{22}$.

Essa imaginação prodigiosa do sr. Mário de Andrade, que abrange, na sua percepção poderosa, quase toda a gama das expressões humanas, que aparece dominando os assuntos musicais e os assuntos literários, - não poderia deixar de sentir, em ${ }^{23}$ primeiro lugar e, com uma penetração maior, os verdadeiros motivos nacionais, aqueles que se vincularam à nossa tradição oral e que vêm sendo transmitidos, constituindo os verdadeiros textos, as verdadeiras fontes, para um estudo consciencioso da alma nacional. Por isso, porque conhece como poucos o folclore nacional é que o autor do Ensaio sobre música brasileira estava apto, como nenhum outro, a escrever romances ou rapsódias de assuntos nitidamente brasileiros, escrevendo-os com o brilho sem par e a riqueza verbal que nos acostumamos a admirar nas suas páginas.

O aparecimento de Macunaíma, em 1928, quando a campanha modernista não tinha ainda atingido plenamente aos seus fins e quando ainda não conseguira se expurgar de certos excessos e de certos valores falsos, constituiu um merecido sucesso, mais comentado pelos renovadores, mais discutido pelos que pretendiam fazer do livro o livro de vanguarda, o aríe-

\footnotetext{
${ }^{22}$ No jornal, lê-se “(...) que ameaçava-nos esmagar.”

${ }^{23}$ No jornal, lê-se “um”. Erro tipográfico.
} 
$\mathrm{te}^{24}$ de campanha, a barricada da insurreição. Agora, que os anos passaram e a rapsódia - como a chama o autor - está na segunda edição, a obra incorporou-se definitivamente à literatura nacional, tornou-se, um dos seus livros mais expressivos, mais espontâneos e mais ricos de sugestão e de imaginação, abrangendo a gama enorme de motivos que a tradição oral vem transmitindo e que constituem a interpretação da natureza e da vida, do desenvolvimento do país e do aparecimento das novas correntes na luta para a constituição duma raça, duma história, duma nação.

Evidentemente a fonte da rapsódia é o folclore e ninguém mais do que o sr. Mário de Andrade estava em condições de escrever livro semelhante, ninguém o escreveria com a leveza, a vivacidade, a expressão, o interesse, a sugestão, que conseguiu pôr nessas páginas que se lêem profundamente apegado a elas, encontrando, a todo momento, essa interpretação nativa do homem em face das forças obscuras da natureza e as lendas e as narrativas e as tradições orais que constituem a totalidade dessa interpretação. Essas páginas de Macunaíma são tão ricas de motivos, tão abundantes de sugestões que um comentário apressado não pode conseguir fixar certos pormenores de valia inestimável, certos episódios cheios de movimento e de colorido, daquele movimento e daquele colorido que, em face da terra, o homem sabia por até mesmo no contar e no descrever aquilo que ele temia. Os deuses desses brasis não eram tormentosos nem medonhos, tinham alguma coisa de familiar e de íntimo. Não apareciam e desapareciam. Quase que conviviam com o homem, quase que se humanizavam.

O aparecimento de Macunaíma, o herói sem nenhum caráter, começa o livro:

“No fundo do mato-virgem nasceu Macunaíma, herói de nossa gente. Era preto retinto e filho do medo da noite. Houve um momento em que o silêncio foi tão grande escutando o murmurejo do Uraricoera, que a índia tapanhumas pariu uma criança feia. Essa criança é que chamaram de Macunaíma.

Já na meninice fez coisas de sarapantar. De primeiro passou mais de seis anos não falando. $\mathrm{Si}^{25} \mathrm{o}$ incitavam a falar exclamava:

— Ai! que preguiça!...

e não dizia mais nada.”.

Depois vem a meninice e a maioridade. Depois, vem Ci, Mãe do Mato. Essas noites dormentes no trópico propiciavam uma vida estranha aos dois amantes. "Quando todas as estrelas incendiadas derramavam sobre a terra um óleo calorento que ninguém não suportava

\footnotetext{
${ }^{24}$ No jornal, lê-se "ariete”.

${ }^{25}$ No jornal, lê-se “Se”.
} 
de tão quente, corria pelo mato uma presença de incêndio. Nem a passarinhada agüentava no ninho. Mexia inquieta o pescoço, voava pro galho em frente e no milagre mais enorme deste mundo inventava, de sopetão uma alvorada preta, cantacantando ${ }^{26}$ que não tinha fim. A bulha era tremenda o cheiro poderoso e o calor inda mais”. No túmulo do filho morto de Macunaíma surge uma plantinha: é o guaraná. Depois, vem o mito da boiúna. Vem Tutu Marambá. Vem muiraquitã. Muiraquitã vai dar trabalho ao herói. Com os manos Maanape e Jiguê ele vai viajar. Toma banho no rio, no socavão em que Sumé pisara, e fica branco, de olhos azuis. Jiguê fica cor de bronze novo. E Maanape continua negro porque só conseguiu branquejar a sola dos pés e a palma das mãos.

Maanape gostava de café. Jiguê só fazia dormir. Macunaíma faz arte com os manos. Bota um bichinho no café de Maanape. Bota tatorana branca na cama de Jiguê. Os manos, ao construírem um papiri, fazem dum tijolo uma bola de couro e jogam em Macunaíma. Macunaíma, de raiva, vira tijolos, telhas, pedras, tudo numa nuvem de içás. E o caso acaba assim: “O bichinho caiu em Campinas. A tatorana caiu por aí. A bola caiu no campo. E foi assim que Maanape inventou o bicho-do-café, Jiguê a lagarta rosada e Macunaíma o futebol, três pragas”.

Depois da luta na busca de muiraquitã, depois da macumba, depois de um ror de coisas que Macunaíma vai fazendo por este mundão. Um papagaio conta a tradição pro escritor. Ele bota a boca no mundo e conta os casos de Macunaíma, herói da nossa gente, até o fim. “Tem mais não”.

NELSON WERNECK SODRÉ

\footnotetext{
${ }^{26}$ No jornal, lê-se "catacantando", forma que aparece na segunda edição (1937) de Macunaíma; na primeira (1928), lê-se "cantacantando".
} 


\section{Os Defeitos de Macunaíma}

BragA, Rubem. “Os defeitos de Macunaíma”. Folha da Manhã: São Paulo, 04 de maio de $1937 .{ }^{27}$

Macunaíma apareceu em $2^{\underline{a}}$ edição, o que aliás não quer dizer que esteja ganhando público. Mário de Andrade continua sendo um literato ${ }^{28}$ muito pouco lido, apesar de seu valor. E a culpa é dele. Mário pegou um jeito de escrever que seria popular se não fosse precioso. Ele faz parte de um pequeno clube fechado de gastrônomos que há em São Paulo. E faz gastronomia na linguagem também - o paladar do povo é simples. Se Mário de Andrade fosse preparar um vatapá, ele faria um vatapá tão bem feito, tão em regra, tão profundamente baiano, seguindo tantas recomendações de regras especialistas, que nenhum baiano gostaria do vatapá dele. Foi para a extrema esquerda da língua. Reagindo contra a aristocracia do fraseado solene e a hierarquia difícil dos pronomes, ele caiu no populismo mais difícil e precioso. Em Macunaíma isso se explica, isso faz parte do livro. A linguagem, aí, está combinando com a ação, com o espírito do livro. Está direito. Apesar disso eu estimaria que alguém fizesse um livro com todo esse material precioso de Macunaíma, todo esse mundo de lendas e de falas brasileiras, de um jeito que fosse accessível ao leitor comum. Um livro onde um brasileiro se embrasileirasse mais, se reconhecesse e se aprendesse. Pelo fato de ser um livro diferente dos outros, muitos exageram o valor de Macunaíma. Impressionados pela montanha de sugestões e de "achados" do livro, começam a dizer que ele será uma obra clássica. Esquecem que na verdade é um bloco de onde poderia sair um verdadeiro livro, é uma façanha, uma proeza grande e bonita de inteligência, e nada mais. Eu digo “e nada mais” porque isso para um sujeito com as possibilidades de Mário de Andrade, é mesmo muito pouco. Para usar a linguagem do seu herói ele "experimentou força”. Prova que tinha muita. E quase que ficou nisso. Mas deixemos o autor e vamos ao herói, que não tem nenhum caráter. Na verdade tem algum. Tem, por exemplo, uma simpatia contínua. É medroso, preguiçoso, mentiroso e semvergonha, mas não é mau sujeito. O que ele quer é gozar, como aquele macaco da anedota. Eu gostaria que ele fosse um pouco mais consistente, pois em certos pedaços do livro sinto que o herói anda no vácuo. Mas depois reage porque já ganhou uma figura própria, já tem o seu

\footnotetext{
${ }^{27}$ Imagem do documento não recuperada pela pesquisa. Texto reproduzido de Banco de Dados Folha - Acervo de Jornais: http://www1.folha.uol.com.br/folha/almanaque/semana5.htm/, com ortografia atualizada.

${ }^{28}$ No texto publicado no site, lê-se "literario".
} 
caráter e se impõe ao autor. O que prejudica uma certa continuidade do herói é ter o autor metido no livro, que deve ter sido feito às pressas, umas coisas que são interessantes em si, mas que ficam deslocadas. O herói tem de viver essas coisas, e vive a contragosto. Sente-se que ele “não está em casa”. Há, na realidade, material que poderia ser jogado fora com proveito, porque destoa do resto. Sente-se a pressa do trabalho. O autor, em certos momentos, foi impressionado pelos processos de ação do herói esquecendo, que, quanto mais absurdos forem os personagens e mais louca for a ação, mais prudente e lógico deve se manter o autor encarregado de contar aquela desordem. Acho que o próprio Mário deve sentir hoje esses defeitos de Macunaíma que, por outro lado, ele não pode corrigir, porque não há nada que seja um fato mais consumado que um livro que a gente já escreveu.

RUBEM BRAGA 


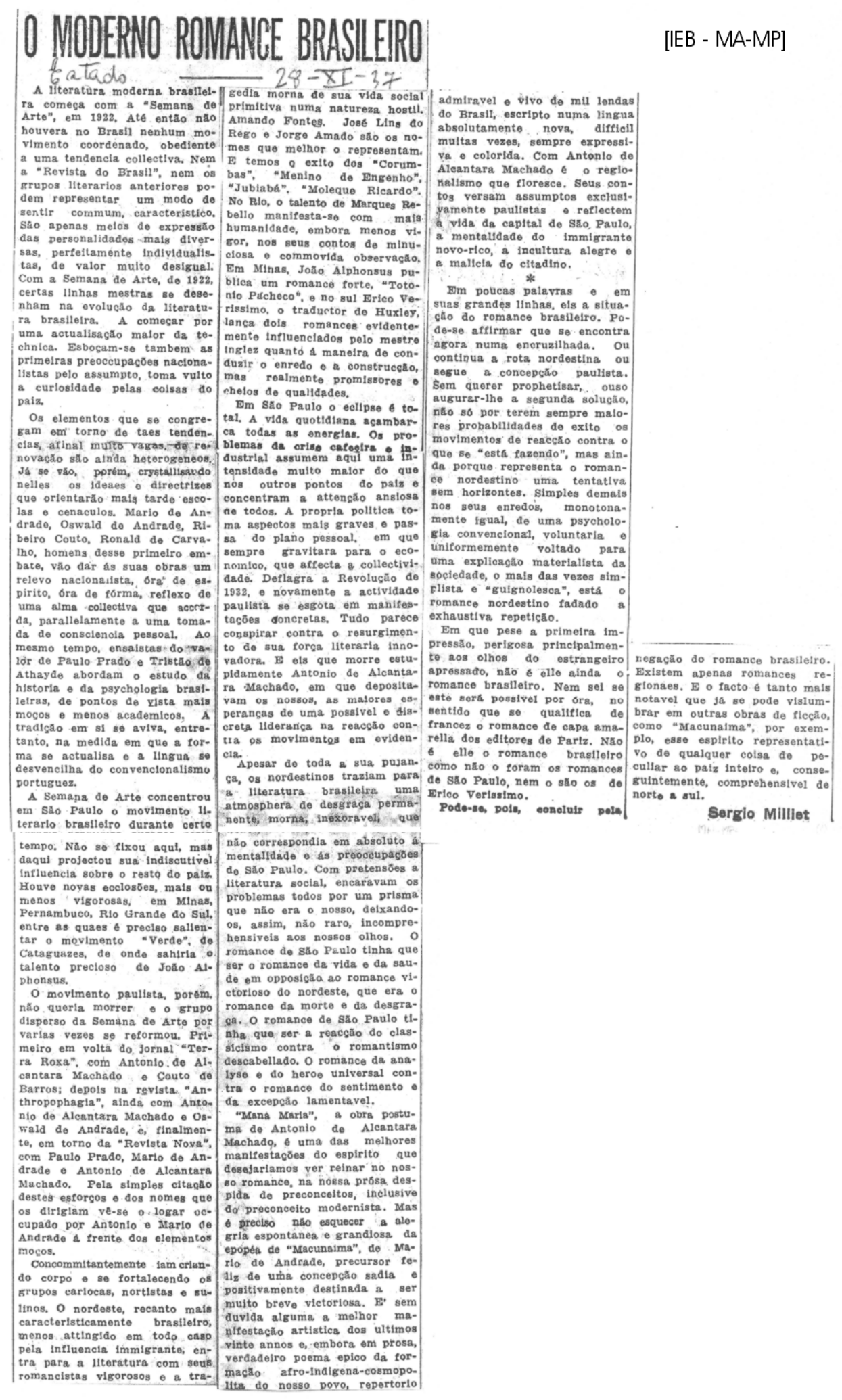




\section{O MODERNo ROMANCE BRASILEIRO}

MiLLIET, Sérgio. “O moderno romance brasileiro”. O Estado de S. Paulo: São Paulo, 28 de novembro de 1937. IEB-USP - MAMP. Recolhido em MiLLIET, Sérgio. Ensaios. São Paulo: Brusco, 1938, p. 183-187.

A literatura moderna brasileira começa com a "Semana de Arte”, em 1922. Até então não houvera no Brasil nenhum movimento coordenado, obediente a uma tendência coletiva. Nem a Revista do Brasil, nem os grupos literários anteriores podem representar um modo de sentir comum, característico. São apenas meios de expressão das personalidades mais diversas, perfeitamente individualistas, de valor muito desigual. Com a Semana da Arte, de 1922, certas linhas mestras se desenham na evolução da literatura brasileira. A começar por uma atualização maior da técnica. Esboçam-se também as primeiras preocupações nacionalistas pelo assunto, toma vulto a curiosidade pelas coisas do país.

Os elementos que se congregam em torno de tais tendências, afinal muito vagas, de renovação são ainda heterogêneos. Já se vão, porém, cristalizando neles os ideais e diretrizes que orientarão mais tarde escolas e cenáculos. Mário de Andrade, Oswald de Andrade, Ribeiro Couto, Ronald de Carvalho, Menotti del Picchia, Guilherme de Almeida ${ }^{29}$, homens desse primeiro embate, vão dar às suas obras um relevo nacionalista, ora de espírito, ora de forma, reflexo de uma alma coletiva que acorda, paralelamente a uma tomada de consciência pessoal. Ao mesmo tempo, ensaístas do valor de Paulo Prado e Tristão de Ataíde abordam o estudo da história e da psicologia brasileiras, de pontos de vista mais moços e menos acadêmicos ${ }^{30}$. A tradição em si se aviva, entretanto, na medida em que a forma se atualiza e a língua se desvencilha do convencionalismo português.

A Semana de Arte concentrou em São Paulo o movimento literário brasileiro durante certo tempo. Não se fixou aqui, mas daqui projetou sua indiscutível influência sobre o resto do país. Houve novas eclosões, mais ou menos vigorosas, em Minas, Pernambuco, Rio Grande do Sul, entre as quais é preciso salientar o movimento Verde, de Cataguases, de onde sairia o talento precioso de João Alphonsus.

\footnotetext{
${ }^{29}$ Os nomes de Menotti del Picchia e de Guilherme de Almeida não constam no texto do jornal; foram acrescentados na edição em livro (1938).

${ }^{30}$ Na edição em livro (1938), lê-se “(...) de pontos de vista menos acadêmicos.”
} 
O movimento paulista, porém, não queria morrer e o grupo disperso da Semana de Arte por várias vezes se reformou. Primeiro em volta do jornal Terra Roxa, com Antônio de Alcântara Machado e Couto de Barros; depois na revista Antropofagia, ainda com Antônio de Alcântara Machado e Oswald de Andrade, e, finalmente, em torno da Revista Nova, com Paulo Prado, Mário de Andrade e Antônio de Alcântara Machado. Pela simples citação destes esforços e dos nomes que os dirigiam vê-se o lugar ocupado por Antônio e Mário de Andrade à frente dos elementos moços.

Concomitantemente iam criando corpo e se fortalecendo os grupos cariocas, nortistas e sulinos. O nordeste, recanto caracteristicamente brasileiro, menos atingido em todo caso pela influência imigrante, entra para a literatura com seus romancistas vigorosos e a tragédia morna de sua vida social primitiva numa natureza hostil. Amando Fontes, José Lins do Rego e Jorge Amado são os nomes que melhor o representam. E temos o êxito dos Corumbas, Menino de engenho, Jubiabá, Moleque Ricardo. No Rio, o talento de Marques Rebello manifestase com mais humanidade, embora menos vigor, nos seus contos de minuciosa e comovida observação. Em Minas, João Alphonsus publica um romance forte Totonio Pacheco, e no sul Érico Veríssimo, o tradutor de Huxley, lança dois romances evidentemente influenciados pelo mestre inglês quanto à maneira de conduzir o enredo e a construção, mas realmente promissores e cheios de qualidades.

Em São Paulo o eclipse é total. A vida quotidiana açambarca todas as energias. Os problemas da crise cafeeira e industrial assumem aqui uma intensidade muito maior do que nos outros pontos do país e concentram a atenção ansiosa de todos. A própria política toma aspectos mais graves e passa do plano pessoal, em que sempre gravitara[,] para o econômico, que afeta a coletividade. Deflagra a Revolução de 1932, e novamente a atividade paulista se esgota em manifestações concretas. Tudo parece conspirar contra o ressurgimento de sua força literária inovadora. E eis que morre estupidamente Antônio de Alcântara Machado, em quem depositavam os nossos as maiores esperanças de uma possível e discreta liderança na reação contra os movimentos em evidência.

Apesar de toda a sua pujança, os nordestinos traziam para a literatura brasileira uma atmosfera de desgraça permanente, morna, inexorável, que não correspondia em absoluto à mentalidade e às preocupações de São Paulo. Com pretensões a literatura social, encaravam os problemas todos por um prisma que não era o nosso, deixando-os, assim, não raro, incompreensíveis aos nossos olhos. O romance de São Paulo tinha que ser o romance da vida e da saúde em oposição ao romance vitorioso do nordeste, que era o romance da morte e da des- 
graça. O romance de São Paulo tinha que ser a reação do classicismo contra o romantismo descabelado. O romance da análise e do herói universal contra o romance do sentimento e da exceção lamentável.

Mana Maria, a obra póstuma de Antônio de Alcântara Machado, é uma das melhores manifestações do espírito que desejaríamos ver reinar no nosso romance, na nossa prosa despida de preconceitos, inclusive do preconceito modernista. Mas é preciso não esquecer a alegria espontânea e grandiosa da epopéia de Macunaíma, de Mário de Andrade, precursor feliz de uma concepção sadia [e positivamente destinada a ser muito breve vitoriosa] ${ }^{31}$. É sem dúvida alguma a melhor manifestação artística dos últimos vinte anos e, embora em prosa, verdadeiro poema épico da formação afro-indígena-cosmopolita do nosso povo, repertório admirável e vivo de mil lendas do Brasil, escrito numa língua absolutamente nova, difícil muitas vezes, sempre expressiva e colorida. Com Antônio de Alcântara Machado é o regionalismo que floresce. Seus contos versam assuntos exclusivamente paulistas e refletem a vida da capital de São Paulo, a mentalidade do imigrante novo-rico, a incultura alegre e a malícia do citadino.

Em poucas palavras e em suas grandes linhas, eis a situação do romance brasileiro. Pode-se afirmar que se encontra agora numa encruzilhada. Ou continua a rota nordestina ou segue a concepção paulista. Sem querer profetizar, ouso augurar-lhe a segunda solução, não só por terem sempre maiores probabilidades de êxito os movimentos de reação contra o que se “está fazendo”, mas ainda porque representa o romance nordestino uma tentativa sem horizontes. Simples demais nos seus enredos, monotonamente igual, de uma psicologia convencional, voluntária e uniformemente voltado para uma explicação materialista da sociedade, o mais das vezes simplista e "guignolesca”, está o romance nordestino fadado a exaustiva repetição.

Em que pese a primeira impressão, perigosa principalmente aos olhos do estrangeiro apressado, não é ele ainda o romance brasileiro. Nem sei se este será possível por ora, no sentido que se qualifica de francês o romance de capa amarela dos editores de Paris. Não é ele o romance brasileiro como não o foram os romances de São Paulo, nem o são os de Érico Veríssimo.

Pode-se, pois, concluir pela negação do romance brasileiro. Existem apenas romances regionais. E o fato é tanto mais notável que já se pode vislumbrar em outras obras de ficção,

\footnotetext{
${ }^{31} \mathrm{O}$ trecho entre colchetes foi suprimido na edição em livro (1938).
} 
como Macunaíma, por exemplo, esse espírito representativo de qualquer coisa de peculiar ao país inteiro e, conseguintemente, compreensível de norte a sul.

SÉRGIO MILLIET 
[Periódico não identificado, s/1, s/d. (1937?). IEB - MA-MP]

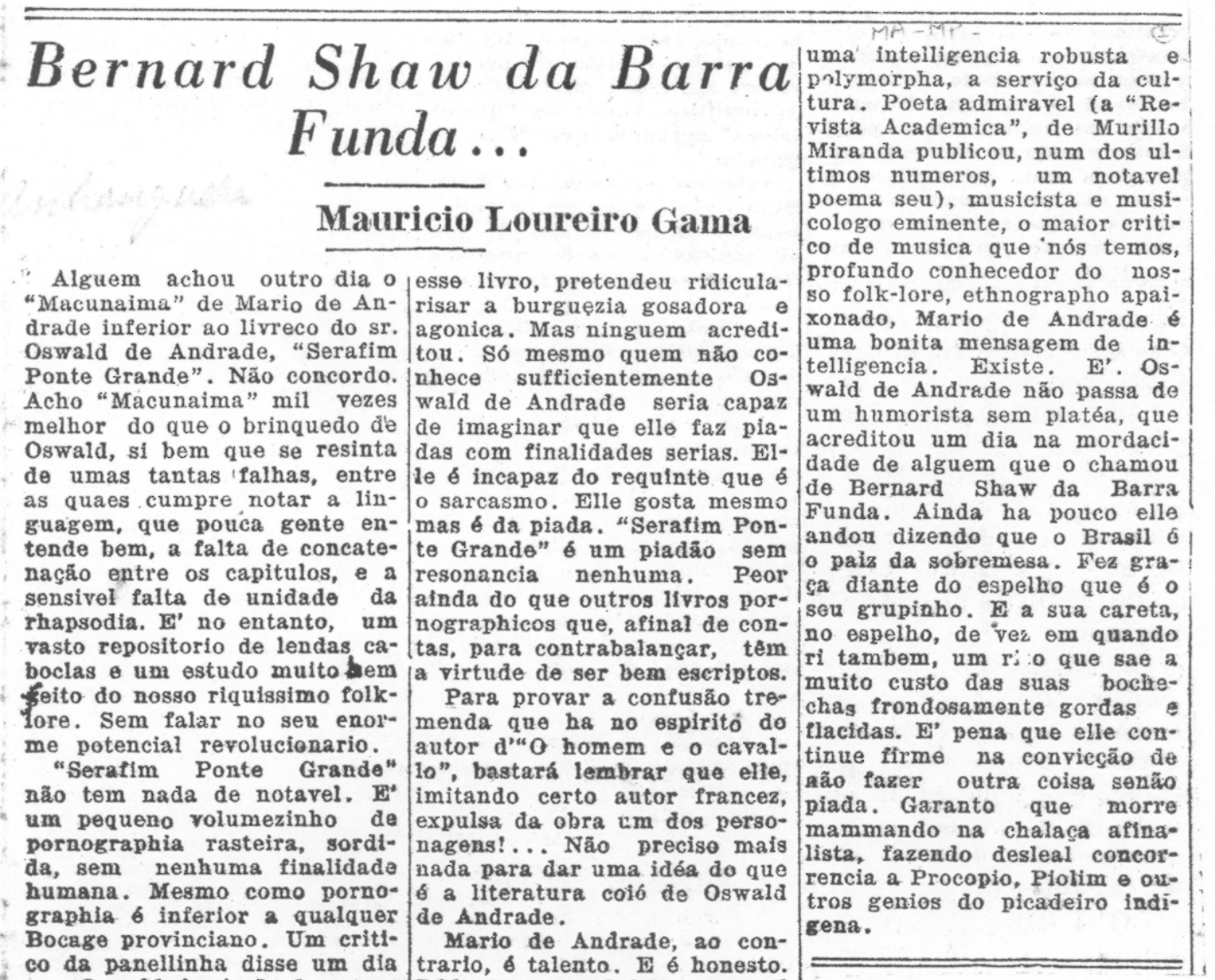




\section{BERNARD SHAW DA BARRA FUNDA}

GAMA, Maurício Loureiro. "Bernard Shaw da Barra Funda”. Periódico não identificado, s/l., s/d. ${ }^{32}$ IEB-USP MA-MP.

Alguém achou outro dia o Macunaíma de Mário de Andrade inferior ao livreco do sr. Oswald de Andrade, Serafim Ponte Grande. Não concordo. Acho Macunaíma mil vezes melhor do que o brinquedo de Oswald, se bem que se ressinta de umas tantas falhas, entre as quais cumpre notar a linguagem, que pouca gente entende bem, a falta de concatenação entre os capítulos e a sensível falta de unidade da rapsódia. É[,] no entanto, um vasto repositório de lendas caboclas e um estudo muito bem feito do nosso riquíssimo folclore. Sem falar no seu enorme potencial revolucionário.

Serafim Ponte Grande não tem nada de notável. É um pequeno volumezinho de pornografia rasteira, sórdida, sem nenhuma finalidade humana. Mesmo como pornografia é inferior a qualquer Bocage provinciano. Um crítico da panelinha disse um dia que Oswald de Andrade, com esse livro, pretendeu ridicularizar a burguesia gozadora e agônica. Mas ninguém acreditou. Só mesmo quem não conhece suficientemente Oswald de Andrade seria capaz de imaginar que ele faz piadas com finalidades sérias. Ele é incapaz do requinte que é o sarcasmo. Ele gosta mesmo é da piada. Serafim Ponte Grande é um piadão sem ressonância nenhuma. Pior ainda do que outros livros pornográficos que, afinal de contas, para contrabalançar, têm a virtude de ser bem escritos.

Para provar a confusão tremenda que há no espírito do autor de O homem e o cavalo, bastará lembrar que ele, imitando certo autor francês, expulsa da obra um dos personagens!... Não preciso mais nada para dar uma idéia do que é a literatura coió de Oswald de Andrade.

Mário de Andrade, ao contrário, é talento. E é honesto. Pode ter seus defeitos, mas é uma inteligência robusta e polimorfa, a serviço da cultura. Poeta admirável (a Revista Acadêmica, de Murilo Miranda[,] publicou, num dos últimos números, um notável poema seu, musicista e musicólogo eminente, o maior crítico de música que nós temos, profundo conhecedor do nosso folclore, etnógrafo apaixonado, Mário de Andrade é uma bonita mensagem de inte-

\footnotetext{
${ }^{32}$ Talvez seja um jornal chamado Anhanguera, a julgar por anotação manuscrita desse nome entre aspas, feita por Mário de Andrade no recorte que figura no álbum R.29 do IEB - Recortes de Mário de Andrade. Não há indicação de local, data e número de página da publicação; talvez, São Paulo, 1937. Outra hipótese: “Anhanguera” seria o pseudônimo do articulista, em outras publicações.
} 
ligência. Existe. É. Oswald de Andrade não passa de um humorista sem platéia, que acreditou um dia na mordacidade de alguém que o chamou de Bernard Shaw da Barra Funda. Ainda há pouco ele andou dizendo que o Brasil é o país da sobremesa. Fez graça diante do espelho que é o seu grupinho. E a sua careta, no espelho, de vez em quando ri também, um riso que sai a muito custo das suas bochechas frondosamente gordas e flácidas. É pena que ele continue firme na convicção de não fazer outra coisa senão piada. Garanto que morre mamando na chalaça afinalista, fazendo desleal concorrência a Procópio, Piolim e outros gênios do picadeiro indígena.

MAURÍCIO LOUREIRO GAMA 
1938 


\section{O MODERNO ROMANCE BRASILEIRO}

Milliet, Sérgio. “O moderno romance brasileiro”. Em: MiLliET, Sérgio. Ensaios. São Paulo: Brusco, 1938, p. 183-187. Reproduzido de $O$ Estado de S. Paulo: São Paulo, 28 de novembro de 1937. IEB-USP - MA-MP: p. 170-174 deste volume. 
1939 


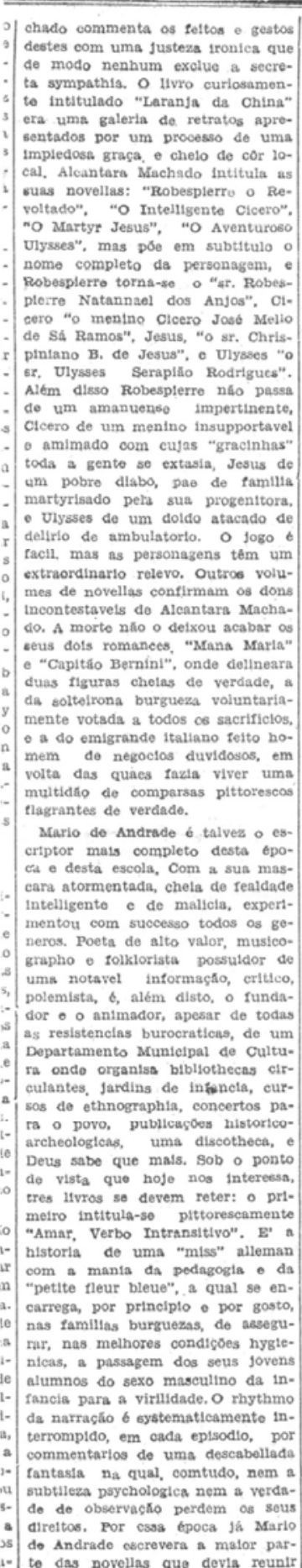

celtos e gestos sete annos depols sob o titulo do a erolur a secre bezazarto. Belazarto o a propria pillsta do povire da siande aldade faustosa, sem phrases, sem theorlas, "Belazarte" evoca misertas theorlas, "Belazartepungentes, repetindo a cada uma vidas assim...". $\mathbf{E}$ a sua linguagere é esse dilalecto saboroso, tncorrecto, chelo de formas negras e de consirucpoes italianas, que nasce do Lso quotidiano e do contacto de dez racas differentes mobre as rutnas da syntaxe portugueza clas-

Mas o grande lltro do Marto de Andrade, llvro absurdo, impossivel de classificar, burtesco como uma parodila, eplco como uma lenda, esso "Macunalma", O herce sem nenlium caracter, que elie publicou em 1928. para o cecrever, o autos vel de lentas indto numero possilos tirados de todos on dialectos de todos 05 calos talados do nore to no sul deser immeneo pata nut. proprio tero bay ito de mata. Eue Cessar, "ha alguns meacs". que se vla em diffleuldades pare entender - Hvro quando the acontecta reler - seu proprio textor E esta Incontineneta de palavras e de historias Bervo-lhe para narrar as aventuras terco-comicas de um Dous di mythologia indigena ao qual os avatares de um destino movimentado trazem um bello dia, do fundo da cua noresta virgem onde se comprazis nas delicias da pregulça da luxurra, ate a plens viah pautista moderna, entre as "machinas".

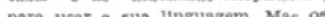
cara usar a sua linguagem. Mas os ceres hus a dues asue grande adveranto de "Macunalma" que "ne vids elvil" tem o nome de Wenceslau Pletro Pietra - itallano, evidentemento - mas que 0 ao mesmo tempo "o gigante Plafman, comedor de gente". Contar-vos as suag aventuras, o o seu regresso is selva natal, para ahi morrer do uma morto digna de um Deus a reapparecer no ceu sob a torma da Ursa Malor, sería correr o risco de ser demaetado longo. Mas "Macunaima" náo of apenas uma invença rintastica do autor: Marto de Anarade acverte-nos expresanmento do due devemos vor nelle "o heros do nosso bom dosensual, indifferente ao dia seguinte, inimigo do esforco prolongado a da continuldade nas idés, tendo por atvlsa e "lett-motiy", "At que pregulecal".

Sobre esto ultimo ponto Marto de Andrade, paulista apesar de tudo, talvez nao gostasse que o wo massemos á letra. Seja como tor, tenha ou náo valor symbolloo, todo o nvro estua de uma alegria poderosa, de uma erudiçá e de um dom verbal algnos de Rabelaits. A comparacto parecera talvez algo es. magadora, mas Marlo de Andrada homem da Renascença a seu modo nato o de moto atrum tadign della

Pierre Hóurcade 


\section{[TÍTULO IGNORADO] ${ }^{33}$}

HourCADE, Pierre. Título ignorado. Revista, 46: Rio de Janeiro, setembro de 1939 (2 $2^{\underline{a}}$ parte $)^{34}$. IEB-USP - MAMP.

\section{(...)}

Mário de Andrade é talvez o escritor mais completo desta época e desta escola [modernismo]. Com a sua máscara atormentada, cheia de fealdade inteligente e de malícia, experimentou com sucesso todos os gêneros. Poeta de alto valor, musicógrafo e folclorista possuidor de notável informação, crítico, polemista, é, além disso, o fundador e o animador, apesar de todas as resistências burocráticas, de um Departamento Municipal de Cultura onde organiza bibliotecas circulantes, jardins de infância, cursos de etnografia, concertos para o povo, publicações histórico-arqueológicas, uma discoteca, e Deus sabe que mais. Sob o ponto de vista que hoje nos interessa, três livros se devem reter: o primeiro intitula-se pitorescamente Amar, verbo intransitivo. É a história de uma “miss” alemã com a mania da pedagogia e da “petite fleur bleue”, a qual se encarrega, por princípio e por gosto, nas famílias burguesas, de assegurar, nas melhores condições higiênicas, a passagem dos seus jovens alunos do sexo masculino da infância para a virilidade. O ritmo da narração é sistematicamente interrompido, em cada episódio, por comentários de uma descabelada fantasia na qual, contudo, nem a sutileza psicológica nem a verdade de observação perdem os seus direitos. Por essa época já Mário de Andrade escrevera a maior parte das novelas que devia reunir sete anos depois sob o título de Belazarte. Belazarte é a própria voz da gente da rua, a voz do homem paulista, do pobre da grande cidade faustosa. Sem frases, sem teorias, Belazarte evoca misérias pungentes, repetindo a cada uma - é a sua filosofia: “Pois é... Há vidas assim...”. E a sua linguagem é esse dialeto saboroso, incorreto, cheio de formas negras e construções italianas, que nasce do uso cotidiano e do contato de dez raças diferentes sobre as ruínas da sintaxe portuguesa clássica.

\footnotetext{
${ }^{33}$ Observação manuscrita de Mário de Andrade, no recorte que se encontra no álbum R.29 do IEB - Recortes de Mário de Andrade -, informa tratar-se de texto de uma conferência proferida na Faculdade de Letras da Universidade de Lisboa.

${ }^{34}$ Identificação do periódico e da data de publicação: LoPEZ, Telê Porto Ancona. "Textos em periódicos". In: ANDRADE, Mário de. Macunaíma o herói sem nenhum caráter. Edição crítica de Telê Porto Ancona Lopez. Op. cit., 1978.
} 
Mas o grande livro de Mário de Andrade, livro absurdo, impossível de classificar, burlesco como uma paródia, épico como uma lenda, é esse Macunaíma, o herói sem nenhum caráter, que ele publicou em 1928. Para o escrever, o autor colecionou o maior número possível de lendas índias e de vocábulos tirados de todos os dialetos e de todos os calões falados do norte ao sul desse imenso país. Ele próprio teve a boa fé de me confessar, "há alguns meses”, que se via em dificuldades para entender o livro quando lhe acontecia reler o seu próprio texto! E esta incontinência de palavras e de histórias serve-lhe para narrar as aventuras heróicômicas de um Deus da mitologia indígena ao qual os avatares de um destino movimentado trazem um belo dia, do fundo da sua floresta virgem onde se comprazia nas delícias da preguiça e da luxúria, até à plena vida paulistana moderna, entre as “máquinas táxi” e as “máquinas telefones”, para usar a sua linguagem. Mas os seres humanos que encontra são também deuses a seu modo, como esse grande adversário de Macunaíma que "na vida civil” tem o nome de Venceslau ${ }^{35}$ Pietro Pietra - italiano, evidentemente - mas que é ao mesmo tempo “o gigante Piaimã, comedor de gente”. Contar-vos as suas aventuras e o seu regresso à selva natal, para aí morrer de uma morte digna de um Deus e reaparecer no céu sob a forma da Ursa Maior, seria correr o risco de ser demasiado longo. Mas Macunaíma não é apenas uma invenção fantástica do autor: Mário de Andrade adverte-nos expressamente de que devemos de ver nele “o herói de nosso bom povo”, como ele generoso, paciente, sensual, indiferente ao dia seguinte, inimigo do esforço prolongado e da continuidade nas idéias, tendo por divisa e "leitmotiv”: “Ai, que preguiça!...”

Sobre este último ponto Mário de Andrade, paulista apesar de tudo, talvez não gostasse que o tomássemos à letra. Seja como for, tenha ou não valor simbólico, todo o livro estua de uma alegria poderosa, de uma erudição e de um dom verbal dignos de Rabelais. A comparação parecerá talvez algo esmagadora, mas Mário de Andrade, homem da Renascença a seu modo, não é de modo algum indigno dela.

\footnotetext{
${ }^{35}$ No jornal, lê-se "Wenceslau".
} 
1940 


\section{Diario de Noticias}

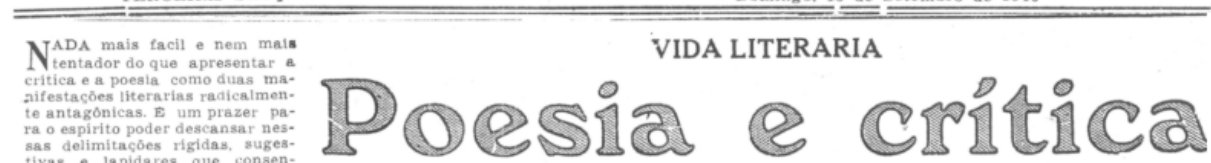

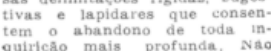

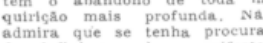

do definir aquelas manifesta.

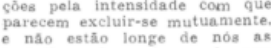

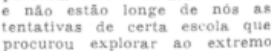

esse suposto antagonismo.
o verdadeiro. o autentico poe.

ta para os surrealistas era aque-
le que sabia alcandorar-se no
sublimes belbutiot do sub-con.

sublimes baibuctoo do sub-con-
sciente, a ponto de poter dis.

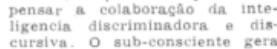

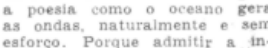

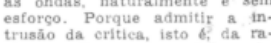

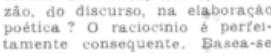

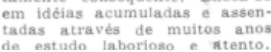

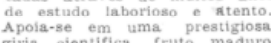

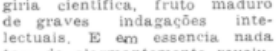

tem de alarmantemente revolu-
cionario. O romantismo em suas
expressóes mais tipicas nâo pre-
tendera outra coisa. O cartaz

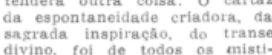

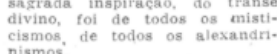

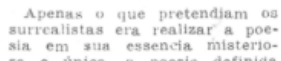

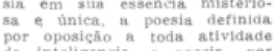

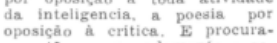

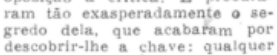

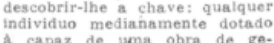

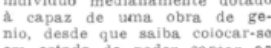

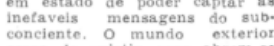

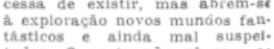

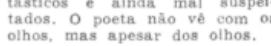

Em realiliade a oposicho en

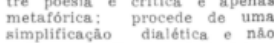

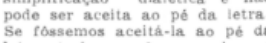

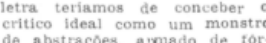

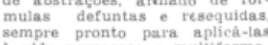

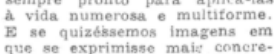

Há pouco menos de um més o DIARIO DE NOTICIAS
teve o dissabor de receber do sr. Mario de Andrade o pedi. do, fundado em respeitaveis motivos de natureza pessoal. de que o substitussemos na critica iteraria desta folha. Por maior que fosse o nosso empenho em conservar, nesse firmado nas nossas colunas, como critico, a sólida repu. taçâo ja obtida nas letras brasileiras como poeta, romancista, folclorista, erudito e historiador da musica, as suas habalaveis razoes nos impediram de uma mator insisten. cia. Dai o convite que dirigimos ao $8 r$. Sergio Buarque de gue, depois do brilho e da actidade espiritual do $s r$. Rosario Fusco, o sr. Mario de Andrade tinha emprestado todo vigor da sua competencia em questóes de estetica e da sua ampla cuttura miteraria. Hotorsator, soctotogo, critico de reputaçâo há muito firmada, estudioso dos mais complexos ubles personalidades de maior destague de Holanda çáo de escritores brasileiros. Os seus livros tá publicados. entre os quais "Raizes do Brasil", assim como os seus pre. facios e anotaçóes a importantes obras estrangeiras de enografia e historia, acreditam como um pesquisador con hecido pela sutileza da sua sensibilidade e pela precisato mantido com essa escolha a alta linha intelectual desta

existencia. Inso se explica erin cia de ser a literatura de ficcún liusoria seducáa de pureza o
autenticidade que hoje perse. Gracis poesia. dernista", reacáo oportuna con.
tra os formalismos academizantes que nos anos de 20 metri"mentalidade propria para soneto", que tao bem descre
veu o or. Pedro Dantas, abri. ram-se perspectivas inesperada-
mente vastas no remanso de que costuma surgir facimment. to Lrasit em casos semethan pediu disciplina e nem rigor: ma!. polimento e alguma compostura, ganhou bem pouco com
mudança. E a açâo do mo fia sido mais de lamentar do que de aprovar, năo tosse asseguram o prestigio .E' cla-
ro que não se pode julgar da. $\circ$ apenas em sua posiç্̃o ne-

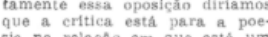
sia na relasao em que esta um
cemiterio para um hospicto de coroso que se procurou forjar rias corresponde bem ao inte-
lectualismo excessivo de nosso.

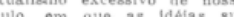
plantaram violentamente os fa.
tos, em que os conceitos for:
mados da realifade sustostitu. pam-se is realluade. os quas. dutiveis sảo um apanaglo do mundo das idéias. Fora dele, na
vida real, nada existe de isolado e de singular. nada tem A verdade é que o primeiro
passo da critica esta na proguintes estao nos reflexos que o produto de semethante
boraça val encontrar no pu. co ha uma parte apreciavel do
re-criacino. Cada individuo, ca. da epoca, recria as obras gosto que lhe sao proprios
familiares. E' graças a essa mi.

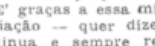
novada - que Hornero ou Cercontemporaneos compondo uma
ordem simultanea com todos os

presente, embora signifiquem averso daquilo que snificaéculo A grande funcé seu critica. sua legitimação até cer-
to ponto, esta na parcela de. para esse esforeso de colaborar
pla recriaça
Ela dilata no tempo e no es. paço un pouco do proprio processo de elaboraçá poética. E
nesse sentido nấ é exagero dizer-se que a critica pode ser O culto exclusivista à espon-
taneidade, à faclidadade, foi uma que Matthew Arnold denunciou com tanta justeza nos poetas
ingleses da primeira metade de superatiça es que, a despeite da energia criadora desses poeuma impressáo irresistivel de Semelhante impressio pode ocorrer-nos a cada passo dian-
te de certas produçós da moderna poesia brasileira. Envem adquirindo uma pujançąa se poderlamos dizer despropor-
cionada, se posta em confronto com outros géneros literarios. a poesia tende ao contrario a
estiolar-se como se năo desco-
brisse-razóes para a propria auliados do chamado moder. E se é bem certo que existe
hoje uma crise de poesia, năd existencia de algum mal conaté aqui tem evoluido meno por meio de revoluçóes perí́da impulso renovador se sige. se de rotina e relaxamento. presentemente a revoluçấ nevoluçāo. Em outras palavras $u m$ movimento tendente a res-
tabelecer, nos devidos limites. "mentalidade propria pas. 0 caso do surrealismo de que há - uco me valf, serve para
llus..ar um dos traços peculiares a essa crise da poosia. Nấ ele dúvidartence ao passado. cres terreno em atue buto e trutificou é o mesmo que pisamos. Nôs, homens de 1940 romantismo, e uma das terapétícas do romantisma é ana-
lisatlo. Por isso convem que em todo vertadeiro poeta haja tamenérgico. Existe talvez um vidagógico, na tendencia para seuntos da realizachá literaria a parte da crittica e a parte dà motivo, que a poetas de pre-
ferencia se confie a critica profissional. Os grandes exemplos delaire servem para mostrar a que ponto ir tho longe sem evocar nome flustre de quem me pro-
cedou nestas páginas? $\mathrm{Em}$ Mar rio de Andrado o crítico esteva sempre a altura do poeta. Figura das mais complexas e im.
portantes em nossa literatura. portantes emo no verso, nos trabaihos de pura erudiḉo, ele tem a ra. ra capacidade de interessar-se mais varios e de poder abor da-los com conhecimento de causa. Convidado para substi. proposta na expectativa, nAC sei se fundada, de que esta
substituicfo seja apenas temporaria e breve.
Para remeessa de livros:
Rua Ronald de Carvalho, s -

SERGIO BUARQUE DE HOLANDA 


\section{VIDA LITERÁRIA: POESIA E CRÍTICA}

HolANDA, Sérgio Buarque de. "Vida literária / Poesia e crítica”. Diário de Notícias: Rio de Janeiro, 15 de setembro de 1940. IEB-USP - MA-MP. Recolhido em HoLANDA, Sérgio Buarque de. O espírito e a letra. Organização, introdução e notas: Antônio Arnoni Prado. São Paulo: Companhia das Letras, 1996, vol. I, p. 274.

(...). O próprio Macunaíma, se quiserem enquadrá-lo em algum gênero, foi mais do que outra coisa obra de poesia. É indiscutível [verificar que com essa obra] ${ }^{36}$ se inaugurou em literatura aquilo a que poderíamos chamar um exame de consciência do Brasil. Hoje esse exame é praticado por sociólogos e romancistas.

O fato de ter contribuído grandemente para que tal coisa se tornasse possível ou, ao menos, para que desaparecessem barreiras de gosto, de prevenção e de falsa tradição — tradição interrompida, aliás, durante algum tempo pelo admirável movimento formado em torno de Monteiro Lobato e da primeira Revista do Brasil — é sem dúvida um dos bons resultados do chamado modernismo.

$(\ldots)$

SÉRGIO BUARQUE DE HOLANDA

\footnotetext{
${ }^{36}$ Período truncado no jornal e corrigido em $O$ espírito e a letra.
} 
1942 
[O Estado de S. Paulo: São Paulo, 22 de fevereiro de 1942. IEB-USP - CAP-MP]

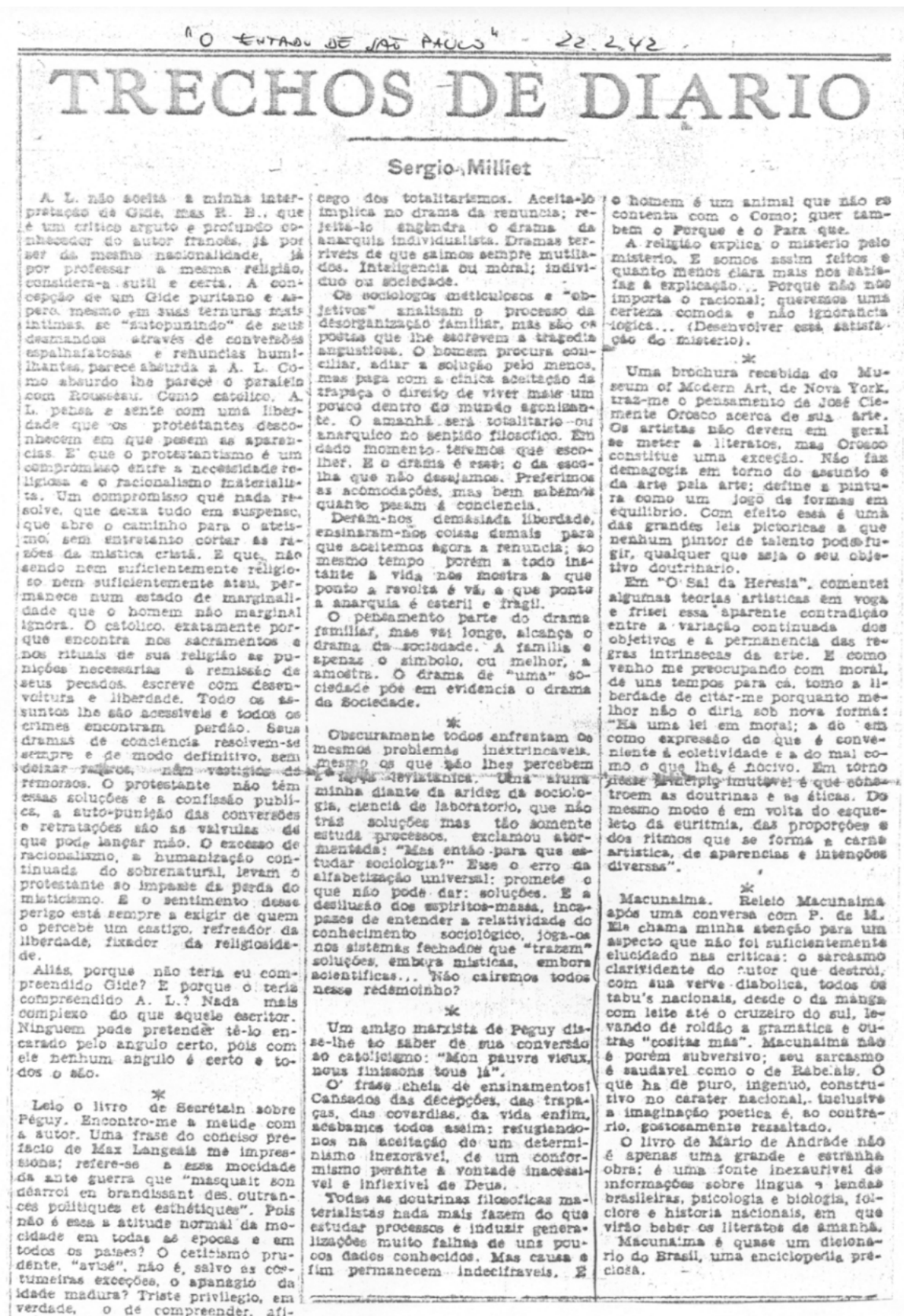

verdade, o de compreender, afi-

nad, que as grandes avutrinas nio
pasecm famats 60 um enessesicol

E triste porque eses percepplio a

rude vich is nos atimgo quandid
ja detints em nos o entuktasmo

jia celintis em nos o entukinsmo *

Quastas gente, emibots reconbeooddo o valor do moralbis, censi-

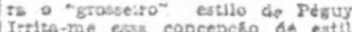
em culo se atere a beitsd de eonrormidece com certos padroes as felezancis. Part mim o bom estid om seus detelios e qualidates 


\section{Trechos de Diário}

Milliet, Sérgio. "Trechos de diário”. O Estado de S. Paulo: São Paulo, 22 de fevereiro de 1942. IEB-USP CAP-MP ${ }^{37}$.

(...)

Macunaíma. Releio Macunaíma após uma conversa com P. de M. ${ }^{38}$. Ele chama minha atenção para um aspecto que não foi suficientemente elucidado nas críticas: o sarcasmo clarividente do autor que destrói, com sua verve diabólica, todos os tabus nacionais, desde o da manga com leite até o Cruzeiro do $\mathrm{Sul}^{39}$, levando de roldão a gramática e outras "cositas mas”. Macunaíma não é porém subversivo; seu sarcasmo é saudável como o de Rabelais. O que há de puro, ingênuo, construtivo no caráter nacional, inclusive a imaginação poética é, ao contrário, gostosamente ressaltado.

O livro de Mário de Andrade não é apenas uma grande e estranha obra: é uma fonte inexaurível de informações sobre língua e lendas brasileiras, psicologia e biologia, folclore e história nacionais, em que virão beber os literatos de amanhã.

Macunaíma é quase um dicionário do Brasil, uma enciclopédia preciosa.

SÉRGIO MILLIET

\footnotetext{
${ }^{37}$ Trecho não reproduzido em MiLliET, Sérgio. Diário crítico de Sérgio Milliet. Introdução de Antonio Candido. $2^{\underline{a}}$ ed. São Paulo: Martins / Edusp, 1981, v. I.

${ }^{38}$ Prudente de Morais, neto, 1904-1977.

${ }^{39}$ No jornal, lê-se “cruzeiro do sul”, em caracteres minúsculos.
} 


\section{A Parlicipação do Aulor de "Don'Ana Sofredora" no Inqué- rilo que vem Sendo Realizado pela "Folha da Manhã " "Todo o Brasil e Tudo que é Essencialmente Brasileiro Está. Contido nas Páginas de "Macunaíma", Declarou á Reporlagem o Escrilor Mario Neme.}

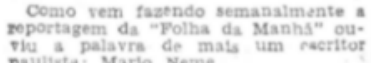

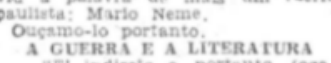

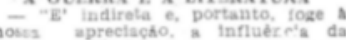
guers na literntura - intelou o nos: ser mediata e. porkso, mals wu me; que representa de fato ums forca

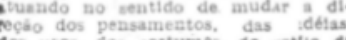
cos usos dos costumes, do stilo di ver tamben indirets, conclue-se que

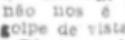

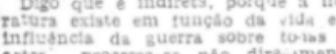

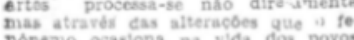
As artes todis refletem a vida. " a suerra. guers innue mutto pouco. cus estuyteratura. dentro da verdade de que afte nutida diratamente da sterr nem pintura. nemi eseultura, nes

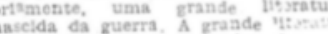

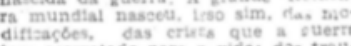

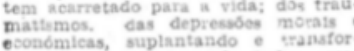
mando os costumes, de todas estin. ats revolucbes das soeledido causasis. Basta refletir sobre o numeso to hos cem ancs, pars Terticicar a p p.

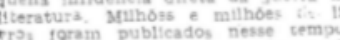
randes livios. 的 quantos zasndea

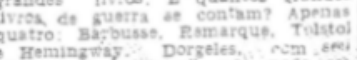

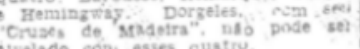

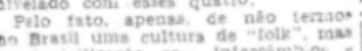
pontantos de tods especie com o res:

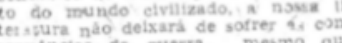
orta nio noe batu A porta, Purgue,

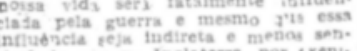

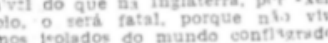

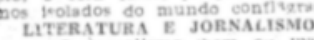

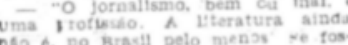
hato e. no bracil pelo mense ve tos hío uni apenas, como exer tito of cutre nos esti tio longe do jormalls mo quanto da mediens. O Mto do ño timplica na impositbriliage d. hover modicos que tainbem tacam 11.
teratura. $\mathbf{E}$ se nilo podimos dicer qug

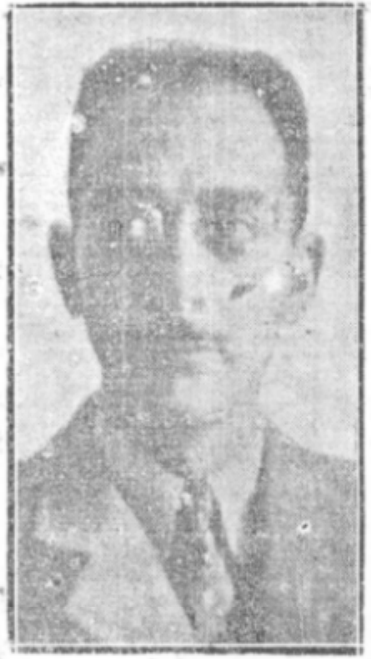

Sr. MARIO NEME
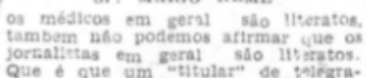

mas tem de uiteratoo a. por jutro is. do, um Iiterato, pelo fato aprnas do noticla de jornaly
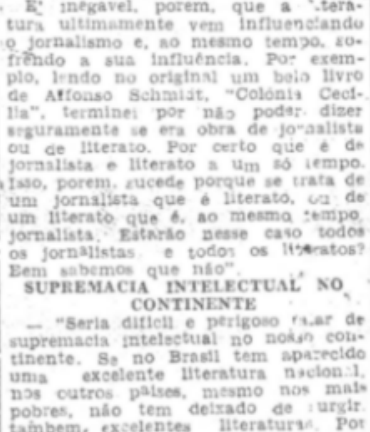

cutro lado, tanto aqui como sutro or
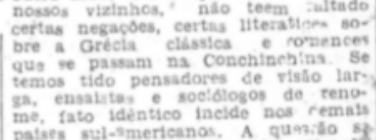

Watses sul-smerieanos, A qumito of

6 porcentagens, na qual a cotatist
terla de comparecer com ress ta

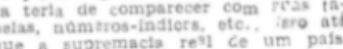

fue a supremacis revl ce um pals
por i moma, se torae evideate

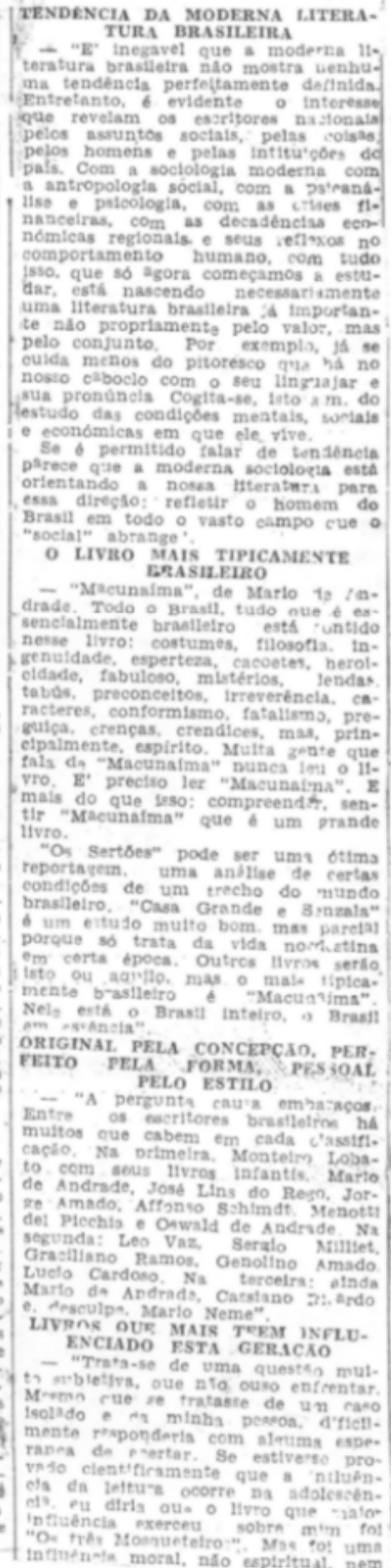




\section{O LIVRO MAIS TIPICAMENTE BRASILEIRO ${ }^{40}$}

NEME, Mário. "O livro mais tipicamente brasileiro”. FoIha da Manhã: São Paulo, 15 de março de 1942. IEBUSP - MA-MP.

\section{(...)}

— Macunaíma, de Mário de Andrade. Todo o Brasil, tudo o que é essencialmente brasileiro está contido nesse livro: costumes, filosofia, ingenuidade, esperteza, cacoetes, heroicidade, fabuloso, mistérios, lendas, tabus, preconceitos, irreverência, caracteres, conformismo, fatalismo, preguiça, crenças, crendices, mas, principalmente, espírito. Muita gente que fala de Macunaíma nunca leu o livro. É preciso ler Macunaíma. E mais do que isso: compreender, sentir Macunaíma que é um grande livro.

Os Sertões pode ser uma ótima reportagem, uma análise de certas condições de um trecho do mundo brasileiro. Casa Grande e Senzala é um estudo muito bom, mas parcial porque só trata da vida nordestina em certa época. Outros livros serão isto ou aquilo, mas o mais tipicamente brasileiro é Macunaíma. Nele está o Brasil inteiro, o Brasil em essência.

(...)

MÁRIO NEME

\footnotetext{
${ }^{40}$ Declaração em entrevista.
} 
1943 


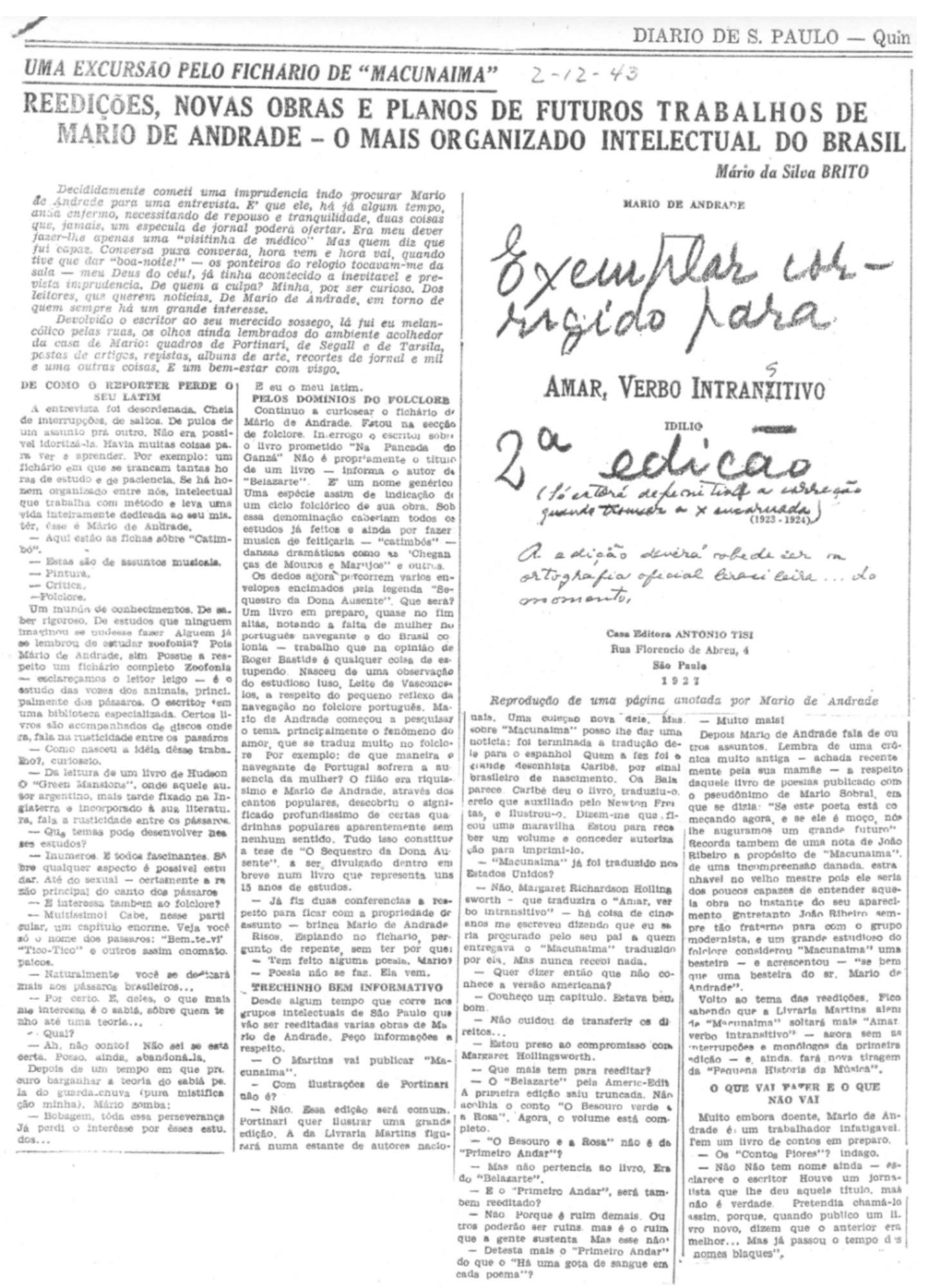


[Mário da Silva Brito, "Uma excursão..." (cont.)

Diário de S. Paulo. São Paulo, 02/12/1943.

IEB - MA-MP]

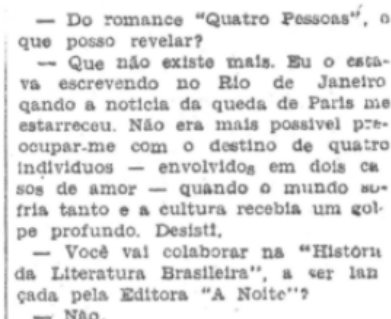

- $\mathbf{z} \circ$ que val ser?

- Uma operar?

Co para um trabatho nesse elemen

Desdo alguns anos que venho ambi-

elonanco, nto uma retorma, mas umo

dignificgélo da opera. Imagine1, en

táo, uma em três atos, inteiramento

de massa, sendo os seus personagens trupos sociais em movirnento $\boldsymbol{Z}$ uma

opera coral. Zserevi o poema e, os amt.

gos que o teram, acham a melhor col

sa que fit fiz. De outubro a dezem
bro do ano passado, trabalhel de 14

a 13 horas por dia, cigarro na boca ulsque ao lado, Fiquel intoxicado. No asya mals em dormiz. A muslca gera do Prapelsco alignone.

"Cate"to

- Provavelmente uma cass editora recem-fundada tire uma edig̣ăo da (isande luxo desse meu altimo trabatho. Frandseo Mignone, por outm lado, tem promessa de execuça da peca nos Eatados Untaos. Vamos ver ao que tica

E, park descansar, enquanto escre. sas o poema corna, Marto de Andrad Padre Jesuino do Monte Carmelo, li. dando com mats de 150 totogratias para identificacelo das obres daqueio sacerdote. E, nessa labuts, alem cu haver pocido realizar o que pretendia conseguiu tambem idensificar o su. tor do um quadro anónimo, depols do quatro ou einoo dias de ininterrupio labor. Porem, quando 1650 ocorreu. quando tez a prova detinitiva, pris acaso, uta amigo descobriu um do. tacllmento... tactimente..

de - sal pela rus "pedindo a bençato DESPAZENDO UMA LENDA

Neste momento, os pontetroe do ro. iogto aponcavem.me s porta da rua Com ravia. A suida. perguntel.

Com rarrios ase historts de aue multo ac tem talado ultimin mente, e verdade?

- Nio. E pândega do Menotu Nunca tive porao. Nesta casa é que

Mario de Andrade, numa charge
de Guevara - Mas esta anunctado que strn. tenlio, mas, nacuete tempo, eu morava no lango Palssandu e o puráo qui extatin ia, nem se poc a entrax escrever Disse- thes. porem que 0
poderta dar ams resposta definitivn

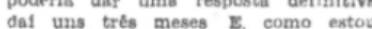
doente. - tenho que repousar, nac. nosso assumtr um compromisso dosseg $\mathrm{E}^{\prime}$ um trabalho que exigiria de mim grandes for
ugora nfio as dA

MACUNAIMA ADERE A OPERA

Confesso que o meu unico prupar sito to entrevistar Mario de Andrudt era obter informascees sobre o 'Oata" - romance que be multo tempo, se espers com sotreguidáo a impacieno a Mas. om outras oportunidades sena pre que ataquel esse assunto, Marb me cribiou, me despistou Desta ves porem nat tou logo:

- Eu tiahs intelado um romance com esse titulo, mas, em 1935. par el. tenoo cornar peguet nele. E aem pre. tas eoleas do 4 gue eqruveitet pato crónicas musicals "A vida do Cants. dor" - recentemente publicada is jornal $-\theta$ do "Cate" andar... 


\section{UMA EXCURSÃO PELO FICHÁRIO DE “MACUNAÍMA” REEDIÇÕES, NOVAS OBRAS E PLANOS DE FUTUROS TRABALHOS DE MÁRIO DE ANDRADE - O MAIS ORGANIZADO INTELECTUAL DO BRASIL}

BRITO, Mário da Silva. "Uma excursão pelo fichário de 'Macunaíma'”. Diário de S. Paulo: São Paulo, 02 de dezembro de 1943. IEB-USP - MA-MP. ${ }^{41}$

Decididamente cometi uma imprudência indo procurar Mário de Andrade para uma entrevista. É que ele, há já algum tempo, anda enfermo, necessitando de repouso e tranqüilidade, duas coisas que, jamais, um especula de jornal poderá ofertar. Era meu dever fazer-lhe apenas uma "visitinha de médico". Mas quem diz que fui capaz. Conversa puxa conversa, hora vem e hora vai, quando tive que dar "boa-noite!” - os ponteiros do relógio tocavam-me da sala - meu Deus do céu! já tinha acontecido a inevitável e prevista imprudência. De quem a culpa? Minha, por ser curioso. Dos leitores, que querem notícias. De Mário de Andrade, em torno de quem sempre há um grande interesse.

Devolvido o escritor ao seu merecido sossego, lá fui eu melancólico pelas ruas, os olhos ainda lembrados do ambiente acolhedor da casa de Mário: quadros de Portinari, de Segall e de Tarsila, pastas de artigos, revistas, álbuns de arte, recortes de jornal e mil e uma outras coisas. É um bem-estar com visgo.

\section{DE COMO O REPÓRTER PERDE O SEU LATIM}

A entrevista foi desordenada. Cheia de interrupções, de saltos. De pulos de um assunto pra outro. Não era possível idortizá-la ${ }^{42}$. Havia muitas coisas para ver e aprender. Por exemplo: um fichário em que se trancam tantas horas de estudo e de paciência. Se há homem organizado entre nós, intelectual que trabalha com método e leva uma vida inteiramente dedicada ao seu mister, esse é Mário de Andrade.

— Aqui estão as fichas sobre "Catimbó”.

— Estas são de assuntos musicais.

- Pintura.

\footnotetext{
${ }^{41}$ Entrevista com Mário de Andrade.

${ }^{42}$ Neologismo criado a partir da sigla IDORT, do Instituto de Organização Racional do Trabalho, fundado em 1931 por Armando de Salles Oliveira e por Roberto Mange, de acordo com o modelo da Taylor Society, dos USA, com o propósito de implementação do taylorismo no Brasil.
} 
- Crítica.

- Folclore.

Um mundo de conhecimentos. De saber rigoroso. De estudos que ninguém imaginou se pudesse fazer. Alguém já se lembrou de estudar zoofonia? Pois Mário de Andrade, sim. Possui a respeito um fichário completo. Zoofonia - esclareçamos o leitor leigo - é o estudo das vozes dos animais, principalmente dos pássaros. O escritor tem uma biblioteca especializada. Certos livros são acompanhados de discos onde $[\ldots]^{43}$.

- Como nasceu a idéia desse trabalho?, curioseio.

— Da leitura de um livro de Hudson. O Green Mansions, onde aquele autor argentino, mais tarde fixado na Inglaterra e incorporado à sua literatura, fala da ${ }^{44}$ rusticidade entre os pássaros.

— Que temas pode desenvolver nesses estudos?

— Inúmeros. E todos fascinantes. Sobre qualquer aspecto é possível estudar. Até do sexual — certamente a razão principal do canto dos pássaros.

— E interessa também ao folclore?

- Muitíssimo! Cabe, nesse particular, um capítulo enorme. Veja você só o nome dos pássaros: "Bem-te-vi”, “Tico-Tico” e outros assim onomatopaicos.

— Naturalmente, você se dedicará mais aos pássaros brasileiros...

— Por certo. E, deles, o que mais me interessa é o sabiá, sobre quem tenho até uma teoria...

- Qual?

— Ah, não conto! Não sei se está certa. Posso, ainda, abandoná-la.

Depois de um tempo em que procuro barganhar a teoria do sabiá pela do guardachuva (pura mistificação minha), Mário zomba:

— Bobagem, toda essa perseverança. Já perdi o interesse por esses estudos...

E eu o meu latim.

\footnotetext{
${ }^{43}$ Período truncado. No jornal, na última linha do $7^{0}$ parágrafo da primeira coluna, lê-se: “(-)ra, fala na rusticidade entre os pássaros”, quase idêntica à linha final do $9^{0}$ parágrafo. A única diferença está no vocábulo posterior ao verbo, que, no segundo caso, é somente o artigo - “... fala a ...”. A revisão do jornal deve ter acrescentado o "n" ao artigo, mas a linotipia, após a composição do bloco corrigido, errou de linha, inserindo-a no fim do $7^{0}$ parágrafo da primeira coluna, que, assim, ficou incompreensível. E o erro foi mantido na linha final do $9^{\circ}$ parágrafo.

${ }^{44}$ No jornal, lê-se "a rusticidade”; v. nota anterior.
} 


\section{PELOS DOMínios do FOLCLORE}

Continuo a curiosear o fichário de Mário de Andrade. Estou na seção de folclore. Interrogo o escritor sobre o livro prometido Na pancada do ganzá. Não é propriamente o título de um livro - informa o autor de Belazarte. É um nome genérico. Uma espécie assim de indicação de um ciclo folclórico de sua obra. Sob essa denominação caberiam todos os estudos já feitos e ainda por fazer[:] música de feitiçaria - “catimbós” - danças dramáticas como as “Cheganças de mouros e marujos” e outros.

Os dedos agora percorrem vários envelopes encimados pela legenda "Seqüestro da Dona Ausente”. Que será? Um livro em preparo, quase no fim, aliás, notando a falta de mulher no português navegante e do Brasil colônia - trabalho que na opinião de Roger Bastide é qualquer coisa de estupendo. Nasceu de uma observação do estudioso luso, Leite de Vasconcelos, a respeito do pequeno reflexo da navegação no folclore português. Mário de Andrade começou a pesquisar o tema[,] principalmente o fenômeno do amor, que se traduz muito no folclore. Por exemplo: de que maneira o navegante de Portugal sofrera a ausência da mulher? O filão era riquíssimo e Mário de Andrade, através dos cantos populares, descobriu o significado profundíssimo de certas quadrinhas populares aparentemente sem nenhum sentido. Tudo isso constitui a tese de "O Seqüestro da Dona Ausente”, a ser divulgado dentro em breve num livro que representa uns 15 anos de estudos.

— Já fiz duas conferências a respeito para ficar com a propriedade do assunto - brinca Mário de Andrade.

Risos. Espiando no fichário, pergunto de repente, sem ter por que:

— Tem feito alguma poesia, Mário?

— Poesia não se faz. Ela vem.

\section{TRECHINHO BEM INFORMATIVO}

Desde algum tempo que corre nos grupos intelectuais de São Paulo que vão ser reeditadas várias obras de Mário de Andrade. Peço informações a respeito.

- O Martins vai publicar Macunaíma.

— Com ilustrações de Portinari, não é?

— Não. Essa edição será comum. Portinari quer ilustrar uma grande edição. A da Livraria Martins figurará numa estante de autores nacionais. Uma coleção nova dele. Mas sobre 
Macunaíma posso lhe dar uma notícia: foi terminada a tradução dele para o espanhol. Quem a fez foi o grande desenhista Caribé, por sinal brasileiro de nascimento. Da Bahia ${ }^{45}$ parece. Caribé leu ${ }^{46}$ o livro, traduziu-o, creio que auxiliado pelo Newton Freitas, e ilustrou-o. Dizem-me que ficou uma maravilha. Estou para receber um volume e conceder autorização para imprimi-lo.

— Macunaíma já foi traduzido nos Estados Unidos?

- Não. Margaret Richardson Hollingsworth - que traduzira o Amar, verbo intransitivo - há coisa de cinco anos me escreveu dizendo que eu seria procurado pelo seu pai a quem entregava o Macunaíma traduzido por ela. Mas nunca recebi nada.

- Quer dizer então que não conhece a versão americana?

— Conheço um capítulo. Estava bem bom.

— Não cuidou de transferir os direitos...

— Estou preso ao compromisso com Margaret Hollingsworth.

— Que mais tem para reeditar?

- O Belazarte pela Americ-Edit. A primeira edição saiu truncada. Não acolhia o conto “O besouro verde e a Rosa”. Agora, o volume está completo.

— “O Besouro e a Rosa” não é de Primeiro andar?

— Mas não pertencia ao livro. Era do Belazarte.

— E o Primeiro andar, será também reeditado?

— Não. Porque é ruim demais. Outros poderão ser ruins, mas é o ruim que a gente sustenta. Mas esse não.

— Detesta mais o Primeiro andar do que o Há uma gota de sangue em cada poema?

— Muito mais!

Depois Mário de Andrade fala de outros assuntos. Lembra de uma crônica muito antiga - achada recentemente pela sua mamãe - a respeito daquele livro de poesias publicado com o pseudônimo de Mário Sobral, em que se dizia: "Se este poeta está começando agora, e se ele é moço, nós lhe auguramos um grande futuro”. Recorda também de uma nota de João Ribeiro a propósito de Macunaíma, de uma incompreensão danada, estranhável no velho mestre pois ele seria dos poucos capazes de entender aquela obra no instante do seu aparecimento. Entretanto, João Ribeiro, sempre tão fraterno para com o grupo modernista, e um grande estu-

\footnotetext{
${ }^{45}$ No jornal, lê-se “Oa Baia”. Erro tipográfico.

${ }^{46}$ No jornal, lê-se “deu”. Erro tipográfico.
} 
dioso do folclore considerou Macunaíma uma besteira - e acrescentou - "se bem que uma besteira do sr. Mário de Andrade»"47.

Volto ao tema das reedições. Fico sabendo que a Livraria Martins, além de Macunaíma, soltará mais Amar, verbo intransitivo - agora sem as interrupções e monólogos da primeira edição - e, ainda, fará nova tiragem da Pequena história da música.

\section{O QUE VAI FAZER E O QUE NÃO VAI}

Muito embora doente, Mário de Andrade é um trabalhador infatigável. Tem um livro de contos em preparo.

— Os “Contos Piores”?, indago.

- Não. Não tem nome ainda - esclarece o escritor. Houve um jornalista que lhe deu aquele título, mas não é verdade. Pretendia chamá-lo assim porque, quando publico um livro novo, dizem que o anterior era melhor... Mas já passou o tempo dos nomes blagues.

— Do romance Quatro pessoas ${ }^{48}$, o que posso revelar?

— Que não existe mais. Eu o estava escrevendo no Rio de Janeiro quando a notícia da queda de Paris me estarreceu. Não era mais possível preocupar-me com o destino de quatro indivíduos - envolvidos em dois casos de amor - quando o mundo sofria tanto e a cultura recebia um golpe profundo. Desisti.

— Você vai colaborar na História da literatura brasileira, a ser lançada pela Editora “A Noite"?

- Não.

— Mas está anunciado que sim.

— É engano. Fui convidado para escrever. Disse-lhes, porém[,] que só poderia dar uma resposta definitiva daí uns três meses. E, como estou doente, e tenho que repousar, não posso assumir um compromisso desses. É um trabalho que exigiria de mim grandes forças. E minha saúde agora não as dá.

\footnotetext{
${ }^{47}$ No artigo de João Ribeiro, lê-se: “... Mário de Andrade é capaz de uma asneira, mas sempre uma asneira respeitável. E, nesse caso, uma asneira de talento”. Cf. p. 44-47 deste Anexo.

${ }^{48} \mathrm{O}$ romance inacabado, Quatro pessoas, foi publicado em 1985 pela editora Itatiaia (Belo Horizonte), com notas críticas de Maria Zélia Galvão de Almeida e posfácio de Tereza de Almeida.
} 


\section{MACUNAÍMA ADERE À ÓPERA}

Confesso que o meu único propósito ao entrevistar Mário de Andrade era obter informações sobre o Café - romance que[,] há muito tempo, se espera com sofreguidão e impaciência. Mas em outras oportunidades sempre que ataquei esse assunto, Mário me driblou, me despistou. Desta vez porém não foi difícil não. Mário contou logo:

- Eu tinha iniciado um romance com esse título, mas, em 1935, parei. Nunca mais peguei nele. E nem pretendo tornar a pegar. Até tirei muitas coisas de lá que aproveitei para crônicas musicais. A vida do cantador - recentemente publicada em jornal - é do Café.

- E o que vai ser?

— Uma ópera.

— Uma ópera?

— Isso mesmo. Dele extraí elementos para um trabalho nesse gênero. Desde alguns anos que venho ambicionando, não uma reforma, mas uma dignificação da ópera. Imaginei, então, uma em três atos, inteiramente de massa, sendo os seus personagens grupos sociais em movimento. É uma ópera coral. Escrevi o poema e, os amigos que o leram, acham a melhor coisa que já fiz. De outubro a dezembro do ano passado, trabalhei de 14 a 15 horas por dia, cigarro na boca e uísque ao lado. Fiquei intoxicado. Nos últimos dias de dezembro, nem pensava mais em dormir. A música será de Francisco Mignone.

— Pretende publicar o poema do Café?

— Provavelmente um casa editora recém-fundada tire um edição de grande luxo desse meu último trabalho. Francisco Mignone, por outro lado, tem promessa de execução da peça nos Estados Unidos. Vamos ver no que fica.

E, para descansar, enquanto escrevia o poema coral, Mário de Andrade prosseguia em seus estudos sobre o padre Jesuíno do Monte Carmelo, lidando com mais de 150 fotografias para identificação das obras daquele sacerdote. E, nessa labuta, além de haver podido realizar o que pretendia, conseguiu também identificar o autor de um quadro anônimo, depois de quatro ou cinco dias de ininterrupto labor. Porém, quando isso ocorreu, quando fez a prova definitiva, por acaso, um amigo descobriu um documento da época que resolvia tudo facilmente...

— Nesse dia - diz Mário de Andrade - saí pela rua “pedindo a bênção pra cachorro”... 


\section{DESFAZENDO UMA LENDA}

Neste momento, os ponteiros do relógio apontavam-me a porta da rua. Autoritários. Implacáveis. Obedeci. Com raiva. À saída, perguntei:

— Mário, essa história do “porão” de que muito se tem falado ultimamente, é verdade?

— Não. É pândega do Menotti. Nunca tive porão. Nesta casa é que tenho, mas, naquele tempo, eu morava no largo Paissandu e o porão que existia lá, nem se podia entrar de tão pequeno que era... Meus livros sempre estiveram no primeiro andar... ${ }^{49}$

MÁRIO DA SILVA BRITO

\footnotetext{
${ }^{49}$ Há duas ilustrações na matéria de Silva Brito: Reprodução de capa anotada por Mário de Andrade, da $1^{\underline{a}}$ edição de Amar, verbo intransitivo, preparado para a $2^{\underline{a}}$ edição, e uma caricatura de Mário de Andrade, por Guevara.
} 
Diário de S. Paulo. São Paulo, 23/12/1943. IEB - MA-MP.

Em manuscrito de Mário de Andrade, lê-se no recorte: "Diário de S. Paulo / 23-XII-43 / Mário da Silva Brito"]

\section{Melancolia versus}

Mario de Andrade completou, faz pouco, cinquenta enos. Alguns escritores aproveitaram esse antversario para frisar o seu sig. idficado no quadro dos acontecimentos literarios nacionais. Houve articultstas que julgarain a ocorrcricia melancólica, valendose is afirmaçós do proprio $\mathrm{Ma}$. rlo nesse sentido, mas em relaço ao papel desempenhado por sua getacáa Entretanto, nunguem conseguiu - e nem teria forças para tanto - subestimar o seu calor. Nega-lo. 'E' que Mario de Ancirade $\dot{e}$, talvez, a mais alta expressio intelectual brasileira. Comparavel, somente a Gilberto Ereyre.

Mas nao possivel taxar de melancolica, em qualguer hipótece, uma existencia fecunia como $a$ de Mario de Andrade. Ai estao es swas obras, todas fruto de estucios e trabalhos rigorosos. De vida intelectual organizada. Responsavel. Posta a serviço da cul. tura. Pondo o nosso pais, do ponto-de-vista da inteligencia, em condiçóes espirituais methores. $U m$ renovador.

Percorram-se os diferentes setores que compōem o'dominio da acdo intelectual. $\mathrm{Em}$ cada um deies, sempre se encontrará uma contribuiçáo preciosa do poeta de "Remate de Males". No folclore. $\mathrm{Na}$ critica literaria. $\mathrm{Na}$ análise da poesia. No estudo das manifestacloes musicats. No conto $e$ no romance. No ensaio. Em todos os recantas, Mario de Andrade ocupa um lugar de proeminencia. Impar, como é, agora, moda dizer. Houve um tempo em que se buscou concentrar num tipo de ticçâ. ou num livro, uma sintees psicologica do Brasil Andous em busca de um D. Quixote ou de um Sancho Pança que pudesse ser identificado, temperalmente ao menos, com o feitio de nossa gente. Sugeriram "Jeca Tatu", "Juca Mulato". Lembraram o."Canaan". E, por af, alcm. Entretanto, cremos, mutto mais aue o maleitoso personagem de Lobato - os outros enfileirados para o pareo - Macunaima concentra certas caracteristicas do nosso jeito de ser. Tem tudo de nos. Ao menos se expande mais nacionalmente do que os outros rebentos da imaginação nacional, que podem ser, quando

\section{"Macunaima"}

muito, sinteses regionais. $M a-$ cunaima se esparrama pelo Bra-. sil todinho. Se expande no modo malicioso e escorregadio de filosofar a vida. De interyretar certos sentimentos frisantemente verde-amarelos. $E^{\prime}$ prectso prestar atenção a esse aspecto de Macunaima Os ensaistas que se manifestem.

Ainda há pouco, Mario de Andrade concedeu para esta pagino. uma entrevista. Comentanda-a. um intelectual achou-a tambem melancólica. Por demais negati-, va. Cheia de desencanto. De desistencias. "Mario abandonou disse - uma porçâo de projetos!". Pois essa oplnido náo está certa. Porque se Mario desistlu de alguns planos, estabeleceu outros. $E$ modificou alguns. Para nealtzdlos de forma diversa dquela anteriormente prevista.

Essa transformaçāo processada ultimamente no espirito de $M$ ario de Anarade é acentiadamente positiva. Reflete uma nova maneir dele encarar os problemas da vida e do mundo enquanto referidos d missấo do escritor na sociedade de agora.

Por tudo isso, julgamos que, em nada, de modo algum, se pode aplicar, para o contista de "Belazarte", o adjetivo melancólico, afinal de contas um adjetivo comprometedor $e$ até sem nobre$z a$. Sem virilidade. $E$ Mario de Andrade sempre foi uma afirmacolo de carater, de coragem, de independencia, portanto, de viriitdade.

Para os que o admiram - e sdo muitos - e o têm ná conta de um dos poucos escritores dignos de uma atenchio maior, divulgamos uma noticia de grande interesse. Um editor de São Paulo vat publicar as obras completas de Mario de Andrade. O que ele it escreveu e o que ele produsir de futuro. 0 fato tem o sev significado. Parece-nos que Mario de Andrade é o primeiro escritor do Brasil a ver editarlas, ex vida, as suas obras completas $\boldsymbol{E}$, por outro lado, o acontecimento precisa ser apreciado do ponto-do vista editorial. Sim, rorque editor ao menos comercialmente, nô costuma errar. E isto soterra a idéta de qualques espocie de melancolia... - M. S. B. 


\section{MELANCOLIA VERSUS "MACUNAÍMA"50}

M. S. B. [Mário da Silva Brito]. "Melancolia versus 'Macunaíma'”. Diário de S. Paulo: São Paulo, 23 de dezembro de 1943. IEB-USP - MA-MP.

Mário de Andrade completou, faz pouco, cinqüenta anos. Alguns escritores aproveitaram esse aniversário para frisar o seu significado no quadro dos acontecimentos literários nacionais. Houve articulistas que julgaram a ocorrência melancólica, valendo-se de afirmações do próprio Mário nesse sentido, mas em relação ao papel desempenhado por sua geração. Entretanto, ninguém conseguiu - e nem teria forças para tanto - subestimar o seu valor. Negá-lo. É que Mário de Andrade é, talvez, a mais alta expressão intelectual brasileira. Comparável, somente[,] a Gilberto Freyre.

Mas não é possível taxar de melancólica, em qualquer hipótese, uma existência fecunda como a de Mário de Andrade. Aí estão as suas obras, todas fruto de estudos e trabalhos rigorosos. De vida intelectual organizada. Responsável. Posta a serviço da cultura. Pondo o nosso país, do ponto de vista da inteligência, em condições espirituais melhores. Um renovador.

Percorram-se os diferentes setores que compõem o domínio da ação intelectual. Em cada um deles, sempre se encontrará uma contribuição preciosa do poeta de Remate de males. No folclore. Na crítica literária. Na análise da poesia. No estudo das manifestações musicais. No conto e no romance. No ensaio. Em todos os recantos, Mário de Andrade ocupa um lugar de proeminência. Ímpar, como é, agora, moda dizer.

Houve um tempo em que se buscou concentrar num tipo de ficção, ou num livro, uma síntese psicológica do Brasil. Andou-se em busca de um D. Quixote ou de um Sancho Pança que pudesse ser identificado, temperalmente ao menos, com o feitio de nossa gente. Sugeriram “Jeca Tatu”, “Juca Mulato”. Lembraram o Canaã. E, por aí, além. Entretanto, cremos, muito mais que o maleitoso personagem de Lobato - e os outros enfileirados para o páreo Macunaíma concentra certas características de nosso jeito de ser. Tem tudo de nós. Ao menos se expande mais nacionalmente do que os outros rebentos da imaginação nacional, que podem ser[,] quando muito, sínteses regionais. Macunaíma se esparrama pelo Brasil todinho. Se ex-

\footnotetext{
${ }^{50}$ Mais uma vez, Mário da Silva Brito utiliza o nome da personagem Macunaíma como metonímia de Mário de Andrade.
} 
pande no modo malicioso e escorregadio de filosofar a vida. De interpretar certos sentimentos frisantemente verde-amarelos. É preciso prestar atenção a esse aspecto de Macunaíma. Os ensaístas que se manifestem.

Ainda há pouco, Mário de Andrade concedeu para esta página uma entrevista. Comentando-a, um intelectual achou-a também melancólica. Por demais negativa. Cheia de desencanto. De desistências. “Mário abandonou - disse - uma porção de projetos!”. Pois esta opinião não está certa. Porque se Mário desistiu de alguns planos, estabeleceu outros. E modificou alguns. Para realizá-los de forma diversa àquela anteriormente prevista.

Essa transformação processada ultimamente no espírito de Mário de Andrade é acentuadamente positiva. Reflete uma nova maneira de ele encarar os problemas da vida e do mundo enquanto referidos à missão do escritor na sociedade de agora.

Por tudo isso, julgamos que, em nada, de modo algum, se pode aplicar para o contista de Belazarte, o adjetivo melancólico, afinal de contas um adjetivo comprometedor e até sem nobreza. Sem virilidade. E Mário de Andrade sempre foi uma afirmação de caráter, de coragem, de independência, portanto, de virilidade.

Para os que o admiram - e são muitos - e o têm na conta de um dos poucos escritores dignos de uma atenção maior, divulgamos uma notícia de grande interesse. Um editor de São Paulo vai publicar as obras completas de Mário de Andrade. O que ele já escreveu e o que ele produzir de futuro. O fato tem o seu significado. Parece-nos que Mário de Andrade é o primeiro escritor do Brasil a ver editadas, em vida, as suas obras completas. E, por outro lado, o acontecimento precisa ser apreciado do ponto de vista editorial. Sim, porque editor, ao menos comercialmente, não costuma errar. E isso soterra a idéia de qualquer espécie de melancolia...

M. S. B. [MÁRIO DA SILVA BRITO] 
1944

$3^{\text {a }}$ edição de Macunaíma 


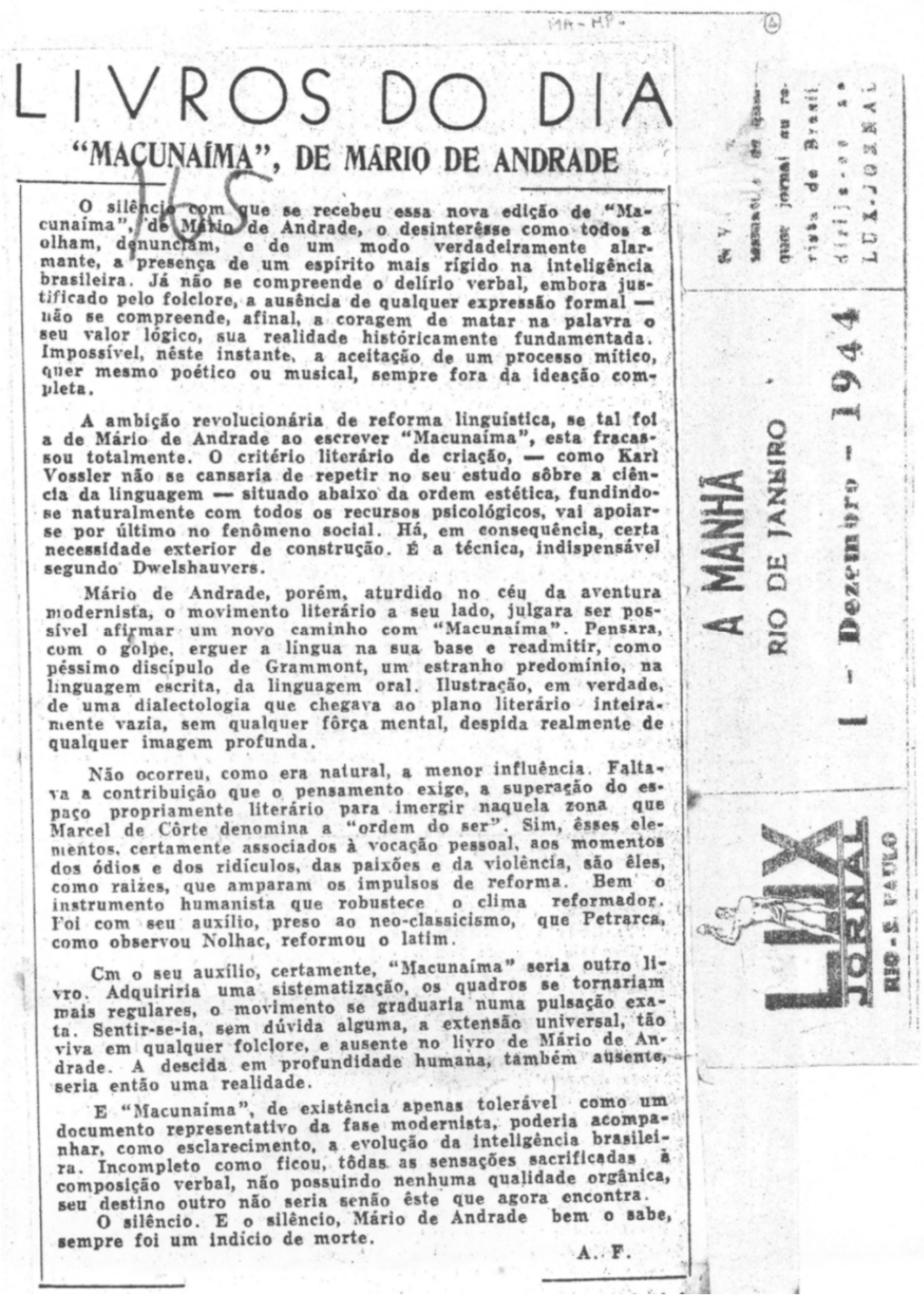




\section{“MACUNAÍMA”, DE MÁRIO DE ANDRADE}

A. F. [Aníbal Fernandes ${ }^{51}$ ]. "Livros do dia / 'Macunaíma’, de Mário de Andrade”. A Manhã: Rio de Janeiro, 01 de dezembro de 1944. IEB-USP - MA-MP.

O silêncio com que se recebeu essa nova edição de Macunaíma, de Mário de Andrade, o desinteresse como todos a olham, denunciam, e de um modo verdadeiramente alarmante, a presença de um espírito mais rígido na inteligência brasileira. Já não se compreende o delírio verbal, embora justificado pelo folclore, a ausência de qualquer expressão formal - não se compreende, afinal, a coragem de matar na palavra o seu valor lógico, sua realidade historicamente fundamentada. Impossível, neste instante, a aceitação de um processo mítico, quer mesmo poético ou musical, sempre fora da ideação completa.

A ambição revolucionária de reforma lingüística, se tal foi a de Mário de Andrade ao escrever Macunaíma, esta fracassou totalmente. O critério literário de criação - como Karl Vossler não se cansaria de repetir no seu estudo sobre a ciência da linguagem - situado abaixo da ordem estética, fundindo-se naturalmente com todos os recursos psicológicos, vai apoiar-se por último no fenômeno social. Há, em conseqüência, certa necessidade exterior de construção. É a técnica, indispensável segundo Dwelshauvers.

Mário de Andrade, porém, aturdido no céu da aventura modernista, o movimento literário a seu lado, julgara ser possível afirmar um novo caminho com Macunaíma. Pensara, com o golpe, erguer a língua na sua base e readmitir, como péssimo discípulo de Grammont, um estranho predomínio, na linguagem escrita, da linguagem oral. Ilustração, em verdade, de uma dialetologia que chegava ao plano literário inteiramente vazia, sem qualquer força mental, despida realmente de qualquer imagem profunda.

Não ocorreu, como era natural, a menor influência. Faltava a contribuição que o pensamento exige, a superação do espaço propriamente literário para imergir naquela zona que Marcel de Corte denomina a "ordem do ser”. Sim, esses elementos, certamente associados à vocação pessoal, aos momentos dos ódios e dos ridículos, das paixões e da violência, são eles,

\footnotetext{
${ }^{51}$ A. F. talvez seja Aníbal Fernandes, autor do artigo publicado em 18 de abril de 1929 no Diário de Pernambuco (recolhido nas pp. 85-89 deste Anexo). Os dois escritos coincidem na mesma restrição à "língua brasileira" e à suposta desconexão compositiva de Macunaíma. Contudo, a matéria de 1929, apesar de adversa, concede algum valor à rapsódia (por exemplo: "esplêndida fantasia”); a de 1944, único pronunciamento crítico documentado no ano da terceira edição da obra, aponta exatamente o silêncio da crítica nessa ocasião como um "indício de morte" do livro.
} 
como raízes, que amparam os impulsos de reforma. Bem o instrumento humanista que robustece o clima reformador. Foi com seu auxílio, preso ao neoclassicismo, que Petrarca, como observou Nolhac, reformou o latim.

Com o seu auxílio, certamente, Macunaíma seria outro livro. Adquiriria uma sistematização, os quadros se tornariam mais regulares, o movimento se graduaria numa pulsação exata. Sentir-se-ia, sem dúvida alguma, a extensão universal, tão viva em qualquer folclore, e ausente no livro de Mário de Andrade. A descida em profundidade humana, também ausente, seria então uma realidade.

E Macunaíma, de existência apenas tolerável como um documento representativo da fase modernista, poderia acompanhar, como esclarecimento, a evolução da inteligência brasileira. Incompleto como ficou, todas as sensações sacrificadas à composição verbal, não possuindo nenhuma qualidade orgânica, seu destino outro não seria senão este que agora encontra.

O silêncio. E o silêncio, Mário de Andrade bem o sabe, sempre foi um indício de morte.

A. F. [ANIBAL FERNANDES?] 
1945

Ano da morte de Mário de Andrade 
[IEB - MA-MP]

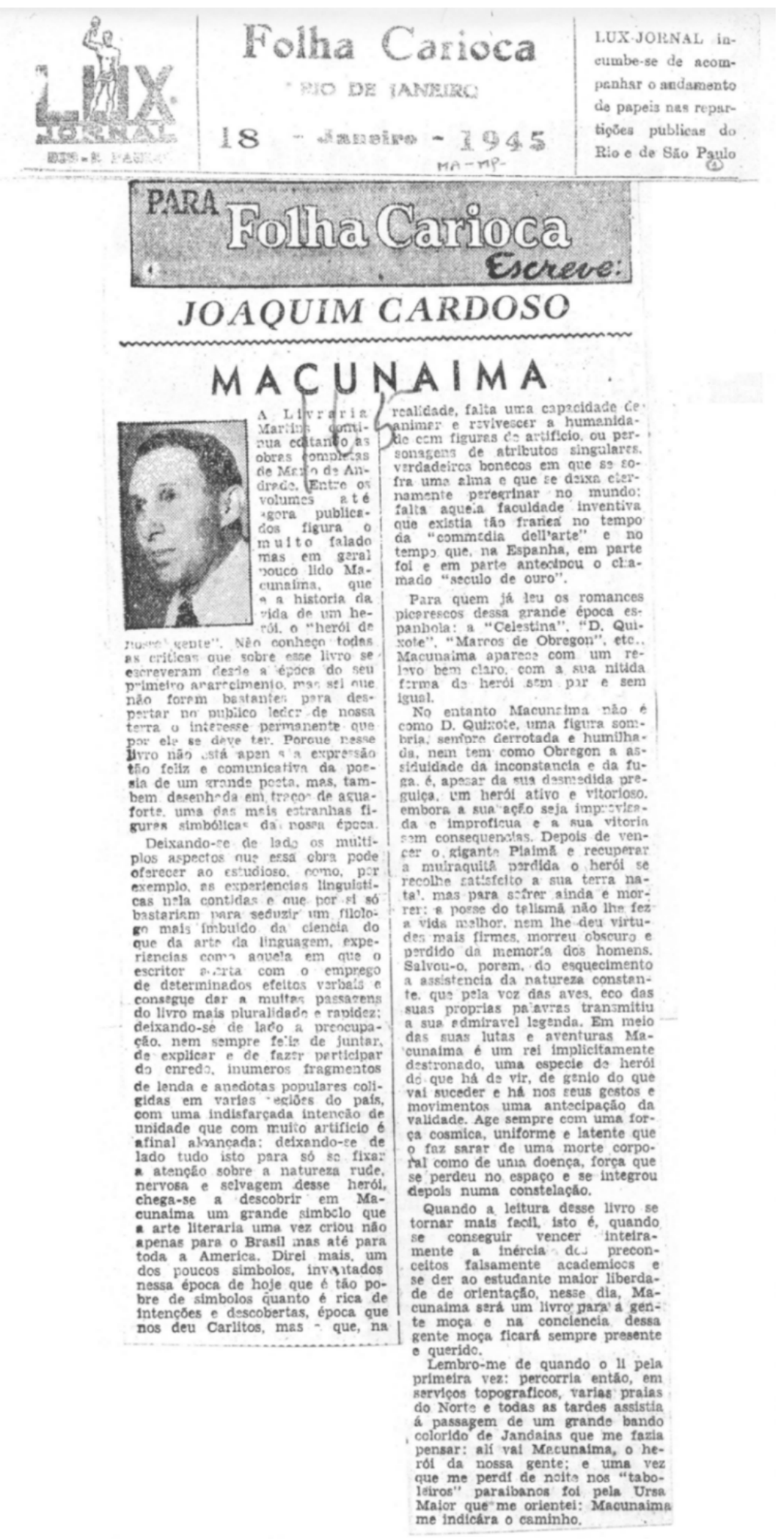




\section{MacunAÍMA}

CARDoso, Joaquim. "Macunaíma”. Folha Carioca: Rio de Janeiro, 18 de janeiro de 1945. IEB-USP - MA-MP.

A Livraria Martins continua editando as obras completas de Mário de Andrade. Entre os volumes até agora publicados figura o muito falado mas em geral pouco lido Macunaíma, que é a história da vida de um herói, o "herói de nossa gente”. Não conheço todas as críticas que sobre esse livro se escreveram desde a época do seu primeiro aparecimento, mas sei que não foram bastantes para despertar no público ledor de nossa terra o interesse permanente que por ele se deve ter. Porque nesse livro não está apenas a expressão tão feliz e comunicativa da poesia de um grande poeta, mas, também[,] desenhada em traços de água-forte, uma das mais estranhas figuras simbólicas da nossa época.

Deixando-se de lado os múltiplos aspectos que essa obra pode oferecer ao estudioso, como, por exemplo, as experiências lingüísticas nela contidas e que por si só bastariam para seduzir um filólogo mais imbuído da ciência do que da arte da linguagem, experiências como aquela em que o escritor acerta com o emprego de determinados efeitos verbais e consegue dar a muitas passagens do livro mais pluralidade e rapidez; deixando-se de lado a preocupação, nem sempre feliz de juntar, de explicar e de fazer participar do enredo inúmeros fragmentos de lenda e anedotas populares coligidas em várias regiões do país, com uma indisfarçada intenção de unidade que com muito artifício é afinal alcançada; deixando-se de lado tudo isso para só se fixar a atenção sobre a natureza rude, nervosa e selvagem desse herói, chega-se a descobrir em Macunaíma um grande símbolo que a arte literária uma vez criou não apenas para o Brasil mas até para toda a América. Direi mais, um dos poucos símbolos, inventados nessa época de hoje que é tão pobre de símbolos quanto é rica de intenções e descobertas, época que nos deu Carlitos, mas a que, na realidade, falta uma capacidade de animar e revivescer a humanidade com figuras de artifício, ou personagens de atributos singulares, verdadeiros bonecos em que se sofra uma alma e que se deixa eternamente peregrinar no mundo; falta aquela faculdade inventiva que existia tão franca no tempo da "commedia dell'arte" e no tempo que, na Espanha, em parte foi e em parte antecipou o chamado “século de ouro”.

Para quem já leu os romances picarescos dessa grande época espanhola: a Celestina, D. Quixote, Marcos de Obregon, etc., Macunaíma aparece com um relevo bem claro, com a sua nítida forma de herói sem par e sem igual. 
No entanto[,] Macunaíma não é como D. Quixote, uma figura sombria, sempre derrotada e humilhada, nem tem como Obregon a assiduidade da inconstância e da fuga, é, apesar de sua desmedida preguiça, um herói ativo e vitorioso, embora a sua ação seja improvisada e improfícua e a sua vitória sem conseqüências. Depois de vencer o gigante Piaimã e recuperar a muiraquitã perdida o herói se recolhe satisfeito a sua terra natal, mas para sofrer ainda e morrer; a posse do talismã não lhe fez a vida melhor, nem lhe deu virtudes mais firmes, morreu obscuro e perdido da memória dos homens. Salvou-o, porém, do esquecimento a assistência da natureza constante que pela voz das aves, eco das suas próprias palavras[,] transmitiu a sua admirável legenda. Em meio das suas lutas e aventuras[,] Macunaíma é um rei implicitamente destronado, uma espécie de herói do que há de vir, de gênio do que vai suceder e há nos seus gestos e movimentos uma antecipação da validade. Age sempre com uma força cósmica, uniforme e latente que o faz sarar de uma morte corporal como de uma doença, força que se perdeu no espaço e se integrou depois numa constelação.

Quando a leitura desse livro se tornar mais fácil, isto é, quando se conseguir vencer inteiramente a inércia dos preconceitos falsamente acadêmicos e se der ao estudante maior liberdade de orientação, nesse dia, Macunaíma será um livro para a gente moça e na consciência dessa gente moça ficará sempre presente e querido.

Lembro-me de quando o li pela primeira vez: percorria então, em serviços topográficos, várias praias do Norte e todas as tardes assistia à passagem de um grande bando colorido de jandaias que me fazia pensar: ali vai Macunaíma, o herói da nossa gente; e uma vez que me perdi de noite nos “taboleiros” paraibanos foi pela Ursa Maior que me orientei: Macunaíma me indicara o caminho. 
[Correio Paulistano. São Paulo, 11/03/1945.

IEB - CAP-MP]

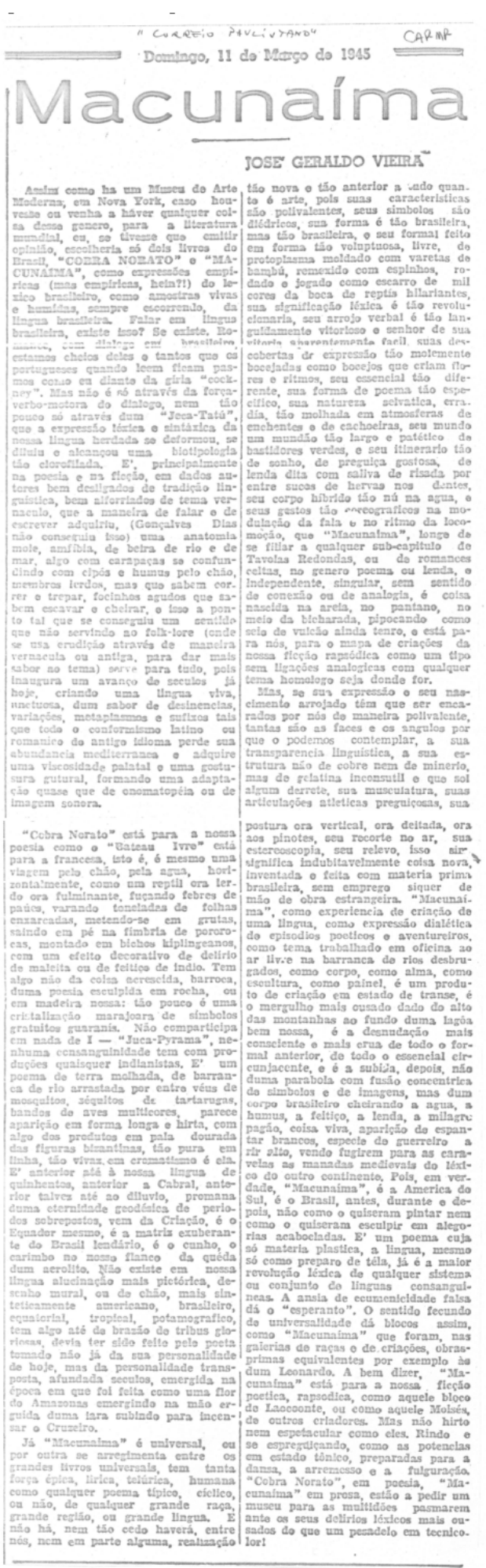




\section{Macunaíma}

VIEIRA, José Geraldo. "Macunaíma”. Correio Paulistano: São Paulo, 11 de março de 1945. IEB-USP - CAPMP.

Assim como há um Museu de Arte Moderna, em Nova York, caso houvesse ou venha haver qualquer coisa desse gênero, para a literatura mundial, eu, se tivesse que emitir opinião, escolheria só dois livros do Brasil, Cobra Norato e Macunaíma, como expressões empíricas (mas empíricas, hein?!) do léxico brasileiro, como amostras vivas e úmidas, sempre escorrendo, da língua brasileira. Falar em língua brasileira, existe isso? Se existe. Romance, com diálogo em brasileiro, estamos cheios deles e tantos que os portugueses quando lêem ficam pasmos como eu diante da gíria “cockney”. Mas não é só através da força-verbo-motora do diálogo, nem tão pouco só através dum “Jeca-Tatu”, que a expressão léxica e sintática da nossa língua herdada se deformou, se diluiu e alcançou uma biotipologia tão clorofilada. É, principalmente na poesia e na ficção, em dados autores bem desligados de tradição lingüística, bem alforriados de tema vernáculo, que a maneira de falar e de escrever adquiriu (Gonçalves Dias não conseguiu isso) uma anatomia mole, anfíbia, de beira de rio e de mar, algo com carapaças se confundindo com cipós e húmus pelo chão, membros lerdos, mas que sabem correr e trepar, focinhos agudos que sabem escavar e cheirar, e isso a ponto tal que se conseguiu um sentido que não servindo ao folclore (onde se usa erudição através de maneira vernácula ou antiga, para dar mais sabor ao tema) serve para tudo, pois inaugura um avanço de séculos já hoje, criando uma língua viva, untuosa, dum sabor de desinências, variações, metaplasmos e sufixos tais que todo o conformismo latino ou românico do antigo idioma perde sua abundância mediterrânea e adquire uma viscosidade palatal e uma gostosura gutural, formando uma adaptação quase que de onomatopéia ou de imagem sonora.

Cobra Norato está para a nossa poesia como o Bateau Ivre está para a francesa, isto é, é mesmo uma viagem pelo chão, pela água, horizontalmente, como um réptil ora lerdo ora fulminante, fuçando febres de pauis, varando toneladas de folhas encharcadas, metendo-se em grutas, saindo em pé na fímbria de pororocas, montado em bichos kiplingianos ${ }^{52}$, com um efeito decorativo de delírio de maleita ou de feitiço de índio. Tem algo não da coisa acrescida,

\footnotetext{
${ }^{52}$ No jornal, lê-se “kiplingeanos”.
} 
barroca, duma poesia esculpida em rocha, ou em madeira nossa: tão pouco é uma cristalização marajoara de símbolos gratuitos guaranis. Não comparticipa em nada de "I-Juca Pirama”, nenhuma consangüinidade tem com produções quaisquer indianistas. É um poema de terra molhada, de barranca de rio arrastada por entre véus de mosquitos, séqüitos de tartarugas, bandos de aves multicores, parece aparição em forma longa e hirta, com algo dos produtos em pala dourada das figuras bizantinas, tão pura em linha, tão vivaz em cromatismo é ela. É anterior até à nossa língua de quinhentos, anterior a Cabral, anterior talvez até ao dilúvio, promana duma eternidade geodésica de períodos sobrepostos, vem da Criação, é o Equador mesmo, é a matriz exuberante do Brasil lendário, é o cunho, o carimbo no nosso flanco da queda dum aerólito. Não existe em nossa língua alucinação mais pictórica, desenho mural, ou de chão, mais sinteticamente americano, brasileiro, equatorial, tropical, potamográfico, tem algo até de brasão de tribos gloriosas, devia ter sido feito pelo poeta tomado não já da sua personalidade de hoje, mas da personalidade transposta, afundada séculos, emergida na época em que foi feita como uma flor do Amazonas emergindo na mão erguida duma iara subindo para incensar o Cruzeiro.

Já Macunaíma é universal, ou por outra se arregimenta entre os grandes livros universais, tem tanta força épica, lírica, telúrica, humana como qualquer poema típico, cíclico, ou não, de qualquer grande raça, grande região, ou grande língua. E não há, nem tão cedo haverá, entre nós, nem em parte alguma, realização tão nova e tão anterior a tudo quanto é arte, pois suas características são polivalentes, seus símbolos são diédricos, sua forma é tão brasileira, mas tão brasileira, o seu formal feito em forma tão voluptuosa, livre, de protoplasma moldado com varetas de bambu, remexido com espinhos, rodado e jogado como escarro de mil cores da boca de répteis hilariantes, sua significação léxica é tão revolucionária, seu arrojo verbal é tão languidamente vitorioso e senhor de sua vitória aparentemente fácil, suas descobertas de expressão tão molemente bocejadas como bocejos que criam flores e ritmos, seu essencial tão diferente, sua forma de poema tão específico, sua natureza selvática, erradia, tão molhada em atmosferas de enchentes e de cachoeiras, seu mundo[,] um mundão tão largo e patético de bastidores verdes, e seu itinerário tão de sonho, de preguiça gostosa, de lenda dita com saliva de risada por entre sucos de ervas nos dentes, seu corpo híbrido tão nu na água, e seus gestos tão coreográficos na modulação da fala e no ritmo da locomoção, que Macunaíma, longe de se filiar a qualquer subcapítulo de Távolas Redondas, ou de romances celtas, no gênero poema ou lenda, e independente, singular, sem sentido de conexão ou de analogia, é coisa nascida na areia, no pântano, no meio da bicharada, pipocando como seio de vulcão ainda tenro, e está 
para nós, para o mapa de criações da nossa ficção rapsódica como um tipo sem ligações analógicas com qualquer tema homólogo seja donde for.

Mas, se sua expressão e seu nascimento arrojado têm que ser encarados por nós de maneira polivalente, tantas são as faces e os ângulos por que o podemos contemplar, a sua transparência lingüística, a sua estrutura não de cobre nem de minério, mas de gelatina inconsútil e que sol algum derrete, sua musculatura, suas articulações atléticas preguiçosas, sua postura ora vertical, ora deitada, ora aos pinotes, seu recorte no ar, sua estereoscopia, seu relevo, isso sim significa indubitavelmente coisa nova, inventada e feita com matéria-prima brasileira, sem emprego sequer de mão-de-obra estrangeira. Macunaíma, como experiência de criação de uma língua, como expressão dialética de episódios poéticos e aventureiros, como tema trabalhado em oficina ao ar livre na barranca de rios desbugrados, como corpo, como alma, como escultura, como painel, é um produto de criação em estado de transe, é o mergulho mais ousado dado do alto das montanhas ao fundo de uma lagoa bem nossa, é a desnudação mais consciente e mais crua de todo o formal anterior, de todo o essencial circunjacente, e é a subida, depois, não duma parábola com fusão concêntrica de símbolos e de imagens, mas dum corpo brasileiro cheirando a água, a húmus, a feitiço, a lenda, a milagre pagão, coisa viva, aparição de espantar brancos, espécie de guerreiro a rir alto, vendo fugirem para as caravelas as manadas medievais do léxico do outro continente. Pois, em verdade, Macunaíma é a América do Sul, é o Brasil, antes, durante e depois, não como o quiseram pintar nem como o quiseram esculpir em alegorias acabocladas. É um poema cuja só matéria plástica, a língua, mesmo só como preparo de tela, já é a maior revolução léxica de qualquer sistema ou conjunto de línguas consangüíneas. A ânsia de ecumenicidade falsa dá o “esperanto”. O sentido fecundo de universalidade dá blocos assim, como Macunaíma que foram, nas galerias de raças e de criações, obras-primas equivalentes por exemplo às dum Leonardo. A bem dizer, Macunaíma está para a nossa ficção poética, rapsódica, como aquele bloco de Laocoonte, ou como aquele Moisés, de outros criadores. Mas não hirto nem espetacular como eles. Rindo e se espreguiçando, como as potências em estado tônico, preparadas para a dança, o arremesso e a fulguração. Cobra Norato, em poesia, Macunaíma[,] em prosa, estão a pedir um museu para as multidões pasmarem ante os seus delírios léxicos mais ousados do que um pesadelo em tecnicolor! 

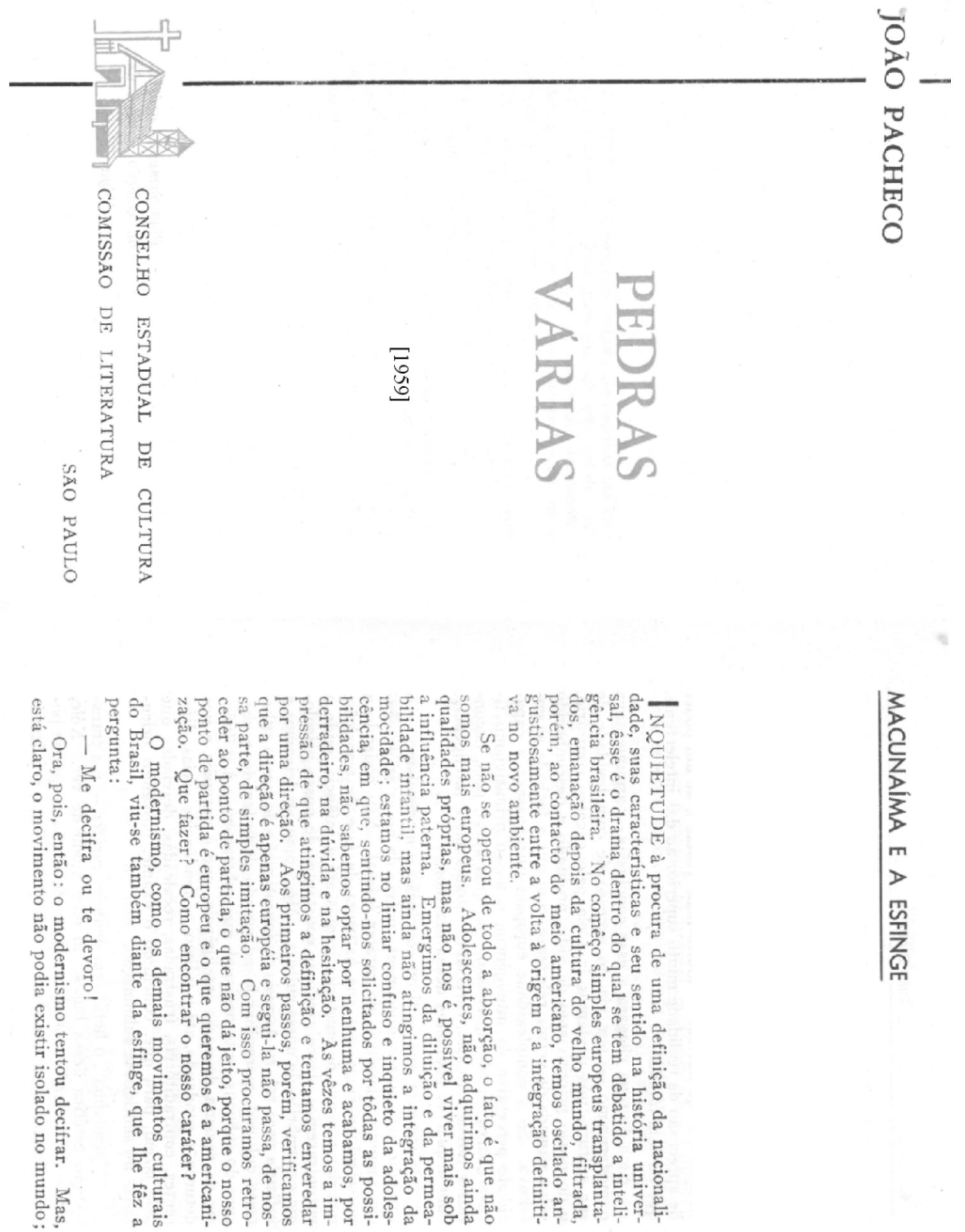


\section{MACUNAÍMA E A ESFINGE}

PACHECO, João. "Macunaíma e a esfinge". O Estado de S. Paulo, São Paulo, 18 de maio de $1945^{53}$. Recolhido em PACHECO, João. Pedras Várias. São Paulo: Conselho Estadual de Cultura, 1959, p. 3-8.

Inquietude à procura de uma definição da nacionalidade, suas características e seu sentido na história universal, esse é o drama dentro do qual se tem debatido a inteligência brasileira. No começo simples europeus transplantados, emanação depois da cultura do velho mundo, filtrada, porém, ao contacto do meio americano, temos oscilado angustiosamente entre a volta à origem e a integração definitiva no novo ambiente.

Se não se operou de todo a absorção, o fato é que não somos mais europeus. Adolescentes, não adquirimos ainda qualidades próprias, mas não nos é possível viver mais sob a influência paterna. Emergimos da diluição e da permeabilidade infantil, mas ainda não atingimos a integração da mocidade; estamos no limiar confuso e inquieto da adolescência, em que, sentindo-nos solicitados por todas as possibilidades, não sabemos optar por nenhuma e acabamos, por derradeiro, na dúvida e na hesitação. Às vezes temos a impressão de que atingimos a definição e tentamos enveredar por uma direção. Aos primeiros passos, porém, verificamos que a direção é apenas européia e segui-la não passa, de nossa parte, de simples imitação. Com isso[,] procuramos retroceder ao ponto de partida, o que não dá jeito, porque o nosso ponto de partida é europeu e o que queremos é a americanização. Que fazer? Como encontrar o nosso caráter?

O modernismo, como os demais movimentos culturais do Brasil, viu-se também diante da esfinge, que lhe fez a pergunta:

— Me decifra ou te devoro!

Ora, pois, então: o modernismo tentou decifrar. Mas, está claro, o movimento não podia existir isolado no mundo; pertenceu a um momento, cuja mentalidade teve de refletir, e as circunstâncias o puseram em contacto com o que se passava no globo, principalmente na Europa, de cujas conquistas culturais se serviu - e nem podia ser de outra maneira, apesar de todo o seu brasileirismo de propósito. Na Europa, descrente da inteligência, predominava a idéia de que a explicação do mistério da vida seria encontrada pelas faculdades instintivas do

\footnotetext{
${ }^{53}$ Imagem de documento não resgatada pela pesquisa.
} 
homem, das quais as sexuais constituíam a força nuclear - muito mais vastas e de um poder de apreensão da realidade muito superior ao das intelectuais, que haviam falhado.

Se a Europa chegara a essa conclusão - argumentava o modernismo - por via do excesso de complexidade de sua cultura, nós devíamos ir a ela pelo excesso contrário, o do nosso primitivismo de vida, profundo e desconhecido sob a camada de verniz reluzente, com que a fachada se enfeitava. Se a complexidade européia ultrapassava a capacidade perceptiva da inteligência, o nosso primitivismo ficava abaixo de sua apreensão. Se queríamos, pois, encontrar a nossa definição, carecíamos abandonar a inteligência, com a qual só podíamos desnaturar-nos.

De maneira que - tirou conclusão o modernismo - o caminho está no reconhecimento prévio da nossa adolescência, quando a ausência de caráter é fatal. Não podendo a nossa adolescência, por sua natureza de fase de transição, nos dar a chave do mistério, iremos até a infância, onde a encontraremos, descobrindo as constantes de nossa psicologia e o embrião de nossa cultura. Mas como, se deixamos a infância para trás? Através da investigação do nosso substrato cultural, mergulhando no mundo desordenado e obscuro do subconsciente nacional, que subtrairemos à influência da censura de nossa inteligência, que é européia e nos deturpa, e sondando, até o ínfimo, as tendências várias, diferentes, contraditórias, frustradas, recalcadas, desviadas que nele jazem, para que, concluído o exame, possamos orientá-las no sentido de sublimação.

Macunaíma, o herói sem nenhum caráter - é a transposição estética dessa busca, no meu modo de ver. Nele, Mário de Andrade tentou, no plano da ficção, o que se poderia chamar, com um certo quê de pedantismo, a psicanálise de nossa cultura (dentro dos limites, está visto, do que pode a ficção). Remontou aos nossos mitos primitivos e, como entre os nossos mitos os mais primitivos são os amazônicos, foi até eles e deles, entregando-se ao processo de rememoração inconsciente, partiu para a reconstituição de toda a subconsciência nacional: tudo nos vem aí de cambulhada, aflora à consciência e imerge de novo no inconsciente, na ânsia de alcançar aquele ponto em que, como queria André Breton, todas as contradições se conciliam e a unidade do ser é captada na própria multiplicidade. Procurando a unidade, através da multiplicidade e por via inconsciente, Macunaíma passa em revista todas as nossas tendências, por meio de associação de imagens, que são transparências de idéias, ditos e símbolos folclóricos e numa linguagem que se abandona a todas as influências léxicas e sintáticas que recebemos. Evoca desde os nossos pequeninos hábitos, sestros e cacoetes, até as preocupações mais letradas e eruditas, caricaturadas na carta às icamiabas, e busca a revelação de 
nossa beleza, fim que, em principal e em virtude de sua natureza artística, e dentro da refração pessoal do autor, se propunha a rapsódia. Ao realizá-la com êxito, Macunaíma chegou a obraprima, em que o estado de espírito nacional daquele momento ficou definitivamente representado.

Nascendo no fundo do mato virgem da Amazônia, onde a força telúrica absorve o homem e em que a natureza tem comunicações com o firmamento, para onde se evadem de contínuo os mitos, transformando-se em estrelas, que têm poderes mágicos sobre os seres terrenos, e onde por tudo paira uma atmosfera de encantamento em que se confundem céu e terra Macunaíma, herói de nossa gente, é filho da indistinção e indistinto em si próprio.

De primeiro passou seis anos sem falar.

— Ai, que preguiça!... que ele murmurava, se o incitavam a falar; e não dizia mais nada.

Só espertava, quando, à vista de dinheiro, “dandava pra ganhar vintém”. Ou quando, indo a família tomar banho no rio, todos juntos e nus, dava mergulho na água e "as mulheres soltavam gritos gozados por causa dos guaiamuns diz que habitando a água doce por lá”.

Preguiça, gosto por dinheiro e costume de bulir nas graças das cunhatãs - tais são as inclinações que Macunaíma revela desde criança de berço e de que mais tarde nunca largará mão, na força de homem feito. Projeção do inconsciente, Macunaíma é infantil, irresponsável e inconseqüente - sua função é "brincar”, a que se entrega e em que se satisfaz, largadamente. Assim, piá ainda, conheceu Sofará, mulher do mano Jiguê, e a linda Iriqui, também esposa do irmão. Até que um dia, passando uma manta no Currupira, a cotia, com quem se encontrara, falou para ele:

- Curumim faz isso não... Vou te igualar o corpo com o bestunto. Mas errou na operação e o herói continuou infantil de juízo.

Então Macunaíma travou-se de amores com Ci, a mãe do Mato, de quem houve um filho, em cuja cabeça chata batia para a achatar ainda mais, dizendo:

— Meu filho, cresce depressa pra você ir pra São Paulo ganhar muito dinheiro.

Porém, vai e acontece, o curumim não cresceu: falece um dia. Com o que, Ci, daí então a companheira pra sempre inesquecível, tirou do colar um muiraquitã famoso, deu-o a Macunaíma e, por meio de um cipó, subiu para o céu, onde agora vive nos trinques passeando. É a Beta do Centauro. O herói ficou padecendo saudades. Do muiraquitã fez um tembetá, colocando-o no beiço inferior que, para isso, furou. De uma feita, ao passar por uma cascata, deu ouvido a uma voz que saia das águas. A voz lhe contava que fora uma linda cunhatã, mas, 
vítima da boiúna Capei, virara em cachoeira e pedia a interferência de Macunaíma para salvála. Ao ouvir a prosa, a cabeça da boiúna emergiu do rio e ameaçou o herói, que jogou no veado, disparando mato a fora, indo topar com o Bacharel de Cananéia:

- Como vai, bacharel! - fez uma saudação.

— Menos mal, ignoto viajor.

— Tomando a fresca, não?

- C’est vrai, como dizem os franceses.

Em meio da corrida Macunaíma botou sentido que perdera o tembetá. Fora roubado pelo gigante Piaimã, mais conhecido por Venceslau Pietro Pietra, residente em São Paulo, para onde se dirigiu o herói e onde viveu muitas aventuras, tendo brincado com muitas francesas, que não tinha no Norte. Em Piratininga foi perseguido por Ceiuci, a velha gulosa, de cuja voracidade, agora unida à avareza por influência do novo meio, foi salvo por uma das filhas dela, propondo três adivinhas ao herói, que não foi capaz de resolver nenhuma. Também em Piratininga se encontra com o Zé Prequeté, a quem aconselha:

— Tira o bicho do pé pra tomar com café!

Esperou muitas vezes o Chico vir de baixo e ficou conhecendo a máquina automóvel e a máquina telefone. Das suas impressões de viagem Macunaíma deu conta numa carta às icamiabas, redigida na língua escrita da terra, que naturalmente diferia da língua falada, espúria e de baixo calão.

A Macunaíma, o próprio símbolo de nosso estádio cultural amorfo, devemos a invenção de muitos de nossos cacoetes. Por exemplo a expressão “Tá solto!” querendo dizer que não fazemos aquilo que nos é pedido, foi inventada por ele, quando, ao espiar por uma fresta, impediu que o mano Jiguê abrisse a porta a Capei, dizendo:

— Está solta!

Foi o inventor do futebol, enquanto o mano Jiguê foi o da lagarta rosada e Maanape criou o bicho-do-café. A objurgatória “Vá tomar banho!” de uma fala de Ceiunoque, a estrela da manhã, ao se recusar a uma brincadeira com o herói, que fedia muito. A ele também se deve a descoberta de uma grande verdade científica:

— Pouca saúde e muita saúva, os males do Brasil são! que ele, com os braços oscilando por cima da pátria, decretou solene, ao se sentir tentado por uma porção “de cunhãs cunhé cunhé se mexemexendo com talento e formosura” por debaixo de uma árvore. Em São Paulo, não pôde resistir à idéia de ir à Europa e pleiteou, junto ao governo, um prêmio de viagem para estudar piano. 
— Mas, se você dispõe de recursos, Macunaíma, por que não vai com dinheiro próprio?

— Poder, ele podia, mas seguir com dinheiro do governo não era muito melhor?

Por fim, Macunaíma regressou a seus pagos, encontrando de caminho a João Ramalho. Hoje é a Ursa Maior, banzando solitária no campo vasto do céu. Fiel, pois, ao signo tradicional da Amazônia, de que proviera, Macunaíma perlustrou as paragens brasileiras e acabou transformado em constelação.

Nele, em seu comportamento livre de censura, se opera a evasão de todos os nossos recalques culturais. Através do pansexualismo pessoal, com que alcança a unidade do próprio ser, Macunaíma, emanação do nosso espírito primitivo, que nele se transfigura, se comunica com as forças do cosmos, em que panteisticamente se absorve e nos absorve. E assim realiza a sua, a nossa, e a unidade do cosmos, e nos explica liricamente e ao universo.

JOÃO PACHECO 

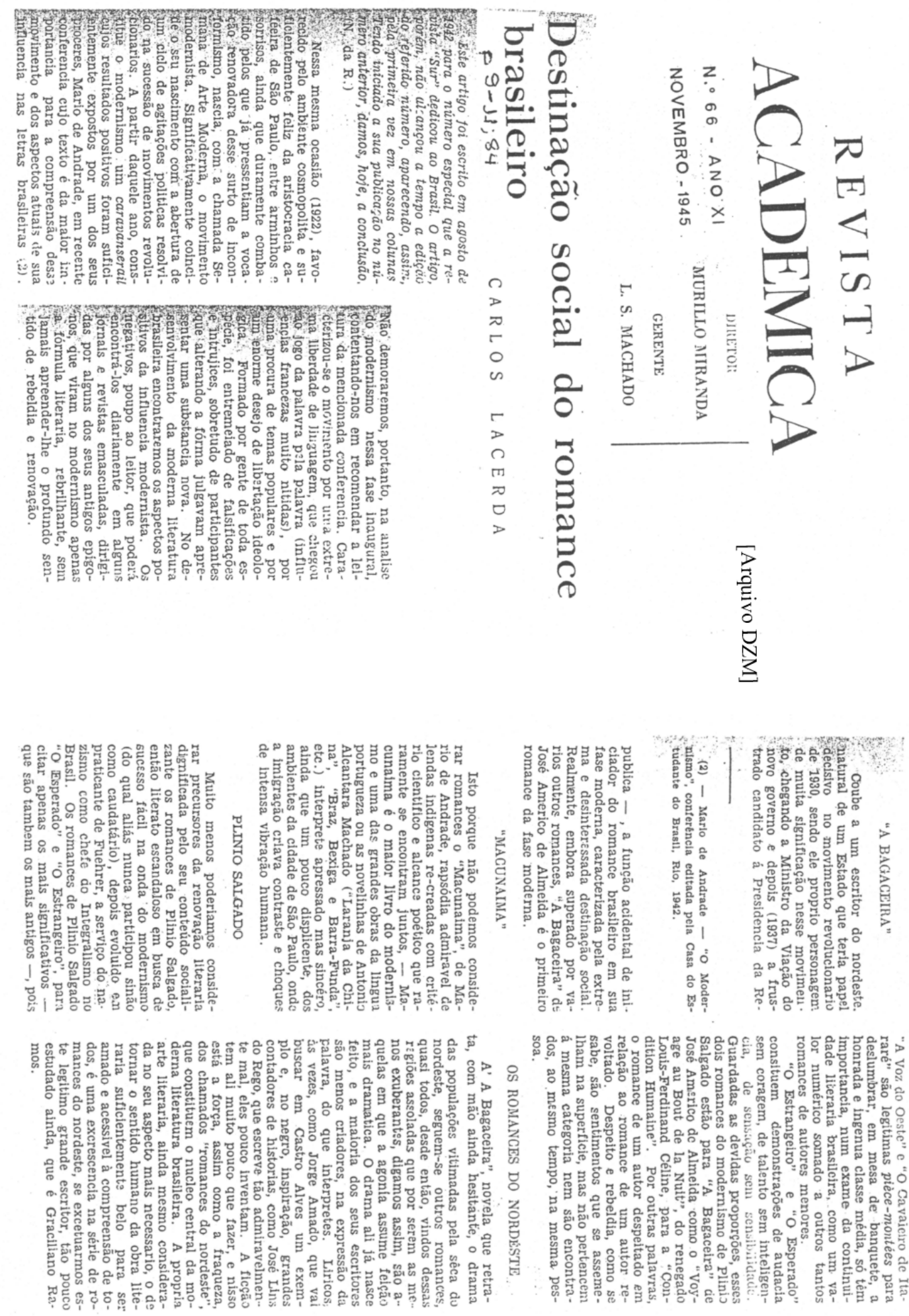

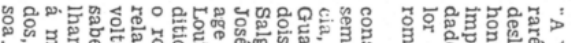

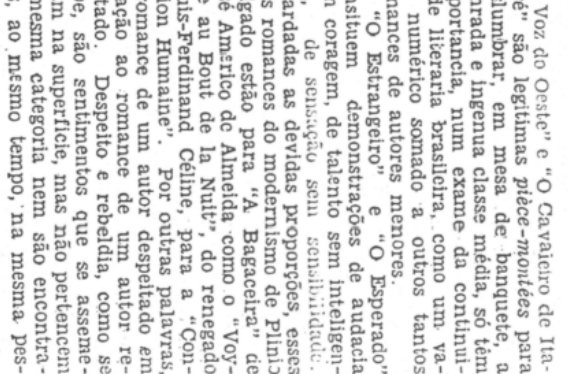




\section{DESTINAÇÃO SOCIAL DO ROMANCE BRASILEIRO}

LACERDA, Carlos. "Destinação social do romance brasileiro”. Revista Acadêmica: Rio de Janeiro, ano XI, nº 66, novembro de 1945. Arquivo DZM.

Este artigo foi escrito em agosto de 1942 para o número especial que a revista "Sur" dedicou ao Brasil. O artigo, porém, não alcançou a tempo a edição do referido número, aparecendo, assim, pela primeira vez em nossas colunas. Tendo iniciado a sua publicação no número anterior, damos, hoje, a conclusão. (N. da R.)

Nessa mesma ocasião (1922), favorecido pelo ambiente cosmopolita e suficientemente feliz da aristocracia cafeeira de São Paulo, entre arminhos e sorrisos, ainda que duramente combatido pelos que já pressentiam a vocação renovadora desse surto de inconformismo, nascia, com a chamada Semana de Arte Moderna, o movimento modernista. Significativamente[,] coincide o seu nascimento com a abertura de um ciclo de agitações políticas resolvido na sucessão de movimentos revolucionários. A partir daquele ano, constitui o modernismo um caravanserail cujos resultados positivos foram suficientemente expostos por um de seus próceres, Mário de Andrade, em recente conferência cujo texto é da maior importância para a compreensão desse movimento e dos aspectos atuais de sua influência nas letras brasileiras ${ }^{54}$. Não demoraremos, portanto, na análise do modernismo nessa fase inaugural, contentando-nos em recomendar a leitura da mencionada conferência. Caracterizou-se o movimento por uma extrema liberdade de linguagem, que chegou ao jogo da palavra pela palavra (influências francesas muito nítidas), por uma procura de temas populares e por um enorme desejo de libertação ideológica. Formado por gente de toda espécie, foi entremeado de falsificações e intrujices, sobretudo de participantes que alterando a forma julgavam apresentar uma substância nova. No desenvolvimento da moderna literatura brasileira encontraremos os aspectos positivos da influência modernista. Os negativos, poupo ao leitor, que poderá encontrá-los diariamente em alguns jornais e revistas emasculadas, dirigidas por alguns dos seus antigos

\footnotetext{
${ }^{54}$ Nota de Carlos Lacerda.: “Mário de Andrade. 'O Modernismo’, conferência editada pela Casa do Estudante do Brasil. Rio, 1942”. O texto dessa conferência, cujo título correto é "O movimento modernista”, foi recolhido em ANDRADE, Mário de. Aspectos da literatura brasileira. 5ํㅡㄹ. ed. São Paulo: Martins, 1974, p. 231-255. A 1ª edição é de 1943.
} 
epígonos, que viram no modernismo apenas a forma literária, rebrilhante, sem jamais apreender-lhe o profundo sentido de rebeldia e renovação.

\section{A BAGACEIRA}

Coube a um escritor do nordeste, natural de um Estado que teria papel decisivo no movimento revolucionário de 1930, sendo ele próprio personagem de muita significação nesse movimento, chegando a Ministro da Viação do novo governo e depois (1937) a frustrado candidato à Presidência da República -, a função acidental de iniciador do romance brasileiro em sua fase moderna, caracterizada pela extrema e desinteressada destinação social. Realmente, embora superado por vários outros romances, A bagaceira[, ]de José Américo de Almeida[,] é o primeiro romance da fase moderna.

\section{Macunaíma}

Isto porque não podemos considerar romances o Macunaíma, de Mário de Andrade, rapsódia admirável de lendas indígenas recriadas com critério científico e alcance poético que raramente se encontram juntos - Macunaíma é o maior livro do modernismo e uma das grandes obras da língua portuguesa [-,] ou as novelinhas de Antônio de Alcântara Machado (Laranja da China; Brás, Bexiga e Barra Funda; etc.)[,] intérprete apressado mas sincero, ainda que um pouco displicente, dos ambientes da cidade de São Paulo, onde a imigração criava contraste e choques de intensa vibração humana.

\section{(...)}


1946 
5 PAULO - DOMINGO, 20 DE JANEIRO DE 1946 [Arquivo FSP]

ASPECTOS DA LITERATURA REGIONAL
(Para a "Folha đa Manhăn")

Năo será ruito ortodoxo falar de aspectos, uma anedota: diante te ums glrafa, considerou-a por vez que o poifedro - literatura regional - só apre- todos os lados, acabando por exclamar:

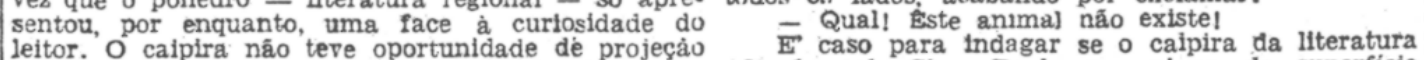
fora do seu habitat. Os mei ss ruraís náo deram um não é real. Stm. Real num plano de superficie poeta, um escritor, um artista ao Brasil. Conse- desprovido de profundidade humana. E' uma conquéncia do ambiente. da defíciência de educacàa vençáo literária, felta do enunciado de modismos e de instruçác, e outros fatôres. da competência reglonais. Nada significa. Táo verdade é que a dessa lacuna é que náo há atguém completamente vras. $\mathrm{B}$ as próprias frases, afinal, nem sempre sẫo capacitado a compreendê-lo e o apresentá-1o taj o que são, mas o que sugerem.

como é o caipira é naturalmente impenetrável. E dificil fazer com que imaginem o sertanejo Nada revela. Os que o descreveram e alguns o fi- um ser humano e náo a sua mera caricatura. de zeram magistralmente, n⿳亠丷厂 conseguiram deslocar o calças de riscado e chapéu de palha viola'a tíracolo zeram ' ângulo de visâo. Nâo se pode negar que agudos ob- e erros gramaticals. E claro que nao posso despl-10 servadores foram além da superficle. Mas nảo de sua fantasia convencional e nem do seu envol-
muito além.

Afrânio Peixoto. que costuma escrever com o alguns excelentes cortes anatốmicas de caboclo.

Muito elucidativo é o glgantesco estudo de Ev. clides da Cunha, que apresentou em "Os Sertరes" a terra e o homem com um discernimento singular.
Alís, a Sociologia féz incomparàvelmente mais para a compreensáo do caboclo que os que militam no terreno da ficçáa pura. Estes parecem ter esquecico que a ficçáo deve uma espécie de fidelidade poética ao real.

Jâ se fêz multo no terreno do folclore, não 0 bastante. E' cítável "Macunaima", nấo próprlamente pelo folclore que contém. mas pelas belas cristalizaçōes do linguajar sertanejo. De resto essas livro estranho é a sua misteriosa esséncla poética. Em última anállse, "Macunaima" é poesia verdeamarela poesia reacionária Poesia afinal.

Em se tratando de Mário de Andrade, em seu encontro com a tradica popular. Isso era. de um certo modo, fatal. Mario de Andrade tinha. como poeta. uma qualldade imanente, hipersensivel a
poesia. Aproveitou magnificamente a poesia de que está impregnada a tradição oral, porém o livro é, do principio ao fim, o seu proprio gênio, sem preocupaçóes de traduzir o pensamento vivo do homem inculto. Nem o autor pretendia, suponho. fazer-ise porta-voz césse homem irrevelado.

Poder-se-ia dizer, parodiando Alexxls Carrel - Calpira. esse descon tocido. A que revelado. Fol visto por espectadores. mais ou menos interessados. que o refletiram, quando nâo deformado, ao menos como o fa:ia um espelho: tirando-lhe a vida. Dercreveram-no sem 0 entender. Sua face de granto continua impenetravel e náo se sabe 0 que sento o segrezado. Fol esquecido como homem, essencialmente eterno. e lembrado apenas em seus caracteristicos diferencia Tatu e se aproximou da incógnita. apresentou um calpira verdadelro, mas verdadeiro como pode ser uma fotografia. Năo sentíu o matuto. Lendo Lobato, poderemos saber como o ser tanejo ê, de um modo superficial e ligeiro, mas nso u que é. E o seu modo de ser e de sentir talvez seja mais importante que a sua maneira pecultar de apresentar-se.

Não e necessária a mençãa dos grandes e nem dos literatos menores. Generalizando, o que se nota no cenárto da literatura regional é isto: do desconhecimento das verdades essencials do sertanejo, surgiu um tipo padronizado. destituido de plastic1dade, com reaçóes estandardizadas, absolutamente postiças. Temos um falso sertanejo, como fá tive- mais próximos da realidade humana do caboclo, fios mesmo tempo tăo mais estranho, ùnicamente por dessa premissa, chega-se à conclusăo de que o unico mesmo tempo táo mais estranho, unicamesta de vida. que o leitor desprevenido, ao caminho para atingir a alma sertaneja. visando

deparar, sem mais nem menos, com um auténtico uma psicologia quado da tradiçăo popular.

Cornélio Plres surgiu seguindo um rumo absoutamente inédito. Teve atuaçáo esplêndida no cenarlo da literatura regional. Comentou-se que seu pura. Em primeiro lugar, Cornélio Pires usuu bas. ante, e muito fielmente. a observação direta, e e acll a comprovaçăo. Em segundo lugar, o estudar mas nấo faz o milagre de nos dar o que nắo temos. A arte è um estádio extremo e requintado da própria vida mas vida essencialmente. vamos dizer que é a vida elevada à beleza. O fato é que caipira do seu âmbito, tấo fielmente como seria de desefar. Veja-se o caso de Valdomiro Sllveira. Velo como um bruxo risonho, as mâos cheias de pedras arte a sinceridade depende do talento, mas, in de capacidade de descrever, qualquer autor o mais que pode fazer é projetar-se, poderosamente ampliado. Cada um dá o que tem. nada mais. Se for ca disso nẩo há salvação.

Há un caminho certo que é não escrever sôbre - que nâo se conhece. Para o resto, nada há a dizer. Quais os novos rumos a seguir? Depois de nâo serei eu quem pretenda redescobrir as cabecel.

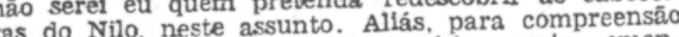
caboclo, minha formula empírica seria, emen. ando Bilac:

"Eu vos direi: amai-os pra entendê-los", o que, a entre nós. nem sempre é fácll.

Apenas o que pretendo sugerir, com tôda esta conversa, é o estudo mais intensificado da tradiçâa será útil. se bem aproveitado. Saber-se-á como interessar o caboclo em problemas que o tocam de erto. Fora das consequências sociais, será basante que afude a compreender-lhe as reaçoes. mer. um sentido de descobrimento è vale por aproximaçă erá de incalculável valor para a literatura. pois que a enriquecerla de mais tipos da estatura do 列 hato, e como o inesquect

Vou llustrar a tese, mencionando nomes que como toques de clarim e que me obrigam a sentimento de profunda humildade.

Joxo Simóes Lopes Neto, Amadeu de Quelros Joåo Simoes Lopes Niram ao tlpo-padrão, e estăo Aránio Pelxoto, que fugir 


\section{ASPECTOS DA LITERATURA REGIONAL}

GuIMARÃES, Ruth. “Aspectos da literatura regional”. Folha da Manhã: São Paulo, 20 de janeiro de 1946, p. 30. BDFSP.

Não será muito ortodoxo falar de aspectos, uma vez que o poliedro ${ }^{55}$ - literatura regional - só apresentou, por enquanto, uma face à curiosidade do leitor. O caipira não teve oportunidade de projeção fora do seu habitat. Os meios rurais não deram um poeta, um escritor, um artista ao Brasil. Conseqüência do ambiente, da deficiência de educação e de instrução, e outros fatores, da competência exclusiva dos sociólogos. O resultado importante dessa lacuna é que não há alguém completamente capacitado a compreendê-lo e a ${ }^{56}$ apresentá-lo tal como é. O caipira é naturalmente impenetrável. Nada revela. Os que o descreveram, e alguns o fizeram magistralmente, não conseguiram deslocar o ângulo de visão. Não se pode negar que agudos observadores foram além da superfície. Mas não muito além.

Afrânio Peixoto, que costuma escrever com o bisturi - não se é médico impunemente - deu-nos alguns excelentes cortes anatômicos de caboclo.

Muito elucidativo é o gigantesco estudo de Euclides da Cunha, que apresentou em Os sertões a terra e o homem com um discernimento singular. Aliás, a sociologia fez incomparavelmente mais para a compreensão do caboclo que os que militam no terreno da ficção pura. Estes parecem ter esquecido que a ficção deve uma espécie de fidelidade poética ao real.

Já se fez muito no terreno do folclore, não o bastante. É citável Macunaíma, não propriamente pelo folclore que contém, mas pelas belas cristalizações do linguajar sertanejo. De resto essas cristalizações são esporádicas. O que o torna um livro estranho é a sua misteriosa essência poética. Em última análise, Macunaíma é poesia verde-amarela, poesia reacionária. Poesia afinal.

Em se tratando de Mário de Andrade, em seu encontro com a tradição popular, isso era, de um certo modo, fatal. Mário de Andrade tinha, como poeta, uma qualidade imanente, hipersensível à poesia. Aproveitou magnificamente a poesia de que está impregnada a tradição oral, porém o livro é, do princípio ao fim, o seu próprio gênio, sem preocupações de traduzir o pensamento vivo do homem inculto. Nem o autor pretendia, suponho, fazer-se portavoz desse homem irrevelado.

\footnotetext{
${ }^{55}$ No jornal, lê-se “poiledro”. Erro tipográfico.

${ }^{56}$ No jornal, lê-se “o”. Erro tipográfico.
} 
Poder-se-ia dizer, parodiando Aléxis Carrel - o Caipira, esse desconhecido. A literatura regional brasileira mais o tem traído do que revelado. Foi visto por espectadores, mais ou menos interessados, que o refletiram, quando não deformado, ao menos como o faria um espelho: tirando-lhe a vida. Descreveram-no sem o entender. Sua face de granito continua impenetrável e não se sabe o que sente o segregado. Foi esquecido como homem, essencialmente eterno, e lembrado apenas em seus característicos diferenciais exteriores. Monteiro Lobato, que nos deu o Jeca Tatu e se aproximou da incógnita, apresentou um caipira verdadeiro, mas verdadeiro como pode ser uma fotografia. Não sentiu o matuto. Lendo Lobato, poderemos saber como o sertanejo é, de um modo superficial e ligeiro, mas não o que é. E o seu modo de ser e de sentir talvez seja mais importante que a sua maneira peculiar de apresentar-se.

Não é necessária a menção dos grandes e nem dos literatos menores. Generalizando, o que se nota no cenário da literatura regional é isto: do desconhecimento das verdades essenciais do sertanejo, surgiu um tipo padronizado, destituído de plasticidade, com reações estandardizadas, absolutamente postiças. Temos um falso sertanejo, como já tivemos um falso indígena. Não que o tenham modificado, mas o original é tão mais simples e ao mesmo tempo tão mais estranho, unicamente por ser dotado de vida, que o leitor desprevenido, ao deparar, sem mais nem menos, com um autêntico caipira, corre o risco de fazer como o homem da anedota: diante de uma girafa, considerou-a por todos os lados, acabando por exclamar:

— Qual! este animal não existe!

É caso para indagar se o caipira da literatura não é real. Sim. Real num plano de superfície desprovido de profundidade humana. É uma convenção literária, feita do enunciado de modismos regionais. Nada significa. Tão verdade é que a alma das frases não está na ortografia das palavras. E as próprias frases, afinal, nem sempre são o que são, mas o que sugerem.

É difícil fazer com que imaginem o sertanejo um ser humano e não a sua mera caricatura, de calças de riscado e chapéu de palha, viola a tiracolo e erros gramaticais. É claro que não posso despi-lo de sua fantasia convencional e nem do seu envoltório de carne opilada e subnutrida para trazê-lo a nu, essência pura, à ribalta.

Cornélio Pires surgiu seguindo um rumo absolutamente inédito. Teve atuação esplêndida no cenário da literatura regional. Comentou-se que seu “caipirismo” e sua maneira de escrever eram arte pura. Em primeiro lugar, Cornélio Pires usou bastante, e muito fielmente, a observação direta, e é fácil a comprovação. Em segundo lugar, o estudar a arte não cria o artista: ela desenvolve dons natos, mas não faz o milagre de nos dar o que não temos. A arte é um estádio extremo e requintado da própria vida, mas vida essencialmente. Vamos dizer que é 
a vida elevada à beleza. $\mathrm{O}$ fato é que não basta entender da arte para transportar o caipira do seu âmbito, tão fielmente como seria de desejar. Veja-se o caso de Valdomiro Silveira. Veio como um bruxo risonho, as mãos cheias de pedras verdes, que supôs serem esmeralda. Huxley diz que, na arte a sinceridade depende do talento, mas, independentemente da capacidade de descrever, qualquer autor o mais que pode fazer é projetar-se, poderosamente ampliado. Cada um dá o que tem, nada mais. Se for caipira de espírito, será um bom autor regional. Fora disso não há salvação.

Há um caminho certo que é não escrever sobre o que não se conhece. Para o resto, nada há a dizer. Quais os novos rumos a seguir? Depois de Cornélio Pires e dos outros que mencionarei adiante, não serei eu quem pretenda redescobrir as cabeceiras do Nilo, neste assunto. Aliás, para compreensão do caboclo, minha fórmula empírica seria, emendando Bilac:

“Eu vos direi: amai-os pra entendê-los”, o que, cá entre nós, nem sempre é fácil.

Apenas o que pretendo sugerir, com toda esta conversa, é o estudo mais intensificado da tradição oral, como instrumento de penetração psicológica. Será útil, se bem aproveitado. Saber-se-á como interessar o caboclo em problemas que o tocam de perto. Fora das conseqüências sociais, será bastante que ajude a compreender-lhe as reações. Tem um sentido de descobrimento e vale por um mergulho na eternidade. Além disso, a aproximação será de incalculável valor para a literatura, pois que a enriqueceria de mais tipos da estatura da avó de Pingo-D’Água, da “Colcha de Retalhos” de Lobato, e como o inesquecível Joaquim Bentinho das estrambólicas aventuras.

Vou ilustrar a tese, mencionando nomes que soam como toques de clarim e que me obrigam a um sentimento de profunda humildade.

João Simões Lopes Neto, Amadeu de Queirós e Afrânio Peixoto, que fugiram ao tipopadrão, e estão mais próximos da realidade humana do caboclo, não são unicamente ficcionistas, mas também folcloristas, o que é altamente significativo. Partindo-se dessa premissa, chega-se à conclusão de que o único caminho para atingir a alma sertaneja, visando uma psicologia que represente a verdade, é a vida oral, ou seja, o estudo da tradição popular.

RUTH GUIMARÃES 

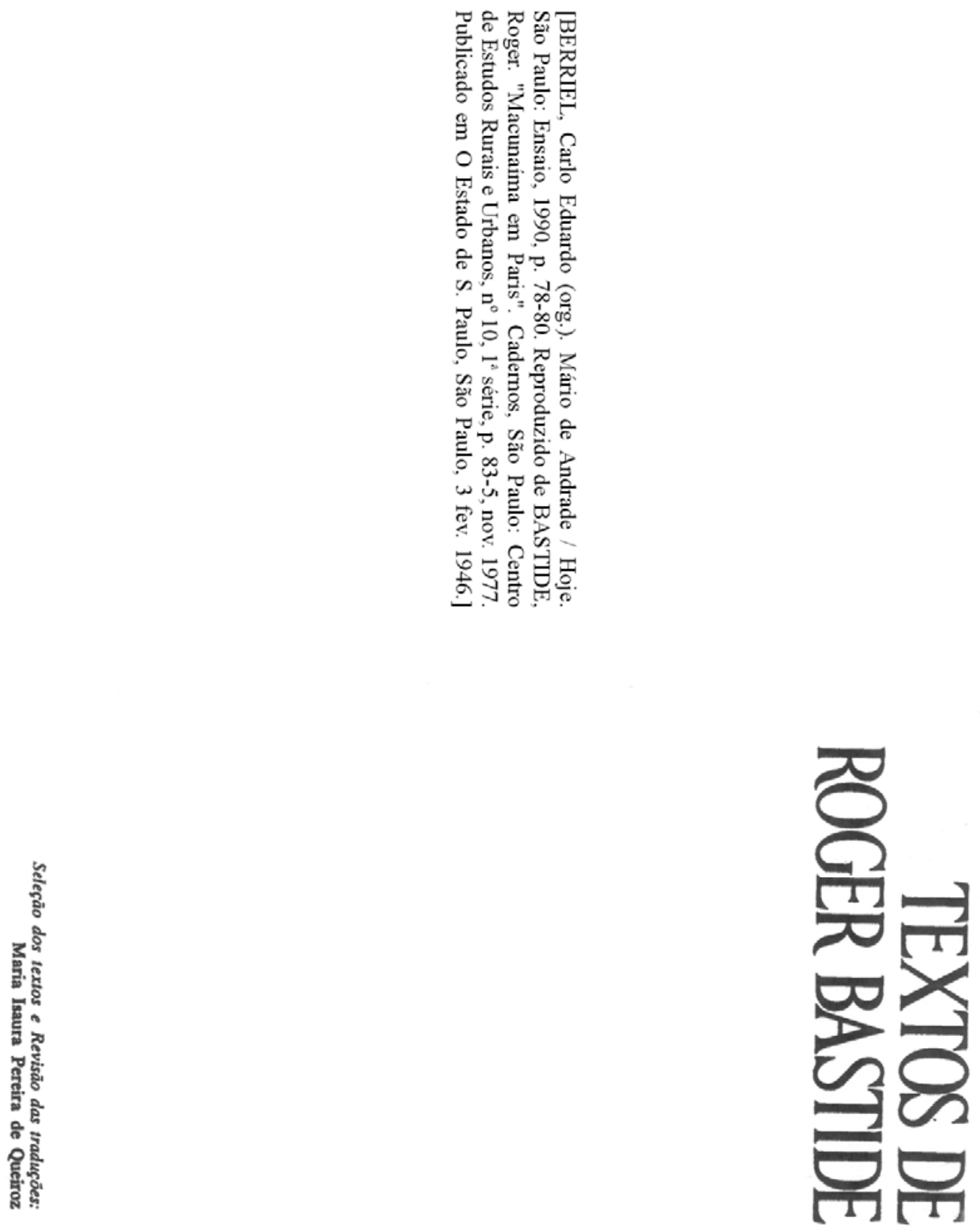


\section{MACUnAÍMA EM PARIS}

BAstide, Roger. "Macunaíma em Paris”. O Estado de S. Paulo, São Paulo, 03 de fevereiro de 1946. Reproduzido em Cadernos: São Paulo, Centro de Estudos Rurais e Urbanos, $\mathrm{n}^{\mathrm{0}}$ 10, $1^{\text {a- }}$ série, novembro de 1977, p. 83-85. Recolhido em BERRIEL, Carlos Eduardo (org.). Mário de Andrade / Hoje. São Paulo: Ensaio, 1990, p. 78-80.

Sonhei esta noite que estava em Paris. E que ali recebia Macunaíma. Havia grandes recepções, uma festa na Embaixada do Brasil, com todas as parisienses fantasiadas de baianas, as norte-americanas de Carmem Miranda e as brasileiras de parisienses; havia uma sessão solene no grande anfiteatro da Sorbonne, com o concurso de France-Amérique, do Instituto de Altos Estudos Brasileiros e todos os amigos do Brasil, os antigos como o prof. Dumas e os novos, que o descobriram entre dois navios; e havia lindos discursos. Em um canto, St.Hilaire e Ferdinand Denis divertiam-se discretamente. Eu era todo olhos, todo ouvidos; de repente, Macunaíma me puxou pelo braço: “São quatro horas. E se fôssemos ver a saída das lycéennes?...”

Pois Macunaíma sabia que nossas normalistas são chamadas lycéennes e que nossas costureirinhas ítalo-afro-hispano-luso-brasileiras se apelidam midinettes; que se os brasileiros ficam parados na beira da calçada para ver passar as mulheres, os parisienses sentam num terraço de café; sabia, enfim, uma porção de coisas que não se aprendem nos livros. Aliás, Macunaíma não sabia ler.

“Onde estão vossas máquinas? Quero quebrá-las!”, disse-me ele. "Paris parece mais selvagem do que São Paulo. Vejo menos máquinas-telefones; desde o tempo de Madame de Sévigné, os parisienses preferem escrever cartas. Vejo menos máquinas-elevadores; depois que surgiram as escadas de Versalhes e das Folies-Bergères, as mulheres daqui preferem descer degraus como Mistinguet ou Cécilie Sorel. Os homens trabalham a madeira e a pedra com suas próprias mãos e com amor. É uma bela terra.”

"Mesmo assim temos algumas máquinas”, observei timidamente. “Temos a máquinaTorre Eiffel, nossa máquina-cadeira de balanço, na qual podemos comer, beber um chope, namorar uma pequena ao balanceio das trepidações da rotação da Terra. Temos a máquinametrô, na qual nos apertamos como sardinhas em lata, espécie de estufa em que o colegial tímido se encosta nas mocinhas, e o sádico belisca as mulheres gordas, e o professor prepara 
sua próxima aula escrevendo notas no bilhete da passagem. Temos a máquina-Exposição Universal, na qual se constroem casas para demoli-las depois, e se juntam tesouros que se dispersam logo a seguir, em meio a fontes luminosas e legiões de honras... E, nos cafés, temos a máquina-papa-níqueis dos trouxas!”

"Basta, basta. Vamos ver então vossas Uiaras.”

E partimos para o campo. Levei-o até à fada Melusina, mas ele pensou que ela havia oxigenado os cabelos, pois não podia conceber a existência de outras beldades além da morena. Ao despedir-se, prometeu-lhe uma caixa de pó-de-arroz ocre para dourar-lhe a neve da tez. Contudo passou um bom momento com ela. Ela se transformou em raio de lua, em sonho de poeta, em uma claridade que tremeluzia sobre o regato: "É uma boa pequena”, disse-me ao sair. "Pena que a gente não possa retê-la.” Conduzi-o ao castelo de Barba-Azul; juntos, eles torturaram algumas vítimas, beberam sangue quente, aumentaram o guarda-roupa das mulheres enforcadas; eu me conservei prudentemente no pátio de fora. Voltou encantado: "Convidei Barba-Azul para me visitar em minha tenda. Ele se entenderá bem com nossos tupinambás; antes, eu o farei ter umas aulas de antropofagia em São Paulo, com o Oswald de Andrade. É bom professor”. Fomos visitar todos os heróis dos contos de Perrault. No começo ele os achou um pouco cavalheirescos demais; mas eles, para lhe serem agradáveis, despiram logo suas pesadas vestes Luís XV, suas perucas, seus sapatos de fivelas, transformando-se nos heróis nus da Gália Céltica, em deuses de florestas não-tropicais mas úmidas e cheias de musgos, delícia das carnes leitosas, gênios de rios que não são o Amazonas mas lentas canções líquidas à sombra dourada dos salgueiros. A Gata Borralheira transformou-se para ele na árvore de inverno que ressuscita ao beijo da primavera. Mas a melhor parte do programa foi quando a madrasta de Pele de Burro, em vez de vomitar víboras, vomitou cascavéis; penso que fora prevenida de nossa chegada e encomendara ao jardim zoológico animais brasileiros. Em todo o caso, Macunaíma pareceu mais contente com essa delicadeza do que com todas as recepções oficiais. E acabamos, já que estávamos no verão, nas praias da Bretanha, as mais selvagens naturalmente, aquelas que têm cartazes assim: “Atenção: freqüentadas por sereias”; aquelas em que pintores montmartrinos e pescadores melancólicos vão às vezes procurar uma esposa, entre as sereias que surgem da espuma das ondas, depositam suas peles de peixe num vão dos rochedos e, estendidas sobre os sargaços, mexem devagar suas pernas novas, entregando-se à volúpia de sentir um sangue repentinamente aquecido correr por milhares de canaizinhos azuis até os dedos róseos de seus pés, até então ignorados. 
Mas Macunaíma desapareceu subitamente de meu sonho. Queimava-me ao sol, o vento cobria-me de sal, e o perfume das algas enchia-me de iodo. Quando me levantei, estava sozinho. Não sei o que se passou depois. Os acontecimentos do sonho ficaram um pouco embaralhados em minha memória. Há uma confusão aqui. Ademais revejo Macunaíma com Gargântua, seu irmão gaulês, bebendo vinho e aguardente, chamando ao rum cachaça, ao cassoulet feijoada, gritando, rindo, invectivando em termos tupis, limoginos, quimbundos, perigordinos, guaranis, saboianos, ítalo-brasileiros, provençais, em langue d'Oc e em langue d’Oil, e Gargântua lhe gritando: "És bem brasileiro; tens lábios de africano, olhos de índio, nariz de português, o lado direito de italiano, o ombro esquerdo de alemão, a ponta do pé de espanhol, o joelho de cristão-novo...” Ao passo que o outro, sem o ouvir, proferia uma catarata de palavras: “Como tu és bem francês: tens crânio romano, olhar celta, bigode gaulês, cabelos de franco, nariz de árabe...” Duas arlequinadas, como teria dito Mário de Andrade, um já transformado, o outro em vias de se transformar em túnica inconsútil.

E ao mesmo tempo, aproximavam-se, uniam-se, fundiam-se um no outro e só havia um ser, o herói do povo, revolucionário e tradicionalista, ao mesmo tempo, franco e puro, homem para o qual o bem supremo é a liberdade, liberdade contra todos os atravessadores da alegria, liberdade de cantar, de amar, de viver à vontade, liberdade de seguir a sabedoria do instinto contra todos os parcimoniosos, os avaros de coração, os gramáticos, os puristas, os fabricantes de Artes Poéticas, de Artes de Viver e de Triunfar, liberdade, enfim, de ser o mais pródigo possível, pródigo de palavras, pródigo de gestos, pródigo como pode sê-lo um ser exuberante de lirismo e de poesia.

Acordei então. Sobre minha mesa de cabeceira estava Macunaíma, história do herói sem nenhum caráter, escrita por Mário de Andrade. 

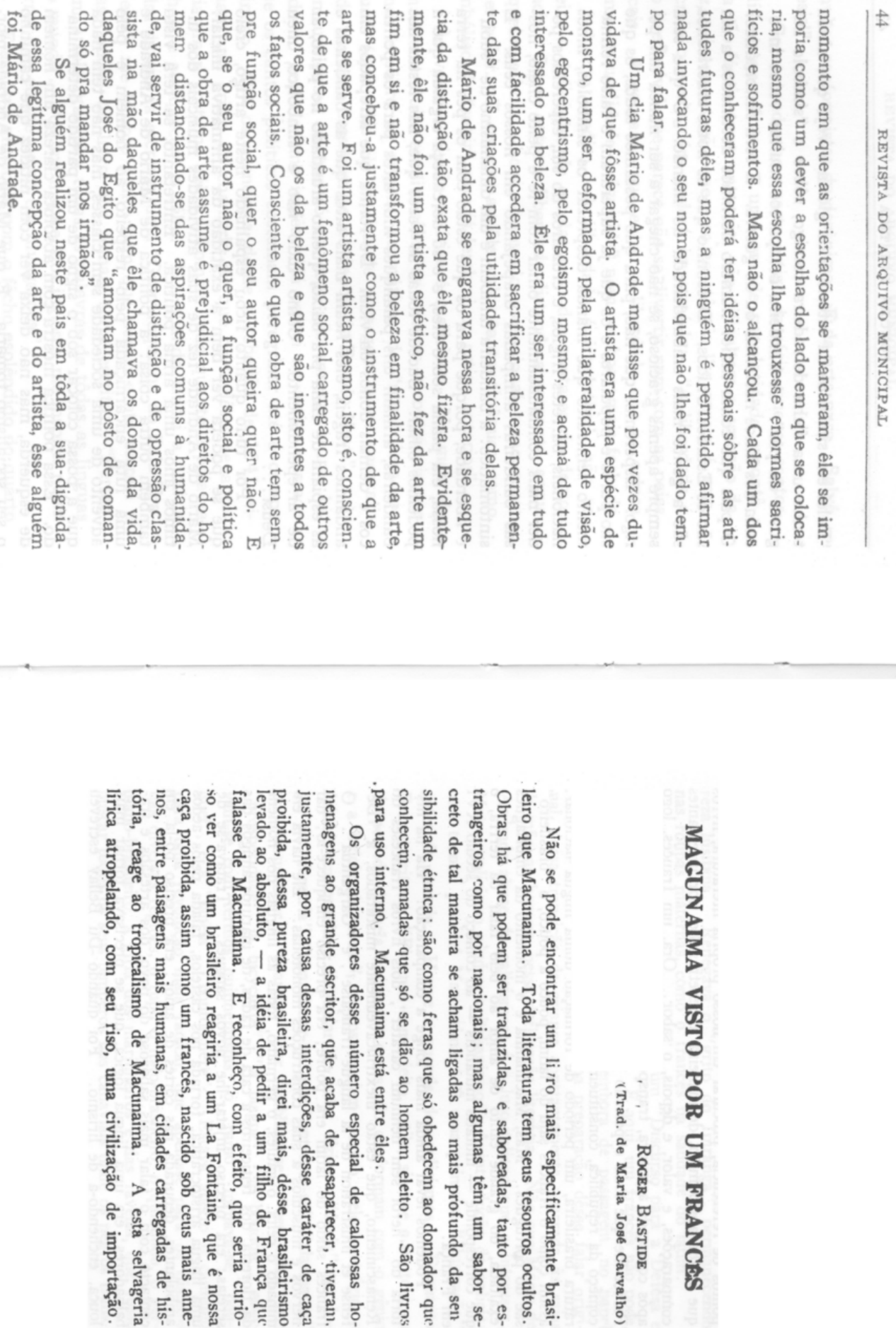


\section{MaCunAíma Visto Por UM FrancêS}

BASTIDE, Roger. "Macunaíma visto por um francês". Trad. Maria José Carvalho. Revista Arquivo Municipal: São Paulo, ano XII, n⿳0 106, p. 45-50, janeiro/fevereiro de 1946. Reproduzido em Revista Arquivo Municipal: São Paulo, $\mathrm{n}^{\mathbf{0}} 198,1990$, p. 45-50 [ed. fac-similar do $\mathrm{n}^{\mathbf{0}} 106$, 1946, mesma revista].

Não se pode encontrar um livro mais especificamente brasileiro que Macunaíma. Toda literatura tem seus tesouros ocultos. Obras há que podem ser traduzidas, e saboreadas, tanto por estrangeiros como por nacionais; mas algumas têm um sabor secreto de tal maneira se acham ligadas ao mais profundo da sensibilidade étnica: são como feras que só obedecem ao domador que conhecem, amadas que só se dão ao homem eleito. São livros para uso interno. Macunaíma está entre eles.

Os organizadores desse número especial de calorosas homenagens ao grande escritor, que acaba de desaparecer, tiveram, justamente, por causa dessas interdições, desse caráter de caça proibida, dessa pureza brasileira, direi mais, desse brasileirismo levado ao absoluto, - a idéia de pedir a um filho de França que falasse de Macunaíma. E reconheço, com efeito, que seria curioso ver como um brasileiro reagiria a um La Fontaine, que é nossa caça proibida, assim como um francês, nascido sob céus mais amenos, entre paisagens mais humanas, em cidades carregadas de história, reage ao tropicalismo de Macunaíma. A esta selvageria lírica atropelando, com seu riso, uma civilização de importação.

Não nos podemos[,] naturalmente, colocar no centro do romance, encontrar-lhe o fundo, o fogo interior, para de lá o irradiar. Devemos, pelo contrário, rodar de início, em torno do livro, dele nos aproximando por fora. Para compreendê-lo, devemos tomar pontos de referência, procurar em nossa ${ }^{57}$ própria literatura, livros que se lhe aproximem, de maneira a penetrar-lhe, por incessantes comparações, o valor ${ }^{58}$, e depois, o sabor. Ora, um francês, logo após começada a leitura, transporta-se ao século do Renascimento. Parece-lhe que todo o período colonial, a monarquia, e o próprio começo da república, constituem como que a Idade Média da literatura brasileira, um período de formação duma língua nacional; assim como o francês saiu do latim, pouco a pouco, o "brasileiro” sai do português. Mas, Macunaíma é o momento

\footnotetext{
${ }^{57}$ Na revista, lê-se “nosso”. Erro tipográfico.

${ }^{58}$ Na revista, lê-se "e valor”. Erro tipográfico.
} 
da embriaguez exaltada, do grande canto de amor ao belo falar da terra, o que corresponde mutatis mutandis - ao começo do século XVI em França. Podemos levar ainda mais longe a comparação. Há na história do "herói sem nenhum caráter”, dois livros franceses do Renascimento, que estão inextricavelmente misturados, a Défense et illustration de la langue française, e Gargantua. O francês saído do latim era pobre; era preciso enriquecê-lo; dar nervos e músculos a suas construções monótonas. Ele havia eliminado o celta, o gaulês, o germano, todas as línguas dos homens da floresta, dos feiticeiros à cata de fadas, de marujos amigos das sereias; era preciso injetar-lhe novos sangues. Tratava-se de uma língua aristocrática, forjada nos castelos, falada pelos aedos ambulantes, depurada nas cortes de amor; era preciso pô-la em contacto com o falar mais saboroso do povo, dos artesãos e trabalhadores; era uma língua lógica, que se precisava tornar mais louca, enchendo-a de lirismo. Foi quando Du Bellay escreveu seu manifesto, não mais pedindo ao escritor saído dos colégios, que falasse grego ou latim, mas que nutrisse a língua francesa com todos os tesouros abandonados, gíria, termos de ofícios, dialetos regionais, criasse novas palavras, inventasse neologismos, transformasse os solecismos em regras gramaticais, e nacionalizasse os barbarismos. É uma festa da palavra, é o som que se encanta consigo mesmo; a língua torna-se um vinho capitoso, que faz andar as cabeças à roda; é uma bebedeira lírica, uma libertinagem da sintaxe.

A língua brasileira também repelia as palavras proletárias, prendendo-se a Camões, a Eça de Queirós, só procurando a pureza lusitana. Renegava o “grito do Ipiranga”, permanecendo nas roupas maternas, como o francês na saudade do latim.

Macunaíma é[,] de início, isso, um “Discurso para a Defesa e a Ilustração da Língua Brasileira”. E aqui, um francês não pode, naturalmente, deixar de pensar, embora de passagem, no papel que os galicismos representaram na preparação desse falar original, nessa transição da criança constantemente agarrada às saias da mãe, ao homem, nessa defloração literária. Não que Mário de Andrade abuse de galicismos; é o luso-italiano que o interessa. Mas o galicismo ajudou o italianismo. A introdução de galicismos tornou possível Macunaíma. É uma primeira "Ilustração” antes da grande. Houve a querela dos galicismos. Enquanto Freyre gritava: "Ficamos com o jeito ${ }^{59}$, estilo, sintaxe e contextura do período daquela língua, os quais não conformam com o gênio e a índole da nossa”, outros sentiam quanto, pelo contrário, o francês enriquecia o linguajar do país; dizia-se “forja” em lugar de "ferraria”, “abandonarse” por “entregar-se”, “alarmante” por “assustador”, “aparecer” por “publicar-se”, “bemestar” por “prosperidade”, “la bicyclette”, “la blague”, "le boudoir”, casavam-se com termos

\footnotetext{
${ }^{59}$ Na revista, lê-se “como jeito”. Erro tipográfico.
} 
quinhentistas; o “ramo” tornava-se "bouquet”, e a "lapela”, "boutonniere”. Estava aberto o caminho para uma revolução mais radical, que apelasse para os dialetos das diversas regiões, o tupi, o ítalo-brasileiro, o quibundo, o germano-brasileiro, a gíria dos marinheiros e das favelas, que fosse buscar todos os seus temperos nos canaviais onde os negros transpiram, nos pântanos onde os caboclos pescam, nos campos onde os índios dançam nus.

Mas Macunaíma não se apresenta como um manifesto. É uma epopéia. Eis porque o francês pensa invencivelmente numa outra epopéia em prosa do Renascimento, onde ele também encontra a mesma licenciosidade de vocabulário, a mesma bebedeira de expressões novas, a mesma voluptuosidade lingüística, é Gargantua[,] de Rabelais. "Jiguê viu que a maloca estava cheia de alimentos, tinha pacova tinha milho tinha macaxeira, tinha aluá e cachiri, tinha maparás e camorins pescados, maracujá-michira ata abio sapota sapotilha, tinha paçoca de viado e carne fresca de cutiara...”60; todas essas litanias carnais, todas essas enumerações pagãs, essas torrentes de expressões, de palavras rolando como seixos, arrastando o leitor numa carreira louca, tudo isso se encontra em Rabelais, é a mesma corrida que se encontrou entre nós nas mil maneiras de se limpar o “c”.....; em “veux-tu des substantives”, “voila”, “tu n’as pas d’adjectifs”, “des verbes”, “je n’ai pas finir de t’étonner”. Macunaíma, Gargantua, dois espessos deltas, duas terras formadas de sedimentos arrancados a todas as montanhas, roubados às mais ricas planícies, do cretáceo, do jurássico, de argila, de areia, da lama negra da África, e do lodo vermelho do Índio, do calcário de Provença e dos aluviões da Guiana.

E é curioso notar, que esse gigantismo do falar está, nos dois casos, ligado a um personagem do folclore[,] a um herói popular. Gargantua despeja inesgotavelmente suas pedras no velho falar francês, como incansavelmente atirava pedras, transformando a planície do “Crau” em uma imensa extensão de calhaus; é uma inundação que tudo carrega, como quando ele urinava sobre as torres de Notre Dame. E Macunaíma lança milhares de flechas, e cada uma, donde quer que seja atirada, das cabanas dos negros, das choças dos índios, dos cortiços das pequenas costureiras luso-ítalo-germano-afro-brasileiras, torna-se uma pérola, uma esmeralda, uma água-marinha da nova linguagem brasileira. O herói sem caráter é Grandgousier, que não sabe se deve rir ou chorar; é Panurge, que não sabe se deve casar-se ou ficar celibatário; é o gigante muito bom de cóleras loucas; é o homem do povo que arrasa as colunas dos falsos templos. A sabedoria de Rabelais está condensada numa única palavra: Bebei; bebei a

\footnotetext{
${ }^{60}$ Citação corrigida de acordo com a edição crítica de Telê Porto Ancona Lopez (Op. cit., $2^{\underline{a}}$ ed., $1^{\underline{a}}$ reimpressão, 1997, p. 19). Na revista, lê-se "Jiguê viu que a maloca estava cheia de alimentos, tinha pacová, tinha milho, tinha macachira, tinha aluá e cachiri, maparás e camerins pescados, maracujá-michira, atá, abio, sapotá, sapotilha, tinha paçoca de veado e carne fresca de cutiara...”
} 
alegria de viver, bebei todos os vinhos da ciência, a astronomia e o hebraico, a mecânica e o grego, a filologia e as matemáticas. Mário de Andrade tem a mesma loucura da vida e da ciência; essas duas coisas, que estão geralmente separadas, reunidas numa mesma embriaguez; o amor à terra e o amor às pequenas normalistas, o folclore e a musicologia, a etnografia indígena e a ciência dos mitos, a filologia e a sociologia. As duas Sumas dos tempos modernos, a do Renascimento francês contra a de Santo Tomás, a do Renascimento brasileiro contra o purismo dos gramáticos.

É assim que eu me aproximo do livro de Mário de Andrade; é assim que um francês forçosamente se lhe aproximará, por referências e atalhos; é pelo caminho que vem de Touraine, que ele penetra nessas florestas virgens de palavras desconhecidas, nesse emaranhado de lianas, árvores e flores; é passando pela Abadia de Thélème, após o encontro com o escolar “limousin”, que ele pode tomar a caravela brasileira; deverá parar nas ilhas dos "Parpaillots” ou dos Papafigos, antes de aportar à terra de Macunaíma, de Carrapato, de Capei, a Lua, da Mãe dos animais e do Pai das plantas. Ele só terá então que mudar de bebedeira, trocando a aguardente das uvas da Borgonha, dos vinhedos do Bordelais, pela cachaça e o cauim.

Por certo, não compreenderá todas as palavras, (e assim muitos brasileiros) como o homem da Amazônia ignora o nome desses milhares de espécies vegetais, que fermentam, que se putrefazem, que nascem e vivem perto dele, nele. Não deverá entretanto pegar um dicionário. Não se trava amor com uma língua, assim como fazem os soldados norte-americanos que cortejam as moças dos países europeus, sob a luz de um bico de gás, com um léxico portátil na mão, um guia bilíngüe no bolso. É preciso perder-se na torrente alegre que vos carrega. Foi assim que eu li Macunaíma: plã, plã, rataplã, ele me fez entrar nas fileiras, marchar a seu passo, impondo-me seu ritmo. Esse herói sem caráter tem um sagrado caráter; colou-me aos lábios seus cigarros de palha; tive que ir atrás dele à Praça da República, ver passar as mocinhas de saias azuis e blusas brancas; sem me deixar respirar um momento sequer, arrastou-me para a casa de Uiara ${ }^{61}$, que tem um sofá feito por um judeu alemão de Manaus, uma rede comprada a um comerciante polonês do largo do Arouche, e que, em minha honra, tornou a vestir seu vestido de peixe prateado; ele de tal maneira gritou, que me fez também gritar até me esganiçar, contra a máquina-telefone, a máquina-ascensor, a máquina-táxi, e eu pusme a inventar uma porção de outras máquinas: a máquina-de-fazer-brasileiros, que pega o imigrante em Santos, passa-o por um tubo, e o devolve ao planalto, assimilado, aculturado, abrasileirado; a máquina-de-aplicar-injeções, que nos injeta na coxa uma gota de sangue afri-

\footnotetext{
${ }^{61}$ Na revista, lê-se “Uara”. Erro tipográfico.
} 
cano, nas costas, uma gota de sangue indígena, nas nádegas uma gota de sangue hispano-ítalogermano-português, no ventre, uma gota das famílias de quatrocentos anos; a máquina-deocidentalizar, que vos transforma num quarto de hora, uma capela barroca em uma igreja ogival, um palacete colonial em um arranha-céu de cimento armado, um cantor de samba, arranhador de viola, num alfabetizado escrevinhador.

Foi assim que li Macunaíma. Ri, berrei, bebi estranhas e maravilhosas bebidas, fiquei completamente bêbado. E, se me enganei, que me digam meus amigos brasileiros.

ROGER BASTIDE (Trad. Maria José Carvalho) 

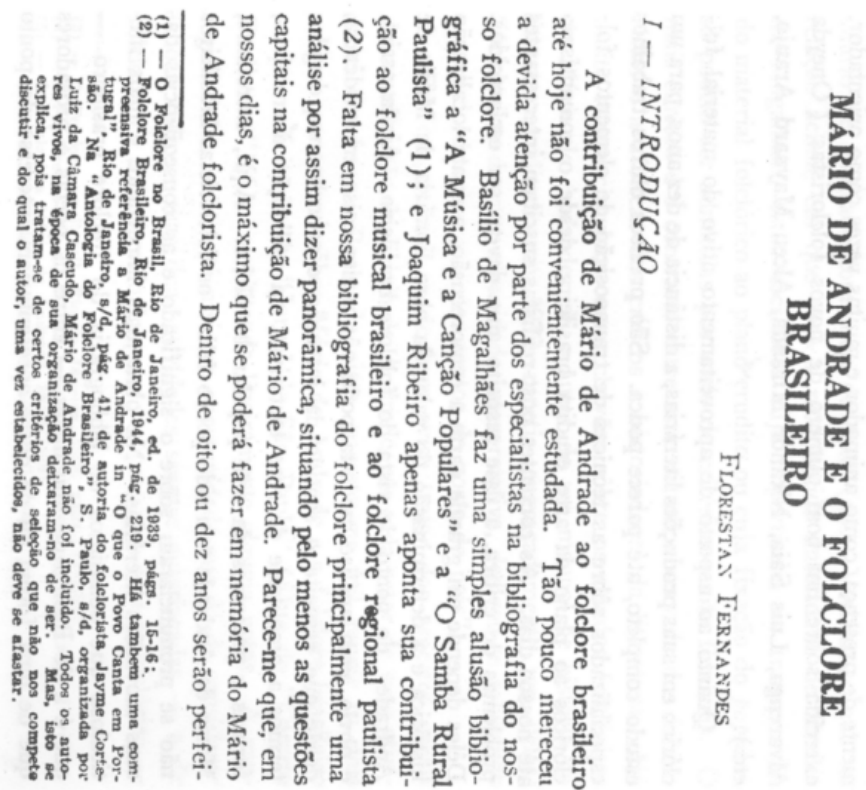


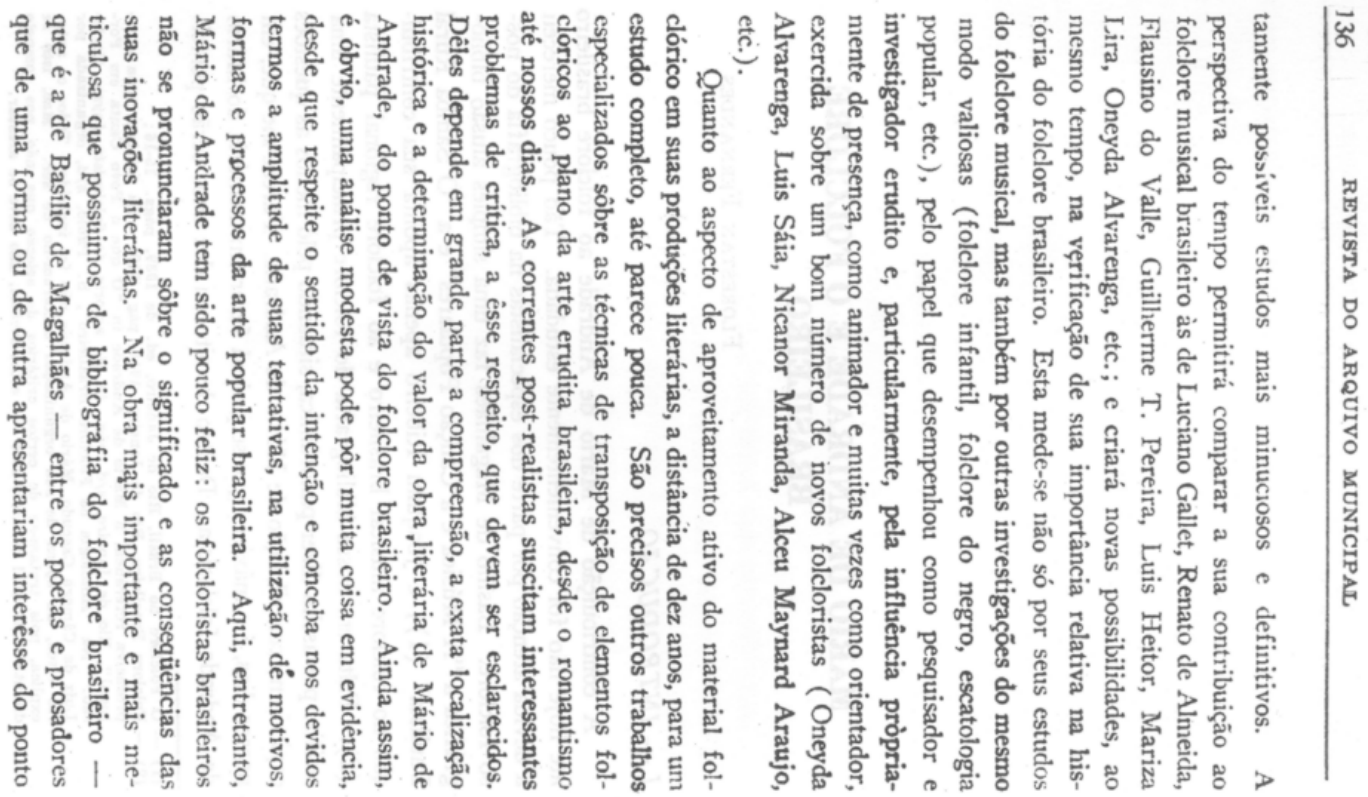

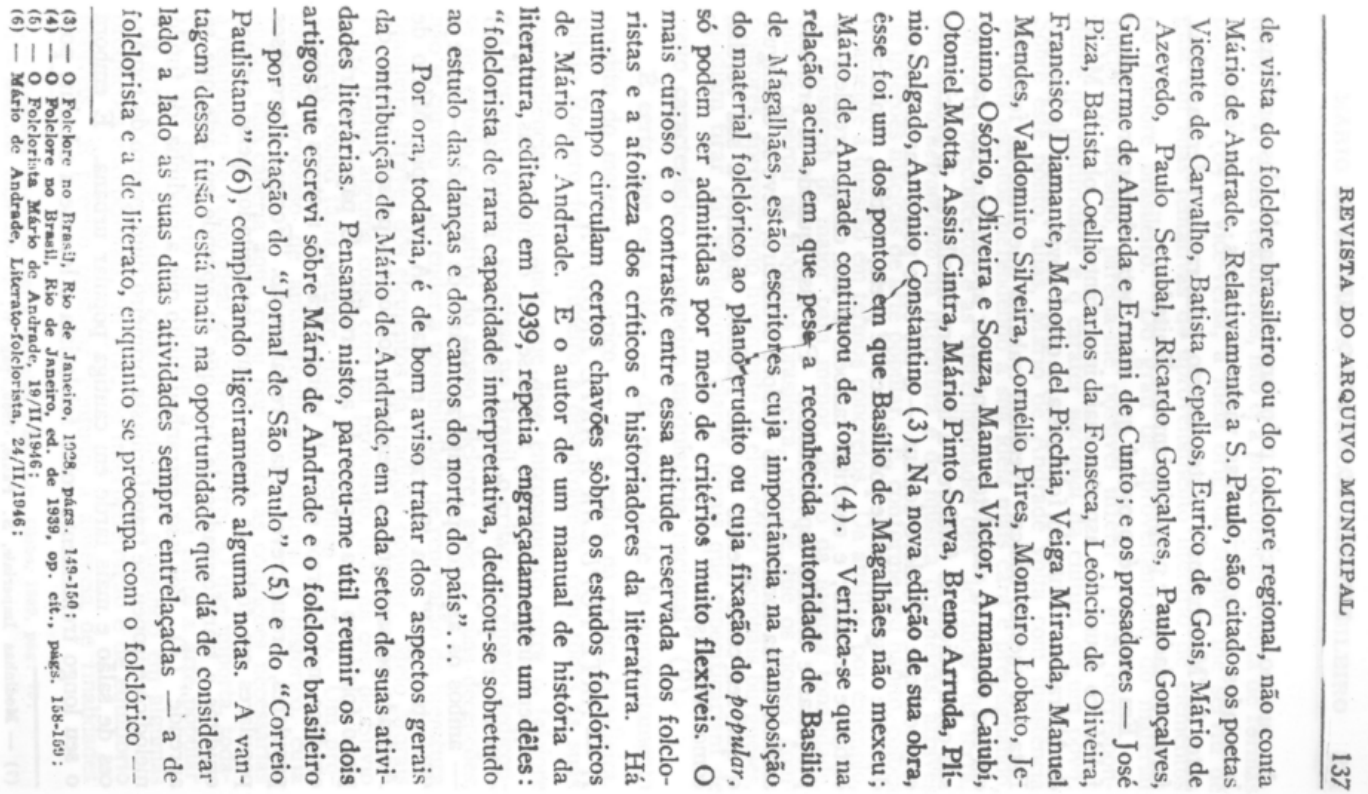




\section{MÁrio de ANDRAde e o FolClore BRASILEIRO}

FERNANDES, Florestan. "Mário de Andrade e o folclore brasileiro”. Revista Arquivo Municipal: São Paulo, ano XII, $\mathrm{n}^{-}$106, p. 135-158, janeiro/fevereiro de 1946. Reproduzido em Revista Arquivo Municipal: São Paulo, $\mathrm{n}^{\mathrm{0}}$ 198, 1990, p. 135-158 [ed. fac-similar do $\mathrm{n}^{-0} 106,1946$, mesma revista].

\section{I - INTRODUÇÃO}

A contribuição de Mário de Andrade ao folclore brasileiro até hoje não foi convenientemente estudada. Tão pouco mereceu a devida atenção por parte dos especialistas na bibliografia do nosso folclore. Basílio de Magalhães faz uma simples alusão bibliográfica a “A Música e a Canção Populares” e a "O Samba Rural Paulista”62; e Joaquim Ribeiro apenas aponta sua contribuição ao folclore musical brasileiro e ao folclore regional paulista ${ }^{63}$. Falta em nossa bibliografia do folclore principalmente uma análise por assim dizer panorâmica, situando pelo menos as questões capitais na contribuição de Mário de Andrade. Parece-me que, em nossos dias, é o máximo que se poderá fazer em memória do Mário de Andrade folclorista. Dentro de oito ou dez anos serão perfeitamente possíveis estudos mais minuciosos e definitivos. A perspectiva do tempo permitirá comparar a sua contribuição ao folclore musical brasileiro às de Luciano Gallet, Renato de Almeida, Flausino do Valle, Guilherme T. Pereira, Luis Heitor, Mariza Lira, Oneyda Alvarenga, etc.; e criará novas possibilidades, ao mesmo tempo, na verificação de sua importância relativa na história do folclore brasileiro. Esta mede-se não só por seus estudos do folclore musical, mas também por outras investigações do mesmo modo valiosas (folclore infantil, folclore do negro, escatologia popular, etc.), pelo papel que desempenhou como pesquisador e investigador erudito e, particularmente, pela influência propriamente de presença, como animador e muitas vezes como orientador, exercida sobre um bom nú-

\footnotetext{
${ }^{62}$ Nota de Florestan Fernandes (F. F.): O folclore no Brasil. Rio de Janeiro, ed. de 1939, págs. 15-16.

${ }^{63}$ Nota de F. F.: Folclore brasileiro. Rio de Janeiro, 1944, pág. 219. Há também uma compreensiva referência a Mário de Andrade in $O$ que o povo canta em Portugal, Rio de Janeiro, s/d, pág. 41, de autoria do folclorista Jayme Cortesão. Na Antologia do folclore brasileiro, S. Paulo, s/d, organizada por Luiz da Câmara Cascudo, Mário de Andrade não foi incluído. Todos os autores vivos, na época de sua organização deixaram-no de ser. Mas, isto se explica, pois tratam-se de certos critérios de seleção que não nos compete discutir e do qual o autor, uma vez estabelecidos, não deve se afastar.
} 
mero de novos folcloristas (Oneyda Alvarenga, Luis Sáia, Nicanor Miranda, Alceu Maynard Araujo, etc.).

Quanto ao aspecto de aproveitamento ativo do material folclórico em suas produções literárias, a distância de dez anos, para um estudo completo, até parece pouca. São precisos outros trabalhos especializados sobre as técnicas de transposição de elementos folclóricos ao plano da arte erudita brasileira, desde o romantismo até nossos dias. As correntes pósrealistas ${ }^{64}$ suscitam interessantes problemas de crítica, a esse respeito, que devem ser esclarecidos. Deles depende em grande parte a compreensão, a exata localização histórica e a determinação do valor da obra literária de Mário de Andrade, do ponto de vista do folclore brasileiro. Ainda assim, é óbvio, uma análise modesta pode pôr muita coisa em evidência, desde que respeite o sentido da intenção e conceba nos devidos termos a amplitude de suas tentativas, na utilização de motivos, formas e processos da arte popular brasileira. Aqui, entretanto, Mário de Andrade tem sido pouco feliz: os folcloristas brasileiros não se pronunciaram sobre o significado e as conseqüências das suas inovações literárias. Na obra mais importante e mais meticulosa que possuímos de bibliografia do folclore brasileiro - que é a de Basílio de Magalhães - entre os poetas e prosadores que de uma forma ou de outra apresentariam interesse do ponto de vista do folclore brasileiro ou do folclore regional, não conta Mário de Andrade. Relativamente a S. Paulo, são citados os poetas Vicente de Carvalho, Batista Cepellos, Eurico de Gois, Mário de Azevedo, Paulo Setubal, Ricardo Gonçalves, Paulo Gonçalves, Guilherme de Almeida e Ernani de Cunto; e os prosadores - José Piza, Batista Coelho, Carros da Fonseca, Leôncio de Oliveira, Francisco Diamante, Menotti del Picchia, Veiga Miranda, Manuel Mendes, Valdomiro Silveira, Cornélio Pires, Monteiro Lobato, Jerônimo Osório, Oliveira e Souza, Manuel Victor, Armando Caiubí, Otoniel Motta, Assis Cintra, Mário Pinto Serva, Breno Arruda, Plínio Salgado, António Constantino ${ }^{65}$. Na nova edição de sua obra, esse foi um dos pontos em que Basílio de Magalhães não mexeu; Mário de Andrade continuou de fo$\mathrm{ra}^{66}$. Verifica-se que na relação acima, em que pese a reconhecida autoridade de Basílio de Magalhães, estão escritores cuja importância na transposição do material folclórico ao plano erudito ou cuja fixação do popular, só podem ser admitidas por meio de critérios muito flexíveis. O mais curioso é o contraste entre essa atitude reservada dos folcloristas e a afoiteza dos críticos e historiadores da literatura. Há muito tempo circulam certos chavões sobre os estudos folclóricos de Mário de Andrade. E o autor de um manual de história da literatura, editado em

\footnotetext{
${ }^{64}$ Na revista, lê-se “post-realistas”.

${ }^{65}$ Nota de F. F.: O folclore no Brasil, Rio de Janeiro, 1928, p. 149-150.

${ }^{66}$ Nota de F. F.: O folclore no Brasil, Rio de Janeiro, ed. de 1939, op. cit., p. 158-159.
} 
1939, repetia engraçadamente um deles: “folclorista de rara capacidade interpretativa, dedicou-se sobretudo ao estudo das danças e dos cantos do norte do país”...

Por ora, todavia, é de bom aviso tratar dos aspectos gerais da contribuição de Mário de Andrade, em cada setor de suas atividades literárias. Pensando nisto, pareceu-me útil reunir os dois artigos que escrevi sobre Mário de Andrade e o folclore brasileiro - por solicitação do “Jornal de São Paulo"67 e do "Correio Paulistano"68, completando ligeiramente algumas ${ }^{69}$ notas. A vantagem dessa fusão está mais na oportunidade que dá de considerar lado a lado as suas duas atividades sempre entrelaçadas - a de folclorista e a de literato, enquanto se preocupa com o folclórico - do que no esclarecimento propriamente falando dos problemas levantados ou implícitos nas várias tentativas e experiências do autor de Macunaíma. Estes, mesmo, pelas razões referidas acima, foram cuidadosa e propositadamente limitados.

Em conjunto é provável que estas notas demonstrem que o folclórico é um dos aspectos mais importantes na obra de Mário de Andrade - tanto do folclorista, o que é óbvio, como do literato. Esta é a questão básica. Nenhum trabalho que trate do folclórico em sua obra será completo, se considerar apenas uma das faces de sua contribuição ao folclore e à literatura brasileira. É preciso não esquecer que o folclore domina - e até certo ponto marca profundamente - sua atividade polimórfica de poeta, contista, romancista, crítico e ensaísta; e constitui também o seu campo predileto de pesquisas e estudos especializados. Por isso, quando se pretende analisar a sua contribuição ao folclore brasileiro, deve-se distinguir o que fez como literato do que realizou, digamos à sua revelia, como folclorista.

\section{II - ARTE POPULAR E ARTE ERUDITA}

Seria inoportuna, aqui, a análise e a discussão das relações entre a "arte popular” e a “arte erudita” ou, de modo mais limitado - ambos os aspectos preocuparam Mário de Andrade - entre a "literatura oral” e a "literatura escrita”. A princípio, Mário de Andrade pensava que os elementos folclóricos passam sempre do plano folclórico para o plano da arte erudita. O papel dos artistas eruditos, nos diversos casos de transposição de motivos e técnicas populares, circunscrever-se-ia à reelaboração. "Formas e processos populares em todas as épocas foram aproveitados pelos artistas eruditos e transformados de arte que se apreende ${ }^{70}$ em arte

\footnotetext{
${ }^{67}$ Nota de F. F.: “O Folclorista Mário de Andrade”, 19/II/1946.

${ }^{68}$ Nota de F. F.: "Mário de Andrade, literato-folclorista”, 24/II/1946.

${ }^{69}$ Na revista, lê-se "alguma”.

${ }^{70}$ Cf. Andrade, Mário de. Modinhas imperiais. Belo Horizonte: Itatiaia, 1980, p. 8. Na revista, lê-se “aprende”.
} 
que se aprende"71. Por isso, estranhou muito que a modinha, de fundo melódico europeu, se transformasse primeiro num gênero de romances de salão e mais tarde em cantiga popular urbana. E embora o seu longo treinamento como folclorista o levasse a admitir, posteriormente estes fenômenos, isto é, a procedência erudita de formas populares ${ }^{72}$ e vice-versa, a idéia original sempre lhe serviu de guia em suas tentativas de aproveitamento literário de elementos do folclore brasileiro. Do grau de aproveitamento do material folclórico, mesmo, parecia-lhe possível inferir o grau correspondente de maturidade e o caráter nacional da cultura de um povo. Sobre este ponto, aliás, Mário de Andrade volta com insistência em seus escritos, defendendo a sua idéia mais cara e propugnando, contra os preconceitos e as suscetibilidades dos "letrados" da terra, pelo abrasileiramento da literatura e da música brasileiras, através de injeções maciças de arte popular. E, conforme seu hábito, coloca friamente a questão em termos concretos. Da análise, por exemplo, da passagem de maior para menor, dentro da mesma tonalidade, que se operou na modinha brasileira, conclui que os nossos compositores, aproveitando livremente os elementos nacionais burgueses, “podiam tirar daí verdadeiros planos tonais que especificariam de jeito característico a maneira modulatória nacional»73.

É certo que essa idéia - da necessidade do aproveitamento erudito do material folclórico - já é velha na crítica brasileira. Sílvio Romero foi o primeiro a desenvolvê-la, com todas as suas conseqüências. Pensando que esse entrosamento entre o folclore e a literatura erudita existisse no Brasil, o crítico sergipano dedicou-se ao estudo exaustivo do nosso folclore; após as suas decepções, não se cansou de defender a possibilidade de renovação da literatura brasileira através dos elementos da tradição popular. Melo Morais Filho tentou alguma coisa com tal propósito, indo na cola de Sílvio Romero, como fazia sempre, mas sem nenhum sucesso. Um prolongado processo de amadurecimento cultural e histórico, cuja análise não caberia aqui, criou por etapas as condições necessárias à realização do velho ideal de Sílvio Romero. O que importa, todavia, é que em Mário de Andrade a distância entre a arte popular e a arte erudita diminui consideravelmente, atingindo em algumas produções excepcionais um grau de interpenetração e de equilíbrio notáveis. É preciso ressaltar, contudo, a ausência de finalidades chauvinistas; é por isso que grifei acima o adjetivo nacional. Nacional aqui significa expressividade, existência de um padrão característico e próprio de cultura. Embora fizesse algumas confusões quando entrava na análise dos fatores explicativos da cultura - no sentido lato, an-

\footnotetext{
${ }^{71}$ Nota de F. F.: Modinhas imperiais. S. Paulo, 1930, p. 8.

${ }^{72}$ Nota de F. F.: Vejam-se Namoros com a medicina. Ed. Liv. Globo, 1939, p. 73.

${ }^{73}$ Nota de F. F.: Modinhas imperiais, op. cit., p. 11.
} 
tropológico - considerados em termos do nosso processo histórico como povo, Mário de Andrade situou bem o problema e desenvolveu sua contribuição pessoal melhor ainda.

Tenho a impressão, entretanto, que só parcialmente essas idéias de Mário de Andrade explicam a transposição do material folclórico ao plano erudito, em sua obra; ou, melhor, elas apenas mostram um objetivo e os meios de o atingir: evidenciando a premência da apropriação dos elementos da tradição oral pelos artistas eruditos brasileiros e as possibilidades de renovação pelo emprego adequado dos processos da arte popular. A parte de realização, propriamente falando, parece-me correr mais por conta daquele estado de simpatia, relativamente ao povo e ao folclore brasileiro, que o próprio Mário de Andrade chamava de “quase amor”. Aí está o alfa e o ômega do assunto. Porque é como um problema psicológico pessoal que Mário de Andrade enfrenta e resolve a questão. Isso torna-se evidente à medida que se penetra no significado ativo de sua obra poética e de sua novelística. Os exemplos poderiam variar muito; é preferível, porém, limitar-mo-nos a diversas amostras de uma só de suas preocupações. Trata-se do próprio problema do homem no Brasil. Abstratamente, problema aqui seria desconversa. Mas existe uma realidade concreta, expressa em quilômetros quadrados e em diferenças regionais agudas - uma realidade sócio-geográfica, pois, digamos rebarbativamente, que dá uma conformação obrigatória ao problema do homem brasileiro. É este o aspecto primário da questão, que não se deve perder de vista. E foi também este o principal escolho às necessidades de participação e de identificação de mestre Mário. Os antagonismos e as limitações provocaram nele uma reação que é um grito épico de revolta, o espetáculo mais emocionante aos meus olhos na literatura brasileira, como exigência afetiva e como inquietação agitada pela falta de sincronização humana de milhares de brasileiros que se ignoram recíproca e simplesmente. Como esta falha de sensação de presença dos homens de nossa terra revela-se sob a forma de conflitos, entre o "progresso" e o “atraso”, a “civilização” e o "interior”, é sob este aspecto que Mário de Andrade fixa dolorosamente o problema. É verdade que existem manifestações ambivalentes, como no “Improviso do Mal da América”. Aí, contudo, está mais o drama do homem da cidade que o seu próprio. Assim mesmo merece nossa atenção, pelo que afirma indiretamente o que vimos acima: "grito imperioso de brancura em mim... as coisas de minha terra são ecos”. "Me sinto branco, fatalizadamente um ser de mundos que nunca vi” (o mundo original dos imigrantes e de culturas exóticas). A negação do índio e do negro - a negação da terra - é apenas aparente ${ }^{74}$. Encobre tenuemente o drama verdadeiro e mais profundo. E a civilização reponta como um dilema terrível, como motivo de alegria, pois

\footnotetext{
${ }^{74}$ Na revista, lê-se “(...) - a negação da terra, é apenas aparente.”
} 
significa aproximação pelo nivelamento ("Noturno de Belo Horizonte”, em que capta de modo maravilhoso a luta entre o progresso e a tradição), e como motivo de dúvida e de ansiedade (“Carnaval Carioca”, por exemplo: “Vitória sobre a civilização? Que civilização?”; e especialmente em Macunaíma. É sintomático que Macunaíma tenha escondido a consciência antes de tocar para São Paulo, para a “civilização”, e que tenha ficado com a inteligência muito perturbada aqui). Mas é no "Acalanto do Seringueiro”, a poesia mais emotiva e brasileiramente mais ecumênica de Mário, que o drama da separação entre o "litorâneo” e o "sertanejo" aparece em toda sua plenitude e brutalidade, marcado pela distância cultural que os toma reciprocamente estranhos e ausentes:

... "e não sinto os seringueiros

Que amo de amor infeliz...

Não boxa, não veste roupa

de palm-beach... Enfim não faz

Um desperdício de coisas

Que dão conforto e alegria”.

Eis aí a outra parte da tese, que tem, pois, dois lados: um lógico; outro por assim dizer psicológico. Ambos complementam-se, levando à mesma necessidade prática de fundir arte popular e arte erudita, em busca de um caráter nacional mais expressivo e verdadeiro, um terceiro termo que implique pelo menos um mínimo de separação humana.

Essa necessidade manifesta-se do mesmo modo na ânsia de recuperação histórica, tema constante nos ensaios e nas poesias tanto quanto em Macunaíma. Seria melhor dizer: na consciência de um passado, de tradições e de antepassados fundamentalmente comuns, dos quais, acreditava, começa a brotar alguma coisa nova e de feições originais já nos fins do século XIX. Este é um problema de difícil tratamento em poucas palavras. Em todo caso, as experiências de Mário de Andrade lembram-me o que van Gennep escreveu algures sobre o entrosamento do histórico no folclórico. Até certo ponto as objetivações populares referem-se diretamente aos acontecimentos da vida em comum e às reações mais vivas que provocam nos indivíduos. Revela-se, portanto, nos elementos folclóricos a parte talvez mais significativa da história de um povo. Deixando fora de cogitação os problemas teóricos, que não nos interessam neste momento, levantam-se dois problemas vitais: 1) a existência de uma memória coletiva, ou, melhor, de elementos que se fixam preferentemente a outros no conjunto de lembranças de um povo; 2) as modalidades estereotipadas formais de conservação ou de expressão 
desses elementos. É claro que, literariamente, achar uma resposta a esses dois problemas ou, antes, a esses dois quesitos de um só problema - é colocar de modo fundamental não só a questão das relações entre arte popular e arte erudita, mas principalmente ferir em cheio a questão essencial por excelência da busca de uma expressão literária em si mesma popular, formal e funcionalmente. Voltamos ao caráter nacional que deve ter a literatura de cada povo, porém agora a perspectiva é mais larga. As duas formas de arte defrontam-se numa relação dialética - tal como Mário de Andrade situa o problema: a arte erudita deve realizar-se na e através da arte popular - e a antítese, no caso a arte popular, cede o lugar a uma terceira forma de arte que do ponto de vista da fatura chama-se ainda arte erudita, mas que é uma coisa nova, mais essencial e mais expressiva. Opera-se assim aquela transformação, que deve ter parecido obscura a alguns leitores de Mário de Andrade, “de arte que se apreende ${ }^{75}$ em arte que se aprende”. Desse modo processa-se também o desencantamento do folclore, pois a arte popular surge como uma etapa necessária no desenvolvimento de uma forma artística superior, nada mais. Nesse sentido, entretanto, a própria arte erudita é posta, no fundo, a serviço das objetivações das camadas populares, matriz e celeiro do folclore, podendo captar da mesma forma que este o significado e o sentido da vida coletiva. Exprimindo-os de modo próprio, mas inteligível e funcionalmente articulada à ordem existencial dos grupos sociais em presença - o que acontece depois da superação das formas e processos estritos da arte popular, como foi visto - a arte erudita, ao mesmo tempo, torna-se independente. Três exemplos interessantes, como tentativas até certo ponto incompletas, são “Carnaval Carioca”, Belazarte e, irregularmente, porém em maiores proporções, Macunaíma. É óbvio que procurava aplicar as suas idéias em várias direções, mas parece-me que só como poeta alcançou resultados positivos. Em todas as obras que tenta a empresa, porém, Mário de Andrade afasta-se fielmente do puro retratismo. É o que dá, aliás, força excepcional às suas produções, localizando-as sob este ponto de vista. Servir não é recolher ou reproduzir com fidelidade acadêmica, mas incorporar e desenvolver segundo processos sempre novos ou melhor dinamicamente renovados pelo próprio viver em comum. Logicamente, a razão está com Mário de Andrade, pois trata-se da realização da arte erudita e não do seu nivelamento à arte popular.

Preciosas, por isso, são as duas lições que ficam. Primeiro, deve-se evitar a todo custo as soluções de continuidade. As ligações entre a arte erudita e a arte popular só serão vitais quando se estabelecerem num plano de igualdade. Isto é, após o seccionamento do cordão umbilical - quando desaparecem os contrastes que alienam de uma o máximo de representati-

\footnotetext{
${ }^{75}$ Na revista, lê-se “aprende”.
} 
vidade e dão a outra somente um mínimo de universalidade. Enquanto uma parasitar sobre a outra ou, mais simplesmente, enquanto permanecer ignorada sua mútua interdependência, ambas correrão o risco de uma crise letal - estiolam-se por falta de desenvolvimento. Segundo, o perigo do esclerosamento da arte erudita - em vez de um enriquecimento de conteúdo, funções e de formas - é afastado com naturalidade. É certo que existe aqui algo que evoca os germes de um formalismo temível; mas, isso cinge-se às aparências. Ou, mais precisamente, trata-se de um formalismo pacífico, incluindo entre suas regras a própria necessidade de inovação permanente. Eis porque o mais importante mesmo é que a libertação da arte erudita, no fim do processo, seria integral. Os contactos iniciais com a arte popular, com o folclórico, portanto, perdem o caráter de um compromisso estreito com a tradição, para adquirir, ao contrário, o caráter de uma nova forma de reelaborar a tradição. Mais do que isso, mesmo, passa a ser um modo de libertação do tradicional, pois, diz em “O Samba Rural Paulista”: “na música popular brasileira, e provavelmente na universal, qualquer peça se empobrece à medida que se estratifica ou tradicionaliza”. É interessante como as preocupações folclóricas de Mário de Andrade levam tão profunda e organicamente a soluções de fato revolucionárias. Em conjunto, porém, são justas e nada têm de paradoxais.

Resta ainda por discutir o problema da transposição do material folclórico ao plano erudito, na obra de Mário de Andrade. O que fica exposto acima é apenas a conseqüência de uma atitude diante dessa transposição, não esgotando o assunto. Adiantarei desde logo que a transposição do material folclórico não é realizada, por Mário de Andrade, de uma única forma. Pode-se distinguir quatro modalidades principais nessa transposição: o aproveitamento dispersivo, a intersecção, a assimilação de formas e processos e a estilização propriamente dita. As duas primeiras modalidades não se confundem, pois há entre elas uma diferença de grau bastante apreciável. A mesma coisa acontece às duas últimas, porque nem sempre assimilação de formas folclóricas redunda em estilização e vice-versa.

O aproveitamento dispersivo do material folclórico não é novo na literatura brasileira. Por ordem cronológica, vem-nos diretamente da preocupação pelo exótico do nosso romantismo, assinalando-se fortemente já em Alencar e Macedo. À medida que se processa a transição para o realismo e desse para o neo-realismo, o emprego dispersivo dos elementos folclóricos aumenta extraordinariamente, em proporção geométrica. Contudo, esta é a modalidade menos importante como técnica de transposição, na obra de Mário de Andrade. Existem exemplos tanto na prosa - como em Amar, verbo intransitivo: "tatu subiu no pau”, "tuturututú, 
parente de tatu e de urubu”, etc., perdidos aqui ou acolá; a mesma coisa observa-se na poesia, como em "Carnaval Carioca”:

Iaiá fruta do conde,

Castanha do Pará, etc.

É mais característica de Mário a intersecção do folclórico ou, mesmo, do popularesco. É a sua técnica por assim dizer predileta. Em “Carnaval Carioca”, verbi gratia, aproveita com bons efeitos poéticos um vulgarizadíssimo provérbio: “eu enxerguei com estes olhos que ainda a terra há de comer”; a mesma coisa faz com uns versos de uma conhecida roda infantil:

"Você também foi rindo pros outros,

Senhora dona Ingrata,

Coberta de ouro e prata".

Na poesia “Maria” do ciclo “Tempo de Maria”, volta novamente à roda infantil:

"Mas que são anjos? são anjos

Da boniteza da vida!

... Que anjos são estes

Que estão me arrodeando

De noite e de dia...

Padre Nosso

Ave! Maria!”

Mas, nos limites do folclore brasileiro, essa forma de utilização da arte popular por mestre Mário, é de fato universal. Exemplo disso é Macunaíma, onde a técnica está melhor desenvolvida.

Todavia, em outras poesias, como "Noturno de Belo Horizonte”, aplica-a também intensivamente - uma quadrinha popular, verbi gratia:

"Meu pangará arreado,

Minha garrucha laporte,

Encostado no meu bem,

Não tenho medo da morte.

Ah!..."

e até uma lenda em prosa (a história do coronel António de Oliveira Leitão). A parte relativa à assimilação de técnicas e formas populares, em Mário de Andrade, exigiria um estudo especi- 
alizado. A começar pela própria linguagem. É com sabor especial que aponta uma verdade que já foi mais verdadeira: "Macunaíma aproveita a espera se aperfeiçoando nas duas línguas da terra, o brasileiro falado e o português escrito”. Até que ponto vai a contribuição de Mário ao advento do brasileiro escrito, todos nós o sabemos. Mas, é claro, este é um dos aspectos apenas da assimilação das formas e processos populares em sua obra. Ao seu lado há o aproveitamento generalizado, nas poesias, do ritmo dos cocos, das modas, dos lundus, etc. E há também a tentativa de desenvolver a poesia erudita nas formas escritas da poética popular, como "Serra do Rola-Moça”, do "Noturno de Belo Horizonte”, e, principalmente, a sua produção mais perfeita no gênero, a "Cantiga do Ai” que pertence ao ciclo “Tempo de Maria”. O próprio desenvolvimento de ciclos - como “Tempo de Maria”, que está longe de ser, todavia, uma realização completa - visa a repetição da técnica popular dos romances velhos (amorosos, marítimos, heróicos, etc.), dos quais ainda há sobrevivências entre nós mesmos nas zonas urbanas. A estilização apresenta-se, por sua vez, de modo verdadeiramente original. Porque nem sempre ocorre de acordo com os cânones tradicionais da passagem da arte popular à arte erudita. Assim, há o aproveitamento livre dos motivos folclóricos, como na citada "Serra do Rola Moça”, no "Poema” - “Neste rio tem uma Iara, etc.”. Mas, a seu lado, processa-se uma como que “desaristocratização" de temas, processos e formas eruditos, por meio ${ }^{76}$ de formas e processos populares - reconhecidamente muito comum em suas poesias. É a manifestação típica do caráter nacional a que Mário de Andrade aspirava e defendia para a nossa literatura e para a nossa música, mostrando que não existe paradoxo no abrasileiramento da arte erudita através da arte popular.

Nas esferas da estilização, entretanto, a obra capital de Mário de Andrade é Macunaíma, uma síntese do folclore brasileiro levada a efeito na forma do romance picaresco. Romances folclóricos, no sentido restrito, só possuímos dois na literatura brasileira. O de José Vieira, que aproveita o ciclo de Pedro Malazartes - que conhecemos quase completamente graças às investigações de Lindolfo Gomes; e este Macunaíma, de Mário de Andrade. A sua tentativa é muito mais ambiciosa e audaciosa. E a realização, devemos reconhecer francamente, está também acima do que José Vieira conseguiu, arriscando-se a uma aventura menos perigosa e portanto mais fácil. Macunaíma é o mais autêntico herói, criado nos moldes dos tipos heróicos populares, em língua portuguesa. O seu estudo minucioso revela em movimento não só as técnicas de transposição do folclórico ao plano erudito, peculiares de Mário de Andrade, mas também a sua compreensão ampla do folclore brasileiro e seus problemas, e das possibilida-

\footnotetext{
${ }^{76}$ Na revista, lê-se “meios”. Erro tipográfico.
} 
des do romance folclórico. Tristão de Ataíde já tratou, com dados fornecidos pelo próprio Mário de Andrade, suficientemente de Macunaíma. Apenas gostaria de insistir sobre o conceito de Macunaíma, como “herói sem nenhum caráter”. Apesar de índio, originalmente preto e depois branco, Macunaíma é o mais mulato dos heróis brasileiros. O representante por excelência de um povo mestiço no sangue e mestiço nas idéias, como já nos definiu Sílvio Romero. Concebido à imagem dos heróis místicos, tudo lhe é possível - vive num clima onde espaço e tempo são reversíveis e imponderáveis. E em que a própria morte aparece como um meio de retorno à vida e de eternização heróica - Macunaíma vira Ursa Maior. Nesse sentido, sua conduta desconhece os padrões de comportamento habituais - por ser herói mítico, mas principalmente por ser brasileiro e culturalmente híbrido. Onde está - é a pergunta indireta de Mário - o padrão de cultura de nossa civilização? Macunaíma não tem caráter - mesmo no sentido de praticar safadezas de toda espécie com as cunhãs bonitas; mas, não é isso uma conseqüência do fato dele incorporar todos os atributos díspares de seu povo? Se fosse europeu, como um Gil Blás, herói doutro quilate, encontraria uma complicação de coisas danadas, começando pelo princípio: a sujeitar-se “à palmatória de um mestre”; e assim sucessivamente, teria que se submeter em todas as situações a regras milenárias, defendidas pelos homens como outras tantas chaves do Santo Sepulcro. Mas não é. Por isso, mostrando a unidade na diversidade, a tradição do novo, etc., Mário de Andrade vai compondo lentamente o seu herói e ao mesmo tempo um compêndio de folclore - Macunaíma é uma introdução ao folclore brasileiro, a mais agradável que se poderia imaginar. Nele pode-se estudar a contribuição folclórica do branco, do preto, do índio, a função modificadora e criadora dos mestiços e dos imigrantes, as lendas, os contos, a paremiologia, as pegas, os acalantos, a escatologia, as práticas mágicas - da magia branca e da magia negra - todo o folclore brasileiro, enfim, num corte horizontal de mestre. É um mosaico, uma síntese viva e uma biografia humanizada do folclore de nossa terra. Mas, aqui, é óbvio, entramos noutro terreno, passando naturalmente para a outra parte deste trabalho.

\section{III - CONTRIBUIÇÃo AO ESTUdO DO FOLCLORE BRASILEIRO}

Os estudos folclóricos de Mário de Andrade têm um significado especial na história do folclore brasileiro, pois inauguram - juntamente com os de Luciano Gallet, Renato de Almeida e outros - um novo campo de investigações: a pesquisa e a análise do folclore musical. Mário de Andrade surge, portanto, num período novo da história do nosso folclore; no mo- 
mento que se iniciam aqui trabalhos senão rigorosamente de especialização, pelo menos desenvolvidos em esferas limitadas, (estudo do folclore musical, do folclore regional, do folclore negro, do cancioneiro literário, do folclore mágico, dos contos, lendas, do folclore infantil, da paremiologia etc.). Não há nenhum inconveniente, entretanto, em tratar essas contribuições como verdadeiros trabalhos de especialização, como o fazem alguns folcloristas - Lindolfo Gomes, Basílio de Magalhães e Joaquim Ribeiro [-], ao traçarem a história do nosso folclore. O importante é assinalar que Mário de Andrade começa a publicar os seus ensaios de folclore quando essa tendência já está bem marcada e acentuava-se decididamente. O imenso material colhido direta ou indiretamente por Sílvio Romero e as preocupações deste pela filiação imediata dos elementos recolhidos - relativamente ao folclore ibérico, ao folclore indígena e ao folclore africano - bem como as investigações de João Ribeiro, sobre as fontes próximas ou remotas de algumas composições folclóricas brasileiras e o seu curso teórico de folclore, dado na Biblioteca Nacional, em 1913, consubstanciavam duas experiências muito sérias. Chamar João Ribeiro de “folclorista-de-gabinete” ou Sílvio Romero de “folclorista-pesquisador”, como fazem certos folcloristas, é dizer apenas meia verdade. Porque ambos foram ao mesmo tempo pesquisadores e investigadores - só que um dedicou-se de preferência à coleta de dados e outro interessou-se mais pelos estudos de filiação histórica. Cada aspecto, não obstante, caracteriza profundamente a obra folclórica de um e de outro, deixando ainda aberto o caminho para uma fase mais fecunda. E essa sucedeu-se logo depois, evidenciando a complementaridade das orientações dos dois maiores folcloristas brasileiros. Mas, é óbvio, este novo desenvolvimento do folclore brasileiro implicava uma restrição cada vez maior do campo de trabalho do folclorista e, pode-se afirmá-lo, está em pleno processo em nossos próprios dias. Enquanto não existirem cursos ou escolas destinadas exclusivamente ao ensino do folclore, predominarão os trabalhos de simples coleta, de feitio irregular e puramente descritivos. Por isso, são mais numerosos os estudos e as obras deste gênero. Mas já os autores mais antigos, apesar dos pontos de contacto que têm, metodologicamente, com Sílvio Romero, logo verificaram a conveniência de limitar suas ambições. Assim, Melo Morais Filho dedicou-se à descrição das festas populares e das influências ciganas no folclore brasileiro; Francisco Pereira da Costa apresenta uma contribuição maciça ao folclore pernambucano; Rodrigues de Carvalho estuda o folclore nordestino; Alexina de Magalhães Pinto e Figueiredo Pimentel interessam-se pelo folclore infantil, principalmente; etc., etc... Ao mesmo tempo, outros autores, contando com maiores recursos teóricos, tentavam, com Lindolfo Gomes, Gustavo Barroso, Artur Ramos, Nina Rodrigues, Manuel Querino, Luís da Câmara Cascudo, Gonçalves Fer- 
nandes, Joaquim Ribeiro, Daniel Gouveia, José Vieira Fazenda, Alberto de Faria, Amadeu Amaral, Renato de Almeida, Luciano Gallet, etc., aprofundar as investigações folclóricas e delimitar ainda mais o seu campo de pesquisas. Mário de Andrade orienta-se neste sentido. Pouco a pouco, o estudo dos textos literários das canções populares, dos cocos, dos lundus, do samba rural, de danças coreográficas, de roda e dramáticas, vai alargando paulatinamente a sua esfera de interesses. Passa ao folclore infantil, ao folclore do negro, ao folclore mágico, à escatologia popular. Em cada um destes setores, porém, dá somente contribuições parciais, embora valiosas; a sua importância maior como folclorista explica-se principalmente por seus trabalhos relativos ao folclore musical - às vezes umas poucas páginas, de seus manuais de história da música, outras vezes ensaios rigorosamente dedicados a uma questão determinada (as danças dramáticas, rodas infantis, canções populares, etc.). Aí estão, todavia, condensadas, laboriosas e pacientes investigações de campo e bibliográficas, e um número enorme de sugestões, de hipóteses a comprovar, e, especialmente, de pistas a seguir - vias abertas a estudos mais especializados e mais profundos. Nesse sentido, mais do que qualquer outro, Mário de Andrade caracteriza-se como um autêntico pioneiro, consciente de suas responsabilidades e de suas limitações. Em vez de desenvolver uma a uma as idéias e sugestões que legou aos musicólogos e folcloristas brasileiros (o que seria fácil a quem, como ele, sempre trabalhava sobre fichas de material recolhido e de leituras), com os riscos correspondentes, preferiu transmitir condensada, laconicamente seria o termo, as suas experiências. É uma atitude prudente que revela ao mesmo tempo compreensão exata da natureza e desenvolvimento dos estudos científicos.

Até agora tenho usado e abusado da palavra folclorista. Entretanto, seria bom repetir o que o próprio Mário de Andrade pensava: “eu não sou folclorista não”77. Mais séria e impressionante, numa terra em que até compositores malandros e cantores de rádio querem ser folcloristas, é a confissão que faz em “O Samba Rural Paulista”. A citação é longa, mas vale a pena $^{78}$ : "De resto e por infelicidade minha, sempre me quis considerar amador em folclore. Disso derivará serem muito incompletas as minhas observações formadas até agora. O fato de me ter dedicado a colheitas [e] estudos folclóricos não derivou nunca de uma preocupação científica que eu julgava superior às minhas forças, tempo disponível e outras preocupações. Com minhas colheitas e estudos mais ou menos amadorísticos, só tive em mira conhecer com

\footnotetext{
${ }^{77}$ Nota de F. F.: Música, doce música. São Paulo, 1933, p. 77. [A 1ª edição, publicada por L. G. Miranda Editor, é datada de 1933 na folha de rosto e de 1934 na capa].

${ }^{78}$ Nota de F. F.: “Festa de Bom Jesus de Pirapora” (Mário Wagner Vieira da Cunha) e "O Samba Rural Paulista”. Separata da Revista do Arquivo Municipal, número 41. São Paulo, 1937, p. 38.
} 
intimidade a minha gente e proporcionar a poetas e músicos, documentação popular mais farta onde se inspirassem”. Nesta questão, todavia, devemos ser mais realista que o próprio rei. Mário de Andrade foi folclorista e, medido pela bitola dos demais folcloristas brasileiros, um grande folclorista.

De fato, se tomássemos o termo num sentido restrito, do folclorista de formação científica e exclusivamente interessado nos problemas teóricos do folclore, Mário de Andrade não era folclorista. Aquele seu estado de espírito que ele chamava de "quase amor”, com que encarava as composições populares brasileiras, não se coadunava muito com as limitações da abordagem científica. E embora sua curiosidade o levasse a ler obras de natureza teórica, mantendo-o bem informado do que acontecia do lado de lá da ciência, embora tivesse grande admiração pelos pesquisadores de formação científica, a verdade é que considerava com alguma ironia os cientistas e os frutos de seus trabalhos. A sua crônica sobre "Sociologia dos Botões”, de 1939, prova-o esclarecedoramente ${ }^{79}$ : “a sociologia está milagrosamente alargando os seus campos de investigação... Estamos todos, para maior felicidade, unanimemente convencidos que uma análise dos nomes das casas que vendem colchões, pode fornecer a razão do excesso de divórcios; e se uns procuram a verdade poenta nos alfarrábios, usando anúncios de jornais, outros constroem doutrinas inteiras sobre a urbanização da humanidade, estudando a rapidez do vôo dos mosquitos”.

O folclore permanece até hoje numa posição incômoda, a cavalo entre a ciência e a arte. Isso por causa de seu próprio objeto. O mesmo nome folclore serve para designar os elementos da tradição oral, da arte popular, e o seu estudo propriamente dito. E tanto é folclorista quem se dedica ao estudo científico do folclore como quem se lhe dá por diletantismo. Entretanto, não se pode negar um caráter muito sério aos trabalhos de Mário de Andrade. Se não são rigorosamente científicos, não são exclusivamente obra de diletantismo. Ao contrário, Mário de Andrade foi um dos primeiros folcloristas brasileiros a se especializar, como vimos, fazendo do folclore musical o seu campo principal de atividades. Por isso, deve-se deixar claro que o abandono dos problemas teóricos em nada invalida a sua contribuição como folclorista. Além disso, dedicou-se a estudos que mais implicam curiosidade e erudição que propriamente a observância de regras deste ou daquele gênero. Daí a fecundidade de sua passagem pelo folclore brasileiro, pois a sua mania de fichar tudo o que via, ouvia e lia, e sua quase católica curiosidade, talharam-no para o papel de folclorista erudito e pesquisador. Avalia-se a importância disto quando se acompanha as suas investigações das fontes mediatas e imediatas

\footnotetext{
${ }^{79}$ Nota de F. F.: Os filhos da Candinha. São Paulo, 1943.
} 
das composições do cancioneiro musical ou do cancioneiro literário brasileiro ${ }^{80}$. Os resultados de suas pesquisas têm o mesmo valor que se fossem realizadas por especialistas longamente treinados. E o que importa, no caso, são exatamente os resultados obtidos, embora os meios de investigação empregados pareçam mais ou menos livres.

Nesse particular, de pesquisas de fontes, Mário de Andrade aproxima-se da orientação de Sílvio Romero, procurando determinar a proveniência imediata dos elementos do folclore brasileiro. Todavia, nas melhores contribuições, ultrapassa os critérios empregados pelo folclorista sergipano ao aprofundar a análise temática ou formal das composições estudadas, principalmente as composições do folclore musical brasileiro. Além do estudo da contribuição do português e do espanhol - do folclore ibérico - do índio e do negro, chega, muitas vezes, como João Ribeiro e Lindolfo Gomes, às fontes mediatas, completando assim a investigação da filiação histórica de certos elementos do folclore brasileiro. Há pronunciada tendência, em nossos dias, em desprezar-se, por “evolucionista”, esses critérios de pesquisa e de explicação folclóricos. Parece, todavia, que nessa atitude há mais comodismo que outra coisa. Se é certo que a determinação de fontes, por si só é insuficiente e pode-se usar métodos de pesquisa, de sistematização e de explicação mais rigorosos e mais de acordo como os modernos recursos das ciências sociais, não é menos certo também que a determinação das fontes do folclore brasileiro conserva ainda toda a sua importância teórica e analítica. E, por sua vez, tem mais valor científico uma contribuição onde os elementos são estudados deste ponto de vista, do que muitos trabalhos contemporâneos, exclusivamente descritivos.

Quando trata da aplicação terapêutica dos excretos, Mário de Andrade faz uma incisiva referência às fontes portuguesas e ao processo de integração dos elementos culturais de que os portugueses eram portadores: “muitas de nossas práticas vieram de Portugal. Algumas são historicamente coloniais, dos tempos em que, mesmo folcloricamente, se pode dizer que o brasileiro não passava de um português emprestado" ${ }^{* 1}$. Mais importante é sua contribuição ao estudo das fontes do nosso folclore musical. De suas pesquisas, concluiu que os portugueses nos deram ${ }^{82}$ : o nosso tonalismo harmônico, a quadratura estrófica, provavelmente a síncopa, desenvolvida posteriormente pelo negro, os instrumentos europeus, como a guitarra (violão), a viola, o cavaquinho, a flauta, o oficlide, o piano, o grupo dos arcos, textos, formas poéticolíricas, como a moda, o acalanto, danças do gênero das rodas infantis, do fandango, danças

\footnotetext{
${ }^{80}$ Nota de F. F.: Cômoda distinção de Jayme Cortesão, O que o povo canta em Portugal; op. cit., pág. 34.

${ }^{81}$ Nota de F. F.: Namoros com a medicina, op. cit., p. 74.

${ }^{82}$ Nota de F. F.: Pequena história da música. São Paulo, 1942, p. 148; Compêndio de história da música, São Paulo, 1933, p. 178-179: Ensaio sobre música brasileira, São Paulo, 1928, p. 9.
} 
dramáticas como os Reisados, as Pastoris, a Marujada, a Chegança, a forma primitiva de Bumba-meu-boi. Considera muito maior porém, a influência portuguesa no cancioneiro literário. Aprofundando suas investigações, põe em evidência duas coisas importantes: 1) a herança musical que recebemos dos portugueses é mais propriamente européia que lusitana; 2) a reciprocidade de influências. Sobre esta questão diz: "é certo que o Brasil deu musicalmente muito a Portugal - fado ${ }^{83}$, provavelmente a modinha ${ }^{84}$, uma parte da rítmica e a melodia brasileira”. De maneira que, em síntese, temos o seguinte quadro: a influência portuguesa no cancioneiro literário é muito grande, mas é menor no cancioneiro musical. Neste ocorreram por sua vez influências brasileiras em Portugal, o que está de acordo com as conclusões de Jayme Cortesão, Luís F. Branco, Rodney Gallop e Renato de Almeida. Mesmo, os textos das canções e dos romances velhos portugueses, "foram modificados e adaptados antropogeograficamente à nossa realidade”, diz Mário de Andrade. E os autos e danças dramáticas, como as Pastoris, Marujadas, Cheganças de Mouro, que conservam alguns versos e melodia lusitanas, "foram construídas integralmente aqui, textos e músicas, e ordenados semi-eruditamente nos fins do século XVIII, ou princípios do século seguinte»85. No folclore infantil, entretanto, aconteceu o contrário. A roda infantil conserva-se européia e particularmente lusitana ${ }^{86}$, ou, dir-se-ia com maior precisão, mantém-se ibérica. Nas influências ibéricas, considera conjuntamente a herança espanhola ao lado da portuguesa. Mas, é claro, aquela é pobre, reduzindose a danças hispano-americanas - como a habanera e o tango ${ }^{87}$.

As informações relativas aos outros dois elementos - os índios e os negros - são menos ricas. Reduz a influência dos índios na música brasileira a alguns instrumentos, certas formas poéticas, o cateretê, os caboclinhos - nome genérico de bailados nordestinos - a nasalação e o ritmo discursivo, em parte devido também à influência gregoriana ${ }^{88}$. Aos negros atribui a nossa grande variedade rítmica[,] algumas palavras, que aparecem em danças dramáticas, como as congadas e mesmo na música popular carioca, instrumentos como o ganzá, o puíta $^{89}$, o atabaque, e as formas primitivas do lundu ${ }^{90}$. Foi em torno de pesquisas de folclore musical, orientadas neste sentido, que Mário de Andrade pôde avaliar a função de cerimônias mágico-religiosas dos negros no desenvolvimento da música popular brasileira - que se exer-

\footnotetext{
${ }^{83}$ Nota de F. F.: Vejam-se também: “Origens do Fado”, in: Música, doce música, op. cit.

${ }^{84}$ Nota de F. F.: Vejam-se também: Modinhas imperiais, op. cit., p. 5-7.

${ }^{85}$ Nota de F. F.: Pequena história da música, op. cit., p. 149.

${ }^{86}$ Nota de F. F.: "Influência portuguesa nas rodas infantis do Brasil”. In: Música, doce música, op. cit., p. 95.

${ }^{87}$ Nota de F. F.: Compêndio de história da música. Op. cit., p. 180.

${ }^{88}$ Nota de F. F.: Idem, p. 173 e seguintes.

89 "Puíta": mesmo que "cuíca”.

${ }^{90}$ Nota de F. F.: Compêndio de história da música. Op. cit., p. 178-179.
} 
ce através dos cantos e danças a elas associados. As músicas de macumbas e de candomblés, por exemplo, embora não sejam puramente africanas, revelam à sua análise constantes melódicas diferentes da música popular brasileira. A rítmica dos cantos usados nas macumbas e catimbós do nordeste, doutro lado, levou-o a estabelecer uma relação entre o estado psíquico dos participantes das cerimônias e as músicas utilizadas. A sonolência, estado de depressão, obter-se-ia por meio da monotonia dos cantos curtos e lerdos; a exaltação, estado de assombramento, conseguir-se-ia pela rítmica de violência marcada ${ }^{91}$. Estas observações são valiosas, pois permitem maior compreensão das fases posteriores do cerimonial - no primeiro caso, a intervenção direta do feiticeiro; no segundo, a descida de Xangô no seu “cavalo de santo” e o significado e funções dos cantos e danças no comportamento dos membros do grupo. Roger Bastide, que colheu excelentes dados sobre a música, os cantos e as danças dos candomblés na Bahia ${ }^{92}$, também observou esta última relação: “Acontece por vezes que, apesar dos convites, os “orixá” se recusam a descer. Então uma música especial é tocada, apressada e insistente, os tambores dão golpes surdos no peito e no estômago, e uma angústia nos oprime; a roda não pára: continua, se acelera, não terminará enquanto os deuses não tiverem saltado na garupa de seus cavalos..."93.

O estudo do samba rural paulista ${ }^{94}$, da canção popular brasileira ${ }^{95}$, de vários romances velhos, como o romance do Veludo ${ }^{96}$, das rodas infantis ${ }^{97}$, da forma, instrumentação, polifonia, melodia e ritmo da música brasileira - erudita e popular, estudo este seguido de um cancioneiro musical com textos ${ }^{98}$ - e das danças dramáticas brasileiras ${ }^{99}$, completam sua contribuição ao folclore musical brasileiro. Ao folclore negro dedicou uma pesquisa importantíssima - sobre as congadas, autos bailados dos negros brasileiros, estudo que se tornou justamente clássico ${ }^{100}$. As investigações históricas levadas a efeito por Mário de Andrade, nesse ensaio, permitiram o esclarecimento de muitos problemas ou pontos obscuros, como o da rainha Ginga, do rei de Congo, das guerras intestinas na África e o seu reflexo no aproveitamento

\footnotetext{
${ }^{91}$ Nota de F. F.: “Terapêutica musical”. In: Namoros com a medicina, op. cit., p. 16 e s.

${ }^{92}$ Nota de F. F.: Imagens do Nordeste místico, em branco e preto. Rio de Janeiro, 1945, passim.

93 Nota de F. F.: Roger Bastide, op. cit., pág. 85.

94 Nota de F. F.: "O Samba Rural Paulista”, op. cit.

95 Nota de F. F.: “A Música e a Canção Populares”. In: Folk-lore Musical, Inst. de Coop. Intel., 1939.

${ }^{96}$ Nota de F. F.: “Romance do Veludo”. In: Música, doce música, op. cit.

${ }^{97}$ Nota de F. F.: "Influência portuguesa (...)”, op. cit.; apesar de ser um ensaio de duas dezenas de páginas, é um dos estudos mais importantes sobre o folclore infantil brasileiro.

${ }^{98}$ Nota de F. F.: "Ensaio sobre música brasileira”, op. cit., passim.

${ }^{99}$ Nota de F. F.: “Danças Dramáticas Iberobrasileiras” In: Música do Brasil, Curitiba, 1941.

${ }^{100}$ Nota de F. F.: “Os Congos”, Bolet. da Soc. Felipe de Oliveira, fevereiro de 1935.
} 
pelos negros de formas portuguesas, como o teatro popular, das “embaixadas”, etc.. Mais tarde, foram completadas por Artur Ramos ${ }^{101}$.

O único trabalho exclusivamente consagrado ao estudo da escatologia no folclore brasileiro foi escrito por Mário de Andrade ${ }^{102}$. Nele são analisados: a aplicação terapêutica dos excretos, a obsessão pelas porcarias, pelas palavras feias, coprolalia, o uso dos excrementos nas práticas mágicas - nas esferas que chamou de “magia baixa”. O material apresentado é riquíssimo, sendo alguns elementos analisados do ponto de vista da filiação histórica. As informações disponíveis sobre essas práticas no Brasil colonial e imperial completam o trabalho. A tese defendida inicialmente por Mário de Andrade não deixa de ser arriscada. Os excretos exercem uma função revitalizadora das terras esgotadas. Dão vida à terra. Por isso, os excretos ficariam associados a funções revitalizadoras. Doutro lado, o excremento tem outra função purificadora e aperfeiçoadora: na refinação do açúcar, verbi gratia. Daí nova associação entre o emprego dos excretos, suas virtudes e conseqüências. É evidente que essa é uma atitude explicativa do pesquisador; as interpretações, ao contrário, devem ser procuradas no meio onde ocorrem os fenômenos analisados, isto é, em seus contextos culturais. A explicação, portanto, corre o risco de ser falsa, embora elaborada logicamente. Mário de Andrade compreendeu o perigo de sua posição, ajuntando: “sem dúvida, não vou até afirmar que destas associações de imagens o povo tire a inspiração primeira que o levou ao emprego medicinal dos excretos”103. Aceita, todavia como correta, apesar das restrições que faz à sua teoria como explicação genética e geral, que se devem procurar associações lógicas. Tratando-se do homem “despaisado” de países civilizados, parece-lhe necessário contrapor o seu pensamento lógico ao pensamento místico dos primitivos. Este apelo a Levy-Bruhl complica em vez de simplificar o problema. E em nada melhora as bases precárias da teoria. O mais conveniente é deixá-la de lado, e aproveitar o imenso material de escatologia popular brasileira que Mário de Andrade reuniu em seu livro. As duas hipóteses que servem de conclusões, contudo, são mais modestas, e talvez mereçam um controle especial em pesquisas futuras: 1 ) originalmente os excretos seriam meios místicos de obtenção de cura e só mais tarde tornar-se-iam remédios propriamente ditos; 2) a cura pela ingestão dos excretos basear-se-ia em fundamentos psicosociais, na noção de sacrifício inerente à prática e imanente ao ato. Neste trabalho nota-se, doutro lado, que Mário de Andrade já não pensa como em 1930-36, a respeito da transforma-

\footnotetext{
${ }^{101}$ Nota de F. F.: O folk-lore negro do Brasil, Rio de Janeiro, 1935.

102 Nota de F. F.: “Medicina dos Excretos”. In: Namoros com a medicina, op. cit.; abrange mais da metade do volume.

${ }^{103}$ Nota de F. F.: Op. cit., pág. 66.
} 
ção das formas populares em formas eruditas. Entre as duas hipóteses, de que as receitas passariam da prática costumeira à farmacopéia científica ou vice-versa, afasta acertadamente qualquer escolha preferencial. Porque, diz, "provavelmente se deram estes dois fenômenos contrários”.

\section{IV - CONCLUSÕES}

Eis aí, em resumo, a contribuição de Mário de Andrade ao folclore brasileiro. A importância de sua passagem, pelos domínios do nosso folclore, como literato e como folclorista, é óbvia. De um lado realizou uma obra de aproveitamento erudito do material folclórico sem precedentes na história da literatura brasileira. Doutro, apresenta um conjunto de ensaios que o credencia como um dos maiores folcloristas contemporâneos, situando-o entre os melhores da história do folclore brasileiro. Pode-se dizer que quantitativamente os trabalhos publicados são pouco representativos - em relação à espantosa produtividade de alguns folcloristas hodiernos - levando-se em conta também que Mário de Andrade repetia-se muito nos seus melhores estudos sobre o folclore musical. Mas, do ponto de vista qualitativo, da contribuição efetiva, das sugestões que deixa e das novas pistas que abre no campo do folclore musical brasileiro, principalmente, a questão muda de figura. E é sob este aspecto, exatamente, que deve ser encarada a sua obra de folclorista.

FLORESTAN FERNANDES 


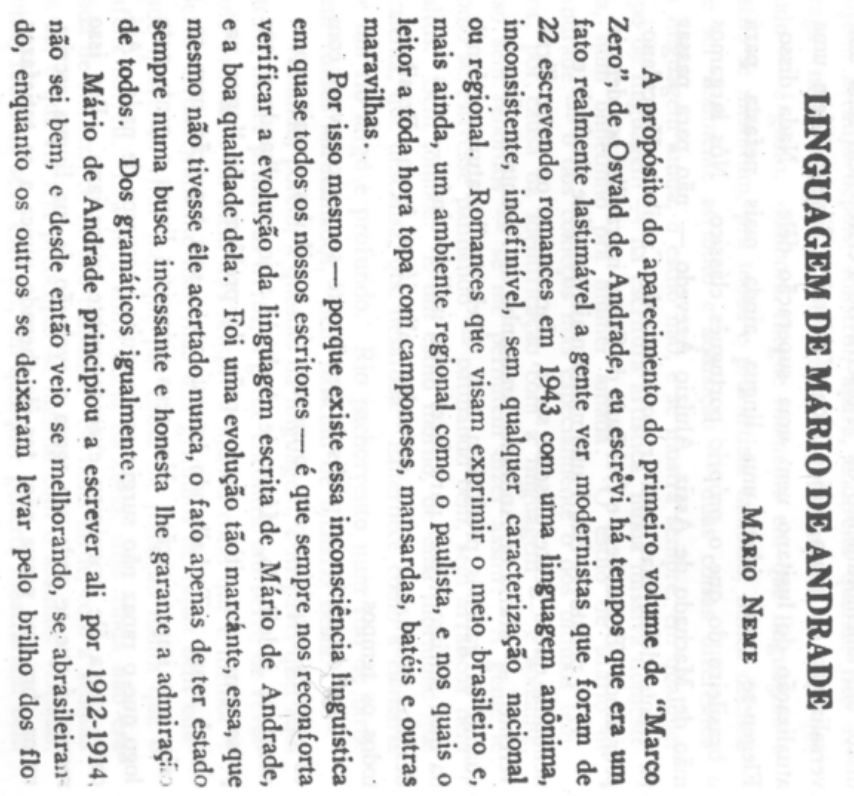




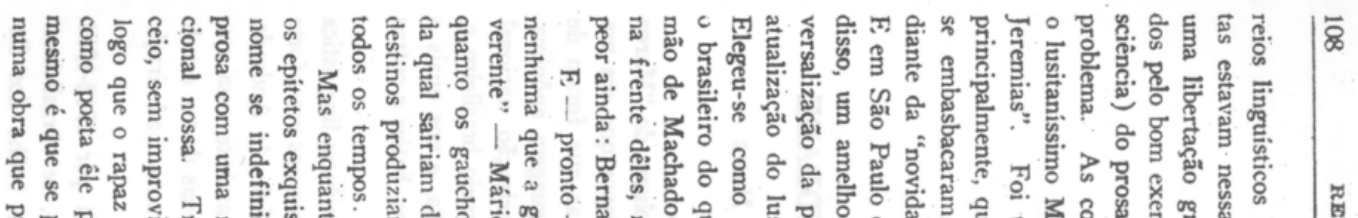

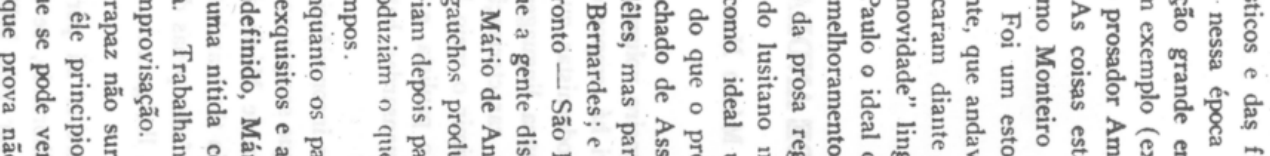

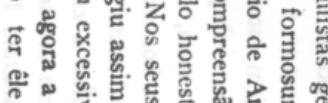

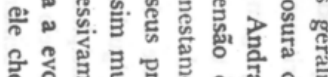

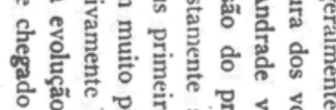

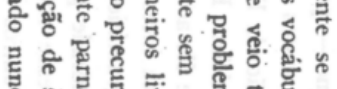

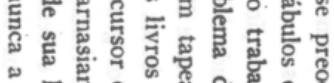

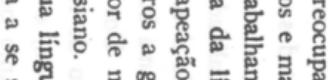

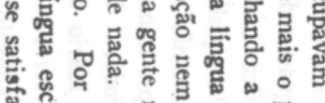

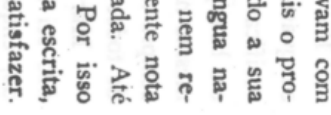

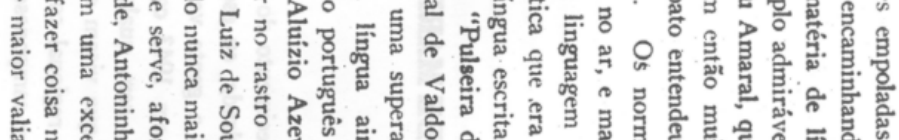

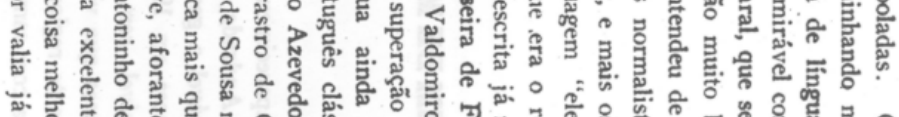
F:

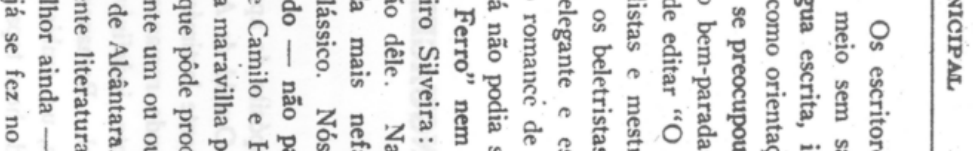

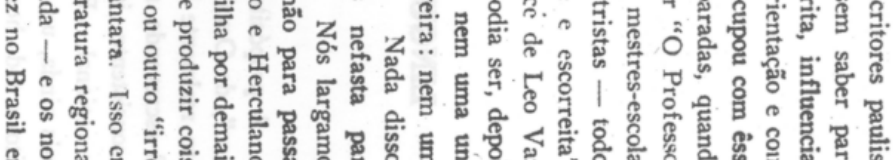

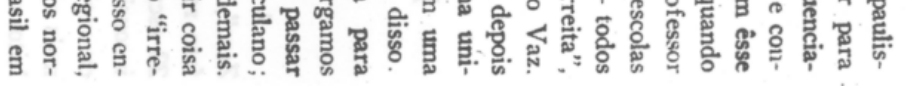

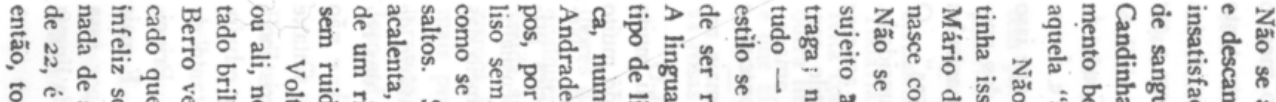

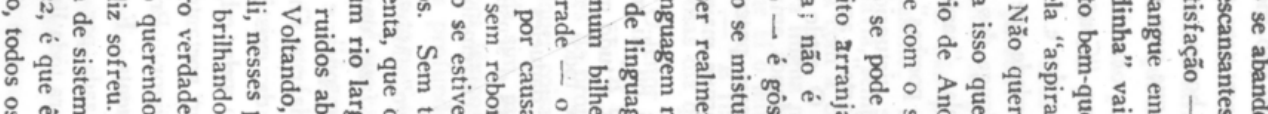

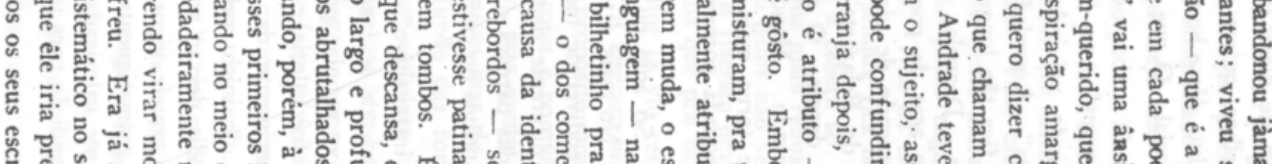

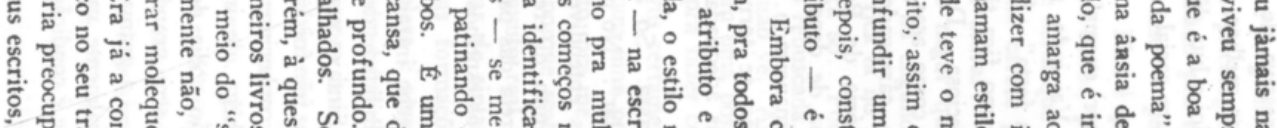

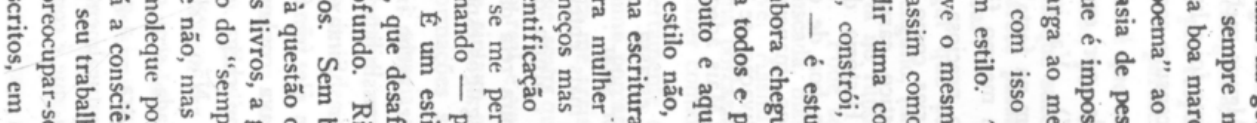

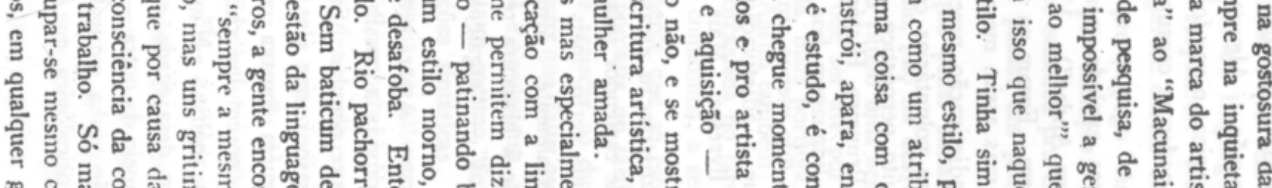

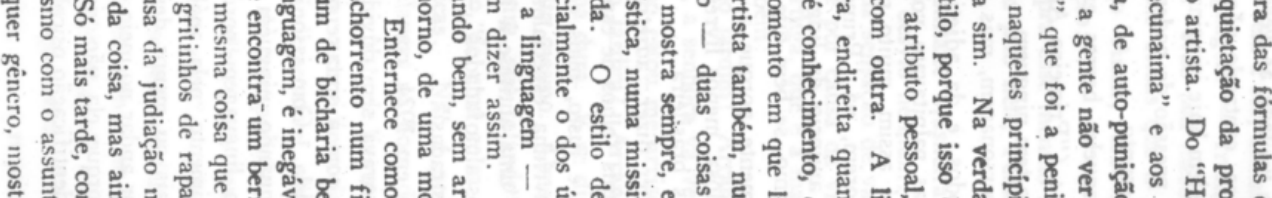

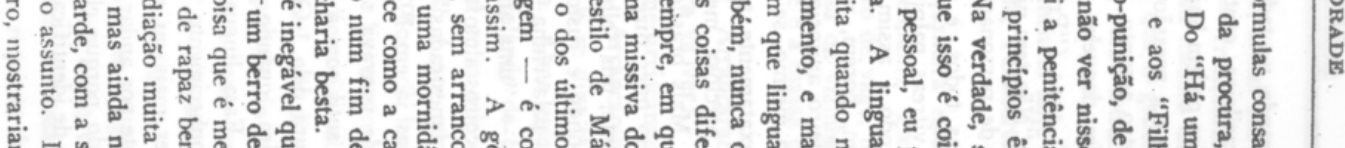

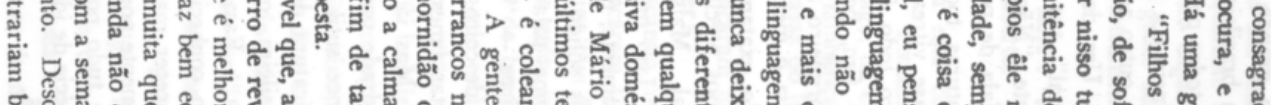

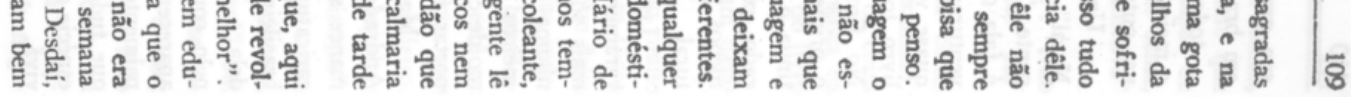




\section{LINGUAGEM DE MÁRIO DE ANDRADE}

Neme, Mário. "Linguagem de Mário de Andrade”. Revista Arquivo Municipal: São Paulo, ano XII, $\mathrm{n}^{0}$ 106, janeiro/fevereiro de 1946, p. 107-114. Reproduzido em Revista Arquivo Municipal: São Paulo, nº 198, 1990, p. 107-114 [ed. fac-similar do $\mathrm{n}^{\mathbf{0}}$ 106, 1946, mesma revista].

A propósito do aparecimento do primeiro volume de Marco zero, de Oswald de Andrade, eu escrevi há tempos que era um fato realmente lastimável a gente ver modernistas que foram de 22 escrevendo romances em 1943 com uma linguagem anônima, inconsistente, indefinível, sem qualquer caracterização nacional ou regional. Romances que visam exprimir o meio brasileiro e, mais ainda, um ambiente regional como o paulista, e nos quais o leitor a toda hora topa com camponeses, mansardas, batéis e outras maravilhas.

Por isso mesmo - porque existe essa inconsciência lingüística em quase todos os nossos escritores - é que sempre nos reconforta verificar a evolução da linguagem escrita de Mário de Andrade, e a boa qualidade dela. Foi uma evolução tão marcante, essa, que mesmo não tivesse ele acertado nunca, o fato apenas de ter estado sempre numa busca incessante e honesta lhe garante a admiração de todos. Dos gramáticos igualmente.

Mário de Andrade principiou a escrever ali por 1912-1914, não sei bem, e desde então veio se melhorando, se abrasileirando, enquanto os outros se deixaram levar pelo brilho dos floreios lingüísticos e das frases empoladas. Os escritores paulistas estavam nessa época se encaminhando meio sem saber para uma libertação grande em matéria de língua escrita, influenciados pelo bom exemplo (exemplo admirável como orientação e consciência) do prosador Amadeu Amaral, que se preocupou com esse problema. As coisas estavam então muito bemparadas, quando o lusitaníssimo Monteiro Lobato entendeu de editar O professor Jeremias ${ }^{104}$. Foi um estouro. Os normalistas e mestres-escolas principalmente, que andavam no ar, e mais os beletristas - todos se embasbacaram diante da linguagem "elegante e escorreita”, diante da “novidade” lingüística que era o romance de Leo Vaz. E em São Paulo o ideal de língua escrita já não podia ser, depois disso, um amelhoramento da "Pulseira de Ferro"105 nem uma universalização da prosa regional de Valdomiro Silveira: nem uma atualização do lusitano nem uma superação dele. Nada disso. Elegeu-se como ideal uma língua ainda mais nefasta para o

\footnotetext{
${ }^{104}$ Nota de Mário Neme (M. N.): VAZ, Leo. O professor Jeremias. São Paulo: Revista do Brasil, 1920.

105 Nota de M. N.: Amaral, Amadeu (pseudônimo de Amadeu Ataliba Penteado). A pulseira de ferro. São Paulo: Soc. Ed. Olegário Ribeiro, 1920.
} 
brasileiro do que o próprio português clássico. Nós largamos mão de Machado de Assis, Aluízio Azevedo - não para passar na frente deles, mas para ir no rastro de Camilo e Herculano; pior ainda: Bernardes; e frei Luís de Sousa maravilha por demais.

E - pronto - São Paulo nunca mais que pôde produzir coisa nenhuma que a gente dissesse serve, aforante um ou outro “irreverente” - Mário de Andrade, Antoninho de Alcântara. Isso enquanto os gaúchos produziam uma excelente literatura regional, da qual sairiam depois para fazer coisa melhor ainda - e os nordestinos produziam o que de maior valia já se fez no Brasil em todos os tempos.

Mas enquanto os paulistas geralmente se preocupavam com os epítetos esquisitos e a formosura dos vocábulos e mais o pronome se indefinido, Mário de Andrade veio trabalhando a sua prosa com uma nítida compreensão do problema da língua nacional nossa. Trabalhando honestamente sem tapeação nem receio, sem improvisação. Nos seus primeiros livros a gente nota logo que o rapaz não surgiu assim muito precursor de nada. Até como poeta ele principiou excessivamente parnasiano. Por isso mesmo é que se pode ver agora a evolução de sua língua escrita, numa obra que prova não ter ele chegado nunca a se satisfazer. Não se abandonou jamais na gostosura das fórmulas consagradas e descansantes; viveu sempre na inquietação da procura, e na insatisfação - que é a boa marca do artista. Do Há uma gota de sangue em cada poema ao Macunaíma e aos Filhos da Candinha vai uma ânsia de pesquisa, de autopunição, de sofri- mento bem-querido, que é impossível a gente não ver nisso tudo aquela “aspiração amarga ao melhor” que foi a penitência dele.

Não quero dizer com isso que naqueles princípios ele não tinha isso que chamam estilo. Tinha sim. Na verdade, sempre Mário de Andrade teve o mesmo estilo, porque isso é coisa que nasce com o sujeito, assim como um atributo pessoal, eu penso. Não se pode confundir uma coisa com outra. A linguagem o sujeito arranja depois, constrói, apara, endireita quando não estraga; não é atributo - é estudo, é conhecimento, e mais que tudo - é gosto. Embora chegue momento em que linguagem e estilo se misturam, pra todos e pro artista também, nunca deixam de ser realmente atributo e aquisição - duas coisas diferentes. A linguagem muda, o estilo não, e se mostra sempre, em qualquer tipo de linguagem - na escritura artística, numa missiva doméstica, num bilhetinho pra mulher amada. O estilo de Mário de Andrade - o dos começos mas especialmente o dos últimos tempos, por causa da identificação com a linguagem - é coleante, liso sem rebordos - se me permitem dizer assim. A gente lê como se estivesse patinando - patinando bem, sem arrancos nem saltos. Sem tombos. É um estilo morno, de uma mornidão que acalenta, que descansa, que desafoba. Enternece como acalmaria de um 
rio largo e profundo. Rio pachorrento num fim de tarde sem ruídos abrutalhados. Sem baticum de bicharia besta.

Voltando, porém, à questão da linguagem, é inegável que, aqui, ou ali, nesses primeiros livros, a gente encontra um berro de revoltado brilhando no meio do "sempre a mesma coisa que é melhor”. Berro verdadeiramente não, mas uns gritinhos de rapaz bem educado querendo virar moleque por causa da judiação muita que o infeliz sofreu. Era já a consciência da coisa, mas ainda não era nada de sistemático no seu trabalho. Só mais tarde, com a semana de 22, é que ele iria preocupar-se mesmo com o assunto. Desdaí, então, todos os seus escritos, em qualquer gênero, mostrariam bem sua grande vontade às vezes até agressiva de dizer isso mesmo em brasileiro, cantando não. Alguns melhor, outros nem tanto - todos podem hoje imaginar o que foi a luta desse homem contra o meio e a pressão de poderosa censura social. O que vem a ser um outro assunto.

Um daqueles berros explode, por exemplo, no “Conto de Natal”, 1914 (Primeiro andar). Vai indo, vai indo, e de repente: “Não tem ninguém. Foram na festa”. É verdade que isso é fala de personagem, mas assim mesmo fica tão longe dos porventuras todos, e da adjetivação preciosa. Daquelas "narículas quase vítreas palpitavam voluntárias como asas de pombas”. O livro todo é assim, muito pernóstico, carregado de virtuosidade. No fim, porém, na "Primeira História de Belazarte”, aparece o primeiro anúncio da linguagem boa de depois. O estilo continua o mesmo, se bem que menos amaneirado. Menos amaneirado exatamente porque a adjetivação se torna mais precisa e menos preciosa, menos livresca. Mais adequada porque mais natural. Mais brasileira.

Isso quer dizer: adjetivação escassa. Só aqui ou ali muito raramente, uns "olhos de esplendor solar”. No mais, é tudo muito mais sólido e justo, mais certo, mais entendível de todos. Nenhuma palavrinha especialmente. Muito diferente daqueles primeiros - "uma antítese à brancura reta das paredes o sensualismo de coiros almofadados" — "esgalgos espelhos no entremeio das portas fenestradas”...

Mas já em 1924, com Amar, verbo intransitivo, Mário de Andrade provava sem dúvida a possibilidade de se fazer um romance sutil com a sintaxe popular. Sintaxe popular pura, e não caricatura dela. Com isso, o que ele fez foi valorizar a sintaxe brasileira, quando ninguém tomava conhecimento da existência dela. Essa linguagem porém lhe chega, de início pelo estudo, pelo conhecimento, pela análise. Não podia deixar portanto de aparecer mais ou menos desajeitada, sem grande vigor. Principalmente por andar no meio da outra - a gramatiquenta. 
E mais que tudo porque ela não vinha naturalmente valorizada por essa espécie de identificação psicológica, que é condição para toda língua viva.

Se o leitor me perguntasse o que vem a ser, afinal das contas, essa identificação psicológica da linguagem - francamente que eu ficaria atrapalhado pra responder. Não sou mesmo capaz de dizer o que seja isso - parece dessas coisas que a gente sente, definir não pode. Mas é que eu pego Amar, verbo intransitivo e leio um período assim, por exemplo:

- "Mas que seria que sucedeu pra esse menino hoje! Não tem parada! Você carece passar um pito nele, Felizberto. Impossível da gente aturar!”

E não posso negar que como sintaxe brasileira está certo, certíssimo. Não há engano, não há desvio nenhum. Exatinho. Todavia, sempre fica lá no fundo uma sensação de vago, de coisa feita com a cabeça só. Pode ser até por causa da vizinhança da outra língua mais rebuscada, mais portuga, que é a massa do livro e que aí o leitor não vê. Assim também:

— “É fizeram uma porcariada no jardim! Arrancaram todas as rosas diz que pra fazer comidinha, a senhora vá ver!”

O leitor já viu certamente que só estou me arriscando muito

— “É fizeram uma porcaria no jardim! Arrancaram todas lhores [sic] de propósito, pra me arriscar na dura. E se digo que falta qualquer coisa é porque sinto que falta mesmo. Uma coisa indefinida sim, mas muito real e verdadeira, não falando de brasileirismos léxicos mas de sintaxe mesmo, de uma coisa que está no mais profundo das formações sintáticas. Não é por certo essa ternura que embeleza e amacia as palavras na boca do brasileiro. Isso até que está bem sensível, embora se trate de linguagem escrita:

- "A gente nunca deve desmanchar a comidinha das crianças”.

O que falta talvez não seja coisa indispensável, não digo tanto. Pode ser mesmo apenas uma questão de transposição de palavras, ou de tempo de verbo. Explicando melhor: um "que será” ou, melhor, um “o que será” em vez de “que seria” - não sei, me parece muito mais da nossa índole, do nosso jeito de falar as coisas; o condicional quase inexistente e muita constância no artigo. Não se lembram daquele, “O que é que há?” Naquele outro caso, eu acredito muito mais característico da língua nacional nossa a presença de uma negativa na frase negativa, sem o requinte da negação indireta: “A gente não deve nunca desmanchar a comidinha das crianças".

Pode ser também que tudo não passe de uma questão de eufonia, e de hábito, e que desse jeito eu esteja indo ao extremo de querer impor à língua mais genericamente brasileira de Mário de Andrade certas características de uma língua meio regional, meio caipira, com a 
qual me acostumei muito. Enfim - para chegar à verdade indiscutível, só mesmo esperando pelos laboratórios apropriados e pelos filólogos não preocupados com Camões.

O que eu posso dizer com segurança é que estamos diante de uma questão de psicologia da linguagem muito difícil da gente entender quanto mais explicar. Porque as evidências são excessivamente sutis e fugidias - escapam da mão - e se condicionam mais à nossa capacidade de sentir do que a qualquer processo de análise cerebral. Não há pedagogia possível: os exemplos não há jeito da gente tirar do cérebro, não podem sair daí. O leitor tem que sentir como sente a beleza de uma flor que tem cor e perfume, além das realidades anatômicas.

A verdade, porém, é que nesses primeiros ensaios de sintaxe brasileira a gente nota a falta da tal identificação psicológica. Mário de Andrade está muito no alto, culturalmente, pra se identificar com a massa. É um intelectual puro, que tem horror ao povo. Foge dele inconscientemente, embora querendo parar no meio da rua pra ficar sendo povo também. Esse horror ao povo - do homem de cultura - é que levará o artista a gritar mais tarde pra todos nós: "Marchem com as multidões".

Bem sei que ele ficaria horrorizado se pudesse ler o que está escrito aí. Na verdade eu também queria que não fosse assim. Mas se eu sinto, Cristo do céu! Eu sinto que falta nesses começos alguma coisa de mais puro, de mais natural, de menos pensado. O que, sem dúvida, continuaria sempre - e sempre se agravando mais, se não sucedesse dele ser artista de verdade, com a sustância suficiente pra vencer de quando em quando o homem de cultura. Tanto que nos trabalhos seguintes - Belazarte[,] Macunaíma e crônicas de jornal - ele haveria de conseguir aquela identificação de uma maneira que melhor não seria possível. Em Macunaíma principalmente. Será uma ${ }^{106}$ questão de léxico? Eu digo que não - o problema não é vocabular, não é de imagens, mas de expressões. Cassiano Ricardo emprega nos seus versos uma infinidade de vocábulos brasileiros, e escreve em português a despeito de tudo.

É inegável que neste último livro houve uma possibilidade muito maior de identificação, por causa da uniformidade da língua usada na rapsódia. Em qualquer página de Macunaíma a gente encontra bons exemplos da mais pura sintaxe brasileira, porque o livro todo é construído assim. Um exemplo: "Nem bem teve seis anos deram água num chocalho pra ele e Macunaíma principiou falando como todos. E pediu pra mãe que largasse da mandioca ralando na cevadeira e levasse ele passear no mato. A mãe não quis porque não podia largar da mandioca não”. Vejam bem que a identificação aí chega a verdadeiro requinte - ultrapassa o

\footnotetext{
${ }^{106}$ Na revista, lê-se “um”. Erro tipográfico.
} 
estudo, o conhecimento, o fichário "largasse da mandioca ralando na cevadeira...” Nunca que um português digno poderia pensar nessa heresia.

O leitor poderá dizer que isso foi possível porque aqui ele não teve necessidade de certas sutilezas indispensáveis pro subjetivismo do Amar, verbo intransitivo. Pode ser, embora no Macunaíma ele também fosse capaz de sutilezas admiráveis, sem nunca usar uma linguagem psicologicamente menos verdadeira. Assim também em Belazarte e nos Filhos da Candinha - contos e crônicas escritos de 1924 a 1939. Seria ir longe demais, num artigo de jornal, juntar exemplos e mais exemplos para mostrar a evolução que teve em todos estes anos a língua escrita de Mário de Andrade no sentido de - sempre permanecendo estilo pessoal e arte se identificar o mais possível com a expressão lingüística do nosso povo. Principalmente porque essa conquista dele, devido à própria natureza da filosofia da linguagem, só pode ser avaliada e compreendida com a vista em conjunto de sua obra, em especial a de ficção. Não quero fazer citações aqui - pois todos os seus trabalhos são datados propositadamente - e de Amar, verbo intransitivo e dos seus contos, anunciam-se agora novas edições.

Concluindo, não posso deixar de dizer que nos últimos tempos uma espécie de desânimo aparentemente atingira esse cinqüentão que, mais do que muitos de 20 e 25 anos permaneceu jovem, agressivamente jovem. Foi há uns cinco anos mais ou menos - Mário de Andrade como que entregou os pontos, desistiu da luta - não vale a pena brigar, brasileiro! Saiu por aí se lastimando, dizendo que "hoje, como normalidade de língua culta e escrita, estamos em situação inferior à de cem anos atrás”107.

Devia ter sido alguma dor no fígado, sem dúvida, se não foi briga com a namorada. Porque a verdade é - que embora sofisticamente - ele sempre esteve bem certo, e convicto, de que o avanço foi grande, ora se foi! - porque ele bem que sabia - a normalidade não importa absolutamente; importa sim aquilo que se distingue da normalidade, importa é a vitória contra a normalidade, contra a "triste moxinifada moluscóide sem vigor nem caráter”"108.

Mário de Andrade nunca que poderia esquecer que há cem anos atrás não existia um Mário de Andrade - e que as normalidades de todos os tempos foram passando, foram passando, graças a Deus - o que ficou? Ficaram as conquistas individuais.

MÁRIO NEME

\footnotetext{
${ }^{107}$ ANDRADE, Mário de. “O movimento modernista”. In: Aspectos da literatura brasileira, op. cit. 108 Idem.
} 
[Leitura. Rio de Janeiro, abr. 1946. FBN - Periódicos]

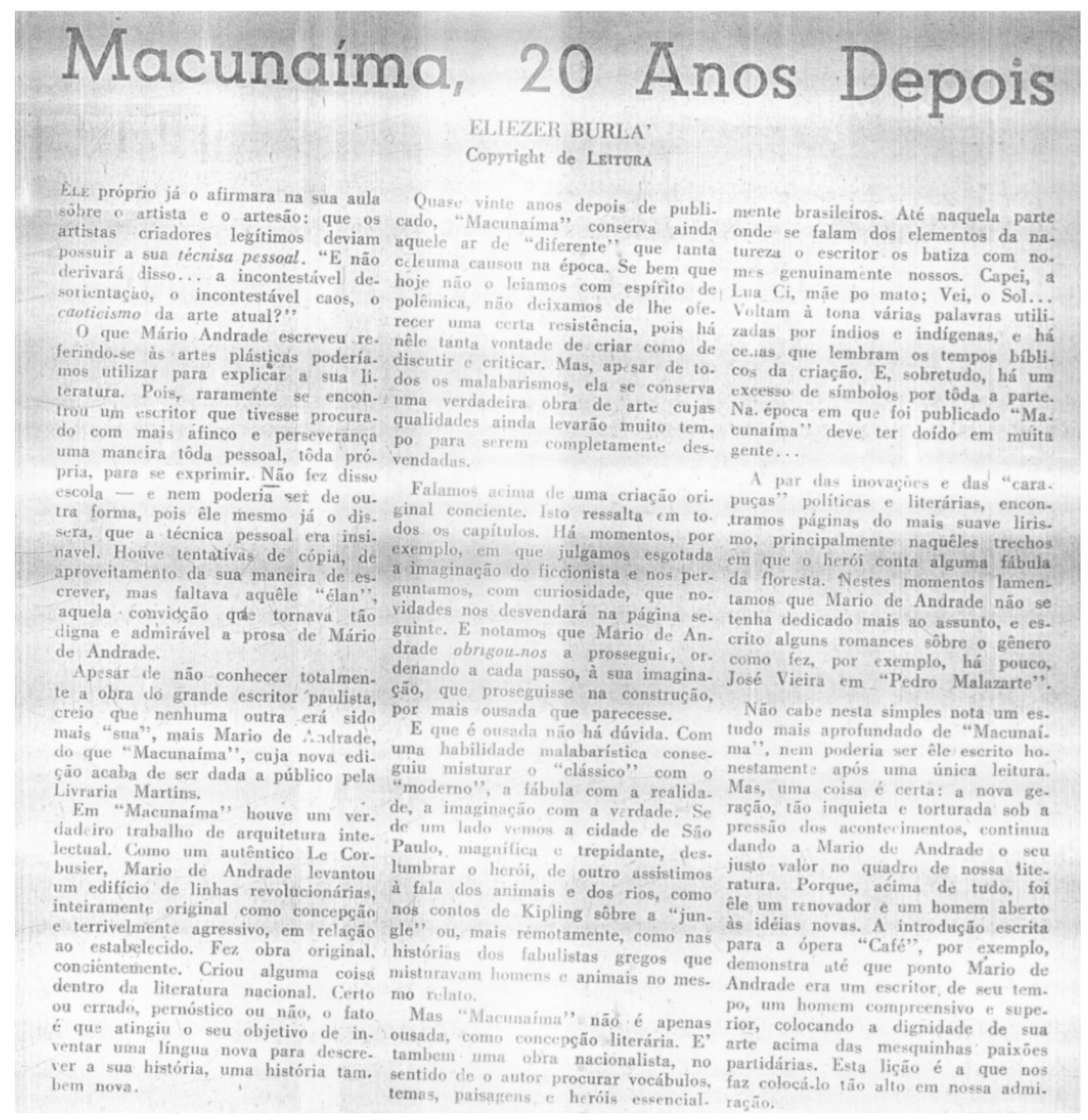




\section{MACUNAÍMA, 20 ANOS DEPOIS}

BuRlÁ, Eliezer. "Macunaíma, 20 anos depois”. Leitura: Rio de Janeiro, ano IV, $n^{0}$ 39, abril de 1946, p. 7. FBN Periódicos.

Ele próprio já o afirmara na sua aula sobre o artista e o artesão: que os artistas criadores legítimos deviam possuir a sua técnica pessoal. "E não derivará disso... a incontestável desorientação, o incontestável caos, o caoticismo da arte atual?”

O que Mário escreveu referindo-se às artes plásticas poderíamos utilizar para explicar a sua literatura. Pois, raramente se encontrou um escritor que tivesse procurado com mais afinco e perseverança uma maneira toda pessoal, toda própria, para se exprimir. Não fez disso escola - e nem poderia ser de outra forma, pois ele mesmo já o dissera, que a técnica pessoal era insinável [sic]. Houve tentativas de cópia, de aproveitamento da sua maneira de escrever, mas faltava aquele “élan”, aquela convicção que tornava tão digna e admirável a prosa de Mário de Andrade.

Apesar de não conhecer totalmente a obra do grande escritor paulista, creio que nenhuma outra terá sido mais “sua”, mais Mário de Andrade, do que Macunaíma, cuja nova edição acaba de ser dada a público pela Livraria Martins.

Em Macunaíma houve um verdadeiro trabalho de arquitetura intelectual. Como um autêntico Le Corbusier, Mário de Andrade levantou um edifício de linhas revolucionárias, inteiramente original como concepção e terrivelmente agressivo, em relação ao estabelecido. Fez obra original, conscientemente. Criou alguma coisa dentro da literatura nacional. Certo ou errado, pernóstico ou não, o fato é que atingiu o seu objetivo de inventar uma língua nova para descrever a sua história, uma história também nova.

Quase vinte anos depois de publicado, Macunaíma conserva ainda aquele ar de "diferente” que tanta celeuma causou na época. Se bem que hoje não o leiamos com espírito de polêmica, não deixamos de lhe oferecer uma certa resistência, pois há nele tanta vontade de criar como de discutir e criticar. Mas, apesar de todos os malabarismos, ela se conserva uma verdadeira obra de arte cujas qualidades ainda levarão muito tempo para serem completamente desvendadas.

Falamos acima de uma criação original consciente. Isso ressalta em todos os capítulos. Há momentos, por exemplo, em que julgamos esgotada a imaginação do ficcionista e nos per- 
guntamos, com curiosidade, que novidades nos desvendará na página seguinte. E notamos que Mário de Andrade obrigou-nos a prosseguir, ordenando a cada passo, à sua imaginação, que prosseguisse na construção, por mais ousada que parecesse.

E que é ousada não há dúvida. Com uma habilidade malabarística conseguiu misturar o “clássico” com o “moderno”, a fábula com a realidade, a imaginação com a verdade. Se de um lado vemos a cidade de São Paulo, magnífica e trepidante, deslumbrar o herói, de outro assistimos à fala dos animais e dos rios, como nos contos de Kipling sobre a "jungle” ou, mais remotamente, como nas histórias dos fabulistas gregos que misturavam homens e animais no mesmo relato.

Mas Macunaíma não é apenas ousada como concepção literária. É também uma obra nacionalista, no sentido de o autor procurar vocábulos, temas, paisagens e heróis essencialmente brasileiros. Até naquela parte onde se falam dos elementos da natureza o escritor os batiza com nomes genuinamente nossos. Capei[,] a Lua, Ci, mãe do mato; Vei, a Sol ${ }^{109}$... Voltam à tona várias palavras utilizadas por índios e indígenas, e há cenas que lembram os tempos bíblicos da criação. E, sobretudo, há um excesso de símbolos por toda a parte. Na época em que foi publicado Macunaíma deve ter doído em muita gente...

A par das inovações e das “carapuças” políticas e literárias, encontramos páginas do mais suave lirismo, principalmente naqueles trechos em que o herói conta alguma fábula da floresta. Nestes momentos lamentamos que Mário de Andrade não se tenha dedicado mais ao assunto, e escrito alguns romances sobre o gênero como fez, por exemplo, há pouco, José Vieira em Pedro Malazarte.

Não cabe nesta simples nota um estudo mais aprofundado de Macunaíma, nem poderia ser ele escrito honestamente após uma única leitura. Mas, uma coisa é certa: a nova geração, tão inquieta e torturada sob a pressão dos acontecimentos, continua dando a Mário de Andrade o seu justo valor no quadro de nossa literatura. Porque, acima de tudo, foi ele um renovador e um homem aberto às idéias novas. A introdução escrita para a ópera Café, por exemplo, demonstra até que ponto Mário de Andrade era um escritor de seu tempo, um homem compreensivo e superior, colocando a dignidade de sua arte acima das mesquinhas paixões partidárias. Esta lição é a que nos faz colocá-lo tão alto em nossa admiração.

ELIEZER BURLÁ

\footnotetext{
${ }^{109}$ No jornal, lê-se “(...) Vei, o Sol (...)”.
} 
1953 


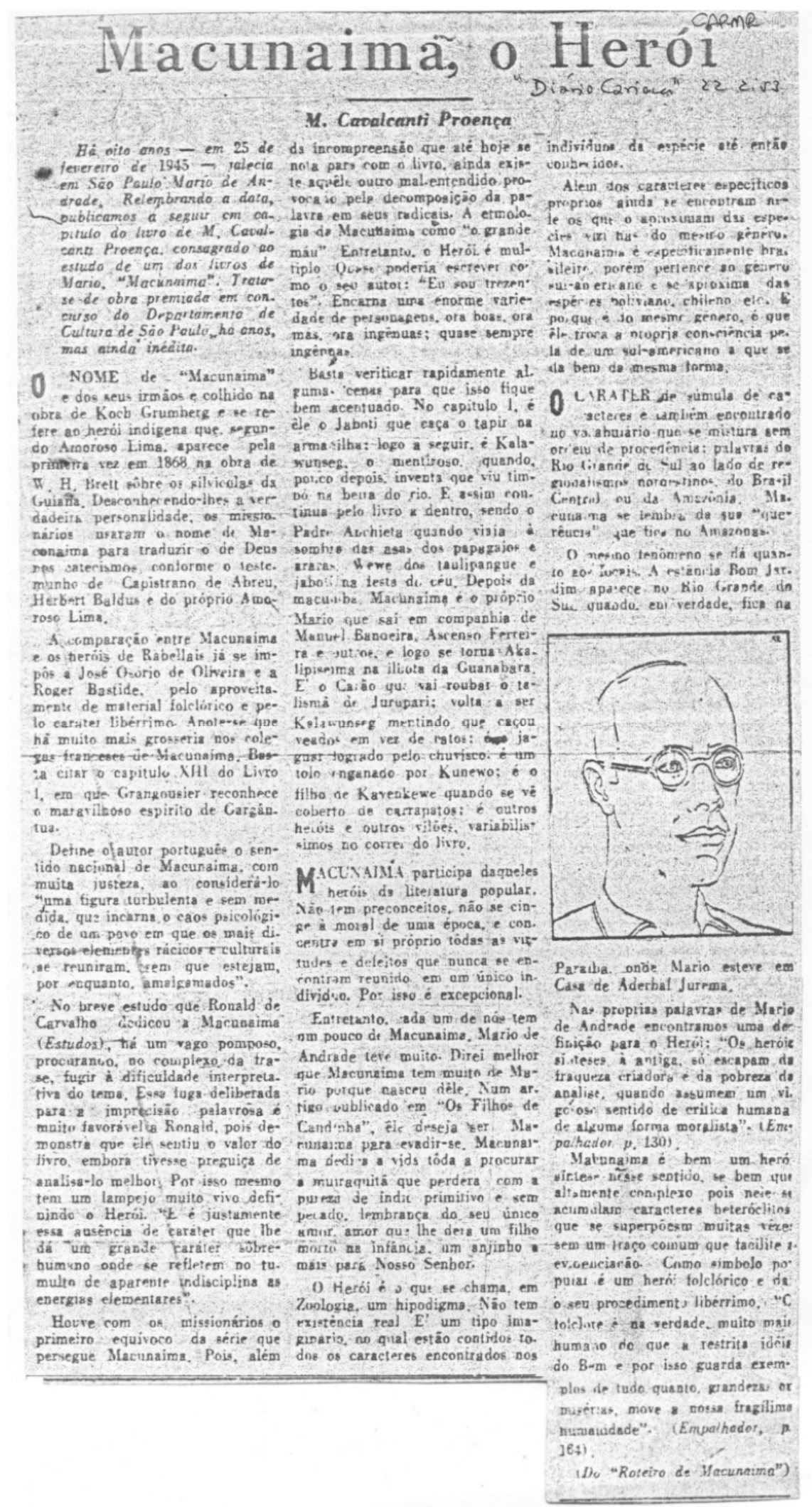




\section{MACUNAÍMA, O HERÓI}

ProençA, M. Cavalcanti. "Macunaíma, o herói”. Diário Carioca: Rio de Janeiro, 22 de fevereiro de 1953. IEB CAP-MP. [Excerto do até então inédito Roteiro de Macunaíma ${ }^{110}$.

Há oito anos - em 25 de fevereiro de 1945 - falecia em São Paulo Mário de Andrade. Relembrando a data, publicamos a seguir um capítulo do livro de M. Cavalcanti Proença, consagrado ao estudo de um dos livros de Mário, Macunaíma. Trata-se de obra premiada em concurso do Departamento de Cultura de São Paulo, há anos, mas ainda inédita.

O nome de Macunaíma e dos ${ }^{111}$ seus irmãos é colhido na obra de Koch Grünberg e se refere ao herói indígena que, segundo Amoroso Lima ${ }^{112}$, aparece pela primeira vez em 1868, na obra de W. H. Brett sobre os silvícolas da Guiana. Desconhecendo-lhe ${ }^{113}$ a verdadeira personalidade, os missionários usaram o nome de Macunaíma para traduzir o de Deus, nos catecismos, conforme o testemunho de Capistrano de Abreu, Herbert Baldus e do próprio Amoroso Lima.

A comparação entre Macunaíma e os heróis de Rabelais já se impôs a J. Osório de Oliveira e a Roger Bastide pelo aproveitamento de material folclórico e pelo caráter libérrimo. Anote-se que há muito mais grosseria nos colegas franceses de Macunaíma. Basta citar o capítulo XIII do Livro I em que Grandgousier reconhece o maravilhoso espírito de Gargântua.

Define o autor português ${ }^{114}$ o sentido nacional de Macunaíma com muita justeza, ao considerá-lo "uma figura turbulenta e sem medida, que encarna o caos psicológico de um povo em que os mais diversos elementos rácicos e culturais se reuniram, sem que estejam, por enquanto, amalgamados.”

No breve estudo que Ronald de Carvalho dedicou a Macunaíma (Estudos ${ }^{115}$ ), há um vago pomposo, procurando no complexo da frase fugir à dificuldade interpretativa do tema. Essa fuga deliberada para a imprecisão palavrosa é muito favorável a Ronald, pois demonstra

\footnotetext{
${ }^{110}$ ProençA, M. Cavalcanti. Roteiro de Macunaíma. 1ae ed. São Paulo: Anhembi, 1955.

${ }^{111}$ No livro, lê-se “de".

112 Referência a ATAÍDE, Tristão de [Alceu Amoroso Lima]. "Macunaíma”. O Jornal: Rio de Janeiro, 09 set. 1928.

113 No jornal, lê-se “Desconhecendo-lhes”. Erro tipográfico sanado na edição em livro.

${ }^{114}$ Cavalcanti Proença se refere ao mencionado J. Osório de Oliveira.

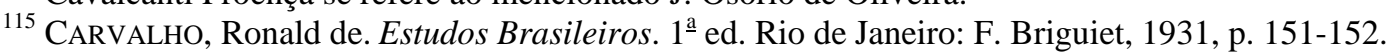


que ele sentiu o valor do livro, embora tivesse preguiça de analisá-lo melhor. Por isso mesmo tem um lampejo muito vivo definindo o herói. "E é justamente essa ausência de caráter que lhe dá um grande caráter sobre-humano onde se refletem no tumulto de aparente indisciplina as energias elementares”.

Houve com os missionários o primeiro equívoco da série que persegue Macunaíma ${ }^{116}$. Pois, além da incompreensão que até hoje se nota para com o livro, ainda existe aquele outro mal-entendido provocado pela decomposição da palavra em seus radicais. A etimologia dá Macunaíma como “o grande mau”. Entretanto o herói é múltiplo. Quase poderia escrever como o seu autor ${ }^{117}$ : “Eu sou trezentos.” Encarna uma enorme variedade de personagens, ora boas, ora más, ora ingênuas; quase sempre ingênuas.

Basta verificar rapidamente algumas cenas para que isso fique bem acentuado. No capítulo I, é ele o Jabuti que caça o Tapir na armadilha; $\operatorname{logo}^{118}$ a seguir é Kalawunseg, o mentiroso, quando, pouco depois, inventa que viu timbó na beira do rio. E assim continua pelo livro adentro, sendo o Pe. Anchieta quando viaja à sombra das asas dos papagaios e araras, Wewe dos taulipangues, o jabuti na festa do céu. Depois da macumba, Macunaíma é o próprio Mário que sai em companhia de Manuel Bandeira, Ascenso Ferreira e outros; e logo se torna Akalipzeima, na ilhota da Guanabara. É o Carão que vai roubar o talismã de Jurupari; volta a ser Kalawunseg, mentindo que caçou veados em vez de ratos, é o jaguar logrado pelo chuvisco, é um tolo enganado por Kunewo, é o filho de Kaynkewe, quando se vê coberto de carrapatos; é outros heróis e outros vilões, variabilíssimo no correr do livro.

Macunaíma participa daqueles heróis da literatura popular. Não tem preconceitos, não se cinge à moral de uma época, e concentra em si próprio todas as virtudes e defeitos que nunca se encontram reunidos em um único indivíduo. Por isso é excepcional.

Entretanto, cada um de nós tem um pouco de Macunaíma. Mário de Andrade teve muito. Direi melhor que Macunaíma tem muito de Mário porque nasceu dele. Num artigo publicado em Os filhos da Candinha, ele deseja ser Macunaíma para evadir-se. Macunaíma dedica a vida toda ${ }^{119}$ a procurar a muiraquitã que perdera com a pureza de índio primitivo e sem pecado, lembrança do seu único amor ${ }^{120}$, amor que lhe dera um filho, morto na infância, um anjinho a mais para Nosso Senhor [e que não continuaria a obra do pai ${ }^{121}$ ].

\footnotetext{
${ }^{116}$ No livro, modificado para “(...) que persegue o nome do herói”.

${ }^{117}$ No livro, modificado para “(...) como Mário”.

${ }^{118}$ No livro, modificado para “(...) na armadilha; a seguir é Kalawunseg (...)”.

${ }^{119}$ No livro, modificado para “(...) a vida a procurar (...)”.

${ }^{120}$ No livro, modificado para “(...) lembrança do único amor de sua vida (...)”.

121 Trecho inserido no livro, que não está no jornal.
} 
O herói é o que se chama, em Zoologia, um hipodigma. Não tem existência real. É um tipo imaginário, no qual estão contidos todos os caracteres encontrados nos indivíduos da espécie até então conhecidos.

Além dos caracteres específicos próprios, ainda se encontram nele os que o aproximam das espécies vizinhas do mesmo gênero. Macunaíma é especificamente brasileiro, porém pertence ao gênero sul-americano e se aproxima das espécies boliviano, chileno, etc. E porque é do mesmo gênero, é que ele ${ }^{122}$ troca a própria consciência pela de um sul-americano ${ }^{123}$ e se dá bem da mesma forma.

O caráter de súmula de caracteres é também encontrado no vocabulário que se mistura sem ordem de procedência: palavras do Rio Grande do Sul ao lado de regionalismos nordestinos, do Brasil Central ou da Amazônia. Macunaíma se lembra de sua “querência”, que fica no Amazonas. ${ }^{124}$

O mesmo fenômeno se dá quanto aos locais. A estância Bom Jardim aparece no Rio Grande do Sul, quando, em verdade, fica na Paraíba, onde Mário esteve em casa de Aderbal Jurema. $^{125}$

Nas próprias palavras de Mário de Andrade encontraremos uma definição para o herói ${ }^{126}$ : “Os heróis-sínteses, à antiga, só escapam da fraqueza criadora e da pobreza de análise, quando assumem um vigoroso sentido de crítica humana, de alguma forma moralista.” (Empalhador, pág. 130).

Macunaíma é bem um herói-síntese nesse sentido, se bem que altamente complexo, pois nele se acumulam caracteres heteróclitos, que se superpõem, muitas vezes sem um traço comum que facilite a evidenciação. Como símbolo popular é um herói folclórico, e daí o seu procedimento libérrimo. "O folclore é, na verdade, muito mais humano que a restrita idéia do Bem e por isso guarda exemplos de tudo quanto, grandezas ou misérias, move a nossa fragílima humanidade.” (Empalhador, pág. 164).

(Do “Roteiro de Macunaíma”)

M. CAVALCANTI PROENÇA

\footnotetext{
${ }^{122}$ No livro, modificado para “(...) gênero, troca a própria consciência(...)”.

${ }^{123}$ Em Macunaíma, o herói se apropria da consciência de um hispano-americano.

124 No livro, modificado para “(...) de sua "querência” no Amazonas.”

${ }^{125}$ No livro, modificado para “(...) na Paraíba e lá esteve Mário, em casa (...)”.

${ }^{126}$ No livro, modificado para “(...) uma definição do herói.”
} 
1954

(sem registro) 


\title{
ORDENAÇÃO CRONOLÓGICA
}

\author{
(1928-1954)
}




\section{8: 1a edição de Macunaíma}

1. S/A [Mário de Andrade]. "Macunaíma. O livro de Mário de Andrade”. Diário Nacional: São Paulo, 07 de agosto de 1928. IEB-USP - CAP-MP.

2. AtAíDE, Tristão de [Alceu Amoroso Lima]. “Macunaíma”. O Jornal: Rio de Janeiro, 09 de setembro de 1928. FBN - Periódicos.

3. J. P. [João Pacheco]. “Bibliografia / 'Macunaíma' - Mário de Andrade - São Paulo”. FoIha Acadêmica: Rio de Janeiro, 13 de setembro de 1928, p. 484. IEB-USP - MA-MP.

4. MotTA Filho, Cândido. “As leituras da semana / Literatura / Macunaíma - Mário Moraes de Andrade - São Paulo - 1928”. Correio Paulistano: São Paulo, 20 de setembro de 1928. IEB-USP - CAP-MP.

5. A. de A. M. [António de Alcântara Machado]. "Um poeta e um prosador / Mário de Andrade - Macunaíma - São Paulo - 1928”. Revista de Antropofagia: São Paulo, a. I, n⿳ํ5, setembro de 1928, p. 4. Edição fac-similar. São Paulo: Abril / Metal Leve, 1975.

6. Andrade, Oswald de. "Esquema ao Tristão de Ataíde”. Revista de Antropofagia: São Paulo, a. I, n⿳ำ 5, setembro de 1928, p. 3. Edição fac-similar. São Paulo: Abril / Metal Leve, 1975.

7. S/A [Ronald de Carvalho]. "Livros / Macunaíma - o herói sem nenhum caráter - de Mário de Andrade”. Movimento: Rio de Janeiro, 01 de outubro de 1928, p. 21. FBN - Periódicos. Recolhido em Carvalho, Ronald de. “Cadernos de imagens / 4 / Macunaíma, de Mário de Andrade”. In: Estudos Brasileiros. 1ª ed. Rio de Janeiro: F. Briguiet, 1931, p. 151-152. Reeditado em: Rio de Janeiro: MEC / Nova Aguilar, 1976, p. 143-144.

8. VíTOR, Nestor. "Macunaíma, o herói sem nenhum caráter”. O Globo: Rio de Janeiro, 08 de outubro de 1928. FBN - Periódicos. Recolhido em VÍTOR, Nestor. “Os de Hoje / Mário de Andrade / Macunaíma”. Obra crítica de Nestor Vítor. Rio de Janeiro: MEC / Fundação Casa de Rui Barbosa, 1973, v. II, p. 360-365. [1ª ed. 1938].

9. RIBEIRO, João. “Crônica literária / Macunaíma - herói sem nenhum caráter - por Mário de Andrade”. Jornal do Brasil: Rio de Janeiro, 31 de outubro de 1928, p. 10. IEB-USP CAP-MP. Recolhido em Os Modernos. Rio de Janeiro: ABL, 1952, p. 81-84, vol. IX das Obras completas de João Ribeiro. Reproduzido em AnDRADE, Mário de. Macunaíma. Edição crítica de Telê Porto Ancona Lopez. Rio de Janeiro: Livros Técnicos e Científicos / São Paulo: Secretaria da Cultura, Ciência e Tecnologia, 1978. 
10. Ferreira, Ascenso. "Brasilidade e dinamismo / a propósito do 'Macunaíma' de Mário de Andrade”. Diário Nacional: São Paulo, 28 de novembro de 1928. IEB-USP - CAP-MP. Republicado no mesmo jornal: 23 de novembro de 1931.

11. VIEIRA, José. “Livros novos / Macunaíma, por Mário de Andrade, S. Paulo, 1928”. Vanguarda: [Rio de Janeiro ${ }^{1}$ ], 10 de dezembro de 1928. IEB-USP - MA-MP.

12. O. M. [Olívio Montenegro]. "Livros novos / Macunaíma - Romance - Mário de Andrade - S. Paulo - 1928”. Periódico não identificado, [Recife ${ }^{2}$ ], s/d. IEB-USP - MA-MP.

13. SchmidT, Augusto F. “A propósito de 'Macunaíma””. A Ordem: Rio de Janeiro, [dezembro?] de 1928, p. 34-38. IEB-USP - CAP-MP.

\section{9}

14. A. M. [Augusto Meyer]. "Macunaíma / por Mário de Andrade”. Revista do Globo: Porto Alegre, a. I, $\mathrm{n}^{\mathrm{0}}$ 1, janeiro de 1929. IEB-USP - MA-MP.

15. MACHADO, Antônio de Alcântara. “O modernismo da literatura de 1928”. A União: [Paraíba, $\mathrm{PB}^{3}$ ], 31 de janeiro de 1929. IEB-USP - MA-MP.

16. TAMANDARÉ [Oswaldo Costa]. "Moquém / II - Hors d'oeuvre”. Revista de Antropofagia. $2^{\underline{a}}$ Dentição. Diário de S. Paulo: São Paulo, 14 de abril de 1929, p. 6. Edição fac-similar. São Paulo: Abril / Metal Leve, 1975.

17. A. F. [Aníbal Fernandes]. "Através dos livros / Macunaíma - Mário de Andrade - S. Paulo”. Diário de Pernambuco: Recife, 18 de abril de $1929^{4}$. IEB-USP - MA-MP.

18. TAMAndaré [Oswaldo Costa]. “Moquém / III - Entradas”. Revista de Antropofagia. $2^{\underline{a}}$ Dentição. Diário de S. Paulo: São Paulo, 24 de abril de 1929, p. 10. Edição fac-similar. São Paulo: Abril / Metal Leve, 1975.

19. Ferreira, Ascenso. "Carta do poeta de Catimbó”. Revista de Antropofagia. $2^{\underline{a}}$ Dentição. Diário de S. Paulo: São Paulo, 19 de julho de 1929, p. 12. Edição fac-similar. São Paulo: Abril / Metal Leve, 1975.

\footnotetext{
${ }^{1}$ No verso do recorte, que se encontra no álbum R.29 do IEB-USP - Recortes de Mário de Andrade -, há indícios de que a cidade do Rio de Janeiro seja o local da publicação.

${ }^{2}$ No verso do recorte, que se encontra no álbum R.29 do IEB-USP - Recortes de Mário de Andrade -, há indícios de que a cidade de Recife seja o local da publicação.

${ }^{3}$ No recorte que se encontra no álbum R.27 do IEB-USP - Recortes de Mário de Andrade -, há uma anotação de Mário de Andrade que identifica a data de publicação, o periódico e a cidade, Paraíba, depois chamada João Pessoa.

${ }^{4}$ Identificação de periódico e data de publicação por anotação de Mário de Andrade no recorte que se encontra no álbum R. 29 do IEB-USP - Recortes de Mário de Andrade. Identificação de autoria por anotação de Ascenso Ferreira, que remeteu o recorte a Mário.
} 
20. Costa, Oswaldo. "Resposta a Ascenso Ferreira”. Revista de Antropofagia. $2^{\underline{a}}$ Dentição. Diário de S. Paulo: São Paulo, 19 de julho de 1929, p. 12. Edição fac-similar. São Paulo: Abril / Metal Leve, 1975.

21. LiMA, Jorge de. “Todos cantam sua terra...”. In: Dois Ensaios. 1ª ed. Maceió, AL: Casa Ramalho, 1929. Recolhido em Obras completas de Jorge de Lima. Rio de Janeiro: Aguilar, 1959, p. 1012-1038, v. I. Reproduzido, parcialmente, com o título de "Um raide do subconsciente nacional”, em ANDRADE, Mário de. Macunaíma. Edição crítica de Telê Porto Ancona Lopez. Rio de Janeiro: Livros Técnicos e Científicos / São Paulo: Secretaria da Cultura, Ciência e Tecnologia, 1978.

\section{0}

22. Meyer, Augusto. “Macunaíma”. Correio de Povo: Porto Alegre, a. 36, nº 153, p. 3. 01 de julho de 1930. Arquivo DZM.

\section{1}

- Ferreira, Ascenso. “Brasilidade e dinamismo: a propósito do 'Macunaíma’ de Mário de Andrade”. Diário Nacional, São Paulo, 23 de novembro de 1931. Transcrito do Diário Nacional de 28 de novembro de 1928. Documento não localizado pela pesquisa [cf. item 10].

- Carvalho, Ronald de. "Cadernos de imagens / 4 / Macunaíma, de Mário de Andrade”. In: Estudos Brasileiros. 1ํㅡㄹ ed. Rio de Janeiro: F. Briguiet, 1931, p. 151-152. Transcrito de "Livros / Macunaíma - o herói sem nenhum caráter - de Mário de Andrade”. Movimento: Rio de Janeiro, 01 de outubro de 1928, p. 21 [cf., acima, o item 7]. Reeditado em: Rio de Janeiro: MEC / Nova Aguilar, 1976, p. 143-144.

\section{4}

23. Cascudo, Luís da Câmara. “Mário de Andrade”. Boletim de Ariel: Rio de Janeiro, a. 3, nº 9, junho de 1934, p. 233-235. IEB-USP - MA-MP.

\section{5}

24. HolandA, Sérgio Buarque de. "O mito de Macunaíma”. O Espelho. Rio de Janeiro, nº 6, p. 54-56, setembro de 1935 (documento original não localizado). Recolhido em HoLANDA, Sérgio Buarque de. O espírito e a letra. Organização, introdução e notas: Antônio Arnoni Prado. São Paulo: Companhia das Letras, 1996, vol. I, p. 260-267. 


\section{7: 2ª edição de Macunaíma}

25. PereirA, Nunes. “A língua de Macunaíma”. Rio Magazine: Rio de Janeiro, n⿳o 8, s/d [1937 ] . IEB-USP - MA-MP.

26. B. B. [Brito Broca]. “A epopéia de um herói sem nenhum caráter. A reedição de Macunaíma, de Mário de Andrade”. A Gazeta: São Paulo, 25 de fevereiro de 1937. FCL-CEDOC.

27. SoDRÉ, Nelson Werneck. "Livros novos / Macunaíma - Mário de Andrade - Livraria José Olympio Editora”. Correio Paulistano: São Paulo, 15 de abril de 1937. IEB-USP - MAMP.

28. Braga, Rubem. “Os defeitos de Macunaíma”. Folha da Manhã: São Paulo, 04 de maio de $1937^{6}$.

29. Milliet, Sérgio. “O moderno romance brasileiro”. O Estado de S. Paulo: São Paulo, 28 de novembro de 1937. IEB-USP - MA-MP. Recolhido em MiLLIET, Sérgio. Ensaios. São Paulo: Brusco, 1938, p. 183-187.

30. GAMA, Maurício Loureiro. "Bernard Shaw da Barra Funda”. Periódico não identificado, s/l., s/d. ${ }^{7}$ IEB-USP - MA-MP.

\section{8}

- Milliet, Sérgio. “O moderno romance brasileiro”. In: Ensaios. São Paulo: Brusco, 1938, p. 183-187. Publicado antes em: O Estado de S. Paulo: São Paulo, 28 de novembro de 1937 [cf. item 29].

\section{9}

31. Hourcade, Pierre. [Título ignorado]. Revista, 46: Rio de Janeiro, setembro de 1939 (2 $2^{\underline{a}}$ parte $)^{8}$. IEB-USP - MA-MP.

\section{0}

32. HolandA, Sérgio Buarque de. "Vida literária / Poesia e crítica”. Diário de Notícias: Rio de Janeiro, 15 de setembro de 1940. IEB-USP - MA-MP. Recolhido em HoLANDA, Sérgio

\footnotetext{
${ }^{5}$ Nota editorial no fim do artigo permite supor que esse date de 1937, pouco antes da publicação da $2^{2}$ edição de Macunaíma.

${ }^{6}$ Imagem do documento não recuperada pela pesquisa. Texto, com ortografia atualizada, reproduzido de Banco de Dados Folha - Acervo de Jornais: http://www1.folha.uol.com.br/folha/almanaque/semana5.htm/

${ }^{7}$ Talvez seja um jornal chamado Anhanguera, a julgar por anotação manuscrita desse nome entre aspas, feita por Mário de Andrade no recorte que figura no álbum R.29 do IEB - Recortes de Mário de Andrade. Não há indicação de local, data e número de página da publicação; talvez, São Paulo, 1937. Outra hipótese: "Anhanguera” seria o pseudônimo do articulista, em outras publicações.

${ }^{8}$ Identificação do periódico e da data de publicação: LoPEz, Telê Porto Ancona. "Textos em periódicos". In: ANDRADE, Mário de. Macunaíma o herói sem nenhum caráter. Edição crítica de Telê Porto Ancona Lopez. Op. cit., 1978.
} 
Buarque de. O espírito e a letra. Organização, introdução e notas: Antônio Arnoni Prado. São Paulo: Companhia das Letras, 1996, vol. I, p. 274.

1942

33. Milliet, Sérgio. “Trechos de diário”. O Estado de S. Paulo: São Paulo, 22 de fevereiro de 1942. IEB-USP - CAP-MP

34. NemE, Mário. “O livro mais tipicamente brasileiro”. Folha da Manhã: São Paulo, 15 de março de 1942 [declaração em entrevista]. IEB-USP - MA-MP.

\section{3}

35. Pimentel, Osmar. “Macunaíma e o porão”. Diário de S. Paulo: São Paulo, 23 de setembro de 1943. IEB-USP - MA-MP.

36. BRito, Mário da Silva. "Uma excursão pelo fichário de 'Macunaíma””. Diário de S. Paulo: São Paulo, 02 de dezembro de 1943. IEB-USP - MA-MP. ${ }^{10}$

37. M. S. B. [Mário da Silva Brito]. "Melancolia versus 'Macunaíma’”. Diário de S. Paulo: São Paulo, 23 de dezembro de 1943. IEB-USP - MA-MP.

\section{4: $3^{\text {a }}$ edição de Macunaíma}

38. A. F. [Aníbal Fernandes?]. "Livros do dia / 'Macunaíma', de Mário de Andrade”. A Manhã: Rio de Janeiro, 01 de dezembro de 1944. IEB-USP - MA-MP.

\section{5: morte de Mário de Andrade}

39. CARdoso, Joaquim. “Macunaíma”. Folha Carioca: Rio de Janeiro, 18 de janeiro de 1945. IEB-USP - MA-MP.

40. VIEIRA, José Geraldo. "Macunaíma”. Correio Paulistano: São Paulo, 11 de março de 1945. IEB-USP - CAP-MP.

41. PACHECO, João. "Macunaíma e a esfinge”. O Estado de S. Paulo, São Paulo, 18 de maio de 1945 (documento original não localizado). Recolhido em PACHECO, João. Pedras Várias. São Paulo: Conselho Estadual de Cultura, 1959, p. 3-8.

42. LACERDA, Carlos. “Destinação social do romance brasileiro”. Revista Acadêmica: Rio de Janeiro, ano XI, $n^{\circ}$ 66, novembro de 1945. Arquivo DZM.

\section{6}

43. Guimarães, Ruth. “Aspectos da literatura regional”. Folha da Manhã: São Paulo, 20 de janeiro de 1946, p. 30. BDFSP.

\footnotetext{
${ }^{9}$ Trecho não reproduzido em Milliet, Sérgio. Diário crítico de Sérgio Milliet. Introdução de Antonio Candido. $2^{\underline{a}}$ ed. São Paulo: Martins / Edusp, 1981, v. I.

${ }^{10}$ Entrevista com Mário de Andrade.
} 
44. BAstide, Roger. "Macunaíma em Paris”. O Estado de S. Paulo, São Paulo, 03 de fevereiro de 1946 (documento original não localizado). Reproduzido em Cadernos: São Paulo, Centro de Estudos Rurais e Urbanos, n⿳ํㅡ 10, 1a série, novembro de 1977, p. 83-85. Reproduzido, também, e recolhido em Berriel, Carlos Eduardo (org.). Mário de Andrade / Hoje. São Paulo: Ensaio, 1990, p. 78-80.

45. BAstide, Roger. "Macunaíma visto por um francês”. Trad. Maria José Carvalho. Revista Arquivo Municipal: São Paulo, ano XII, n⿳ํㅜ 106, p. 45-50, janeiro/fevereiro de 1946. Reproduzido em Revista Arquivo Municipal: São Paulo, nº 198, 1990, p. $45-50$ [ed. facsimilar do $\mathrm{n}^{0}$ 106, 1946, da mesma revista].

46. Fernandes, Florestan. "Mário de Andrade e o folclore brasileiro”. Revista Arquivo Municipal: São Paulo, ano XII, n⿳0 106, p. 135-158, janeiro/fevereiro de 1946. Reproduzido em Revista Arquivo Municipal: São Paulo, nํ198, 1990, p. 135-158 [ed. fac-similar do no 106, 1946, da mesma revista].

47. Neme, Mário. “Linguagem de Mário de Andrade”. Revista Arquivo Municipal: São Paulo, ano XII, nº 106, p. 107-114, janeiro/fevereiro de 1946. Reproduzido em Revista Arquivo Municipal: São Paulo, n⿳ำ 198, 1990, p. 107-114 [ed. fac-similar do $\mathrm{n}^{0}$ 106, 1946, da mesma revista].

48. Burlá, Eliezer. "Macunaíma, 20 anos depois”. Leitura: Rio de Janeiro, ano IV, nº 39, abril de 1946, p. 7. Arquivo FBN.

\section{3}

49. ProençA, M. Cavalcanti. “Macunaíma, o herói”. Diário Carioca: Rio de Janeiro, 22 de fevereiro de 1953 [excerto do até então inédito ProençA, M. Cavalcanti. Roteiro de Macunaíma]. IEB-USP - CAP-MP.

1954

- Sem registro. 


\section{MACUNAÍMA, DE MÁRIO DE ANDRADE 77 ANOS DE FORTUNA CRÍTICA NO BRASIL $(1928-2005)$}

Pesquisa: Diléa Zanotto Manfio Colaboração: José de Paula Ramos Jr. 


\section{ARTIGOS, ENSAIOS E ESTUDOS DE MACUNAÍMA \\ BIBLIOGRAFIA CRÍTICA PUBLICADA EM PERIÓDICOS E EM LIVROS NO BRASIL}

\section{CONVENÇÕES}

ABRALIC: Associação Brasileira de Literatura Comparada.

BDFSP: Banco de dados Folha de S. Paulo.

CAP-MP: Arquivo Carlos Alberto Passos - matéria em periódicos.

DZM: Arquivo particular da Profa. Dra. Diléa Zanotto Manfio.

FBN: Fundação Biblioteca Nacional.

FCL-CEDOC: Fundação Cásper Líbero - Centro de Documentação.

IEB-USP: Instituto de Estudos brasileiros - Universidade de São Paulo

MA-MP: Arquivo Mário de Andrade - matéria em periódicos.

A. de A. M. [Antônio de Alcântara Machado]. "Um poeta e um prosador / Mário de Andrade - Macunaíma - São Paulo - 1928”. Revista de Antropofagia: São Paulo, a. I, nº 5, setembro de 1928, p. 4. Edição fac-similar. São Paulo: Abril / Metal Leve, 1975.

A. F. [Aníbal Fernandes?]. “Livros do dia / 'Macunaíma’, de Mário de Andrade”. A Manhã: Rio de Janeiro, 01 de dezembro de 1944. IEB-USP - MA-MP.

A. F. [Aníbal Fernandes]. “Através dos livros / Macunaíma - Mário de Andrade - S. Paulo”. Diário de Pernambuco: Recife, 18 de abril de $1929^{1}$. IEB-USP - MA-MP.

A. M. [Augusto Meyer]. "Macunaíma / por Mário de Andrade”. Revista do Globo: Porto Alegre, a. I, $\mathrm{n}^{\mathbf{0}}$ 1, janeiro de 1929. IEB-USP - MA-MP.

\footnotetext{
${ }^{1}$ Identificação de periódico e data de publicação por anotação de Mário de Andrade no recorte que se encontra no álbum R. 29 do IEB-USP - Recortes de Mário de Andrade. Identificação de autoria por anotação de Ascenso Ferreira, que remeteu o recorte a Mário.
} 
Adonias Filho. "Vida dos livros: o caso de Mário de Andrade”. Jornal de Letras: Rio de Janeiro, a. 8, $\mathrm{n}^{-0}$ 73, julho de 1955. Republicado em: Jornal do Commercio: Rio de Janeiro, 19 de janeiro de 1958, p. 11, com supressão das últimas treze linhas. Recolhido em Adonias Filho. Modernos ficcionistas brasileiros. Rio de Janeiro: O Cruzeiro, 1958, p. 235-242.

Alencar, Miriam. “Dina, a mulher guerreira de Macunaíma”. Caderno B Jornal do Brasil: Rio de Janeiro, 02 de novembro de 1969.

Ambrósio, Oscar d’. Mito e símbolos em Macunaíma. São Paulo: Selinunte, 1994.

ANDRADE, Carlos Drummond de. "Imagens de aniversário: Macunaíma”. Correio da Manhã: Rio de Janeiro, 12 de maio de 1963.

ANDRADE, Carlos Drummond de. "Mário esclarece Macunaíma". Jornal de Letras: Rio de Janeiro, fevereiro/março de 1965, p. 5.

ANDRADE, Carlos Drummond de. “Macunaíma, Pluft, etc.”. Caderno B Jornal do Brasil: Rio de Janeiro, 20 de fevereiro de 1975.

Andrade, Fábio de S. “Os ancestrais de Macunaíma”. Folha de S. Paulo: São Paulo, 26 de junho de 1994.

Andrade, Mário de. Macunaíma. Edição crítica de Telê Porto Ancona Lopez. Rio de Janeiro: Livros Técnicos e Científicos; São Paulo: Secretaria da Cultura, Ciência e Tecnologia, 1978.

ANDRADE, Mário de. Macunaíma, o herói sem nenhum caráter. Edição crítica coordenada por Telê Porto Ancona Lopez. 1ํㅡㄹ ed. Paris: ALLCA XX; Brasília: CNPq, 1988. Coleção Arquivos, 6. 2ª ed. 1996. Primeira reimpressão, 1997.

Andrade, Mário de. Mário de Andrade: Ficção. Apresentação e org. de M. Cavalcanti Proença. $1^{\underline{a}}$ ed. Rio de Janeiro: Agir, 1960, il. Nossos Clássicos, 50. Antologia. [2aa ed., 1969; $4^{\mathrm{a}}$ ed., 1978].

ANDRADE, Oswald de. “Esquema ao Tristão de Ataíde”. Revista de Antropofagia: São Paulo, a. I, $\mathrm{n}^{0}$ 5, setembro de 1928, p. 3. Edição fac-similar. São Paulo: Abril / Metal Leve, 1975.

Antelo, Raúl. “A costela de Macunaíma”. Cultura, O Estado de S. Paulo: São Paulo, a. 2, n⿳o 98, 17 de setembro de 1978, p. 3.

Antelo, Raúl. Na Ilha de Marapatá: Mário de Andrade lê os hispano-americanos. São Paulo: Hucitec; Brasília: MINC/Pró-Memória/INL. 1986. 
ANTELO, Raúl. “Macunaíma: apropriação e originalidade”. In: ANDRADE, Mário de. Macunaíma, o herói sem nenhum caráter. Edição crítica. Op. cit., 1988, p. 255-265.

Antelo, Raúl. “Macunaíma e a ficção de fronteira”. Arca: Porto Alegre, nº 1, 1993, p. 19-29.

ARAnTES, Urias. “Macunaíma ou mito da nacionalidade”. Discurso: São Paulo, n⿳0 20, 1993, p. 157-174. [Revista do Departamento de Filosofia - USP].

AraúJo, Gislene Silva. Macunaíma e as faces da crítica. Dissertação de mestrado. Orientação: Maria Aparecida Junqueira. PUC-SP, 2005 [inédita].

Armando, Paulo. "Lopes Chaves, 546, a casa onde nasceu Macunaíma”. Revista Capixaba: Rio de Janeiro, a. 4, n⿳ํㅡㄹ 36, fevereiro de 1970, p. 46-50, il.

AtAíDE, Tristão de [Alceu Amoroso Lima]. “Macunaíma”. O Jornal: Rio de Janeiro, 09 de setembro de 1928. FBN - Periódicos.

ATAÍDE, Vicente de. “Macunaíma e Sagarana: ruptura e tradição, I”. Suplemento Literário Minas Gerais: Belo Horizonte, nº 382, 22 de dezembro de 1973, p. 4-5.

ATAÍDE, Vicente de. “Macunaíma e Sagarana: ruptura e tradição, II”. Suplemento Literário Minas Gerais: Belo Horizonte. nº 383, 29 de dezembro de 1973, p. 6-7.

Autran, Cristina. "Macunaíma: o valor de uma linguagem”. Jornal dos Transportes, São Paulo, nº 9-10, 1969.

ÁvilA, Affonso. “Macunaíma: tradição e atualidade”. Suplemento Literário O Estado de S. Paulo, São Paulo, a. 7, n⿳ํㅡㄹ 346, 07 de setembro de 1963, p. 6. Reproduzido em: Suplemento Literário Minas Gerais: Belo Horizonte, nº 94, 15 de junho de 1968, p. 5.

B. B. [Brito Broca]. “A epopéia de um herói sem nenhum caráter. A reedição de Macunaíma, de Mário de Andrade”. A Gazeta: São Paulo, 25 de fevereiro de 1937. FCL-CEDOC.

BAR, Décio e ArcoflexA, Jairo. “O que fez Macunaíma”. Veja: São Paulo, 26 de julho de 1978, p. 92-94.

BAstide, Roger. “Macunaíma em Paris”. O Estado de S. Paulo, São Paulo, 03 de fevereiro de 1946. Reproduzido em Cadernos: São Paulo, Centro de Estudos Rurais e Urbanos, $\mathrm{n}^{\mathrm{o}}$ 10, $1^{\mathrm{a}}$ série, novembro de 1977, p. 83-85. Reproduzido, também, em: BERRIEL, Carlos Eduardo (org.). Mário de Andrade / Hoje. São Paulo: Ensaio, 1990, p. 78-80.

BAstidE, Roger. "Macunaíma visto por um francês”. Trad. Maria José Carvalho. Revista Arquivo Municipal: São Paulo, ano XII, nº 106, p. 45-50, janeiro/fevereiro de 1946. Reproduzido em Revista Arquivo Municipal: São Paulo, nº 198, 1990, p. 45-50 [ed. facsimilar do $\mathrm{n}^{\mathrm{0}}$ 106, 1946, da mesma revista]. 
BERRIEL, Carlos E. O. “A Uiara enganosa”. In: (org.). Mário de Andrade/Hoje. São Paulo: Ensaio, 1990, p. 133-137. Cadernos Ensaio, 4.

Berriel, Carlos E. O. “Macunaíma: curtas observações sobre gênero e época”. Textos: Araraquara, $\mathrm{SP}, \mathrm{n}^{\mathrm{0}}$ 7, 1988, p. 75-126.

Berriel, Carlos E. O. “O herói sem caráter tem vocação para ser reavaliado”. Folha de S. Paulo: São Paulo, 26 de julho de 1988, p. A-33.

Berriel, Carlos E. O. Dimensões de Macunaíma: filosofia, gênero e época. Dissertação de mestrado. Orientação: Roberto Schwarz. UNICAMP, 1987 [inédita].

Berriel, Carlos Eduardo. “A odisséia anti-industrialista”. Folha de S. Paulo: São Paulo, 09 de julho de 1978.

BezerRA, João Clímaco. “Macunaíma”. O Jornal: Rio de Janeiro, 14 de agosto de 1955.

Bopp, Raul. “Macunaíma”. In: Movimentos modernistas no Brasil. Rio de Janeiro: São José, 1966.

BORA, Zélia. “Nação e identidade periférica em Macunaíma e Los rios profundos”. Florianópolis, SC: ABRALIC, 1998.

Bosi, Alfredo. "Mário de Andrade”. In: História concisa da literatura brasileira. $1^{\mathrm{a}}$ ed. São Paulo: Cultrix, 1970, p. 396-399.

Bosı, Alfredo. "Situação de Macunaíma”. In: . Céu, Inferno. São Paulo: Ática, 1988, p. 127-141. Reproduzido em: ANDRADE, Mário de. Macunaíma, o herói sem nenhum caráter. Edição crítica. Op. cit., 1988, p. 171-181.

Braga, Rubem. “Os defeitos de Macunaíma”. Folha da Manhã: São Paulo, 04 de maio de $1937^{2}$.

BrASIL, Ubiratan. “Mário de Andrade consultou Gilberto Freyre sobre rendeira”. Cultura, O Estado de S. Paulo: São Paulo, a. 19, nº 1011, março de 2000.

Brito, Mário da Silva. “Uma excursão pelo fichário de 'Macunaíma””. Diário de S. Paulo: São Paulo, 02 de dezembro de 1943. IEB-USP - MA-MP. ${ }^{3}$

BuEno, Raquel I. “Macunaíma: a Iara e a máquina - apenas realidades do mundo”. Florianópolis, SC: ABRALIC, 1998.

BuRLÁ, Eliezer. “Macunaíma, 20 anos depois”. Leitura: Rio de Janeiro, ano IV, nº 39, abril de 1946, p. 7. FBN - Periódicos.

\footnotetext{
${ }^{2}$ Imagem do documento não recuperada pela pesquisa. Texto reproduzido de Banco de Dados Folha - Acervo de Jornais: http://www1.folha.uol.com.br/folha/almanaque/semana5.htm/, com ortografia atualizada.

${ }^{3}$ Entrevista com Mário de Andrade.
} 
BusATO, Luiz. “O jogo intertextual em Macunaíma”. In: Amor de asas \& outros ensaios. Rio de Janeiro: Tempo Brasileiro, 1985, p. 59-85.

CABRAL, Leonor Scliar. “As idéias lingüísticas de Mário de Andrade”. In: CHAVES, Flávio Loureiro (org.). Aspectos do modernismo brasileiro. $1^{\underline{a}}$ ed. Porto Alegre: UFRS, 1970, p. 105-107.

Callado, Antonio. “Macunaíma fala a 35 milhões de otários”. Folha de S. Paulo: São Paulo, 26 de dezembro de 1992.

CAllado, Antonio. "Macunaíma encontra seu irmão gêmeo”. Folha de S. Paulo: São Paulo, 02 de julho de 1994.

CAMARgo, Maria Susana. “Satiricon e Macunaíma”. Suplemento Literário Minas Gerais: Belo Horizonte, $\mathrm{n}^{0}$ 288, 04 de março de 1972, p. 2.

CAMARgo, Maria Susana. Estudo minucioso do grande e inestimável Macunaíma à luz das concepções teóricas do famoso crítico russo Mikhail Bakhtin, sobre escritos dos consagrados autores Fiódor Dostoievski e mestre François Rabelais, doutor em medicina. Tese de doutorado. Orientação: Bóris Schnaidermann. FFLCH-USP, 1976. Publicada em: CAMARgo, Suzana. Macunaíma - ruptura e tradição. São Paulo: Massao Ohno/João Farkas Editores, 1977.

CAmpos, Haroldo de. “Miramar e Macunaíma, I”. Suplemento Literário O Estado de S. Paulo: São Paulo, a. 7, nº 340, 27 de junho de 1963, p. 3.

CAMPos, Haroldo de. “Miramar e Macunaíma, II”. Suplemento Literário O Estado de S. Paulo, São Paulo, a. 7, nº 342, 03 de agosto de 1963, p. 6.

CAMPOS, Haroldo de. "Morfologia de Macunaíma”. Correio da Manhã: Rio de Janeiro, 26 de novembro de 1967.

CAmpos, Haroldo de. “Questão de método”. Correio da Manhã, Rio de Janeiro, 07 de janeiro de 1968.

CAMPOS, Haroldo de. Para uma teoria da prosa modernista brasileira. Tese de doutorado. Orientação: Antonio Candido de Mello e Souza. FFLCH-USP, 1972. Publicada em: CAmpos, Haroldo de. Morfologia do Macunaíma. 1ª ed. São Paulo: Perspectiva, 1973, il. Coleção Estudos, 19.

CAMPOS, Haroldo de. "Mário de Andrade: a imaginação estrutural”. Manchete: Rio de Janeiro, $\mathrm{n}^{0}$ 16, 10 de fevereiro de 1973. Reeditado em: ANDRADE, Mário de. Macunaíma. Edição crítica de Telê Porto Ancona Lopez. Op. cit., 1978. Reeditado, também, em: CAMPOS, Haroldo de. Metalinguagem \& outras metas. Ensaios de teoria e crítica lite- 
rária. 4르 ed. rev. e ampl. São Paulo: Perspectiva, 1992, p. 167-182. Debates, $247^{4}$. Reproduzido, ainda, em: Revista Biblioteca Municipal Mário de Andrade, v. 51, janeiro/dezembro de 1993, p. 113-119.

CAMPos, Haroldo de. “Macunaíma de Mário de Andrade. Obras primas que poucos leram”. Manchete: Rio de Janeiro, $\mathrm{n}^{\circ}$ 16, 10 de fevereiro de 1978.

CANDido, Antonio \& CASTEllo, José Aderaldo. Presença da literatura brasileira. $1^{\mathrm{a}}$ ed. São Paulo: DIFEL, 1964, vol. III, p. 92-97. Antologia [breve apresentação de Macunaíma e reprodução de excerto do cap. XI: “A velha Ceiuci”. $2^{\underline{a}}$ ed., 1966; 3ª ed., 1968; $4^{\underline{a}}$ ed., 1972; 5 $5^{\underline{a}}$ ed. 1975. Em 1985, essa antologia foi refundida em dois volumes].

CARdoso, Joaquim. “Macunaíma”. Folha Carioca: Rio de Janeiro, 18 de janeiro de 1945. IEB-USP - MA-MP.

CARYBÉ, Hector Júlio Barnabé, il. Macunaíma: Ilustrações do mundo do herói sem nenhum caráter. Introdução de Carybé e notas de Antonio Bento. Rio de Janeiro: Livros Técnicos e Científicos; São Paulo: Edusp, 1979.

CASAnOva, Pascale. “Macunaíma, o anti-Camões”. In: A república mundial das letras. Tradução de Marian Appenzeller. São Paulo: Estação Liberdade, 2002, p. 343-356.

CAscudo, Luís da Câmara. "Mário de Andrade”. Boletim de Ariel: Rio de Janeiro, a. 3, nº 9, junho de 1934, p. 233-235. IEB-USP - MA-MP.

Castello Branco, Carlos Heitor. Macunaíma e a viagem grandota. Cartas inéditas de Mário de Andrade. $1^{\underline{a}}$ ed. São Paulo: Conselho Estadual de Cultura / Quatro Artes, 1970 [cinco cartas de Mário de Andrade ao Prefeito de Humaitá].

Castello Branco, Carlos Heitor. "Meio século de Macunaíma”. In: Silva, Benedito Luz e. Em Revista, 3. Antologia. São Paulo: Ed. do Escritor, 1973, p. 69-76.

CASTElo BranCo, Wilson. “Macunaíma, o herói”. Suplemento Literário Minas Gerais: Belo Horizonte, $\mathrm{n}^{\mathrm{0}}$ 608, 27 de maio de 1978, p. 9.

CASTRO, Acyr e BrAsiL, José Carlos. “Uma fábula latino-americana: Macunaíma”. Jornal do Brasil: Rio de Janeiro, 13 de junho de 1970.

CAstro, Sílvio. "Mário de Andrade”. In: A revolução da palavra: origem e estrutura da literatura brasileira moderna. Petrópolis, RJ: Vozes, p. 106$112 ; 116-124$.

\footnotetext{
${ }^{4}$ Nota de Diléa Zanotto Manfio (DZM): Este ensaio não está presente nas $1^{\underline{a}}$, $2^{2 \mathrm{a}}$ e $3^{\mathrm{a}}$ edições.
} 
Chamie, Mário. “Citrodia, Blau e Riobaldo”. Suplemento Literário O Estado de S. Paulo, São Paulo, a. 9, n⿳ำ 402, 17 de outubro de 1964, p. 6.

CHAMIE, Mário. Intertexto: escrita rapsódica - ensaio de leitura produtora. São Paulo: Práxis, 1970.

CHAmie, Mário. A transgressão do texto. Macunaíma: linguagem dialógica. $1^{\underline{a}}$ ed. São Paulo: Práxis, 1972. Publicado, também, em: Revista Letras da Universidade Federal do Paraná. Curitiba, PR, nº 20, 1972, p. 59-88.

CHAmie, Mário. "Mário de Andrade: fato aberto e discurso carnavalesco". Jornal da Tarde: São Paulo, 01 de novembro de 1975, p. 14. Reproduzido em: Boletim Bibliográfico Biblioteca Municipal Mário de Andrade: São Paulo, v. 38, nº 1-2, p. 11-23, janeiro/junho de $1977^{5}$.

Chaves, Flávio Loureiro. “Contribuição de Oswald de Andrade e Mário de Andrade ao romance brasileiro". In: (org.). Aspectos do modernismo brasileiro. $1^{\underline{a}}$ ed. Porto Alegre: UFRS, 1970, p. 22-32.

COLARES, Otacílio. "Macunaíma, a volta ao nacionalismo”. Revista de Letras: Fortaleza, CE, vol. 6, nํㅗㄹ 1/2, janeiro/dezembro de 1983, p. 101-112.

Costa, Oswaldo. "Resposta a Ascenso Ferreira”. Revista de Antropofagia. $2^{\underline{a}}$ Dentição. Diário de S. Paulo: São Paulo, 19 de julho de 1929, p. 12. Edição fac-similar. São Paulo: Abril / Metal Leve, 1975.

Couri, Norma. "Macunaíma, nosso herói chegou a Nova York”. Folha de S. Paulo: São Paulo, 27 de março de 1985.

CunHA, Alice. "O ato criador do Macunaíma”. Caderno Cultural Correio Brasiliense: Brasília, $\mathrm{n}^{\mathrm{0}}$ 281, 21 de setembro de 1973.

CuRI, Norma. “Carlos Augusto, aliás Macunaíma. Se Deus te assinalou é porque alguma coisa Ele achou”. Caderno B, Jornal do Brasil: Rio de Janeiro, 27 de outubro de 1979, p. 1.

CuRY, Maria Zilda F. “Arte e criação em Macunaíma”. In: Ensaios de Semiótica. Belo Horizonte: FLUMG, nº 6, 1981.

D’AmBrósıo, Oscar. “Macunaíma, o grande mau”. DO Leitura: São Paulo, a. 11, nº 133, junho de 1993.

\footnotetext{
${ }^{5}$ Segundo observação de Diléa Zanotto Manfio, trata-se de texto originariamente produzido para conferência proferida em 23 de outubro de 1975, no ciclo de palestras "Mês Mário de Andrade”, na Biblioteca Municipal "Mário de Andrade” em São Paulo.
} 
DAdié, Christian Kacou. Uso do elemento primitivista em Macunaíma de Mário de Andrade. Dissertação de mestrado. Orientação: Luiz Dagobert de Aguirra Roncari. FFLCHUSP, 2002 [inédita].

DALCANAL, José Hildebrando. “O romance europeu e o romance brasileiro do modernismo”. In: CHAVES, Flávio Loureiro (org.). Aspectos do modernismo brasileiro. Porto Alegre: UFRS, 1970, p. 189-217.

EsPínOlA, Adriano. “Carta a Marionaíma: um dançarino brasileiro”. Anais do Seminário "Um desejo quasi enraivecido de Rio”. Rio de Janeiro: Fundação Casa de Rui Barbosa, 1996, p. 49-60.

FARIA, Otávio de. “Macunaíma”. Cultura: Rio de Janeiro, a. 3, nº 26, agosto de 1969, p. 1617.

FERnANDES, Florestan. "Mário de Andrade e o folclore brasileiro”. Revista Arquivo Municipal: São Paulo, ano XII, n⿳ํㅡㄹ 106, p. 135-158, janeiro/fevereiro de 1946. Reproduzido em Revista Arquivo Municipal: São Paulo, n⿳ํㅜ 198, 1990, p. 135-158 [ed. fac-similar do $\mathrm{n}^{0}$ 106, 1946, da mesma revista].

FerRAz, José Bento Faria. “Mário de Andrade”. Suplemento Literário Minas Gerais, Belo Horizonte, MG, $\mathrm{n}^{0}$ 627, 07 de outubro de 1978, p. 4.

FERreIRA, Ascenso. “Brasilidade e dinamismo / a propósito do 'Macunaíma’ de Mário de Andrade”. Diário Nacional: São Paulo, 28 de novembro de 1928. IEB-USP - CAPMP. Republicado no mesmo jornal em 23 de novembro de 1931.

Ferreira, Ascenso. “Carta do poeta de Catimbó”. Revista de Antropofagia. $2^{\underline{a}}$ Dentição. Diário de S. Paulo: São Paulo, 19 de julho de 1929, p. 12. Edição fac-similar. São Paulo: Abril / Metal Leve, 1975.

FINAZZI-AgRO, Ettore. “La parola in gioco: la reinvenzione della memoria in Macunaíma”. Novos Estudos/CEBRAP: São Paulo, nº 3, 1988, p. 79-94.

FINAZZI-AGRÓ, Ettore. “O sentido da metamorfose: precariedade e permanência em Macunaíma”. Tradução de Maria Eneida Victor Farias. Revista de Estudos de Literatura: Belo Horizonte, vol. 1, n⿳ำ 1, outubro de 1993, p. 145-152.

FISCHER, Luís A. “Macunaíma, pretenso algoz de Miramar e de Serafim Ponte Grande”. In: Dalcanal, J. H., Fischer, L. A. e Weber, J. H. O romance modernista. Porto Alegre, RS: Ed. UFRS, 1990, p. 49-52.

FonseCA, Maria Augusta. “A carta pras Icamiabas”. In: ANDRADE, Mário de. Macunaíma, o herói sem nenhum caráter. Edição crítica. Op. cit., 1988, p. 278-294. 
FonsECA, Maria Augusta. “Exílio e paraíso: a carta de Macunaíma”. Arca: Porto Alegre, nº 1, 1993, p. 31-37.

FonseCA, Maria Augusta. “Macunaíma na pátria de doutores e saúvas”. Revista Biblioteca Municipal Mário de Andrade, São Paulo, v. 51, janeiro/dezembro de 1993, p. 105-112, il.

FonseCA, Maria Augusta. “Macunaíma, Horácio e Virgílio”. Revista IEB: São Paulo, nº 36, 1994, p. 67-79.

GAMA, Maurício Loureiro. "Bernard Shaw da Barra Funda”. Periódico não identificado, s/l., s/d. ${ }^{6}$ IEB-USP - MA-MP.

GARRITANO, Ida Fátima. “A renovação modernista e a brasilidade em Mário de Andrade”. Suplemento Literário Minas Gerais: Belo Horizonte, nº 762, 09 de maio de 1981, p. 3. George, David. “A montagem de Macunaíma”. In: Teatro e antropofagia. Tradução de Eduardo Brandão. São Paulo: Global, 1985.

GEORGE, David. “Macunaíma”. In: Grupo Macunaíma: carnavalização e mito. São Paulo: Edusp/Perspectiva, 1990, p. 41-77.

GonÇALVES, Robson Pereira. “Macunaíma revisitado: neurose e identidade”. Letras UFSM: Santa Maria, RS, $n^{0}$ 7, 1993, p. 90-96.

GonÇALVES, Robson Pereira. Macunaíma: carnaval e malandragem. Dissertação de mestrado. Orientação: Affonso Romano de Santana. PUC-RJ, julho de 1980. Publicada em: GonÇALVeS, Robson Pereira. Macunaíma: carnaval e malandragem. Santa Maria, RS: Impr. Universitária, 1982, il.

GoNZÁLEZ, Mario M. “Macunaíma”. In: A saga do anti-herói. São

Paulo: Nova Alexandria / Embajada de Spaña, 1994, p. 297-314.

GouvÊA, Carolina Maria. “Macunaíma em ressonâncias pré-socráticas”. Carmina, UFRJ: Rio de Janeiro, a. 7, $\mathrm{n}^{\mathrm{0}}$ 7, 1993, p. 91-101.

Guimarães, Elisa. “Nova edição crítica de Macunaíma”. Cultura, O Estado de S. Paulo: São Paulo, a. 7, $\mathrm{n}^{\mathrm{0}}$ 449, 25 de fevereiro de 1989, p. 5.

GuimarÃEs, Maria I. de O. "Macunaíma e o projeto pragmático de Mário de Andrade”. Letras UFSM: Santa Maria, RS, nº 7, 1993, p. 77-89.

\footnotetext{
${ }^{6}$ Talvez seja um jornal chamado Anhanguera, a julgar por anotação manuscrita desse nome entre aspas, feita por Mário de Andrade no recorte que figura no álbum R.29 do IEB - Recortes de Mário de Andrade. Não há indicação de local, data e número de página da publicação; talvez, São Paulo, 1937. Outra hipótese: “Anhanguera” seria o pseudônimo do articulista, em outras publicações.
} 
GuimarãES, Ruth. “Aspectos da literatura regional”. Folha da Manhã: São Paulo, 20 de janeiro de 1946, p. 30. BDFSP.

HELENA, Lúcia. "Macunaíma: rapsódia e alegoria”. In: Uma literatura antropofágica. Rio de Janeiro: Cátedra; Brasília: MEC/INL, 1982, p. 143-155.

Holanda, Sérgio Buarque de. “O mito de Macunaíma”. O Espelho. Rio de Janeiro, nº 6, p. 54-56, setembro de 1935. Recolhido em HolAndA, Sérgio Buarque de. O espírito e a letra. Organização, introdução e notas: Antônio Arnoni Prado. São Paulo: Companhia das Letras, 1996, vol. I, p. 260-267.

HolandA, Sérgio Buarque de. "Vida literária / Poesia e crítica”. Diário de Notícias: Rio de Janeiro, 15 de setembro de 1940. IEB-USP - MA-MP. Recolhido em HoLANDA, Sérgio Buarque de. O espírito e a letra. Op. cit., 1996, vol. I, p. 274.

HollandA, Heloisa Buarque de. Macunaíma - da literatura ao cinema. Rio de Janeiro: José Olympio/Embrafilme, 1978.

HoRTA, Arnaldo Pedroso d'. “Revolução não é só tiroteio”. Suplemento Literário O Estado de S. Paulo: São Paulo, a. 4, nº 171, 27 de fevereiro de 1960, p. 3.

HourCADE, Pierre. [Título ignorado]. Revista, 46: Rio de Janeiro, setembro de 1939 (2aㅡ parte) ${ }^{7}$. IEB-USP - MA-MP.

InOJOSA, Joaquim. “Macunaíma e Cobra Norato”. O Jornal: Rio de Janeiro, 26 de fevereiro de 1970. Recolhido em: Os Andrades e outros aspectos do modernismo. $1^{\underline{a}}$ ed. Rio de Janeiro: Civilização Brasileira; Brasília: MEC/INL, 1975, p. $62-63^{8}$.

ITIBERÊ, Susana Uchôa. “Macunaíma encarna espírito rabelaisiano”. Cultura. O Estado de S. Paulo: São Paulo, a. 14, nº 702, 12 de fevereiro de 1994.

J. P. [João Pacheco]. “Bibliografia / 'Macunaíma' - Mário de Andrade - São Paulo”. Folha Acadêmica: Rio de Janeiro, 13 de setembro de 1928, p. 484. IEB-USP - MA-MP.

JAFFE, Noemi. Macunaíma. São Paulo: Publifolha, 2001. Série Folha Explica.

Johnson, Randal. Macunaíma: do modernismo na literatura ao cinema novo. Tradução de Aparecida de G. Johnson. São Paulo: T. A. Queiroz, 1982. Estudos Brasileiros, 5.

\footnotetext{
${ }^{7}$ Identificação do periódico e da data de publicação: LoPEZ, Telê Porto Ancona. "Textos em periódicos”. In: ANDRADE, Mário de. Macunaíma o herói sem nenhum caráter. Edição crítica de Telê Porto Ancona Lopez. Op. cit., 1978.

${ }^{8}$ Nota de DZM: Reunião de artigos e crônicas, publicados em O Jornal, Rio de Janeiro, de 1968-1974 e no suplemento de O Estado de S. Paulo, de 1973.
} 
JoRDÃO, Marina Pacheco. Macunaíma gingando entre contradições. São Paulo: FAPESP/Annablume, 2000 [originariamente, dissertação de mestrado apresentada ao Instituto de Psicologia - USP].

José, Paulo. “Do nariz de Macunaíma e de outros casos”. Folha de S. Paulo: São Paulo, 31 de julho de 2000.

Kossovitch, Elisa Angotti. Mário de Andrade plural. 2ª ed. Campinas, SP: UNICAMP, 1990.

LACERDA, Carlos. “Destinação social do romance brasileiro”. Revista Acadêmica: Rio de Janeiro, ano XI, $\mathrm{n}^{0}$ 66, novembro de 1945 . Arquivo DZM.

LANDERS, Vasda Bonafini. De Jeca a Macunaíma: Monteiro Lobato e o modernismo. Rio de Janeiro: Civilização Brasileira, 1988.

LAURIA, Márcio José. “De Macunaíma a Cobra Norato”. Il. de Sumiko Arimori. DO Leitura: São Paulo, a. 7, nº 79, dezembro de 1988, p. 2-3.

LiMA, Jorge de. “Todos cantam sua terra...”. In: Dois Ensaios. 1a ed. Maceió, AL: Casa Ramalho, 1929. Recolhido em Obras completas de Jorge de Lima. Rio de Janeiro: Aguilar, 1959, p. 1012-1038, vol. I. Reproduzido, parcialmente, com o título de "Um raide do subconsciente nacional”, em ANDRADE, Mário de. Macunaíma. Edição crítica. Op. cit., 1978.

LinHARES, Temístocles. “Um roteiro pouco literário”. Diário de Notícias: Rio de Janeiro, 14 de agosto de 1955.

LOPEZ, Telê Porto Ancona. “A margem e o texto: contribuição para o estudo de Macunaíma”. Boletim Bibliográfico Biblioteca Municipal “Mário de Andrade”: São Paulo, nº especial, p. 9-81, fevereiro de 1970. Reeditado em Macunaíma: a margem e o texto. São Paulo: Secretaria Cultura, Esporte e Turismo / Hucitec, 1974.

LoPEZ, Telê Porto Ancona. “Exemplificando a marginália”. Suplemento Literário O Estado de S. Paulo: São Paulo, a. 14, nº 662, 28 de fevereiro de 1970, p. 5.

Lopez, Telê Porto Ancona. Mário de Andrade: ramais e caminho. São Paulo: Duas Cidades, 1972.

LOPEZ, Telê Porto Ancona. “Travessia de uma edição crítica”. Cultura, O Estado de S. Paulo: São Paulo, ano III, nº 121, 25 de fevereiro de 1979, p. 3-4.

LOPEZ, Telê Porto Ancona. “Rapsódia e resistência”. In: ANDRADE, Mário de. Macunaíma, o herói sem nenhum caráter. São Paulo: Metal Leve; Belo Horizonte: Itatiaia, 1984. E- 
dição fora do comércio. Reproduzido em: ANDRADE, Mário de. Macunaíma, o herói sem nenhum caráter. Edição crítica. Op. cit., 1988, p. 266-277.

LoPEz, Telê Porto Ancona. “Vontade/Variante”. In: ANDRADE, Mário de. Macunaíma, o herói sem nenhum caráter. Edição crítica. Op. cit., 1988, p. XXV-LII.

Lopez, Telê Porto Ancona. “O texto e o livro”. In: ANDRADE, Mário de. Macunaíma, o herói sem nenhum caráter. Edição crítica. Op. cit., 1988, p. 311-315.

LoPEz, Telê Porto Ancona. “Textos, etapas, variantes: o itinerário da escritura”. Revista IEB: São Paulo, nº 31, 1990, p. 147-159.

LOPEZ, Telê Porto Ancona. "Matrizes, marginália, manuscritos”. Congresso ABRALIC. Literatura e memória cultural: Anais, v. 1/2. Belo Horizonte, MG: ABrALIC, 1991, v. 1, p. 431-440. Reproduzido em: . "Matrizes, marginália, manuscritos”. Revista Biblioteca Municipal Mário de Andrade: São Paulo, v. 50, janeiro/dezembro de 1992, p. 89-93.

LOUREIRO, Rita. Interpretação de Macunaíma; textos extraídos de Macunaíma, de Mário de Andrade. São Paulo: MAM, 1982.

LOUSADA, Wilson. “Notas sobre o modernismo”. In: O espelho de Orfeu. Rio de Janeiro: MEC, 1968, p. 151-159.

M. S. B. [Mário da Silva Brito]. "Melancolia versus 'Macunaíma’”. Diário de S. Paulo: São Paulo, 23 de dezembro de 1943. IEB-USP - MA-MP.

MACHADO, Antônio de Alcântara. “O modernismo da literatura de 1928”. A União: [Paraíba, $\mathrm{PB}^{9}$ ], 31 de janeiro de 1929. IEB-USP - MA-MP.

MaCKesan, Luiz. “Macunaíma são muitos, somos todos”. Caderno B, Jornal do Brasil: Rio de Janeiro, 08 de outubro de 1979, p. 1.

MACKeSAN, Luiz. "Mário de Andrade revive”. Caderno B, Jornal do Brasil: Rio de Janeiro, 05 de outubro de 1979, p. 7.

MALlARD, Letícia. “De volta ao herói sem caráter”. Leia: São Paulo, a. 40, n⿳ํㅗ 135, janeiro de 1990, p. 4.

MANFIO, Diléa Zanotto. “Bibliografia Comentada”. In: ANDRADE, Mário de. Macunaíma, o herói sem nenhum caráter. Edição crítica. Op. cit., 1988, p. 194-205.

ManfIO, Diléa Zanotto. “Jamachi”. In: ANDRAde, Mário de. Macunaíma, o herói sem nenhum caráter. Edição crítica. Op. cit., 1988, p. 436-463.

\footnotetext{
${ }^{9}$ No recorte que se encontra no álbum R.27 do IEB-USP - Recortes de Mário de Andrade -, há uma anotação de Mário de Andrade que identifica a data de publicação, o periódico e a cidade, Paraíba, depois chamada João Pessoa.
} 
MARQues FILHo, Teotônio. "Macunaíma (Mário de Andrade)”. O Lutador: Belo Horizonte, 17 de novembro de 1973, p. 6-7.

Martins, Marília. “Macunaíma, internacional”. Jornal do Brasil: Rio de Janeiro, 27 de outubro de 1988.

MARTINS, Wilson. “Macunaíma”. In: O modernismo. $1^{\mathrm{a}}$ ed. São Paulo: Cultrix, 1967, p. 185-195. [2 $2^{\mathrm{a}}$ ed., 1977].

MARTins, Wilson. “Ursa maior”. Jornal do Brasil: Rio de Janeiro, n 366, 02 de outubro de 1993, p. 4.

MELlo e SouzA, Gilda de. “O exílio da preguiça elevada”. Boletim Bibliográfico Biblioteca Municipal Mário de Andrade: São Paulo, novembro de 1975, p. 10-23.

Mello e SouZA, Gilda de. O tupi e o alaúde: uma interpretação de Macunaíma. São Paulo: Duas Cidades, 1979.

Merquior, José Guilherme. “Macunaíma sem ufanismo”. Cultura, O Estado de S. Paulo: São Paulo, a. 5, nํ 44, 12 de abril de 1981, p. 8.

Meyer, Augusto. "Macunaíma”. Correio de Povo: Porto Alegre, a. 36, nº 153, p. 3. 01 de julho de 1930. Arquivo DZM.

MiCHALSKY, Yan. “Macunaíma, um espetáculo revolucionário”. Caderno B, Jornal do Brasil: Rio de Janeiro, 09 de outubro de 1979, p. 10.

MilaRÉ, Sebastião. “Resistir é preciso”. In: . Antunes Filho e a dimensão utópica. São Paulo: Perspectiva, 1994.

Milliet, Sérgio. “O moderno romance brasileiro”. O Estado de S. Paulo: São Paulo, 28 de novembro de 1937. IEB-USP - MA-MP. Recolhido em MiLliET, Sérgio. Ensaios. São Paulo: Brusco, 1938, p. 183-187.

Milliet, Sérgio. “Trechos de diário”. O Estado de S. Paulo: São Paulo, 22 de fevereiro de 1942. IEB-USP - CAP-MP ${ }^{10}$.

Milton, Heloisa Costa. “Comparações plausíveis: uma leitura de Macunaíma à luz da picaresca clássica”. Anuário Brasileño de Estudios Hispânicos: Brasília, DF, nº 1, 1991, p. 179-192.

Milton, Heloisa Costa. “Macunaíma no reino hispânico (a propósito da tradução)”. Revista de Letras Unesp: [Assis?], SP, $\mathrm{n}^{-0}$ 33, 1993, p. 55-70. ${ }^{11}$

\footnotetext{
${ }^{10}$ Trecho não reproduzido em MiLliET, Sérgio. Diário crítico de Sérgio Milliet. Introdução de Antonio Candido. $2^{2}$ ed. São Paulo: Martins / Edusp, 1981, v. I.

${ }^{11}$ Nota de DZM: Sobre a tradução de Héctor Olea para a língua espanhola: Macunaíma el héroe sin ningún carácter.
} 
MonteIro, Adolfo Casais. “O romance em ascensão”. Suplemento Literário O Estado de S. Paulo: São Paulo, a. 1, nº 19, 16 de fevereiro de 1957, p. 1.

MoRSE, Richard M. "McLuhanaíma: the solid gold hero ou o herói com bastante caráter”. In: A volta de Mcluhanaíma. Cinco estudos solenes e uma brincadeira séria. Tradução de Paulo Henriques Britto. São Paulo: Cia. das Letras, 1990, p. 247-274 [cf. 1977, item 115].

Morse, Richard M. "McLuhanaíma: the solid gold hero. O herói com bastante caráter (uma fuga)”. Almanaque: São Paulo, $\mathrm{n}^{-0}$ 3, 1977, p. 61-74. Reeditado em: . A volta de Mcluhanaíma. Cinco estudos solenes e uma brincadeira séria. Tradução de Paulo Henriques Britto. São Paulo: Cia. das Letras, 1990, p. 247-274.

MoRsE, Richard. “T. S. Eliot e Mário de Andrade”. In: A volta de $M-$ cluhanaíma. Cinco estudos solenes e uma brincadeira séria. Tradução de Paulo Henriques Britto. São Paulo, Cia. das Letras, 1990, p. 98-118.

MotTA FiLHo, Cândido. “As leituras da semana / Literatura / Macunaíma - Mário Moraes de Andrade - São Paulo - 1928”. Correio Paulistano: São Paulo, 20 de setembro de 1928. IEB-USP - CAP-MP.

MotTa FiLho, Cândido. “Macunaíma para valer”. Revista Arquivo Municipal: São Paulo, a. 33, v. 180, janeiro/março de 1970, p. 11-16.

MourÃo, Ronaldo de F. “A cosmologia do Macunaíma”. Caderno B, Jornal do Brasil: Rio de Janeiro, 31 de outubro de 1979, p. 8.

MourÃo, Ronaldo de F. “Os astros de Macunaíma, I”. Jornal do Brasil. Caderno B: Rio de Janeiro, 17 de outubro de 1979.

MourÃo, Ronaldo F. “Os astros de Macunaíma, II”. Caderno B, Jornal do Brasil: Rio de Janeiro, 24 de outubro de 1979.

MourÃo, Ronaldo de F. “Os astros de Macunaíma, III”. Caderno B, Jornal do Brasil: Rio de Janeiro, 31 de outubro de 1979.

MourÃo, Ronaldo de F. Astronomia do Macunaíma. 1ํㅡㄹ ed. Rio de Janeiro: F. Alves, 1984. Reedição: Belo Horizonte: Itatiaia, 2000, il.

MoutinHo, G. Nogueira. “O personagem do livro à toda”. Folha de S. Paulo: São Paulo, 04 de dezembro de 1969.

MoutinHo, Nogueira. “Do herói sem caráter”. Folha de S. Paulo, Ilustrada: São Paulo, 25 de fevereiro de 1979, p. 35. 
Mutran, Munira. “Ulisses: uma leitura de Mário de Andrade”. Cultura, O Estado de S. Paulo: São Paulo, a. 2, nº 86, 03 de janeiro de 1982.

NADER, Alceu Simões. “O homem que fez Macunaíma falar francês”. O Estado de S. Paulo: São Paulo, 07 de novembro de 1977.

NASCIMENTO, Dalma. “Édipo e outros mitos no sertão de Macunaíma”. Anais da XIV Semana de Estudos Clássicos, UFRJ: Rio de Janeiro, 1994, p. 212-216.

NASCIMENTO, Dalma. “Macunaíma. Memórias ameríndias em diálogos com situações e mitos gregos”. Carmina, UFRJ: Rio de Janeiro, a. 7, nํㅜ 7, 1993, p. 78-90. ${ }^{12}$

NASCIMENTO, Dalma. “Memórias culturais na pós-modernidade de Macunaíma”. In: Actes du $X I X^{\text {ème. }}$ Congrès de la Fédération Internationale des Langues et Litterature Modernes: Brasília, DF, 1996, p. 1346-1350.

Neme, Mário. “Linguagem de Mário de Andrade”. Revista Arquivo Municipal: São Paulo, ano XII, n⿳0 106, p. 107-114, janeiro/fevereiro de 1946. Reproduzido em Revista Arquivo Municipal: São Paulo, nº 198, 1990, p. 107-114 [ed. fac-similar do nº 106, 1946, da mesma revista].

NEME, Mário. “O livro mais tipicamente brasileiro”. Folha da Manhã: São Paulo, 15 de março de $1942^{13}$. IEB-USP - MA-MP.

Nogueira Moutinho. “Morfologia do Macunaíma”. Folha de S. Paulo: São Paulo, 11 de setembro de 1973.

Nolasco, Paulo S. Nas malhas da rede. Ensaio de literatura comparada. Belo Horizonte: Ed. UFMG, $1993 .^{14}$

NunES FILHO, Augusto. “Macunaíma - origem do discurso, discurso de origem”. O Eixo e a Roda: Belo Horizonte, MG, a. 2, nº 2, 1984, p. 98-104.

O. M. [Olívio Montenegro]. "Livros novos / Macunaíma - Romance - Mário de Andrade - S. Paulo - 1928”. Periódico não identificado, $\left[\right.$ Recife $^{15}$ ], s/d. IEB-USP - MA-MP.

OliveIRA, Franklin. “Os heróis literários depois de Macunaíma”. Folha de S. Paulo: São Paulo, 09 de julho de 1978.

\footnotetext{
${ }^{12}$ Nota de DZM: Originalmente, conferência proferida no 19º International Congress, em Brasília, em 28.08.93.

${ }^{13}$ Declaração de Mário Neme em entrevista.

${ }^{14}$ Nota de DZM: [o estudo] compara Mário de Andrade e Virgínia Wolff. Originalmente dissertação de mestrado.

${ }^{15}$ No verso do recorte, que se encontra no álbum R.29 do IEB-USP - Recortes de Mário de Andrade -, há indícios de que a cidade de Recife seja o local da publicação.
} 
Pacheco, João. “Macunaíma e a esfinge”. O Estado de S. Paulo, São Paulo, 18 de maio de 1945. Recolhido em Pacheco, João. Pedras Várias. São Paulo: Conselho Estadual de Cultura, 1959, p. 3-8.

PAES, José Paulo. “V. Macunaíma”. In: A aventura literária. Ensaios sobre ficção e ficções. São Paulo: Companhia das Letras, 1990, p. 83-89. 1ª reimpressão: 2000 .

PAIXÃO, Fernandes. “Desvios e continuidade da poesia macunaímica”. Travessia, Revista de Literatura Brasileira: Florianópolis, SC, a. 12, nº 24, 1992, p. 7-16.

PAssos, José Luiz. Ruínas de linhas puras. Quatro ensaios em torno a Macunaíma. Apresentação de Randal Johnson. 1ํㅗㄹ ed. São Paulo: Annablume, 1998.

PAStA JR., José A. “Tristes estrelas da Ursa - Macunaíma”. Cadernos Porto \& Vírgula: Porto Alegre, Secretaria Municipal Cultura, nº 4, 1993, p. 27-32.

PAUla RAmOS JR. José de. “A fortuna crítica de Macunaíma”. Revista USP: São Paulo, março/abril/maio de 2005, p. 125-130.

PereirA, Nunes. “A língua de Macunaíma”. Rio Magazine: Rio de Janeiro, nº 8, s/d [1937 $\left.{ }^{16}\right]$. IEB-USP - MA-MP.

Perrone-Moisés, Leila. “Tupi or not tupi”. Cultura, O Estado de S. Paulo: São Paulo, 27 de janeiro de 1980, p. 3-4, il.

PICCHIO, Luciana Stegagno. "Mario de Andrade: a consciência criadora”. In: História da literatura brasileira. Tradução de Pérola de Carvalho e Alice Kyoko. Rio de Janeiro: Nova Aguilar, 1997, p. 486-490.

PiMentel, Osmar. “Macunaíma e o porão”. Diário de S. Paulo: São Paulo, 23 de setembro de 1943. IEB-USP - MA-MP.

PIMENTEL, Osmar. "De Ariel a Macunaíma”. In: A cruz e o martelo (Ensaios de literatura e psicologia). São Paulo: Conselho Estadual de Cultura, 1970, p. 129-141, Coleção Ensaio, 67.

Pires, Vera Lúcia G. A. A linguagem dos personagens de Macunaíma. Alienação e consciência. Dissertação de mestrado. Orientação: Eneida do R. M. Bomfin. PUC-RJ, 1976 [inédita?].

Pontes, José Alfredo O. V. “SAMPASTERRASDOTIETÊ”. Memória: São Paulo, ano V, nº 17, janeiro/fevereiro/março de 1993, p. 35-38, il.

\footnotetext{
${ }^{16}$ Nota editorial no fim do artigo permite supor que esse date de 1937, pouco antes da publicação da $2^{2}$ edição de Macunaíma.
} 
Prado, Antonio Arnoni. "Makunaíma herói na Hungria”. Folha de S. Paulo: São Paulo, 09 de junho de 1984.

Prado, Antonio Lázaro de A. "No país dos Andrades: Miramar e Macunaíma: radicalidade na arte e na práxis”. Revista de Letras da Faculdade de Ciências e Letras: Assis, SP, v. 17, 1975, p. 205-230.

ProençA, M. Cavalcanti. “Macunaíma, o herói”. Diário Carioca: Rio de Janeiro, 22 de fevereiro de 1953 [excerto do até então inédito Roteiro de Macunaíma]. IEB-USP - CAPMP.

ProençA, M. Cavalcanti. Roteiro de Macunaíma. $1^{\underline{a}}$ ed. São Paulo: Anhembi, 1955. [2ª ed.

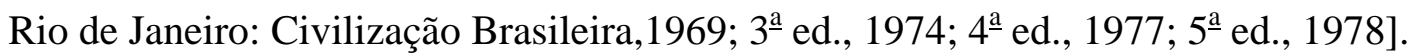

ProençA, M. Cavalcanti. “Mário de Andrade ficcionista”. Suplemento Literário O Estado de S. Paulo, São Paulo, a. 4, no 171, il., 27 de fevereiro de 1960, p. 6. Recolhido em Estudos literários. Prefácio de Antônio Houaiss. Rio de Janeiro: José Olympio, 1971, p. 337-345. Coleção Documentos Brasileiros, 147. ${ }^{17}$

ProençA, M. Cavalcanti. “Macunaíma, pioneiro”. Jornal de Letras: Rio de Janeiro, fevereiro/março de 1965, p. 6. Recolhido em Estudos Literários. Op. cit., 1971, p. 352-354.

ProençA, M. Cavalcanti. "Homenagem a Mário de Andrade”. In: Revista brasileira de folclore. Rio de Janeiro: Ministério da Educação e Cultura, ano VI, $\mathrm{n}^{\mathbf{0}}$ 5, março/agosto de 1966, p. 191-194. Recolhido em . Estudos Literários. Op. cit., 1971, p. 354-358.

RAmos, Tânia R. O. "Morte e vida de Macunaíma: um choro bem brasileiro”. Travessia: Florianópolis, SC, a. 6, nํ12, 1986, p. 113-123.

RAngel, Maria Lúcia. "Herói de nossa gente”. Caderno B, Jornal do Brasil: Rio de Janeiro, 05 de outubro de 1979, p. 7.

RAngel, Maria Lúcia. “Mário dos anos 20, 60, 70...”. Caderno B, Jornal do Brasil: Rio de Janeiro, 08 de outubro de 1979, p. 1.

REIPERT, Herman José. "Mário e a linguagem brasileira”. Boletim Bibliográfico Biblioteca Municipal “Mário de Andrade”: São Paulo, nº especial, fevereiro de 1970, p. 7-8.

REIS, Edgar Pereira. “Macunaíma, um texto montagem e ponto de vista”. Suplemento Literário Minas Gerais: Belo Horizonte, nํ212, 19 de setembro de 1970, p. 6-7.

\footnotetext{
${ }^{17}$ É preciso verificar essa informação. Segundo nota da p. 337 de Estudos literários, o artigo "Mário de Andrade ficcionista” foi publicado no Suplemento Literário O Estado de S. Paulo, na edição de 12 de fevereiro de 1957.
} 
REIS, Roberto. “A fala impura, I”. Suplemento Literário Minas Gerais: Belo Horizonte, nº 700, 01 de março de 1980, p. 2-4.

REIS, Roberto. “A fala impura, II”. : Belo Horizonte, $\mathrm{n}^{\mathrm{o}}$ 701, 08 de março de 1980, p. 6-7.

REIS, Roberto. “A fala impura, III”. : Belo Horizonte, $\mathrm{n}^{\mathrm{o}}$ 702, 15 de março de 1980, p. 6-7.

REzende, Darcilene de S. "Bibliografia”. In: AndRAde, Mário de. Macunaíma, o herói sem nenhum caráter. Edição crítica. Op. cit., 1988, p. 464-480.

Rezende, Maria Ângela de Araújo. “'Vou ir com Macunaíma’. Manuel de Barros e Mário de Andrade: uma leitura intertextual”. Florianópolis, SC: ABRALIC, 1998.

RIBEIRO, Darcy. “Liminar”. In: ANDRADE, Mário de. Macunaíma, o herói sem nenhum caráter. Edição crítica. Op. cit., 1988, p. XVII-XXII.

RIBEIRO, João. “Crônica literária / Macunaíma - herói sem nenhum caráter - por Mário de Andrade”. Jornal do Brasil: Rio de Janeiro, 31 de outubro de 1928, p. 10. IEB-USP CAP-MP. Recolhido em Os Modernos. Rio de Janeiro: ABL, 1952, p. 81-84, vol. IX das Obras completas de João Ribeiro. Reproduzido em AndRADE, Mário de. Macunaíma. Edição crítica de Telê Porto Ancona Lopez. Rio de Janeiro: Livros Técnicos e Científicos / São Paulo: Secretaria da Cultura, Ciência e Tecnologia, 1978.

RiBEIRO, Leo Gilson. “Astuto ou generoso. Mas sempre amoral”. Jornal da Tarde: São Paulo, 22 de julho de 1978.

RIBEIRO, Sílvia Aparecida da Rocha. Macunaíma e a cidade de São Paulo: caminhos mutantes. Dissertação de mestrado. Orientação: Maria José Palo. PUC-SP, 2005 [inédita].

Rossı, Giuseppe C. "Influência e motivos da literatura italiana nos romances de Graça Aranha e Mário de Andrade”. Suplemento Literário Minas Gerais: Belo Horizonte, nํㅡ 602, 15 de abril de 1978, p. 4-5.

Rovedo, Salomão. “Macunaíma em versos”. DO Leitura: São Paulo, a. 6, nํㅜ 63, agosto de 1987.

S/A [Mário de Andrade]. “Macunaíma. O livro de Mário de Andrade”. Diário Nacional: São Paulo, 07 de agosto de 1928. IEB-USP - CAP-MP.

S/A [Ronald de Carvalho]. "Livros / Macunaíma - o herói sem nenhum caráter - de Mário de Andrade”. Movimento: Rio de Janeiro, 01 de outubro de 1928, p. 21. FBN - Periódicos. Recolhido em CARvalho, Ronald de. "Cadernos de imagens / 4 / Macunaíma, de Mário de Andrade”. In: Estudos Brasileiros. 1ª ed. Rio de Janeiro: F. Briguiet, 1931, 
p. 151-152. Reeditado em: Estudos Brasileiros. Rio de Janeiro: MEC / Nova Aguilar, 1976, p. 143-144.

S/A. “Autor nacionalista até o fim”. Folha de S. Paulo: São Paulo, 26 de julho de 1988, p. A33.

S/A. "Macunaíma ainda vive 25 anos depois de sua morte”. O Globo: Rio de Janeiro, 25 de fevereiro de 1970.

Sá, Lúcia de.”Tricksters indígenas pervertem a literatura nacional: o caso Macunaíma”. Anais do VI Congresso da Associação Brasileira de Literatura Comparada. Florianópolis, SC: ABRALIC, 1998.

SANDRONI, Carlos. Mário contra Macunaíma: cultura e política em Mário de Andrade. São Paulo: Vértice; Rio de Janeiro: IPERJ, 1988 [originariamente, dissertação de mestrado apresentada ao Instituto Universitário de Pesquisas do Rio de Janeiro].

SANGIRARDI JR. "Divindades e heróis: dois mitos indígenas da Amazônia”. DO Leitura: São Paulo, a. 6, nํㅜ 63, agosto de 1987.

SANTIAGO, Silviano. “A trajetória de um livro”. In: AndRADE, Mário de. Macunaíma, o herói sem nenhum caráter. Edição crítica. Op. cit., 1988, p. 182-193. Reproduzido em Nas Malhas da Letra. São Paulo: Cia. das Letras, 1989, p.

124-139, com o título alterado para "História de um livro". Reeditado em Nas Malhas da Letra. 2aㅡ. ed. Rio de Janeiro: Rocco, 2002,

p. 145-163.

ScAlzo, Nilo. “A literatura em 78”. Cultura, O Estado de S. Paulo: São Paulo, 26 de dezembro de 1978.

SCHILD, Susana. "Macunaíma com rigor e emoção”. Jornal do Brasil: Rio de Janeiro, 04 de dezembro de 1982.

SchmidT, Augusto F. “A propósito de 'Macunaíma””. A Ordem: Rio de Janeiro, [dezembro?] de 1928, p. 34-38. IEB-USP - CAP-MP.

SCHNAIDERMAN, Bóris. “Prefácio”. In: PropP, W. I. Morfologia do conto maravilhoso. Rio de Janeiro: Forense-Universitária, 1984.

SCHNAIDERMANN, Bóris. "Macunaíma - um diálogo entre surdos”. Suplemento Literário O Estado de S. Paulo: São Paulo, a. 19, nํ900, 27 de outubro de 1974, p. 1.

SCHULKe, Evelyn. "O mais nítido perfil dos brasileiros. Em julgamento”. Jornal da Tarde: São Paulo, 22 de julho de 1978. 
SiLVeIRA, Regina da Costa. Macunaíma e Ti-Noel: reflexões para uma leitura ideológica. Tese de doutorado. Orientação: Flávio L. Chaves. UFRGS, 1990 [inédita?].

SIMÕES, Neusa Quirino. “Mário de Andrade anotando a bagaceira”. Boletim Bibliográfico Biblioteca Municipal Mário de Andrade: São Paulo, v. 40, nº 1-4, janeiro/dezembro de 1979, p. 53-61.

SoARES, Luzia. “Cédula macunaímica”. Memória: São Paulo, ano V, noํ17, janeiro/fevereiro/março de 1993, p. 5, il.

SODRÉ, Nelson Werneck. "Livros novos / Macunaíma - Mário de Andrade - Livraria José Olympio Editora”. Correio Paulistano: São Paulo, 15 de abril de 1937. IEB-USP MA-MP.

SouZA, Eneida Maria de. “A pedra mágica do discurso”. In: ANDRADE, Mário de. Macunaíma, o herói sem nenhum caráter. Edição crítica. Op. cit., 1988, p. 295-308. Excertos de A pedra mágica do discurso. Jogo e linguagem em Мacunaíma. Belo Horizonte: UFMG, 1988. $2^{\underline{a}}$ ed. revista e ampliada: A pedra mágica do discurso. Belo Horizonte: UFMG, 1999.

SouzA, Eneida Maria de. "Preguiça e saber”. Revista de Letras Unesp: [Assis?], SP, nº 33, 1993, p. 81-89. Publicado, também, em: Letras UFSM: Santa Maria, RS, nº 7, 1993, p. 7-18.

SouZA, Tânia Regina. “Macunaíma: a memória social no relatório biográfico”. Anuário de Literatura: Florianópolis, SC, nํㅡㄹ 1, 1993, p. 9-14. ${ }^{18}$

Sperber, G. B. “Common roots in Mário de Andrade’s Macunaíma and Alfred Döblin’s Amazonas”. Brasil/Brazil: Porto Alegre, PUC-RS / Brown University (EUA), ano VI, $\mathrm{n}^{\mathbf{0}}$ 10, 1993, p. 47-56.

TAMAndaré [Oswaldo Costa]. “Moquém / II - Hors d'oeuvre”. Revista de Antropofagia. $2^{\underline{a}}$ Dentição. Diário de S. Paulo: São Paulo, 14 de abril de 1929, p. 6. Edição fac-similar. São Paulo: Abril / Metal Leve, 1975.

TAMAndaré [Oswaldo Costa]. “Moquém / III - Entradas”. Revista de Antropofagia. $2^{\underline{a}}$ Dentição. Diário de S. Paulo: São Paulo, 24 de abril de 1929, p. 10. Edição fac-similar. São Paulo: Abril / Metal Leve, 1975.

Toledo, Marlene P. M. F. “Macunaíma o herói sem nenhum caráter”. DO Leitura: São Paulo, a. $68, n^{0}$ 134, julho de 1993, p. 8-9.

\footnotetext{
${ }^{18}$ Nota de DZM: Revista de pós-graduação em Letras.
} 
Toledo, Sérvullo Pompeu de. "Macunaíma”. Anhembi: São Paulo, nº 90, maio de 1958, p. 496-511.

TORREs, Marie-Hélène C. “Macunaíma herói de um romance de aprendizagem”. Arca: Porto Alegre, $n^{0} 1,1993$, p. 39-43. ${ }^{19}$

VAsconcelos, Sandra Guardini Teixeira. “Macunaíma: a arte como resistência”. Boletim Bibliográfico da Biblioteca Municipal Mário de Andrade: São Paulo, vol. 42, nº 1, janeiro/março de 1981, p. 103-114. Também publicado em Uniletras, Revista do Departamento de Letras UEPG: Ponta Grossa, PR, nº 3, 1981, p. 20-32.

Viany, Alex. "Macunaíma: o filme em questão”. Jornal do Brasil: Rio de Janeiro, 07 de novembro de 1969.

VIEIRA, José Geraldo. “Macunaíma”. Correio Paulistano: São Paulo, 11 de março de 1945. IEB-USP - CAP-MP.

VIEIRA, José. “Livros novos / Macunaíma, por Mário de Andrade, S. Paulo, 1928”. Vanguar$d a:$ [Rio de Janeiro ${ }^{20}$ ], 10 de dezembro de 1928. IEB-USP - MA-MP.

VillaçA, Antonio Carlos. “Futuro de Macunaíma”. Suplemento Literário Minas Gerais: Belo Horizonte, $\mathrm{n}^{0}$ 608, 27 de maio de 1978, p. 9.

VILLAÇA, Nízia. “Macunaíma: uma releitura do projeto antropofágico cultural”. Florianópolis, SC: ABRALIC, 1998.

VíTOR, Nestor. "Macunaíma, o herói sem nenhum caráter”. O Globo: Rio de Janeiro, 08 de outubro de 1928. FBN - Periódicos. Recolhido em VÍTOR, Nestor. “Os de Hoje / Mário de Andrade / Macunaíma”. Obra crítica de Nestor Vítor. Rio de Janeiro: MEC / Fundação Casa de Rui Barbosa, 1973, v. II, p. 360-365. [1ª ed. 1938].

WALLY, Ivete Lara Camargo. “Macunaíma: herói cômico?”. Suplemento Literário Minas Gerais: Belo Horizonte, $\mathrm{n}^{0}$ 625, 23 de setembro de 1978, p. 8-9.

WISNIK, José Miguel. “A rotação das utopias - Rapsódia”. In: BERRIEL, C. E. O. (org.). Mário de Andrade/Hoje. São Paulo: Ensaio, 1990, p. 179-193. Cadernos Ensaio, 4.

WYLER, Vivian. “À procura do brasileiro típico na ficção nacional”. Caderno B, Jornal do Brasil: Rio de Janeiro, 13 de outubro de 1979, p. 10.

\footnotetext{
${ }^{19}$ Nota de DZM: Estudo baseado na concepção de Bakhtin sobre romance de aprendizagem.

${ }^{20}$ No verso do recorte, que se encontra no álbum R.29 do IEB-USP - Recortes de Mário de Andrade -, há indícios de que a cidade do Rio de Janeiro seja o local da publicação.
} 


\section{ÍNDICE DA DOCUMENTAÇÃO}




\section{CORPUS}

S/A [Mário de Andrade]. Macunaíma. O livro de Mário de Andrade, 6

Tristão de Ataíde [Alceu Amoroso Lima]. Macunaíma, 9

J. P. [João Pacheco]. Macunaíma, 20

Cândido Motta Filho. Macunaíma - Mário de Andrade, 23

A. de A. M. [António de Alcântara Machado]. Um poeta e um prosador, 26

Oswald de Andrade. Esquema ao Tristão de Ataíde, 29

S/A [Ronald de Carvalho]. Macunaíma - o herói sem nenhum caráter - de Mário de Andrade, 33

Nestor Vítor. Macunaíma, o herói sem nenhum caráter, 36

João Ribeiro. Macunaíma - herói sem nenhum caráter - por Mário de Andrade, 44

Ascenso Ferreira. Brasilidade e dinamismo - a propósito do “Macunaíma” de Mário de Andrade, 48

José Vieira. Macunaíma, por Mário de Andrade, 56

O. M. [Olívio Montenegro]. Macunaíma - Romance - Mário de Andrade, 61

Augusto F. Schmidt. A propósito de “Macunaíma”, 66

A. M. [Augusto Meyer]. Macunaíma - por Mário de Andrade, 74

António de Alcântara Machado. O modernismo da literatura de 1928, 76

Tamandaré [Oswaldo Costa]. Moquém II - Hors d’oeuvre, 81

A. F. [Aníbal Fernandes]. Macunaíma - Mário de Andrade - S. Paulo, 85

Tamandaré [Oswaldo Costa]. Moquém III - Entradas, 90

Ascenso Ferreira. Carta do poeta de Catimbó, 94

Oswaldo Costa. Resposta a Ascenso Ferreira, 96

Jorge de Lima. Todos cantam sua terra..., 99

Augusto Meyer. Macunaíma, 127

Luís da Câmara Cascudo - Mário de Andrade, 134

Sérgio Buarque de Holanda - O mito de Macunaíma, 144 


\section{MATÉRIA AGREGADA}

Nunes Pereira. A língua de Macunaíma, 155

B. B. [Brito Broca]. A epopéia de um herói sem nenhum caráter. A reedição de Macunaíma, de Mário de Andrade, 159

Nelson Werneck Sodré. Macunaíma - Mário de Andrade - Livraria José Olympio Editora, 163

Rubem Braga. Os defeitos de Macunaíma, 168

Sérgio Milliet. O moderno romance brasileiro, 170

Maurício Loureiro Gama. Bernard Shaw da Barra Funda, 175

Pierre Hourcade. [Título ignorado], 181

Sérgio Buarque de Holanda. Poesia e crítica, 185

Sérgio Milliet. Trechos de diário, 188

Mário Neme. O livro mais tipicamente brasileiro, 190

Mário da Silva Brito. Uma excursão pelo fichário de "Macunaíma”, 193

M. S. B. [Mário da Silva Brito]. Melancolia versus “Macunaíma”, 202

A. F. [Aníbal Fernandes?]. Macunaíma, de Mário de Andrade, 206

Joaquim Cardoso. Macunaíma, 210

José Geraldo Vieira. Macunaíma, 213

João Pacheco. Macunaíma e a esfinge, 217

Carlos Lacerda. Destinação social do romance brasileiro, 223

Ruth Guimarães. Aspectos da literatura regional, 227

Roger Bastide. Macunaíma em Paris, 231

Roger Bastide. Macunaíma visto por um francês, 235

Florestan Fernandes. Mário de Andrade e o folclore brasileiro, 241

Mário Neme. Linguagem de Mário de Andrade, 262

Eliezer Burlá. Macunaíma, 20 anos depois, 270

M. Cavalcanti Proença. Macunaíma, o herói, 274 